RICARDO CRUVINEL DORNELAS

\title{
ESTUDO DE MÉTODOS PARA PROGNÓSTICO DA PRODUTIVIDADE NA EXECUÇÃO DE RODOVIAS: \\ TERRAPLENAGEM E PAVIMENTAÇÃO ASFÁLTICA - UMA NOVA ABORDAGEM.
}

Tese apresentada à Escola Politécnica da Universidade de São Paulo para obtenção do título de Doutor em Engenharia. 


\section{ESTUDO DE MÉTODOS PARA PROGNÓSTICO DA PRODUTIVIDADE NA EXECUÇÃO DE RODOVIAS: TERRAPLENAGEM E PAVIMENTAÇÃO ASFÁLTICA - UMA NOVA ABORDAGEM.}

Tese apresentada à Escola Politécnica da Universidade de São Paulo para obtenção do título de Doutor em Engenharia.

Área de atuação:

Engenharia de Construção Civil Tecnologia e Gestão na Produção de Edifícios

Orientador:

Prof. Dr. Ubiraci Espinelli Lemes de Souza 


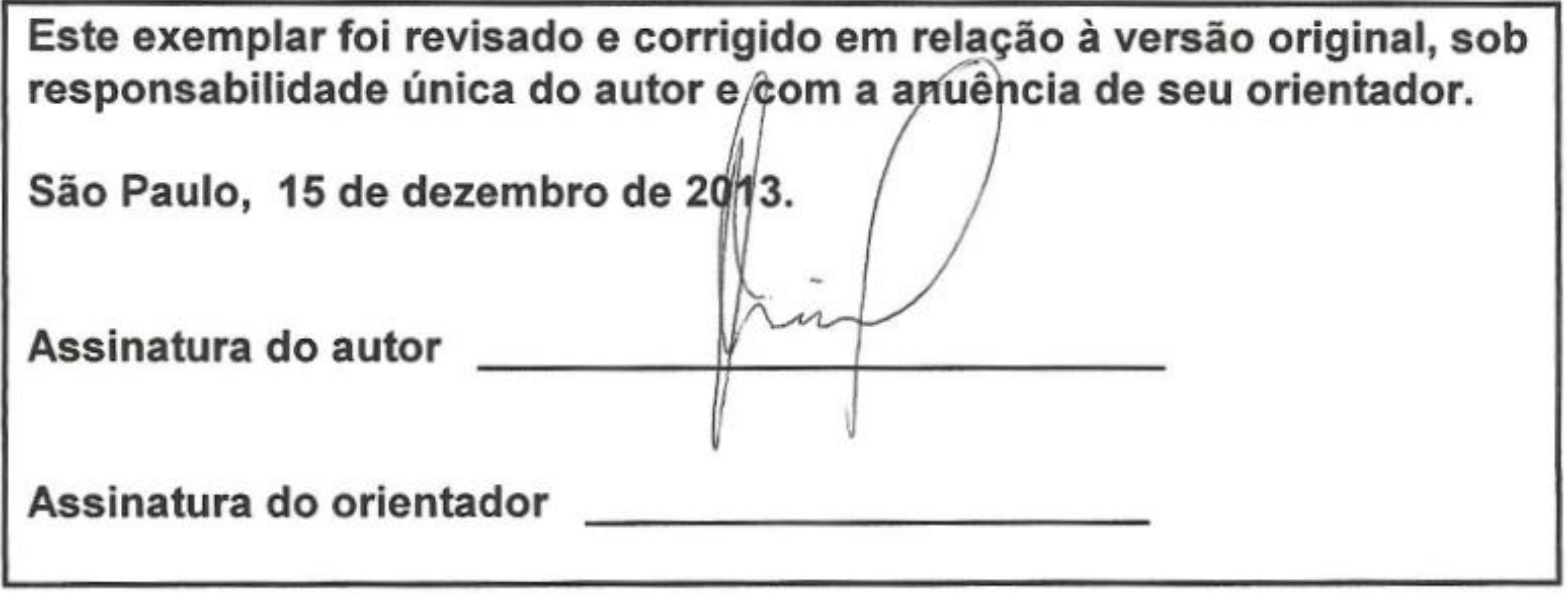

FICHA CATALOGRÁFICA

\section{Dornelas, Ricardo Cruvinel}

Estudo de métodos para prognóstico da produtividade na execução de rodovias: terraplenagem e pavimentação asfáltica uma nova abordagem / R.C. Dornelas. - versão corr. -- São Paulo, 2013.

308 p.

Tese (Doutorado) - Escola Politécnica da Universidade de Săo Paulo. Departamento de Engenharia de Construção Civil.

1.Rodovias (Projeto e construção;Produtividade) 2.Terraplenagem 3.Pavimentaçăo asfáltica I. Universidade de São Paulo. Escola Politécnica. Departamento de Engenharia de Construção Civil II. t. 

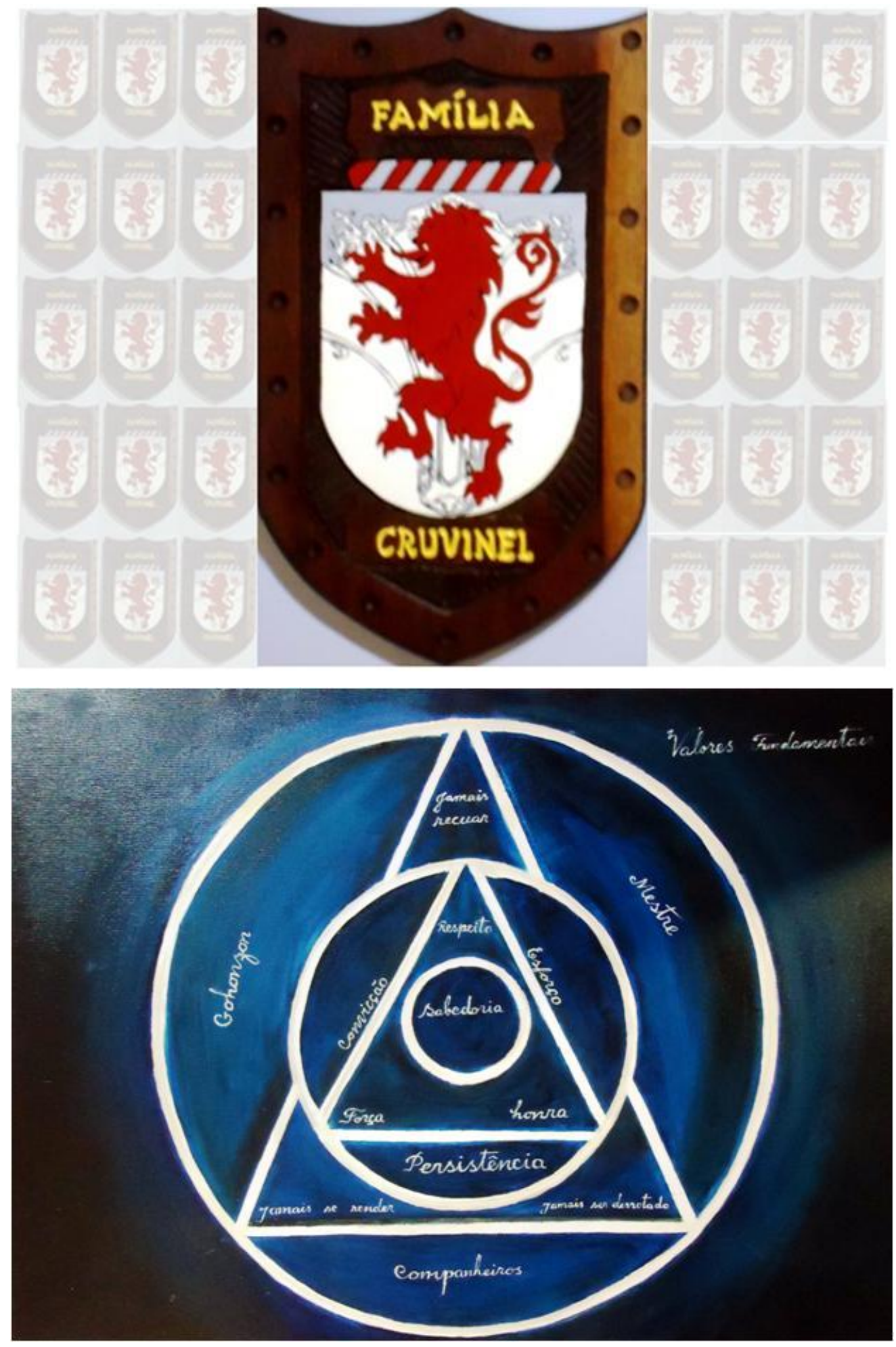

À minha família, Núbia, Virgílio e Benjamin

e aos Valores Fundamentais que nos unem e fortalecem nosso amor. 


\section{AGRADECIMENTOS}

\section{Aos Mestres:}

Nas artes marciais, aprendemos que aquele que ensina pelo exemplo, que tenha grande conhecimento, habilidade, experiência e habilidade para ensinar é um verdadeiro mestre. Estes agradecimentos são para três grandes mestres que mudaram a minha vida.

O primeiro agradecimento é ao Mestre Daisaku Ikeda, que ensinou a "riqueza da vida" e iluminou o coração de um jovem.

Eu tinha 15 anos, sem esperança e poucas diretrizes. Na época minha mãe lutava bravamente para garantir o pão nosso de cada dia e para vencer uma grave doença. Foi quando me encontrei com o Mestre lkeda e aprendi os fundamentos da "Revolução Humana". Tal como a areia seca absorve a água, ouvi li e reli todos os seus ensinamentos. "Seja o autor de sua própria história embasada nos ensinamentos budistas" eram os principais ensinamentos. Assim como o fogo forja a espada, diariamente e ininterruptamente, pratiquei a "riqueza da vida" que aborda valores fundamentais tais como: de ser tão forte que nada abalará a paz de meu espírito; de não esquecer os erros do passado e avançar decidido a obter os melhores resultados no futuro; e de ser forte contra o medo, nobre contra a cólera e firme contra a dúvida. Como os raios do sol nas primeiras horas do dia, o meu caminho se iluminou e o meu coração se encheu de esperança.

O segundo agradecimento é ao Mestre João Fernando Dias, que acreditou no potencial de um homem em desvantagem.

2003, ano em que o país passava por uma série crise econômica e não se tinha obras para construir. De São Paulo, junto com minha família, retornei para Uberlândia. Após vários sucessos enquanto engenheiro, planejador, gerente e diretor de multinacional eu me encontrava desempregado. Com muitas críticas e poucos incentivos, procurei o Prof. João Fernando Dias. Na ocasião eu lhe disse "estou decidido a me tornar um professor universitário, o que é preciso fazer?", sua resposta "tem que ser doutor para ser professor em nível federal." Agradeci e me retirei. Um ano depois o professor me ligou e me incentivou a participar em um 
concurso para professor substituto. A partir daí, minha história enquanto professor universitário teve início. Como na Odisseia de Homero, eu progredia de desafio em desafio, superando cada um, não porque fosse mais forte que meus adversários ou situações, mas porque eu tinha o apoio do Prof. João Fernando Dias. É indispensável que se tenha, ao sair em busca do objetivo, o apoio familiar e de pessoas que possam ajudá-lo a suportar as asperezas da caminhada. Ai está a grandeza do professor. Seus ensinamentos virtuosos me influenciaram a me tornar uma pessoa melhor e a seguir em frente. Quando muitos me criticavam, o Prof. João Fernando Dias foi o mestre que acreditou em meu potencial.

O terceiro agradecimento e ao Mestre Ubiraci Espinelli Lemes de Souza, que orientou e tornou possível a concretização de um sonho.

Após o término do mestrado, em 2007, iniciei imediatamente o doutoramento na Escola Politécnica da USP. Enquanto meu orientador o Prof. Ubiraci se encarregou de ações vitais para o meu crescimento: viabilizou financeiramente os meus estudos; criou oportunidades para o desenvolvimento de trabalhos acadêmicos; orientou-me no desenvolvimento da tese. É vital que o doutorando procure não apenas o melhor orientador possível, mas um bom mestre. $O$ doutorando precisa ser ensinado, quase tutelado, e não apenas direcionado. O Prof. Ubiraci me desafiava. E eu entendia que o desafio e a cobrança não eram punições. Ele me desafiava porque, muitas vezes, acreditava mais em mim do que eu mesmo. Sempre entendi o desafio como uma forma de tentar me levar além do ponto máximo que eu achava capaz de atingir, de me levar ao ponto além. Obrigado Prof. Ubiraci pelas suas orientações! Pois, você mostrou simplicidade, humildade e certamente amor ao próximo. Em novembro de 2008, surgiu um concurso em nível federal, além de me apoiar, o Prof. Ubiraci me orientou em todos os detalhes para garantir o meu sucesso. Em março de $2009 \mathrm{eu}$ assumia o cargo de professor assistente na Universidade Federal de Goiás. Com o mestre Ubiraci, meu sonho iniciado em 2003, o de ser um professor universitário, se concretizou.

Sempre estive consciente do respeito que esses três Mestres tiveram para comigo. Em retribuição, realizo um rito não apenas em sua honra, mas também em reverência a todos os mestres que já me ensinaram, que recomendo a todo 
discípulo: queimo incenso no altar budista e prometo a mim mesmo a sempre agir conforme os "Valores Fundamentais". Agora olho para trás, vejo que eu, minha esposa e filhos, nossas duas gerações, nos beneficiamos enormemente com os ensinamentos desses três Mestres. Onde encontrarei palavras para expressar minha gratidão?

\section{Aos membros da banca:}

Agradeço os Professores José Tadeu Balbo e Hermes Fajersztajn pela contribuição no momento da qualificação do doutorado e no desenvolvimento do texto final.

\section{Aos especialistas:}

Agradeço todos os especialistas que colaboraram direta ou indiretamente neste trabalho em especial: o Eng. Gino Ricci, Eng. Pedro Cesar Spina, Eng. Rodrigo Pires Leandro, Eng. Giulliano Renato Molinero, Eng. Januário Molinero Neto, Eng. Marcelo Loes Alcala, Dr. Carlos Alberto Felizola Freire, Dr. Osvaldo Luiz Valinote.

\section{Às instituições:}

Ao Departamento de Engenharia de Construção Civil da Escola Politécnica da USP. Às Capes, pelo apoio financeiro ao desenvolvimento deste trabalho.

\section{Em especial:}

Agradeço o amigo Rodrigo Gustavo Delalibera pelo apoio no desenvolvimento deste trabalho.

\section{Aos amigos de ontem, de hoje e de amanhã:}

Agradeço aos que percorreram o caminho antes de mim, aos que o percorreram ao meu lado e, como não poderia deixar de ser, aos que o hão de percorrer no futuro.

\section{À família:}

Pelo incentivo e apoio irrestrito, agradeço à Núbia, minha querida esposa, Virgílio e Benjamin, filhos maravilhosos. 
Não sabendo que era impossível, ele foi lá e fez!

(Jean Cocteau) 


\section{RESUMO}

Esta tese propõe um novo método para o prognóstico da produtividade na execução de rodovias com ênfase na terraplenagem e pavimentação asfáltica. O método foi desenvolvido com base no conhecimento dos principais manuais, estudando o assunto e acompanhando a execução de obras, além de ter recebido a contribuição de especialistas no assunto. Neste texto, inicialmente, descreve-se a metodologia de pesquisa. Em seguida os principais conceitos para a compreensão do tema são apresentados. Os principais manuais de orçamentação são estudados e uma nova forma de abordagem para os serviços de execução de rodovias é proposta. Em paralelo, dois estudos de caso foram desenvolvidos no período de 131 dias. Ao final, especialistas foram consultados e com sua contribuição o método foi finalizado. Este método tem a contribuição inovadora de propor composições (empregando métodos teóricos e experimentais) para as diferentes fases executivas de cada tipo de serviço e de apresentar os indicadores por meio de faixas de valores (que representam a produtividade variável) associadas a faixas de fatores orientadores para a tomada de decisão sobre qual valor adotar. Esta nova abordagem subsidia a tomada de diversas decisões: das relacionadas ao estudo de orçamentação até aquelas associadas à gestão da produção.

Palavras-chave: Construção de rodovias. Terraplenagem. Pavimentação asfáltica. Orçamento. Composição unitária. 


\begin{abstract}
This thesis proposes a new method to allow the forecast of the productivity in highways execution with emphasis on earthwork and asphalt paving. The method was developed based on the knowledge of the main estimating manuals, studying the issue and monitoring the execution of work "in situ", and received cooperation from experts on the subject. This text initially describes the research methodology. Afterward the main concepts for the comprehension of the subject are presented. The main estimating (budgeting) manuals are studied and a new approach to the execution services of highways is proposed. In parallel, two case studies were developed through 131 days of direct observation. In the end, experts are consulted and with their contribution the method is finished. This method has the innovative contribution of proposing compositions (using theoretical and empirical methods) for the different executive phases of each sort of service and displays the indicators through values ranges (which represent the variable productivity) associated with guiding factors ranges to alow the decision-making about which value to adopt. This new approach subsidizes the taking of several decisions: since those ones related to the study of budgeting until those associated with production management.
\end{abstract}

Keywords: Construction of highways. Earthworks. Asphalt paving. Budget. Unit Composition. 


\section{SUMÁRIO}

1. INTRODUÇÃO

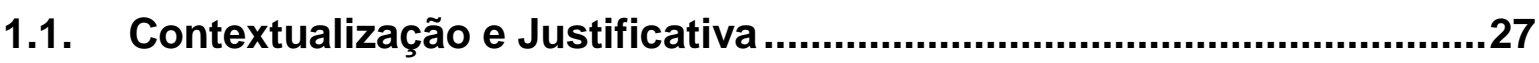

1.1.1. A infraestrutura como agente de desenvolvimento ............................27

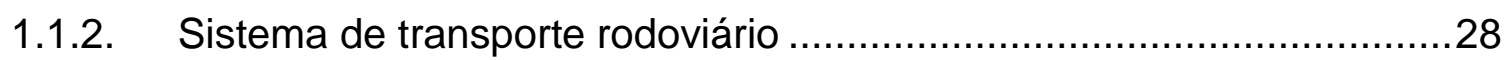

1.1.3. Fatores limitantes na concepção de pavimentação rodoviária ............29

1.1.4. Processos licitatórios e orçamentários de obras rodoviárias ................30

1.1.5. Representatividade da terraplenagem e da pavimentação a executar no processo de construção de rodovias.

1.1.6. Importância do estudo da produtividade nos serviços de terraplenagem

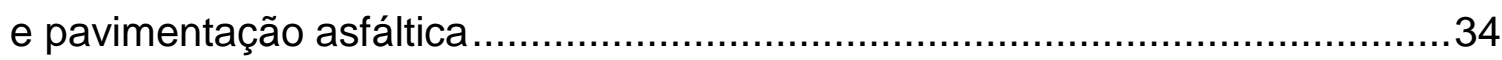

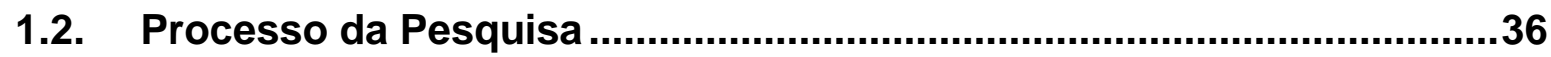

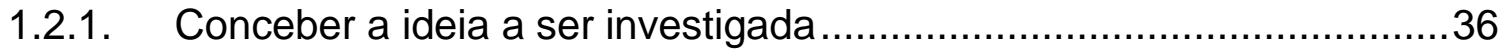

1.2.2. Formulação do problema de pesquisa: objetivos e questões do estudo..

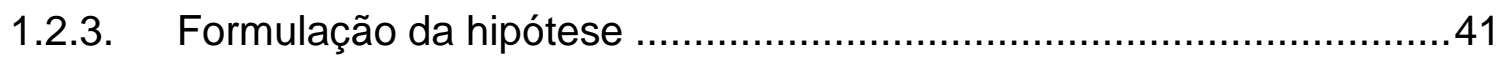

1.2.4. Classificação da pesquisa a ser realizada .........................................42

1.2.5. Método da pesquisa.................................................................. 42

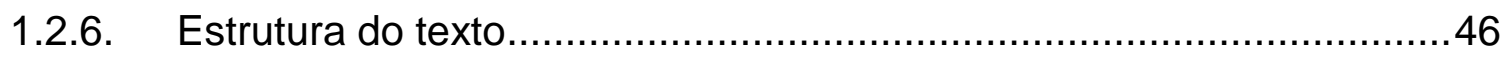

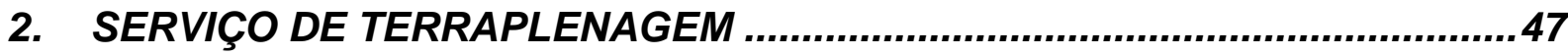

2.1. Terraplenagem - Entendimento Geral ..................................................47

2.2. Etapas de Serviços de Terraplenagem .................................................49

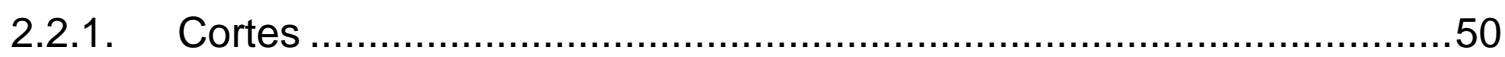

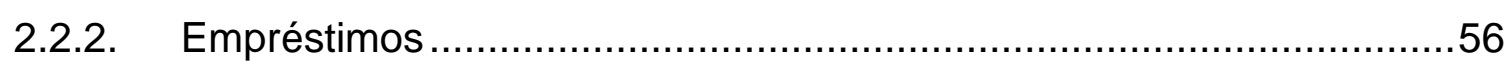

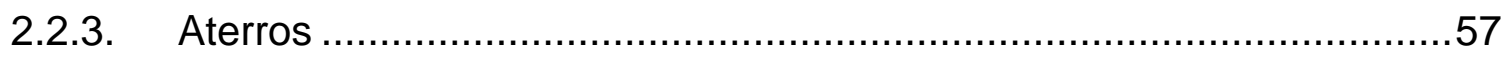

2.2.4. Depósito de materiais excedentes - DME ..........................................66

2.3. Composições Orçamentárias Aplicáveis à Terraplenagem .................67

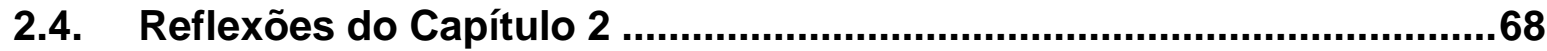

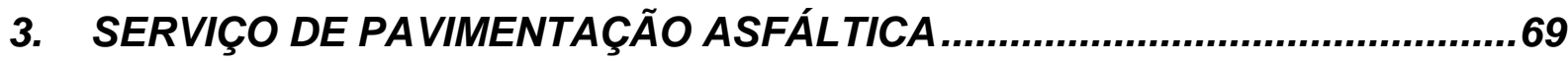

3.1. Pavimentação Asfáltica - Entendimento Geral .....................................69

3.2. Etapas de Serviços de Pavimentação Asfáltica ....................................70

3.2.1. Revestimento asfáltico ................................................................

3.2.2. Pinturas asfálticas e imprimações..................................................78 


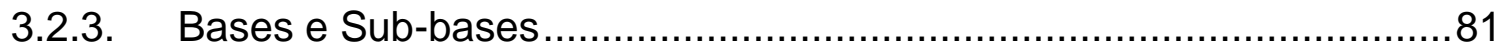

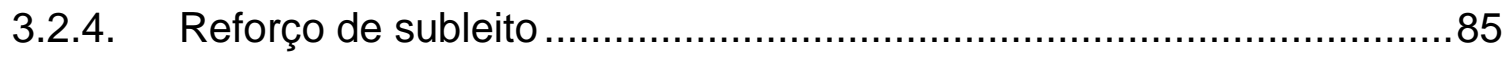

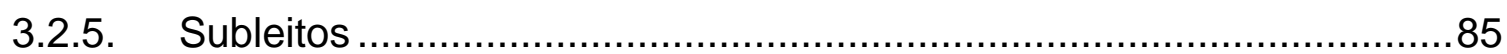

3.3. Composições Orçamentárias Aplicáveis à Pavimentação Asfáltica ....86

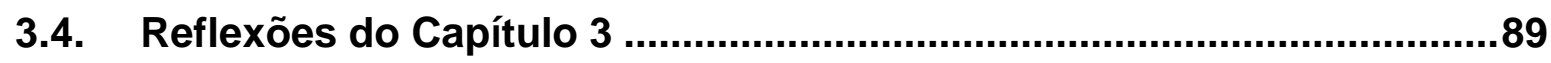

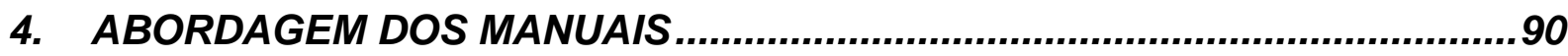

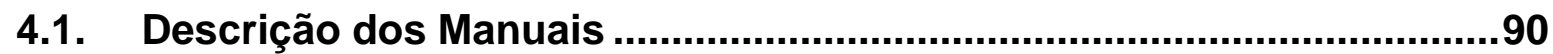

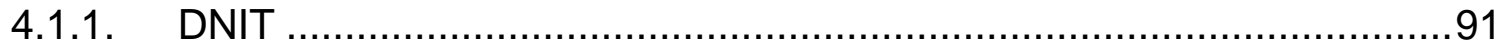

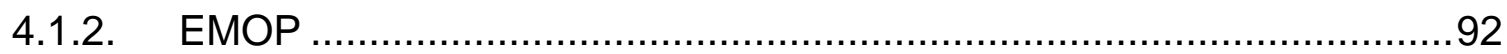

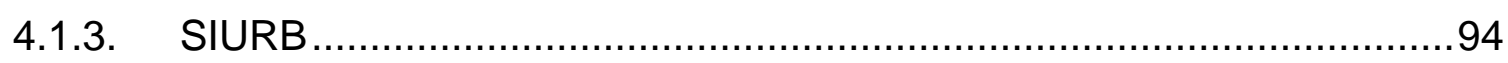

4.1.4. TCPO

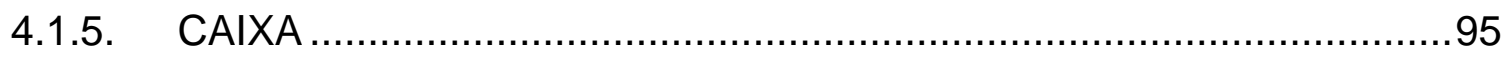

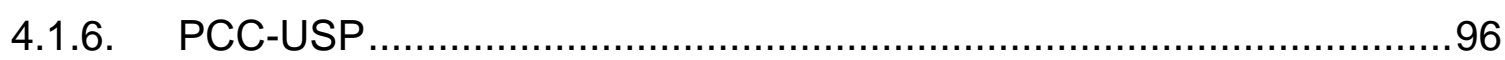

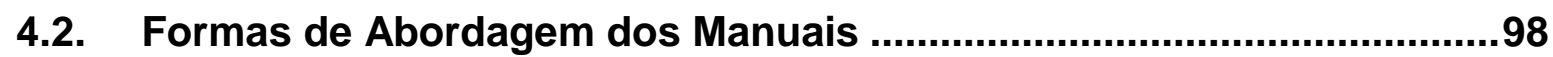

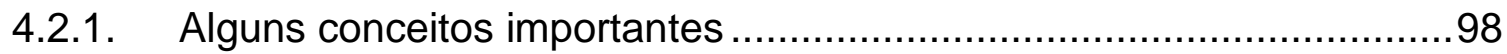

4.2.2. Montagem das composições de custos unitários..............................101

4.2.3. Ciclo dos equipamentos..........................................................102

4.2.4. Equilíbrio das equipes mecânicas ou patrulhas ................................103

4.2.5. Tempo operativo e tempo improdutivo ...........................................104

4.2.6. Resumo dos termos contidos nos manuais ....................................105

4.2.7. Custos de Implantação de uma Rodovia .........................................107

4.2.8. Custos unitários dos serviços ....................................................109

4.2.9. Custo horário de equipamentos ..................................................110

4.2.10. Produção das equipes mecânicas ..................................................111

4.2.11. Método teórico do DNIT ..........................................................112

4.2.12. Método teórico do TCPO ……………....................................116

4.2.13. Modelos de composições unitárias ...................................................118

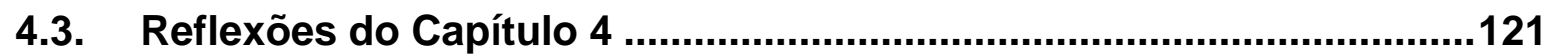

5. PROPOSTA DE ABORDAGEM PARA AS COMPOSIÇÕES .........................124

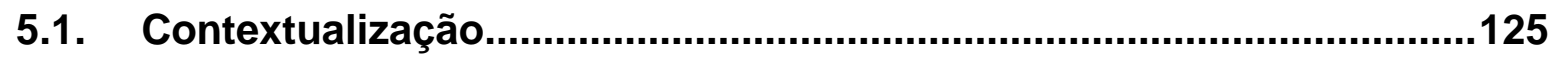

5.2. Produtividade da Mão de obra e dos Equipamentos .........................126

5.3. Razão Unitária de Produção ….......................................................126

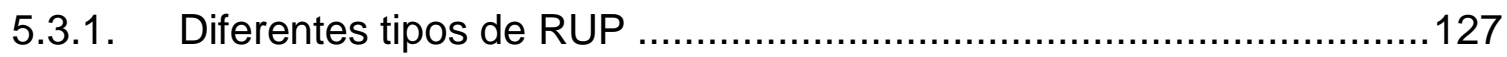

5.3.2. Mão de obra e equipamento contemplado......................................127 


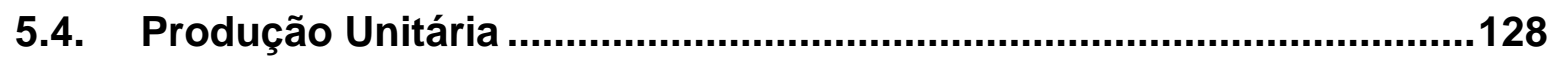

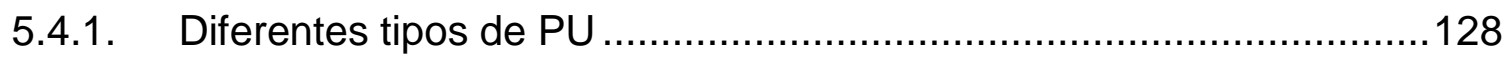

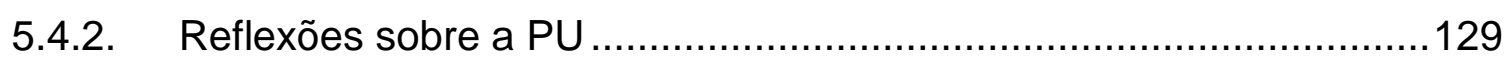

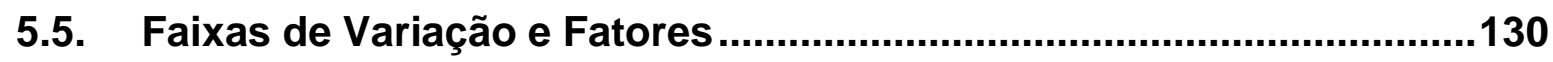

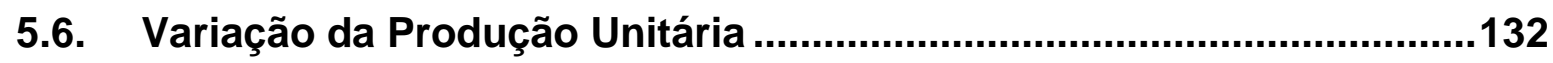

5.7. Detalhamento das Horas de Equipamentos ....................................133

5.8. Método das Observações Instantâneas............................................136

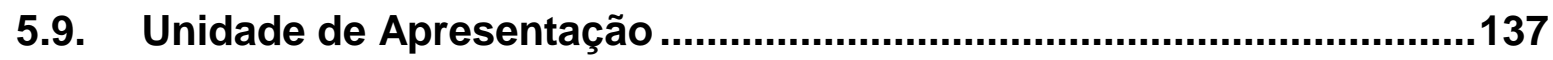

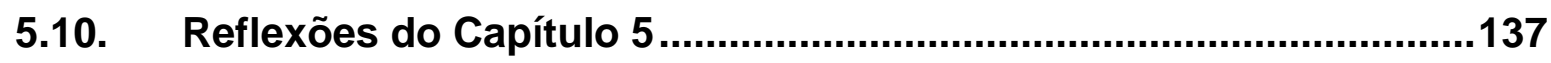

6. ESTUDOS DE CASO

6.1. Aeroporto Internacional de Guarulhos ............................................139

6.1.1. Método de coleta .................................................................141

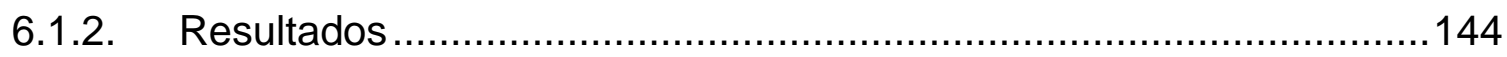

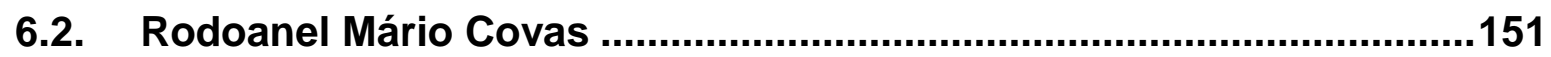

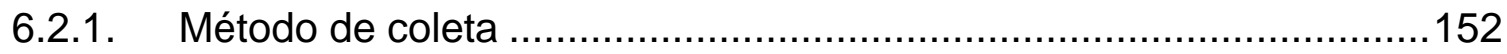

6.2.2. Processamento dos dados coletados ...........................................153

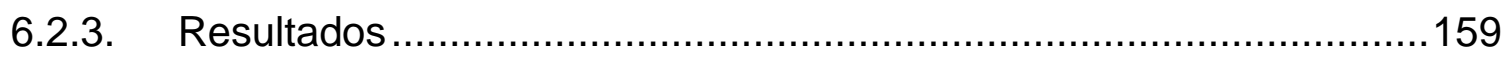

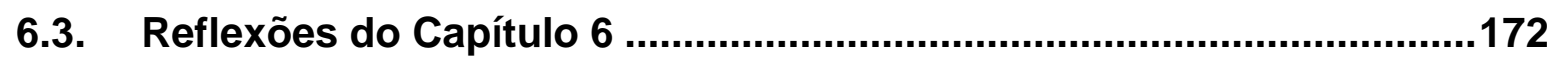

7. INDICADORES DOS MANUAIS CONFORME NOVA PROPOSTA DE

ABORDAGEM

7.1. Listagem de Tabelas Conforme o Manual .......................................175

7.2. Composições Orçamentárias Conforme Nova Proposta de Abordagem

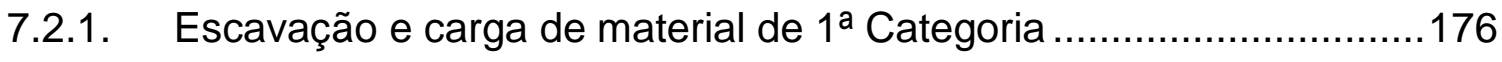

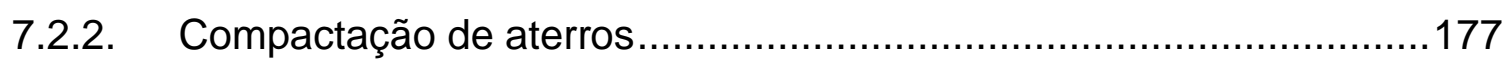

7.2.3. Base de brita graduada simples - BGS ........................................177

7.2.4. Base de brita graduada tratada com cimento - BGTC .....................178

7.2.5. Base de solo cimento e mistura na pista ........................................179

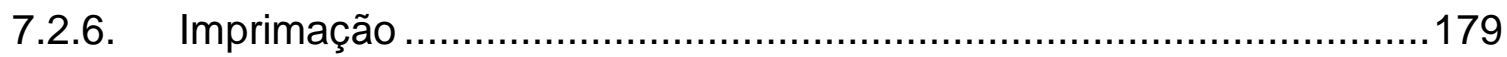

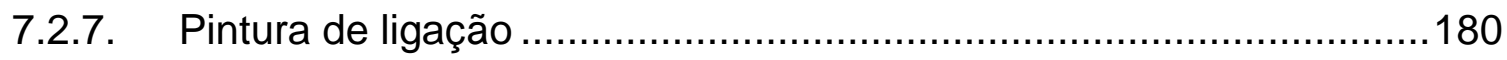

7.2.8. Concreto betuminoso usinado a quente - capa de rolamento .............180

7.2.9. Concreto betuminoso usinado a quente - binder ..............................181

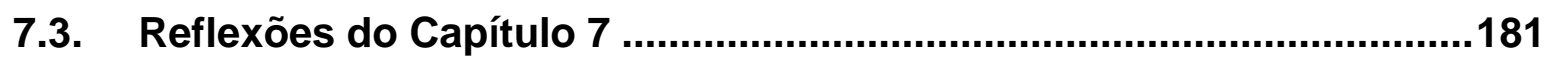


8. MANUAL DE APLICAÇÃO NAS ENTREVISTAS COM OS ESPECIALISTAS....

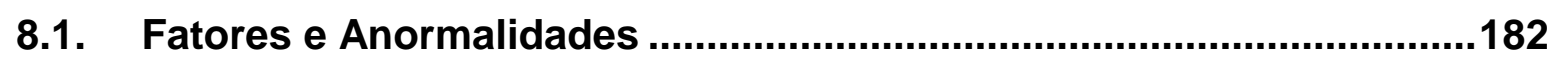

8.2. Etapas de Aplicação das Entrevistas ............................................183

8.3. Caracterização do Grupo de Especialistas Consultados ....................184

8.4. Lista dos Serviços Abrangidos nas Entrevistas ...............................185

8.5. Faixas de Valores, Anormalidades e Fatores segundo cada serviço. 186

8.5.1. Escavação e carga de material de $1^{\mathrm{a}}$ categoria.................................186

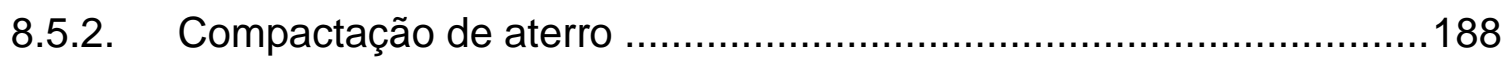

8.5.3. Base de solo cimento com mistura na pista....................................190

8.5.4. Brita graduada simples - BGS....................................................193

8.5.5. Brita graduada tratada com cimento - BGTC .................................. 198

8.5.6. Concreto betuminoso usinado a quente ….....................................201

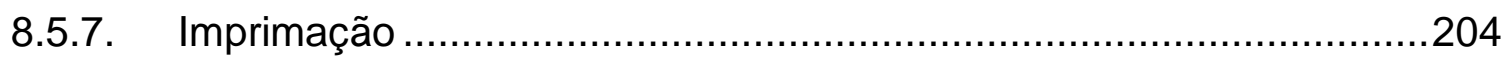

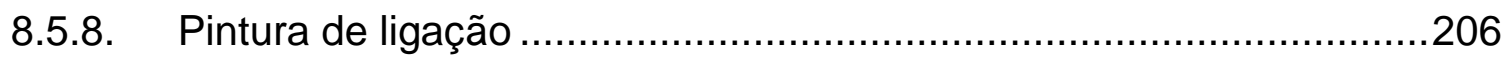

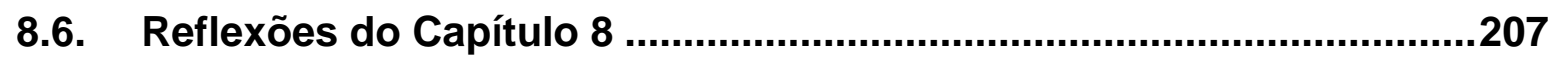

9. MÉTODO PARA PROGNÓSTICO DA PRODUTIVIDADE............................208

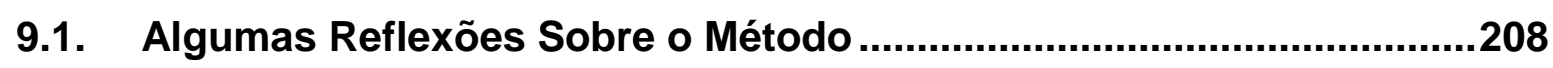

9.2. Abrangência do Método ….........................................................209

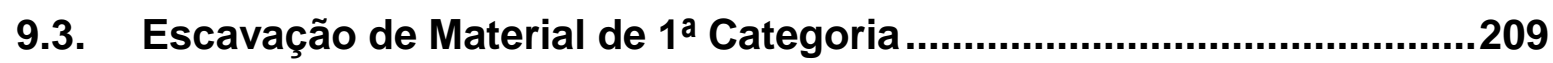

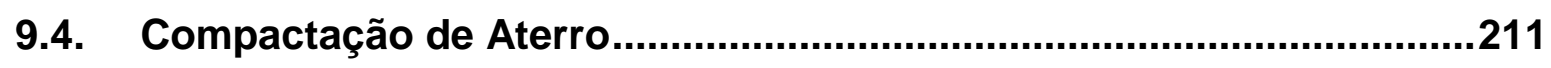

9.5. Base de Solo Cimento com Mistura na Pista ....................................214

9.6. Base de Brita Graduada Simples - BGS.........................................217

9.7. Base de Brita Graduada Tratada com Cimento - BGTC.....................221

9.8. Concreto Betuminoso Usinado a Quente CBUQ - Capa e Binder......223

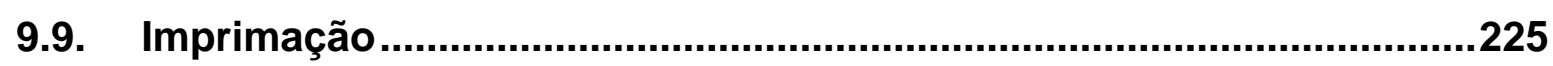

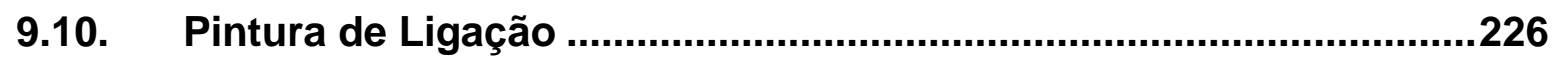

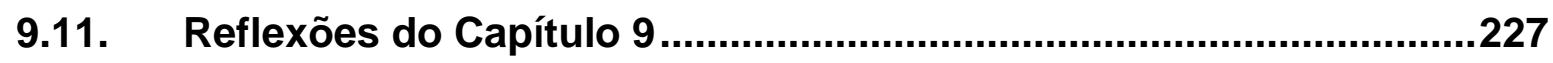

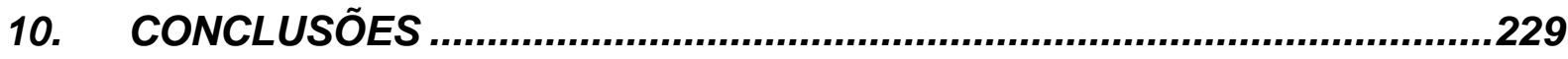

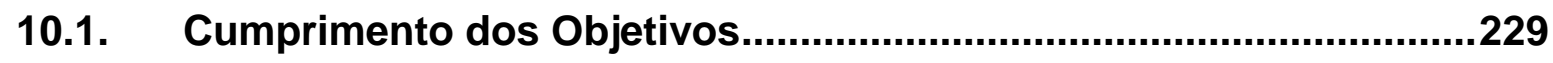

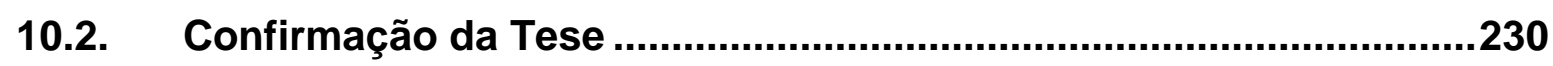

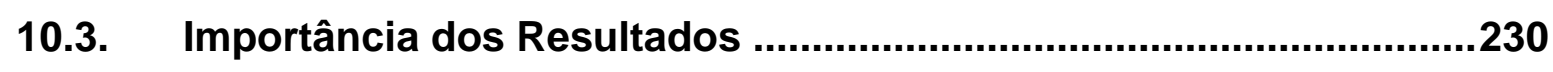

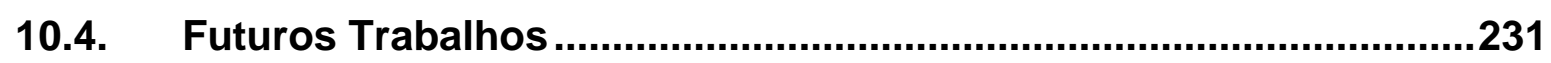

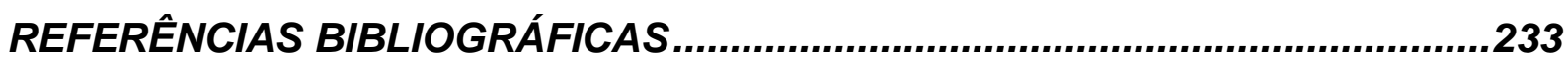


APÊNDICE A - EXEMPLO DE APLICAÇÃO DO MÉTODO TEÓRICO DO DNIT .242 APÊNDICE B - CONJUNTO DE DADOS DO AEROPORTO DE GUARULHOS...244 APÊNDICE C - MÉTODO DE COLETA DE DADOS DO RODOANEL ..................250

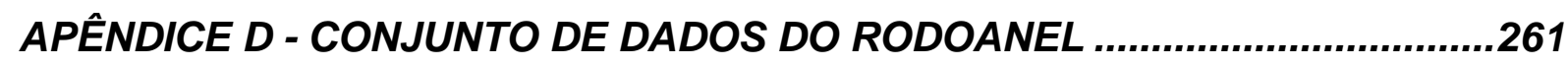

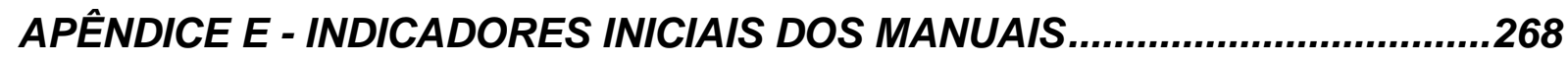
APÊNDICE F - PROCESSAMENTO DOS INDICADORES DOS MANUAIS.........279 APÊNDICE G - PROCESSAMENTO DOS INDICADORES INDICADOS PELOS ESPECIALISTAS. 


\section{LISTA DE FIGURAS}

Figura 1 - Exemplo de estrutura de um pavimento e os esforços atuantes 30

Figura 2 - Variação (\%) entre as produtividades para o serviço de CBUQ (quantidade de horas de equipamento para lançamento de uma tonelada de material)

Figura 3 - Variação (\%) entre as produtividades para o serviço de escavação (quantidade de horas de equipamento para escavar um metro cúbico de solo) 35

Figura 4 - Esquema do processo de pesquisa 36

Figura 5 - Fluxograma do método da pesquisa

Figura 6 - Plataforma abaixo do terreno natural

Figura 7 - Plataforma acima do terreno natural 48

Figura 8 - Plataforma mista 48

Figura 9 - Faixa de ocupação.

Figura 10 - Área de transição de aterro para corte.

Figura 11 - a) trator de esteira com lâmina frontal; b) trator de esteira com lâmina frontal e escarificador traseiro; c) moto-scraper; d) pá carregadeira sobre esteiras; e) pá carregadeira sobre pneus; f) escavadeira hidráulica; g) retroescavadeira. Figura 12 - a) espalhamento com motoniveladora; b) aeração do solo com grade de disco; c) tratamento da umidade com caminhão tanque; d) compactação de solo com rolo pé de carneiro; e) caminhão distribuidor de cimento; f) recicladora (mistura o solo com o cimento); g) rolo liso metálico para compactação de pavimento; h) rolo de pneus para compactação de pavimento.

Figura 13 - Quebra do serviço de escavação e carga de material de 1ª categoria ..67

Figura 14 - Quebra do serviço de compactação de aterro 67

Figura 15 - Exemplo de estrutura de pavimento asfáltico. 70

Figura 16 - Exemplo de padrão de rolagem para compactação de mistura asfáltica76 Figura 17 - a) vibroacabadora; b) rolo tandem liso; c) rolo de pneus; d) rolo vibratório

Figura 18 - Caminhão espargidor.

Figura 19 - Classificação das bases e sub-bases flexíveis e semi-rígidas 81

Figura 20 - Quebra do serviço de execução de revestimentos asfálticos 86

Figura 21 - Quebra do serviço de execução de pinturas asfálticas e imprimações impermeabilizantes

Figura 22 - Quebra do serviço de execução de BGS e BGTC 
Figura 23 - Quebra do serviço de execução de solo cimento. .88

Figura 24 - Elementos de uma composição unitária...........................................102

Figura 25 - Estimativa do tempo de ciclo da escavadeira hidráulica ......................103

Figura 26 - Equipamento eleito como principal................................................. 103

Figura 27 - Interação entre os componentes do custo total de uma rodovia ...........108 Figura 28 - Sistematização da metodologia de composição de custo unitário de um

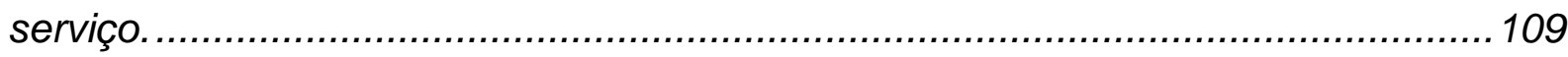

Figura 29 - Modelo de composição unitária - TCPO.......................................117

Figura 30 - Modelo de nota explicativa que acompanha a composição unitária ....118

Figura 31 - Modelo de composição unitária - SICRO 2 .....................................119

Figura 32 - Modelo de composição unitária - EMOP .......................................... 120

Figura 33 - Modelo de composição unitária - SIURB.........................................120

Figura 34 - Modelo de composição unitária - CAIXA ........................................ 121

Figura 35 - Modelo de composição unitária - POLI-USP .................................... 121

Figura 36 - Definição da produtividade ......................................................126

Figura 37 - Modelo dos Fatores para a Produtividade na Construção ..................... 129

Figura 38 - Faixa de variação da produção unitária: compactação de aterro $\left(\mathrm{m}^{2} / \mathrm{h}\right)$

Figura 39 - Classificação dos fatores influenciadores da produção unitária ...........131

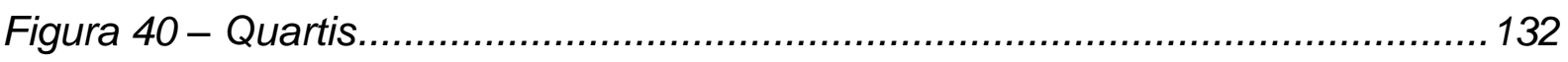

Figura 41 - Produtividade variável: serviço de compactação de aterro ..................133

Figura 42 - Classificação das horas de equipamento para fins de estudo do seu

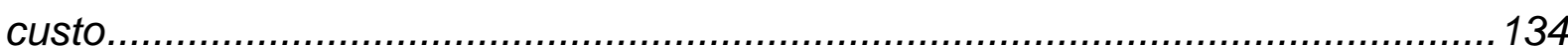

Figura 43 - Diferentes momentos no serviço de compactação de CBUQ ..............135

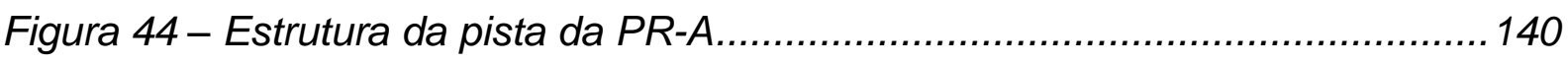

Figura 45 - Estrutura do pavimento do sistema viário ........................................ 140

Figura 46 - Fluxograma geral do método .................................................... 141

Figura 47- Traçado do Rodoanel (a marca dentro do retângulo é referente ao lote 2)

Figura 48 - Detalhe do Trecho Sul - Lote 2 (Trevo da Anchieta e Eixo) ................ 151

Figura 49 - Compilação dos dados conforme nova abordagem ...........................152

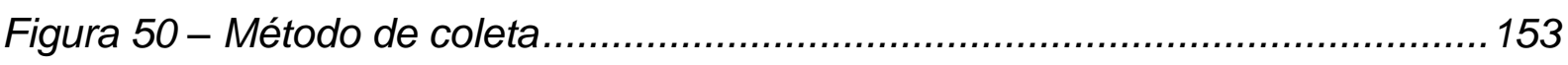

Figura 51 - Metodologia para o processamento dos dados coletados ................... 153

Figura 52 - Compilação dos manuais conforme nova abordagem ........................174 
Figura 53 - Sistema de compilação: produtividade variável, fatores e anormalidades 182

Figura 54 - Etapas para o desenvolvimento do método. 208

Figura 55 - Tempos de ciclo (min) e produção horária do caminhão basculante de $14 m^{3}$ no transporte de material de $1^{a}$ categoria em rodovia em leito natural - carga com escavadeira 243

Figura 56 - Exemplo de composição do serviço de escavação ..............................243

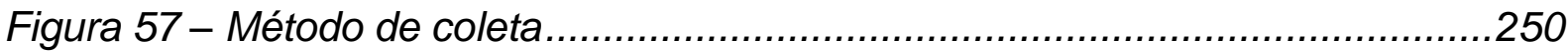

Figura 58 - Quebra do serviço: camada final de terraplenagem...........................251

Figura 59 - Modelo de esquema de produção das atividades em execução -

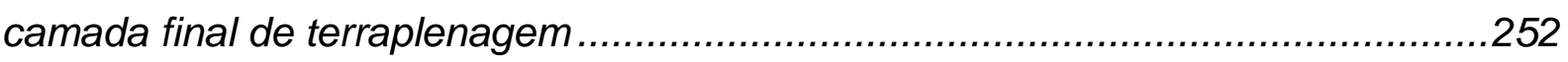

Figura 60 - Metodologia para o registro dos dados coletados............................255

Figura 61 - Registro simplificado do dia em que termina a subtarefa....................256

Figura 62 - Registro diário dos equipamentos disponíveis (1 = quantidade de

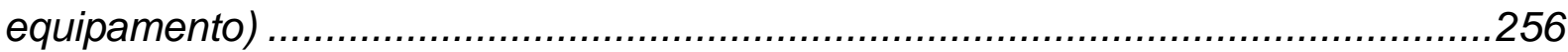

Figura 63 - Registro detalhado do dia em que termina a subtarefa......................257

Figura 64 - Apresentação das camadas finais de terraplenagem e a data final de conclusão de suas atividades: Corte 204 - Pista externa 259

Figura 65 - Detalhamento das atividades ocorridas, conforme execução de camada final de terraplenagem: no Corte 204 - Pista externa 260 


\section{LISTA DE TABELAS}

Tabela 1- Resumo das porcentagens/componentes conforme custos unitários ......32 Tabela 2- Participação dos componentes da pavimentação em relação à construção de rodovias. .33

Tabela 3- Resumo da classificação de pesquisa desenvolvida nesta tese 42

Tabela 4 - Apresentação da estrutura dos capítulos 46

Tabela 5 - Definição de cortes pelo DNER. .50

Tabela 6 - Categorias dos materiais escavados. .51

Tabela 7 - Condicionantes para escolha de processos de escavação .52

Tabela 8 - Controles aplicáveis a serviços de escavação . .54

Tabela 9 - Tipos de máquinas para escavação de solos. .55

Tabela 10 - Formações de patrulhas para escavação. .56

Tabela 11 - Condicionantes e implicações para a compactação. .58

Tabela 12 - Controles aplicáveis ao processo de aterro. .63

Tabela 13 - Tipos de equipamentos de compactação. .64

Tabela 14 - Formação de patrulha para compactação .66

Tabela 15 - Exemplos de aplicações dos materiais em camadas de pavimentos. ...70

Tabela 16 - Fatores que afetam a compactação de misturas asfálticas.................... 73

Tabela 17 - Fatores que afetam o tempo de rolagem........................................ 74

Tabela 18 - Formação de patrulha para execução de revestimento asfáltico ...........78

Tabela 19 - Tipos e aplicações das emulsões asfálticas (exemplos). ...................... 79

Tabela 20 - Tipos e aplicações dos asfaltos diluídos (exemplos)........................... 79

Tabela 21 - Taxas de aplicação (exemplos)................................................... 79

Tabela 22 - Formações de patrulhas para execução de pinturas asfálticas e imprimações. .80

Tabela 23 - Formações de patrulhas para execução de brita graduada simples $\left(m^{3}\right)$

Tabela 24 - Formações de patrulhas para execução de solo cimento, mistura na pista $\left(m^{3}\right)$ .85

Tabela 25 - Composições de preços unitários disponibilizadas pela CAIXA .............96

Tabela 26 - Classificação das composições segundo os grupos. ...........................97

Tabela 27 - Condições de trabalho para escavação e carga ................................. 100

Tabela 28 - Termos e formas abordadas pelos manuais estudados......................106

Tabela 29 - Custo horário de equipamentos ..................................................111 
Tabela 30 - Fator de conversão: relação entre o volume do corte e o volume do material solto

Tabela 31 - Relação entre a capacidade efetiva do equipamento e sua capacidade nominal.

Tabela 32 - Cálculo de produção de equipe mecânica.

Tabela 33 - Modelo de apresentação das horas em serviço $\left(H_{\text {serv }}\right)$ e horas em funcionamento ( $H_{\text {funcionamento }}$ ).

Tabela 34 - Modelo de planilha de medição

Tabela 35 - Escavação de material de $1^{a}$ categoria $\left(m^{3}\right)$.

Tabela 36 - Escavação de material de $1^{a}$ categoria. Registro de horas, quantidades e processamento das PU's. Etapa: escavação e carga - patrulha $\left(\mathrm{m}^{3}\right)$. 148

Tabela 37 - Escavação de material de $1^{\underline{a}}$ categoria. Registro de horas, quantidades e processamento das PU's. Etapa: escavação e carga - mão de obra $\left(m^{3}\right)$. 148

Tabela 38 - Exemplo de composição 149

Tabela 39 - Produtividades variáveis para os diversos serviços ..... 150

Tabela 40 - Exemplo de diário de obras: camada final de terraplenagem. 155

Tabela 41 - Exemplo de registro dos cálculos e das ponderações. 156

Tabela 42 - Exemplo de síntese das anormalidade e dos fatores: CFT .................158

Tabela 43 - Exemplo de composição 159

Tabela 44 - Faixa de valores de escavação e carga de material de 1a categoria com escavadeira hidráulica. 160

Tabela 45 - Anormalidades e fatores encontrados na produção de escavação e carga de material de $1^{a}$ categoria (continua). 160

Tabela 46 - Faixa de valores de compactação de aterro - esp. até $30 \mathrm{~cm}$ 161 Tabela 47 - Anormalidades e fatores encontrados na produção de compactação de aterros (continua) 161

Tabela 48 - Faixa de valores de CFT - esp. até $20 \mathrm{~cm}$. 163

Tabela 49 - Anormalidades e fatores encontrados na produção de CFT (continua) 163

Tabela 50 - Faixa de valores de BGS - esp. até $20 \mathrm{~cm}$ 164

Tabela 51 - Anormalidades e fatores encontrados na produção de BGS (continua) 165

Tabela 52 - Faixa de valores de BGTC - esp. até $20 \mathrm{~cm}$. 166 
Tabela 53 - Anormalidades e fatores encontrados na produção de BGTC (continua)

Tabela 54 - Faixa de valores de binder - esp. até $5 \mathrm{~cm}$ 168

Tabela 55 - Anormalidades e fatores encontrados na produção de binder (continua) 169

Tabela 56 - Faixas de valores de imprimação e pintura de ligação. 171

Tabela 57 - Anormalidades e fatores encontrados na produção de imprimação e pintura de ligação

Tabela 58 - Escavação e carga de material de $1^{\underline{a}}$ categoria: com trator de esteiras (resumo dos manuais)

Tabela 59 - Escavação e carga de material de $1^{\underline{a}}$ categoria: com escavadeira

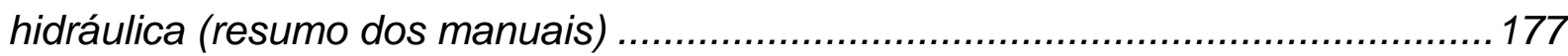

Tabela 60 - Compactação de aterros - esp. até $30 \mathrm{~cm}$ (resumo dos manuais) .....177 Tabela 61 - Base de brita graduada, com distribuidor de agregados - esp. até $20 \mathrm{~cm}$ (resumo dos manuais).

Tabela 62 - Base de brita graduada, com vibroacabadora - esp. até $20 \mathrm{~cm}$ (resumo dos manuais)

Tabela 63 - Base de brita graduada tratada com cimento, com distribuidor de agregados - esp. até $20 \mathrm{~cm}$ (resumo dos manuais) 178

Tabela 64 - Base de brita graduada tratada com cimento, com vibroacabadora esp. até $20 \mathrm{~cm}$ (resumo dos manuais)

Tabela 65 - Base de solo cimento e mistura na pista - esp. até $20 \mathrm{~cm}$ (resumo dos manuais).....

Tabela 66 - Imprimação (resumo dos manuais) ...............................................180

Tabela 67 - Pintura de ligação (resumo dos manuais) ........................................ 180

Tabela 68 - Concreto betuminoso usinado a quente (capa de rolamento) - esp. até 5 $\mathrm{cm}$ (resumo dos manuais). 180

Tabela 69 - Concreto betuminoso usinado a quente (binder) - esp. até $5 \mathrm{~cm}$ (resumo dos manuais)

Tabela 70 - Escavação e carga de material de $1^{\underline{a}}$ categoria com trator de esteiras $\left(m^{3} / h\right)$ 186

Tabela 71 - Escavação e carga de material de 1aㅡ categoria com escavadeira hidráulica $\left(m^{3} / h\right)$... 
Tabela 72 - Síntese dos fatores e das anormalidades: escavação e carga de

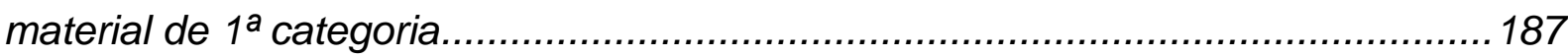

Tabela 73 - Compactação de aterro - esp. até $30 \mathrm{~cm}\left(\mathrm{~m}^{2}\right)$................................... 188

Tabela 74 - Síntese dos fatores e das anormalidades: Compactação de Aterro

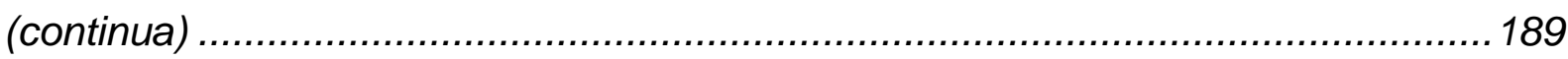

Tabela 75 - Base de solo cimento com mistura na pista - esp. até $20 \mathrm{~cm}\left(\mathrm{~m}^{2}\right)$ (continua)

Tabela 76 - Síntese dos fatores e das anormalidades: Base de solo cimento com mistura na pista (continua)

Tabela 77 - Brita graduada simples - BGS com distribuidor de agregados - esp. até $20 \mathrm{~cm}\left(\mathrm{~m}^{2}\right)$ (continua)

Tabela 78 - Brita graduada simples - BGS com vibroacabadora - esp. até $20 \mathrm{~cm}\left(\mathrm{~m}^{2}\right)$ (continua)

Tabela 79 - Síntese dos fatores e das anormalidades: Brita Graduada Simples BGS (continua).

Tabela 80 - Brita graduada tratada com cimento - BGTC - esp. até $20 \mathrm{~cm}\left(\mathrm{~m}^{2}\right)$ (continua)

Tabela 81 - Síntese dos fatores e das anormalidades: Brita graduada tratada com cimento - BGTC (continua) 199

Tabela 82 - Concreto betuminoso usinado a quente - capa ou binder - esp. até $5 \mathrm{~cm}$ $\left(m^{2}\right)$ (continua) 201

Tabela 83 - Síntese dos fatores e das anormalidades: CBUQ (continua). 203

Tabela 84 - Imprimação $\left(m^{2}\right)$ 204

Tabela 85 - Síntese dos fatores e das anormalidades: Imprimação. 205

Tabela 86 - Pintura de ligação $\left(\mathrm{m}^{2}\right)$.... 206

Tabela 87 - Síntese dos fatores e das anormalidades: Pintura de ligação (continua)

Tabela 88 - Escavação e carga de material de $1^{a}$ categoria, com trator de esteiras

Tabela 89 - Escavação e carga de material de $1^{a}$ categoria, com escavadeira hidráulica.....

Tabela 90 - Fatores e anormalidades: escavação e carga de material de $1^{a}$ categoria 
Tabela 92 - Fatores e anormalidades: compactação de aterro

Tabela 93 - Base de solo cimento com mistura na pista - esp. até $20 \mathrm{~cm}$.

Tabela 94 - Fatores e anormalidades: base de solo cimento com mistura na pista216 Tabela 95 - Base de brita graduada simples - BGS com distribuidor de agregados esp. até $20 \mathrm{~cm}$

Tabela 96 - Base de brita graduada simples - BGS com vibroacabadora - esp. até 20 $\mathrm{cm}$

Tabela 97 - Fatores e anormalidades: brita graduada simples.

Tabela 98 - Base de brita graduada tratada com cimento - BGTC - esp. até $20 \mathrm{~cm}$

Tabela 99 - Fatores e anormalidades: brita graduada tratada com cimento 222

Tabela 100 - Concreto betuminoso usinado a quente - capa ou binder - esp. até 5 $\mathrm{cm}$

Tabela 101 - Fatores e anormalidades: concreto betuminoso usinado a quente capa ou binder

Tabela 102 - Imprimação 225

Tabela 103 - Fatores e anormalidades: imprimação ........................................226

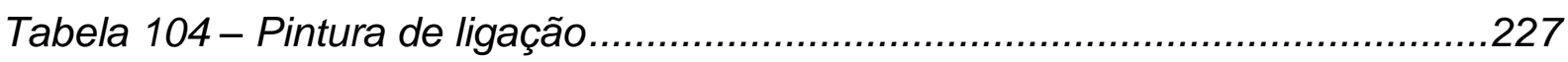

Tabela 105 - Fatores e anormalidades: pintura de ligação..................................227

Tabela 106 - Exemplo de aplicação da planilha de composição ...........................242

Tabela 107 - Escavação de material de 1aㅡ categoria. Etapa: escavação e carga $\left(\mathrm{m}^{3}\right)$

- Guarulhos.

Tabela 108 - Escavação de material de $1^{a}$ categoria - mão de obra $\left(m^{3}\right)$ -

Guarulhos. 244

Tabela 109 - Compactação de aterro $\left(m^{3}\right)$ - Guarulhos

Tabela 110 - Brita graduada tratada com cimento - BGTC $\left(\mathrm{m}^{3}\right)$ : acabadora -

Guarulhos

Tabela 111 -Brita graduada tratada com cimento - BGTC - mão de obra $\left(m^{3}\right)$ -

Guarulhos.

Tabela 112 - Brita graduada tratada com cimento - BGTC $\left(\mathrm{m}^{3}\right)$ : rolo compactador Guarulhos.

Tabela 113 - Brita graduada tratada com cimento - BGTC $\left(\mathrm{m}^{3}\right)$ : rolo de pneus Guarulhos. 
Tabela 114 - Concreto betuminoso usinado a quente - CBUQ. Etapa: lançamento e acabamento $\left(\mathrm{m}^{3}\right)$ - Guarulhos

Tabela 115 - Concreto betuminoso usinado a quente - CBUQ. Mão de obra $\left(m^{3}\right)$ Guarulhos (continua)

Tabela 116 - Concreto betuminoso usinado a quente - CBUQ. Rolo compactador $\left(m^{3}\right)$ - Guarulhos 248

Tabela 117 - Concreto betuminoso usinado a quente - CBUQ. Rolo pneus $\left(m^{3}\right)-$ Guarulhos (continua)..... 248

Tabela 118 - Imprimação $\left(m^{2}\right)$ - Guarulhos

Tabela 119 - Pintura de ligação $\left(m^{2}\right)$ - Guarulhos 249

Tabela 120 - Modelo de planilha de acompanhamento das atividades de cada equipamento. 254

Tabela 121 - Planilha modelo e exemplo de aplicação do Método das Observações Instantâneas"......

Tabela 122 - Registro detalhado de horas em funcionamento (originado do Método das Observações Instantâneas)...

Tabela 123 - Medição do ciclo dos equipamentos na execução de camada final de terraplenagem. 258

Tabela 124 - Camada final de terraplenagem: Ramo 204 (mão de obra) 258

Tabela 125 - Escavação e carga de material de $1^{\underline{a}}$ categoria - resumo 262

Tabela 126 - Compactação de aterros - resumo (continua) 262

Tabela 127 - Camada final de terraplenagem - Ramo 204 - resumo. 263

Tabela 128 - Camada final de terraplenagem - outros ramos - resumo 263

Tabela 129 - Camada final de terraplenagem "observações instantâneas" 264

Tabela 130 - BGS e BGTC "observações instantâneas" 264

Tabela 131 - Brita graduada simples BGS - resumo 265

Tabela 132 - Ramo AP-I e EIXO (BGTC). 265

Tabela 133 - Binder: "observações instantâneas" 265

Tabela 134 - Binder - resumo 266

Tabela 135 - Imprimação (resumo) 267

Tabela 136 - Imprimação "observações instantâneas"........................................267

Tabela 137 - Escavação e carga material de $1^{\text {a }}$ categoria $\left(\mathrm{m}^{3} / \mathrm{h}\right)$...... 269

Tabela 138 - Compactação de aterros, em camadas de $20 \mathrm{~cm}$, GC: de $90 \%$ a 95\% $\left(m^{3} / h\right)$ 
Tabela 139 - Compactação de aterros, em camadas de $20 \mathrm{~cm}$, GC: $100 \%\left(\mathrm{~m}^{3} / \mathrm{h}\right) 271$ Tabela 140 - Construção de reforço de subleito $\left(\mathrm{m}^{3} / \mathrm{h}\right)$........................................271

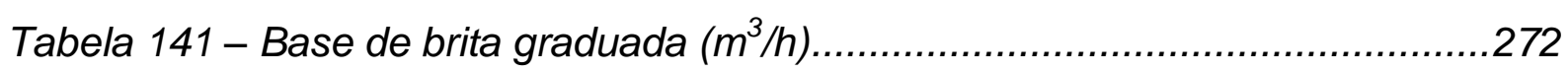

Tabela 142 - Base de brita graduada com distribuidor de agregados com controle de

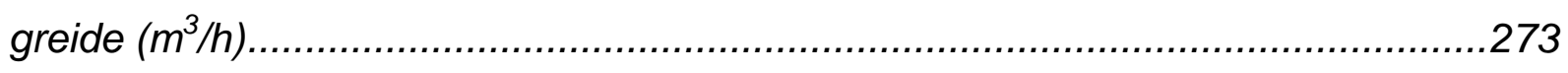

Tabela 143 - Base de brita graduada tratada com cimento $\left(\mathrm{m}^{3} / \mathrm{h}\right)$........................273

Tabela 144 - Base de solo cimento com 3\% de cimento e mistura na pista $\left(\mathrm{m}^{3} / \mathrm{h}\right) 274$

Tabela 145 - Base de solo cimento com 4\% de cimento e mistura na pista $\left(\mathrm{m}^{3} / \mathrm{h}\right) 275$

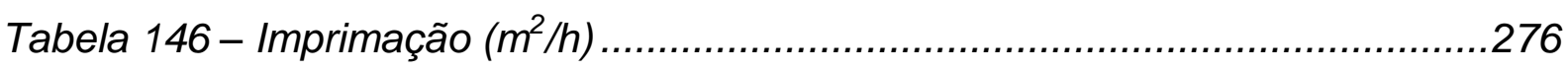

Tabela 147 - Pintura de ligação $\left(m^{2} / h\right)$......................................................2. 276

Tabela 148 - Concreto betuminoso usinado a quente - capa de rolamento (t/h) ....277

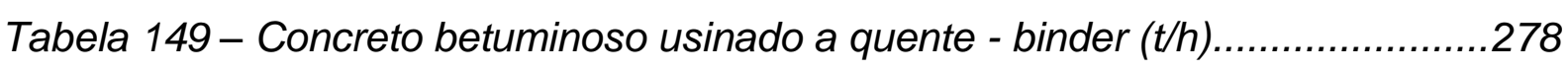

Tabela 150 - Resumo do processamento dos indicadores dos manuais (continua)

Tabela 151 - Escavação e carga de material de $1^{\text {ạ }}$ categoria com trator de esteiras (especialistas)

Tabela 152 - Escavação e carga de material de $1^{\text {ạ }}$ categoria com escavadeira hidráulica (especialistas) ............................................................................... 283

Tabela 153 - Compactação de aterro - esp. até $30 \mathrm{~cm}$ (especialistas)....................284

Tabela 154 - Base de solo cimento com mistura na pista - esp. até $20 \mathrm{~cm}$ (especialistas) ......

Tabela 155 - Brita graduada simples - BGS com distribuidor de agregados - esp. até $20 \mathrm{~cm}$ (especialistas).

Tabela 156 - Brita graduada simples - BGS com vibroacabadora - esp. até $20 \mathrm{~cm}$ (especialistas) 289

Tabela 157 - Brita graduada tratada com cimento - BGTC - esp. até $20 \mathrm{~cm}$ (especialistas)

Tabela 158 - Concreto betuminoso usinado a quente - capa ou binder - esp. até $5 \mathrm{~cm}$ (especialistas) 291

Tabela 159 - Imprimação (especialistas) 294

Tabela 160 - Pintura de ligação (especialistas) 295

Tabela 161 - Síntese dos fatores e das anormalidades: escavação e carga de material de $1^{\text {a }}$ categoria

Tabela 162 - Síntese dos fatores e das anormalidades: compactação de aterro ...297 
Tabela 163 - Síntese dos fatores e das anormalidades: base de solo cimento com

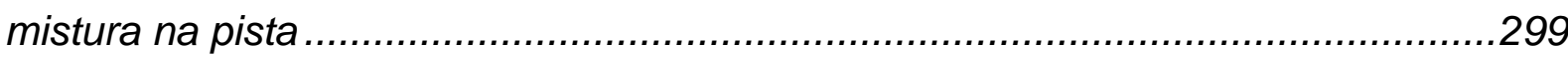

Tabela 164 - Síntese dos fatores e das anormalidades: brita graduada simples $B G S$. 301

Tabela 165 - Síntese dos fatores e das anormalidades: brita graduada tratada com cimento - BGTC 303

Tabela 166 - Síntese dos fatores e das anormalidades: CBUQ 305

Tabela 167 - Síntese dos fatores e das anormalidades: imprimação. 307

Tabela 168 - Síntese dos fatores e das anormalidades: pintura de ligação 308 


\section{INTRODUÇÃO}

Este trabalho se insere no contexto de pesquisa do Grupo de Tecnologia e Gestão da Produção na Construção Civil (TGP), do Departamento de Engenharia de Construção Civil e Urbana, da Escola Politécnica de São Paulo, especificamente na linha de gestão com base em indicadores (coordenado pelo Professor Doutor Ubiraci Espinelli Lemes de Souza).

A partir dos avanços promovidos por pesquisas anteriores quanto à gestão com base em indicadores, este trabalho agrega valor na linha de pesquisa à qual pertence, na medida em que propõe a utilização de indicadores de produtividade na execução de rodovias: terraplenagem e pavimentação asfáltica, temática pouco explorada nas teses e dissertações precedentes.

\subsection{Contextualização e Justificativa}

\subsubsection{A infraestrutura como agente de desenvolvimento}

Historicamente, a construção de infraestrutura, como por exemplo rodovias, em vastas extensões de terra tem sido apontada como um ato heroico de desenvolvimento (MEYBOOM, 2009).

Estudos na área de crescimento econômico indicam que o desenvolvimento da infraestrutura é essencial na determinação do nível de renda "per capita" de um país. De fato, um acréscimo de $10 \%$ na disponibilidade de rodovias pavimentadas por habitante de um país eleva em 1,1\% o nível de $\mathrm{PIB}^{1}$ "per capita", com efeito direto sobre o desenvolvimento humano dado pela melhoria das condições materiais de vida. Isso se deve essencialmente ao aumento da produtividade que se observa quando as empresas e trabalhadores têm à sua disposição uma malha rodoviária maior e melhor (CONSTRUÇÃO, 2006).

Prover a infraestrutura representa grandes investimentos públicos e um planejamento de longo prazo. É imprescindível que a funcionalidade esteja em sintonia com a vida útil do empreendimento. Seu uso se estende por várias gerações durante as quais a sociedade passará por mudanças dramáticas. Esse longo intervalo de tempo significa que o desenvolvimento no transporte de pessoas e

\footnotetext{
${ }^{1}$ PIB: Produto Interno Bruto
} 
mercadorias deve ser avaliado e planejado com bastante antecedência a fim de fazer as escolhas certas, não só para hoje, mas também para amanhã (FEHRL, 2008).

Atento a essa realidade e ciente da importância social e carências do setor, entre 2007 e 2010 diversas obras foram concluídas no Brasil: 1.306 quilômetros de estradas foram duplicados, 1.789 quilômetros foram pavimentados e 3.282 quilômetros foram concedidos para empresas privadas, que administram 15 mil quilômetros - menos de $1 \%$ da malha pavimentada. Há obras de duplicação em 1.592 quilômetros e de pavimentação em 3.524 quilômetros em execução, além de serviços de sinalização e de manutenção contratados para mais de 50 mil quilômetros da malha. Para o setor privado, há potencial imediato para a concessão de, no mínimo, mais 12 mil quilômetros (ABDIB, 2011).

\subsubsection{Sistema de transporte rodoviário}

Um eficiente sistema de transportes rodoviários é visto em vários países como prérequisito para o desenvolvimento da economia. $O$ transporte rodoviário é considerado a chave para o processo de desenvolvimento social e econômico (ROBINSON; DANIELSON; SNAITH, 1988).

O aumento do tráfego rodoviário e preocupações de segurança muitas vezes justificam a construção de novas estradas ou o realinhamento e expansão de rodovias existentes. Agências rodoviárias são desafiadas a localizar e projetar as melhores alternativas possíveis. Encontrar alternativas de rodovias requer recursos consideráveis (por exemplo, mão de obra e tempo). Além disso, as agências muitas vezes se deparam com decisões complexas para estimar o custo total do investimento e quantificar as necessidades de melhoria da qualidade dos pavimentos (KANGA; JHA; SCHONFELD, 2012).

Por exemplo, nos EUA existem em torno de 4 milhões de milhas (6,436 milhões de quilômetros) de rodovias e ruas, com investimento anual superior a $\$ 1$ trilhão. Agências governamentais de transporte são responsáveis pelo gerenciamento do uso e de seu desempenho (LI, 2003).

No Brasil, nas últimas décadas, o investimento em infraestrutura rodoviária se encontra bem aquém das necessidades do país, havendo uma crescente insatisfação do setor produtivo com esse nível de investimento. O levantamento do 
IPEA $^{2}$, de 2010, demonstrou que dos U\$ 89,8 bilhões ${ }^{3}$ necessários para as rodovias federais brasileiras, o Programa de Aceleração do Crescimento - PAC só prevê investimentos equivalentes a $13 \%$ da demanda ${ }^{4}$.

Uma pesquisa da Confederação Nacional dos Transportes (CNT), em 2010, revelou que em torno de $60 \%$ do nosso sistema rodoviário é deficiente, e as rodovias de padrão adequado praticamente restringem-se ao Estado de São Paulo (rodovias estaduais) ${ }^{5}$. Para completar, dentre todas as estradas brasileiras somente $10 \%$ são asfaltadas $^{6}$.

Neste contexto, Balbo (2007) já afirmava: "há de se considerar que pavimentação é uma área tecnológica com um atraso bastante significativo em relação aos países tecnologicamente mais evoluídos, e que necessitamos de investimentos ordenados em vários setores: de pesquisa (desenvolvimento de novas e apropriadas técnicas), de engenharia consultiva (atualização profunda de normas de projeto $e$ especificações construtivas com base em pesquisas e experiências genuinamente nacionais), de construção (superação da obsolescência de equipamentos de construção e melhoria brutal de mão de obra) e de controle de qualidade (emprego de técnicas coerentes e modernas de conformidade de execução de materiais)".

\subsubsection{Fatores limitantes na concepção de pavimentação rodoviária}

A concepção de um pavimento rodoviário se apoia na utilização de diversos métodos de dimensionamento, permitindo comparações que podem e devem levar a requisitos compatíveis com as reais necessidades dos usuários, tais como: garantia de melhores condições de conforto no deslocamento; melhoria na segurança e incremento no conforto ambiental (SENÇO, 2008b).

Além dos requisitos já citados para a pavimentação de vias, há que se lembrar que as estruturas de pavimento (Figura 1) têm como função essencial suportar os esforços oriundos de cargas e de ações climáticas, sem que apresentem processos de deterioração de modo prematuro. Em outras palavras, seleciona-se e dimensiona-se

\footnotetext{
2 Ipea: Instituto de Pesquisa Econômica Aplicada

3 R\$ 183,5 bilhões igual a U\$ 89,8 bilhões (cotação do dólar a $\mathrm{R} \$ 2,044$ ). Disponível em: < http://www1.folha.uol.com.br/indicadores/1093555-moedas.shtml>. Acesso em: 22/05/2012.

${ }_{4}$ Veja. Infraestrutura. Disponível em: <http://veja.abril.com.br/noticia/economia/rodovias-precisam-r183-5-bi-diz-ipea>. Acessado em: 27/09/2011.

${ }^{5}$ Correio do Brasil, Ano XI, Número 4286, 15/09/2010.

6 O Empreiteiro. Uma malha longa, de vida curta. Disponível em: http://www.revistao empreiteiro.com.br/index.php?page=materia. .php\&id=119>. Acessado em: 27/09/2011.
} 
um pavimento em função do tráfego e das condições ambientais, além das questões de economia e disponibilidade de materiais, sempre presentes. Tais estruturas devem suportar, de modo adequado, as ações externas assim impostas (BALBO, 2007).

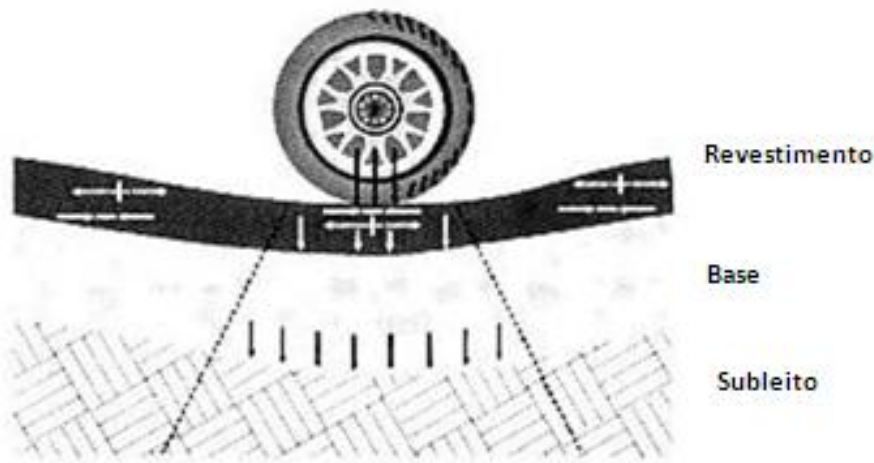

Figura 1 - Exemplo de estrutura de um pavimento e os esforços atuantes Fonte: (BALBO, 2007)

O objetivo imediato na escolha e seleção de tipos de pavimento a serem empregados em determinada obra e, por consequência, dos materiais a serem aplicados, é a minimização dos custos, mantidas as demais condições e exigências de projeto, Balbo (2007). Porém, na prática, este processo de escolha e seleção, tradicionalmente, consome muito tempo e mão de obra e, na maioria das vezes, não satisfaz as necessidades do processo de orçamentação (HONGYAN; SUOZHONG, 2010).

\subsubsection{Processos licitatórios e orçamentários de obras rodoviárias}

Os processos licitatórios de obras públicas visam assegurar igualdade de condições a todos os concorrentes. No entanto, fatores prejudiciais à orçamentação e à execução dificultam o cumprimento dos prazos, tais como: projetos básicos superficiais; utilização de manuais orçamentários inapropriados; e emprego de técnicas e materiais incoerentes geram a apresentação de propostas fora das especificações contratuais e, conseqüentemente, questionamentos judiciais. Quais as conseqüências de tudo isto? Orçamentos "furados", obras "paralisadas", "interrompidas" e "abandonadas".

Neste sentido, a elaboração de um orçamento com correção é determinante para que a empresa obtenha ganhos e não seja surpreendida com perdas de faturamento 
ou custos adicionais que podem ser evitados com a correta elaboração de um orçamento.

De uma forma geral, a execução das obras rodoviárias dá-se pela contratação de empresas privadas pelos órgãos públicos, antecedidas por licitação pública. Os orçamentos de obras rodoviárias são o resultado da associação dos quantitativos de serviços extraídos de projetos e as composições de preços unitários dos serviços (PEDROZO, 2001).

Deve existir uma intimidade entre os componentes do produto final de um projeto de pavimentação de rodovias, ou seja, o trinômio preço $x$ prazo x qualidade, cuja ligação deveria ser sempre observada na formação do preço unitário.

Preço unitário é o valor proposto pelos licitantes e indicado na proposta comercial como um preço por unidade de medida para materiais ou serviços. O preço unitário deve incluir o custo de entrega, seguros, impostos, mão de obra, materiais, supervisão, despesas gerais, lucro, incidentes, e o uso de todos os equipamentos e ferramentas necessárias para completar 0 trabalho (TEXAS HIGHWAY DEPARTMENT, 1972; AASHTO, 1985; KIMLEY-HORN, 2012).

Considerando a importância dos equipamentos, no total do custo unitário de obras rodoviárias, são relevantes as seguintes considerações: a) requerem grandes investimentos iniciais (alto custo); b) exigem serviços racionalmente planejados e executados, o que só pode ser conseguido por meio de empresas de alto padrão de eficiência; c) reduzem substancialmente a mão de obra empregada mas, por outro lado, provocam a especialização profissional e, consequentemente, melhor remuneração; d) permitem a movimentação de grandes volumes de terra em prazos curtos, o que leva a preços unitários baixos apesar do custo elevado do equipamento (RICARDO; CATALANI, 1990).

Orçar a construção de obras rodoviárias é um grande desafio para o setor público e privado. A estimativa de custo é um fator importante para uma gestão bem sucedida da execução do projeto, desde o início da fase de planejamento até a sua conclusão (DIAB; NASSAR, 2012).

A experiência mostra que a atividade ORÇAR deve sempre estar associada à atividade EXECUTAR (GADELHA, 2006).

De acordo com Rowuings Jr (2003), o orçamento é, em geral, utilizado para se ter uma ideia do valor do projeto que será executado. Geralmente, os envolvidos no processo de concepção de um projeto tendem a fazer a seguinte pergunta: "quanto 
custará a execução do projeto?". Para responder esta pergunta, vários tipos de orçamentos e estimativas devem ser desenvolvidos. A meta do orçamentista é se aproximar do real custo da execução.

Quanto melhores os indicadores da empresa, seu banco de dados, a experiência do orçamentista e o nível de detalhamento do projeto, mais chances de se aproximar do real custo de execução, possibilitando, com isso, diminuir os riscos de implementação do empreendimento.

\subsubsection{Representatividade da terraplenagem e da pavimentação a executar no processo de construção de rodovias.}

Independente do tipo de contrato (por preço global ou por preços unitários) ou do sistema construtivo adotado, o fator preponderante na implementação de um projeto rodoviário é o custo de construção.

Considerando a construção da "State Highway 52, 5.2 miles construction" como um exemplo, segundo Lapinski (1978), o serviço de movimentação de terra (incluindo limpeza e destocamento do terreno, escavação e terraplenagem) representou em torno de $48 \%$ e o serviço de pavimentação (incluindo base e o revestimento) representou $47 \%$ do custo total do empreendimento (os $5 \%$ restantes referem-se às outras atividades, como, por exemplo galerias de drenagem).

Outro exemplo é o resultado da pesquisa de Pedrozo (2001) registrado na Tabela 1 que apresenta a participação de materiais, mão de obra, equipamentos e transportes para os serviços de terraplenagem, pavimentação e drenagem. E, na Tabela 2, esse pesquisador indica o percentual de $47 \%$ de participação do serviço de pavimentação no custo total do empreendimento (analisou trinta e três orçamentos de obras rodoviárias do DAER-RS ${ }^{7}$ entre 1997 e 2000).

Tabela 1- Resumo das porcentagens/componentes conforme custos unitários

\begin{tabular}{l|c|c|c|c}
\hline & MATERIAIS & MÃO DE OBRA & EQUIPAMENTOS & TRANSPORTES \\
\hline Terraplenagem & $18 \%$ & $15 \%$ & $52 \%$ & $15 \%$ \\
\hline Pavimentação & $74 \%$ & $3 \%$ & $19 \%$ & $4 \%$ \\
\hline Drenagem & $69 \%$ & $23 \%$ & $4 \%$ & $4 \%$ \\
\hline
\end{tabular}

Fonte: Pedrozo (2001)

\footnotetext{
${ }^{7}$ DAER-RS: Departamento Autônomo de Estradas de Rodagem do Estado do Rio Grande do Sul.
} 
Tabela 2- Participação dos componentes da pavimentação em relação à construção de rodovias

\begin{tabular}{c|c}
\hline COMPONENTES & $\%$ \\
\hline Materiais & $34,8 \%$ \\
\hline Mão de obra & $1,4 \%$ \\
\hline Equipamentos & $8,9 \%$ \\
\hline Transportes & $1,9 \%$ \\
\hline Total de participação da pavimentação & $\mathbf{4 7 \%}$ \\
\hline
\end{tabular}

Fonte: Pedrozo (2001)

Em relação às características de tráfego do pavimento, Pedrozo (2001) não apresenta nenhuma informação a este respeito. Os dados da Tabela 2 referem-se aos Preços Oficiais ou de Referência, elaborados pelo DAER/RS, calculados pela Equipe de Economia Rodoviária do órgão.

Tendo os equipamentos (um dos importantes recursos físicos utilizados na produção de serviços de terraplenagem e construção de pavimentos) como outra referência, estudos indicam que seus custos de utilização variam de $25 \%$ a $40 \%$ do custo total de um empreendimento de construção de rodovias (GOKHALE, 2003).

Os equipamentos participam do processo de transformação que, a partir dos materiais disponíveis, e com a participação da mão de obra, gera o serviço final.

Em termos do estudo de custos dos equipamentos e, principalmente, de sua incidência sobre um serviço sendo executado, é interessante perceber que os mesmos, em termos do processo de produção em que estão envolvidos, podem ser necessários nas operações finais ou podem aparecer antes delas, dando-lhes suporte.

Além do setor rodoviário, outro setor da construção civil que sofre uma grande influência nos custos relacionados à movimentação de terra e pavimentação é o setor habitacional. O peso, em percentual, da pavimentação de um sistema urbano é de $36 \%{ }^{8}$ quando comparado com o custo total da infraestrutura de um conjunto habitacional. Valor médio apresentado por projetos da Companhia de

\footnotetext{
${ }^{8}$ Este percentual inclui os serviços de terraplenagem.
} 
Desenvolvimento Habitacional e Urbano (CDHU), conforme dados de um estudo realizado internamente na CDHU (INOUYE; SOUZA, 2004).

\subsubsection{Importância do estudo da produtividade nos serviços de terraplenagem e pavimentação asfáltica}

Os agentes participantes da cadeia da Construção Civil têm, cada vez mais, sido cobrados quanto ao aumento de sua eficiência, como fruto de uma série de mudanças no mercado, tais como o acirramento da competição entre as empresas atuantes, a maior conscientização do consumidor e o controle mais eficaz pelo Poder Público.

Desta forma, os agentes da Construção Civil têm trabalhado no sentido de buscar tal aumento de competência, o que pode levar a alterações nos indicadores utilizados nas composições unitárias disponíveis para auxiliar o prognóstico de custos. Portanto, considera-se necessário o contínuo aperfeiçoamento dos sistemas de indicadores de produtividade para balizar as análises de custos no subsetor da Construção Pesada.

A produtividade de um evento significa produção maior com os mesmos meios e sem esforço adicional do elemento humano. O principal objetivo da produtividade é produzir com economia e eficiência, através de metodização e racionalização dos meios e dos serviços (CIMINO, 1987).

Para a previsão da produtividade é comum a utilização de manuais de orçamentação. Cada manual se apresenta com uma metodologia própria de se "ver" os serviços, porém, nem sempre estão explícitos os fatores influenciadores dos dados apresentados. E, geralmente, estes dados foram gerados por métodos teóricos, carecendo de verificação em campo. Esses manuais apresentam composições individuais para cada serviço, sendo que, para cada um deles, indicase somente um valor relativo à demanda média por materiais, mão de obra e equipamentos para se executar uma unidade do produto.

No entanto, percebe-se, na prática, que os indicadores de produtividade podem ter uma grande variabilidade, requerendo o conhecimento dos fatores que os fazem variar.

No trabalho desenvolvido pela Escola Politécnica da USP (EPUSP, 2008a) de revisão/aperfeiçoamento dos prognósticos de custos efetuados pela Caixa 
Econômica Federal, no que se refere à construção aeroportuária (o resultado deste trabalho contribuiu para a discussão do Sistema Nacional de Pesquisa de Custos e Índices da Construção Civil - SINAPI) encontrou-se uma grande variabilidade de eficiências relativas aos serviços de terraplenagem e pavimentação (segundo o estudo em campo e consulta a especialistas, manuais e documentos técnicos). Exemplos de variabilidades são apresentados na Figura 2 e na Figura 3.

\section{Concreto betuminoso usinado a quente (CBUQ)}

\begin{tabular}{|c|c|c|c|c|c|}
\hline $\begin{array}{l}\text { Rolo compactador - } \\
\text { tandem }(\mathrm{h})\end{array}$ & $\begin{array}{l}\text { Rolo compactador de } \\
\text { pneus }(\mathrm{h})\end{array}$ & Vibrc & ra de & \multicolumn{2}{|c|}{ Servente (h) } \\
\hline 0,0014 & 0,0100 & 0,0010 & 0,0060 & 0,0071 & 0,0490 \\
\hline $771 \%$ & $879 \%$ & & & & \\
\hline
\end{tabular}

Figura 2 - Variação (\%) entre as produtividades para o serviço de CBUQ (quantidade de horas de equipamento para lançamento de uma tonelada de material)

Escavação e carga de material de 1aㅡ categoria

\begin{tabular}{|c|c|c|}
\hline $\begin{array}{l}\text { Carregadeira de pneus } \\
\text { (h) }\end{array}$ & $\begin{array}{l}\text { Trator de esteiras } \\
\text { c/lâmina D8 (h) }\end{array}$ & Servente (h) \\
\hline 0,008 & 0,008 & 0,108 \\
\hline $771 \%$ & $879 \%$ & $1874 \%$ \\
\hline
\end{tabular}

Figura 3 - Variação (\%) entre as produtividades para o serviço de escavação (quantidade de horas de equipamento para escavar um metro cúbico de solo)

Este exemplo, que apresenta variações de 535\% a $1874 \%$, é alerta sobre a impossibilidade de se tomarem decisões confiáveis com base na imprecisão de indicadores médios.

Em síntese, em relação aos serviços de terraplenagem e pavimentação asfáltica, existem muitos manuais, porém cada um aborda as etapas de execução de maneira diferente e os indicadores de produtividade apresentados são extremamente variáveis. Além disso, não é possível saber (lendo o manual) quais os fatores que foram considerados quando o manual indica um determinado valor para certo serviço. Portanto, a utilização dos manuais brasileiros, enquanto ferramenta de orçamentação e gestão, é pouco eficiente. 


\subsection{Processo da Pesquisa}

O processo de pesquisa é constituído de diversas etapas, passos ou fases, organizados de uma maneira lógica, sequencial e dinâmica. Isso não quer dizer que não seja possível retornar a uma etapa anterior ou visualizar as etapas subsequentes. Na Figura 4 apresenta-se o modelo de esquema do processo de pesquisa utilizado neste trabalho. Os passos 1 ao 5 serão tratados como segue. Os demais capítulos da tese representam o passo 6 (implementar o método da pesquisa).

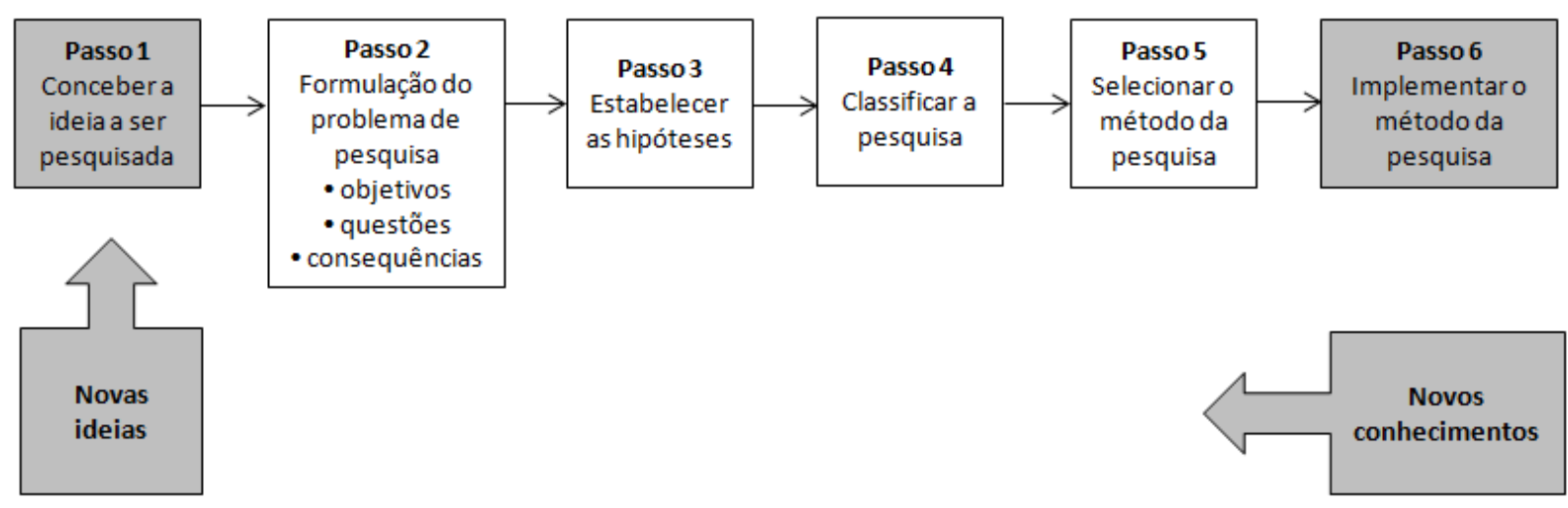

Figura 4 - Esquema do processo de pesquisa

Fonte: Adaptado de Sampieri; Collado e Lucio (2006)

\subsubsection{Conceber a ideia a ser investigada}

A ideia a ser investigada é o conjunto construído, em torno de uma questão principal, pelas hipóteses de pesquisa e pelas linhas de análise que permitirão tratar o assunto escolhido (BEAUD, 2002).

Desta forma, a concepção da idéia a ser investigada parte das seguintes considerações, entendimentos e situações: Considerando que rodovias é uma área tecnológica com potencial de desenvolvimento e que necessita de investimentos ordenados em vários setores: de pesquisa, de engenharia consultiva, de construção e de controle de qualidade. Com base no entendimento de que em função da tipologia de um pavimento, verifica-se a importância do conhecimento da eficiência de sua execução. Visto que, uma grande variabilidade de eficiências relativas aos serviços de terraplenagem e pavimentação asfáltica é passível de ser encontrada nos diversos manuais brasileiros. 
Síntese da idéia concebida:

"Existem muitos manuais, relacionados aos serviços de terraplenagem e pavimentação asfáltica, mas os indicadores de produção unitária apresentados são teóricos, extremamente variáveis e os fatores que os fazem variar não são percebidos. Esta imprecisão impossibilita a tomada de decisões confiáveis, inviabilizando os processos orçamentários e a gestão da produção. Um novo modelo de prognóstico da produtividade destes serviços pode resolver estas falhas e assim contribuir para levar o processo de gestão da produção de rodovias a um novo patamar de produtividade e eficiência".

\subsubsection{Formulação do problema de pesquisa: objetivos e questões do estudo}

Um bom trabalho científico é aquele cujos resultados apresentem reflexões ou possíveis soluções para o problema; portanto, o enfoque central para a pesquisa é o problema que, posteriormente, trará uma contribuição científica e pessoal (FACHIN, 1993).

Os elementos para formular um problema são três e estão relacionados entre si: os objetivos que se pretendem alcançar; as questões de pesquisa; e a justificativa do estudo (apresentada na seção 1.1 deste capítulo).

\subsubsection{O objetivo da pesquisa}

Os objetivos da pesquisa visam mostrar o que se deseja e devem ser expressos com clareza, pois são as orientações do estudo (SAMPIERI; COLLADO; LUCIO, 2006).

Com base na "ideia a ser investigada", este trabalho propõe um novo modelo de prognóstico da produtividade para os serviços de terraplenagem e pavimentação asfáltica de rodovias. Desenvolvido com base no conceito de produtividade variável que, além de inédito (no subsetor de construção pesada), utiliza a abordagem do 
Modelo dos Fatores ${ }^{9}$. Esta abordagem preconiza uma previsão baseada na observação cuidadosa de vários aspectos relacionados a uma expectativa maior ou menor de produtividade da mão de obra e da eficiência dos equipamentos num dado serviço.

Neste sentido, o objetivo principal desta tese de doutorado consiste em:

“Elaborar um método que auxilie o prognóstico da produtividade na execução de rodovias visando subsidiar a tomada de diversas decisões: das relacionadas à orçamentação até àquelas associadas à gestão da produção. Com ênfase nas seguintes partes: terraplenagem e pavimentação asfáltica. Esta tese tem a contribuição inovadora: a) de ser fundamentada na opinião de especialistas (já que não se dispõe de quantidade de dados suficiente para tirar uma conclusão inquestionável); b) empregar métodos teóricos e experimentais; c) de rever as diferentes fases executivas de cada tipo de serviço; d) apresentar os indicadores destes serviços por meio de faixas de valores (que representam a produtividade variável); e) e aliados às faixas estão os fatores orientadores para a tomada de decisão sobre qual valor adotar."

Os objetivos parciais desta pesquisa estão relacionados às seguintes atividades:

a) estudar as diferentes partes (quebra) dos serviços e propor indicadores que se adequem a essas partes;

b) levantar/organizar um banco de dados de indicadores de produção unitária e correlacioná-los aos fatores que os determinam;

c) criação de faixas de valores (indicando-se os valores mínimo, mediano e máximo) para o consumo de equipamentos e mão de obra, relativos aos serviços estudados, e os fatores orientadores para a tomada de decisão sobre qual valor adotar.

\footnotetext{
${ }^{9} \mathrm{O}$ Modelo dos Fatores foi proposto por H. Randolph Thomas, da Pensylvania State University - Estados Unidos da América (SOUZA, 1996). De acordo com este modelo, a produtividade da mão de obra é avaliada no âmbito da equipe de trabalho levando-se em consideração o efeito da curva de aprendizagem de atividades repetitivas, assim como os outros fatores que interferem no seu valor (PALIARI, 2008).
} 
Os serviços de terraplenagem e pavimentação asfáltica, a serem abordados no desenvolvimento do método, são os relacionados abaixo:

a) Escavação de material de $1^{\text {a }}$ categoria com trator de esteiras $\left(\mathrm{m}^{3}\right)$;

b) Escavação de material de $1^{\text {a }}$ categoria com escavadeira hidráulica $\left(\mathrm{m}^{3}\right)$;

c) Compactação de aterro - espessura até $30 \mathrm{~cm}\left(\mathrm{~m}^{2}\right)$;

d) Base de solo cimento com mistura na pista - esp. até $20 \mathrm{~cm}\left(\mathrm{~m}^{2}\right)$;

e) Brita graduada simples - BGS com distribuidor de agregados - esp. até $20 \mathrm{~cm}$ $\left(\mathrm{m}^{2}\right)$;

f) Brita graduada simples - BGS com vibroacabadora - esp. até $20 \mathrm{~cm}\left(\mathrm{~m}^{2}\right)$;

g) Brita graduada tratada com cimento - BGTC - esp. até $20 \mathrm{~cm}\left(\mathrm{~m}^{2}\right)$;

h) Concreto betuminoso usinado a quente - capa ou binder - esp. até $5 \mathrm{~cm}\left(\mathrm{~m}^{2}\right)$;

i) Imprimação $\left(\mathrm{m}^{2}\right)$;

j) Pintura de ligação $\left(\mathrm{m}^{2}\right)$.

\subsubsection{Questões da pesquisa}

Sugere-se que a forma da questão - em termos de "quem", "o que", "onde", "como" e "por que" - forneça uma pista importante para estabelecer a estratégia de pesquisa mais relevante a ser utilizada. É mais provável que a estratégia de estudo de caso ${ }^{10}$ seja apropriada a questões do tipo "como" e "por que"; assim a tarefa inicial é precisar, com clareza, a natureza das questões de estudo nesse sentido (YIN, 2005). Com base no exposto, formulam-se as questões de pesquisa.

a) Quais são os principais manuais, para prognóstico da produtividade, utilizados na implantação da infraestrutura de rodovias?

b) Como esses manuais dividem as fases executivas de cada serviço (quebra do serviço)?

c) A quebra dos serviços é tratada da mesma maneira pelos manuais?

d) Esses manuais utilizaram qual método, teórico ou experimental, para gerar os indicadores?

${ }^{10}$ Estudo de caso: duas fontes de evidências: observação direta dos acontecimentos que estão sendo estudados e entrevistas das pessoas neles envolvidas são predominantes neste tipo de estudo (YIN, 2005). 
e) Como os manuais apresentam os indicadores de produção unitária?

f) Estes indicadores apresentados são muito diferentes?

g) Observando os manuais, o porquê destas variações pode ser identificado?

h) Os fatores considerados pelos manuais, quando eles apresentam um indicador para um determinado serviço, são visíveis?

i) A forma como estes indicadores são apresentados subsidia a tomada de decisões confiáveis?

j) Uma nova proposta de prognóstico da produtividade destes serviços pode vir a sanar estes problemas?

k) Em que esta nova proposta pode ser diferente?

Complementando os três elementos, apresentados anteriormente (objetivo, questões e justificativa), Sampieri; Collado e Lucio (2006) sugerem as consequências da pesquisa.

\subsubsection{Consequências da pesquisa}

A expectativa quanto ao método é que ele aborde diferentes formas para coleta de dados em campo. Seja mais detalhado (em relação às diferentes partes dos serviços), mais abrangente (apresente faixas de valores), mais orientador (contenha os fatores que orientam sobre qual indicador adotar) e mais aprimorado (embasado na opinião de especialistas).

Espera-se que a explicitação minuciosa do "método para prognóstico da produtividade na execução de rodovias: terraplenagem e pavimentação asfáltica" seja um instrumento útil para a melhoria contínua dos sistemas de gestão da produção de rodovias e contribua na adequação da transmissão dos conhecimentos dessa área da engenharia (em empresas, órgãos públicos e cursos de engenharia), por meio dos resultados desta pesquisa. Que contribua na formação de usuários no exercício constante de entender melhor a produtividade variável. O que constitui uma capacidade altamente valorizável no ambiente mutável e competitivo em que as empresas de construção civil vivem. 


\subsubsection{Formulação da hipótese}

A hipótese é entendida como a fase executiva do trabalho científico. Em função dos fenômenos observados ou dos fatos conhecidos, ou fundamentada em dados teóricos, a que foram subordinados um projeto de pesquisa, tenta-se descobrir novos conhecimentos. Para quem se propõe a desenvolver uma pesquisa de cunho científico, a norma mais adequada para obter resultados adequados é através da elaboração da hipótese (FACHIN, 1993).

Neste sentido, formula-se a seguinte hipótese:

"As imprecisões contidas nos manuais orçamentários estudados (quebra de serviço diferenciada, embasamento teórico, indicadores variáveis e ausência dos fatores de conteúdo, contexto e anormalidades) impossibilita a tomada de decisões confiáveis. Esta nova abordagem, que leva em conta a produção unitária variável e o modelo dos fatores, representa um avanço no estudo da produtividade na execução de rodovias e pode subsidiar a tomada de diversas decisões: das relacionadas à orçamentação até àquelas associadas à gestão da produção."

Com base nos objetivos, nas questões de pesquisa e na hipótese tem-se a seguinte tese:

"Existem muitos manuais, mas cada um quebra os serviços de maneira diferente. Os indicadores apresentados, geralmente, são embasados em métodos teóricos, são extremamente variáveis e não dá para saber (lendo os manuais) quais os fatores que os fazem variar. Esta imprecisão impossibilita a tomada de decisões confiáveis, inviabilizando os processos de orçamentação e a gestão da produção. Portanto, com base no conhecimento dos principais manuais, estudando o assunto, acompanhando a execução de obras e ouvindo a opinião de especialistas, um novo modelo de prognóstico da produtividade na execução de terraplenagem e pavimentação asfáltica será criado. Este modelo tem a contribuição inovadora: a) de ser fundamentada na opinião de especialistas; b) empregar métodos teóricos e experimentais; c) de 
rever as diferentes fases executivas de cada tipo de serviço; d) apresentar os indicadores destes serviços por meio de faixas de valores (que representam a produtividade variável); e) e aliada às faixas estão os fatores orientadores para a tomada de decisão sobre qual valor adotar."

O mesmo se aplica às etapas: de orçamentação (proporciona segurança para a correta estimativa); e de gestão da produção (verificação dos parâmetros de produtividade, aferindo os processos orçamentários).

\subsubsection{Classificação da pesquisa a ser realizada}

Apresenta-se (Tabela 3) um resumo da localização da pesquisa objeto desta tese, nos moldes das classificações propostas por diversos autores que tratam desta questão de forma mais aprofundada, dentre os quais os citados neste trabalho: Fachin (1993), Lakatos (2001), Beaud (2002), Yin (2005), Sampieri; Collado e Lucio (2006).

Tabela 3- Resumo da classificação de pesquisa desenvolvida nesta tese

\begin{tabular}{c|l}
\hline $\begin{array}{c}\text { Atributo relacionado a esta } \\
\text { pesquisa }\end{array}$ & \multicolumn{1}{c}{ Detalhamento } \\
\hline \multirow{2}{*}{ Tipo de pesquisa } & Exploratória: quando se busca ampliar os estudos já existentes; \\
\cline { 2 - 2 } & $\begin{array}{l}\text { Descritiva: quando a literatura nos revela que há "partes" de teoria } \\
\text { com poder experimental moderado; }\end{array}$ \\
\cline { 2 - 2 } & $\begin{array}{l}\text { Correlacional: quando se deseja saber como se comporta uma } \\
\text { variável conhecendo o comportamento de outras variáveis } \\
\text { relacionadas; }\end{array}$ \\
\hline Enfoque & $\begin{array}{l}\text { Misto (quantitativo e qualitativo): consiste em consultar a literatura e } \\
\text { a teoria vinculada com o tema }\end{array}$ \\
\hline Modelo de pesquisa & $\begin{array}{l}\text { Pesquisa não experimental: se realiza sem manipular } \\
\text { deliberadamente as variáveis. }\end{array}$ \\
\hline
\end{tabular}

\subsubsection{Método da pesquisa}

O fluxograma do método de pesquisa, adotado para o desenvolvimento desta tese, é apresentado na Figura 5. O seu detalhamento é descrito a seguir.

a) Revisão bibliográfica acerca do serviço de terraplenagem de rodovias;

- estudo dos manuais verificando a forma de abordagem do serviço,

- quebra dos serviços em partes onde caibam composições orçamentárias.

b) Revisão bibliográfica acerca do serviço de pavimentação asfáltica;

- estudo dos manuais verificando a forma de abordagem do serviço, 
- quebra dos serviços em partes onde caibam composições orçamentárias.

c) Entendimento da forma como os manuais abordam as composições.

d) Proposta de abordagem para as composições.

e) Estudos de caso, buscando levantar os indicadores de produtividade e identificar os fatores que os fazem variar.

f) Transformação dos indicadores dos manuais conforme nova proposta de abordagem.

g) Submeter aos especialistas as faixas de produtividade variável (dos manuais e estudos de caso) e os fatores encontrados.

h) Criação do método de prognóstico da produtividade na execução de rodovias: terraplenagem e pavimentação asfáltica. 


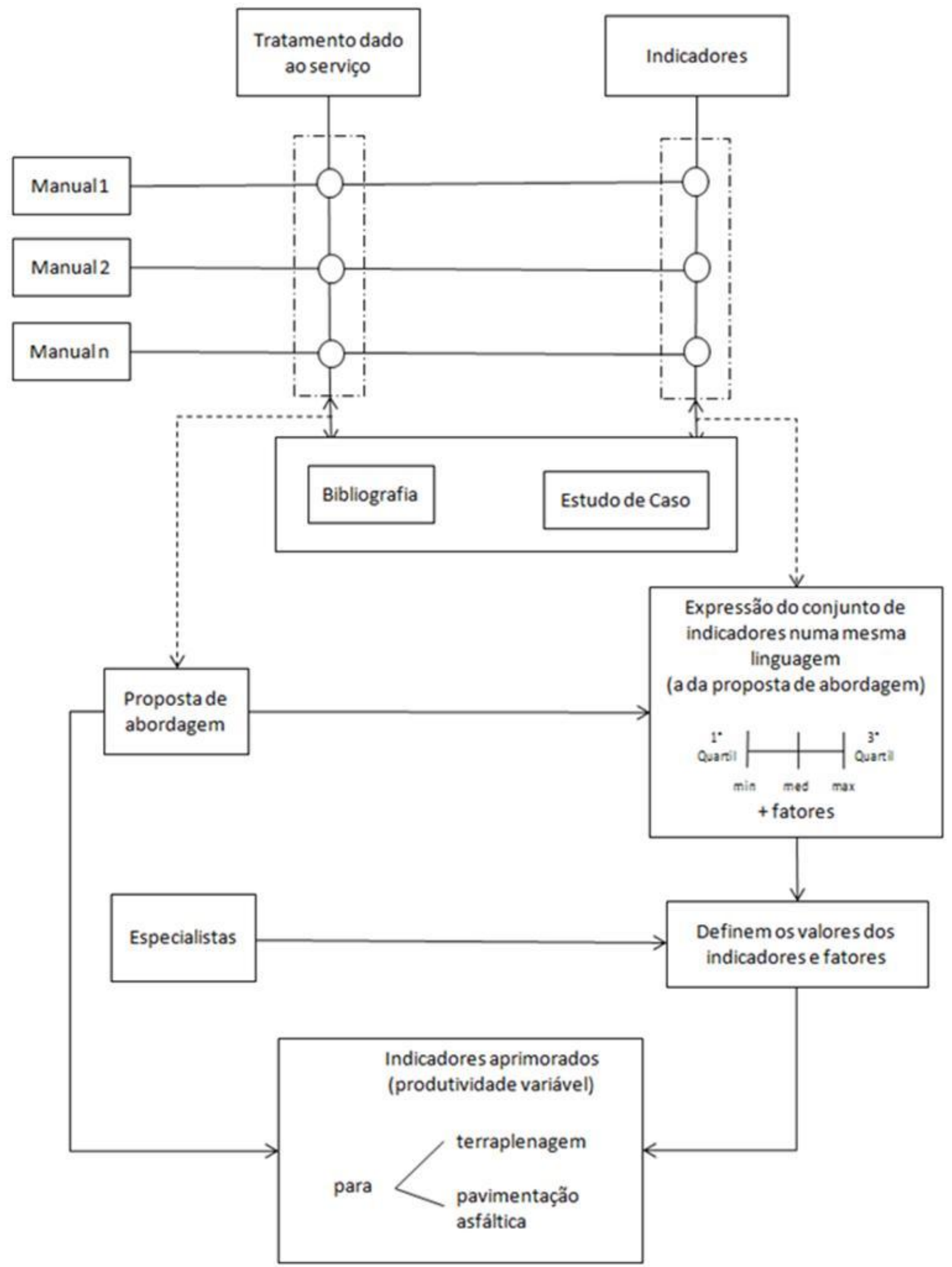

Figura 5 - Fluxograma do método da pesquisa 
Enquanto metodologia empregada, apresenta-se a seguir o resumo do esforço empreendido para se cumprir todos os objetivos desta pesquisa.

a) Quantidade de manuais analisados:

- Nacionais: os 6 principiais manuais nacionais foram envolvidos na pesquisa. Indiretamente estudaram-se mais 3 manuais nacionais.

- Estrangeiros: indiretamente estudaram-se 3 manuais internacionais.

b) Quantidade de normas analisadas: 7 normas brasileiras.

c) Quantidade de referências bibliográficas analisadas:

- Livros: 29.

- Relatórios: 21.

- Artigos e textos técnicos: 41 entre nacionais e internacionais:

- Nacionais: 29.

- Internacionais: 12

- Dissertações e teses: 10 de cinco universidades diferentes.

- Notas de aula: 4

- Sites: 23 sites

d) Dias de coleta em campo: 131 dias de coleta efetiva.

e) Tipos de serviços e quantidade de atividades estudadas:

- 10 serviços diferentes.

- 43 atividades.

f) Quantidade de composições analisadas: 358 composições.

g) Quantidade de dados analisados: 9.259 dados.

h) Quantidade de dados gerados: 485 dados. 


\subsubsection{Estrutura do texto}

O presente trabalho é composto de 10 capítulos, contando com este, conforme ilustrado na Tabela 4

Tabela 4 - Apresentação da estrutura dos capítulos

\begin{tabular}{l|l|c}
\hline Capítulo & Conteúdo & $\begin{array}{c}\text { Etapa do método da } \\
\text { pesquisa }\end{array}$ \\
\hline Capítulo 1 & Introdução & - \\
\hline Capítulo 2 & Serviço de terraplenagem & $\mathrm{a}$ \\
\hline Capítulo 3 & Serviço de pavimentação asfáltica & $\mathrm{b}$ \\
\hline Capítulo 4 & Abordagem dos manuais & $\mathrm{c}$ \\
\hline Capítulo 5 & Proposta de abordagem para as composições & $\mathrm{d}$ \\
\hline Capítulo 6 & Estudos de caso & $\mathrm{e}$ \\
\hline Capítulo 7 & $\begin{array}{l}\text { Indicadores dos manuais conforme nova proposta de } \\
\text { abordagem }\end{array}$ & $\mathrm{f}$ \\
\hline Capítulo 8 & Manual de aplicação nas entrevistas com os especialistas & $\mathrm{g}$ \\
\hline Capítulo 9 & $\begin{array}{l}\text { Método para prognóstico da produtividade: terraplenagem e } \\
\text { pavimentação asfáltica }\end{array}$ & $\mathrm{h}$ \\
\hline Capítulo 10 & Conclusões & - \\
\hline
\end{tabular}




\section{SERVIÇO DE TERRAPLENAGEM}

Neste capítulo apresenta-se o serviço de terraplenagem. Inicia com a conceituação geral. Em seguida abordam-se as etapas de serviço: cortes; empréstimos; aterros; e depósito de materiais excedentes. Finaliza-se com a apresentação das composições orçamentárias aplicáveis à terraplenagem.

\subsection{Terraplenagem - Entendimento Geral}

O movimento de terra é uma das atividades de implantação da infraestrutura de rodovias. Esta movimentação se faz por meio da terraplenagem.

Chama-se terraplenagem ${ }^{11}$ o conjunto de operações de escavação, carga, transporte, descarga, compactação e acabamento executadas a fim de transformar o terreno natural na plataforma projetada (SENÇO, 1980; SHIMIZU, 2002).

$\mathrm{Na}$ fase de construção, pode-se encontrar três situações no que se refere à posição do terreno natural e a plataforma projetada.

a) Plataforma abaixo do terreno natural:

A operação a ser executada, consiste na escavação do material até atingir o nível previsto para a plataforma. É a operação de corte (Figura 6).

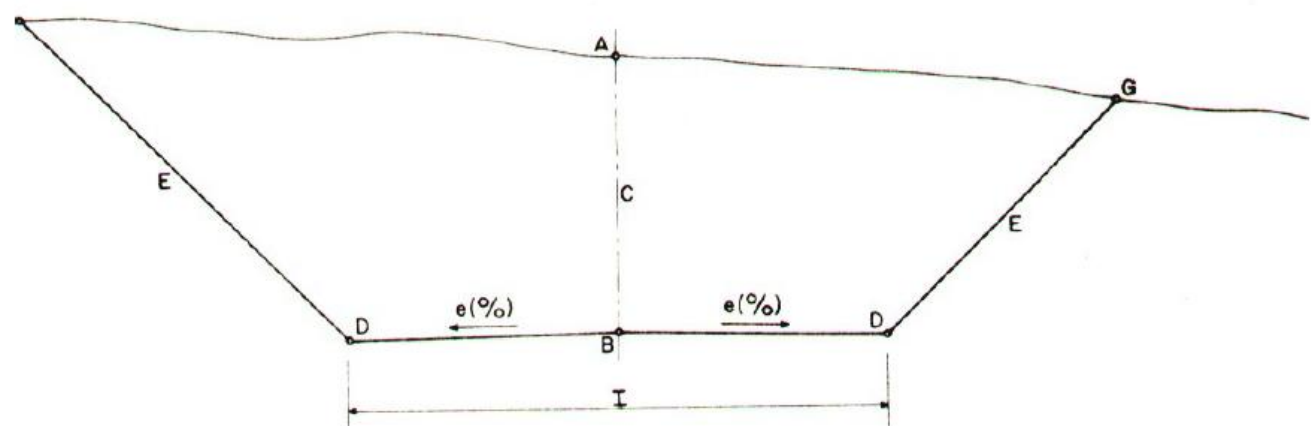

Figura 6 - Plataforma abaixo do terreno natural

Fonte: Pereira et al (2010)

b) Plataforma acima do terreno natural:

Na verdade, o aterro, cria um suporte para a elevação da plataforma, ao nível previsto no projeto. Por se tratar de um maciço construído, sua condição final estará inteiramente dependente da execução.

11 Terraplenagem: ter.ra.ple.na.gem - sf (terraplenar+agem) 1 Ato ou efeito de terraplenar. 2 Terrapleno. 3 Qualquer trabalho que tenha por fim modificar o relevo natural de um terreno por meio de aterros. Var: terraplanagem (MICHAELIS, 2012). 
A operação consiste no depósito e compactação do material até atingir-se 0 nível da plataforma. É a operação aterro (Figura 7).

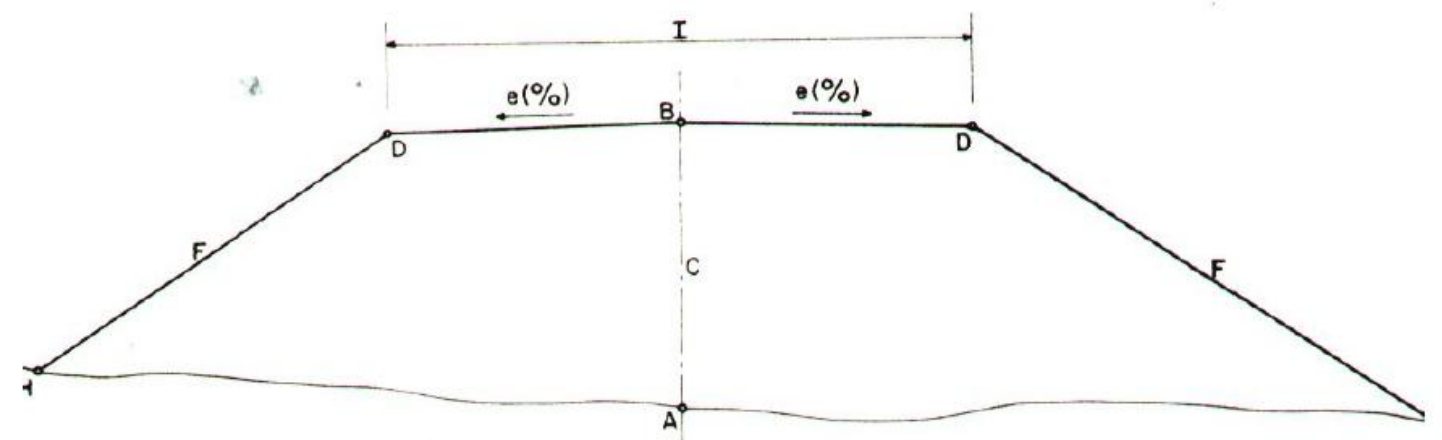

Figura 7 - Plataforma acima do terreno natural

Fonte: Pereira et al (2010)

c) Plataforma parte abaixo e parte acima do terreno:

Neste caso, há necessidade das duas operações, para se atingir a plataforma (Figura 8).

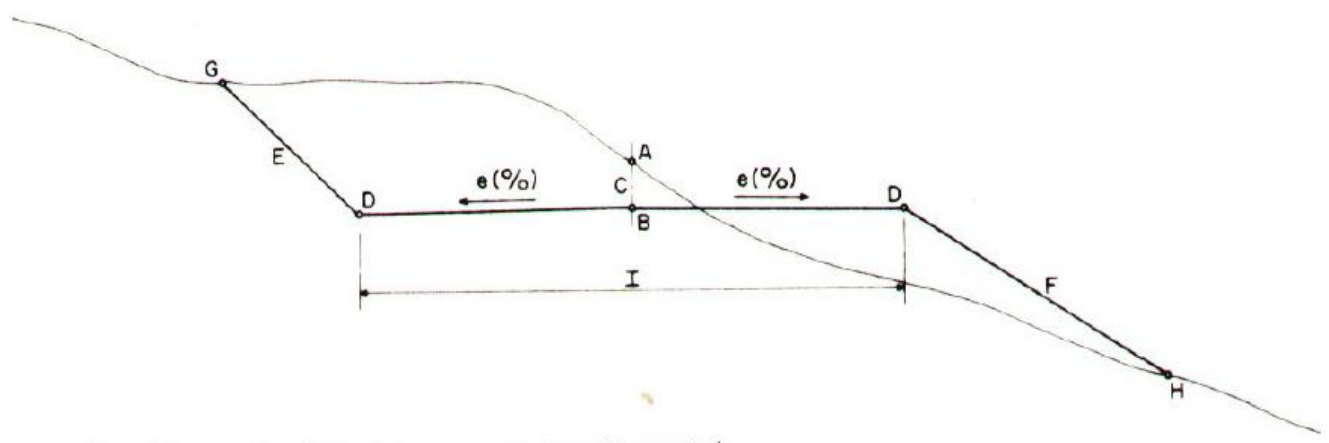

Figura 8 - Plataforma mista

Onde:

Fonte: Pereira et al (2010)
A - cota do terreno natural no eixo;
B - Cota no greide de terraplenagem no eixo;
C - Cota vermelha (cota do terreno - cota do greide, no eixo);
D - Bordo da plataforma de terraplenagem;
E - Talude de corte;
F - Talude de aterro;
G - Off-set de corte;
$\mathrm{H}$ - Off-set de aterro;
I - Plataforma de terraplenagem;
e (\%) - Abaulamento ou declividade transversal.

A faixa do terreno natural que serve de apoio aos aterros ou onde se deve iniciar os cortes, para atingir a largura correta de plataforma, no nível previsto, chamase "faixa de ocupação" (Figura 9). 


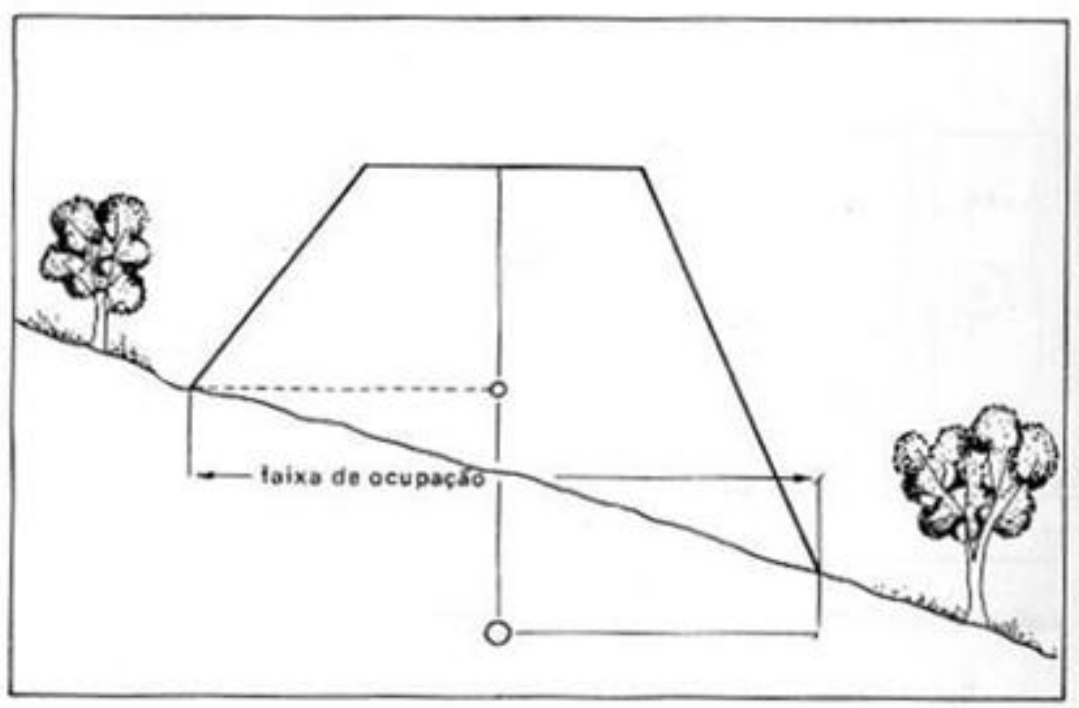

Figura 9 - Faixa de ocupação

Fonte: Adaptado de Senço (1980)

A terraplenagem visa, assim, estabelecer o suporte para a plataforma, a qual deve satisfazer as condições geométricas exigidas pelas normas do projeto.

\subsection{Etapas de Serviços de Terraplenagem}

Segundo o DNER (1996), a execução de terraplenagem abrange duas modalidades de serviços: serviços ordinários e serviços especiais.

Os serviços ordinários abrangem as seguintes etapas:

a) serviços preliminares;

- instalação do canteiro de obra,

- transporte dos equipamentos,

- consolidação dos terrenos e fundação dos aterros,

- locação topográfica,

- limpeza da faixa, desmatamento e destocamento,

b) caminhos de serviço;

- construção de estradas de serviço e obras de arte provisórias,

c) cortes;

d) empréstimo;

e) aterros;

f) depósito de material excedente (DME) ou "bota fora"12.

${ }^{12}$ O termo "bota-fora" foi substituído pelo termo Depósito de Materiais Excedentes - DME. 
Os serviços especiais abrangem as seguintes etapas:

a) aterros sobre solos inconsistentes;

- aterros não reforçados sobre solos moles,

- aterros reforçados sobre solos moles,

b) sistemas de contenção.

Em função dos objetivos deste trabalho e de forma resumida, os serviços de cortes, empréstimos, aterros e depósito de material excedente serão apresentados a seguir.

\subsubsection{Cortes}

Para a definição de cortes, adota-se o exposto pelo DER-SP (2006a): "escavação e carga de material consiste-se nas operações de remoção do material constituinte do terreno nos locais onde a implantação da geometria projetada requer a sua remoção, ou escavação de áreas de empréstimo de material, incluindo a carga e o transporte dos materiais para seu destino final: aterro ou depósito de materiais excedentes". Para complementar, a Tabela 5 apresenta as definições do DNER.

Tabela 5 - Definição de cortes pelo DNER

\begin{tabular}{c|c|l}
\hline Fonte & Descrição da Fonte & \multicolumn{1}{c}{ Definição } \\
\hline $\begin{array}{c}\text { DNER } \\
(1996)\end{array}$ & $\begin{array}{c}\text { Manual de Implantação } \\
\text { Básica }\end{array}$ & $\begin{array}{l}\text { Cortes - segmentos que requerem escavação } \\
\text { no terreno natural para se alcançar a linha do } \\
\text { greide projetado, definido assim transversal e } \\
\text { longitudinalmente o corpo estradal. }\end{array}$ \\
\hline $\begin{array}{c}\text { DNER } \\
(1997 a)\end{array}$ & $\begin{array}{c}\text { Especificação de Serviço } \\
\text { DNER-ES 280/97 }\end{array}$ & $\begin{array}{l}\text { Cortes - segmentos de rodovia, em que a } \\
\text { implantação requer a escavação do terreno } \\
\text { natural, ao longo do eixo e no interior dos } \\
\text { limites das seções do projeto off-set } \\
\text { definem o corpo estradal. }\end{array}$ \\
\hline
\end{tabular}

Convencionalmente, os materiais explorados em jazidas para as obras civis são diferenciados, do ponto de vista de terraplenagem, quanto à sua dificuldade de escavação. Neste sentido, será tratado tão somente a escavação dos materiais ditos de $1^{\underline{a}}$ e de $2^{\underline{a}}$ categorias (Tabela 6 ).

${ }^{13}$ Off-set: limites necessários à implantação dos cortes e aterros. 
Tabela 6 - Categorias dos materiais escavados

\begin{tabular}{c|l|l}
\hline Categoria & \multicolumn{1}{|c}{ Descrição } & \multicolumn{1}{|c}{ Exemplo de aplicação } \\
\hline Primeira & $\begin{array}{l}\text { Material escavável com os } \\
\text { equipamentos normais, ainda que se } \\
\text { apresentem bastante rijos, em razão } \\
\text { de baixo teor de umidade. }\end{array}$ & $\begin{array}{l}\text { Solos transportados, residuais e } \\
\text { saprolíticos, materiais soltos, extração } \\
\text { de areia de cava ou barranco. }\end{array}$ \\
\hline Segunda & $\begin{array}{l}\text { São mais resistentes ao desmonte e } \\
\text { não admitem o uso dos } \\
\text { equipamentos comuns, a não ser } \\
\text { após o emprego de algum } \\
\text { tratamento prévio por meio de } \\
\text { escarificadores ou explosivos de } \\
\text { baixa potência e de forma } \\
\text { descontínua. }\end{array}$ & $\begin{array}{l}\text { Rochas fraturadas e alteradas, solos } \\
\text { saprolíticos muito compactos. }\end{array}$ \\
\hline
\end{tabular}

Fonte: Ricardo, Catalani (1990); Balbo (2007)

Conforme o DER-SP (2006a) as operações de escavação e carga compreendem:

a) escavação e carga do material em áreas de corte até o greide de terraplenagem;

b) escavação e carga de material em áreas de corte situadas abaixo do greide de terraplenagem no caso em que o subleito é constituído por materiais impróprios, na espessura fixada em projeto ou pela fiscalização;

c) escavação e carga de material de degraus ou arrasamentos nos alargamentos de aterros existentes;

d) escavação e carga de material de degraus em terrenos de fundação fortemente inclinados;

e) escavação e carga de material, quando houver necessidade de remoção da camada vegetal, em profundidades superiores a $20 \mathrm{~cm}$;

f) escavação e carga de materiais de área de empréstimos;

g) escavação com equipamento convencional de terraplenagem, destinados à alteração de cursos d'água objetivando eliminar travessias ou posicioná-las de forma mais conveniente em relação ao traçado, os assim chamados corta rios.

\subsubsection{Condicionantes para escolha do processo de escavação}

Em função da quantidade de operações é importante estudar a escavação conforme os aspectos técnicos nela envolvidos (CARDOSO; SHIMIZU, 2002). O processo de escavação dos solos dependerá de inúmeros fatores relacionados 
ao tipo de material, sua localização, as condições gerais da obra, cronograma de execução, aspectos relacionados a custos etc. Toda a seleção de processos de escavação dependerá de estudo preliminar das condições localmente existentes para uma decisão abalizada sobre tipos de máquinas e equipamentos a serem empregados, equipes e serviços de apoio necessários à manutenção dos equipamentos. Na Tabela 7 são apresentados alguns dos fatores que influenciam a tomada de decisão sobre os processos mais adequados de escavação a serem empregados em uma determinada obra.

Tabela 7 - Condicionantes para escolha de processos de escavação

\begin{tabular}{c|c|l}
\hline Condicionantes & Tipos & \multicolumn{1}{c}{ Detalhamento } \\
\hline \multirow{2}{*}{ Naturais } & $\begin{array}{c}\text { Solo a ser } \\
\text { escavado }\end{array}$ & $\begin{array}{l}\text { Características como granulometria e umidade interferem } \\
\text { com o equipamento. }\end{array}$ \\
\cline { 2 - 3 } & $\begin{array}{c}\text { Topografia do } \\
\text { terreno }\end{array}$ & $\begin{array}{l}\text { Terrenos acidentados são limitantes para vários } \\
\text { equipamentos. }\end{array}$ \\
\cline { 2 - 3 } De execução & $\begin{array}{c}\text { Condições } \\
\text { climáticas } \\
\text { locais }\end{array}$ & $\begin{array}{l}\text { Períodos de chuva podem exigir, em consequência dos } \\
\text { solos e caminhos disponíveis na obra, equipamentos } \\
\text { específicos. }\end{array}$ \\
\hline \multirow{2}{*}{ De custos } & $\begin{array}{c}\text { Prazos } \\
\text { Distância de } \\
\text { transporte }\end{array}$ & $\begin{array}{l}\text { O cronograma de execução ajustado ao prazo determinado } \\
\text { para a obra afeta as quantidades de equipamentos. } \\
\text { distâncias entre escavações e a aplicação do material } \\
\text { escavado. Grandes distâncias elevam os custos para a } \\
\text { execução da obra. }\end{array}$ \\
\cline { 2 - 3 } & $\begin{array}{c}\text { Volumes de } \\
\text { escavação }\end{array}$ & $\begin{array}{l}\text { Grandes volumes de escavação e transporte exigem } \\
\text { equipamentos de elevada produção. }\end{array}$ \\
\cline { 2 - 3 } & $\begin{array}{c}\text { Tipo de } \\
\text { equipamento }\end{array}$ & $\begin{array}{l}\text { Equipamentos pesados e de grande porte normalmente } \\
\text { representam maiores custos de investimento e depreciação } \\
\text { ou de aluguel. }\end{array}$ \\
\hline
\end{tabular}

Fonte: Balbo (2007)

\subsubsection{Descrição da execução do processo de escavação}

Para a execução dos cortes, segundo o DNER (1997a) e DER-SP (2006a), as considerações apresentadas a seguir são importantes.

Todas as escavações devem ser executadas nas larguras e com a inclinação dos taludes indicados no projeto.

A operação de escavação deve ser precedida dos serviços de desmatamento, destocamento e limpeza.

A escavação dos cortes deve obedecer aos elementos técnicos fornecidos pelo projeto de terraplenagem e nas notas de serviço.

O desenvolvimento dos trabalhos deve otimizar a utilização adequada, ou rejeição dos materiais extraídos. Apenas são transportados para constituição 
dos aterros, os materiais que pela classificação e caracterização efetuados nos cortes, sejam compatíveis com as especificações de execução dos aterros.

Constatada a conveniência técnica e econômica de reserva de materiais escavados em cortes, para execução de camadas superficiais da plataforma, é recomendável o depósito dos referidos materiais em locais indicados pela fiscalização para sua oportuna utilização.

Os taludes ao final das escavações devem possuir a geometria indicada em projeto e superfície desempenada, obtida pelos equipamentos de escavação.

As cristas de corte e entradas dos taludes devem ser arredondadas e as banquetas, sempre que possível, devem possuir concordância com terreno natural, o que pode envolver escavações não previstas em projeto, cabendo a fiscalização autorizar estas escavações adicionais.

Os taludes em que houver diferentes inclinações, a concordância deve ser contínua, e executada de modo a evitar a formação de elevações e depressões.

Nas áreas de transição de aterros para corte, precedendo este último, a escavação transversal ao eixo deverá ser executada até profundidade necessária para evitar recalques diferenciais. O DER-SP (2006a) trata este assunto da seguinte forma: "deve ser executada a escavação e remoção de 0,60 m abaixo da cota de terraplenagem, na área de corte, na extensão mínima de 2,0 m. O material escavado deve ser substituído por materiais com as mesmas características dos 0,60 m da camada final de aterro" (Figura 10).

SEÇÃO LONGITUDINAL

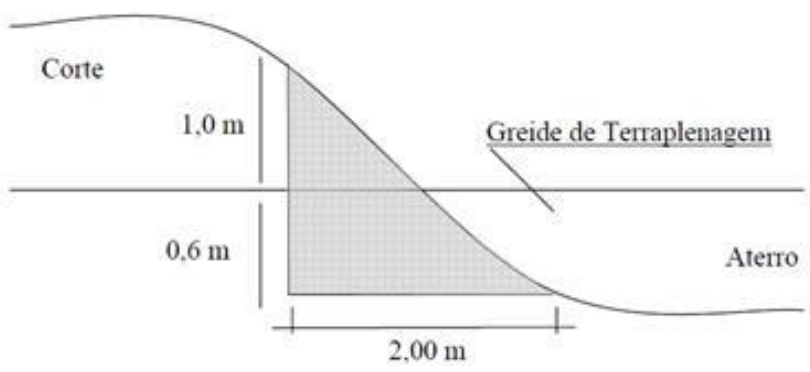

Figura 10 - Área de transição de aterro para corte Fonte: DER-SP (2006a)

Durante a execução dos cortes devem ser implantados, simultaneamente, os dispositivos de drenagem superficial, drenos sub-horizontais e elementos de proteção de talude, indicadas no projeto.

Não devem ser permitidos materiais soltos provenientes de limpeza ou escavação nas proximidades das linhas de off-set's dos cortes. 


\subsubsection{Controles aplicáveis ao processo de escavação}

Os serviços de escavação, desde o princípio, são objeto de controle, sendo previamente necessária a locação topográfica das linhas de offset, da posição do eixo e demais pontos notáveis da plataforma estradal. Na Tabela 8 são apresentados os aspectos mais importantes relacionados aos controles aplicáveis à escavação de solos em obras rodoviárias.

Tabela 8 - Controles aplicáveis a serviços de escavação

\begin{tabular}{|c|c|c|}
\hline Tipo de Controle & Métodos & Objetivo \\
\hline $\begin{array}{c}\text { Locação de } \\
\text { pontos limites de } \\
\text { escavação }\end{array}$ & Locação topográfica & $\begin{array}{l}\text { Evitar alterações de limites de escavação } \\
\text { em planta. }\end{array}$ \\
\hline $\begin{array}{l}\text { Inclinação de } \\
\text { cortes }\end{array}$ & $\begin{array}{l}\text { Taqueometria }{ }^{14} \\
\text { Régua e nível de bolha }\end{array}$ & $\begin{array}{l}\text { Evitar erros grosseiros que poderiam } \\
\text { aumentar muito o volume de escavação. }\end{array}$ \\
\hline $\begin{array}{l}\text { Cotas da } \\
\text { plataforma }\end{array}$ & $\begin{array}{c}\text { Nivelamento e } \\
\text { contranivelamento } \\
\text { geométrico }\end{array}$ & $\begin{array}{l}\text { Variações de cotas de camada final de } \\
\text { terraplenagem dentro de limites toleráveis. }\end{array}$ \\
\hline $\begin{array}{l}\text { Largura de } \\
\text { plataforma }\end{array}$ & Taqueometria & $\begin{array}{l}\text { Manter os padrões projetados de faixas, } \\
\text { acostamentos, canteiros etc. }\end{array}$ \\
\hline $\begin{array}{l}\text { Tipo de material } \\
\text { escavado }\end{array}$ & Por categorias & Estabelecer o tipo e o custo de escavação. \\
\hline $\begin{array}{l}\text { Volumes } \\
\text { escavados }\end{array}$ & $\begin{array}{l}\text { Cálculo de áreas e } \\
\text { volumes no corte com } \\
\text { auxílio de topografia }\end{array}$ & $\begin{array}{l}\text { Checar precisamente os volumes } \\
\text { escavados. }\end{array}$ \\
\hline $\begin{array}{c}\text { Volume } \\
\text { transportado }\end{array}$ & $\begin{array}{l}\text { Distância média de } \\
\text { transporte }\end{array}$ & $\begin{array}{l}\text { Checar precisamente a distância entre local } \\
\text { de escavação e destino do material. }\end{array}$ \\
\hline
\end{tabular}

\subsubsection{Equipamentos para escavação de solos}

Os equipamentos de terraplenagem são divididos em grupos de acordo com sua principal função (ROCHA, 2009). A terminologia das máquinas e equipamentos de terraplenagem é normalizada pela NBR 6141, ABNT (1996). As máquinas empregadas na execução de escavação de material de $1^{\underline{a}}$ e $2^{\underline{a}}$ categorias são descritas na Tabela 9. Os equipamentos listados referem-se apenas àqueles empregados em escavações de jazidas e cortes. Na Figura 11 são apresentadas as máquinas mais tipicamente empregadas nos serviços de escavação de solos para construção viária.

\footnotetext{
${ }^{14}$ A taqueometria, do grego "takhys" (rápido), "metren" (medição), compreende uma série de operações que constituem um processo rápido e econômico para a obtenção indireta da distância horizontal e diferença de nível. Disponível em: < http://www.ufrgs.br /geodesia/trabalhosdidaticos/Topografia_IProfa_\%20Andrea_Jelinek/Teoria/Taqueometria.pdf. Acessado em: 05/10/2011.
} 
Tabela 9 - Tipos de máquinas para escavação de solos

\begin{tabular}{c|c|c|c}
\hline $\begin{array}{c}\text { Unidades de } \\
\text { escavação }\end{array}$ & Tipo & Características & $\begin{array}{c}\text { Aplicações e } \\
\text { limitações }\end{array}$ \\
\hline $\begin{array}{c}\text { Escavo } \\
\text { empurradoras }\end{array}$ & $\begin{array}{c}\text { Tratores com implementação } \\
\text { de lâmina frontal ou } \\
\text { escarificador traseiro (para } \\
\text { desmonte prévio de material } \\
\text { de 2 } 2^{\text {a }} \text { categoria). }\end{array}$ & $\begin{array}{c}\text { De pneus para terrenos } \\
\text { planos e bom suporte. } \\
\text { De esteiras para terrenos } \\
\text { ingremes, baixo suporte ou } \\
\text { pouca aderência. }\end{array}$ & $\begin{array}{c}\text { Pequenas distâncias } \\
\text { (até } 50 \text { m). } \\
\text { Empurra, não carrega. }\end{array}$ \\
\hline $\begin{array}{c}\text { Escavo } \\
\text { transportadoras }\end{array}$ & $\begin{array}{c}\text { Scraper rebocado com } \\
\text { tratores de esteiras } \\
\text { Moto-scraper (só pneus). }\end{array}$ & $\begin{array}{c}\text { Os moto-scrapers podem ter } \\
\text { um ou dois motores e tração } \\
\text { nas quatro rodas; possuem } \\
\text { lâmina de corte móvel no } \\
\text { fundo da caçamba. }\end{array}$ & $\begin{array}{c}\text { Scrapers rebocados } \\
\text { são para distâncias de } \\
\text { até 200 m; moto- } \\
\text { scrapers, de 100 m a } \\
1.000 \text { m. }\end{array}$ \\
\hline carregadeiras & Pás-carregadeiras & $\begin{array}{c}\text { Tratores sobre esteiras ou } \\
\text { pneus com caçamba frontal } \\
\text { carregadeira. }\end{array}$ & $\begin{array}{c}\text { Dependem de unidades } \\
\text { específicas para o } \\
\text { transporte. }\end{array}$ \\
\cline { 2 - 5 } & Escavadeiras ou & $\begin{array}{c}\text { Trator sobre plataforma com } \\
\text { esteira ou pneus com lança } \\
\text { e pá frontal (shovel). }\end{array}$ & $\begin{array}{c}\text { Dependem de unidades } \\
\text { específicas para o } \\
\text { transporte. }\end{array}$ \\
\hline
\end{tabular}

Fonte: Balbo (2007)

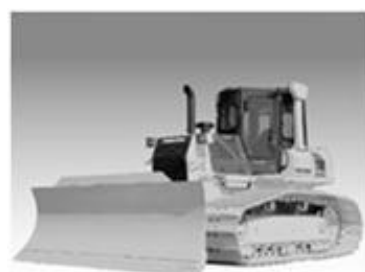

(a)

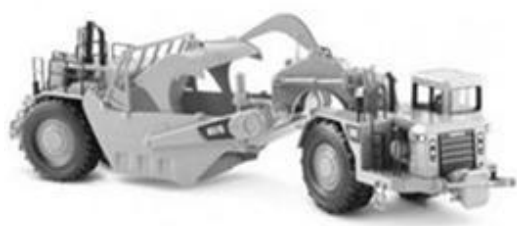

(c)

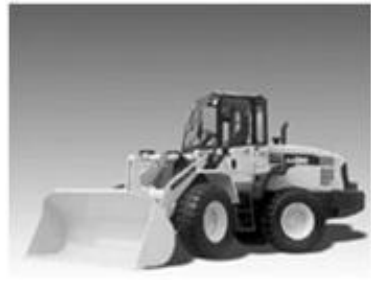

(e)

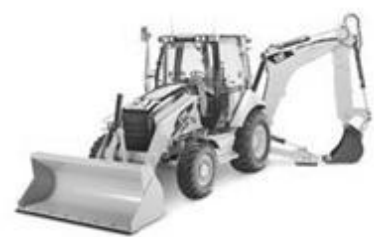

(g)

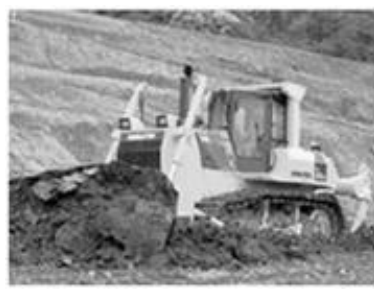

(b)

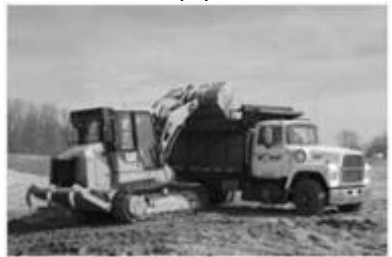

(d)

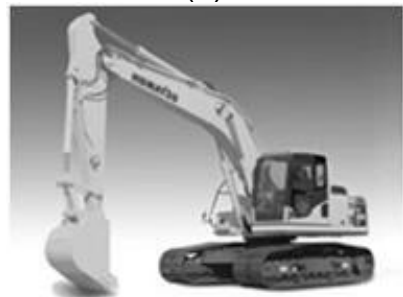

(f)

Figura 11 - a) trator de esteira com lâmina frontal ${ }^{15}$; b) trator de esteira com lâmina frontal e escarificador traseiro ${ }^{16}$; c) moto-scraper ${ }^{17}$; d) pá carregadeira sobre esteiras ${ }^{18}$; e) pá carregadeira sobre pneus $^{19}$; f) escavadeira hidráulica ${ }^{20}$; g) retroescavadeira ${ }^{21}$.

\footnotetext{
${ }^{15}$ Komatsu (2012a)
} 


\subsubsection{Formação de equipes de escavação}

O dimensionamento de máquinas e de equipes mecânicas ${ }^{22}$ é controlado pela produção horária e afeta diretamente os custos de execução dos serviços. Sua formação está relacionada aos tipos de equipamentos utilizados ou disponíveis. Neste contexto, em termos qualitativos, pode-se encontrar (Tabela 10) exemplos de formações de equipes de escavação e carga de material de $1^{\underline{a}}$ categoria.

Tabela 10 - Formações de patrulhas para escavação

\begin{tabular}{l|c|c}
\hline \multicolumn{1}{c|}{ Discriminação } & \multicolumn{2}{c}{$\begin{array}{c}\text { Exemplo de } \\
\text { patrulha }\end{array}$} \\
\hline Escavação e carga material de $1^{\text {a }}$ categoria $\left(\mathrm{m}^{3}\right)$ & $1^{\mathrm{a}}$ & $2^{\mathrm{a}}$ \\
\hline Trator de esteiras, com lâmina & $\mathrm{x}$ & - \\
\hline Carregadeira de pneus & $\mathrm{x}$ & - \\
\hline Escavadeira hidráulica - sobre esteira & - & $\mathrm{x}$ \\
\hline
\end{tabular}

No exemplo dado, a 1 $1^{\text {a }}$ patrulha é formada de trator de esteiras (escava o material e o amontoa) e carregadeira de pneus (carrega o caminhão) e a $2^{\text {a }}$ patrulha é formada de escavadeira hidráulica (escava o material e carrega 0 caminhão).

\subsubsection{Empréstimos}

A escavação em empréstimos visa obter materiais para a complementação de volumes necessários à constituição dos aterros, por insuficiência do volume de cortes, ou por motivos de ordem tecnológica de seleção de materiais, ou de ordem econômica.

\footnotetext{
${ }^{16}$ Komatsu (2012b)

${ }_{17}^{17}$ Worldwide Machinery (2012)

${ }^{18}$ Caterpillar (2012a)

${ }^{19}$ Komatsu (2012c)

${ }^{20}$ Komatsu (2012d)

${ }^{21}$ Caterpillar (2012b)

22 Também conhecido pelo nome de "patrulha".
} 
Dependendo do volume e da qualidade dos materiais pode-se classificar dois tipos distintos de empréstimos: laterais ${ }^{23}$ e concentrados (ou localizados) ${ }^{24}$.

\subsubsection{Aterros}

Segundo o DNER (1997b) e o DER-SP (2006b), aterros são segmentos da rodovia cuja implantação requer deposição de materiais provenientes de cortes ou de empréstimos, no interior dos limites das seções de projeto ("offsets") que definem o corpo estradal ou, a substituição de materiais inadequados, previamente removidos do subleito dos cortes ou materiais existentes na fundação dos próprios aterros.

Para o entendimento deste conceito. De acordo com o DER-SP (2006b), são adotadas também as seguintes definições:

a) corpo de aterro: parte do aterro constituída de material lançado e compactado em camadas de espessuras uniformes, situadas no horizonte entre o terreno natural e a linha delimitadora do início da camada final do aterro;

b) camada final: parte do aterro constituído de material selecionado lançado e compactado em camadas de espessuras uniformes, situadas no horizonte entre o greide de terraplenagem e o corpo de aterro.

As operações de aterro compreendem:

a) a descarga;

b) o espalhamento;

c) o nivelamento;

\footnotetext{
${ }^{23}$ Os empréstimos laterais são escavações efetuadas sempre dentro da faixa de domínio. No caso de segmentos de cortes se processa o alargamento da plataforma com consequente deslocamento dos taludes e no caso de aterro, escavações do tipo "valetões" em um ou ambos os lados são executados.

${ }^{24}$ Os empréstimos concentrados são definidos por escavações efetuadas em áreas fora da faixa de domínio, em locais que contenham materiais em quantidade e qualidade adequada para confecção dos aterros. A utilização desses ocorre quando não existem materiais adequados nas faixas laterais dos cortes ou aterros para efetivação de empréstimos laterais, ou quando esses últimos não proporcionam a retirada do volume total necessário.
} 
d) conveniente umedecimento ou aeração (contempla a mistura do material visando a homogeneidade ou o revolvimento do material para perder umidade);

e) e a compactação dos materiais.

\subsubsection{Condicionantes para a escolha do processo de compactação}

Em razão da extrema diversidade dos solos e da variedade de equipamentos disponíveis, a compactação é um trabalho difícil de predeterminar com segurança a forma mais rápida e econômica de executá-la (RICARDO, CATALANI, 1990). O conhecimento dos condicionantes que influem na execução é um facilitador no controle do processo de compactação. Segundo Balbo (2007), há muitos anos, os processos de controle de compactação a posteriori têm sido substituídos por processo de controle a priori, como ocorre no Reino Unido e na França. $\mathrm{Na}$ Tabela 11, são apresentadas algumas condicionantes e suas implicações para o processo de compactação dos solos.

Tabela 11 - Condicionantes e implicações para a compactação

\begin{tabular}{|c|c|c|}
\hline Condicionante & Aspecto & Implicações \\
\hline \multirow{4}{*}{ Equipamento } & Tipo de cilindro ou rolo & $\begin{array}{l}\text { A forma da superfície deve ser adequada ao } \\
\text { tipo de solo. }\end{array}$ \\
\hline & Peso do rolo & $\begin{array}{l}\text { Atingir a compactação adequada no fundo da } \\
\text { camada. }\end{array}$ \\
\hline & Comprimento do rolo & Distribuição linear do peso do rolo. \\
\hline & Velocidade de rolagem & $\begin{array}{l}\text { Valores acima de } 2 \mathrm{~km} / \mathrm{h} \text { dificultam o ganho } \\
\text { de peso específico. }\end{array}$ \\
\hline \multirow{4}{*}{$\begin{array}{l}\text { Solo (ou outro } \\
\text { material) a ser } \\
\text { compactado }\end{array}$} & Umidade & $\begin{array}{l}\text { Deve estar dentro de faixas toleráveis para } \\
\text { permitir o GC* desejado; deve ser } \\
\text { homogênea; umidade excessiva torna os } \\
\text { solos argilosos muito plásticos. }\end{array}$ \\
\hline & Granulometria & Define o tipo de rolo a ser empregado. \\
\hline & Homogeneidade & $\begin{array}{l}\text { Fundamental para se evitar a segregação nos } \\
\text { agregados bem graduados. }\end{array}$ \\
\hline & Espessura da camada & $\begin{array}{l}\text { Camadas espessas exigem grande energia e } \\
\text { muitas passagens de rolo para atingir massa } \\
\text { específica de fundo. }\end{array}$ \\
\hline $\begin{array}{l}\text { Suporte da camada } \\
\text { de apoio }\end{array}$ & $\begin{array}{l}\text { Deformabilidade da } \\
\text { camada inferior }\end{array}$ & $\begin{array}{l}\text { Quanto maior for sua deformabilidade, maior } \\
\text { será o número de passadas. }\end{array}$ \\
\hline
\end{tabular}

Fonte: Balbo (2007) 
${ }^{*}$ Chama-se grau de compactação ${ }^{25}$ (GC), o quociente da divisão do peso específico obtido no campo, pelo peso específico máximo obtido no laboratório (Equação 1).

Eq. 1

\subsubsection{Descrição da execução do processo de aterro}

O início das operações deve ser precedido da execução dos serviços de desmatamento, destocamento e limpeza.

No caso de execução de aterros a meia encosta, onde o terreno natural possui inclinação acentuada (o DER-SP adota: superior a 25\%), o talude deve ser previamente cortado em degraus (o DER-SP adota: com altura aproximada de $1,0 \mathrm{~m}$ ) antes do lançamento do material para execução da respectiva camada de aterro.

A execução das camadas deve ser iniciada pelo lado mais baixo, os degraus executados no talude devem ter largura suficiente para deslocamento dos equipamentos ao realizar as operações de descarga e compactação das camadas lançadas.

Os cortes horizontais para formação dos degraus devem ser iniciados na interseção do terreno natural com a superfície da última camada lançada e compactada. O material resultante da escavação deve ser espalhado e compactado no aterro em execução, se a quantidade de material for insuficiente, resultando uma camada muito delgada, isto é, inferior as espessuras definidas nesta especificação, deve ser adicionado mais material de aterro para completar a espessura. Os materiais devem ser misturados, homogeneizados e compactados em única camada.

Nos alargamentos de aterros ou no caso de correções de erosões, o talude existente deve ser cortado em degraus, com largura suficiente para permitir as operações de deposição, espalhamento e compactação do material.

Os cortes horizontais no aterro antigo devem ser executados conforme 0 especificado para aterros na meia encosta. A superfície das camadas compactadas deve possuir inclinação para fora do aterro de alargamento ou

${ }^{25}$ Brasil (2006) 
correção, a fim de não acumular água de chuva nos pontos de junção do aterro antigo com o aterro novo.

Desde o início das obras até seu recebimento, os aterros construídos ou em construção devem ser protegidos contra ação erosiva das águas e mantidos em condições que assegurem a drenagem eficiente.

Nos aterros de acesso de encontros das pontes, o enchimento das cavas das fundações e as trincheiras de bueiros, bem como todas as áreas de difícil acesso ao equipamento usual de compactação, devem ser compactadas com o uso de equipamento adequado, como soquetes manuais e sapos mecânicos.

Em regiões onde houver predominância de areia, admite-se a execução de aterros com seu emprego, desde que previsto em projeto. Exige-se a proteção das camadas de areia, através da execução de camadas subsequentes, na espessura definida em projeto, com material terroso devidamente compactado.

Durante todo o tempo que durar a construção, até o recebimento do aterro, os materiais e os serviços devem estar protegidos contra ação destrutiva das águas pluviais, do trânsito e de outros agentes que possam danificá-los. A responsabilidade desta conservação é da executante e não é objeto de medição.

\section{a) Aterro em Solo}

Os aterros devem ser executados em camadas sucessivas, com espessura solta, definida pela fiscalização, em função das características geotécnicas do material e do equipamento de compactação utilizado. O lançamento do material deve ser feito em camadas sucessivas em toda largura da seção transversal e em extensões tais que permitam seu umedecimento e compactação.

São aceitas camadas compactadas com espessuras superiores a $15 \mathrm{~cm}$, desde que autorizadas pela fiscalização e comprovadas em aterro experimental, isto é, desde que o equipamento utilizado confira o grau de compactação exigido de 100\% em relação ao Proctor Normal ${ }^{26}$, conforme NBR 7182 (1986). Admitem-se

\footnotetext{
${ }^{26}$ Ensaio de Proctor (Normal, Intermediário ou Modificado) é realizado através de sucessivos impactos de um soquete padronizado na amostra. Por meio deste ensaio é possível obter a correlação entre o teor de umidade e o peso específico aparente seco de um solo quando compactado com determinada energia (NBR 7182, 1986). Peso especifico (é o quociente do peso do material e o seu volume).
} 
espessuras de até $30 \mathrm{~cm}$ de espessura para as camadas do corpo do aterro e do máximo $20 \mathrm{~cm}$ para as camadas finais de aterro, isto é, o último um metro.

As camadas individuais do aterro devem ser constituídas preferencialmente por material homogêneo. Quando os materiais provenientes da escavação forem heterogêneos, os materiais devem ser misturados com emprego de grades de disco e motoniveladoras, a fim de se obter, ao final destas operações, a homogeneidade do material.

Durante a compactação das camadas de aterro, o equipamento deve se deslocar sobre a camada de maneira a proporcionar a cobertura uniforme de toda área. A compactação deve ser realizada com equipamentos adequados ao tipo de solo.

As condições de compactação exigidas para aterro e as variações de umidade admitidas são:

- a variação do teor de umidade admitido para o material do corpo de aterro é de $\pm 3 \%$ em relação a umidade ótima de compactação e o grau de compactação mínimo exigido é de $95 \%$ em relação ao peso específico aparente seco máximo conforme NBR 7182 (1986), na energia normal;

- para as camadas situadas no último um metro, camada final de aterro, a variação de umidade do material admitida é de $\pm 3 \%$ para as camadas iniciais, e de $\pm 2 \%$ para as três últimas camadas, em relação à umidade ótima de compactação determinado conforme NBR 7182 (1986), na energia adotada para compactação do material;

- o grau de compactação exigido para as camadas finais situadas no último um metro é de $100 \%$ em relação ao peso específico aparente seco máximo, determinada conforme NBR 7182 (1986), na energia adotada para compactação do material.

A energia de compactação a ser adotada deve ser a maior energia que o material empregado suporte, perante as condições dos equipamentos utilizados. Deve-se assegurar que os valores obtidos para o $\mathrm{CBR}^{27}$ sejam superiores ou

\footnotetext{
${ }^{27}$ Índice de Suporte Califórnia (ISC) ou California Bearing Ratio (CBR). O ensaio de CBR consiste na determinação da relação entre a pressão necessária para produzir uma penetração de um pistão num corpo de prova de solo, e a pressão necessária para produzir a mesma penetração numa brita padronizada. $O$ valor dessa relação, expressa em percentagem, permite determinar, por meio de equações empíricas, a espessura de pavimento flexível necessária, em função do tráfego. (BRASIL, 2006). Os resultados são influenciados pela textura, pela massa específica e pela umidade do solo ou material granular em estudo (BALBO, 2007).
} 
iguais ao previsto no projeto, bem como as expansões sejam inferiores às especificadas também em projeto.

\section{b) Camada Final}

Conforme o DER-SP (2006b), os materiais empregados na execução da camada final de terraplenagem, quando não estiver definido no projeto, devem possuir as seguintes características:

- $\quad$ pertencer aos grupos de classificação $\mathrm{MCT}^{28}$, especificados em projeto;

- nos 0,30 m iniciais os solos devem possuir CBR > $3 \%$ e expansão $\leq 2 \%$;

- nos 0,40 m intermediários os solos devem possuir CBR > 5\% e expansão $\leq$ $2 \%$;

- nos 0,30 m finais, os solos devem possuir CBR > 10\% e expansão $\leq 2 \%$;

- nos cortes onde o material do subleito não apresentar CBR mínimo de 10\%, deve ser feita a substituição do material, numa espessura mínima de 0,40 m, com materiais que atendam os parâmetros CBR $\geq 10 \%$ e expansão $\leq 2 \%$.

\subsubsection{Controles aplicáveis ao processo de aterro}

Do ponto de vista de comportamento mecânico, a compactação dos solos é realizada para atingir as características desejáveis em termos de resistência e de módulo de resiliência, que naturalmente estão associados ao nível de densificação atingido pelo material (BALBO, 2007). A Tabela 12 apresenta os tipos de controle tecnológico aplicáveis ao processo de aterro.

\footnotetext{
${ }^{28}$ MCT: M - miniatura; C - compactação; $T$ - tropical. Baseado em propriedades mecânicas e hidráulicas de solos compactados (DER-SP, 1989).
} 
Tabela 12 - Controles aplicáveis ao processo de aterro

\begin{tabular}{|c|c|}
\hline Fase & Tipo de Controle \\
\hline \multirow{4}{*}{ Materiais } & CBR e expansão na energia normal. \\
\hline & CBR e expansão na energia adotada para compactação. \\
\hline & Classificação MCT e perda de massa por imersão. \\
\hline & Análise granulométrica. \\
\hline \multirow{4}{*}{$\begin{array}{l}\text { Execução } \\
\text { (ensaios e } \\
\text { verificações in situ) }\end{array}$} & Determinação do teor de umidade. \\
\hline & Determinação do peso específico seco máximo e umidade ótima. \\
\hline & Determinação do peso específico in situ e da umidade in situ. \\
\hline & $\begin{array}{l}\text { Verificação da espessura do material solto lançado no aterro, e } \\
\text { acompanhamento do número de passadas do equipamento }{ }^{29} \text {, ida e } \\
\text { volta. }\end{array}$ \\
\hline \multirow{2}{*}{ Geométrico } & Controle de espessura e cotas. \\
\hline & Controle da largura e alinhamentos. \\
\hline
\end{tabular}

Fonte: adaptado de DER-SP (2006b)

\subsubsection{Equipamentos para execução de compactação}

Cada tipo de solo necessita de emprego de equipamento adequado de compactação. Existe uma grande variedade de tipos e marcas de equipamentos de compactação no mercado, e, na Tabela 13, apresenta-se uma visão geral deles. Exemplos dos equipamentos, incluindo outros equipamentos além dos compactadores, encontram-se na Figura 12.

${ }^{29}$ O número de passadas do equipamento é definido em função do tipo de equipamento utilizado, das características geotécnicas do material e do grau de compactação exigido para a respectiva camada. O número de passadas deve ser constante para camadas similares. 
Tabela 13 - Tipos de equipamentos de compactação.

\begin{tabular}{|c|c|c|c|c|c|}
\hline \multirow{2}{*}{$\begin{array}{c}\text { Classificação dos } \\
\text { rolos } \\
\text { compactadores }\end{array}$} & \multirow[b]{2}{*}{ Tipo } & \multirow{2}{*}{$\begin{array}{l}\text { Esforço de } \\
\text { compactação }\end{array}$} & \multicolumn{3}{|c|}{ Características básicas } \\
\hline & & & $\begin{array}{c}\text { Forma de } \\
\text { compactação. }\end{array}$ & $\begin{array}{l}\text { Tipos de } \\
\text { solos }\end{array}$ & $\begin{array}{l}\text { Espessura. } \\
\text { Acabada }\end{array}$ \\
\hline \multirow{3}{*}{ Metálicos } & Liso & $\begin{array}{l}\text { Pressão/ } \\
\text { vibração }\end{array}$ & $\begin{array}{l}\text { Da superfície } \\
\text { para o fundo. }\end{array}$ & $\begin{array}{c}\text { Areias, } \\
\text { arenosos, } \\
\text { granulares }\end{array}$ & $400 \mathrm{~mm}$ \\
\hline & $\begin{array}{l}\text { De grade ou } \\
\text { de grelha }\end{array}$ & Pressão & $\begin{array}{l}\text { Da superfície } \\
\text { para o fundo. }\end{array}$ & $\begin{array}{c}\text { Fragmento } \\
\mathrm{s} \text { grossos } \\
\text { de } \\
\text { desmonte } \\
\text { de rocha. }\end{array}$ & $200 \mathrm{~mm}$ \\
\hline & $\begin{array}{l}\text { Pé de } \\
\text { carneiro }\end{array}$ & Amassamento & $\begin{array}{l}\text { Do fundo para } \\
\text { a superfície; } \\
\text { grande número } \\
\text { de passadas. }\end{array}$ & $\begin{array}{c}\text { Argila e } \\
\text { argilosos. }\end{array}$ & $400 \mathrm{~mm}$ \\
\hline Pneumáticos & $\begin{array}{l}\text { Lisos ou } \\
\text { ranhurados }\end{array}$ & $\begin{array}{l}\text { Pressão } \\
\text { (regulável) }\end{array}$ & $\begin{array}{c}\text { Com quatro } \\
\text { rodas } \\
\text { dianteiras e } \\
\text { cinco traseiras, } \\
\text { possui pressão } \\
\text { variável e } \\
\text { lastro. }\end{array}$ & \begin{tabular}{|c} 
Quase \\
todos os \\
tipos, \\
exceto \\
areias e \\
agregados \\
uniformes.
\end{tabular} & $\begin{array}{l}150 \mathrm{~mm} \\
\text { (rolos leves) } \\
350 \mathrm{~mm} \\
\text { (rolos } \\
\text { pesados) }\end{array}$ \\
\hline \multirow{2}{*}{ Combinados } & $\begin{array}{l}\text { Pneumático/ } \\
\text { liso metálico }\end{array}$ & $\begin{array}{l}\text { Pressão/ } \\
\text { vibração }\end{array}$ & $\begin{array}{l}\text { Da superfície } \\
\text { para o fundo. }\end{array}$ & $\begin{array}{l}\text { Quase } \\
\text { todos os } \\
\text { tipos. }\end{array}$ & $200 \mathrm{~mm}$ \\
\hline & $\begin{array}{c}\text { Pneumático/ } \\
\text { pé de } \\
\text { carneiro } \\
\end{array}$ & $\begin{array}{c}\text { Pressão/ } \\
\text { amassamento }\end{array}$ & $\begin{array}{l}\text { Do fundo para } \\
\text { a superfície. }\end{array}$ & $\begin{array}{l}\text { Argilas, } \\
\text { argilosos. }\end{array}$ & $200 \mathrm{~mm}$ \\
\hline
\end{tabular}

Fonte: Balbo (2007) 


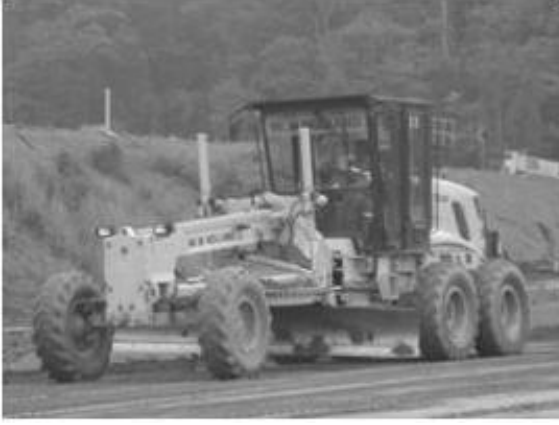

(a)

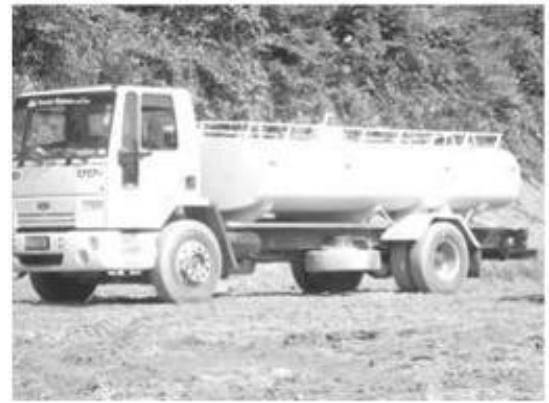

(c)

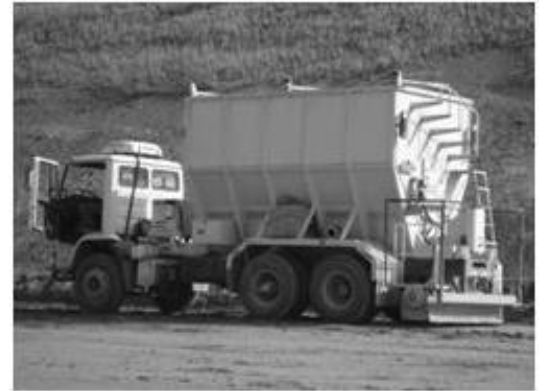

(e)

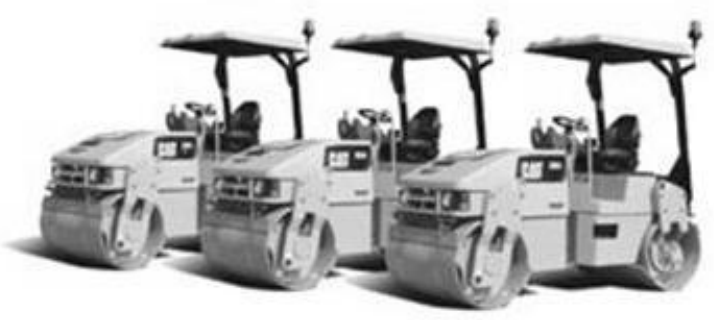

(g)

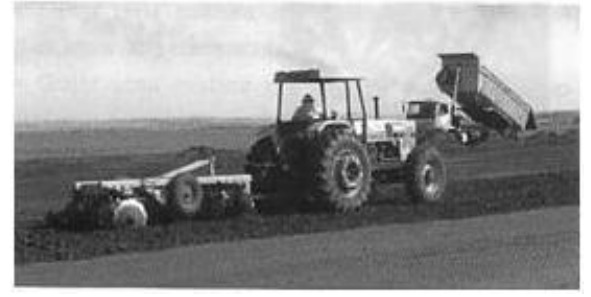

(b)

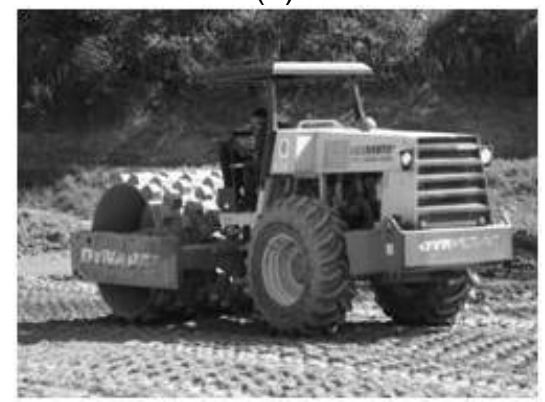

(d)

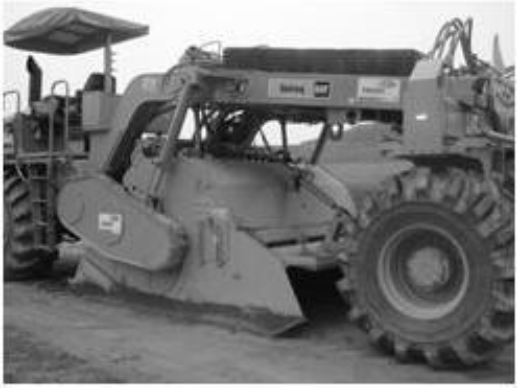

(f)

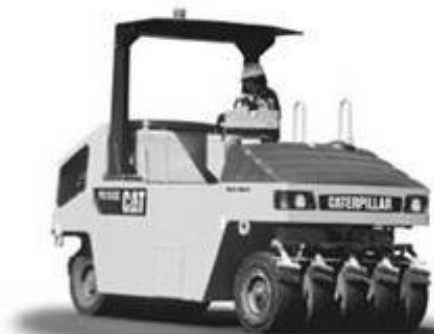

(h)

Figura 12 - a) espalhamento com motoniveladora; b) aeração do solo com grade de disco $^{30}$; c) tratamento da umidade com caminhão tanque; d) compactação de solo com rolo pé de carneiro; e) caminhão distribuidor de cimento; f) recicladora (mistura o solo com o cimento); g) rolo liso metálico para compactação de pavimento ${ }^{31}$; h) rolo de pneus para compactação de pavimento ${ }^{32}$.

\footnotetext{
${ }^{30}$ Balbo (2007)

${ }^{31}$ Caterpillar (2012c)

${ }^{32}$ Caterpillar (2012d)
} 


\subsubsection{Formação de equipes}

O dimensionamento do conjunto de equipamentos (patrulhas) é controlado pela produção horária e afeta diretamente os custos de execução dos serviços. Sua formação está relacionada aos tipos de equipamentos utilizados ou disponíveis. Neste contexto, em termos qualitativos, a Tabela 14 apresenta um exemplo de formação de equipe de compactação de aterros.

Tabela 14 - Formação de patrulha para compactação

\begin{tabular}{l|c}
\hline \multicolumn{1}{c|}{ Compactação de aterros, em camadas de $\mathbf{2 0 c m}-\mathbf{m}^{3}$} & $\begin{array}{c}\text { Exempão } \\
\text { patrulha }\end{array}$ \\
\hline Trator de esteiras com lâmina & $\mathrm{x}$ \\
\hline Caminhão Tanque & $\mathrm{x}$ \\
\hline Trator Agrícola com grade de discos rebocável & $\mathrm{x}$ \\
\hline Motoniveladora & $\mathrm{x}$ \\
\hline Rolo compactador pé de carneiro vibratório autopropelido & $\mathrm{x}$ \\
\hline
\end{tabular}

No exemplo dado, o trator de esteiras com lâmina espalha o solo (descarregado pelos caminhões), o caminhão tanque umedece o solo buscando a umidade de projeto (se necessário), o trator agrícola com grade de discos homogeneíza o solo (se necessário), a motoniveladora nivela a camada e o rolo compactador pé de carneiro efetua a compactação da camada.

\subsubsection{Depósito de materiais excedentes - DME}

Os depósitos de materiais excedentes ${ }^{33}$ são os volumes de materiais que, por excesso ou por condições geotécnicas insatisfatórias, são escavados nos cortes e destinados a depósitos em áreas alheias à construção rodoviária, ou seja: são os volumes de materiais escavados não utilizáveis na terraplenagem.

\footnotetext{
${ }^{33}$ O termo "bota-fora" foi substituído pelo termo Depósito de Materiais Excedentes - DME.
} 


\subsection{Composições Orçamentárias Aplicáveis à Terraplenagem}

Dentre as opções para a constituição da terraplenagem, a execução de corte e aterro foram mais detalhadas neste capítulo. Cada um dos elementos de corte e aterro pode demandar esforços diferentes na sua produção. Assim, para melhor entender a produtividade, adota-se a abordagem analítica, isto é, que leva em consideração as diferentes partes que constituem o serviço a executar (quebra do serviço).

A proposição da quebra dos serviços de corte e aterro leva em consideração todo o conhecimento adquirido por meio do estudo bibliográfico, dos manuais e da experiência acumulada nos estudos de caso. Portanto, embora alguns destes assuntos sejam apresentados nos demais capítulos, eles contribuíram para o entendimento da quebra dos serviços de terraplenagem.

A quebra do serviço de execução de escavação do solo de $1^{1}$ a categoria pode ser expressa como apresentada na Figura 13.

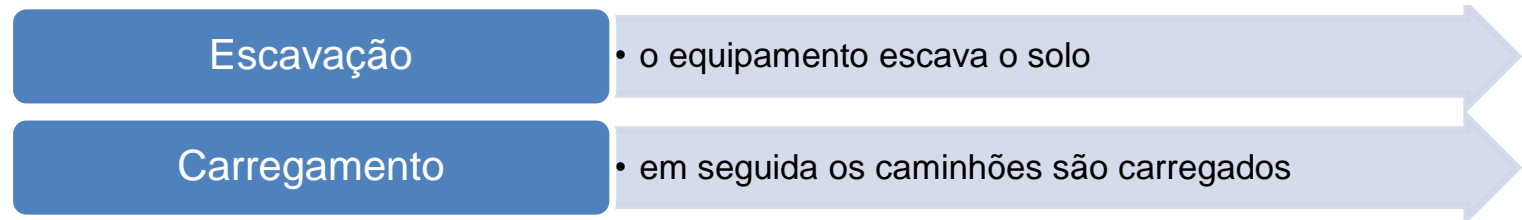

Figura 13 - Quebra do serviço de escavação e carga de material de $1^{\text {a }}$ categoria

A quebra do serviço de compactação de aterro pode ser expressa como apresentada na Figura 14.

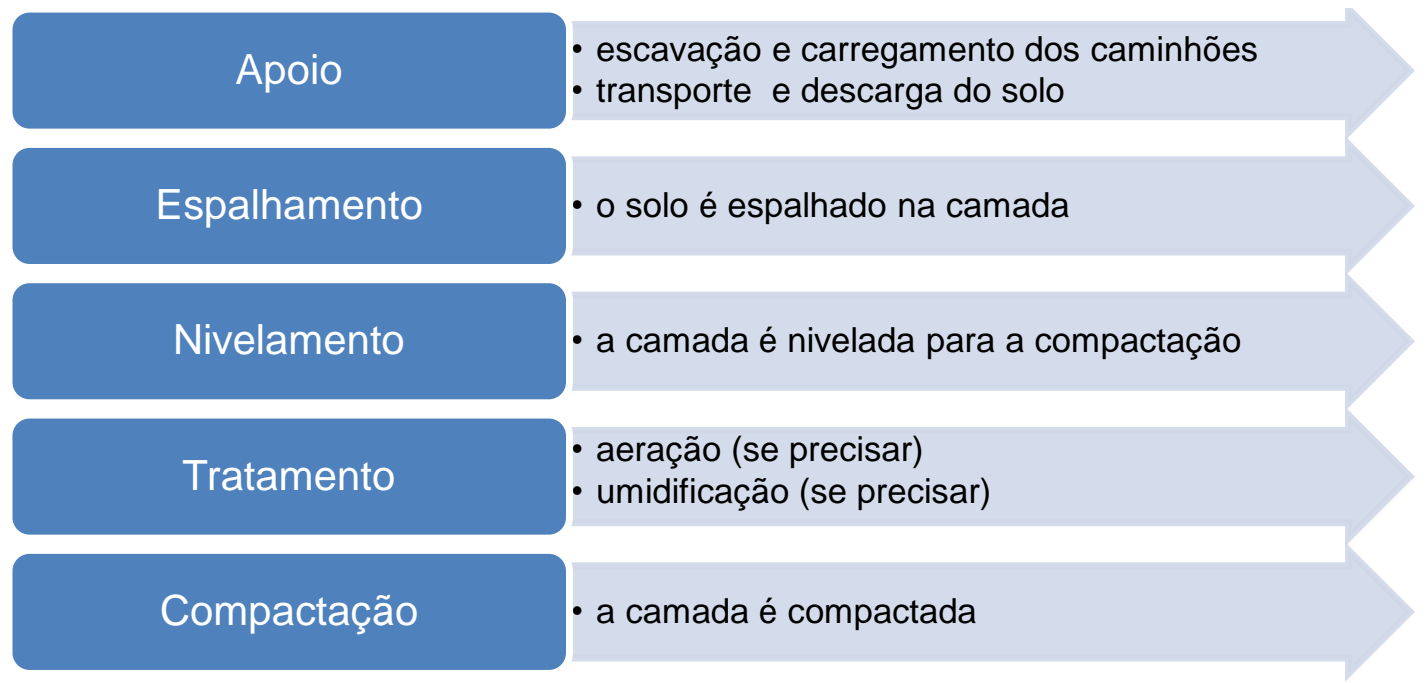

Figura 14 - Quebra do serviço de compactação de aterro 
$\mathrm{Na}$ medida em que se pretende entender os custos de terraplenagem, é importante conhecer a demanda relativa a cada um dos dois serviços (corte e aterro). O entendimento das partes de cada serviço possibilitou a proposição dos tipos e das quantidades de composições orçamentárias apresentadas a seguir:

a) Cortes

- escavação,

- carga.

b) Aterros

- espalhamento,

- nivelamento,

- tratamento (aeração e/ou umidificação - se precisar),

- compactação.

\subsection{Reflexões do Capítulo 2}

Este capítulo possibilitou o entendimento geral do serviço de terraplenagem na execução de rodovias. Em especial, as modalidades de serviço de corte e aterro foram apresentadas. As condicionantes para a escolha dos processos construtivos e os controles aplicáveis subsidiarão a proposição dos fatores. 0 conhecimento dos tipos de equipamentos e as formações de equipes embasarão o entendimento relativo à produtividade variável e a proposição de faixas de valores. A quebra dos serviços subsidiará a definição da quantidade de composições orçamentárias a serem propostas nos capítulos subsequentes. 


\section{SERVIÇO DE PAVIMENTAÇÃO ASFÁLTICA}

Neste capítulo apresenta-se o serviço de pavimentação asfáltica. Inicia com a conceituação geral. Em seguida abordam-se as etapas de serviço relacionadas às quatro camadas principais de um pavimento: revestimento asfáltico, base, sub-base e reforço do subleito. Finaliza-se com a apresentação das composições orçamentárias aplicáveis à pavimentação asfáltica.

\subsection{Pavimentação Asfáltica - Entendimento Geral}

Pavimento é a estrutura constituída sobre a terraplenagem e destinada, técnica e economicamente a: resistir aos esforços verticais oriundos do tráfego e distribuí-los; melhorar as condições de rolamento quanto ao conforto e segurança; resistir aos esforços horizontais (desgaste), tornando mais durável a superfície de rolamento (PAPACOSTAS; PREVEDOUROS, 2005; SENÇO, 2008a).

Neste sentido, os pavimentos asfálticos são aqueles em que o revestimento é composto por uma mistura constituída basicamente de agregados e ligantes asfálticos. Segundo Bernucci et al. (2007) e Balbo (2007), os pavimentos asfálticos são formados por quatro camadas principais: revestimento asfáltico, base, sub-base e reforço do subleito. O revestimento asfáltico pode ser composto por camada de rolamento - em contato direto com as rodas dos veículos e por camadas intermediárias ou de ligação, por vezes denominadas de binder. Dependendo do tráfego e dos materiais disponíveis, pode-se ter ausência de algumas camadas. As camadas da estrutura repousam sobre 0 subleito, ou seja, a plataforma da estrada terminada após a conclusão dos cortes e aterros (Figura 15). 


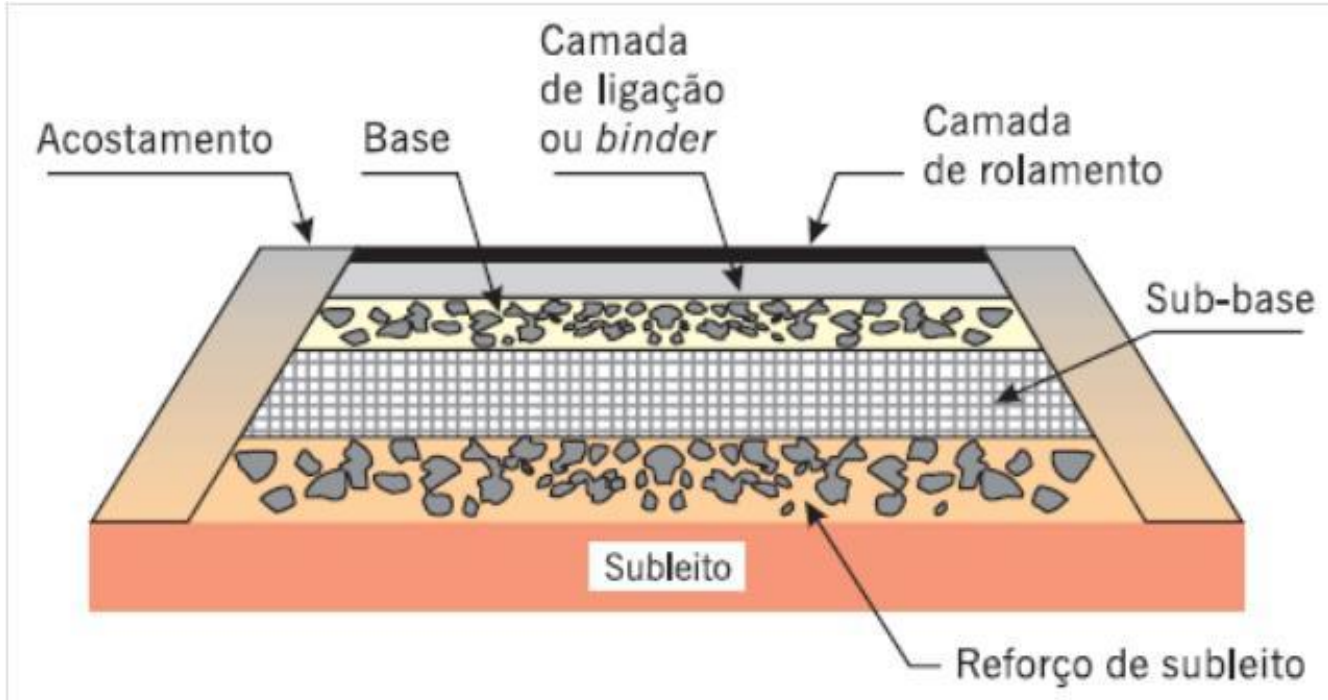

Figura 15 - Exemplo de estrutura de pavimento asfáltico Fonte: Bernucci et al. (2007)

Os pavimentos asfálticos são estruturas multicamadas (ver Tabela 15) com a finalidade de suportar esforços de uma combinação entre a ação das cargas do tráfego e os efeitos do clima, com variações de temperatura e umidade ao longo do tempo (VILLELA, 2012).

Tabela 15 - Exemplos de aplicações dos materiais em camadas de pavimentos.

\begin{tabular}{c|l}
\hline Camada & \multicolumn{1}{c}{ Materiais } \\
\hline Revestimento & Concreto asfáltico usinado à quente. \\
\hline Base & Brita graduada tratada com cimento. \\
\hline Sub-base & Brita graduada simples. \\
\hline Reforço do subleito & Solo-brita ou solo agregado. \\
\hline Subleito & Camada final de terraplenagem. \\
\hline Fonte: Adaptado de Balbo (2007)
\end{tabular}

\subsection{Etapas de Serviços de Pavimentação Asfáltica}

Segundo Fwa (2003), o atendimento aos requisitos da mecânica dos pavimentos implica em considerar o tipo de pavimento, que leva, em seguida, às seguintes etapas: 
a) selecionar os tipos de materiais;

b) conhecer os esforços que o pavimento será submetido e definir o tipo e espessura das camadas;

c) desenvolver um sistema de drenagem;

d) elaborar o projeto geométrico e de drenagem;

e) executar o pavimento.

Estas etapas se relacionam diretamente às quatro camadas principais de um pavimento asfáltico: revestimento asfáltico, base, sub-base e reforço do subleito. Conceitos apresentados a seguir.

\subsubsection{Revestimento asfáltico}

É a camada, tanto quanto possível impermeável, que recebe diretamente a ação do tráfego e destinada a melhorar a superfície de rolamento quanto às condições de conforto e segurança, além de resistir ao desgaste, ou seja, aumentando a durabilidade da estrutura.

Segundo Balbo (2007), os revestimentos asfálticos são muitas vezes subdivididos em duas ou mais camadas por razões técnicas, construtivas e de custo. Assim, é comum encontrar expressões como "camada de rolamento" e "camada de ligação" (do inglês binder) para descrever um revestimento dividido em duas camadas de diferentes materiais. Os materiais que podem ser utilizados são os tratamentos superficiais betuminosos e as misturas asfálticas em geral, descritas a seguir:

a) Concreto Asfáltico Usinado a Quente, designado CAUQ ou simplesmente CA, também costumeiramente designado Concreto Betuminoso Usinado a Quente (CBUQ), é um material para a construção de revestimentos de pavimentos, incluindo as capas de rolamento e camadas de ligação imediatamente subjacentes aos revestimentos, obtido a partir da mistura e homogeneização de agregados minerais e de cimento asfáltico de petróleo (CAP).

b) Pré-misturado a Quente (PMQ) é uma mistura asfáltica semelhante ao CAUQ, porém elaborado sem a introdução de material de enchimento, resultando em misturas mais abertas. São preferencialmente utilizados como camada de regularização ou de ligação. 
Em todos os métodos de dimensionamento, a camada de revestimento tem espessura adotada, seja em função de critérios próprios, seja em função do tráfego previsto. Para vias simples - duas faixas de tráfego e duas mãos de direção - espessuras de 3 a 5 cm são habituais (SENÇO, 2008a).

\subsubsection{Condicionantes para a execução do revestimento asfáltico}

Fatores como incorreções na usinagem, deficiência de compactação, falta de controle de umidade e de temperatura, variabilidade de solos em jazidas, inadequação de cura de materiais estabilizados ou tratados com cimento e de concretos comprometem seriamente o desempenho do pavimento que foi dimensionado para parâmetros característicos (de projeto) no que tange a sua resistência, devendo ser elaborados (dosados, usinados e compactados) de tal forma que, em pista, sejam reproduzidas as características potenciais dos materiais aferidas em laboratório. "A negligência e muitas vezes a ausência de controle tecnológico adequado têm sido a grande mazela de obras rodoviárias no Brasil' (BALBO, 2007).

O lançamento de uma mistura asfáltica e o início de um serviço de compactação de uma camada de revestimento asfáltico, segundo Bernucci et al. (2007), devem ser precedidos por um planejamento onde são considerados detalhes importantes no processo, como por exemplo:

a) continuidade e sequência de operações;

b) número de vibroacabadoras necessárias para a execução do serviço;

c) número e tipos de rolos compactadores necessários;

d) número de caminhões transportadores necessários;

e) a cadeia de comando para dar e receber instruções;

f) razões para possível rejeição de mistura asfáltica;

g) condições climáticas e de temperatura;

h) controle de tráfego.

Como o peso específico obtido em pista está vinculado à temperatura de compactação e à forma de rolagem do material, muitas das causas do mau comportamento de misturas asfálticas se associam a processos construtivos inadequados. Na Tabela 16 são sistematicamente descritos os principais fatores que afetam a compactação de misturas asfálticas. 
Tabela 16 - Fatores que afetam a compactação de misturas asfálticas

\begin{tabular}{|c|c|c|}
\hline $\begin{array}{l}\text { PROPRIEDADES DOS } \\
\text { MATERIAIS }\end{array}$ & $\begin{array}{c}\text { QUESTÕES DE NATUREZA } \\
\text { CONSTRUTIVA }\end{array}$ & $\begin{array}{c}\text { FATORES DE CARÁTER } \\
\text { AMBIENTAL }\end{array}$ \\
\hline Ligantes asfálticos: & Usinagens: & - Temperatura do ar. \\
\hline - Teor de ligante; & $\begin{array}{l}\text { - Tipo de usina (controle por } \\
\text { peso ou por volume); }\end{array}$ & $\begin{array}{l}\text { - Temperatura da camada } \\
\text { de apoio. }\end{array}$ \\
\hline $\begin{array}{l}\text { - Propriedades físico- } \\
\text { químicas. }\end{array}$ & - Distância de transporte; & - Velocidade do vento. \\
\hline Agregados: & - Caçambas térmicas. & - Radiação solar. \\
\hline $\begin{array}{l}\text { - Composição } \\
\text { granulométrica; }\end{array}$ & Compactação: & - Umidade do ar. \\
\hline - Diâmetro dos grãos; & - Tipos de rolos; & - Chuva. \\
\hline - Forma dos grãos; & - Quantidade de rolos; & \multirow{5}{*}{ - } \\
\hline - Faces fraturadas; & - Número de passadas; & \\
\hline - Volume. & - Velocidade de rolagem; & \\
\hline & - Espessura solta; & \\
\hline & $\begin{array}{l}\text { - Deformabilidade das } \\
\text { camadas inferiores. }\end{array}$ & \\
\hline
\end{tabular}

Fonte: Adaptado de Balbo (2007)

Segundo Senço (2008b), os trabalhos de compactação, quer no que tange à velocidade de operação na pista, quer no que tange aos resultados obtidos no adensamento da camada, podem ser resumidos nas seguintes observações:

a) constância volumétrica, ou seja, a camada espalhada e compactada não deve sofrer acentuada compactação pela ação do tráfego, o que produziria deformações na superfície de rolamento;

b) aumento da estabilidade, que se reflete no valor estrutural da camada. Estudos demonstram a influência do peso específico na estabilidade da massa asfáltica;

c) impermeabilização relativa da camada, que se reflete na durabilidade do pavimento. Estudos indicam que a impermeabilização é influenciada acentuadamente, não só pelo tipo dos agregados da mistura, mas também pelo tipo de equipamento empregado na compactação;

d) temperatura da mistura. Temperaturas fora da faixa permitida para a compressão, implica em perda dos serviços, inclusive dos materiais já submetidos a transporte, o que pode representar um custo significativo. 
São vários os fatores que influem na temperatura da mistura e determinam o tempo necessário de rolagem (ver Tabela 17).

Tabela 17 - Fatores que afetam o tempo de rolagem.

\begin{tabular}{c|c|c}
\hline Principais fatores que afetam o tempo de rolagem & $\begin{array}{c}\text { Permite mais } \\
\text { tempo }\end{array}$ & $\begin{array}{c}\text { Permite menos } \\
\text { tempo }\end{array}$ \\
\hline Espessura da camada em execução & Espessa & Delgada \\
\hline Temperatura da mistura em compactação & Alta & Baixa \\
\hline Temperatura da superfície da camada subjacente & Alta & Baixa \\
\hline
\end{tabular}

Fonte: Bernucci et al (2007)

A rolagem de compactação pode ser iniciada com rolos compactadores vibratórios ou rolos tandem lisos estáticos e em seguida são utilizados os rolos de pneus. Em algumas obras, inicia-se diretamente com os rolos de pneus. $O$ número de rolos a serem utilizados deve ser o necessário para a obtenção do grau de compactação desejado, com a mistura asfáltica mantendo sua temperatura dentro da faixa de trabalho. A rolagem de acabamento é executada com rolos tandem lisos estáticos.

$\mathrm{Na}$ execução de camadas com misturas asfálticas com agregados de granulometria descontínua, a rolagem é realizada somente com o rolo tandem liso estático, pois é fundamental evitar a segregação durante o processo e também manter a estrutura pétrea desejada na camada compactada.

\subsubsection{Descrição da execução do processo de revestimento asfáltico}

Segundo Bernucci et al. (2007) e Senço (2008b), as etapas que envolvem a execução da camada de revestimento asfáltico são apresentadas como segue.

a) Usinagem da mistura asfáltica.

b) Transporte da mistura asfáltica: as misturas asfálticas são levadas ao local de execução do pavimento por meio de caminhões que possuam preferivelmente caçambas metálicas. Tendo-se em vista as eventuais perdas de temperatura da caçamba durante o transporte, costuma-se recobri-la com lonas. O número de caminhões necessários é determinado por alguns fatores tais como: a velocidade de produção da mistura asfáltica 
na usina; a distância de transporte; o tipo de tráfego no percurso e o tempo estimado para descarregamento. O número de caminhões necessários para manter constante o lançamento da mistura asfáltica na pista pode ser estimado considerando-se o tempo de ida e volta dividido pelo tempo de carregamento de cada caminhão mais um.

c) Lançamento da mistura asfáltica: a base recém construída, sobre a qual deverá ser aplicada a massa deverá estar imprimada convenientemente. A mistura asfáltica deve ser lançada em camada uniforme de espessura e seção transversal definidas, pronta para a compactação. O lançamento é realizado por vibroacabadoras que sejam capazes de executar camadas de menos de $25 \mathrm{~mm}$ até aproximadamente $300 \mathrm{~mm}$ de espessura, em larguras ajustáveis de acordo com o serviço. As velocidades de deslocamento são reguláveis e podem atingir até $20 \mathrm{~m} / \mathrm{min}$. Estes equipamentos, além de promoverem o espalhamento da massa na espessura e largura desejadas, executam parte do trabalho de compactação.

As vibroacabadoras são compostas por duas unidades:

- Unidade tratora - tem como funções o deslocamento da vibroacabadora e o recebimento, condução e lançamento uniforme da carga de mistura asfáltica à frente da unidade de nivelamento.

- Unidade de nivelamento - tem como funções nivelar e pré-compactar a mistura asfáltica sobre a superfície em que foi lançada, de acordo com especificações de geometria previamente definidas.

d) Compactação da mistura asfáltica: imediatamente após a distribuição da massa pela acabadora, tem início a operação de rolagem. A compactação de uma camada asfáltica de revestimento aumenta a estabilidade da mistura asfáltica, reduz seu índice de vazios, proporciona uma superfície suave e desempenada e aumenta sua vida útil. Para que a compactação possa ser executada de maneira eficiente, duas condições fundamentais devem estar presentes: existência de confinamento ao compactar e temperatura adequada da mistura asfáltica.

O processo de execução de uma camada asfáltica geralmente é compreendido por duas fases: a rolagem de compactação e a rolagem de acabamento. É na fase de rolagem de compactação que se alcança a densidade, a impermeabilidade e grande parte da suavidade superficial. $\mathrm{Na}$ 
rolagem de acabamento são corrigidas marcas deixadas na superfície da camada pela fase de rolagem anterior.

A escolha do padrão de rolagem adequado deve ser realizada através da execução de uma pista-teste com monitoramento de densidade por meio de densímetros. Nesta pista teste devem ser definidos quatro parâmetros:

- número de passagens necessárias para uma cobertura da largura da faixa ou pista em execução;

- número de repetições necessárias para alcançar o grau de compactação de projeto;

- velocidade de rolagem;

- faixa de temperatura correta de aplicação e rolagem.

A Figura 16 apresenta um modelo de padrão de rolagem para compactação de uma camada de mistura asfáltica.

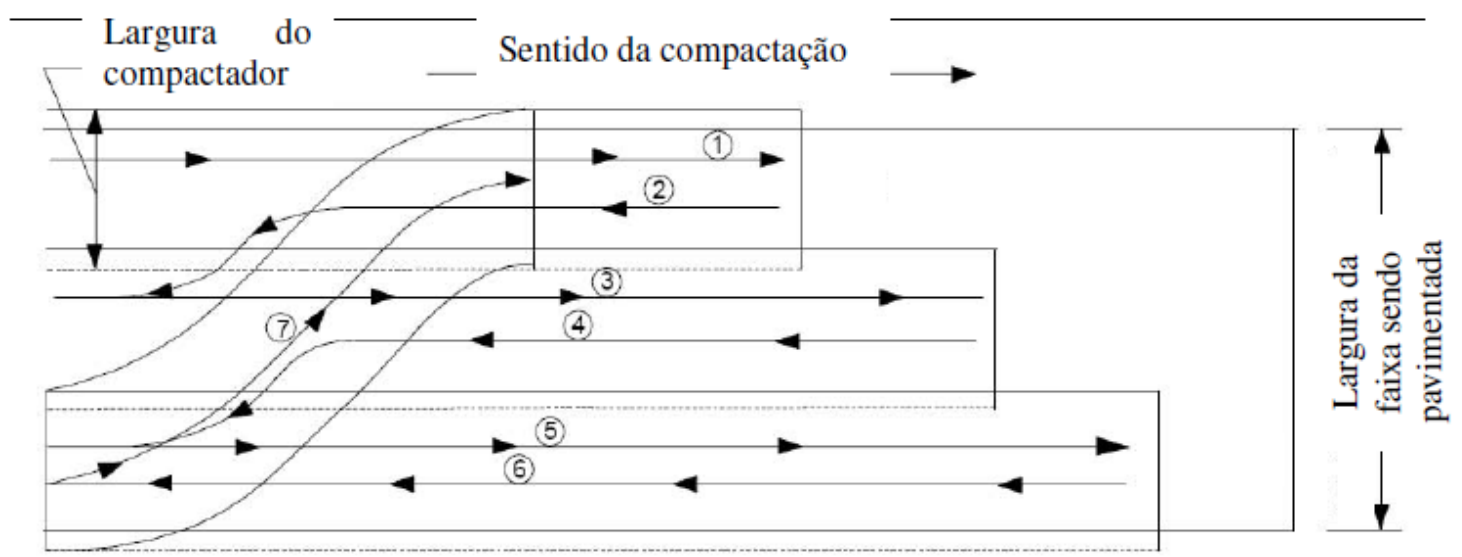

Figura 16 - Exemplo de padrão de rolagem para compactação de mistura asfáltica Fonte: Sotomayor (2008)

\subsubsection{Controles aplicáveis ao processo de revestimento asfáltico}

Para garantir o sucesso da execução do revestimento asfáltico, devem ser realizadas todas as preparações e inspeções necessárias. Normalmente os seguintes itens são verificados (BERNUCCI et al, 2007):

a) superfície da base ou revestimento existente apropriadamente preparada (imprimação ou pintura de ligação executadas);

b) plano de execução do serviço; 
c) sincronia apropriada de produção da mistura asfáltica, lançamento e compactação;

d) equipamentos em boas condições e calibrados;

e) meios para pesagem da mistura asfáltica;

f) planejamento de amostragem e ensaios de controle.

Segundo Balbo (2007), o que não deve acontecer na pista ao lançar e compactar a mistura asfáltica é apresentado a seguir:

a) a mistura não deve segregar;

b) a mistura não deve afundar durante sua compactação;

c) a mistura não deve exsudar durante a compactação.

\subsubsection{Equipamentos para execução de revestimento asfáltico}

A Figura 17 apresenta modelos de equipamentos de execução de misturas asfálticas.

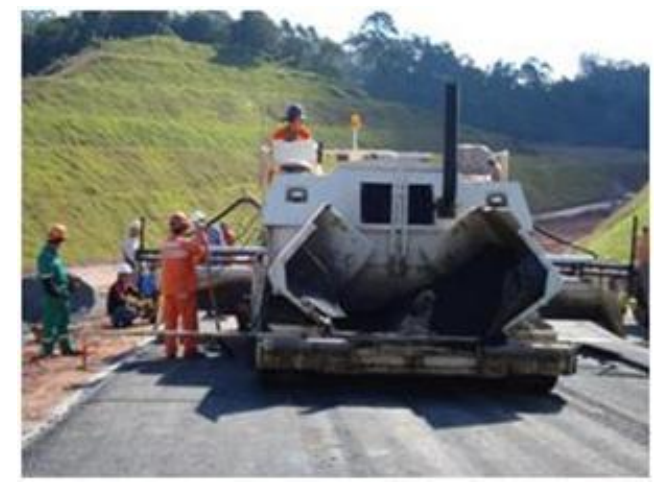

(a)

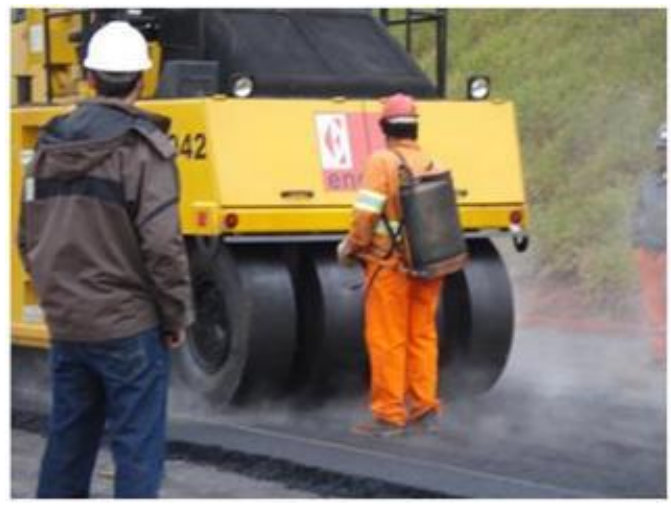

(c)

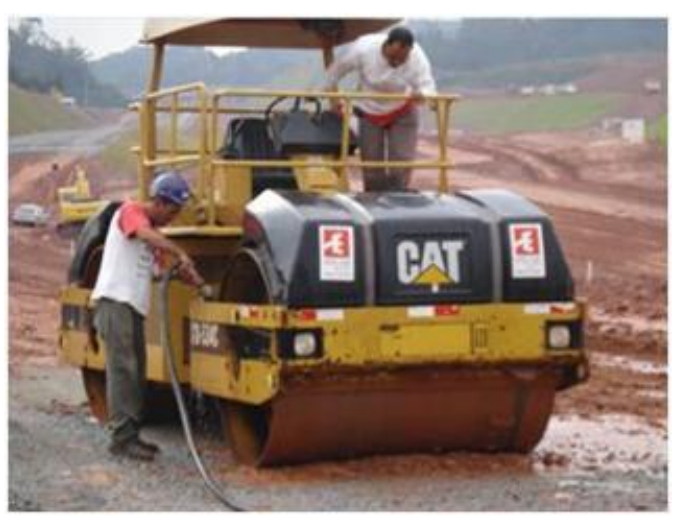

(b)

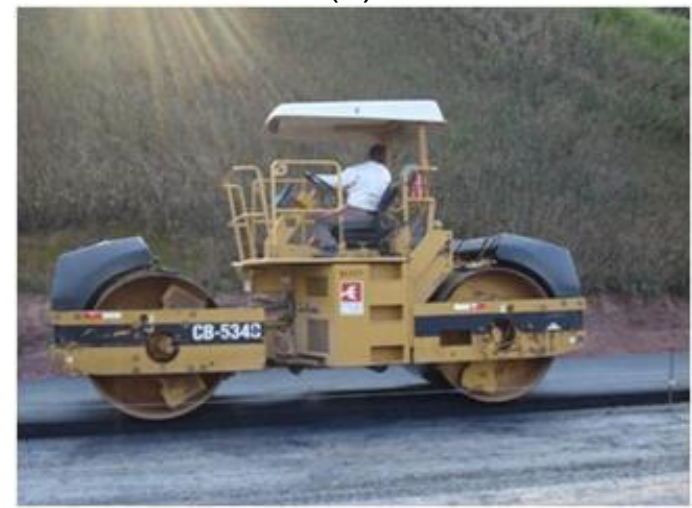

(d)

Figura 17 - a) vibroacabadora; b) rolo tandem liso; c) rolo de pneus; d) rolo vibratório 
A função de cada equipamento é: a vibroacabadora lança e nivela a massa asfáltica, o rolo tandem liso e ou vibratório faz a pré compactação e dá o acabamento final, e o rolo de pneus faz a compactação propriamente dita.

\subsubsection{Equipes para execução de revestimento asfáltico}

O dimensionamento de conjunto de equipamentos (patrulhas) é controlado pela produção horária e afeta diretamente os custos de execução dos serviços. Sua formação está relacionada aos tipos de equipamentos utilizados ou disponíveis. Neste contexto, em termos qualitativos, a Tabela 18 apresenta um exemplo de formação de equipe de execução de revestimento asfáltico.

Tabela 18 - Formação de patrulha para execução de revestimento asfáltico

\begin{tabular}{l|c}
\hline \multicolumn{1}{c|}{ Discriminação } & $\begin{array}{c}\text { Exemplo de } \\
\text { patrulha }\end{array}$ \\
\hline Vibroacabadora de asfalto - sobre esteiras & $\mathrm{x}$ \\
\hline Rolo compactador de pneus autopropelido (21t) & $\mathrm{x}$ \\
\hline Rolo compactador tipo tandem (10,9ton) & $\mathrm{x}$ \\
\hline Servente & $\mathrm{x}$ \\
\hline
\end{tabular}

No exemplo dado, a vibroacabadora recebe e espalha a mistura asfáltica, deixando a camada nivelada, o rolo tipo tandem faz a pré compactação, o rolo de pneus executa a compactação e o rolo tipo tandem volta para dar o acabamento final. Todo o serviço é acompanhado por serventes que executam serviços de reparos, garantindo a qualidade do serviço.

\subsubsection{Pinturas asfálticas e imprimações}

Entre muitas das camadas de pavimento mencionadas, faz-se necessária a execução de um filme asfáltico, que será denominado de "pintura de ligação" (com função de aderir uma camada à outra) ou "imprimação impermeabilizante" (com a função de impermeabilizar uma camada de solo ou granular antes do lançamento da camada superior). Entre quaisquer camadas de revestimento asfáltico, sempre é aplicada uma pintura de ligação. As pinturas de ligação são 
executadas com emulsões asfálticas (Tabela 19), e as imprimações impermeabilizantes com asfaltos diluídos (Tabela 20).

Tabela 19 - Tipos e aplicações das emulsões asfálticas (exemplos).

\begin{tabular}{c|l}
\hline Tipo & Aplicações \\
\hline RR-1C & Pintura de ligação, tratamentos superficiais, macadame betuminoso. \\
\hline RR-2C & Pintura de ligação, tratamentos superficiais, macadame betuminoso. \\
\hline
\end{tabular}

Fonte: Adaptado de Balbo (2007) e Senço (2008b)

Tabela 20 - Tipos e aplicações dos asfaltos diluídos (exemplos).

\begin{tabular}{c|l}
\hline Tipo & Aplicações \\
\hline CM-30 & Imprimação de superfícies com textura fechada. \\
\hline CM-70 & Imprimação de superfícies com textura aberta. \\
\hline
\end{tabular}

Fonte: Adaptado de Balbo (2007) e Senço (2008b)

\subsubsection{Descrição da execução de pinturas asfálticas e imprimações}

A base a ser imprimada deve ser varrida por processo manual ou mecânico, de modo a eliminar todo o pó e os materiais soltos existentes. A aplicação das pinturas de ligação e das imprimações se dá por meio de bicos espargidores ou por barra espargidora fixada no caminhão que se movimenta. As falhas que possam ocorrer geralmente são sanadas com a aplicação manual de mistura asfáltica. As taxas de aplicação são controladas conforme o material utilizado e a sua finalidade de aplicação (Tabela 21). Os controles a serem efetuados devem ser de quantidade, de temperatura e de qualidade.

Tabela 21 - Taxas de aplicação (exemplos).

\begin{tabular}{l|l}
\hline \multicolumn{1}{c|}{ Aplicação } & Taxa de aplicação \\
\hline Pintura de ligação & $0,5 \mathrm{l} / \mathrm{m}^{2}$ \\
\hline Imprimação & $0,8 \mathrm{l} / \mathrm{m}^{2}$ e $1,6 \mathrm{l} / \mathrm{m}^{2}$ \\
\hline
\end{tabular}

Fonte: Balbo (2007) e Senço (2008b) 


\subsubsection{Equipamentos e equipes de pinturas asfálticas e imprimações}

A Figura 18 apresenta um exemplo de caminhão espargidor munido de tanque e de barra espargidora.

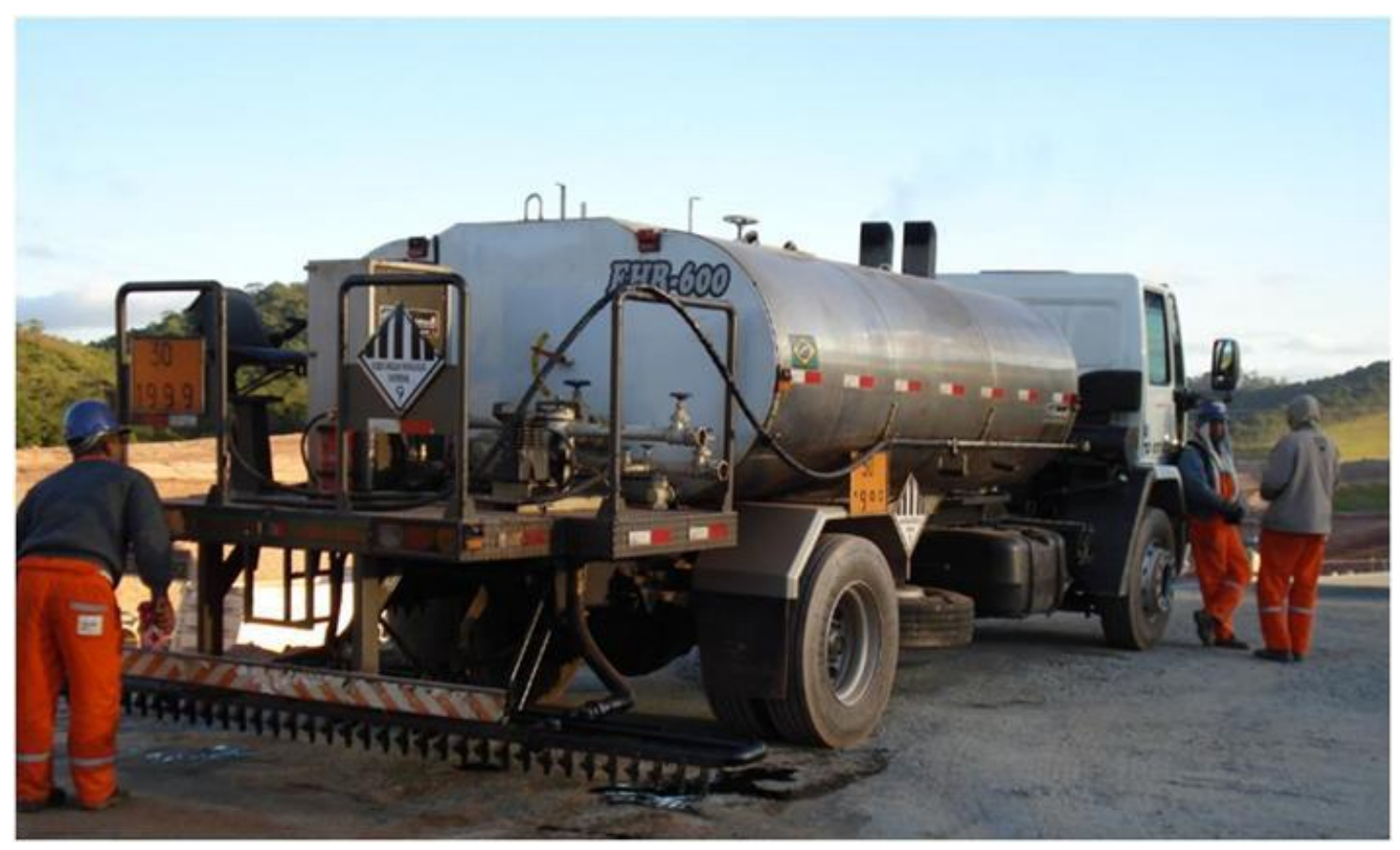

Figura 18 - Caminhão espargidor

O dimensionamento de conjunto de equipamentos (patrulhas) é controlado pela produção horária e afeta diretamente os custos de execução dos serviços. Sua formação está relacionada aos tipos de equipamentos utilizados ou disponíveis. Neste contexto, em termos qualitativos, a Tabela 22 apresenta um exemplo de formação de equipe de execução de pinturas asfálticas e imprimações.

Tabela 22 - Formações de patrulhas para execução de pinturas asfálticas e imprimações

\begin{tabular}{l|c}
\multicolumn{1}{c|}{ Discriminação } & $\begin{array}{c}\text { Exemplo de } \\
\text { patrulha }\end{array}$ \\
\hline Distribuidor de betume $(6.000 \mathrm{I})$ & $\mathrm{x}$ \\
\hline Servente & $\mathrm{x}$ \\
\hline
\end{tabular}

No exemplo dado, o distribuidor de betume aplica o material betuminoso adequado, na temperatura de aplicação própria desse material. O servente atua como apoio ao motorista. 


\subsubsection{Bases e Sub-bases}

Para resistir às ações dos veículos e transmiti-las convenientemente ao subleito, suportando diretamente os esforços verticais, surgem as camadas de base e sub-base, que também podem desempenhar papel importante na drenagem subsuperficial dos pavimentos (PASTANA, 2006).

As bases e sub-bases podem ser flexíveis (granulares) ou semi rígidas (estabilizadas com aditivos). Na Figura 19 apresenta esta classificação.

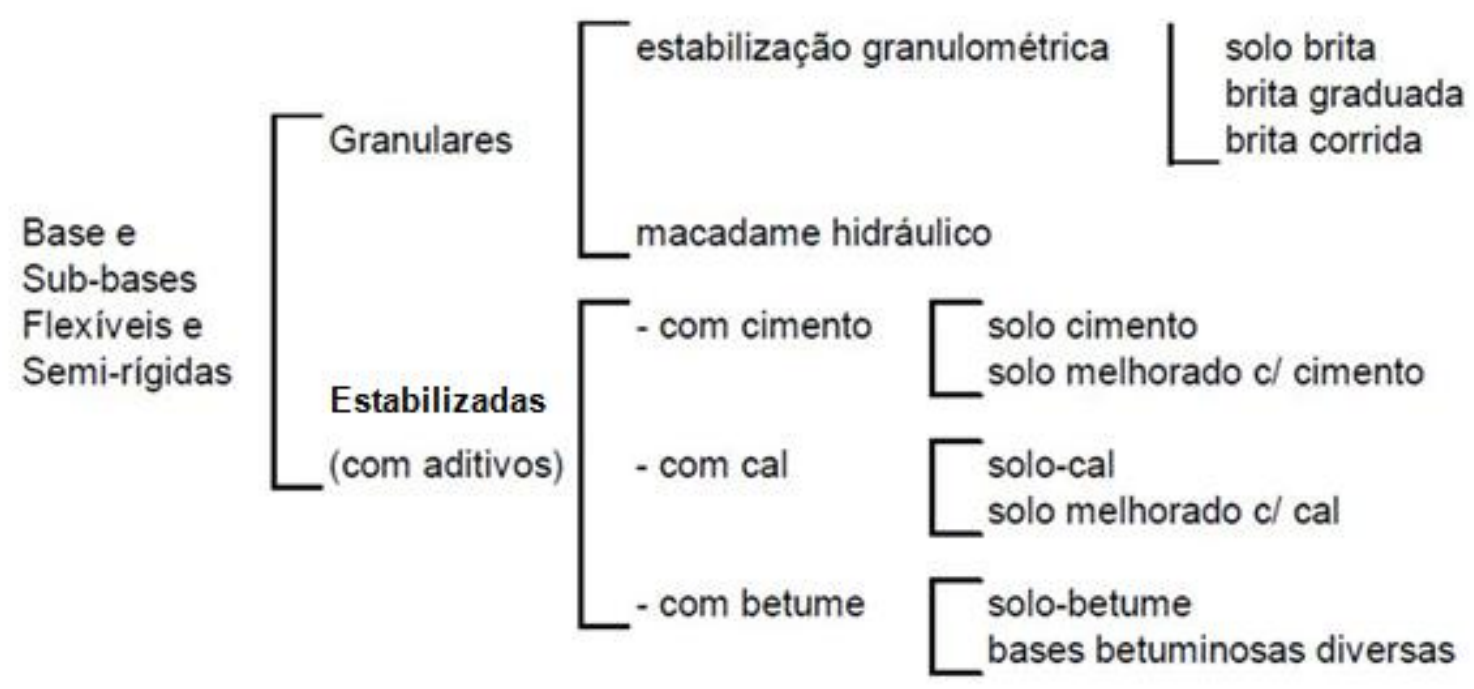

Figura 19 - Classificação das bases e sub-bases flexíveis e semi-rígidas

Fonte: DNIT (2006)

\subsubsection{Descrição da execução de bases e sub-bases}

Dentre os materiais preparados para bases e sub-bases, sem a intenção de apresentar todos e de se esgotar o assunto, apresenta-se a seguir, segundo Balbo (2007) e Senço (2008b), a descrição da execução da brita graduada simples; brita graduada tratada com cimento; solo melhorado com cimento; e solo cimento.

a) Brita Graduada Simples (BGS)

Trata-se de um tipo de base introduzido no Estado de São Paulo no final dos anos 60 e que ganhou rapidamente a aceitação e preferência dos engenheiros 
rodoviários, pelas facilidades de execução que oferece, associadas à facilidade de obtenção de um produto acabado bastante uniforme.

As etapas que envolvem a execução da camada de BGS são as seguintes:

- usinagem da BGS em usina gravimétrica de solos ou agregados;

- transporte da BGS e colocação do material em pista;

- espalhamento do material solto em pista: o espalhamento da mistura - em camadas que não devem exceder a espessura que resultará em $15 \mathrm{~cm}$ de camada acabada - pode ser realizado com o auxílio da motoniveladora empregando-se distribuidor de agregados ou com vibroacabadoras;

- compactação da BGS com auxílio de rolo de pneus com 2,5 t por roda e pressão regulável (até $0,7 \mathrm{MPa}$ ) e de rolo liso metálico (vibratório ou não) com cilindro de, no mínimo, 3 t.

b) Brita Graduada Tratada com Cimento (BGTC)

A BGTC compreende uma mistura de agregados do tipo BGS (pedras britadas) com uma pequena quantidade de cimento Portland, em geral de $3 \%$ a $4 \%$ em peso da mistura total. Esse baixo consumo de cimento significa algo em torno de $75 \mathrm{~kg} / \mathrm{m}^{3}$.

As etapas que envolvem a execução da camada de BGTC são as seguintes:

- usinagem da BGTC em usina tipo pugmill (de agregados) com rosca semfim, devendo o cimento e a água serem introduzidos na própria misturadora, empregada para o preparo de brita graduada simples;

- transporte da BGTC e colocação do material em pista;

- espalhamento do material solto em pista: diferente da BGS, deverá ser compactada em espessura única e não em camadas sobrepostas. Tal exigência implica limitações no emprego de vibroacabadoras para sua distribuição na pista;

- compactação da BGTC: semelhante à BGS. 
c) Solo Melhorado com Cimento (SMC)

O solo melhorado com cimento é um material resultante da mistura do solo natural com ligante hidráulico, que pode ser realizado tanto em pista quanto em usina de solo. Busca-se tão somente uma estabilização do solo de maneira a torná-lo menos expansivo, para que seja possível o seu emprego como material de pavimentação dentro das restrições comuns de projeto. Não se trata de pretender, por exemplo, que a mistura resista à compressão simples com valores significativos, mas de se conseguir, por exemplo, a redução de plasticidade a níveis compatíveis com a necessidade.

d) Solo-Cimento (SC)

A distinção mais clara entre o SMC e o SC é realizada pela quantidade de cimento empregado nas misturas e também pela finalidade dessa mistura (camada estável à ação de água ou camada trabalhando em flexão, de resistência muito elevada).

No processo de dosagem na usina, para se obter um comportamento adequado sob a ação do tráfego, dois requisitos devem ser observados: a utilização de um teor conveniente de cimento Portland misturado com o solo solto e que a mistura seja feita com o teor ótimo de umidade.

As etapas que envolvem a execução da camada de SMC ou SC são as seguintes:

- pode-se preparar as misturas de SMC ou SC de duas formas: em usina misturadora de solos ou em pista. No caso de mistura em pista, a seguinte sequência básica é adotada:

- espalhamento do solo na espessura solta;

- correção da umidade do solo com emprego de caminhão tanque;

- colocação de cimento em sacarias (ou caminhão distribuidor de cimento), controlando-se o volume de cimento em função do volume de solo ainda solto, seguido de homogeneização com pulvomisturadora.

- compactação da mistura com rolo pé de carneiro ou de pneus de pressão regulável ou ainda rolo liso. 
- execução da imprimação, com caminhão espargidor, da superfície acabada para proteção do material (cura).

\subsubsection{Equipes para execução de bases, sub-bases e camadas anteriores}

O dimensionamento de conjunto de equipamentos (patrulhas) é controlado pela produção horária e afeta diretamente os custos de execução dos serviços. Sua formação está relacionada aos tipos de equipamentos utilizados ou disponíveis. Neste contexto, em termos qualitativos, as tabelas a seguir apresentam exemplos de formações de equipes: Brita graduada simples (Tabela 23); Solocimento (Tabela 24).

Tabela 23 - Formações de patrulhas para execução de brita graduada simples $\left(\mathrm{m}^{3}\right)$

\begin{tabular}{l|c|c|c}
\hline \multirow{2}{*}{\multicolumn{1}{c|}{ Discriminação }} & \multicolumn{3}{c}{ Exemplo de patrulha } \\
\cline { 2 - 4 } & $\mathbf{1}^{\mathbf{a}}$ & $\mathbf{2}^{\mathbf{a}}$ & $\mathbf{3}^{\mathbf{a}}$ \\
\hline Distribuidor de agregados - autopropelido & $\mathrm{x}$ & - & - \\
\hline Vibroacabadora de asfalto - sobre esteiras & - & $\mathrm{x}$ & - \\
\hline Motoniveladora & - & - & $\mathrm{x}$ \\
\hline Rolo compactador de pneus autopropelido & $\mathrm{x}$ & $\mathrm{x}$ & $\mathrm{x}$ \\
\hline Rolo compactador tipo tandem & $\mathrm{x}$ & $\mathrm{x}$ & $\mathrm{x}$ \\
\hline Servente & $\mathrm{x}$ & $\mathrm{x}$ & $\mathrm{X}$ \\
\hline
\end{tabular}

No exemplo dado, o espalhamento da brita graduada simples e o nivelamento da camada podem ser executados de três maneiras: a) pelo distribuidor de agregados; b) pela vibroacabadora; c) pela motoniveladora. O rolo tipo tandem faz a pré compactação, o rolo de pneus executa a compactação e o rolo tipo tandem volta para dar o acabamento final. Todo o serviço é acompanhado por serventes que executam serviços de reparos, garantindo a qualidade do serviço. 
Tabela 24 - Formações de patrulhas para execução de solo cimento, mistura na pista $\left(\mathrm{m}^{3}\right)$

\begin{tabular}{l|c|c}
\multicolumn{1}{c|}{ Discriminação } & \multicolumn{2}{c}{ Exemplo de patrulha } \\
\cline { 2 - 3 } & $\mathbf{1}$ & $\mathbf{2}^{\mathbf{a}}$ \\
\hline Trator de esteiras com lâmina & $\mathrm{x}$ & $\mathrm{x}$ \\
\hline Motoniveladora & $\mathrm{x}$ & $\mathrm{x}$ \\
\hline Pulvomisturador & - & $\mathrm{x}$ \\
\hline Recicladora & - & $\mathrm{x}$ \\
\hline Trator agrícola com grade de discos rebocável & $\mathrm{x}$ & - \\
\hline Caminhão tanque de 10.000 I & $\mathrm{x}$ & - \\
\hline Rolo compactador pé de carneiro vibratório autopropelido & $\mathrm{x}$ & $\mathrm{x}$ \\
\hline Rolo compactador de pneus autopropelido & $\mathrm{x}$ & $\mathrm{x}$ \\
\hline Servente & $\mathrm{x}$ & - \\
\hline
\end{tabular}

No exemplo dado, o trator de esteiras espalha o solo e a motoniveladora nivela a camada. A distribuição de cimento pode ser feita de duas maneiras: a) manualmente (feita pelos serventes); b) mecanicamente (feita pelo pulvomisturador). A mistura do solo com o cimento pode ser feita de duas maneiras: a) com o trator agrícola com grade de discos; b) com a recicladora (que acrescenta água caso necessário). O caminhão tanque é utilizado para acrescentar água na camada (quando necessário). O rolo compactador pé de carneiro executa a compactação e o rolo de pneus faz o acabamento (selar a camada).

\subsubsection{Reforço de subleito}

É uma camada de espessura constante, construída, se necessário, acima do subleito, com características tecnológicas superiores às do subleito e inferiores às da camada imediatamente superior, ou seja, a sub-base. O reforço do subleito também resiste e distribui esforços verticais, não tendo as características de absorver definitivamente esses esforços, o que é característica do subleito (SENÇO, 2008b).

\subsubsection{Subleitos}

É o terreno de fundação do pavimento. Se a terraplenagem é recente, o subleito deverá apresentar as características geométricas definitivas. 


\subsection{Composições Orçamentárias Aplicáveis à Pavimentação Asfáltica}

Dentre as opções para a constituição da pavimentação asfáltica, a execução de revestimentos asfálticos, pinturas asfálticas e imprimações impermeabilizantes, bases, sub-bases e reforços de subleitos foram detalhados neste capítulo. Cada um desses serviços podem demandar esforços diferentes na sua produção. Assim, para melhor entender a produtividade, adota-se a abordagem analítica, isto é, que leva em consideração as diferentes partes que constituem o serviço a executar (quebra do serviço).

A proposição da quebra destes serviços leva em consideração todo o conhecimento adquirido por meio do estudo bibliográfico, dos manuais e da experiência acumulada nos estudos de caso. Portanto, embora alguns destes assuntos sejam apresentados nos demais capítulos, eles contribuíram para o entendimento da quebra dos serviços de pavimentação asfáltica.

A quebra do serviço de execução de revestimentos asfálticos pode ser expressa como a apresentada na Figura 20.

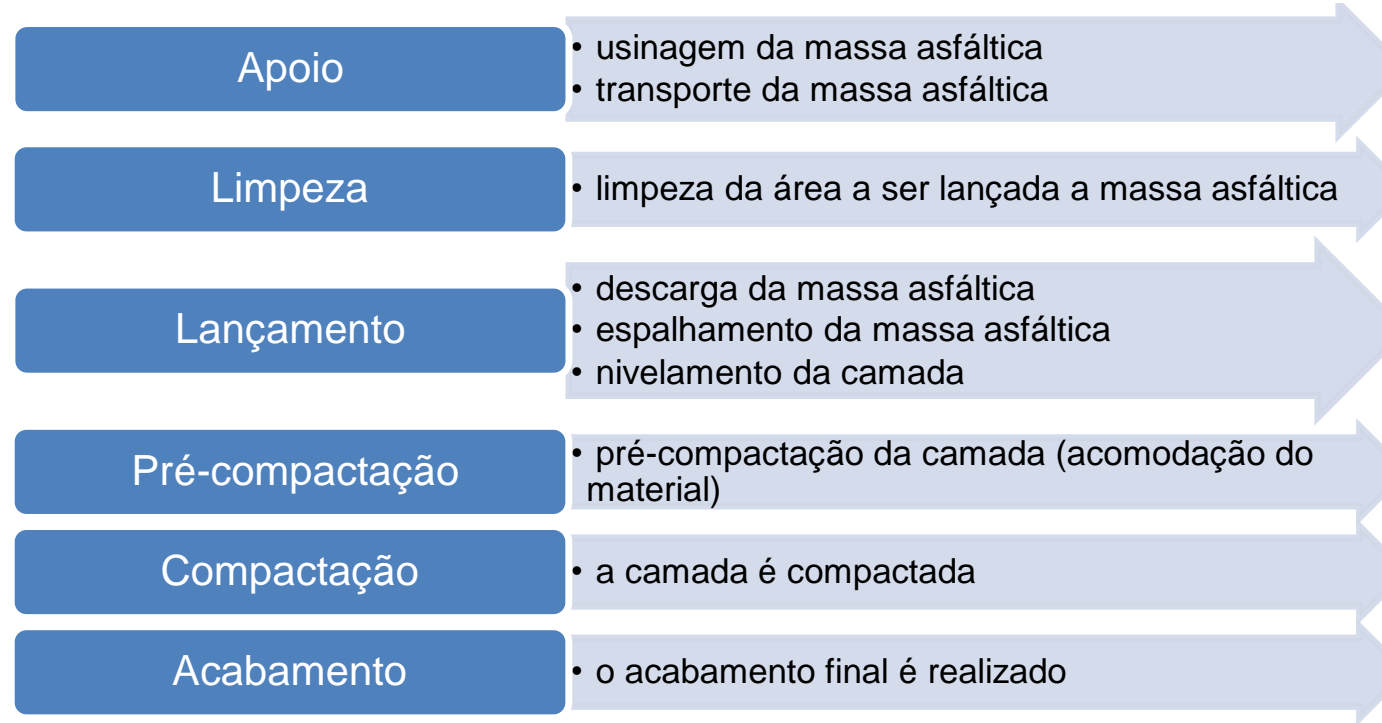

Figura 20 - Quebra do serviço de execução de revestimentos asfálticos 
A quebra do serviço de pinturas asfálticas e imprimações impermeabilizantes pode ser expressa como a apresentada na Figura 21.

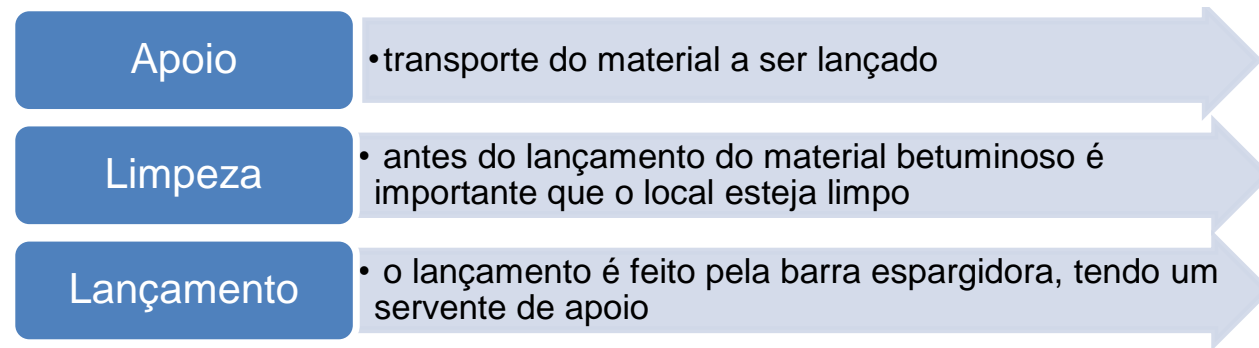

Figura 21 - Quebra do serviço de execução de pinturas asfálticas e imprimações impermeabilizantes

A quebra do serviço de BGS e BGTC pode ser expressa como a apresentada na Figura 22.

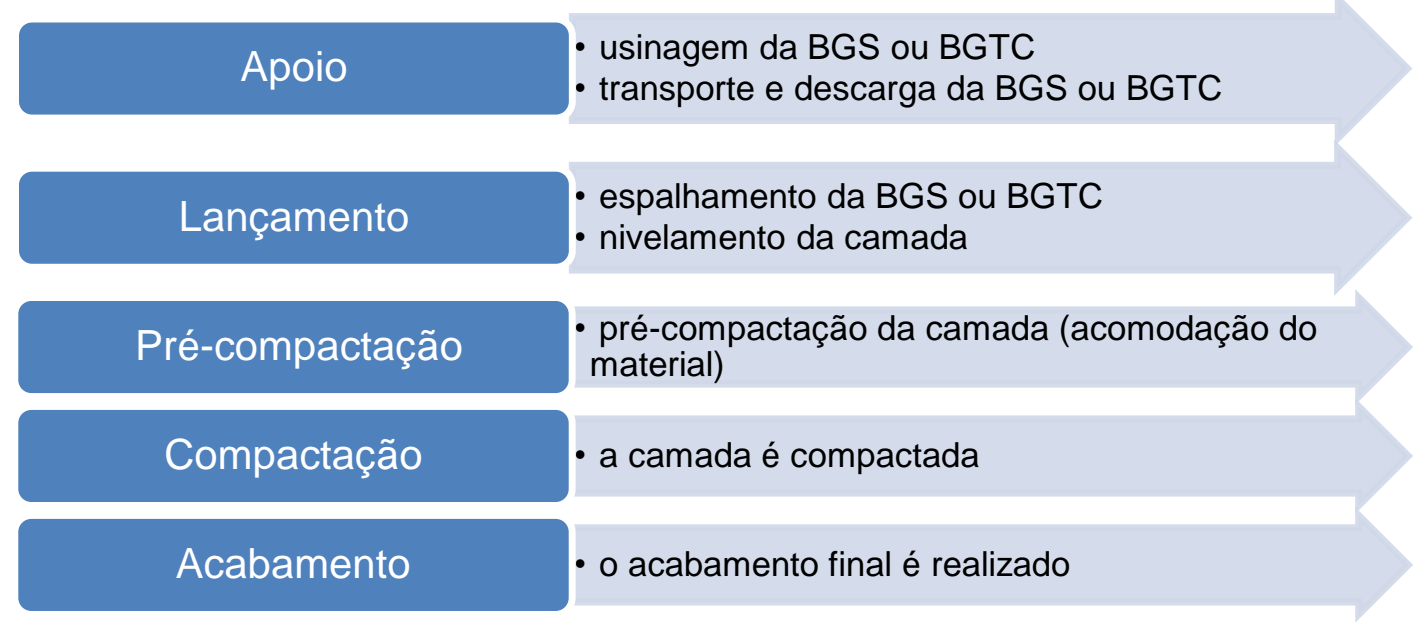

Figura 22 - Quebra do serviço de execução de BGS e BGTC 
A quebra do serviço de solo cimento pode ser expressa como apresentada na Figura 23.

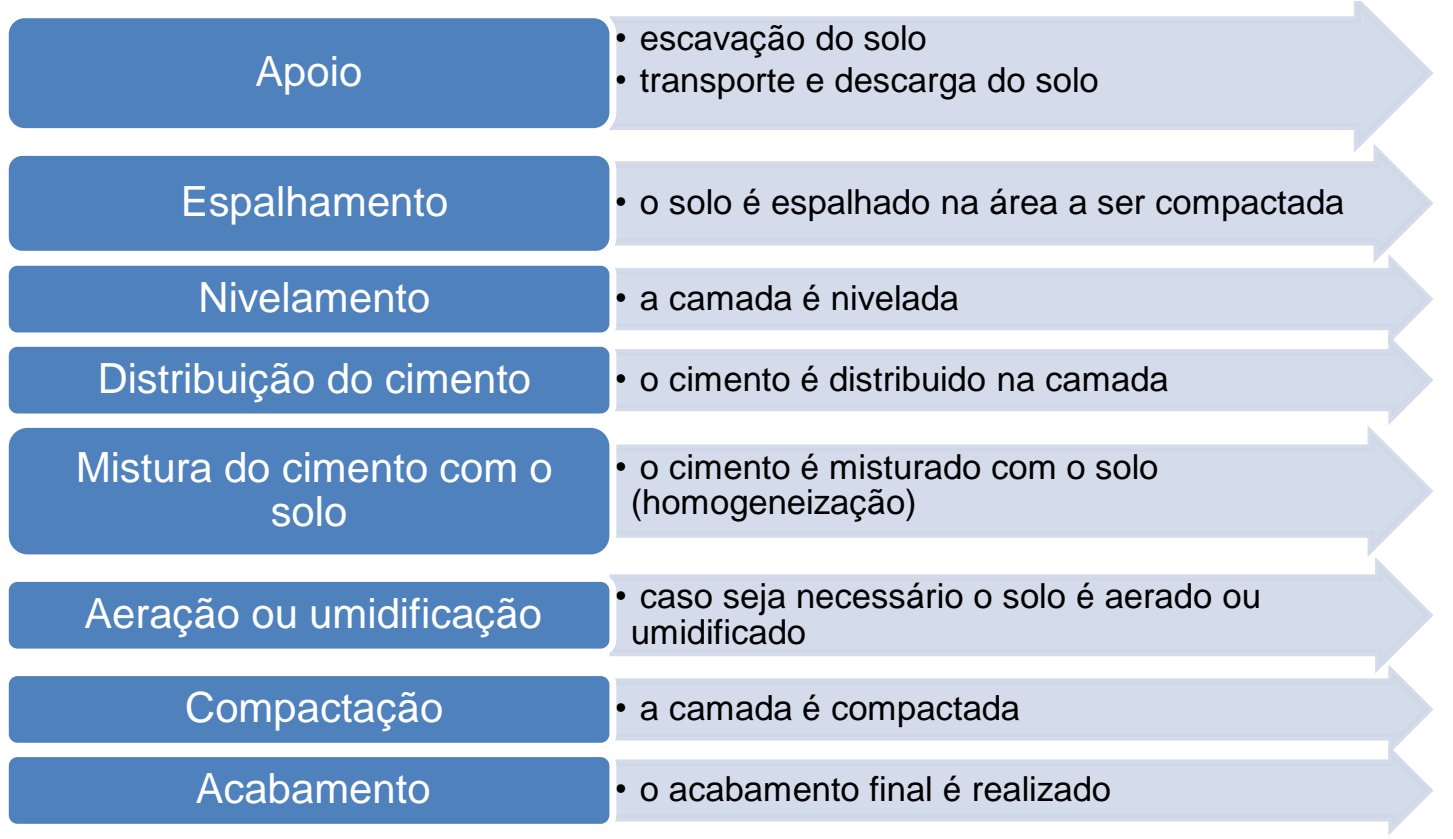

Figura 23 - Quebra do serviço de execução de solo cimento

A mistura do solo com cimento pode ser previamente preparada em usina tendo neste caso a dispensa dos processos de distribuição do cimento e posterior mistura com o solo.

Em função dos tipos de equipamentos e mão de obra disponíveis as "quebras dos serviços" propostas anteriormente podem ser diferentes.

$\mathrm{Na}$ medida em que se pretende entender os custos de pavimentação, é importante conhecer a demanda relativa a cada um destes serviços. $O$ entendimento das partes de cada serviço possibilitou a proposição dos tipos e das quantidades de composições orçamentárias apresentadas a seguir:

a) Concreto betuminoso usinado a quente - capa de rolamento e binder

- limpeza,

- lançamento,

- pré-compactação,

- compactação,

- acabamento; 
b) Pinturas asfálticas e imprimações

- limpeza,

- lançamento;

c) Bases, sub-bases e reforços de subleitos

- Base de brita graduada e brita graduada tratada com cimento;

- lançamento,

- pré-compactação,

- compactação,

- acabamento;

- Base de solo cimento e mistura na pista;

○ espalhamento,

○ nivelamento,

- distribuição do cimento,

- mistura do cimento com o solo,

- aeração e/ou umidificação (se precisar),

- compactação,

○ acabamento.

\subsection{Reflexões do Capítulo 3}

Este capítulo possibilitou o entendimento geral do serviço pavimentação asfáltica na execução de rodovias. Em especial, as modalidades de serviço de revestimento asfáltico, pinturas asfálticas e imprimações impermeabilizantes, bases, sub-base e reforços de subleitos foram apresentadas. As condicionantes para a escolha dos processos construtivos e os controles aplicáveis subsidiarão a proposição dos fatores. Os conhecimentos dos tipos de equipamentos e as formações de equipes embasarão o entendimento relativo à produtividade variável e a proposição de faixas de valores. A quebra dos serviços subsidiará a definição da quantidade de composições orçamentárias a serem propostas nos capítulos subsequentes. 


\section{ABORDAGEM DOS MANUAIS}

Embora os procedimentos usados na coleta dos dados constantes dos manuais não sejam normalmente conhecidos e possam variar de um para 0 outro, os manuais de orçamento representam uma experiência acumulada que não pode ser desprezada. "Principalmente porque coletar dados em construção não é uma tarefa fácil nem barata” (SOUZA, 1996).

Este capítulo visa proporcionar o entendimento sobre as metodologias contidas nos diversos manuais, conhecer a abordagem dos serviços de terraplenagem e pavimentação asfáltica, os critérios utilizados para a formação dos indicadores de produtividade e as partes contempladas de cada serviço.

Os seguintes critérios foram adotados na escolha dos manuais adotados como fontes de dados: reconhecimento técnico; grau de detalhe quanto à descrição dos casos analisados; evitar-se uso de manuais com mesmas fontes de informação.

\subsection{Descrição dos Manuais}

Os manuais ${ }^{34}$ utilizados neste estudo são originados das seguintes fontes ${ }^{35}$ :

a) Departamento Nacional de Infraestrutura de Transportes (DNIT);

b) Empresa de Obras Públicas do Estado do Rio de Janeiro (EMOP);

${ }^{34}$ Embora cada fonte utilizada nesta pesquisa se apresente diferentemente uma da outra (DNIT - manual; TCPO - manual; EMOP - composições; SIURB - composições; CAIXA composições; e PCC-USP - relatórios), todas foram consideradas como manuais de orçamento.

${ }^{35}$ Outros manuais existentes, porém não utilizados:

a) Brasileiros:

- Secretaria da Infraestrutura do Estado do Ceará (SEINFRA-CE, 2012). Não utilizado por ser semelhante ao SIURB;

- Secretaria de Estado de Infraestrutura de Goiás (SEINFRA-GO, 2012). Não utilizado por ser semelhante ao SIURB;

- Departamento Autônomo de Estradas de Rodagem do Estado do Rio Grande do Sul (DAER-RS, 2012). Não utilizado por ser semelhante ao DNIT;

b) Internacionais:

- "Heavy Construction Cost Book" da Dodge (1998);

- "Construction Cost Management - Learning From Case Studies" de Potts (2008);

- "Heavy Construction Cost Data" da RS Means (2012).

Como o objetivo deste trabalho é espelhar a realidade brasileira, os manuais internacionais não fizeram parte deste estudo. 
c) Secretaria Municipal de Infraestrutura Urbana e Obras do município de São Paulo (SIURB);

d) Tabela de Composição de Preços para Orçamentos (TCPO);

e) Caixa Econômica Federal (CAIXA);

f) Departamento de Engenharia de Construção Civil da Escola Politécnica da Universidade de São Paulo (PCC-USP).

\subsubsection{DNIT}

O Departamento Nacional de Infraestrutura de Transportes (DNIT) é o órgão executor da política de transportes determinada pelo Governo Federal. Autarquia vinculada ao Ministério dos Transportes, implantada em fevereiro de 2002, para desempenhar as funções relativas à construção, manutenção e operação de infraestrutura dos segmentos do Sistema Federal de Viação sob administração direta da União nos modais rodoviário, ferroviário e aquaviário, conforme Decreto № 4.129 de 13/02/2002 (BRASIL, 2010).

Para gerenciar os modais rodoviário, ferroviário, aquaviário e suas edificações o DNIT utiliza o Sistema de Custos Referenciais de Obras $\left(\right.$ SICRO $\left.^{36}\right)$. Como metodologia para elaboração de orçamentos de obras, o Manual de Custos Rodoviários de 2003 (SICRO 2) é o utilizado até que seja oficialmente publicada nova consulta pública ao SICRO 3 e a consequente aprovação do novo sistema.

O SICRO é um Manual que contém a descrição das metodologias e conceitos utilizados no desenvolvimento do Sistema Nacional de Custos de Infraestrutura de Transportes (SINCTRAN), cuja finalidade é a elaboração de custos referenciais de infraestrutura.

O Manual, em sua versão integral, é apresentado em nove volumes. Os volumes utilizados nesta tese de doutoramento foram:

a) Volume 1: Metodologia e Conceitos;

O presente manual define uma metodologia para a elaboração de composições de custos ${ }^{37}$.

\footnotetext{
${ }^{36} \mathrm{http}: / /$ www.dnit.gov.br/menu/SICRO/sicro/document_view.

${ }^{37}$ DNIT (2007a)
} 
b) Volume 4: Manual de Custos Unitários de Obras Rodoviárias;

Neste volume são abordados os critérios gerais adotados e os parâmetros utilizados na elaboração das composições integrantes do SINCTRAN ${ }^{38}$.

c) Volume 8: Manual de Aferição das Composições de Custos;

Este documento apresenta a metodologia e os critérios adotados para 0 cálculo dos custos unitários dos insumos e serviços necessários à execução das obras rodoviárias, ferroviárias, aquaviárias e de edificações gerenciadas pelo DNIT. Apresenta, ainda, as rotinas e procedimentos empregados pelo sistema informatizado implantado para o cálculo dos custos unitários de referência ${ }^{39}$.

d) Volume 9: Composições de Custos Unitários de Referência por Fase Construtiva.

As Composições de Custos Unitários de Referência por Fase Construtiva estão no Volume 9 do Manual, subdividas em 6 tomos e 36 fases. As fases utilizadas nesta tese foram: fase $4-$ Terraplenagem $^{40}$; e fase 20 - Pavimentações ${ }^{41}$.

\subsubsection{EMOP}

A Empresa de Obras Públicas do Estado do Rio de Janeiro (EMOP) ${ }^{42}$, empresa pública de direito privado, com 32 anos de atuação no mercado da construção civil, com áreas de abrangência em todo Estado do Rio de Janeiro e sede própria no município do Rio de Janeiro, é representada por oito subsedes: cujo negócio é gerir serviços de engenharia e arquitetura.

Sua missão é assegurar aos projetos governamentais espaços adequados à prestação de serviços, mediante construção, transformação e manutenção dos bens públicos voltados ao bem estar social.

A EMOP edita, mensalmente, o Boletim de Custos com os preços e índices oficiais de custo das obras públicas no Estado. O trabalho é executado pela

\footnotetext{
38 DNIT (2007b)

39 DNIT $(2007 \mathrm{c})$

40 DNIT $(2007 d)$

${ }^{41}$ DNIT (2007e)

42 Para aquisição, a EMOP disponibiliza os Boletins e Catálogos de Referência no seguinte endereço: <http://www.emop.rj.gov.br/cad_catalogo.asp>
} 
Divisão da Composição de Preços da Diretoria Técnica da EMOP, que pesquisa mais de três mil itens (materiais e serviços) por mês. $O$ boletim é referência indispensável para levantamento de custos, execução de orçamentos, pagamento de faturas e reajustamento de preços. Utilizado por todas as firmas de construção civil que realizam obras para o Estado, além de clientes como Caixa Econômica Federal, que utiliza os índices como referência para a construção de habitações.

O Manual, em sua versão integral ${ }^{43}$, consiste de três catálogos e um boletim mensal, conforme descrito a seguir:

a) Catálogo de Referência (12ª Edição);

Descreve os serviços usuais em orçamentos, codificados de maneira a permitir a utilização do Boletim Mensal de Custos;

b) Catálogo de Composição de Serviços (2ª Edição);

Apresenta, detalhadamente, as quantidades de materiais, equipamentos e mão de obra necessários à determinação dos custos unitários dos serviços descritos no Catálogo de Referência (12 $2^{\underline{a}}$ Edição);

c) Catálogo de Materiais, Equipamentos, Mão de obra e Serviços (5를ição);

Descreve os insumos, de interesse na execução dos orçamentos das obras, codificados de maneira a permitir a utilização do Boletim Mensal de Custos;

d) Boletim Mensal de Custos.

Contém os custos unitários dos serviços descritos no Catálogo de Referência, os preços elementares dos insumos descritos no Catálogo de Materiais e os índices de custos (famílias de reajustamento) utilizados na atualização ou regressão dos custos unitários dos serviços orçados e/ou contratados.

Embora os demais Catálogos sejam consultados, o Catálogo de Composição de Serviços (2 ${ }^{\mathrm{a}}$ Edição) é o principal catálogo utilizado neste trabalho, que, em sua versão integral é apresentado em 26 categorias. As categorias utilizadas nesta tese de doutoramento são: Categoria 03: Movimento de terra; e a Categoria 20: Custos rodoviários.

${ }^{43}$ Rio de Janeiro (1999) 


\subsubsection{SIURB}

A Secretaria de Infraestrutura Urbana e Obras (SIURB), da Prefeitura de São Paulo, tem as seguintes finalidades: programar, orientar e organizar projetos completos de obras viárias, assegurando sua execução; examinar o planejamento de obras e serviços que venham a ser realizados nas vias e logradouros públicos, aprovando e autorizando a ocupação das vias públicas; executar obras de recuperação estrutural e construção de pontes e viadutos; executar obras de edificações na cidade; executar obras de reparos e reformas gerais na cidade; manutenção preventiva e corretiva; autorizar obras que atendam a municipalidade e propor planos de drenagem para a cidade e implantá-los.

A serem adotadas em todas as licitações realizadas pela SIURB, essa Secretaria desenvolveu as Tabelas de Custos Unitários: tabelas de Edificações e de Infraestrutura Urbana.

As tabelas de custos unitários, utilizadas nesta tese, são as tabelas de Edificações ํo 41 e de Infraestrutura Urbana, data-base Julho/2009 Processos no 2009-0.237.444-0 e 2009-0.237.446-644.

O Manual, em sua versão integral, é apresentado em três categorias com os seguintes títulos:

Categoria 01: Arquivos Gerais;

- BDI, composições auxiliares, encargos sociais, equipamentos - custos unitários, equipamentos - memória de calculo, equipamentos parâmetros, insumos, mão de obra horista, mão de obra mensalista.

Categoria 02 - Cálculos;

- Cálculo dos encargos sociais e horas efetivamente trabalhadas.

Categoria 03 - Infraestrutura Urbana.

- Composições de infraestrutura, critérios de infraestrutura, e custos unitários de infraestrutura.

A Categoria 03, Infraestrutura Urbana, foi o volume utilizado nesta tese de doutoramento.

\footnotetext{
44 A SIURB disponibiliza estas tabelas em: <.http://www2.prefeitura.sp.gov.br /secretarias/infraestruturaurbana/tabela_de_precos/0023/\#apresentacao>
} 


\subsubsection{TCPO}

O TCPO - Tabelas de Composições de Preços para Orçamentos constitui uma das principais referências para a preparação de orçamentos de obras no Brasil. A primeira edição foi lançada em 1955 e, desde então, os profissionais do setor têm acesso a um manancial de dados e informações para estimar os consumos de materiais e de mão de obra necessários para execução dos serviços de construção. Para fazer uma unidade de serviço de obra, esses dados são imprescindíveis na montagem do orçamento.

As composições estão organizadas de acordo com a classificação PINI, o que possibilita a correta identificação do item e conexão direta com os demais produtos da PINI, como revistas, softwares e sistemas de internet (TCPO, 2008).

Este Manual, em sua versão integral, é apresentado em dezoito partes e quinze categorias. A Categoria 02 - Canteiro de obras e materiais básicos: escavação e aterro; subgrade e leitos rodoviários; bases e lastros com ligante; e pavimentos flexíveis, foi a utilizada nesta tese de doutoramento.

\subsubsection{CAIXA}

Trata-se de um projeto de pesquisa, acordado entre a Caixa Econômica Federal (CAIXA) e a Escola Politécnica da USP (este projeto está apresentado na seção 4.1.6) no qual, no âmbito do SINAPI, a CAIXA disponibilizou, para o Departamento de Engenharia de Construção Civil (PCC-USP), um conjunto de Composições de Preços Unitários (CPU) propostas pela INFRAERO.

Estas CPU se referem ao Anexo XII do Orçamento de Referência - Aeroporto Internacional de São Paulo / Guarulhos - Governador André Franco Montoro Terminal de Passageiros № 3 (TPS 3), do Viaduto (VDT), do Sistema Viário Interno (SVI), do Edifício Garagem (EDG), do Pátio de Estacionamento de Aeronaves (PPT) e Projetos (INFRAERO, 2005).

Dentre as noventa e duas CPU disponibilizadas, vinte e três estão relacionadas aos serviços de terraplenagem e pavimentação asfáltica (Tabela 25). 
Tabela 25 - Composições de preços unitários disponibilizadas pela CAIXA

\begin{tabular}{|c|c|}
\hline ITEM $^{45}$ & DESCRIÇÃO \\
\hline 03 & Escavação e Carga de Material de $1^{\underline{a}}$ categoria \\
\hline 04 & Escavação e Carga de Material Brejoso \\
\hline 05 & Escavação e Carga de Empréstimo, c/ fornecimento de terra \\
\hline 06 & Escavação e Carga de Material de $1^{a}$ Categoria, do Aterro de Sobrecarga \\
\hline 07 & Aterro Compactado, GC > 90\% Proctor Modificado \\
\hline 08 & Aterro Compactado, GC > 85\% Proctor Modificado \\
\hline 09 & Aterro de Sobrecarga \\
\hline 10 & Transporte de Material de $1^{\text {a }}$ categoria até $3 \mathrm{~km}$ \\
\hline 11 & Transporte de Material de $1^{1}$ categoria além de $3 \mathrm{~km}$ \\
\hline 12 & Transporte de Material Brejoso até $3 \mathrm{~km}$ \\
\hline 13 & Transporte de Material Brejoso além de $3 \mathrm{~km}$ \\
\hline 14 & Espalhamento de Material Brejoso \\
\hline 15 & Espalhamento de Material de Limpeza \\
\hline 16 & Lastro de brita \\
\hline 63 & Sub-base ou Base de Brita Graduada Simples \\
\hline 64 & Sub-Base ou Base de Brita Graduada Tratada com cimento 4\% em peso \\
\hline 65 & Sub-Base ou Base de Brita Graduada Tratada com cimento 3\% em peso \\
\hline 66 & Pré-Misturado à Quente ( PMQ )(Sistema Viário) \\
\hline 68 & Imprimação \\
\hline 69 & Pintura de Ligação \\
\hline 70 & Concreto Betuminoso Usinado à Quente (CBUQ)(Sistema Viário) \\
\hline 72 & Concreto Betuminoso Usinado à Quente (BINDER)(sistema Viário) \\
\hline 74 & Transporte de massa asfáltica (CBUQ, PMQ) \\
\hline
\end{tabular}

\subsubsection{PCC-USP}

A ideia de melhorar os sistemas de indicadores vale para quaisquer subsetores da Indústria da Construção. Em especial, dada a necessidade de se fomentar novas obras neste subsetor, torna-se ainda mais importante o aprimoramento dos indicadores utilizados na Construção Pesada.

Neste contexto, a Caixa Econômica Federal, no âmbito do SINAPI, desenvolveu um banco de composições para subsidiar este subsetor, em especial as obras de aeroportos. Tal banco de dados nasceu de um conjunto de composições disponibilizadas pela INFRAERO e que foi aprimorado no sentido de se aumentar sua confiabilidade. A necessidade deste aprimoramento foi detectada e solicitada pela CAIXA ao Departamento de Engenharia de Construção Civil da Escola Politécnica da USP (PCC-USP).

\footnotetext{
${ }^{45}$ Foi mantida a numeração das composições cedidas pela Caixa Econômica Federal
} 
As composições citadas (Tabela 25) foram revisadas, através da atualização dos seus indicadores de produtividade da mão de obra, de consumo unitário de materiais e de horas gastas de equipamentos.

O aprimoramento dos indicadores usou informações advindas de diferentes fontes:

a) manuais de orçamentação disponíveis considerados bons tecnicamente;

b) experiência acumulada do PCC-USP e da CAIXA;

c) entrevistas aos especialistas;

d) pesquisa de campo.

A pesquisa foi desenvolvida ao longo de 14 meses e foi dividida em duas partes: 6 meses para os levantamentos e geração dos relatórios, com acompanhamento dos técnicos da Caixa; e mais 8 meses para análises e discussões entre a equipe do PCC-USP e os técnicos da CAIXA e INFRAERO.

O Prof. Dr. Ubiraci Espinelli Lemes de Souza, Prof. Dr. Orestes Marraccini Gonçalves e o Doutorando Ricardo Cruvinel Dornelas, foram os principais integrantes da equipe do PCC-USP.

O trabalho envolveu 0 aprimoramento dos indicadores constantes nas composições, enviadas pela CAIXA, classificadas nos grupos apresentados na Tabela 26.

Tabela 26 - Classificação das composições segundo os grupos.

\begin{tabular}{l}
\hline CLASSE \\
\hline 1. Itens gerais \\
\hline 2. Movimento de terra \\
\hline 4. Infra e superestrutura de concreto \\
\hline 5. Estrutura metálica e outros pré-fabricados \\
\hline 6. Pavimentos \\
\hline 7. Outros serviços
\end{tabular}


Para cada uma das classes foi redigido um relatório ${ }^{46}$ discorrendo sobre os indicadores revisados; em muitos dos casos foi feita uma distinção entre os indicadores relativos à mão de obra, materiais e aos equipamentos. Para alguns temas foi adotada a entrevista com especialistas/fornecedores/usuários/ construtores como principal fonte de dados e, para outros, foi efetuado um levantamento presencial de dados.

\subsection{Formas de Abordagem dos Manuais}

Esta seção busca apresentar, sucintamente, as formas em que os diferentes manuais abordam os serviços de terraplenagem e pavimentação asfáltica, com ênfase mais na metodologia do que na execução dos serviços (já discorridos nos Capítulos 2 e 3). Os seguintes temas são apresentados a seguir:

a) alguns conceitos importantes;

b) montagem das composições de custos unitários;

c) ciclo dos equipamentos;

d) equilíbrio das equipes mecânicas ou patrulhas;

e) tempo operativo e tempo improdutivo;

f) resumo dos termos contidos nos manuais;

g) custos de implantação de uma rodovia;

h) custos unitários dos serviços;

i) custo horário de equipamentos;

j) produção das equipes mecânicas;

k) método teórico do DNIT;

I) método teórico do TCPO;

m) modelos de composições unitárias.

\subsubsection{Alguns conceitos importantes}

Dentre os conceitos importantes encontram-se os seguintes assuntos: tarefa de levantamento de insumos; superfície de operação; mão de obra e chuvas.

\footnotetext{
${ }^{46}$ Ao todo foram gerados 17 relatórios.
} 
a) Tarefa de levantamento de insumos

A tarefa de levantamento de insumos, implica, em primeiro lugar, na seleção da tecnologia de execução a ser empregada para a realização de cada um dos serviços que compõem a obra. Assim, cada composição reflete uma opção tecnológica, que é função do planejamento da obra. Como tal, tem que levar em conta o conjunto de circunstâncias que caracterizam o meio onde seu emprego está sendo cogitado. Destas, não podem ser omitidos: as especificações e as quantidades dos serviços a realizar, contidos no Projeto Final de Engenharia, as características dos materiais naturais a serem trabalhados, as distâncias de transporte previstas, o cronograma da obra, o elenco qualitativo e quantitativo de mão de obra e de equipamentos de que se poderá dispor, as condições climáticas da região onde se localiza a obra e a logística do empreendimento (DNIT, 2007a).

A seleção da tecnologia, sujeita às condicionantes acima, será feita sempre com vista a conciliar dois objetivos: eleger a melhor técnica de execução com maior economicidade. É necessário esclarecer que nem sempre tais objetivos são convergentes, impondo-se, na maior parte dos casos, uma solução de compromisso, ditada pelo bom senso.

b) Superfície de operação

Segundo a metodologia do DNIT (2007a), com base na classificação dos tipos de solos, $1^{\underline{a}}, 2^{\underline{a}}$ ou $3^{\underline{a}}$ categoria, classificam-se as condições de trabalho em leves, médias e pesadas para os serviços de escavação, carga e transporte, que são justamente aqueles usualmente realizados pelos equipamentos em questão, conforme pode ser observado na Tabela 27. Nas composições apresentadas no Manual do SINCTRAN os custos horários desses equipamentos foram calculados considerando-os operando em condições médias. 
Tabela 27 - Condições de trabalho para escavação e carga

\begin{tabular}{|c|c|c|}
\hline Condições leves & Condições médias & Condições pesadas \\
\hline 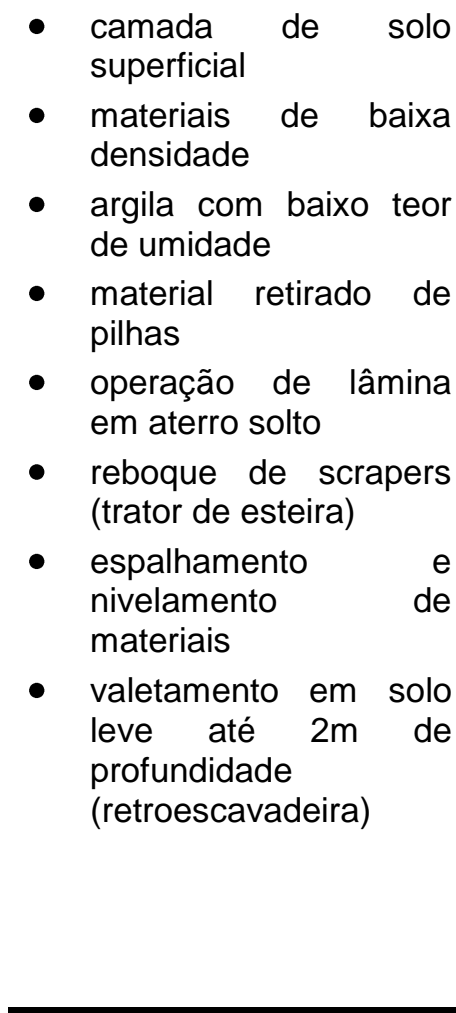 & 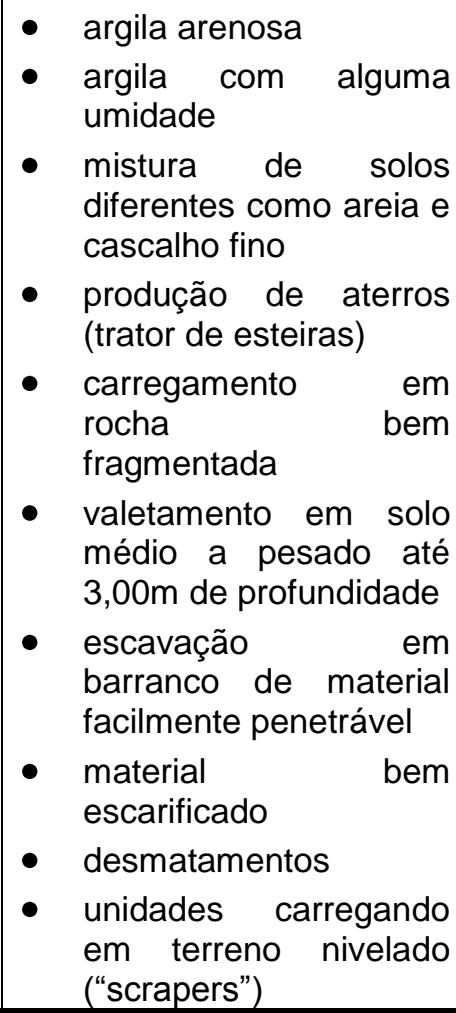 & $\begin{array}{l}\text { - } \text { pedras frequentes ou afloramento } \\
\text { - ce rochas } \\
\text { - } \text { escarificação pesada em rocha } \\
\text { - trabalho em pedreiras } \\
\text { - carregamento contínuo em solos } \\
\text { compactados como xisto argiloso, } \\
\text { cascalho consolidado, etc. } \\
\text { - valetamento em profundidades } \\
\text { superiores a 3m } \\
\text { - carregamento em rocha escarificada } \\
\text { (para scrapers) } \\
\text { - restrições constantes } \\
\text { comprimento ou largura, de } \\
\text { operação. }\end{array}$ \\
\hline
\end{tabular}

Fonte: DNIT (2007a)

c) Mão de obra

Em relação aos manuais SICRO 2 e SICRO 3, o DNIT, de um manual para o outro manual, retirou de todas as composições os "encarregados de turma", de pavimentação e de britagem. Essas categorias foram incluídas nas composições de "administração da obra".

O operador do equipamento está contido no custo unitário do equipamento.

\section{d) Chuvas}

As produções adotadas pelo DNIT não contemplam a ocorrência de condições climáticas desfavoráveis, as quais influenciam, em função da frequência e intensidade, e de modo específico, alguns tipos de serviços. 


\subsubsection{Montagem das composições de custos unitários}

Dentre os manuais estudados, o que apresentou detalhadamente uma metodologia de montagem das composições de custos unitários foi o manual do DNIT (2007a). Resumidamente, esta metodologia é apresentada a seguir.

O primeiro ponto a ser observado é a adequação tecnológica da composição. Uma vez que a tecnologia tenha sido corretamente selecionada, a atenção deve se voltar para o dimensionamento desses recursos, com ênfase nos equipamentos.

Na maior parte dos casos, os serviços de construção são realizados por grupos de equipamentos de diferentes tipos, que trabalham em conjunto constituindo $o$ que usualmente se denomina equipe mecânica ou patrulha. Do fato de ter cada um desses equipamentos (nas condições em que trabalha) uma determinada produção efetiva, resulta a necessidade de se dimensionar a quantidade dos diferentes tipos de equipamentos de forma a maximizar a produção da patrulha. Isso é usualmente denominado otimização do equilíbrio interno ou sincronismo da patrulha.

Outro ponto a ser observado é o que se refere à determinação da incidência dos insumos na composição, que é a quantidade de determinado insumo, necessária à realização de uma unidade de produção. A "produção unitária" traduz a quantidade de serviço produzido pelo equipamento por hora de operação, e seu inverso - horas de operação por unidade de serviço representa a incidência desse equipamento na composição. Da mesma maneira, a incidência da mão de obra e dos materiais é determinada a partir da quantidade desses insumos necessária à produção de uma unidade de serviço. Cabe observar que ao se montar uma composição de serviço será sempre necessário ajustar incidências em função das relações entre as respectivas "produções unitárias".

A Figura 24 apresenta uma síntese dos elementos de uma composição unitária, onde: (1) produção unitária $192 \mathrm{~m}^{3} / \mathrm{h}$; (2) razão unitária de produção $1 \mathrm{~h} / 192 \mathrm{~m}^{3}=$ 0,0052; (3) equipe mecânica ou patrulha. 


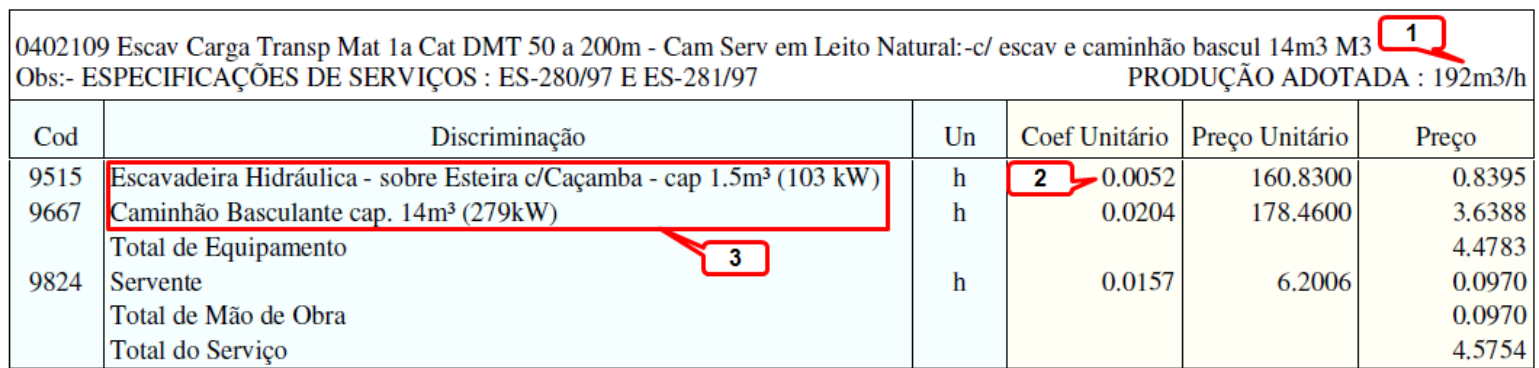

Figura 24 - Elementos de uma composição unitária

Fonte: Adaptado de DNIT (2007d)

\subsubsection{Ciclo dos equipamentos}

Conforme metodologia do DNIT (2007a), os equipamentos, em geral, realizam operações repetitivas, ou seja, trabalham em ciclos. Entende-se por ciclo o conjunto de ações ou movimentos que o equipamento realiza desde sua partida, de uma determinada situação, até seu retorno a uma situação semelhante, que marca o início de um novo ciclo. O tempo decorrido entre as duas situações é denominado "duração do ciclo" ou "tempo total do ciclo", que determina um intervalo, durante o qual o equipamento em questão realiza certa quantidade de serviço. A quantificação do serviço realizado durante um ciclo e seu tempo total de duração são elementos fundamentais para a determinação da produção unitária do equipamento, para dimensionar e equilibrar o restante dos equipamentos que com ele formam patrulha, bem como para calcular a produção da própria patrulha.

Alguns manuais, tais como: Caterpillar (2000); Komatsu (2006); e Dynapac (2010), indicam os tempos totais de ciclo de seus equipamentos. Exemplificando, o Manual de Produção da Caterpillar indica, para a escavadeira hidráulica, os tempos totais de ciclo de 0,27 min, considerando material de $1^{\underline{a}}$ categoria (Figura 25). Este dado é referente ao Modelo $330 \mathrm{~B}$, que tem os seguintes tempos:

- carregar a caçamba: 0,09 min,

- oscilar caçamba carregada: 0,07 min,

- despejar caçamba: 0,04 min,

- oscilar caçamba vazia: 0,07 min,

- tempo total de ciclo: 0,27 min. 
Tabela de Estimativa do Tempo do Ciclo

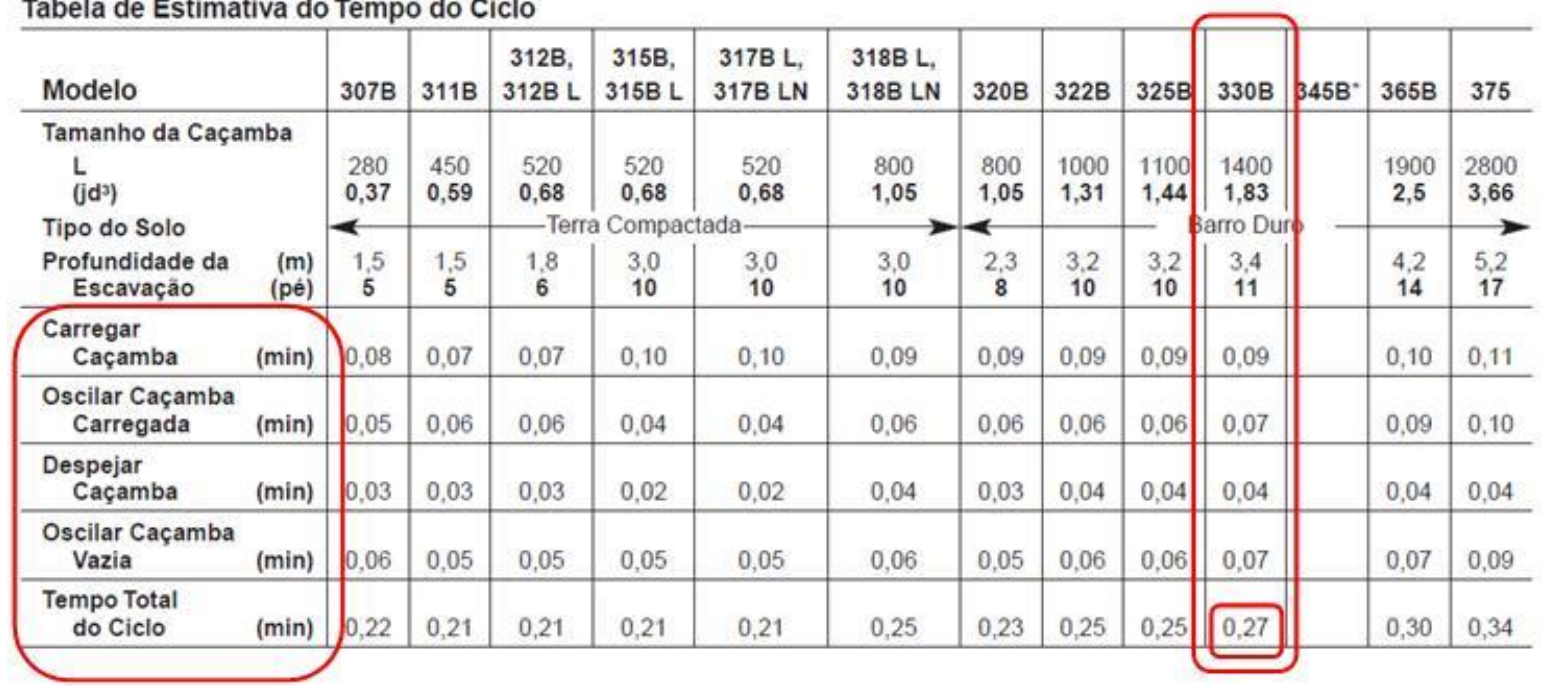

Figura 25 - Estimativa do tempo de ciclo da escavadeira hidráulica Fonte: Caterpillar (2000)

\subsubsection{Equilíbrio das equipes mecânicas ou patrulhas}

De acordo com o manual do DNIT (2007a), promover o equilíbrio de uma patrulha de equipamentos é a atividade que consiste em selecionar seus componentes e dimensionar a quantidade de cada um deles, de tal forma que a harmonia do conjunto resulte numa produção otimizada, ou seja, que tire o melhor partido das capacidades individuais. Em primeiro lugar, é preciso saber que tipos de equipamentos devem ser reunidos para realizar determinada tarefa. Note-se que nem sempre este problema oferece uma única solução; o mais comum é que se disponha de várias opções, remetendo a questão à escolha da tecnologia mais adequada.

Em termos práticos, o equilíbrio se dá sempre em torno do equipamento eleito como principal ou que comandará o ritmo da patrulha, figurando os demais como seus coadjuvantes (ver Figura 26). Em vista disso, se obterá sempre maior economicidade no trabalho da patrulha quando o equipamento escolhido para comandar seu ritmo for aquele de maior custo horário.

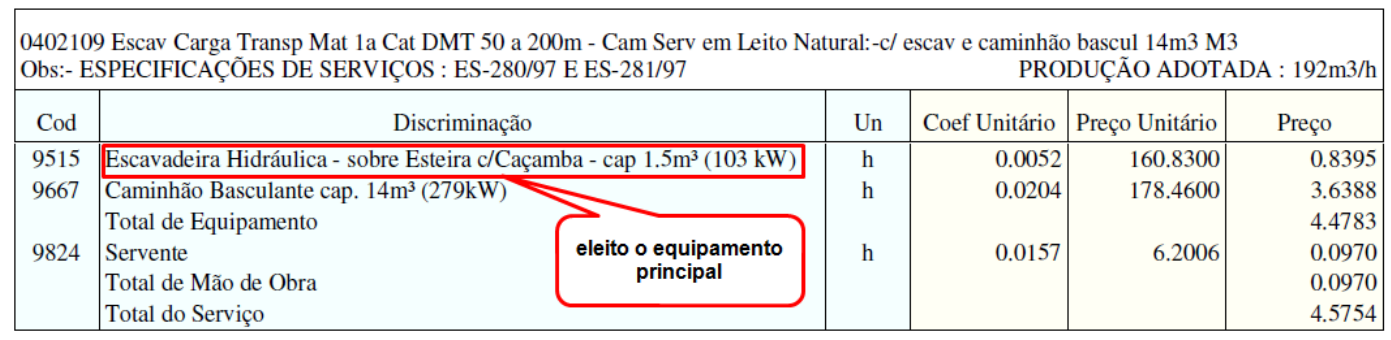

Figura 26 - Equipamento eleito como principal

Fonte: Adaptado de DNIT (2007d) 


\subsubsection{Tempo operativo e tempo improdutivo}

Os conceitos e o modelo matemático adotados no cálculo dos preços unitários do DNIT (2007a) consideram dois períodos de tempo diferentes na atuação dos equipamentos: a hora operativa e a hora improdutiva. Durante a hora operativa, o equipamento está operando normalmente, sujeito às restrições que são levadas em conta quando se aplica o fator eficiência. Na hora improdutiva, o equipamento está parado, com 0 motor desligado, aguardando que 0 equipamento que comanda a equipe permita-Ihe operar ${ }^{47}$.

Assim, tempo operativo é aquele em que o equipamento está dedicado ao serviço, na frente de trabalho, com seus motores ou acionadores ligados, quando for o caso, ou em condições de trabalho, quando se tratar de equipamento não propelido mecanicamente. $O$ equipamento operativo comporta duas situações: produtivo e em espera.

No seu tempo produtivo, o equipamento está efetivamente executando alguma das tarefas a ele inerentes.

Quando em espera, o equipamento está aguardando que algum outro componente da patrulha complete sua parte, de modo a abrir frente para que ele possa atuar. Tais esperas têm sua origem em desequilíbrios internos, e resultam de se juntar numa mesma patrulha equipamentos com capacidades e níveis de produtividades diferentes, de tal sorte que o ritmo do mais lento condiciona a produção do conjunto. Aplica-se este conceito apenas quando as esperas forem de curta duração que não justifiquem desligamento de motores. Durante as esperas, assim caracterizadas, os motores estarão funcionando em marcha lenta ou os equipamentos realizando pequenos deslocamentos para melhor se posicionarem.

Os tempos improdutivos, por sua vez, comportam paradas de mais longa duração, em que os equipamentos continuam vinculados ao serviço e seus operadores permanecem mobilizados, mesmo que seus motores tenham sido desligados.

Matematicamente, a improdutividade aparece quando se compara a produção horária da equipe com a dos equipamentos individuais. O coeficiente de

\footnotetext{
${ }^{47}$ Nota: esta metodologia se apresenta incompleta pois, não contempla (ou não deixa explicito) as ociosidades entre frentes, as quebras e manutenções dos equipamentos.
} 
utilização produtivo é o quociente de divisão da produção da equipe pela produção de cada tipo de equipamento e é sempre menor ou igual a 1. 0 coeficiente de utilização improdutiva é obtido por diferença.

Os percentuais produtivos e improdutivos são obtidos conforme:

Eq. 2

onde:

$\mathrm{Np}=$ número de unidades do equipamento que comanda a produção da equipe;

$P p=$ produção do equipamento que comanda a equipe;

N1 = número de unidades do equipamento que se está calculando a utilização;

$\mathrm{P} 1$ = produção do equipamento que se está calculando a utilização.

O percentual improdutivo é calculado por:

Eq. 3

Pelo que foi exposto até aqui, com relação aos tempos improdutivos dos equipamentos, pode-se depreender que sua quantificação só é possível quando se estuda caso a caso, pois ela é inteiramente função de como se pretende conduzir cada frente de serviço. Assim sendo, as Composições de Serviços contidas no SINCTRAN incluem o custo do tempo improdutivo dos equipamentos pela aplicação de um percentual adicionado ao valor da hora produtiva. Esse percentual, de 3\%, foi estabelecido levantando-se, em cada item de serviço do SICRO2, o quociente: valor das horas improdutivas / valor das horas produtivas e calculando-se a média. Observa-se que, na prática, este percentual parece muito baixo pois, conforme levantamentos em campo (ver Capítulo 6), os valores encontrados são muito superiores.

\subsubsection{Resumo dos termos contidos nos manuais}

Um resumo dos termos e formas abordadas pelos manuais é apresentada na Tabela 28: 
Tabela 28 - Termos e formas abordadas pelos manuais estudados.

\begin{tabular}{|c|c|c|c|}
\hline \multirow{3}{*}{ DNIT } & $\begin{array}{cc}\text { Hora operativa } & \\
-\quad \text { Tempo operativo } \\
\circ & \text { Tempo produtivo } \\
0 & \text { Tempo em espera } \\
\end{array}$ & $\begin{array}{l}\text { Custo horário } \\
\text { operativo }\end{array}$ & $\begin{array}{l}d+m+o(j u r o s d e \\
\text { capital vai no BDI)* }\end{array}$ \\
\hline & $\begin{array}{c}\text { Hora improdutiva } \\
\text { • Tempo improdutivo }\end{array}$ & $\begin{array}{l}\text { Custo horário } \\
\text { improdutivo }\end{array}$ & mdo* \\
\hline & $\begin{array}{l}\text { Obs.: SICRO } 2 \text { - na composição de } \\
\text { operativa e utilização improdutiva } \\
\text { Obs.: SICRO } 3 \text { - embora se trate do } \\
\text { aparece nenhuma nomenclatura }\end{array}$ & $\begin{array}{l}\text { h unitários }(\mathrm{CPU}) \\
\text { horário operativ }\end{array}$ & $\begin{array}{l}\text { parece utilização } \\
\text { na CPU não }\end{array}$ \\
\hline \multirow[b]{3}{*}{ TCPO } & Hora produtiva & $\begin{array}{l}\text { Custo horário } \\
\text { produtivo }\end{array}$ & $d+j+m+o^{*}$ \\
\hline & Hora improdutiva & $\begin{array}{l}\text { Custo horário } \\
\text { improdutivo }\end{array}$ & $d+j+m d o^{*}$ \\
\hline & \multicolumn{3}{|c|}{$\begin{array}{l}\text { Apresenta conceitualmente (sem no entanto aplicar às composições) uma nova } \\
\text { abordagem para os custos de equipamentos, embasada nos seguintes conceitos: } \\
\text { - Tempo em funcionamento } \\
\text { - Tempo em processamento } \\
\text { - Tempo disponível para o serviço } \\
\text { - Tempo disponível de equipamento }\end{array}$} \\
\hline \multirow{2}{*}{$\begin{array}{l}\text { CAIXA - } \\
\text { INFRAERO }\end{array}$} & Utilização operativa & $\begin{array}{l}\text { Custo horário } \\
\text { operativo }\end{array}$ & - \\
\hline & Utilização improdutiva & $\begin{array}{c}\text { Custo horário } \\
\text { improdutivo }\end{array}$ & - \\
\hline \multirow[b]{2}{*}{ EMOP } & Hora produtiva & $\begin{array}{l}\text { Custo horário } \\
\text { produtivo - CP }\end{array}$ & $d+j+m+o^{*}$ \\
\hline & Hora improdutiva & $\begin{array}{l}\text { Custo horário } \\
\text { improdutivo - } \\
\text { Cl }\end{array}$ & $d+j+m d o^{*}$ \\
\hline SIURB & \multicolumn{3}{|c|}{ Obs.: não aparece nenhuma nomenclatura } \\
\hline \multicolumn{4}{|c|}{$\begin{array}{l}\text { *Legenda: } \\
d=\text { depreciação } \quad j=\text { juros de capital } \quad m=\text { manutenção } \\
\begin{array}{ll}0=\text { operação (inclui mdo) } \quad \text { mdo = mão de obra }\end{array}\end{array}$} \\
\hline
\end{tabular}

Reflexões acerca da Tabela 28:

a) Tempo operativo;

- Exceto o SIURB, o tempo operativo é tratado de maneira semelhante pelos manuais. O DNIT complementa considerando os momentos em que o equipamento está trabalhando ou em espera.

b) Tempo improdutivo;

- O SIURB e o SICRO 3 não apresentam as horas improdutivas. Os demais manuais tratam o tempo improdutivo de maneira semelhante. 
c) Custo horário operativo;

- O TCPO e o EMOP consideram os mesmos custos (depreciação + juros de capital + manutenção + operação) no momento de calcular o custo horário operativo. Para o DNIT os "juros de capital" devem ser considerados no momento de definição do $\mathrm{BDI}^{48}$. CAIXA-INFRAERO e SIURB não apresentam nenhuma metodologia.

d) Custo horário improdutivo;

- O TCPO e o EMOP consideram os mesmos custos (depreciação + juros de capital + mão de obra) no momento de calcular o custo horário improdutivo. No SICRO 2 considera-se somente o custo da "mão de obra". Já o SICRO 3 define que o custo horário improdutivo equivale a $3 \%$ do custo horário operativo. CAIXAINFRAERO e SIURB não apresentam nenhuma metodologia.

e) Nova abordagem para os custos de equipamentos. Na $13^{a}$ edição do TCPO, TCPO (2008), foi proposta uma nova postura para a abordagem dos custos dos equipamentos. Segundo o autor, trata-se de um caminho um pouco mais complexo que o tradicional, ao definir subdivisões um pouco mais detalhadas que a postura usual de distinguir apenas tempos produtivos e improdutivos. Trata-se de uma proposição conceitual, demandando, caso se queira aplicá-la, um envolvimento do responsável pela estimativa em termos do desenvolvimento do seu uso quanto a sua aplicação aos vários equipamentos e nas várias situações em que os mesmos podem comparecer. Neste caso, quatro tempos são apresentados: tempo em funcionamento; tempo em processamento; tempo disponível para o serviço; e tempo disponível de equipamento.

\subsubsection{Custos de Implantação de uma Rodovia}

Ao longo de todas as fases de implantação, ocorre uma interação entre os componentes do custo total de uma rodovia. O objetivo é buscar uma solução

\footnotetext{
${ }^{48} \mathrm{BDI}$ : benefícios e despesas indiretas. Expresso através de um percentual sobre os Custos Diretos, que engloba, além do lucro e das despesas indiretas, tudo o mais que deve ser executado e não consta da planilha de custos.
} 
economicamente viável. Na Figura 27 mostra-se, esquematicamente, o ponto ótimo de investimento para a escolha dos padrões de uma rodovia.

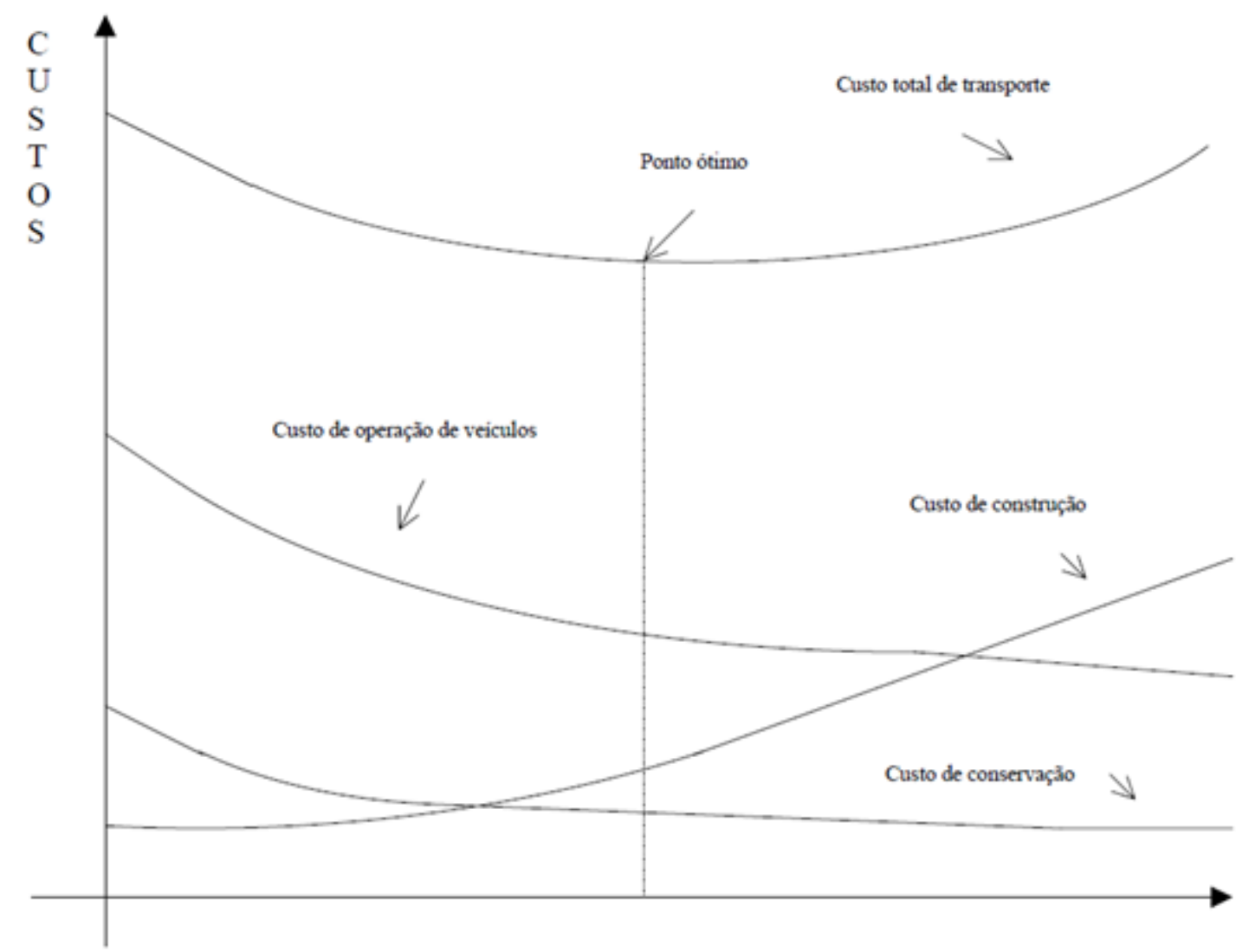

MELHOR PADRÃO DA RODOVIA

Figura 27 - Interação entre os componentes do custo total de uma rodovia Fonte: Aranovich (1998)

Como se pode observar, à medida que aumenta o capital inicial investido na construção da rodovia (custo de construção), diminui o custo de operação de veículos e de conservação. A curva relativa ao custo total de transporte representa a totalidade dos custos, isto é, o capital inicial investido somado ao custo de operação e conservação. Assim, a otimização do custo do ciclo de vida de uma rodovia fica representada pelo ponto ótimo.

Isso demonstra que não seria prudente buscar reduções de custos atacando apenas um de seus componentes. Ao contrário, sempre se faz necessário considerar as relações recíprocas. A tentativa de reduzir custos específicos, sem olhar para o conjunto, pode não beneficiar o sistema como um todo, já que a redução em um elemento de custo geralmente provoca aumento em outros. Assim, é sempre necessário considerar o efeito que cada tentativa de redução pode provocar sobre o custo total do ciclo de vida. 


\subsubsection{Custos unitários dos serviços}

O custo total de produção de uma rodovia tem dois componentes: o custo indireto ou fixo e o direto ou variável, que, para serem definidos em uma categoria ou outra, depende do horizonte de tempo com o qual se está lidando. Uma boa análise destes componentes é feita por Pindyck e Rubinfeld (1999). Segundo os autores, os Custos Indiretos ou Fixos são os custos que a empresa terá, independente do nível de produção obtido, e não serão modificados em curto prazo. São indiretamente envolvidos na produção. Os Custos Diretos ou Variáveis são os diretamente associados à execução (produção) dos serviços.

A sistematização da metodologia adotada pelo DAER-RS ${ }^{49}$, para o cálculo do custo unitário de um serviço, é apresentada na Figura 28.

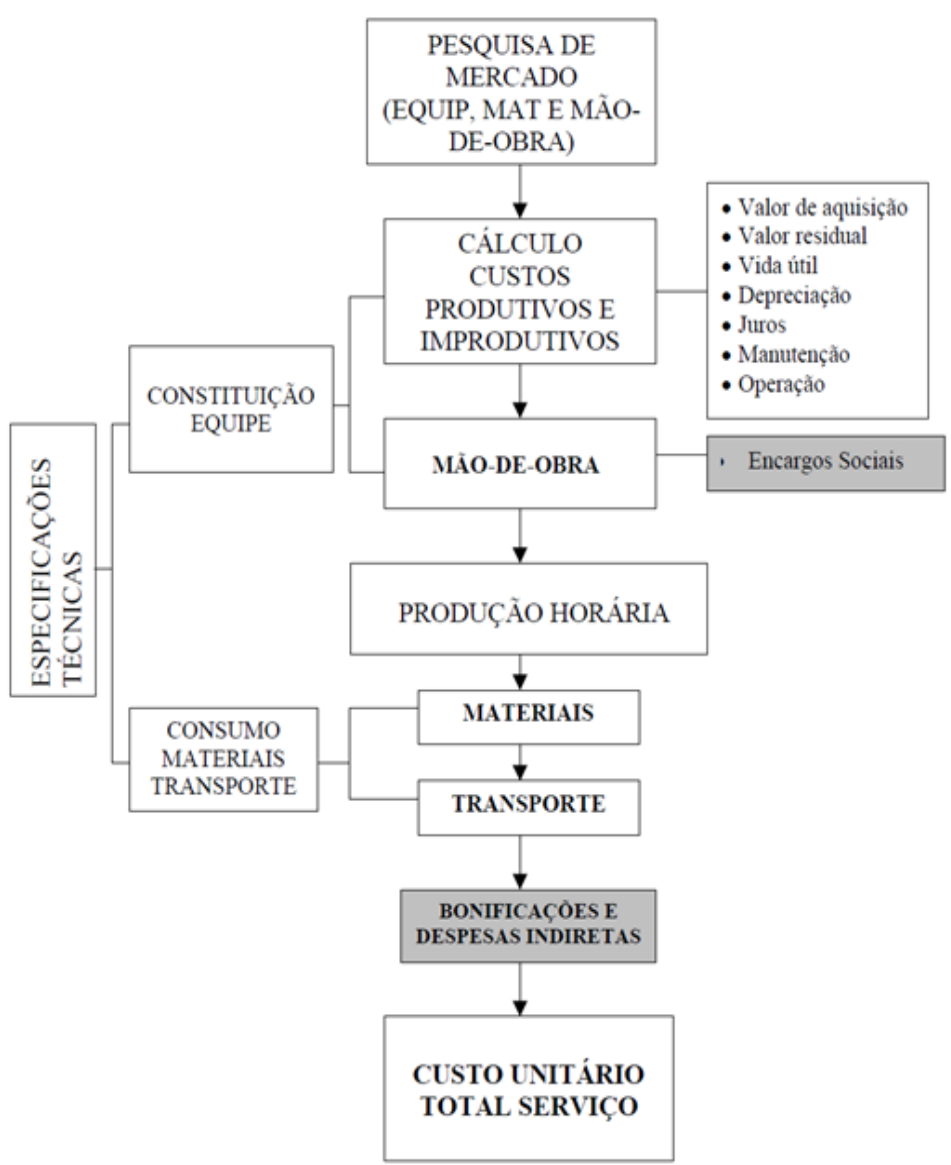

Figura 28 - Sistematização da metodologia de composição de custo unitário de um serviço. Fonte: Pedrozo (2001)

${ }^{49}$ DAER-RS: Departamento Autônomo de Estradas de Rodagem do Estado do Rio Grande do Sul. 
Inicia-se com a pesquisa de mercado. Depois com as especificações técnicas que se dividem em dois caminhos: a) constituição da equipe (cálculo dos custos produtivos e improdutivos, definição da mão de obra e da produção horária); b) determinação do consumo de materiais e transporte. As bonificações e despesas indiretas são calculadas. Tendo ao final, o custo unitário total do serviço.

\subsubsection{Custo horário de equipamentos}

Uma das parcelas componentes do custo dos serviços rodoviários é o custo horário de utilização dos equipamentos empregados em sua execução. Deste modo é importante estabelecer critérios que definam a forma como serão levados em conta os diferentes componentes desse custo.

Em função de sua necessidade, Kauffmann et al (2001) sugerem que, para o estudo dos custos horários de equipamentos, as três categorias de referências, apresentadas a seguir, são fundamentais:

a) Textos de engenharia econômica: textos avançados em engenharia econômica geralmente incluem capítulos que abordam os métodos e as questões de análise de substituição dos equipamentos. Park e Gunter (1990) e John et al (2005) são exemplos de livros didáticos abrangentes, contendo uma discussão aprofundada dos métodos de engenharia econômica.

b) Modelos de vida útil de equipamentos (custo de propriedade): Jones, Zydiak e Hopp (1989), Jones, Zydiak e Hopp (1992), Jones e Zydiak (1999) e Jlarc (2008) são exemplos que abordam conceitos teóricos gerais que são amplamente aplicáveis a este estudo.

c) Referências práticas e manuais: Douglas, Popscu e Ryan (2006) e Tatum et al (2006) são exemplos deste tipo de material de referência. 
Segundo o manual do DNIT e do TCPO, as despesas que são consideradas para o cálculo do custo horário de um equipamento estão apresentadas na Tabela 29.

Tabela 29 - Custo horário de equipamentos

\begin{tabular}{|c|c|}
\hline DNIT & TCPO \\
\hline $\begin{array}{l}\text { a) custos de propriedade; } \\
\text { b) depreciação; } \\
\text { c) custo de oportunidade do capital; } \\
\text { d) seguros e impostos; } \\
\text { e) custos de manutenção; } \\
\text { f) reparos em geral; } \\
\text { g) material rodante / pneus; } \\
\text { h) partes de desgaste (bordas cortantes, } \\
\text { dentes de caçamba, ferramenta de } \\
\text { i) custos de operação; } \\
\text { j) combustível; } \\
\text { k) filtros e lubrificantes; } \\
\text { l) mão de obra de operação. }\end{array}$ & $\begin{array}{l}\text { a) custos de propriedade } \\
\text { - remuneração do capital investido; } \\
\text { - reposição da perda de valor } \\
\text { (depreciação). } \\
\text { b) custos de manutenção } \\
\text { - preventiva; } \\
\text { - corretiva; } \\
\text { c) custos de operação } \\
\text { - energia para o funcionamento do } \\
\text { equipamento; } \\
\text { - remuneração dos trabalhadores que } \\
\text { operam o equipamento. }\end{array}$ \\
\hline
\end{tabular}
Fonte: DNIT (2007a)

Fonte: TCPO (2008)

Em resumo, o custo horário de um equipamento é a soma dos custos de propriedade, manutenção e operação referidos à unidade de tempo (hora). Ele é utilizado para o cálculo dos custos unitários dos serviços que o equipamento produz.

Considerando a importância dos equipamentos no total do custo unitário de um serviço de rodovia, este assunto deve ser melhor estudado. Sua breve apresentação se justifica como uma introdução para o entendimento da produção das equipes mecânicas.

\subsubsection{Produção das equipes mecânicas}

No manual do DNIT (2007a) a produção das equipes mecânicas corresponde sempre à de seu equipamento principal, devido ao próprio princípio através do qual as patrulhas são compostas. A produção das equipes mecânicas pode ser determinada por métodos teóricos, que levam em conta as características de 
catálogo do equipamento, ou por meio de métodos experimentais, que implicam medições feitas diretamente no campo. As informações do SINCTRAN relativas às produções de equipes mecânicas foram inicialmente geradas pelo método teórico.

\subsubsection{Método teórico do DNIT}

O método teórico para determinação da produção de uma equipe mecânica parte do princípio de que esta será sempre igual à produção do seu equipamento principal. Desta forma, conhecendo-se a produção horária do equipamento principal, estará determinada a produção da patrulha.

\subsubsection{Descrição do método}

A produção do equipamento principal, por sua vez, é calculada através de fórmulas específicas para cada tipo de equipamento.

As fórmulas levam em conta uma série de variáveis intervenientes, que são função das características do equipamento e do serviço que este realiza (capacidade, largura, velocidade, tempo de carga, descarga, manobras etc.) bem como alguns fatores de correção, cuja finalidade é adaptar os resultados às condições reais em que os serviços são realizados.

Usualmente são empregados os seguintes fatores de correção:
a) Fator de Eficiência;
b) Fator de Conversão;
c) Fator de Carga.

Os referidos fatores comportam as seguintes considerações:

a) Fator de Eficiência: o fator de eficiência de um equipamento é a relação entre o tempo de produção efetiva e o tempo de produção nominal.

Para calcular o fator de eficiência, devem ser observados os seguintes critérios: para cada hora do seu tempo total de trabalho, será estimada a produção efetiva de 50 minutos, para que sejam levados em consideração os tempos gastos em alterações de serviço ou deslocamentos, preparação da máquina para o trabalho e sua manutenção (Equação 4). 
Eq. 4

b) Fator de Conversão: o fator de conversão é a relação entre o volume do material para o qual está sendo calculado o custo unitário e o volume do mesmo material que está sendo manuseado. Na terraplenagem, representa a relação entre o volume do corte e o volume do material solto (Equação 5).

Eq. 5

$\mathrm{Na}$ Tabela 30 apresentam-se os valores adotados pelo DNIT.

Tabela 30 - Fator de conversão: relação entre o volume do corte e o volume do material solto

\begin{tabular}{c|c|c}
\hline Material de $\mathbf{1}^{\mathbf{a}}$ categoria & Material de 2 ${ }^{\mathbf{a}}$ categoria & Material de $\mathbf{3}^{\mathbf{a}}$ categoria \\
\hline $\mathrm{FC}=1,0 / 1,30=0,77$ & $\mathrm{FC}=1,0 / 1,39=0,72$ & $\mathrm{FC}=1 / 1,75=0,57$ \\
\hline
\end{tabular}

Fonte: DNIT (2007a)

c) Fator de Carga: o fator de carga é a relação entre a capacidade efetiva do equipamento e sua capacidade nominal. Os valores adotados encontram-se nas faixas recomendadas pelos fabricantes e são apresentados na Tabela 31.

Tabela 31 - Relação entre a capacidade efetiva do equipamento e sua capacidade nominal

\begin{tabular}{c|c|c}
\hline Material de $1^{\text {a }}$ categoria & Material de $2^{\text {a }}$ categoria & Material de $3^{\text {a }}$ categoria \\
\hline Categoria: 0,90 & Categoria: 0,80 & Categoria: 0,70 \\
\hline
\end{tabular}

Fonte: DNIT (2007a)

Uma vez dispondo de todos os elementos necessários ao cálculo, este é feito com o auxílio da planilha de Produção das Equipes Mecânicas, autoexplicativa, cujo modelo é apresentado na Tabela 32 
Tabela 32 - Cálculo de produção de equipe mecânica

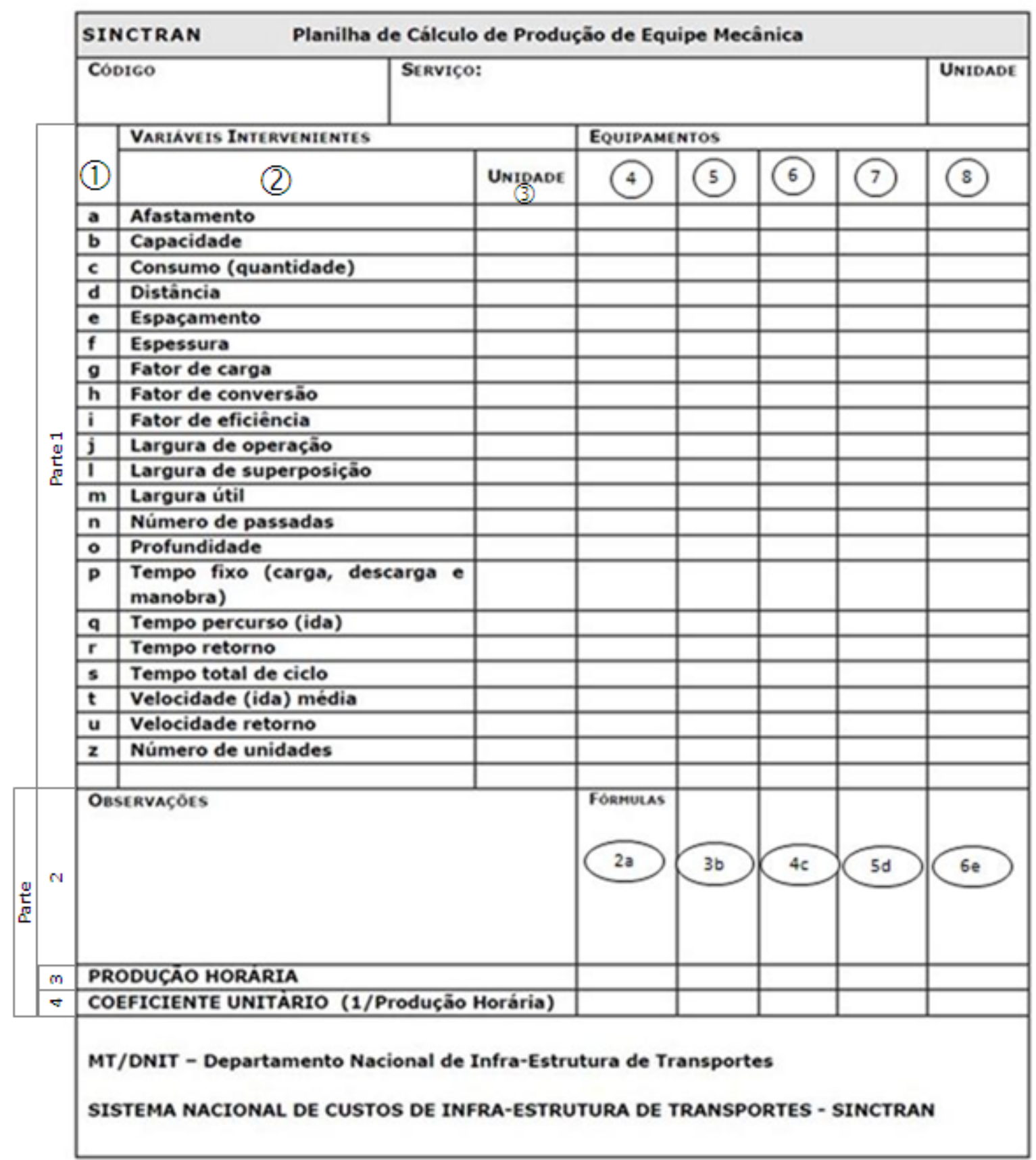

Fonte: DNIT (2007a)

A sistemática de preenchimento da tabela é apresentada a seguir.

\section{Parte 1}

Coluna 1 - Referência: nesta coluna estão enumeradas alfabeticamente as referências das variáveis intervenientes.

Coluna 2 - Variáveis Intervenientes: nesta coluna estão discriminadas as diversas variáveis que influenciam na produção da equipe; são elas: 
a) Afastamento - é a distância entre furos nas minas no sentido transversal à frente de ataque do serviço. Utilizado nas extrações a fogo.

b) Capacidade - é a medida que indica a dimensão do equipamento em termos de produção. A capacidade teórica, indicada nas especificações do equipamento; é chamada capacidade nominal.

c) Consumo (quantidade) - é o gasto que tem o equipamento para executar um serviço (por exemplo: uma perfuratriz de determinado tipo consome 3,3 $\mathrm{m}^{3} / \mathrm{min}$ de ar comprimido).

d) Distância - é o intervalo de lugar onde o equipamento está atuando.

e) Espaçamento - é a distância entre furos das minas no sentido da frente de ataque do serviço.

f) Espessura - são as alturas com que são executadas as diversas camadas de aterro em terraplenagem e da seção estrutural do pavimento.

g) Fator de carga - é a relação entre a capacidade efetiva e a capacidade nominal.

h) Fator de conversão - é a relação entre o volume do material no corte e o volume do material solto.

i) Fator de eficiência - é a relação entre a produção efetiva e a produção nominal.

j) Largura de operação - é a dimensão lateral em que o equipamento atua.

I) Largura de superposição - é o recobrimento lateral necessário para se dar continuidade à execução do serviço.

m) Largura útil - é a dimensão lateral útil de operação do equipamento. É obtida subtraindo-se a largura da operação da largura de superposição.

n) Número de passadas - é o número de vezes que tem que atuar o equipamento, num mesmo lugar, para executar o serviço.

o) Profundidade - é a penetração atingida pelo equipamento na execução dos serviços.

p) Tempo fixo - é o intervalo de tempo gasto pelo veículo com carga, descarga e manobra.

q) Tempo de percurso (ida) - é o intervalo de tempo gasto pelo veículo para ir carregado, do ponto de carregamento até o ponto de descarga.

r) Tempo de retorno - é o intervalo de tempo gasto pelo veículo para retornar vazio do ponto de descarga até o ponto de carga. 
s) Tempo total de ciclo - é a soma dos tempos fixos, tempo de percurso e tempo de retorno.

t) Velocidade (ida) média - é a relação da distância entre os locais de carga e de descarga, e o tempo de percurso.

u) Velocidade de retorno - é a relação da distância entre os locais de carga e de descarga, e o tempo de retorno.

z) Número de unidades.

Coluna 3 - Unidade: nesta coluna são transcritas as unidades em que as variáveis intervenientes são medidas para sua apreciação no cálculo da produção do equipamento.

Colunas 4, 5, 6, 7 e 8 - Equipamentos: nestas colunas são colocadas as variáveis intervenientes que afetam a produção, de todos os equipamentos que compõem uma determinada equipe.

\section{Parte 2}

Coluna 1 - Observações: nesta coluna são colocadas as observações necessárias ao bom entendimento dos cálculos efetuados.

Colunas $\mathbf{2}_{a}, \mathbf{3}_{\mathrm{b}}, \mathbf{4}_{\mathrm{c}}, \mathbf{5}_{\mathrm{d}}$ e $\mathbf{6}_{\mathrm{e}}$ - Fórmulas: nestas colunas são colocadas as fórmulas utilizadas na determinação da produção do equipamento.

Parte 3 - Produção Horária: nesta célula é colocada a produção horária dos diversos equipamentos que compõem a equipe, obtida através das fórmulas de cálculo e das variáveis intervenientes.

Parte 4 - Coeficiente Unitário: apresenta a Razão Unitária de Produção

Um exemplo de aplicação deste método é apresentado no Apêndice A.

\subsubsection{Método teórico do TCPO}

Em termos de indicadores de produtividade, as composições apresentadas no TCPO (2008), apresentam as horas produtivas do equipamento (ver Figura 29). Uma nota explicativa, acompanhando a composição unitária, descreve quatro pontos importantes quanto à execução dos serviços, quais sejam: conteúdo do 
serviço; critério de medição; procedimento executivo; e normas técnicas (ver Figura 30).

02315.8.9.1 COMPACTAÇÃO de aterro - unidade: $\mathrm{m}^{3}$

\begin{tabular}{|c|c|c|c|}
\hline 000160 & COMPONENTES & UNid. & CONSUMOS \\
\hline 0122000.451 & Servente & h & 0,015 \\
\hline$* 22500.9 .2 .1$ & $\begin{array}{l}\text { Caminhão irrigadeira, diesel, potência } 167 \mathrm{HP} \\
(125 \mathrm{~kW}) \text {, capacidade } 8.000 \text { I-vida útil } 8.000 \mathrm{~h}\end{array}$ & h prod. & 0,01 \\
\hline .22700 .9 .109 & $\begin{array}{l}\text { Rolo compactador autopropelido vibratório com } \\
\text { pneus de tração, cilindro pé-de-carneiro em aço, } \\
\text { diesel, potência } 150 \mathrm{HP}(112 \mathrm{~kW} \text { ), peso operacional } \\
11,60 \mathrm{t} \text {, fator de carga médio - vida útil } 8.000 \mathrm{~h}\end{array}$ & h prod. & 0,005 \\
\hline$* 22700.2153$ & $\begin{array}{l}\text { Trator sobre pneus, diesel, potência } 92 \mathrm{HP} \\
(68 \mathrm{~kW}) \text { - vida útil } 8.000 \mathrm{~h}\end{array}$ & h prod. & 0,01 \\
\hline$\cdots 227029.41$ & $\begin{array}{l}\text { Grade de disco rebocável, faixa de trabalho } \\
3,5 \mathrm{~m} \text { - vida útil } 20.000 \mathrm{~h}\end{array}$ & h prod. & 0,01 \\
\hline$\cdot 207009.510$ & $\begin{array}{l}\text { Motoniveladora sobre pneus, diesel, fator de carga } \\
\text { médio, com lâmina reta, potência no volante do motor: } \\
135 \mathrm{HP}(101 \mathrm{~kW}) \text { - vida útil } 8.000 \mathrm{~h}\end{array}$ & h prod. & 0,005 \\
\hline$\cdot * 227009.9 .9 .3$ & $\begin{array}{l}\text { Rolo compactador autopropelido estático de pneus, } \\
\text { diesel, potência } 99 \mathrm{HP}(74 \mathrm{~kW}) \text {, peso operacional } \\
6 \mathrm{t} \text { - vida útil } 8.000 \mathrm{~h}\end{array}$ & h prod. & 0,005 \\
\hline
\end{tabular}

Figura 29 - Modelo de composição unitária - TCPO

Fonte: TCPO (2008) 


\section{CONTEÚDO DO SERVIÇO}

1) 0 serviço de compactação de aterro compreende o espalhamento, aeração, umedecimento e acabamento do material da área de empréstimo, já depositado no local. Náo incluso material de empréstimo.

2) Prever o transporte dos equipamentos até o local da obra e posterior retorno.

3) Produção considerada para a equipe: $200 \mathrm{~m}^{3} / \mathrm{h}$.

4) Equipamentos utilizados mais adequados para compactaçáo de solos coesivos.

5) Os coeficientes de consumo são para atingir energia normal de compactação; para atingir energia intermediária, aumentar em aproximadamente $25 \%$ os coeficientes dos rolos compactadores, e para atingir energia modificada, aumentar em $50 \mathrm{~s}$, ou utilizar rolos compactadores compativeis.

$\left({ }^{* *}\right)$ Esse(s) coefibiente(s) tem como base o custo horário do equipamento (ver divisáo 22). CRITÉRIO DE MEDIÇÁO

Volume medido por camada acabada.

PROCEDIMENTO EXECUTIVO

1) Iniciar o aterro sempre no ponto mais baixo, em camadas horizontais superpostas de até $30 \mathrm{~cm}$ e camada final de até $20 \mathrm{~cm}$.

2) Prever o caimento lateral ou longitudinal para rápido escoamento das águas pluviais, evitando 0 acúmulo em qualquer ponto.

3) Há três etapas distintas na execuçáo: o lançamento do material pelo equipamento de transporte, o espalhamento em camadas e a compactação propriamente dita. Sempre que as condiçōes locais permitirem, os serviços devem ser organizados para que se tenha uma ou mais frentes de trabaho em que as citadas etapas sejam devidamente escalonadas.

4) Harendo precipitaçbes pluviais nessa etapa, a percolaçăo da água aumenta a umidade do solo muito acima da ótima, sendo necessária uma secagem posterior ou remoção do sola. Em materiais argilosos, a diminuição do teor de umidade é muito demorada, quer seja feita por evaporaçäo natural ou induzida; nesse caso, considerar o uso de equipamentos especiais como arados, grades ou làmina da motoniveladora.

5) Se a camada já estiver lançada e regularizada, havendo risco de precipitaçăo imprevista, considerar o uso de rolos lisos ou pneumáticos para selar a camada.

NORMASTECNICAS

NBR 5681 - Controle tecnologico da execuçăo de aterros em obras de edificaç⿸̄es

Para Procedimento Executivo, consultar também a seguinte literatura:

A Técnica de Edificar, item 4.3.

Caderno de Encargos, item P.03.ATE.1.

Figura 30 - Modelo de nota explicativa que acompanha a composição unitária Fonte: TCPO (2008)

\subsubsection{Modelos de composições unitárias}

Os modelos de composições unitárias, adotados pelos manuais, são apresentados a seguir.

\subsubsection{DNIT}

O modelo de composição unitária, utilizado no SICRO 3, foi apresentado na

Figura 24. 
Pode-se observar que o modelo se refere apenas ao custo horário operativo. Diferente do apresentado no SICRO 2 que apresenta utilização operativa, utilização improdutiva e a quantidade de recursos (Figura 31).

Analisando a composição intitulada: Escavação, carga e transporte de material de 1 categoria para a distância média de transporte (DMT) entre 50 e 200m, o equipamento líder da equipe é a escavadeira hidráulica, cuja utilização operativa é igual a "1" (100\%). Sua produção de 192 m³/h gera ociosidade para os demais membros da equipe. Exemplo, a motoniveladora tem 95\% $(0,95)$ de ociosidade e o caminhão basculante 4\% $(0,04)$.

Mais que isto, a designação de uma motoniveladora é desnecessária para este tipo de serviço, haja vista que a atividade se resume em escavar (escavadeira hidráulica) o material e em seguida carregar o caminhão.

\begin{tabular}{|c|c|c|c|c|}
\hline \multirow{2}{*}{\multicolumn{4}{|c|}{$\begin{array}{l}\text { DNIT - Sistema de Custos Rodoviários } \\
\text { Composiçáo de Custo Unitário de Referència }\end{array}$}} & SICRO2 \\
\hline & & & & CTR0220 \\
\hline \multicolumn{5}{|c|}{ Construçäo Rodoviảria } \\
\hline \multicolumn{5}{|c|}{ Atividade / Serviço: 2 S 0110022 - Esc. carga transp. mat $1^{2}$ cat DMT 50 a $200 \mathrm{~m}$ c/e } \\
\hline Prode & $192,0000 \mathrm{~m} 3$ & Adicional de Mäo-d & Obra: & $0,00(\%)$ \\
\hline \multicolumn{5}{|c|}{ Lucro e Despesas Indiretas: } \\
\hline \multicolumn{2}{|c|}{ A - Equipamento } & Quantidade & \multicolumn{2}{|c|}{$\begin{array}{c}\text { Utilizacão } \\
\text { Operativa Improd }\end{array}$} \\
\hline E006 & Motoniveladora - $(93 \mathrm{~kW})$ & 1.00 & 0.05 & 0.95 \\
\hline E062 & Escavadeira Hidráulica - com esteira - cap. $1,7 \mathrm{~m} 3(166 \mathrm{~kW})$ & 1,00 & 1,00 & 0,00 \\
\hline E432 & Caminhão Basculante - $20 \mathrm{t}(279 \mathrm{~kW})$ & 2,00 & 0,96 & 0,04 \\
\hline \multicolumn{2}{|c|}{ B - Mão-de-Obra } & Quantidade & & \\
\hline T501 & Encarregado de turma & 1,00 & & \\
\hline $\mathrm{T} 701$ & Servente & 3.00 & & \\
\hline
\end{tabular}

Observaçöes: OBS: Especificaçōes de serviço : DNER-ES-280 E DNER-ES-281.

Figura 31 - Modelo de composição unitária - SICRO 2

Fonte: DNIT (2003b)

\subsubsection{EMOP}

O modelo de composição unitária, utilizado no EMOP, é apresentado na Figura 32. Nesta composição estão descritos: o código; o serviço; os insumos; a unidade; o indicador de produtividade - coeficiente (razão entre a hora e a quantidade de serviço); coeficiente produtivo (CP); e coeficiente improdutivo (Cl). 


\begin{tabular}{|c|c|c|c|c|}
\hline CÓD. & DESCRIÇÃO & UNID. & QUANT. & PERC. \\
\hline \multicolumn{5}{|c|}{$03.021 .005 .1(01665) \quad \mathrm{m}^{2}$} \\
\hline \multicolumn{5}{|c|}{$\begin{array}{l}\text { ESCAVAÇÃ̃O MECÂNICA, A CÉU ABERTO, EM MATERIAL DE 1: } \\
\text { CATEGORIA, COM ESCAVADEIRA HIDRÁULICA }\end{array}$} \\
\hline 01114 & $\begin{array}{l}\text { 19.005.008-2 Escavader } \\
\text { ra hidráulica, com motor } \\
\text { diesel de } 92 \mathrm{CV} \text {, capaci- } \\
\text { dade de } 0,78 \mathrm{~m}^{3} \text { (CP) }\end{array}$ & h & 0,0134 & \\
\hline 01116 & $\begin{array}{l}\text { 19.005.008-4 Escavader- } \\
\text { ra hidráulica, com motor } \\
\text { diesel de } 92 \mathrm{CV} \text {, capact- } \\
\text { dade de } 0.78 \mathrm{~m}^{3}(\mathrm{Cl}\end{array}$ & $n$ & 0,0058 & \\
\hline 01999 & Servente & n & 0,0192 & \\
\hline
\end{tabular}

Figura 32 - Modelo de composição unitária - EMOP Fonte: Rio de Janeiro (1999)

\subsubsection{SIURB}

O modelo de composição unitária, utilizado no SIURB, é apresentado na Figura 33. Nesta composição estão descritos: o código; o serviço; os insumos; a unidade (de cada insumo); o custo unitário, o indicador de produtividade - coef. (razão entre a hora e a quantidade de serviço); a unidade do serviço; o valor parcial (custo unitário x o indicador de produtividade); e o valor total (somatória dos valores parciais).

\begin{tabular}{|c|c|c|c|c|c|c|c|c|}
\hline CÓDIGo & \multicolumn{3}{|c|}{ NOME DO SERVIÇO } & & UNID & Vpare & VALOR \\
\hline \multirow[t]{4}{*}{$04-11-00$} & ESCAVAÇ. & IO MECANICA, CARGA E REMOC,ÃO DE T & ISTÁN & A MÉDLA DE & окМ & M3 & & 9,37 \\
\hline & 94008 & CAMNHÃO BASCULANTE - 10M3 & H & 93,98 & 0,047040 & & 4,4207 & \\
\hline & 94015 & PÁ CARREGADEIRA DE PNEUS - 1,80 M3 & H & 98,76 & 0,028000 & & 2,7653 & \\
\hline & 94061 & TRATOR DE ESTEIRA - 9 TON. & н & 77,83 & 0,028000 & & 2,1793 & \\
\hline
\end{tabular}

Figura 33 - Modelo de composição unitária - SIURB Fonte: São Paulo (2010)

\subsubsection{TCPO}

O modelo de composição unitária, utilizado no TCPO, foi apresentado na Figura 29.

\subsubsection{Caixa Econômica Federal}

O modelo de composição unitária, utilizado na CAIXA, é apresentado na Figura 34. Nesta composição estão descritos: o código; o serviço; os insumos; a unidade; a quantidade de cada insumo; o indicador de produtividade (utilização 
operativa); o indicador de improdutividade (utilização improdutiva); o custo operativo; o custo improdutivo; e o custo horário.

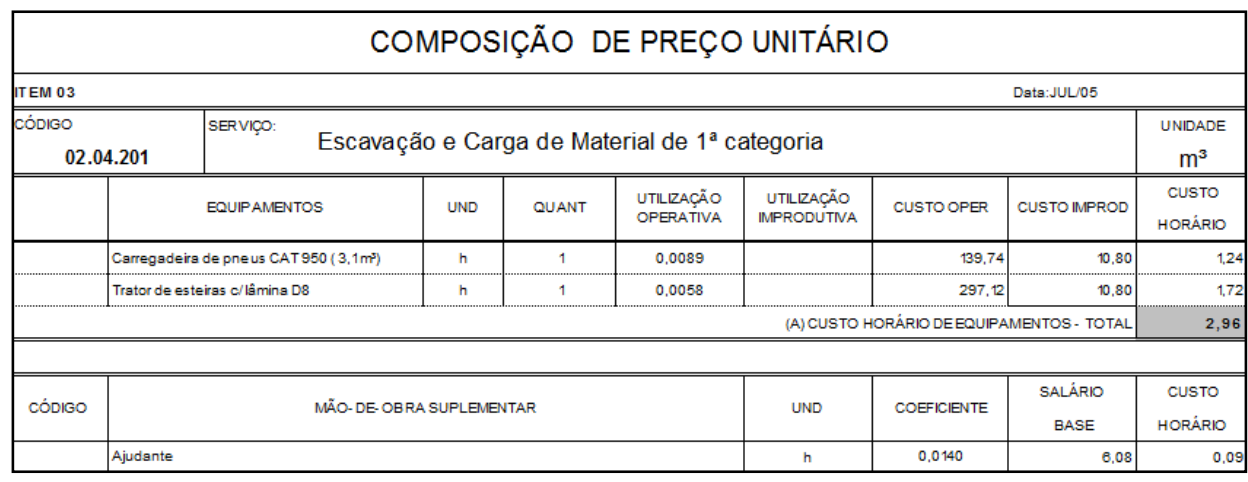

Figura 34 - Modelo de composição unitária - CAIXA Fonte: Infraero (2005)

\subsubsection{POLI-USP}

O modelo de composição unitária, utilizado na POLI-USP, é apresentado na Figura 35. Nesta composição estão descritos: o código SPCl; a numeração do item; o código INFRAERO; a classificação (classe e tipo); os insumos; a unidade; o indicador de produtividade (utilização operativa); e o indicador de improdutividade (utilização improdutiva).

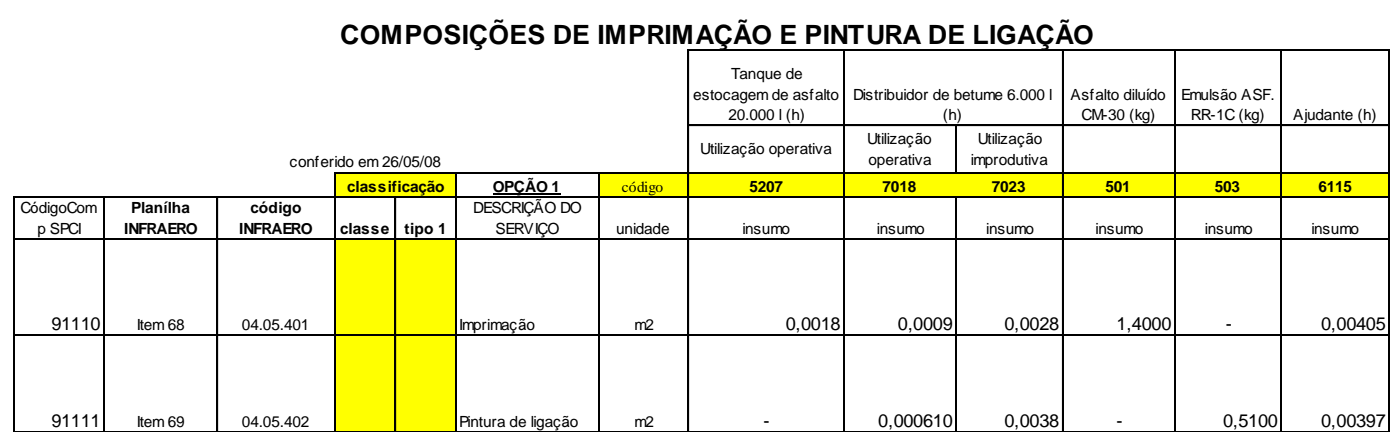

Figura 35 - Modelo de composição unitária - POLI-USP

Fonte: EPUSP (2008a)

\subsection{Reflexões do Capítulo 4}

Este capítulo possibilitou o esclarecimento das seguintes questões de pesquisa (apresentadas no Capítulo 1): 
a) Quais são os principais manuais, para prognóstico da produtividade, utilizados na implantação da infraestrutura de rodovias?

Resposta: embora existam outros manuais, os principais são o DNIT; EMOP; SIURB; TCPO; CAIXA; e PCC-USP.

b) Como esses manuais dividem as fases executivas de cada serviço (quebra do serviço)?

Resposta: geralmente as fases executivas não são apresentadas (conforme a estruturação de cada manual).

c) Esta quebra dos serviços é tratada da mesma maneira pelos manuais?

Resposta: cada manual trata a quebra dos serviços de maneira diferenciada.

d) Estes manuais utilizaram qual método, teórico ou experimental, para gerar os indicadores?

Resposta: a maioria dos manuais não deixa claro o método utilizado. $O$ DNIT (o principal manual para o subsetor de rodovias), por exemplo, se embasou no teórico e não foi confirmado conclusivamente de forma experimental $^{50}$.

e) Como os manuais apresentam os indicadores?

Resposta: todos apresentam um valor unitário para cada elemento da composição. O TCPO, para alguns serviços que não são rodoviários, iniciou a prática de apresentação de faixas de produtividade variável.

f) Estes indicadores apresentados são muito diferentes?

Resposta: os indicadores são muito diferentes, por exemplo, para o serviço de CBUQ, encontrou-se variações de até $879 \%$ para o rolo compactador de pneus e $1874 \%$ para os auxiliares.

g) Observando os manuais, o porquê destas variações pode ser interpretado?

Resposta: após um estudo minucioso de cada manual, o porquê das variações não está explicito claramente.

h) Os fatores considerados pelos manuais, quando eles apresentam um indicador para um determinado serviço, são visíveis?

Resposta: os fatores e anormalidades não são identificáveis nos manuais.

\footnotetext{
${ }^{50}$ Nota do SINCTRAN.
} 
i) A forma como estes indicadores são apresentados subsidia a tomada de decisões confiáveis?

Resposta: por serem apresentados somente os valores unitários e em função da grande variação dos indicadores, esta forma não subsidia a tomada de decisões confiáveis.

j) Uma nova proposta de prognóstico da produtividade destes serviços pode vir a sanar estes problemas?

Resposta: por meio da apresentação de uma faixa de valores e os fatores orientadores sobre qual valor adotar, o processo de orçamentação e planejamento de uma obra rodoviária pode se tornar mais preciso. Neste sentido, um novo modelo de prognóstico da produtividade destes serviços pode amenizar e/ou resolver as falhas apontadas anteriormente e assim contribuir para levar o processo de gestão da produção de rodovias a um novo patamar de produtividade e eficiência.

Atingido esse patamar de entendimento da problemática até aqui apresentada, desenvolveu-se a seguir a proposta de abordagem para as composições. 


\section{PROPOSTA DE ABORDAGEM PARA AS COMPOSIÇÕES}

Foi apresentado nos capítulos anteriores que em relação aos serviços de terraplenagem e pavimentação asfáltica, existem muitos manuais porém, cada um aborda as etapas de execução de maneira diferente e os indicadores de produtividade apresentados são extremamente variáveis. Além disso, não é possível saber, com base na leitura dos manuais, quais fatores foram considerados quando se indica um determinado valor para certo serviço. Portanto, a sua utilização (dos manuais), enquanto ferramenta de orçamentação e gestão, é pouco eficiente. Outro ponto a ser observado é que apropriar dados em construção é uma tarefa complexa que envolve custo, tempo e disponibilidade. Este trabalho, que envolve o estudo de seis manuais, duas obras e entrevistas com especialistas, se encaixa perfeitamente neste cenário de dificuldades.

Segundo SOUZA (1996), apesar de, na maioria das vezes, as definições sobre como medir a produtividade representarem uma razão entre entradas e saídas do processo que se deseja avaliar, pode haver variações quanto a sua abrangência, ao que se mede como entradas e saídas e à constituição da razão entre entradas e saídas, entre outros. O autor enfatiza que, quando se discute a produtividade, tanto em debates entre profissionais de campo ou especialistas, quanto em artigos técnicos sobre o assunto, paira sempre uma grande dúvida sobre como foram calculados os indicadores que estão sendo utilizados. Segundo o mesmo autor, para que isto possa acontecer sobre base sólida, há que se ter uma definição clara de como se padronizar a mensuração da produtividade. Esta proposta de abordagem para as composições visa atender a todos estes parâmetros.

Este capítulo visa apresentar uma proposta de abordagem para as composições a serem estudadas (contidas nos seis manuais e dois estudos de caso). Esta abordagem se baseia, principalmente, nos conceitos de Produtividade Variável, no Modelo dos Fatores (que enfatiza as anormalidades e fatores que fazem a produtividade variar) e nos momentos de incidência das horas de equipamentos (horas disponíveis para o serviço e horas em funcionamento). 


\subsection{Contextualização}

Os indicadores de produtividade na Construção Civil, tanto no Brasil quanto no exterior, tradicionalmente têm sido apresentados por composições individuais para cada serviço, sendo que, para cada um deles, indica-se a demanda média por materiais, mão de obra e por equipamentos para se executar uma unidade do produto. Por exemplo, no caso da produção de $1 \mathrm{~m}^{3}$ de escavação de material de $1^{\text {a }}$ categoria, a composição 0401953 do DNIT (2007d) indica a necessidade de 0,0052 h de escavadeira hidráulica. Tal postura, embora de fácil entendimento e aplicação, vinha sendo criticada, nos últimos anos, em função da diversidade de tipologias de produtos, de tecnologias utilizáveis e das diferentes formas de organização e gestão dos serviços que vêm sendo adotadas pelas empresas de construção. Além disso, com o aumento da competição no mercado, as diferenças de desempenho, que já eram uma marca do setor, tornaram-se ainda mais importantes de serem consideradas para garantir o sucesso das empresas. Enfim, a ideia de se adotarem valores médios de produtividade para um serviço significa uma postura talvez simplificada demais ante as atuais necessidades de entendimento mais aprofundado das atividades de construção. Imagina-se que, para fins de orçamento, o conhecimento dos limites, máximos e mínimos, dos desempenhos característicos de um serviço, permitirá, quando considerado necessário pela empresa, um aprimoramento da estimativa dos recursos demandados pelo mesmo além disso, o simples conhecimento da faixa de valores que caracteriza o mercado facilitará uma comparação com o conjunto de empresas concorrentes, subsidiando decisões de cunho mais estratégico por parte dos gestores. É conveniente salientar ainda que, além de permitir uma melhoria no processo de orçamentação, uma postura mais analítica pode ser bastante útil como subsídio para: o aprimoramento da programação (tanto no nível de cronogramas físicos de obras quanto na definição da constituição de equipes de trabalho para um determinado serviço), o controle da produtividade, a escolha de tecnologias e da forma de gestão, a política de remuneração de operários e de subcontratados, dentre outros (TCPO, 2008). Enfim, imagina-se que a apresentação do conceito e de valores relativos à PRODUTIVIDADE VARIÁVEL possa contribuir para, paulatinamente, ter-se um

instrumento útil a diversas fases de empreendimento de terraplenagem e pavimentação asfáltica e indutor de uma maior integração entre as mesmas. Espera- 
se que os efeitos de sua aplicação possam ser sentidos no planejamento governamental em se tratando da destinação de orçamentos e verbas.

Para definir o que seja a já citada produtividade variável, é preciso antes definir os seguintes conceitos: produtividade da mão de obra e dos equipamentos; razão unitária de produção; produção unitária; faixas de variação e fatores.

\subsection{Produtividade da Mão de obra e dos Equipamentos}

Em face da importância do estudo da produtividade da mão de obra e dos equipamentos, há que se discutir como proceder à avaliação da mesma. Souza (2006) recomenda: para que se consiga discutir produtividade, de uma maneira proveitosa, é necessário definir uma linguagem padronizada para o assunto.

Do ponto de vista físico, a produtividade poderia ser definida (Figura 36) como a eficiência (e, na medida do possível, a eficácia) na transformação do esforço dos trabalhadores ou equipamentos em produtos de construção (a obra ou suas partes).

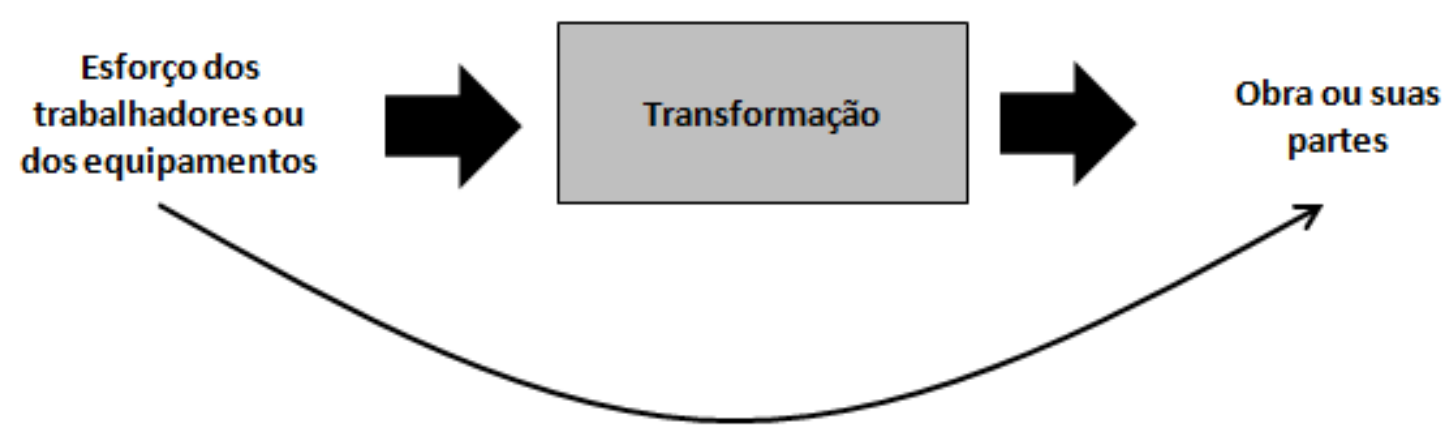

Eficiência na transformação

Figura 36 - Definição da produtividade

Fonte: Souza (2006)

\subsection{Razão Unitária de Produção}

Aceita a definição de produtividade ilustrada na Figura 36, Souza (2006) sugere adotar 0 indicador denominado razão unitária de produção (RUP) ${ }^{51}$ como mensurador da produtividade, relacionando o esforço humano, avaliado em Homens

\footnotetext{
${ }^{51}$ O termo Razão Unitária de Produção (RUP) é normalmente utilizado para medir a eficiência da mão de obra. O seu emprego para medir a eficiência de equipamentos também é aplicável.
} 
$x$ hora $(\mathrm{Hh})$ ou Equipamento $x$ hora (Eqh), com a quantidade de serviço realizado (Equação 6).

$$
\text { RazãoUnitária de Produção }=\frac{H \times h}{\text { Quantidade de serviço }} \quad \text { Eq. } 6
$$

Ressalta-se que, em função da definição feita, um valor alto de RUP indica produtividade pior que um valor baixo.

\subsubsection{Diferentes tipos de RUP}

Na metodologia proposta por Souza (2006), podem-se definir diferentes períodos de tempo aos quais se associarão as mensurações das RUP, e, portanto, das entradas ( $\mathrm{H}$ e $\mathrm{h}$ ou Eq e $\mathrm{h}$ ) e saídas (quantidade de serviço produzido em um determinado tempo - QS):

a) o dia de trabalho, quando, a cada dia útil de serviço, medem-se entradas e saídas, calculando-se a RUP que, nesse caso, será denominada RUP diária $\left(R_{\mathrm{U}}\right)$;

b) um período acumulado, quando as quantidades de entradas e saídas são acumuladas desde o primeiro dia do estudo até a data de sua avaliação; neste caso, tem-se a RUP cumulativa (RUP cum $_{\text {); }}$

RUP potencial (RUP pot) seria um valor da RUP diária $\left(R U P_{d}\right)$ associado à sensação de bom desempenho e que, ao mesmo tempo, mostra-se factível em função dos valores de $R U P_{d}$ detectados. Matematicamente a RUP pot é calculada como o valor da mediana das RUP $P_{d}$ inferiores ao valor da RUP cum ao final do período de estudo (SOUZA, 2006).

\subsubsection{Mão de obra e equipamento contemplado}

Sendo o foco deste estudo a produtividade nos serviços de terraplenagem e pavimentação asfáltica, a preocupação recai sobre os equipamentos e a mão de obra de produção. Assim, embora a gestão seja extremamente importante, a definição das RUP's não envolverá o esforço dos gestores e sim somente o dos comandados por eles. Interessam os operários que "põem a mão na massa". 
Para fins do estudo da produtividade física dos equipamentos e da mão de obra de produção, em um determinado serviço, interessa detectar quem está alocado ao serviço, se está envolvido no objetivo fim (por exemplo, lançamento de mistura asfáltica) ou em atividades meio (por exemplo, produção da mistura asfáltica em usina).

\subsection{Produção Unitária}

A produção unitária (PU) traduz a quantidade de serviço produzido pelo equipamento (ou mão de obra) por hora disponível para o serviço. É o inverso da RUP (Equação 7).

Eq. 7

\subsubsection{Diferentes tipos de PU}

Assim como a RUP, em relação à Produção Unitária (PU) podem-se definir diferentes períodos de tempo aos quais se associarão suas mensurações e, portanto, das entradas (Eq e h) e saídas (QS):

a) o dia de trabalho, quando, a cada dia útil de serviço, medem-se entradas e saídas, calculando-se a PU que, nesse caso, será denominada PU diária $\left(\mathrm{PU}_{\mathrm{d}}\right)$;

b) um período acumulado, quando as quantidades de entradas e saídas são acumuladas desde o primeiro dia do estudo até a data de sua avaliação; neste caso, tem-se a PU cumulativa ( $\left.\mathrm{PU}_{\text {cum }}\right)$;

PU potencial $\left(P U_{\text {pot }}\right)$ seria um valor da $P U$ diária $\left(P U_{d}\right)$ associado à sensação de bom desempenho e que, ao mesmo tempo, mostra-se factível em função dos valores de $\mathrm{PU}_{\mathrm{d}}$ detectados. Matematicamente a $\mathrm{PU}_{\text {pot }}$ é calculada como o valor da mediana das $\mathrm{PU}_{\mathrm{d}}$ superiores ao valor da $\mathrm{PU}_{\text {cum }}$ ao final do período de estudo. Neste caso, um valor alto de produção unitária indica uma melhor produtividade. 


\subsubsection{Reflexões sobre a PU}

O entendimento da produtividade tem sido comumente abordado, nos trabalhos feitos no âmbito do Departamento de Engenharia de Construção Civil e Urbana, da Escola Politécnica de São Paulo ${ }^{52}$, na forma de expressá-la como a soma de duas parcelas: seu valor potencial $\left(\mathrm{PU}_{\mathrm{pot}}\right)$ e o afastamento do mesmo $(\Delta)$ (ver Equação 8).

Eq. 8

Enquanto o potencial (referência) é definido pelos fatores ligados ao conteúdo e contexto, o afastamento tem sua explicação ligada à maior ou menor ocorrência de anormalidades (ver Figura 37).

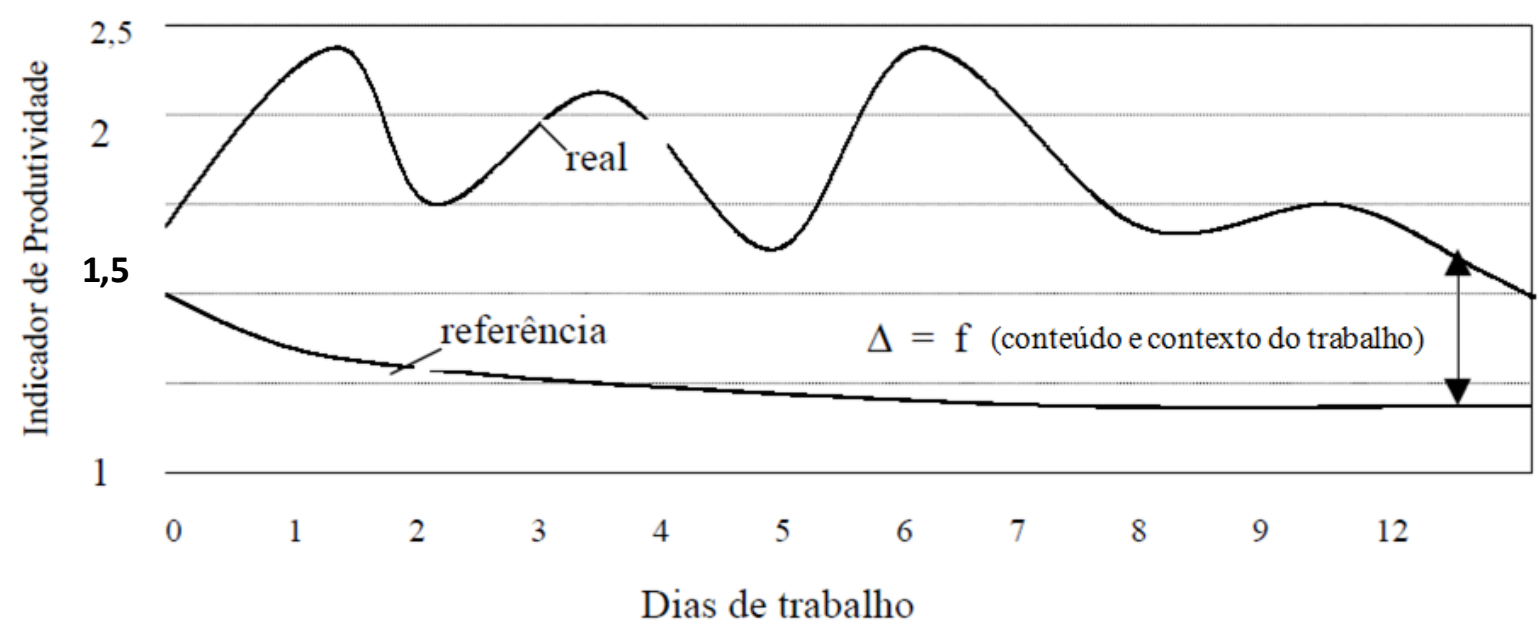

Figura 37 - Modelo dos Fatores para a Produtividade na Construção ${ }^{53}$ Fonte: Souza (1996)

Embora este seja o caminho para a criação de um modelo de previsão de base matemática, neste trabalho, em função de se reunirem dados de origens diferentes (coleta pelo autor, manuais e opinião de especialistas), visando suprir a deficiência de dados de campo de mesma base metodológica, julgou-se mais coerente expressar a variação da PU com base na explicitação do valor central da faixa de dados (mediana), associado à apresentação dos quartis ( $1^{\circ}$ e $\left.3^{\circ}\right)$; o uso dos valores máximo e mínimo para definir variação não foram considerados adequados devido

${ }^{52}$ Especificamente na linha de gestão com base em indicadores (coordenado pelo Professor Doutor Ubiraci Espinelli Lemes de Souza).

${ }^{53}$ A descrição deste modelo é apresentada na seção 5.5 . 
aos riscos de se estar valorizando uma eventual anormalidade (ou mesmo erro de definição) extraordinária.

\subsection{Faixas de Variação e Fatores}

Segundo Souza (2006), a produção unitária dos equipamentos e da mão de obra pode apresentar variações segundo faixas de amplitude bastante grandes. A Figura 38 justifica tal afirmação ao demonstrar que a produção unitária, para o serviço de compactação de aterro, varia de $884 \mathrm{~m}^{2} / \mathrm{h}$ a $2743 \mathrm{~m}^{2} / \mathrm{h}$. A grande variação da produção unitária vigente nas obras de construção leva à seguinte conclusão: não é possível tomar boas decisões sem o conhecimento de tais faixas e das razões que levam às suas variações.

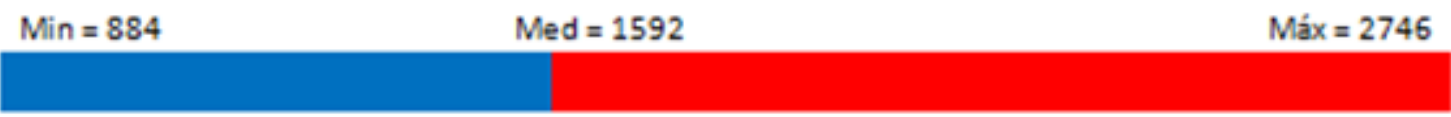

Figura 38 - Faixa de variação da produção unitária: compactação de aterro $\left(\mathrm{m}^{2} / \mathrm{h}\right)$

Chega-se, então, a outra importante questão: por que a produção unitária dos equipamentos e da mão de obra varia?

Conceitualmente, o Modelo dos Fatores $^{54}$ teria uma resposta à questão. $\mathrm{Na}$ tentativa de classificar os fatores potencialmente alteradores da produção unitária presentes nas várias partes do processo de produção, diz-se que a produção unitária pode ser influenciada, Figura 39, na vigência de condições normais, por fatores ligados ao conteúdo e por fatores ligados ao contexto do serviço em estudo; além disso, a produção unitária pode ser alterada quando anormalidades acontecem. Normalmente os fatores ligados ao conteúdo dizem respeito às características do "produto" sendo executado e dos "recursos transformados", tais como materiais e componentes. Os fatores de contexto normalmente se associam aos "recursos de transformação", tais como mão de obra e equipamentos e às "condições de contorno", tais como temperatura e postura dos sindicatos usuais. As anormalidades seriam "afastamentos" acentuados quanto às características regulares do conteúdo e contexto citados.

\footnotetext{
${ }^{54}$ O Modelo dos Fatores foi proposto por H. Randolph Thomas, da Pensylvania State University - Estados Unidos da América (SOUZA, 1996). Vários trabalhos foram produzidos empregando este modelo, dentre eles estão: Souza (1996); Paliari (2008); Inouye (2009); Marchiori (2009); e Salim Neto (2009).
} 


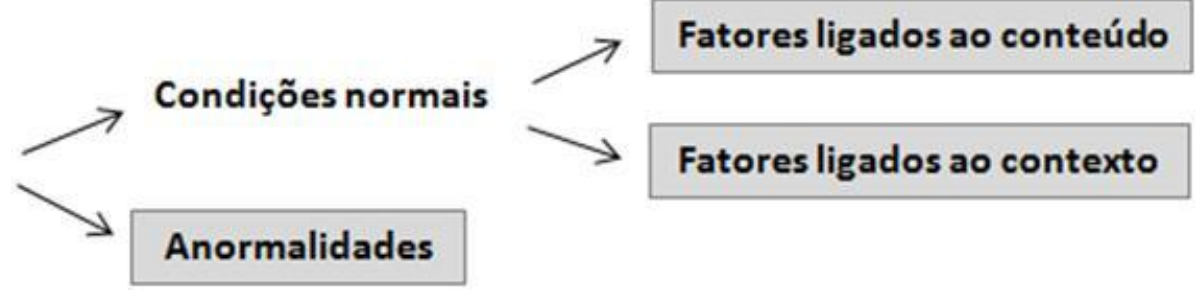

Figura 39 - Classificação dos fatores influenciadores da produção unitária Fonte: Souza (2006)

Devido a importância e por seu um referencial nesta tese, um breve histórico acerca do Modelo dos Fatores se faz necessário.

Fundado em 1983, o "Construction Industry Institute" (CII) incumbiu pesquisadores da Pennsylvania State University (PSU) de conduzir estudos quanto ao levantamento das formas mais comuns de medição da produtividade e à possibilidade de padronização desta. Num segundo estudo encomendado pela mesma entidade, gerou-se um manual (THOMAS; KRAMER, 1987) contendo os fundamentos para a padronização dos estudos relativos à produtividade em construção (SOUZA, 1996).

Cumprida a tarefa de criação de uma "linguagem comum", as fases seguintes seriam o entendimento das variações da produtividade, isto é, a detecção dos porquês da sua ocorrência e a quantificação destas influências. O passo final seria representado pela previsão do que ocorrerá em um empreendimento com base em informações anteriores vindas de fontes tais como o projeto, o método construtivo escolhido, ou a avaliação da produtividade já ocorrida no mesmo. Grande parte dos estudos posteriores feitos na PSU após definirem um determinado serviço versaram sobre: o levantamento de fatores que influenciam significativamente a produtividade da mão de obra; o entendimento da extensão desta influência através do desenvolvimento de modelos estatísticos explanatórios, isto é, cujos termos indicam quais foram os fatores importantes e qual a extensão da sua influência em definir a produtividade em serviços anteriormente executados; a previsão de produtividade para serviços por executar, baseando-se também na aplicação ferramental estatístico (SOUZA, 1996).

O Modelo dos Fatores assume a existência de uma condição padrão de trabalho; sob esta, a produtividade diária será a "ideal" (pode-se o não assumir a existência de aprendizado); variações no conteúdo ou no contexto do trabalho fazem a produtividade real variar em relação ao valor ideal. O modelo relaciona a produtividade real diária às características diárias do trabalho (SOUZA, 1996). 


\subsection{Variação da Produção Unitária}

A proposta de abordagem para as composições, desta tese, é aplicar os conceitos de Produtividade Variável nos serviços de terraplenagem e pavimentação asfáltica. Produtividade variável será aqui tratada quanto à apresentação dos indicadores relativos aos recursos demandados para se fazer uma unidade de produto, por meio da postura: em lugar de apenas citar um valor médio histórico, inclui-se a apresentação de uma faixa de valores (indicando-se os valores mínimo, mediano e máximo) para o consumo de mão de obra e equipamentos.

Tal faixa é composta com base: na observação real do desempenho ocorrido (estudo de caso); nos dados contidos nos manuais; e na opinião de especialistas.

Os valores máximo e mínimo representam os extremos da faixa, representando, obviamente, situações limite do banco de dados disponível; o valor mediano representa a região central do conjunto de dados, isto é, representa o valor central do conjunto de dados.

Completando este raciocínio, para a determinação dos valores altos e baixos, o conceito de Quartil será empregado. Os Quartis permitem a divisão de um conjunto de dados em quatro partes iguais (Figura 40).

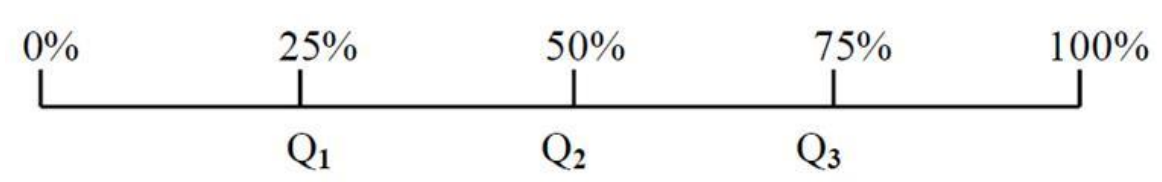

Figura 40 - Quartis

Alternativamente à apresentação dos valores máximo e mínimo levantados, o processamento dos dados será concentrado no Primeiro ${ }^{55}$ e Terceiro ${ }^{56}$ Quartil como extremos da faixa de variação a ser discutida.

Ramos (2003) recomenda esta metodologia (a aplicação de quartis) enquanto ferramenta de controle estatístico. Na construção civil é indicada por alguns autores, tais como: Souza (1998); Albuquerque, Costa e Pereira (2007); Duarte e Lamounier (2007).

\footnotetext{
${ }^{55}$ Primeiro Quartil - Q1: Separatriz que divide a distribuição em duas partes, tal que $25 \%$ dos valores sejam menores que ele e $75 \%$ maiores que ele. (BALESTRASSI, P. P.; PAIVA, A. P., 2007)

${ }_{56}$ Terceiro Quartil - Q3: Valor que deixa $75 \%$ dos valores à sua esquerda e os $25 \%$ restante à sua direita. (MIGUEL; COUTINHO, 2012).
} 
Associados, portanto, às faixas, têm-se vários fatores considerados responsáveis pelos desempenhos variáveis, isto é, são indicadas as razões que levaram o desempenho a se afastar mais para a esquerda ou para a direita da faixa. Portanto, para se adotar um valor mais ou menos afastado do valor mediano, em direção ao valor mínimo ou ao máximo, seria interessante avaliar-se a previsão quanto à ocorrência dos fatores indutores de variação.

Na Figura 41 apresenta-se um exemplo de faixa de variação da produção unitária para a execução de compactação de aterro.

$\operatorname{Min}=884$

Med $=1592$

Máx $=2746$

Produção unitária: rolo compactador pé de carneiro $\left(\mathrm{m}^{2} / \mathrm{h}\right)$

\begin{tabular}{|l|l|}
\hline $\begin{array}{l}\text { Camadas mais espessas }(>20 \mathrm{~cm} \\
\text { e }<30 \mathrm{~cm})\end{array}$ & Camadas menos espessas $(<20 \mathrm{~cm})$ \\
\hline $\begin{array}{l}\text { Maior a deformabilidade da } \\
\text { camada inferior }\end{array}$ & Menor deformabilidade da camada inferior \\
\hline $\begin{array}{l}\text { Maior quantidade de passadas } \\
\text { dos compactadores (número de } \\
\text { fechas para atingir o GC) }\end{array}$ & $\begin{array}{l}\text { Menor quantidade de passadas dos compactadores } \\
\text { (número de fechas para atingir o GC) }\end{array}$ \\
\hline $\begin{array}{l}\text { Equipe de equipamentos menos } \\
\text { compatível (equipamentos } \\
\text { diferentes, pesos diferentes, } \\
\text { quantidade incompatível com o } \\
\text { GC) }\end{array}$ & $\begin{array}{l}\text { Equipe de equipamentos compatível (equipamentos } \\
\text { semelhantes, pesos parecidos, quantidade compatível } \\
\text { com o GC) }\end{array}$ \\
\hline $\begin{array}{l}\text { Equipe de laboratório menos } \\
\text { treinada }\end{array}$ & Equipe de laboratório treinada \\
\hline
\end{tabular}

Figura 41 - Produtividade variável: serviço de compactação de aterro

\subsection{Detalhamento das Horas de Equipamentos}

A seguir, em concordância com proposta descrita por TCPO (2008), serão apresentadas as diretrizes acerca do detalhamento das horas de equipamento.

Dentre os conceitos para se distinguirem os diversos momentos na vida de um equipamento, cabe inicialmente indicar a necessidade de se definir o que seja VIDA ÚTIL. Esta será considerada o período de tempo que vai desde a aquisição do equipamento até o momento em que se considera que o equipamento não deve mais ser usado para a atividade para a qual foi adquirido, não valendo mais a pena fazer intervenções de manutenção.

Tal vida útil pode ser expressa em termos das horas de equipamento disponível para a empresa. 
É comum se ter a situação de possuir um equipamento e, durante alguns períodos de tempo, não ter obra para alocá-lo, ficando o mesmo ocioso na empresa. A multiplicação das horas disponíveis para a empresa pela porcentagem de tempo em que se imagina ter serviço para uso do equipamento leva à definição das "horas disponíveis para um serviço".

Dentro do período em que o equipamento está disponível para o serviço tem o momento em que ele está efetivamente trabalhando ou seja, o equipamento está ligado. Esta situação leva à definição das "horas em funcionamento".

Para o desenvolvimento deste trabalho serão utilizados estes dois momentos de incidência das horas de equipamentos: as horas disponíveis para o serviço $\left(\mathrm{H}_{\text {serv. }}\right)$; e as horas em funcionamento $\left(\mathrm{H}_{\text {func }}\right.$ ou $\left.\mathrm{H}_{\text {funcionamento }}\right)$. A Figura 42 ilustra estas duas definições. O custo do equipamento não está incluído nesta discussão ${ }^{57}$.

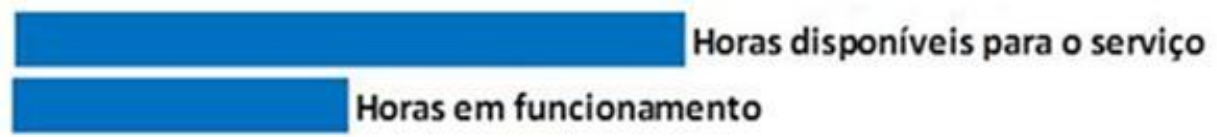

Figura 42 - Classificação das horas de equipamento para fins de estudo do seu custo Fonte: Adaptado de TCPO (2008)

Subtraindo-se das "horas disponíveis para o serviço" as "horas em funcionamento" tem-se as "horas improdutivas" ( $\left.\mathrm{H}_{\text {improd }}\right)$.

Na Figura 43 apresenta-se um exemplo de aplicação destas definições.

\footnotetext{
${ }^{57}$ Este trabalho trata apenas dos gastos físicos dos insumos, ou seja, seus indicadores de produção unitária (equipamentos ou mão de obra). O custo horário do equipamento e seu operador não está contemplado.
} 


\section{a) Tempo disponivel para o serviço (Hserv)}

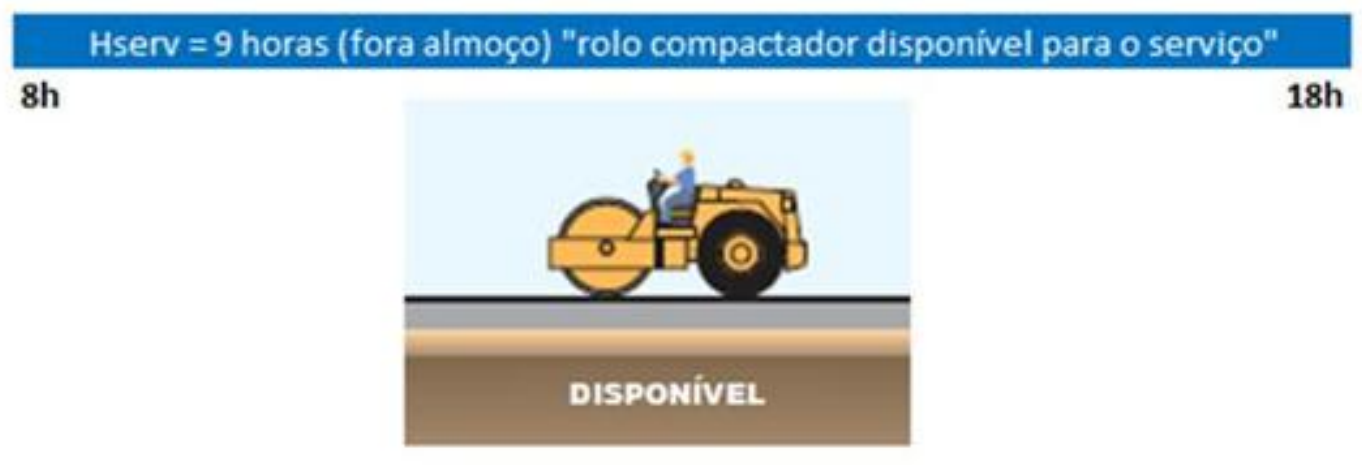

b) Tempo em funcionamento (Hfunc)

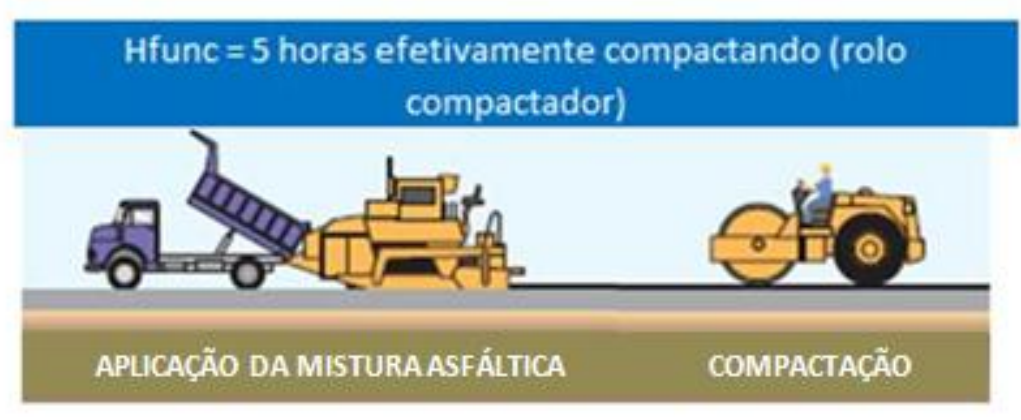

Figura 43 - Diferentes momentos no serviço de compactação de CBUQ

A apresentação destes dois momentos, nas faixas de produtividade variável, será conforme mostra o exemplo da Tabela 33, tendo-se as $\mathrm{H}_{\text {funcionamento }}$ expressas em \% das $\mathrm{H}_{\text {serv. }}$

Tabela 33 - Modelo de apresentação das horas em serviço $\left(H_{\text {serv }}\right)$ e horas em funcionamento ( $\left.\mathrm{H}_{\text {funcionamento }}\right)$.

\begin{tabular}{|c|c|c|c|c|c|c|c|}
\hline \multirow{2}{*}{$\begin{array}{l}\text { Compactação de } \\
\text { CBUQ } \\
\text { Discriminação }\end{array}$} & \multirow[b]{2}{*}{ Qtde } & \multicolumn{3}{|c|}{ Produção Unitária (m³/ Hserv) } & \multicolumn{3}{|c|}{ Hfuncionamento } \\
\hline & & 1ㅇ Quartil & Mediana & 3 Quartil & 10 Quartil & Mediana & 3 Quartil \\
\hline Rolo compactador liso & 1 & 1563 & 1695 & 1923 & $64 \%$ & $68 \%$ & $71 \%$ \\
\hline
\end{tabular}

Para a determinação das horas em funcionamento $\left(\mathrm{H}_{\text {funcionamento }}\right)$, quando foi possível, o Método das Observações Instantâneas foi utilizado. 


\subsection{Método das Observações Instantâneas}

O Método das Observações Instantâneas foi empregado no estudo de caso do Rodoanel Mário Covas. O objetivo foi registrar as horas em funcionamento dos equipamentos. Sua utilização nesta tese é embasada na seguinte recomendação do DNIT: "preconiza-se que os levantamentos dos tempos característicos das fases de trabalho dos equipamentos sejam feitos mediante a utilização do Método das Observações Instantâneas" (DNIT, 2007a). Outros autores também sugerem o seu emprego.

De acordo com Barnes (1963), este método é ideal para medir o tempo de atividades e esperas de equipamentos - por exemplo, determinar a porcentagem de tempo em um dia no qual um equipamento trabalha e a porcentagem do tempo no qual ele não trabalha. Segundo Reis (1978), desde 1933 a indústria mundial emprega o Método das Observações Instantâneas como ferramenta para se medir a produção. Adamor Júnior, Rocha e Sabá (2002) reforçam essa ideia: "este método é o mais empregado na indústria para a medida do trabalho" ${ }^{\circ 8}$.

Ele é recomendado quando se deseja coletar dados rapidamente e a custos acessíveis sobre o trabalho de uma ou mais máquinas e/ou pessoas. Exemplo: levantar a porcentagem do tempo que um operador gasta com tempos improdutivos (TOLEDO JÚNIOR, 2004 apud DANIEL FILHO, 2010).

Amostragem "n". Segundo este autor, em vez de acompanhamento contínuo, o equipamento é observado em momentos específicos, quando então a atividade que estiver exercendo será classificada em "trabalhando" ou "disponível para o serviço" ou seja, equipamento sem operação. Uma sucessão de "n" observações constitui uma amostra e define o percentual de vezes em que cada uma das fases de trabalho (trabalhando ou disponível para o serviço) foi observada. Para simplificar a determinação do "n", neste trabalho e quando aplicável, definiu-se que seriam feitas 108 observações por dia, ou seja, o registro da situação do equipamento a cada cinco minutos ${ }^{59}$.

\footnotetext{
${ }^{58}$ Este assunto também é tratado pelos seguintes autores: Barnes (1977), Novaski e Sugai (2001), PRONACI (2003), Carvalho, Heineck e Jungles (2004).

${ }^{59}$ Outra forma de se definir o "n" seria por meio da teoria da amostragem aleatória. Selecionam-se amostras "ao acaso", de um conjunto e, quando um número suficiente delas tiver sido selecionado, arrisca-se uma previsão para o grupo todo.
} 
Erro relativo nas medidas fornecidas pela amostragem " $n$ " do trabalho. Barnes (1963) considera que, para diversos tipos de medida, um erro relativo de $\pm 5 \%$ é considerado satisfatório ${ }^{60}$. A Equação 9 é a utilizada para se determinar o erro relativo para um dado número de observações.

Eq. 9

Onde: $p=$ porcentagem de ocorrência da atividade

$\mathrm{n}=$ dimensão da amostra (neste trabalho $\mathrm{n}=108$ observações por dia)

A utilização do método das observações instantâneas e do cálculo do erro relativo está registrada no Apêndice $\mathrm{C}$ e no apêndice $\mathrm{D}$.

\subsection{Unidade de Apresentação}

Embora os serviços de terraplenagem e pavimentação asfáltica tenham sido mensurados, nos diversos manuais, em metro cúbico $\left(\mathrm{m}^{3}\right)$ ou tonelada $(\mathrm{t})$, optou-se neste trabalho (exceto para escavação) por trabalhar com os serviços na unidade de metro quadrado $\left(\mathrm{m}^{2}\right)$. Esta proposta visa facilitar o entendimento da produção unitária (produtividade física) para um determinado serviço por exemplo: uma patrulha cuja produção unitária é de $171 \mathrm{~m}^{2} / \mathrm{h}$ de CBUQ (com espessura de $5 \mathrm{~cm}$ ), para uma pista de largura de $8,6 \mathrm{~m}$, produzirá em um dia (de $8 \mathrm{~h}$ ) o equivalente a $159 \mathrm{~m}$ de rodovia, ou seja

\subsection{Reflexões do Capítulo 5}

Este capítulo apresentou uma proposta de abordagem para as composições. Os seguintes conceitos foram apresentados: produtividade da mão de obra e dos equipamentos; razão unitária de produção; produção efetiva; faixas de variação e fatores; produtividade variável; horas de equipamentos; e unidade de apresentação. Este capítulo possibilitou o esclarecimento das seguintes questões de pesquisa (apresentadas no Capítulo 1):

\footnotetext{
${ }^{60}$ As 108 observações por dia, adotadas neste trabalho, resultaram em erros de $2 \%$ a $7 \%$ (Apêndice C). Justificando a sua adoção.
} 
a) Em que esta nova proposta pode ser diferente?

Resposta: esta proposta possibilita conhecer o valor potencial e os limites dos desempenhos característicos de um serviço (faixa de valores). Para a definição de qual valor adotar, os fatores orientadores acompanham estas faixas.

O resultado desta proposta melhora os indicadores, na medida em que usa 0 conhecimento de diversas fontes, quais sejam: dos manuais; dos levantamentos experimentais; e do conhecimento de especialistas.

b) Esta nova proposta pode contribuir de que maneira com a medição do desempenho da produção de rodovias?

Resposta: Imagina-se que esta proposta permitirá, quando considerado necessário pela empresa, um aprimoramento da estimativa dos recursos demandados pelo serviço; além disso, o simples conhecimento da faixa de valores que caracteriza o mercado facilitará uma comparação com o conjunto de empresas concorrentes, subsidiando decisões de cunho mais estratégico por parte dos gestores. 


\section{ESTUDOS DE CASO}

Nove fontes de dados são utilizadas nesta pesquisa: seis manuais de orçamentação (Capítulo 4); entrevistas com especialistas (Capítulo 8); e dois estudos de caso.

A pesquisa de campo é frequentemente empregada em investigações que procuram avaliar a eficácia de um conjunto de processos (FACHIN, 1993). É aquela utilizada com o objetivo de conseguir informações e/ou conhecimentos acerca de um problema, para o qual se procura uma resposta, ou de uma hipótese, que se queira comprovar, ou, ainda, descobrir novos fenômenos ou as relações entre eles (LAKATOS, 2001).

Esta estratégia de pesquisa se beneficia do desenvolvimento prévio de proposições teóricas para conduzir a coleta e a análise de dados (YIN, 2005).

Este capítulo faz uma apresentação das obras estudadas ao longo do desenvolvimento desta tese: Aeroporto Internacional de Guarulhos; e Rodoanel Mário Covas.

A forma de exposição segue três etapas: na primeira, busca-se descrever brevemente a obra; em seguida, apresenta-se o método de coleta de dados; e finaliza, com os dados e resultados obtidos.

\subsection{Aeroporto Internacional de Guarulhos}

A Caixa Econômica Federal, no âmbito do SINAPI, solicitou ao Departamento de Engenharia de Construção Civil da Escola Politécnica da USP (PCC-USP) 0 aprimoramento de um conjunto de composições. Para este estudo, como pesquisa de campo, visitaram-se as obras do Aeroporto Internacional de São Paulo, na cidade de Guarulhos.

Estas Obras são referentes à "Concorrência № 012/DAAG/SBGR/2003 - Técnica e Preço - Fase 2 - Aeroporto Internacional de São Paulo / Guarulhos".

Neste contrato, a Empresa Brasileira de Infraestrutura Aeroportuária (INFRAERO), Superintendência Regional do Sudeste (SRGR), se apresenta como a 
CONTRATANTE. O Consórcio Evixplan se apresenta como GERENCIADORA e o Consórcio: Queiroz Galvão, Constran e Serveng se apresenta como CONTRATADA.

A Concorrência consta das seguintes fases:

a) ampliação, adequação e revitalização do sistema de pistas e pátios;

b) adequação da interface com o pátio do futuro terminal de passageiros no-3 (TPS-3);

c) recuperação das pistas 09R/27L e 09L/27R;

d) recuperação e revitalização do sistema de macrodrenagem existente;

e) implantação do sistema separador de água/óleo no sistema de drenagem;

f) revitalização e recuperação do sistema viário.

Em relação ao sistema de pistas e pátios, para exemplo, apresenta-se na Figura 44 uma seção transversal típica.

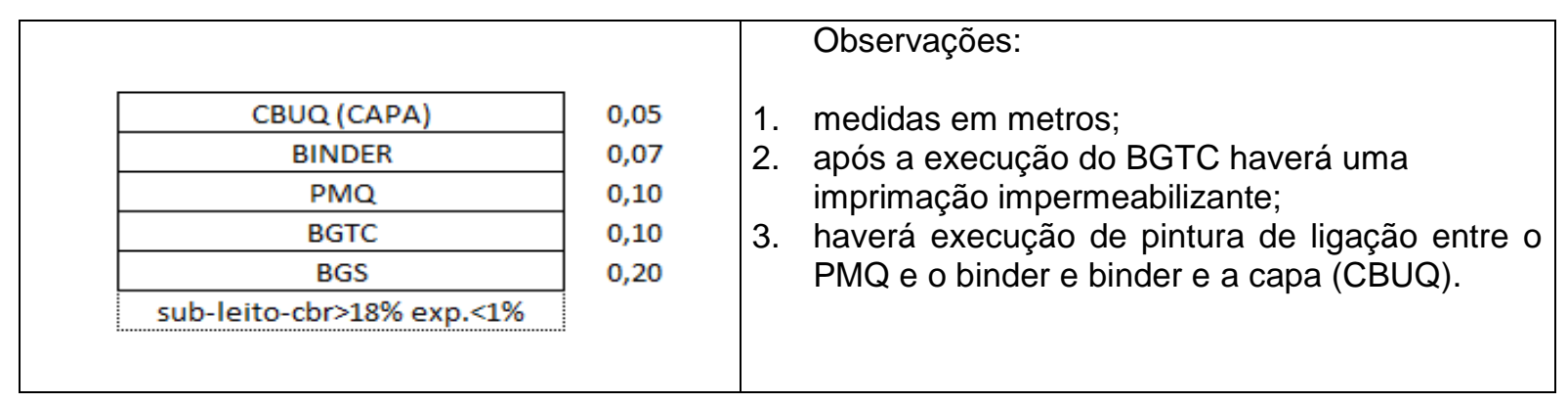

Figura 44 - Estrutura da pista da PR-A

Em relação ao sistema viário, para exemplo, apresenta-se na Figura 45 uma seção transversal típica.

\begin{tabular}{|c|c|c|}
\hline & \multirow{3}{*}{$\begin{array}{l}0,04 \\
0,04\end{array}$} & \multirow{7}{*}{$\begin{array}{l}\text { 1. medidas em metros; } \\
\text { 2. após a execução do BGTC haverá uma } \\
\text { imprimação impermeabilizante; } \\
\text { 3. haverá execução de pintura de ligação entre o } \\
\text { PMQ e o binder e binder e a capa (CBUQ). }\end{array}$} \\
\hline CBUQ (CAPA) & & \\
\hline BINDER & & \\
\hline PMQ & 0,05 & \\
\hline BGTC & 0,15 & \\
\hline BGS & 0,25 & \\
\hline RACHÃO & 0,47 & \\
\hline
\end{tabular}

Figura 45 - Estrutura do pavimento do sistema viário 


\subsubsection{Método de coleta}

Esta seção busca apresentar o método de coleta utilizado pelos pesquisadores do PCC-USP.

Inicialmente, através de um fluxograma de atividades (Figura 46) apresenta-se a ideia geral do método de trabalho. $\mathrm{E}$, com base nas ações previstas no fluxograma, indicam-se os passos percorridos ao longo dos levantamentos efetuados.

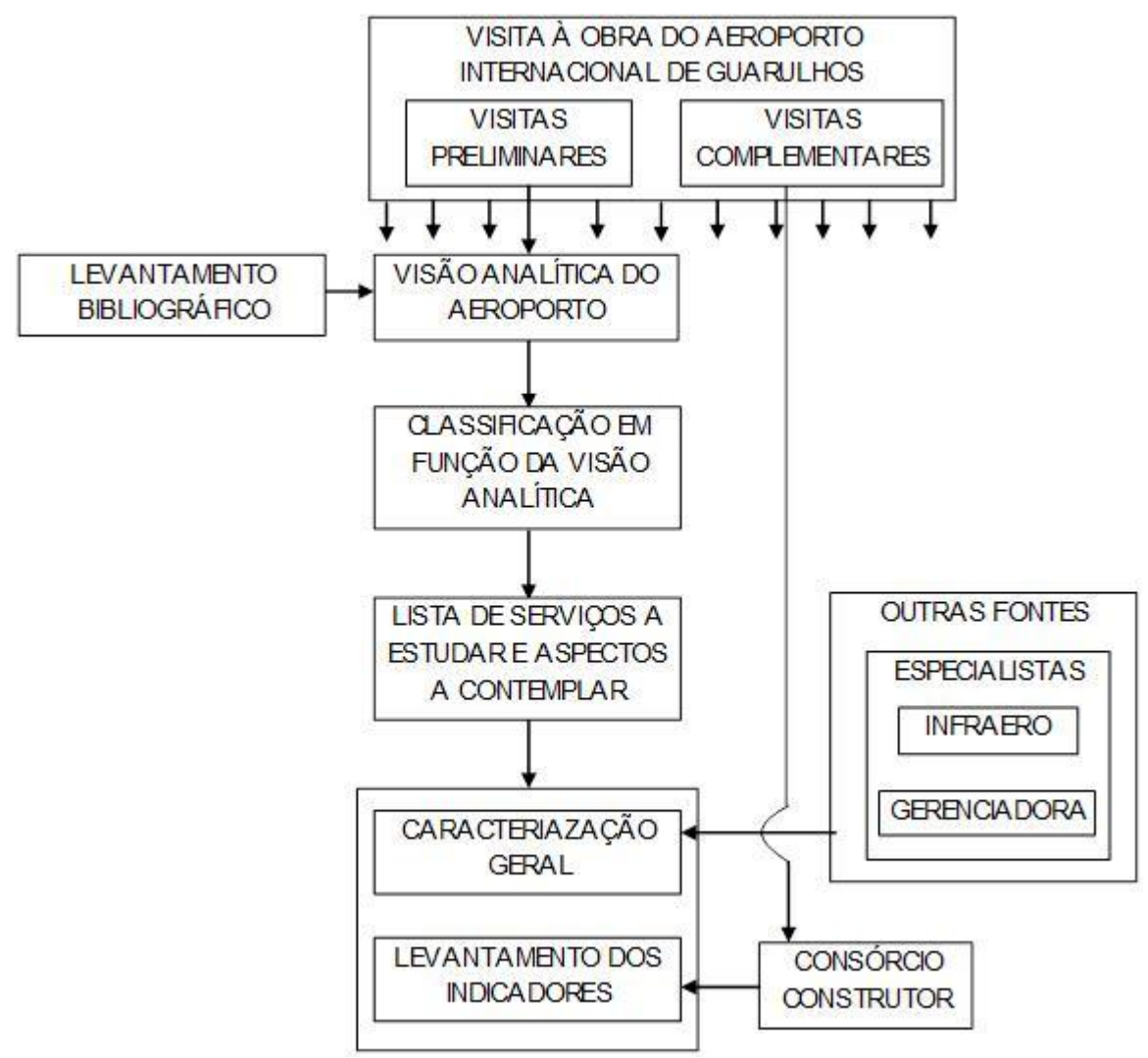

Figura 46 - Fluxograma geral do método

Fonte: EPUSP (2008b)

Este método se inicia com as visitas preliminares e complementares à obra de Guarulhos.

As visitas preliminares, juntamente com o levantamento bibliográfico, objetivou desenvolver uma visão analítica do aeroporto.

Esta visão analítica possibilitou a classificação das composições a serem analisadas. 
Uma vez, classificadas as composições, desenvolveu-se uma lista de serviços a estudar, juntamente com os aspectos a serem contemplados sobre os mesmos.

A caracterização geral de cada composição, portanto, é fruto de várias etapas: do levantamento bibliográfico e da consulta a especialistas: da INFRAERO, do Consórcio Gerenciador e da USP.

O levantamento dos indicadores é resultado do levantamento realizado na base de dados do Consórcio Construtor e no acompanhamento diário da execução dos serviços ${ }^{61}$.

Para o acompanhamento diário da execução dos serviços, o Consórcio Construtor utilizou o modelo de planilha apresentado na Tabela 34.

A utilização desta planilha se dá da seguinte maneira:

a) munido de planilhas de medição, o apontador ${ }^{62}$ faz inicialmente os seguintes registros: detalha a frente de serviço(1); descreve o equipamento(2), coloca a data(4) do dia; indica qual é a empresa designada para o trabalho (5); identifica o equipamento (6); e anota o horímetro inicial (7);

b) no campo "horas trabalhadas (9)", o apontador registra, com um risco, os intervalos de tempo em que o equipamento efetivamente operou na frente de trabalho;

c) no campo "horas de paralisação (10", o apontador registra, também com um risco, os intervalos de tempo em que as atividades com o equipamento foram paralisadas. Neste caso, o código da paralisação (ver legenda na planilha de medição) acompanha o risco. A planilha comporta o registro de observações, caso necessário;

d) ao final do dia o apontador anota a produção do equipamento (3) e o horímetro final 8 .

\footnotetext{
${ }^{61}$ Observação: o levantamento da produtividade diária, das diversas equipes em andamento, foi executado por apontadores do Consórcio Construtor. O pesquisador, embora tenha acompanhado a execução de alguns serviços, utilizou os dados levantados pelo Consórcio.

62 Apontador: profissional designado pelo Consórcio Construtor para levantar diariamente os dados de produção.
} 
Tabela 34 - Modelo de planilha de medição

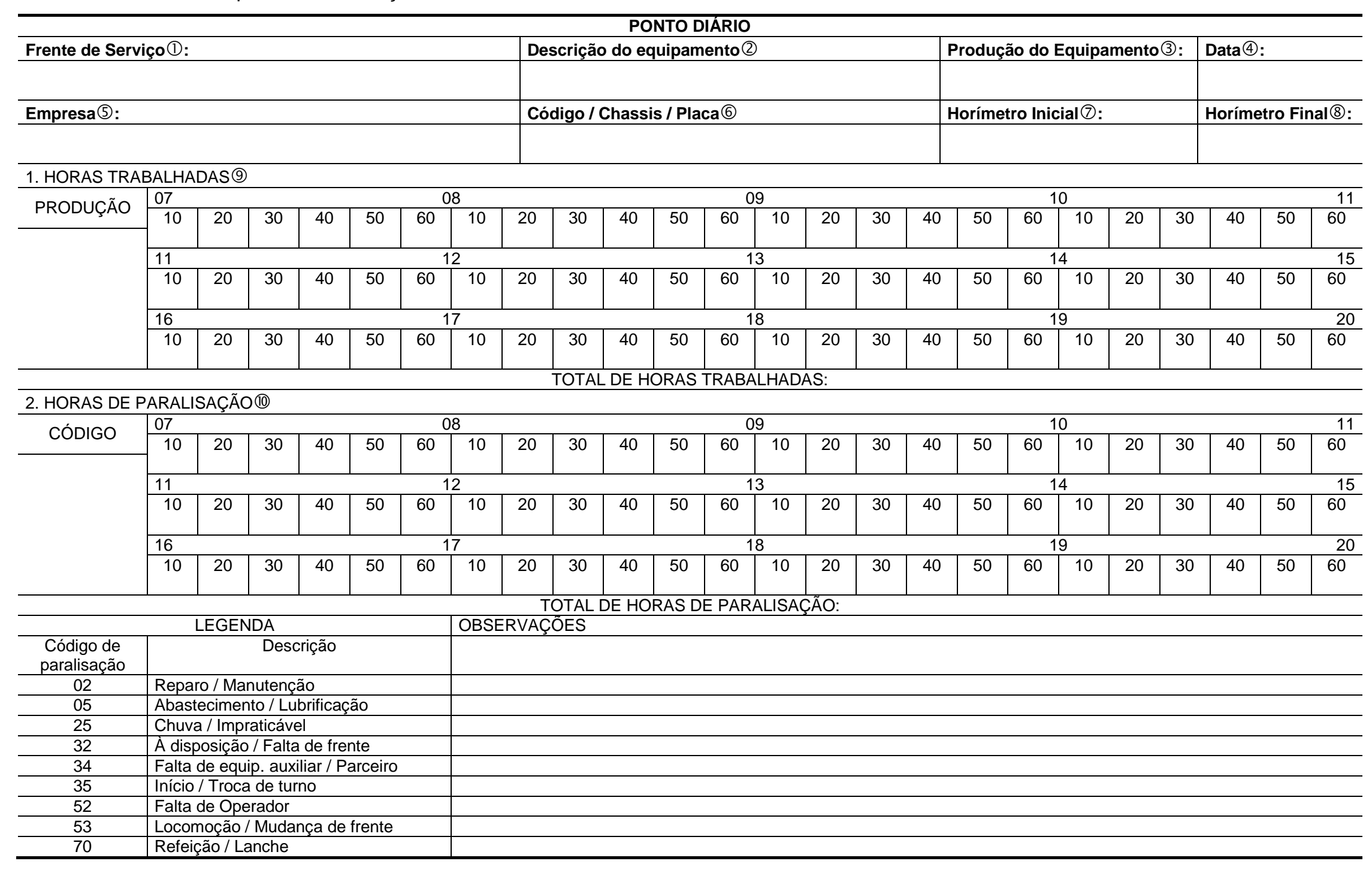




\subsubsection{Resultados}

Em função da grande quantidade de dados obtidos na obra, para a sua apresentação, optou-se pelo seguinte sistema:

a) apresentar, em forma de exemplo (Tabela 35), os indicadores obtidos no Consórcio Construtor;

b) apresentar um modelo de processamento destes indicadores (Tabela 35);

c) apresentar resumidamente no Apêndice B, o conjunto de indicadores obtidos no Consórcio Construtor;

d) apresentar, no formato de produtividade variável, para os serviços estudados, o conjunto de indicadores.

Conforme a lista de estudo, os serviços levantados são assinalados abaixo:

a) escavação de material de $1^{\underline{a}}$ categoria com trator de esteiras $\left(m^{3}\right)-$ não estudado;

b) escavação de material de $1^{\text {a }}$ categoria com escavadeira hidráulica $\left(\mathrm{m}^{3}\right)$;

c) compactação de aterro - espessura até $30 \mathrm{~cm}\left(\mathrm{~m}^{2}\right)$;

d) base de solo cimento com mistura na pista - esp. até $20 \mathrm{~cm}\left(\mathrm{~m}^{2}\right)$ - não estudado;

e) brita graduada simples - BGS com distribuidor de agregados - esp. até $20 \mathrm{~cm}$ $\left(m^{2}\right)$ - não estudado;

f) brita graduada simples - BGS com vibroacabadora - esp. até $20 \mathrm{~cm}\left(\mathrm{~m}^{2}\right)$ - não estudado;

g) brita graduada tratada com cimento - BGTC - esp. até $20 \mathrm{~cm}\left(\mathrm{~m}^{2}\right)$;

h) concreto betuminoso usinado a quente - capa ou binder - esp. até $5 \mathrm{~cm}\left(\mathrm{~m}^{2}\right)$;

i) imprimação $\left(\mathrm{m}^{2}\right)$;

j) pintura de ligação $\left(\mathrm{m}^{2}\right)$. 


\subsubsection{Etapas de processamento dos dados levantados em campo}

Neste estudo de caso utilizou-se duas etapas para entender e processar os dados levantados.

$\mathrm{Na}$ primeira etapa, com base na planilha de medição, o Consórcio Construtor desenvolveu um resumo da produção de cada equipamento. Estes resumos foram disponibilizados pelo Consórcio Construtor. A Tabela 35 apresenta um exemplo deste resumo, onde ${ }^{63}$ :

a) $\mathrm{HT}=$ horas trabalhadas;

b) $\mathrm{HD}=$ horas disponíveis (corresponde às horas paralisadas);

c) Produção horária = produção / HT;

d) Coeficiente de produção = 1 / produção horária.

${ }^{63}$ Note que existem diferenças entre a metodologia empregada pelo Consórcio Construtor e a proposta de abordagem deste trabalho. Dentre as diferenças se destacam:

a) HT (Consórcio Construtor: corresponde às horas trabalhadas) é diferente de Hserv ( nova abordagem: corresponde às horas disponíveis para o serviço);

b) Produção horária (Consórcio Construtor: produção / HT) é diferente de Produção Unitária (nova abordagem: produção / Hserv).

c) Coeficiente de produção (Consórcio Construtor: 1 / produção horária) é diferente de RUP (nova abordagem: 1 / produção unitária). 
Tabela 35 - Escavação de material de $1^{\text {a }}$ categoria $\left(\mathrm{m}^{3}\right)$

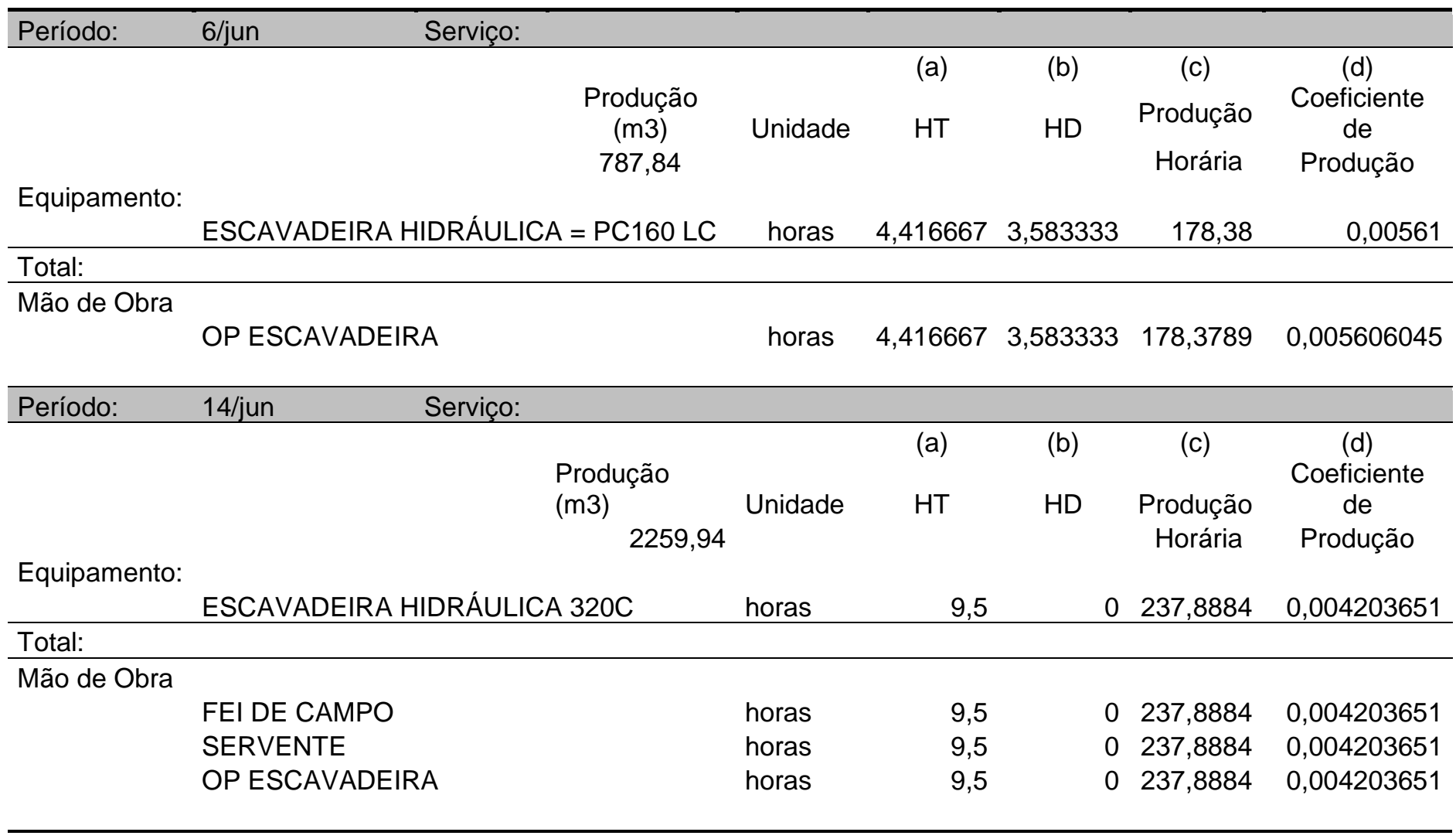

Fonte: Consórcio Construtor 
Na segunda etapa, as $\mathrm{PU}$ diárias $\left(\mathrm{PU}_{\mathrm{d}}\right)$, PU cumulativa $\left(\mathrm{PU}_{\text {cum }}\right)$, e $\mathrm{PU}$ potencial $\left(\mathrm{PU}_{\mathrm{pot}}\right)$ são calculadas. A Tabela 36 e Tabela 37 apresentam um exemplo deste tipo de processamento.

O significado das colunas destas planilhas é descrito como segue:

(1) registro da data de ocorrência da atividade;

(2) registro da quantidade de ocorrências do período levantado;

(3) registro da produção da equipe/patrulha;

(4) registro da quantidade de horas em funcionamento e as improdutivas (disponíveis para o serviço, porém, sem atividade);

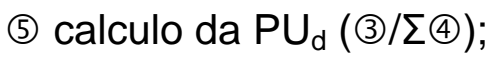

(6) calculo da $\mathrm{PU}_{\text {cum }}(\Sigma(3) / \Sigma(4)$;

(7) calculo da $\mathrm{PU}_{\text {pot }}$ (mediana de (5) dos valores maiores que o último valor de (6);

(8) relação entre as horas em funcionamento e a somatória das horas em (4);

(9) $\Delta$ representa as variações de conteúdo ou de contexto do trabalho que fazem a produtividade mediana variar em relação à de referência ( $\left.P U_{\text {pot }}\right)$. 
Tabela 36 - Escavação de material de $1^{\underline{a}}$ categoria. Registro de horas, quantidades e processamento das PU's. Etapa: escavação e carga - patrulha $\left(\mathrm{m}^{3}\right.$

\begin{tabular}{|c|c|c|c|c|c|c|c|c|c|}
\hline \multicolumn{10}{|c|}{ ESCAVADEIRA HIDRÁULICA 320C } \\
\hline \multirow[b]{2}{*}{ Data (1) } & \multirow[b]{2}{*}{ Etapa (2) } & \multirow{2}{*}{$\begin{array}{c}\text { QS(3) } \\
\text { m3 }\end{array}$} & \multicolumn{2}{|c|}{ Horas (4) } & \multirow{2}{*}{$\begin{array}{c}\begin{array}{c}\text { PUd(5) } \\
\left(\mathrm{m}^{3} / \mathrm{Eh}\right)\end{array} \\
\text { Hserv }\end{array}$} & \multirow{2}{*}{$\begin{array}{c}\begin{array}{c}\text { PUcum 6) } \\
\left(\mathrm{m}^{3} / \mathrm{Eh}\right)\end{array} \\
\text { Hserv }\end{array}$} & \multirow{2}{*}{$\begin{array}{c}\text { PUpot } 7 \\
\left(\mathrm{~m}^{3} / \mathrm{Eh}\right)\end{array}$} & \multirow[b]{2}{*}{ Hfunc (8) } & \multirow{2}{*}{$\Delta(9)$} \\
\hline & & & Hfunc & Himprod & & & & & \\
\hline 06/jun & 1 & 787,84 & 4,42 & 3,58 & 98,48 & 98,48 & \multirow{10}{*}{196,8} & $55 \%$ & \multirow{10}{*}{108,9} \\
\hline 14/jun & 2 & 2259,94 & 9,5 & 0 & 237,89 & 174,16 & & $100 \%$ & \\
\hline 19/jun & 3 & 1245,82 & 4,5 & 3,5 & 155,73 & 168,38 & & $56 \%$ & \\
\hline 20/jun & 4 & 3060,47 & 10,5 & 0 & 291,47 & 204,28 & & $100 \%$ & \\
\hline 21/jun & 5 & 3803,86 & 21,83 & 5 & 141,78 & 177,59 & & $81 \%$ & \\
\hline 28/jun & 6 & 618,3 & 3 & 5 & 77,29 & 166,26 & & $38 \%$ & \\
\hline 23/jan & 7 & 679,65 & 15,33 & 0,67 & 42,48 & 143,45 & & $96 \%$ & \\
\hline 24/jan & 8 & 580,53 & 13 & 3 & 36,28 & 126,78 & & $81 \%$ & \\
\hline 25/jan & 9 & 245,27 & 2 & 6 & 30,66 & 119,84 & & $25 \%$ & \\
\hline 25/jan & 10 & 353,27 & 3 & 5 & 44,16 & 114,74 & & $38 \%$ & \\
\hline
\end{tabular}

Tabela 37 - Escavação de material de 1aㅡ categoria. Registro de horas, quantidades e processamento das PU's. Etapa: escavação e carga - mão de obra $\left(\mathrm{m}^{3}\right)$

\begin{tabular}{|c|c|c|c|c|c|c|c|}
\hline \multicolumn{8}{|c|}{ MÃO DE OBRA DE APOIO - SERVENTE } \\
\hline & Etam & QS & Horac & PUd & $\begin{array}{l}\text { PUcum } \\
\left(\mathrm{m}^{3} / \mathrm{Hh}\right)\end{array}$ & $\begin{array}{l}\text { PUpot } \\
\left(\mathrm{m}^{3} / \mathrm{Hh}\right)\end{array}$ & $\Delta$ \\
\hline 14/jun & 2 & 2259,94 & 9,5 & 237,89 & 237,89 & \multirow{8}{*}{213,7} & \multirow{8}{*}{128,8} \\
\hline 19/jun & 3 & 1245,82 & 5,83 & 213,69 & 228,69 & & \\
\hline 20/jun & 4 & 3060,47 & 21 & 145,74 & 180,74 & & \\
\hline 21/jun & 5 & 3803,86 & 44,83 & 84,85 & 127,77 & & \\
\hline 28/jun & 6 & & 0 & & 127,77 & & \\
\hline 23/jan & 7 & 679,65 & 18 & 37,76 & 111,43 & & \\
\hline 24/jan & 8 & 580,53 & 10 & 58,05 & 106,54 & & \\
\hline 25/jan & 9 & 245,27 & 4,5 & 54,50 & 104,48 & & \\
\hline
\end{tabular}




\subsubsection{Produtividade variável dos serviços levantados}

Antes de apresentar as produtividades variáveis, conforme cada tipo de serviço levantado, a Tabela 38 demonstra os detalhes de um exemplo de composição.

Tabela 38 - Exemplo de composição

\begin{tabular}{|c|c|c|c|c|c|c|c|}
\hline \multicolumn{8}{|c|}{$\begin{array}{l}\text { Camada final de terraplenagem - esp. até } 20 \mathrm{~cm}\left(\mathrm{~m}^{2}\right) \text { (1) } \\
\text { Etapa: Compactação }\end{array}$} \\
\hline \multirow{2}{*}{ Discriminação (2) } & \multirow[b]{2}{*}{ Qtde (3) } & \multicolumn{3}{|c|}{$\begin{array}{l}\text { Produção Unitária } \\
\left(\mathrm{m}^{2} / \text { Hserv }\right) \text { (4) }\end{array}$} & \multicolumn{3}{|c|}{ Hfuncionamento (5) } \\
\hline & & $\begin{array}{c}10 \\
\text { Quartil }\end{array}$ & Mediana & $\begin{array}{c}3^{\circ} \\
\text { Quartil } \\
\end{array}$ & $\begin{array}{c}1^{0} \\
\text { Quartil }\end{array}$ & Mediana & $\begin{array}{c}3^{\circ} \\
\text { Quartil }\end{array}$ \\
\hline $\begin{array}{l}\text { Rolo compactador pé de } \\
\text { carneiro }\end{array}$ & 4 & 79,26 & 112,19 & 151,71 & $44 \%$ & $53 \%$ & $72 \%$ \\
\hline Rolo compactador de pneus & 1 & 371,33 & 453,78 & 852,89 & $6 \%$ & $8 \%$ & $10 \%$ \\
\hline Caminhão tanque & 1 & 424,67 & 588,78 & 793,77 & $10 \%$ & $15 \%$ & $25 \%$ \\
\hline
\end{tabular}

Neste formato, são apresentados:

(1) o tipo e a etapa do serviço;

(2) discriminação do equipamento;

(3) a quantidade de equipamento;

(4) a produção (em $\mathrm{m}^{2}$ ) do equipamento em função da hora disponível para o serviço. Lembrando que, conforme adotado no Capítulo 5, hora disponível para o serviço corresponde ao tempo em que o equipamento está na frente de trabalho (inclui a improdutividade);

(5) o percentual (estimado) de horas em funcionamento para cada equipamento.

Em relação à Produção Unitária, o seu calculo é feito com base no $1^{\circ}$ e no $3^{\circ}$ Quartil e na mediana da PU diária.

Em relação às horas em funcionamento: o $1^{\circ}$ e $03^{\circ}$ Quartil e a mediana são calculadas com as informações registradas na Tabela 36, por exemplo, coluna (8).

Segue, na Tabela 39, a apresentação das produtividades variáveis conforme cada tipo de serviço. 
Tabela 39 - Produtividades variáveis para os diversos serviços

\begin{tabular}{|c|c|c|c|c|c|c|c|}
\hline \multirow{2}{*}{$\begin{array}{l}\text { Escavação de material de } 1^{\text {a }} \\
\text { categoria. Etapa: escavação e } \\
\text { carga }\end{array}$} & \multirow[b]{2}{*}{ Qtde } & \multicolumn{3}{|c|}{$\begin{array}{l}\text { Produção Unitária } \\
\left(\mathrm{m}^{3} / \mathrm{Hserv}\right)\end{array}$} & \multicolumn{3}{|c|}{ Hfuncionamento } \\
\hline & & $\begin{array}{c}1^{0} \\
\text { Quartil }\end{array}$ & Mediana & $\begin{array}{c}3^{\circ} \\
\text { Quartil }\end{array}$ & $\begin{array}{c}10 \\
\text { Quartil }\end{array}$ & Mediana & $\begin{array}{c}3^{0} \\
\text { Quartil }\end{array}$ \\
\hline Escavadeira hidráulica 320C & 1 & 42,9 & 87,9 & 152,2 & $42 \%$ & $69 \%$ & $92 \%$ \\
\hline Serventes & 1 & 56,3 & 84,9 & 179,7 & & & \\
\hline \multirow{2}{*}{$\begin{array}{l}\text { Compactação de aterro - esp. até } \\
30 \mathrm{~cm}\end{array}$} & & \multicolumn{3}{|c|}{$\begin{array}{l}\text { Produção Unitária } \\
\left(\mathrm{m}^{2} / \text { Hserv }\right)\end{array}$} & \multicolumn{3}{|c|}{ Hfuncionamento } \\
\hline & Qtde & $\begin{array}{c}10 \\
\text { Quartil }\end{array}$ & Mediana & $\begin{array}{c}3^{\circ} \\
\text { Quartil }\end{array}$ & $\begin{array}{c}10 \\
\text { Quartil }\end{array}$ & Mediana & $\begin{array}{c}3^{\circ}= \\
\text { Quartil }\end{array}$ \\
\hline Motoniveladora & 1 & 788,8 & 1501,5 & 2779,2 & $77 \%$ & $82 \%$ & $91 \%$ \\
\hline Trator de pneus agrícola & 1 & 842,2 & 1596,8 & 2752,1 & $55 \%$ & $57 \%$ & $63 \%$ \\
\hline Trator de esteira & 1 & 670,8 & 1277,1 & 2596,2 & $47 \%$ & $71 \%$ & $86 \%$ \\
\hline Rolo pé de carneiro & 3 & 884,1 & 1592,2 & 2746,4 & $31 \%$ & $36 \%$ & $49 \%$ \\
\hline Caminhão Pipa & 1 & 1032,7 & 1608,3 & 2756,4 & $18 \%$ & $29 \%$ & $31 \%$ \\
\hline \multirow{2}{*}{$\begin{array}{l}\text { Brita graduada tratada com } \\
\text { cimento - BGTC - esp. até } 20 \mathrm{~cm}\end{array}$} & & \multicolumn{3}{|c|}{$\begin{array}{c}\text { Produção Unitária } \\
\left(\mathrm{m}^{2} / \text { Hserv }\right)\end{array}$} & \multicolumn{3}{|c|}{ Hfuncionamento } \\
\hline & Qtde & $\begin{array}{c}1^{\circ} \\
\text { Quartil }\end{array}$ & Mediana & $\begin{array}{c}3^{\circ} \\
\text { Quartil }\end{array}$ & $\begin{array}{c}10 \\
\text { Quartil }\end{array}$ & Mediana & $\begin{array}{c}3^{\circ} \\
\text { Quartil }\end{array}$ \\
\hline Rolo de pneus autopropelido & 2 & 42,3 & 69,5 & 78,2 & $45 \%$ & $59 \%$ & $75 \%$ \\
\hline Rolo compactador tipo tandem & 1 & 70,9 & 92,0 & 130,8 & $46 \%$ & $63 \%$ & $90 \%$ \\
\hline Acabadora de asfalto com esteira & 1 & 82,0 & 103,1 & 143,4 & $46 \%$ & $61 \%$ & $78 \%$ \\
\hline Serventes & 5 & 15,9 & 21,6 & 28,1 & & & \\
\hline \multirow{2}{*}{$\begin{array}{l}\text { Concreto betuminoso usinado a } \\
\text { quente - CBUQ - esp. até } 5 \mathrm{~cm}\end{array}$} & & \multicolumn{3}{|c|}{$\begin{array}{l}\text { Produção Unitária } \\
\left(\mathrm{m}^{2} / \text { Hserv }\right)\end{array}$} & \multicolumn{3}{|c|}{ Hfuncionamento } \\
\hline & Qtde & $\begin{array}{c}1^{\circ} \\
\text { Quartil }\end{array}$ & Mediana & $\begin{array}{c}3^{\circ} \\
\text { Quartil } \\
\end{array}$ & $\begin{array}{c}1^{\circ} \\
\text { Quartil }\end{array}$ & Mediana & $\begin{array}{c}3^{\circ} \\
\text { Quartil } \\
\end{array}$ \\
\hline Rolo de pneus autopropelido & 2 & 60,6 & 101,8 & 144,3 & $100 \%$ & $100 \%$ & $100 \%$ \\
\hline Rolo compactador tipo tandem & 1 & 193,7 & 249,6 & 420,1 & $75 \%$ & $100 \%$ & $100 \%$ \\
\hline Acabadora de asfalto com esteira & 1 & 229,5 & 272,4 & 407,0 & $87 \%$ & $100 \%$ & $100 \%$ \\
\hline Serventes & 12 & 24,5 & 45,3 & 57,8 & & & \\
\hline \multirow{2}{*}{ Imprimação } & & \multicolumn{3}{|c|}{$\begin{array}{l}\text { Produção Unitária } \\
\left(\mathrm{m}^{2} / \mathrm{Hserv}\right)\end{array}$} & \multicolumn{3}{|c|}{ Hfuncionamento } \\
\hline & Qtde & $\begin{array}{c}10 \\
\text { Quartil }\end{array}$ & Mediana & $\begin{array}{c}3^{\circ} \\
\text { Quartil }\end{array}$ & $\begin{array}{c}10 \\
\text { Quartil }\end{array}$ & Mediana & $\begin{array}{c}3^{\circ} \\
\text { Quartil }\end{array}$ \\
\hline Caminhão distribuidor de betume & 1 & 152,8 & 214,4 & 378,3 & $6 \%$ & $8 \%$ & $13 \%$ \\
\hline Serventes & 1 & 152,8 & 214,4 & 378,3 & & & \\
\hline \multirow{2}{*}{ Pintura de ligação } & & \multicolumn{3}{|c|}{$\begin{array}{l}\text { Produção Unitária } \\
\left(\mathrm{m}^{2} / \text { Hserv }\right)\end{array}$} & \multicolumn{3}{|c|}{ Hfuncionamento } \\
\hline & Qtde & $\begin{array}{c}1^{0} \\
\text { Quartil } \\
\end{array}$ & Mediana & $\begin{array}{c}3^{\circ} \\
\text { Quartil } \\
\end{array}$ & $\begin{array}{c}10 \\
\text { Quartil } \\
\end{array}$ & Mediana & $\begin{array}{c}3^{\circ} \\
\text { Quartil } \\
\end{array}$ \\
\hline Caminhão distribuidor de betume & 1 & 158,1 & 224,9 & 261,3 & $11 \%$ & $13 \%$ & $16 \%$ \\
\hline Serventes & 1 & 158,1 & 224,9 & 261,3 & & & \\
\hline
\end{tabular}




\subsection{Rodoanel Mário Covas}

A parte estudada do Rodoanel Mário Covas foi o Trecho Sul - Lote 2. Situado entre a BR-116 - Rodovia Regis Bittencourt e o acesso à av. Papa João Paulo XXIII, no município de Mauá. O Lote 2 compreende da estaca 31.480 à estaca $31.825(6,9 \mathrm{~km})$ e mais interligação com a Via Anchieta $(3,0 \mathrm{~km})$. O Canteiro Central foi situado na Estrada Martim Afonso de Souza, 331 - Vila Balneária CEP.: 09822-250 - São Bernardo do Campo - SP (Figura 47 e Figura 48).

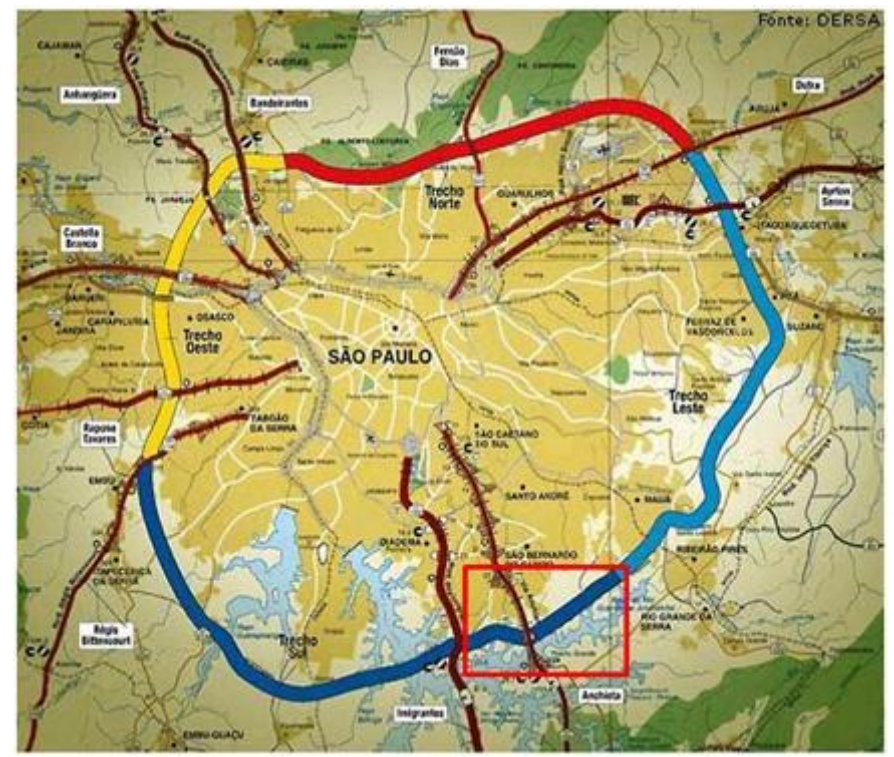

Figura 47 - Traçado do Rodoanel (a marca dentro do retângulo é referente ao lote 2) Fonte: Rocha (2010)

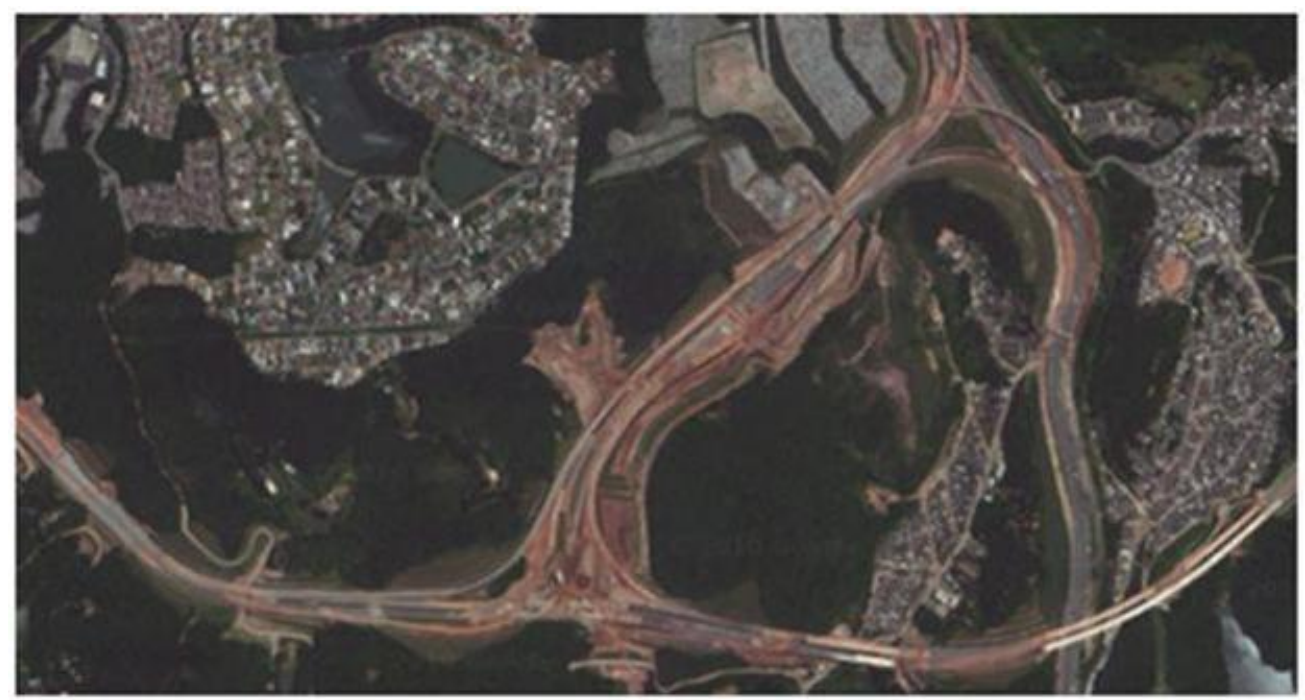

Figura 48 - Detalhe do Trecho Sul - Lote 2 (Trevo da Anchieta e Eixo) Fonte: DERSA (2011) 
Obra do Governo do Estado de São Paulo no valor de $\mathrm{R} \$ 495.555 .807,02$. Iniciada em maio de 2005 e com prazo contratual de 36 meses.

Neste contrato de $n^{\circ}$ 3584/06, o Desenvolvimento Rodoviário S.A. (DERSA) se apresenta como a CONTRATANTE. O Consórcio Rodosul se apresenta como SUPERVISORA e o Consórcio Arcosul: Construtora Norberto Odebrecht S.A. e Constran S.A, se apresenta como CONTRATADA.

\subsubsection{Método de coleta}

Com base na proposta de abordagem das composições, apresentada no Capítulo 5, procurou-se elaborar o método de coleta utilizado na obra do Rodoanel. Seu desenvolvimento se deu aos poucos, sendo evoluído na medida em que se conhecia a realidade da obra.

O resultado da compilação dos dados coletados é originado do sistema apresentado na Figura 49. As siglas ${ }^{64}$ Eixo, Ramo PE-APN, Ramo APS PE, dentre outros, se referem às partes da obra no qual foram coletados dados.

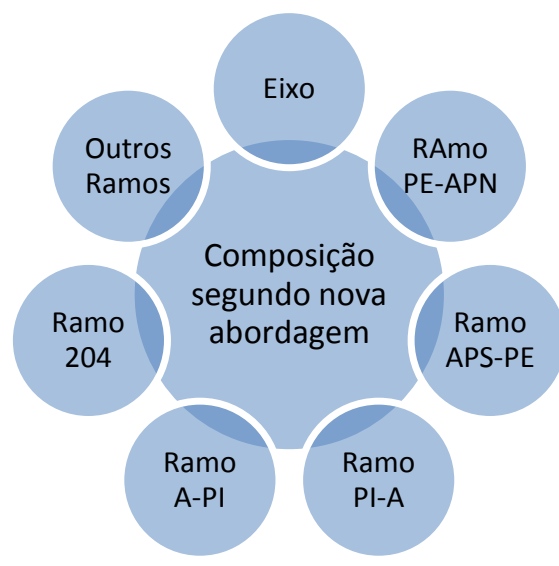

Figura 49 - Compilação dos dados conforme nova abordagem

Partindo da visita à obra, a Figura 50 apresenta os passos trilhados para o levantamento de dados.

\footnotetext{
${ }^{64}$ Siglas definidas pelo Consórcio, exemplo: PE-APN: Pista Externa - Anchieta Pista Norte.
} 
a) Escolha do serviço

b) Escolha do ramo

c) Quebra do serviço em partes

d) Equipe/patrulha envolvida

e) Esboço das atividades

f) Entendimento do método de trabalho

g) Coleta dos dados

- acompanhamento da execução dos serviços

- determinação do tempo de ciclo dos equipamentos

- anotação das horas produtivias "Método das Observações Instantâneas"

- anotação dos fatores e anormalidades

Figura 50 - Método de coleta

Cada uma das etapas representadas no método de coleta é detalhado no Apêndice C.

\subsubsection{Processamento dos dados coletados}

Para o processamento dos dados coletados, primeiramente partiu-se para o preenchimento do diário de obras, depois para os cálculos e as ponderações. $\mathrm{Na}$ sequência, sintetizaram-se as anormalidades e os fatores para, finalmente, montar as faixas de valores. A Figura 51 apresenta um resumo da metodologia empregada.

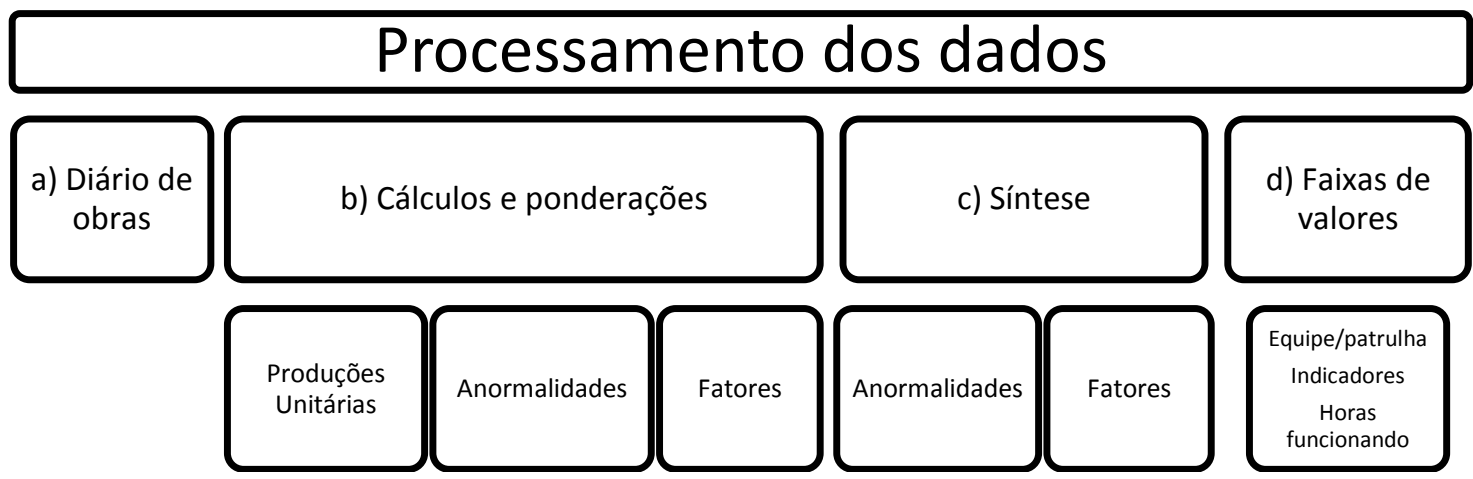

Figura 51 - Metodologia para o processamento dos dados coletados 
a) Diário de obras

A Tabela 40 apresenta um exemplo de diário de obras. Conforme a numeração (de 1 a 23), o significado de cada coluna é apresentado como segue:

- 1 e 2: indica a data e o dia da semana que ocorreu a atividade;

- 3: local de registro (resumido) das atividades diárias;

- 4: total de horas, disponíveis para o serviço, dos equipamentos;

- 5 a 12: registro da quantidade de cada equipamento;

- 13 e 14: registro da quantidade de mão de obra;

- 15 a 17: registro do comprimento, largura e espessura da via produzida;

- 18 a 21: caso o trecho tenha sido atendido por um corte, registra-se a quantidade de escavadeira, caminhões, viagens e a distância média de transporte;

- 22: registro das características da via (reta, pouco inclinada ou muito inclinada);

- 23: registro das observações do dia.

b) Cálculo das Produções Unitárias e ponderações relacionadas às anormalidade e aos fatores.

A Tabela 41 apresenta um exemplo de detalhamento para o cálculo das Produções Unitárias (PU's) e o registro das anormalidades e dos fatores. 
Tabela 40 - Exemplo de diário de obras: camada final de terraplenagem

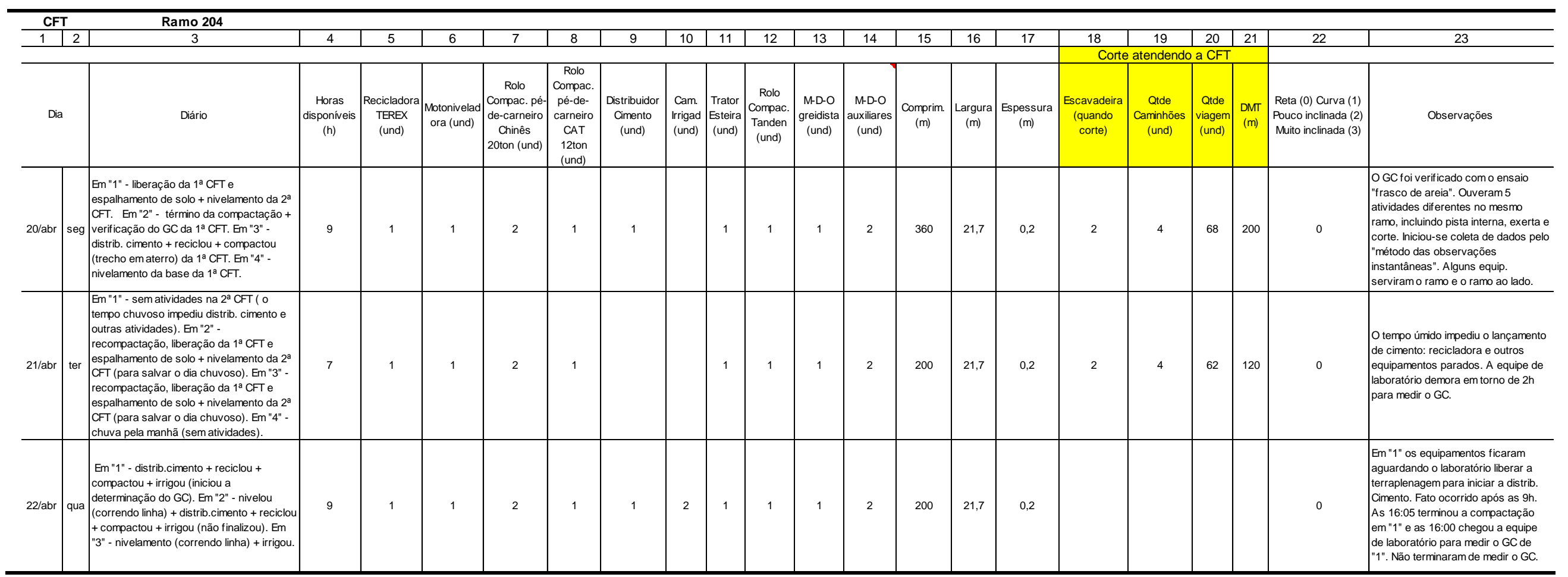


Tabela 41 - Exemplo de registro dos cálculos e das ponderações.

\begin{tabular}{|c|c|c|c|c|c|c|c|c|c|c|c|c|c|c|c|c|c|c|c|c|c|c|c|c|c|c|}
\hline 1 & \begin{tabular}{|l|l|}
2 & \\
\end{tabular} & 3 & 4 & 5 & 6 & 7 & 8 & 9 & 10 & 11 & 12 & 13 & 14 & 15 & 16 & 17 & 18 & 19 & 20 & 21 & 22 & 23 & 24 & 25 & 26 & 27 \\
\hline \multirow{3}{*}{ Data } & \multirow{3}{*}{ Dia } & \multirow[t]{2}{*}{$\begin{array}{c}\text { Jornad } \\
\text { a }\end{array}$} & \multirow[t]{2}{*}{$\begin{array}{l}\text { Qtde } \\
\text { estacas }\end{array}$} & \multirow[t]{2}{*}{ Produção } & \multicolumn{6}{|c|}{$\begin{array}{l}\text { Lançamento da camada - } m 2 \\
\text { (A) }\end{array}$} & \multicolumn{4}{|c|}{$\begin{array}{c}\text { Tratamento da camada - m2 } \\
\text { (T) }\end{array}$} & \multirow{2}{*}{\multicolumn{2}{|c|}{\begin{tabular}{|c|}
$\begin{array}{c}\text { Compactação } \\
\text { da camada - m2 } \\
\text { (C) }\end{array}$ \\
Compactação \\
\end{tabular}}} & \multirow{2}{*}{\multicolumn{2}{|c|}{$\begin{array}{c}\text { Liberação da } \\
\text { camada - m2 (L) }\end{array}$}} & \multirow{2}{*}{\multicolumn{2}{|c|}{ Trator esteira }} & \multirow{2}{*}{\multicolumn{2}{|c|}{ Motoniveladora }} & \multirow{2}{*}{\multicolumn{2}{|c|}{ Distrib. Cim. }} & \multirow{2}{*}{\multicolumn{2}{|c|}{ Recicladora }} \\
\hline & & & & & \multicolumn{3}{|c|}{ Externa } & \multicolumn{3}{|c|}{ Interno } & \multicolumn{2}{|c|}{ Externa } & \multicolumn{2}{|c|}{ Interna } & & & & & & & & & & & & \\
\hline & & $\mathrm{h}$ & und & $\mathrm{m}$ & \begin{tabular}{|l|} 
Lançament \\
o do solo \\
(ls)
\end{tabular} & $\begin{array}{c}\text { Espalhament } \\
\text { o do solo } \\
\text { (es) }\end{array}$ & \begin{tabular}{|c} 
Nivelament \\
o da \\
camada
\end{tabular} & $\begin{array}{c}\text { Lançament } \\
\text { o do solo } \\
\text { (Is) }\end{array}$ & $\begin{array}{c}\begin{array}{c}\text { Espalhament } \\
\text { o do solo } \\
\text { (es) }\end{array} \\
\text { (a) }\end{array}$ & \begin{tabular}{|c} 
Nivelament \\
o da \\
camada
\end{tabular} & \begin{tabular}{|c|} 
Distribuiçã \\
o do \\
cimento
\end{tabular} & \begin{tabular}{|l|} 
Mistura \\
do solo \\
+
\end{tabular} & \begin{tabular}{|c|} 
Distribuiçã \\
o do \\
cimento
\end{tabular} & $\begin{array}{l}\text { Mistura } \\
\text { do solo } \\
+\end{array}$ & Externa & Interna & Externa & Interna & Qtde & $\begin{array}{l}\text { Pudia } \\
\mathrm{m} / \mathrm{H}\end{array}$ & Qtde & $\begin{array}{l}\text { Pudia } \\
\mathrm{m} / \mathrm{H}\end{array}$ & Qtde & $\begin{array}{l}\text { Pudia } \\
\mathrm{m} 2 / \mathrm{H}\end{array}$ & Quant. & $\begin{array}{l}\text { Pudia } \\
\mathrm{m} 2 / \mathrm{H}\end{array}$ \\
\hline 20/abr & seg & 9 & 18 & 360 & 2170 & 2170 & 2170 & & & 2170 & 434 & 434 & & & 1228 & & 2170 & & 1 & 241 & 1 & 482 & 1 & 48 & 1 & 48 \\
\hline $21 / \mathrm{abr}$ & ter & 7 & 10 & 200 & 3472 & 3472 & 3472 & & & & & & & & 3038 & & 3472 & & 1 & 496 & 1 & 496 & 0 & & 1 & \\
\hline $22 / \mathrm{abr}$ & qua & 9 & 10 & 200 & & & & & & & 4340 & 4340 & & & 3596 & & & & 1 & & 1 & & 1 & 482 & 1 & 482 \\
\hline $23 / \mathrm{abr}$ & qui & 9 & 18 & 360 & 2604 & 2604 & & & & 2170 & 1302 & 1302 & & & 1602 & & 2604 & & 1 & 289 & 0 & & 1 & 145 & 1 & 145 \\
\hline
\end{tabular}

\begin{tabular}{|c|c|c|c|c|c|c|c|c|c|c|c|c|c|c|c|c|c|c|c|c|c|c|}
\hline & & & & & & & & & & 38 & 39 & 40 & 41 & 42 & 43 & 44 & 45 & 46 & 47 & 48 & 49 & 50 \\
\hline \begin{tabular}{|l|}
28 \\
\end{tabular} & 29 & 30 & 31 & 32 & 33 & 34 & 35 & 36 & 37 & \multicolumn{2}{|c|}{ Anormalidades } & \multicolumn{7}{|c|}{ Fatores conteúdo } & \multicolumn{4}{|c|}{ Fatores contexto } \\
\hline \multicolumn{4}{|c|}{ Rolo pé-de-carneiro } & \multicolumn{2}{|c|}{ Rolo Tanden } & \multicolumn{2}{|c|}{ Pipa } & \multirow{3}{*}{$\begin{array}{l}\text { № } \\
\text { Frentes }\end{array}$} & \multirow{3}{*}{$\begin{array}{c}\text { recompactaçã } \\
0\end{array}$} & \multirow{3}{*}{ Chuva } & \multirow{3}{*}{$\begin{array}{c}\text { Camada } \\
\text { saturada }\end{array}$} & \multirow{3}{*}{ Largura } & \multirow{3}{*}{ Espessura } & \multirow{3}{*}{ Proctor } & \multirow{3}{*}{ Umidade } & \multirow{3}{*}{$\begin{array}{c}\% \\
\text { cimento }\end{array}$} & \multirow{3}{*}{\begin{tabular}{|c|} 
Tipo de \\
solo
\end{tabular}} & \multirow{3}{*}{\begin{tabular}{|c|} 
Reta (0) \\
Curva (1) \\
Rampa (2)
\end{tabular}} & \multirow{3}{*}{$\begin{array}{c}\text { Mudança } \\
\text { equipamento }\end{array}$} & \multirow{3}{*}{\begin{tabular}{|c|} 
Viga \\
Benkelma \\
$\mathrm{n}$
\end{tabular}} & \multirow{3}{*}{ Composição patrulha } & \multirow{3}{*}{$\begin{array}{c}\text { Frente } \\
\text { junta }(0) \\
\text { separada } \\
\quad(1)\end{array}$} \\
\hline \begin{tabular}{|l|}
$12 \mathrm{t}$ \\
\end{tabular} & $18 \mathrm{t}$ & $20 \mathrm{t}$ & & & & & & & & & & & & & & & & & & & & \\
\hline Qtde & Qtde & Qtde & $\mathrm{m} 2 / \mathrm{H}$ & Qtde & $\begin{array}{l}\text { Pudia } \\
\mathrm{m} 2 / \mathrm{H}\end{array}$ & Qtde & $\begin{array}{l}\text { Pudia } \\
\mathrm{m} 2 / \mathrm{H}\end{array}$ & & & & & & & & & & & & & & & \\
\hline \begin{tabular}{|llll} 
& 1 & & \\
\end{tabular} & & 2 & 45 & 1 & 136 & & 0 & 4 & 1 & & & 21,7 & 0,2 & $100 \%$ normal & (+-) $2 \%$ & $2 \%$ & * & 0 & & & \begin{tabular}{|l|} 
A patrulha atendeu a pista \\
interna e externa e o ramo \\
ao lado (alguns \\
equipamentos)
\end{tabular} & 1 \\
\hline 1 & & 2 & 145 & 1 & 434 & & 0 & 2 & 1 & & $x$ & 21,7 & 0,2 & $100 \%$ normal & $(+-) 2 \%$ & $2 \%$ & * & 0 & & & $\begin{array}{l}\text { Em função da umidade, o } \\
\text { planejamento, para salvar o } \\
\text { dia, se resumiu em lançar o } \\
\text { solo e nivelar. }\end{array}$ & 0 \\
\hline 1 & & 2 & 133 & 1 & 400 & 2 & 200 & 3 & & & & 21,7 & 0,2 & $100 \%$ normal & $(+-) 2 \%$ & $2 \%$ & * & 0 & & & $\begin{array}{l}\text { Embora tenham } 2 \text { pipas, eles } \\
\text { não trabalharam ao mesmo } \\
\text { tempo. }\end{array}$ & 0 \\
\hline 1 & & 2 & 59 & 1 & 178 & 1 & 178 & 4 & 2 & Forte & & 21,7 & 0,2 & $100 \%$ normal & (+-) $2 \%$ & $2 \%$ & * & 0 & & & \begin{tabular}{|l|} 
O trator de esteiras \\
trabalhou em "4" cortando e \\
transportando o solo e \\
nivelando a camada
\end{tabular} & 1 \\
\hline
\end{tabular}


Conforme a numeração (de 1 a 50 ), o significado de cada coluna é apresentado como segue:

- 1 e 2: indica a data e o dia da semana que ocorreu a atividade;

- 3: registro da duração da jornada de trabalho;

- 4: registro da quantidade de estacas abrangidas (o estaqueamento é de 20 em 20 metros);

- 5: registro da produção (3) x (4);

- 6 a 11: em relação ao lançamento da camada e levando em consideração as duas pistas (interna e externa), faz o registro das sub-tarefas (lançamento e espalhamento do solo e nivelamento da camada);

- 12 a 15: em relação ao tratamento da camada, faz o registro das sub-tarefas (distribuição do cimento e mistura do solo com o cimento - pista interna e externa);

- 16 e 17: registro da produção de compactação da camada (pista interna e externa);

- 18 e 19: registro da área liberada conforme atendimento do grau de compactação e da umidade de projeto;

- 20 a 35: cálculo da $\mathrm{PU}_{\text {diária }}$ conforme a quantidade do equipamento e a produção;

- 36: registro da quantidade de frentes que os equipamentos atenderam;

- 37: conforme o registro manual do esboço das atividades, do dia anterior e do atual, e segundo a aprovação do GC (feita pela equipe de laboratório), o registro da recompactação (caso ocorra) é efetuado;

- 38 e 39: em relação às anormalidades, registro da ocorrência de chuva ou se a camada está saturada;

- 40 a 46: em relação aos fatores de conteúdo, registro da largura e espessura da pista, tipo de Proctor, umidade de projeto, percentual de cimento, tipo de solo e características da pista;

- 47 a 50: em relação aos fatores de contexto, registro da mudança de equipamento e se houve ensaio com a Viga Benkelman, observações quanto a composição da patrulha e se as atividades ocorreram em mais de uma frente (juntas ou separadas). 
c) Síntese das anormalidades e dos fatores

A Tabela 42 apresenta um exemplo de síntese das anormalidades e dos fatores (de conteúdo e contexto) relativos à execução de cada serviço. Na coluna "observações" estão descritos os efeitos gerados pela ocorrência da anormalidade ou fator. Em alguns casos são apresentados exemplos de sua ocorrência.

Tabela 42 - Exemplo de síntese das anormalidade e dos fatores: CFT

\begin{tabular}{|c|c|}
\hline ANORMALIDADES & OBSERVAÇÕES \\
\hline Chuva & Paralisa a atividade no dia e no seguinte. \\
\hline Camada saturada & Paralisa a atividade no dia e pode paralisar no seguinte. \\
\hline \multirow[t]{2}{*}{ Falta de operador } & Paralisa a atividade no dia. \\
\hline & $\begin{array}{l}\text { Exemplos de ocorrência: } \\
\text { - } \quad \text { o operador da esteira faltou, parado o dia todo. Faltou o } \\
\text { motorista do distribuidor de cimento, parado até as } 13 \mathrm{~h} .\end{array}$ \\
\hline FATORES DE CONTEÚDO & OBSERVAÇÕES \\
\hline Largura & Condicionante para formação da patrulha. \\
\hline Espessura & $\begin{array}{l}\text { Condicionante para formação da patrulha, determina o no de fechas } \\
\text { para atingir o GC. }\end{array}$ \\
\hline \multirow[t]{2}{*}{ Proctor } & $\begin{array}{l}\text { Condicionante para formação da patrulha, determina o no de fechas } \\
\text { para atingir o GC. }\end{array}$ \\
\hline & $\begin{array}{l}\text { Exemplos de ocorrência: } \\
\text { - } \quad \text { A patrulha aguardou a determinação do GC das 8:55 às } 11 \mathrm{~h} . \\
\text { - } \quad \text { Passou de } 16 \text { fechas para } 20 .\end{array}$ \\
\hline \multirow[t]{2}{*}{ Umidade } & Determina o $\mathrm{n}^{\circ}$ de fechas, condicionante para atingir o GC \\
\hline & $\begin{array}{l}\text { Exemplo de ocorrência: } \\
\text { - } \quad \text { Em função da umidade, o planejamento, para salvar o dia, se } \\
\text { resumiu em lançar o solo e nivelar. }\end{array}$ \\
\hline FATORES DE CONTEXTO & OBSERVAÇÕES \\
\hline № de frentes & $\begin{array}{l}\text { Quanto mais frentes mais horas operativas dos equipamentos (evita } \\
\text { ociosidade). }\end{array}$ \\
\hline \multirow[t]{2}{*}{ Mudança de equipamento } & Pode contribuir ou não na patrulha. \\
\hline & $\begin{array}{l}\text { Exemplos de ocorrência: } \\
\text { - Foi acrescentado mais um rolo compactador de 12t. (melhorou a } \\
\text { produtividade). } \\
\text { - Foi acrescentado mais um caminhão tanque (não fez efeito na } \\
\text { produtividade). }\end{array}$ \\
\hline Viga Benkelman & O serviço de terraplenagem é paralisado até sua execução. \\
\hline
\end{tabular}

d) Faixas de valores

A Tabela 43 apresenta um modelo de dados condensados (embora seja a mesma da Tabela 38 optou-se em reapresentá-la para facilitar o entendimento), referentes ao serviço camada final de terraplenagem, em formato de faixa de valores (produtividade variável). 
Tabela 43 - Exemplo de composição

\begin{tabular}{|c|c|c|c|c|c|c|c|}
\hline \multicolumn{8}{|c|}{$\begin{array}{l}\text { Camada final de terraplenagem - esp. até } 20 \mathrm{~cm} \text { (1) } \\
\text { Etapa: Compactação }\end{array}$} \\
\hline \multirow{2}{*}{ Discriminação (2) } & \multirow{2}{*}{$\begin{array}{l}\text { Qtde } \\
\text { (3) }\end{array}$} & \multicolumn{3}{|c|}{$\begin{array}{l}\text { Produção Unitária } \\
\left(\mathrm{m}^{2} / \text { Hserv }\right) \text { (4) }\end{array}$} & \multicolumn{3}{|c|}{ Hfuncionamento (5) } \\
\hline & & $\begin{array}{c}1^{0} \\
\text { Quartil }\end{array}$ & Mediana & $\begin{array}{c}3^{\circ} \\
\text { Quartil }\end{array}$ & $\begin{array}{c}1^{\circ} \\
\text { Quartil }\end{array}$ & Mediana & $\begin{array}{c}3^{0} \\
\text { Quartil }\end{array}$ \\
\hline $\begin{array}{l}\text { Rolo compactador pé de } \\
\text { carneiro }\end{array}$ & 4 & 79,26 & 112,19 & 151,71 & $44 \%$ & $53 \%$ & $72 \%$ \\
\hline Rolo compactador de pneus & 1 & 371,33 & 453,78 & 852,89 & $6 \%$ & $8 \%$ & $10 \%$ \\
\hline Caminhão tanque & 1 & 424,67 & 588,78 & 793,77 & $10 \%$ & $15 \%$ & $25 \%$ \\
\hline
\end{tabular}

Neste formato, são apresentados:

(1) o tipo e a etapa do serviço;

(2) discriminação do equipamento;

(3) a quantidade de equipamento;

(4) a produção (em $\mathrm{m}^{2}$ ) do equipamento em função da hora disponível para o serviço. Lembrando que, conforme adotado no Capítulo 5, hora disponível para o serviço corresponde ao tempo em que o equipamento está na frente de trabalho (inclui a improdutividade);

(5) o percentual (estimado) de horas em funcionamento para cada equipamento.

Em relação à Produção Unitária, o seu calculo é feito com base no $1^{\circ}$ e no $3^{\circ}$ Quartil e na mediana da PU diária.

As horas em funcionamento são obtidas conforme aplicação do Método das Observações Instantâneas (apresentado no Capítulo 5 e no Apêndice D).

\subsubsection{Resultados}

Em função da grande quantidade de dados obtidos na obra, para a sua apresentação, optou-se pelo seguinte sistema:

a) apresentar resumidamente no formato de produtividade variável, para os serviços estudados, o conjunto de indicadores (composições orçamentárias);

b) apresentar, para os serviços estudados, uma síntese das anormalidades e fatores (de contexto e conteúdo);

c) apresentar no Apêndice $D$, o conjunto de dados que deram origem às composições orçamentárias. 
Conforme a lista de estudo, os serviços levantados são assinalados abaixo:

a) escavação de material de $1^{\underline{a}}$ categoria com trator de esteiras $\left(\mathrm{m}^{3}\right)$ - não estudado;

b) escavação de material de $1^{\text {a }}$ categoria com escavadeira hidráulica $\left(\mathrm{m}^{3}\right)$;

c) compactação de aterro - espessura até $30 \mathrm{~cm}\left(\mathrm{~m}^{2}\right)$;

d) base de solo cimento com mistura na pista - esp. até $20 \mathrm{~cm}\left(\mathrm{~m}^{2}\right)$;

e) brita graduada simples - BGS com distribuidor de agregados - esp. até $20 \mathrm{~cm}$ $\left(m^{2}\right)$ - não estudado;

f) brita graduada simples - BGS com vibroacabadora - esp. até $20 \mathrm{~cm}\left(\mathrm{~m}^{2}\right)$;

g) brita graduada tratada com cimento - BGTC - esp. até $20 \mathrm{~cm}\left(\mathrm{~m}^{2}\right)$;

h) concreto betuminoso usinado a quente - capa ou binder - esp. até $5 \mathrm{~cm}\left(\mathrm{~m}^{2}\right)$;

i) imprimação $\left(\mathrm{m}^{2}\right)$;

j) pintura de ligação $\left(\mathrm{m}^{2}\right)$.

A Tabela 44 apresenta a faixa de valores (produtividade variável) e a Tabela 45 apresenta a síntese das anormalidades e fatores relativos ao serviço de escavação e carga de material de $1^{\text {a }}$ Categoria.

Tabela 44 - Faixa de valores de escavação e carga de material de $1^{\underline{a}}$ categoria com escavadeira hidráulica

\begin{tabular}{l|c|c|c|c|c|c|c}
\hline \multirow{2}{*}{ Discriminação } & & \multicolumn{3}{c|}{ Produção Unitária (m³/Hserv) } & \multicolumn{4}{c}{ Hfuncionamento } \\
\cline { 3 - 9 } & Qtde & 10 Quartil & Mediana & 30 Quartil & 10 Quartil & Mediana & 30 Quartil \\
\hline $\begin{array}{l}\text { Escavadeira } \\
\text { hidráulica }\end{array}$ & 1 & 59,5 & 73,1 & 103,1 & $74 \%$ & $82 \%$ & $95 \%$ \\
\hline
\end{tabular}

Tabela 45 - Anormalidades e fatores encontrados na produção de escavação e carga de material de $1^{\underline{a}}$ categoria (continua)

\begin{tabular}{l|l}
\hline ANORMALIDADES & OBSERVAÇÕES \\
\hline Chuva & Paralisa a atividade no dia e no seguinte. \\
\hline \multirow{2}{*}{ Camada saturada } & $\begin{array}{l}\text { Paralisa a atividade no dia e pode paralisar no seguinte (caminhos } \\
\text { de serviço). }\end{array}$ \\
\cline { 2 - 2 } & $\begin{array}{l}\text { Exemplo de ocorrência: } \\
\bullet \quad \text { Atividades interrompidas devido a forte chuva. }\end{array}$ \\
\hline Falta de operador & A escavadeira ficou disponível pois não tinha operador. \\
\hline FATORES DE CONTEÚDO & OBSERVAÇÕES \\
\hline Tipo de solo & Determina a velocidade do ciclo (escavação e carga). \\
\hline FATORES DE CONTEXTO & OBSERVAÇÕES \\
\hline № de frentes & $\begin{array}{l}\text { Quanto mais frentes e mais próximas, mais horas operativas dos } \\
\text { equipamentos (evita ociosidade). }\end{array}$
\end{tabular}


Tabela 45 - Anormalidades e fatores encontrados na produção de escavação e carga de material de $1^{\underline{a}}$ categoria (conclusão)

\begin{tabular}{l|l}
\hline Mudança de equipamento & Pode contribuir ou não na patrulha.
\end{tabular}

Exemplo de ocorrência:

- Em determinado momento acrescentou-se uma pá-

carregadora para ajudar no carregamento dos caminhões

(melhorou a produtividade), porém, depois a escavadeira passou o restante do tempo escavando e amontoando o solo.

Quantidade de caminhões $\quad$ É essencial para o incremento da produtividade.

Exemplo de ocorrência:

- O fornecimento de solo, vindo dos cortes, é diretamente proporcional à quantidade dos caminhões.

Frente junta ou separada

Contribui no incremento da produtividade se as frentes embora separadas forem próximas (diminui a ociosidade).

Exemplo de ocorrência:

- A escavadeira atendeu a pista interna, externa e o ramo ao lado

Outros

Boa parte da manhã a escavadeira ficou escavando e amontoando o solo. À tarde começou a carregar os caminhões.

A Tabela 46 apresenta a faixa de valores (produtividade variável) e a Tabela 47 apresenta a síntese das anormalidades e fatores relativos ao serviço de compactação de aterro.

Tabela 46 - Faixa de valores de compactação de aterro - esp. até $30 \mathrm{~cm}$

\begin{tabular}{l|c|c|c|c|c|c|c}
\hline \multirow{2}{*}{ Discriminação } & \multirow{2}{*}{ Qtde } & \multicolumn{3}{|c|}{ Produção Unitária (m²/Hserv) } & \multicolumn{3}{c}{ Hfuncionamento* } \\
\cline { 3 - 9 } & 1 & $1^{\circ}$ Quartil & Mediana & $3^{\circ}$ Quartil & $1^{\circ}$ Quartil & Mediana & $3^{\circ}$ Quartil \\
\hline Trator esteiras & 1 & 221,7 & 311,1 & 387,6 & $*$ & & \\
\hline $\begin{array}{l}\text { Trator agrícola com } \\
\text { grade de disco }\end{array}$ & 1 & 221,7 & 311,1 & 387,6 & & & \\
\hline Caminhão tanque & 1 & 997,5 & 1400,0 & 1744,2 & & & \\
\hline Rolo pé de carneiro & 4 & 55,4 & 77,8 & 96,9 & & & \\
\hline Motoniveladora & 1 & 221,7 & 311,1 & 387,6 & & & \\
\hline
\end{tabular}

${ }^{*}$ não foi medido

Tabela 47 - Anormalidades e fatores encontrados na produção de compactação de aterros (continua)

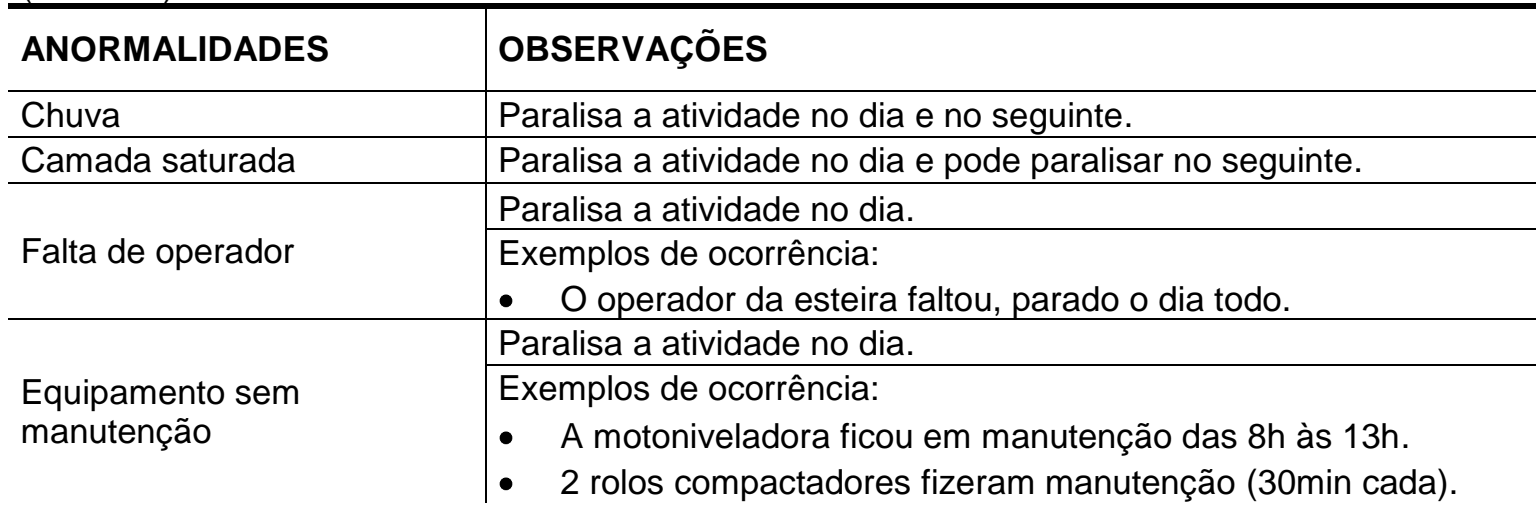


Tabela 47 - Anormalidades e fatores encontrados na produção de compactação de aterros (conclusão)

\begin{tabular}{|c|c|}
\hline FATORES DE CONTEÚDO & OBSERVAÇÕES \\
\hline Largura & Condicionante para formação da patrulha. \\
\hline Espessura & $\begin{array}{l}\text { Condicionante para formação da patrulha, determina o } \mathrm{n}^{\circ} \text { de } \\
\text { fechas para atingir o GC. }\end{array}$ \\
\hline \multirow[t]{2}{*}{ Proctor } & $\begin{array}{l}\text { Condicionante para formação da patrulha, determina o } \mathrm{n}^{\circ} \text { de } \\
\text { fechas para atingir o GC. }\end{array}$ \\
\hline & $\begin{array}{l}\text { Exemplos de ocorrência: } \\
\text { - A patrulha aguardou a determinação do GC das } 8: 55 \text { às } 11 \mathrm{~h} \text {. } \\
\text { - Passou de } 16 \text { fechas para } 20 \text {. }\end{array}$ \\
\hline \multirow[t]{2}{*}{ Umidade } & Determina o no de fechas, condicionante para atingir o GC. \\
\hline & $\begin{array}{l}\text { Exemplo de ocorrência: } \\
\text { - Em função da umidade, o planejamento, para salvar o dia, se } \\
\text { resumiu em lançar o solo e nivelar. }\end{array}$ \\
\hline Tipo de solo & Determina o no de fechas, condicionante para atingir o GC. \\
\hline Reta, curva ou rampa & À princípio o grau de dificuldade é o mesmo. \\
\hline FATORES DE CONTEXTO & OBSERVAÇÕES \\
\hline № de frentes & $\begin{array}{l}\text { Quanto mais frentes mais horas operativas dos equipamentos } \\
\text { (evita ociosidade). }\end{array}$ \\
\hline \multirow[t]{2}{*}{ Mudança de equipamento } & Pode contribuir ou não na patrulha. \\
\hline & $\begin{array}{l}\text { Exemplos de ocorrência: } \\
\text { - Foi acrescentado mais um rolo compactador de 12t. } \\
\text { (melhorou a produtividade). } \\
\text { - Foi acrescentado mais um caminhão tanque (não fez efeito na } \\
\text { produtividade). }\end{array}$ \\
\hline Viga Benkelman & O serviço de terraplenagem é paralisado até sua execução. \\
\hline \multirow[t]{2}{*}{ Composição da patrulha } & $\begin{array}{l}\text { É essencial para o incremento da produtividade, determina o } \\
\text { número de fechas }\end{array}$ \\
\hline & $\begin{array}{l}\text { Exemplos de ocorrência: } \\
\text { - Embora tenham } 2 \text { tanques, eles não trabalharam ao mesmo } \\
\text { tempo. } \\
\text { - O trator de esteiras trabalhou em outra frente cortando, } \\
\text { transportando o solo e nivelando a camada. } \\
\text { - O rolo compactador tipo tandem não é o mais adequado para } \\
\text { selar as camadas. } \\
\text { - O caminhão tanque e a recicladora não trabalharam. }\end{array}$ \\
\hline \multirow[t]{2}{*}{ Quantidade de caminhões } & É essencial para o incremento da produtividade \\
\hline & $\begin{array}{l}\text { Exemplo de ocorrência: } \\
\text { O fornecimento de solo, vindo dos cortes, é diretamente } \\
\text { proporcional à quantidade dos caminhões. }\end{array}$ \\
\hline \multirow[t]{2}{*}{ Frente junta ou separada } & $\begin{array}{l}\text { Contribui no incremento da produtividade se as frentes embora } \\
\text { separadas forem próximas (diminui a ociosidade). }\end{array}$ \\
\hline & $\begin{array}{l}\text { Exemplos de ocorrência: } \\
\text { - A patrulha atendeu a pista interna e externa e o ramo ao lado } \\
\text { (diminuiu a ociosidade). }\end{array}$ \\
\hline \multirow[t]{2}{*}{ Outros } & Interdependência entre tarefas. \\
\hline & $\begin{array}{l}\text { Exemplo de ocorrência: } \\
\text { - Não lançará o } 2^{\circ} \text { ref. Subleito enquanto o dreno não ficar } \\
\text { pronto. }\end{array}$ \\
\hline
\end{tabular}


A Tabela 48 apresenta a faixa de valores (produtividade variável) e a Tabela 49 apresenta a síntese das anormalidades e fatores relativos ao serviço de camada final de terraplenagem - CFT.

Tabela 48 - Faixa de valores de CFT - esp. até $20 \mathrm{~cm}$

\begin{tabular}{l|c|c|c|c|c|c|c}
\hline \multirow{2}{*}{ Discriminação } & \multirow{2}{*}{} & \multicolumn{2}{|c|}{ Produção Unitária (m²/Hserv) } & \multicolumn{3}{c}{ Hfuncionamento } \\
\cline { 3 - 8 } & Qtde & 10 Quartil & Mediana & 3 o Quartil & 10 Quartil & Mediana & 3 Quartil \\
\hline Trator esteiras & 1 & 512,3 & 654,7 & 748,0 & $12 \%$ & $28 \%$ & $34 \%$ \\
\hline Motoniveladora & 1 & 229,9 & 389,7 & 439,0 & $36 \%$ & $60 \%$ & $79 \%$ \\
\hline Distribuidor cimento & 1 & 369,7 & 444,7 & 581,7 & $6 \%$ & $8 \%$ & $13 \%$ \\
\hline Recicladora & 1 & 399,7 & 464,7 & 777,4 & $11 \%$ & $23 \%$ & $25 \%$ \\
\hline Rolo pé de carneiro & 4 & 79,3 & 112,2 & 151,7 & $44 \%$ & $53 \%$ & $72 \%$ \\
\hline Rolo de pneus & 1 & 371,3 & 453,8 & 852,9 & $6 \%$ & $8 \%$ & $10 \%$ \\
\hline Caminhão tanque & 1 & 424,7 & 588,8 & 793,8 & $10 \%$ & $15 \%$ & $25 \%$ \\
\hline Serventes & 3 & 88,9 & 144,3 & 178,9 & & & \\
\hline
\end{tabular}

Tabela 49 - Anormalidades e fatores encontrados na produção de CFT (continua)

\begin{tabular}{|c|c|}
\hline ANORMALIDADES & OBSERVAÇÕES \\
\hline Chuva & Paralisa a atividade no dia e no seguinte. \\
\hline Camada saturada & Paralisa a atividade no dia e pode paralisar no seguinte. \\
\hline \multirow[t]{2}{*}{ Falta de operador } & Paralisa a atividade no dia. \\
\hline & $\begin{array}{l}\text { Exemplos de ocorrência: } \\
\text { - O operador da esteira faltou, parado o dia todo. Faltou o } \\
\text { motorista do distribuidor de cimento, parado até as } 13 \mathrm{~h} \text {. }\end{array}$ \\
\hline \multirow{2}{*}{$\begin{array}{l}\text { Equipamento sem } \\
\text { manutenção }\end{array}$} & Paralisa a atividade no dia. \\
\hline & $\begin{array}{l}\text { Exemplos de ocorrência: } \\
\text { - } \quad \text { motoniveladora ficou em manutenção das } 8 \mathrm{~h} \text { às } 13 \mathrm{~h} \text {. } \\
\text { - } 2 \text { rolos compactadores fizeram manutenção, } 30 \text { min cada. }\end{array}$ \\
\hline FATORES DE CONTEÚDO & OBSERVAÇÕES \\
\hline Largura & Condicionante para formação da patrulha. \\
\hline Espessura & $\begin{array}{l}\text { Condicionante para formação da patrulha, determina o } \mathrm{n}^{\circ} \text { de } \\
\text { fechas para atingir o GC. }\end{array}$ \\
\hline \multirow[t]{2}{*}{ Proctor } & $\begin{array}{l}\text { Condicionante para formação da patrulha, determina o } n^{0} \text { de } \\
\text { fechas para atingir o GC. }\end{array}$ \\
\hline & $\begin{array}{l}\text { Exemplos de ocorrência: } \\
\text { - A patrulha aguardou a determinação do GC das } 8: 55 \text { às } 11 \mathrm{~h} \text {. } \\
\text { - Passou de } 16 \text { fechas para } 20 \text {. }\end{array}$ \\
\hline \multirow[t]{2}{*}{ Umidade } & Determina o $\mathrm{n}^{\circ}$ de fechas, condicionante para atingir o $\mathrm{GC}$ \\
\hline & $\begin{array}{l}\text { Exemplo de ocorrência: } \\
\begin{array}{l}\text { - Em função da umidade, o planejamento, para salvar o dia, se } \\
\text { resumiu em lançar o solo e nivelar. }\end{array} \\
\end{array}$ \\
\hline$\%$ de cimento & Determina a carga no caminhão distribuidor de cimento e ensaios. \\
\hline Tipo de solo & Determina o $\mathrm{n}^{\circ}$ de fechas, condicionante para atingir o GC. \\
\hline Reta, curva ou rampa & À princípio o grau de dificuldade é o mesmo. \\
\hline
\end{tabular}


Tabela 49 - Anormalidades e fatores encontrados na produção de CFT (conclusão)

\begin{tabular}{|c|c|}
\hline FATORES DE CONTEXTO & OBSERVAÇÕES \\
\hline № de frentes & $\begin{array}{l}\text { Quanto mais frentes mais horas operativas dos equipamentos } \\
\text { (evita ociosidade). }\end{array}$ \\
\hline \multirow[t]{2}{*}{ Mudança de equipamento } & Pode contribuir ou não na patrulha. \\
\hline & $\begin{array}{l}\text { Exemplos de ocorrência: } \\
\text { - Foi acrescentado mais um rolo compactador de } 12 \mathrm{t} . \\
\text { (melhorou a produtividade) } \\
\text { - Foi acrescentado mais um caminhão tanque (não fez efeito na } \\
\text { produtividade). }\end{array}$ \\
\hline Viga Benkelman & O serviço de terraplenagem é paralisado até sua execução. \\
\hline \multirow[t]{2}{*}{ Composição da patrulha } & $\begin{array}{l}\text { É essencial para o incremento da produtividade, determina o } \\
\text { número de fechas. }\end{array}$ \\
\hline & $\begin{array}{l}\text { Exemplos de ocorrência: } \\
\text { - O distribuidor de cimento fica maior parte do tempo } \\
\text { esperando. } \\
\text { - Embora tenham } 2 \text { tanques, eles não trabalharam ao mesmo } \\
\text { tempo. } \\
\text { O trator de esteiras trabalhou em outra frente cortando, } \\
\text { transportando o solo e nivelando a camada } \\
\text { - O rolo compactador tipo tandem não é o mais adequado para } \\
\text { selar as camadas. } \\
\text { - O caminhão tanque e a recicladora não trabalharam. }\end{array}$ \\
\hline \multirow[t]{2}{*}{ Frente junta ou separada } & $\begin{array}{l}\text { Contribui no incremento da produtividade se as frentes embora } \\
\text { separadas forem próximas (diminui a ociosidade). }\end{array}$ \\
\hline & $\begin{array}{l}\text { Exemplos de ocorrência: } \\
\text { - A patrulha atendeu a pista interna e externa e o ramo ao lado } \\
\text { (diminuiu a ociosidade). }\end{array}$ \\
\hline \multirow[t]{2}{*}{ Outros } & Interdependência entre tarefas. \\
\hline & $\begin{array}{l}\text { Exemplo de ocorrência: } \\
\text { - Não lançará o } 2^{\circ} \text { ref. Subleito enquanto o dreno não ficar } \\
\text { pronto. }\end{array}$ \\
\hline
\end{tabular}

A Tabela 50 apresenta a faixa de valores (produtividade variável) e a Tabela 51 apresenta a síntese das anormalidades e fatores relativos ao serviço de brita graduada simples - BGS.

Tabela 50 - Faixa de valores de BGS - esp. até $20 \mathrm{~cm}$

\begin{tabular}{|c|c|c|c|c|c|c|c|}
\hline \multirow{2}{*}{$\begin{array}{c}\text { Discriminação } \\
\text { Patrulha }\end{array}$} & \multirow[b]{2}{*}{ Qtde } & \multicolumn{3}{|c|}{ Produção Unitária ( $\mathrm{m}^{2} / \mathrm{Hserv}$ ) } & \multicolumn{3}{|c|}{ Hfuncionamento } \\
\hline & & $1^{\circ}$ Quartil & Mediana & 3 Quartil & 1ㅇ Quartil & Mediana & 3 Quartil \\
\hline Vibroacabadora & 1 & 193,5 & 200,7 & 207,8 & $26 \%$ & $27 \%$ & $27 \%$ \\
\hline Rolo de pneus & 2 & 136,2 & 143,3 & 169,6 & $24 \%$ & $25 \%$ & $26 \%$ \\
\hline Rolo tandem & 1 & 193,5 & 200,7 & 207,8 & $31 \%$ & $32 \%$ & $34 \%$ \\
\hline Caminhão tanque & 1 & 193,5 & 200,7 & 265,2 & $4 \%$ & $5 \%$ & $6 \%$ \\
\hline Serventes & 5 & 29,1 & 31,6 & 38,9 & & & \\
\hline
\end{tabular}


Tabela 51 - Anormalidades e fatores encontrados na produção de BGS (continua)

\begin{tabular}{|c|c|}
\hline ANORMALIDADES & OBSERVAÇÕES \\
\hline Chuva & Paralisa a atividade no dia e no seguinte. \\
\hline \multirow[t]{2}{*}{ Camada saturada } & Paralisa a atividade no dia e pode paralisar no seguinte. \\
\hline & $\begin{array}{l}\text { Exemplos de ocorrência: } \\
\text { - Choveu forte na madrugada, o trecho ficou sem acesso e a } \\
\text { BGS saturada (na usina). Sem atividades no BGS. }\end{array}$ \\
\hline Outras & $\begin{array}{l}\text { O rolo de pneus ficou parado até as } 12: 30 \text { por falta de } \\
\text { combustível. }\end{array}$ \\
\hline FATORES DE CONTEÚDO & OBSERVAÇÕES \\
\hline \multirow[t]{2}{*}{ Largura } & Condicionante para formação da patrulha. \\
\hline & $\begin{array}{l}\text { Exemplos de ocorrência: } \\
\text { - A vibroacabadora não trabalhou na capacidade máxima, sua } \\
\text { régua de lançamento ficou em } 4,30 \mathrm{~m} \text { e não em } 7 \mathrm{~m} \text {. }\end{array}$ \\
\hline Espessura & $\begin{array}{l}\text { Condicionante para formação da patrulha, determina o no de } \\
\text { fechas para atingir o GC. }\end{array}$ \\
\hline \multirow[t]{2}{*}{ Proctor } & $\begin{array}{l}\text { Condicionante para formação da patrulha, determina o no de } \\
\text { fechas para atingir o GC. }\end{array}$ \\
\hline & $\begin{array}{l}\text { Exemplos de ocorrência: } \\
\text { - O plano de amostragem para determinação do GC influencia } \\
\text { no incremento da produtividade. }\end{array}$ \\
\hline \multirow[t]{2}{*}{ Umidade } & $\begin{array}{l}\text { Determina o no de fechas, condicionante para atingir o GC e para } \\
\text { execução dos serviços. }\end{array}$ \\
\hline & $\begin{array}{l}\text { Exemplo de ocorrência: } \\
\text { - BGS saturada na usina - sem atividades. }\end{array}$ \\
\hline Reta, curva ou rampa & À princípio o grau de dificuldade é o mesmo. \\
\hline FATORES DE CONTEXTO & OBSERVAÇÕES \\
\hline № de frentes & $\begin{array}{l}\text { Quanto mais frentes mais horas operativas dos equipamentos } \\
\text { (evita ociosidade). }\end{array}$ \\
\hline \multirow[t]{2}{*}{ Mudança de equipamento } & Pode contribuir ou não na patrulha. \\
\hline & $\begin{array}{l}\text { Exemplos de ocorrência: } \\
\text { - Na parte da tarde chegou outro rolo de pneus. (melhorou a } \\
\text { - } \quad \text { Acrodutividade). } \\
\text { produtividade). }\end{array}$ \\
\hline Viga Benkelman & O serviço de BGS é paralisado até sua execução. \\
\hline \multirow[t]{2}{*}{ Composição da patrulha } & $\begin{array}{l}\text { É essencial para o incremento da produtividade, determina o } \\
\text { número de fechas. }\end{array}$ \\
\hline & $\begin{array}{l}\text { Exemplos de ocorrência: } \\
\text { - Cada equipamento tem uma função específica: } \\
\text { vibroacabadora lança e nivela a BGS + tandem entra para } \\
\text { acomodar o material + rolo liso entra para compactar o } \\
\text { material + tandem entra para remover as marcas de pneus. No } \\
\text { caso do rolo de pneus, o peso e a calibração dos pneus } \\
\text { interfere diretamente na compactação. }\end{array}$ \\
\hline \multirow[t]{2}{*}{ Composição da equipe } & É essencial para o incremento da produtividade. \\
\hline & $\begin{array}{l}\text { Exemplos de ocorrência: } \\
\text { A equipe (operadores e serventes) não está, totalmente, } \\
\text { treinada. Tem muitos conflitos entre as experiências passadas } \\
\text { e a necessidade da obra (os operadores fazem diferente ao } \\
\text { que foi acordado na ausência do coordenador). }\end{array}$ \\
\hline
\end{tabular}


Tabela 51 - Anormalidades e fatores encontrados na produção de BGS (conclusão)

\begin{tabular}{|c|c|}
\hline \multirow[t]{2}{*}{ Produção de BGS na usina } & É essencial para o incremento da produtividade. \\
\hline & $\begin{array}{l}\text { Exemplos de ocorrência: } \\
\text { - A usina não trabalhou na capacidade máxima (era o início das } \\
\text { atividades, a pá carregadora não é suficiente para manter os } \\
\text { silos carregados o tempo todo e o número de caminhões foi } \\
\text { insuficiente). } \\
\text { - A vibroacabadora ficou paralisada em alguns momentos por } \\
\text { falta de alimentação. }\end{array}$ \\
\hline \multirow[t]{2}{*}{ Quantidade de caminhões } & É essencial para o incremento da produtividade. \\
\hline & $\begin{array}{l}\text { Exemplos de ocorrência: } \\
\text { - A vibroacabadora não trabalhou na capacidade máxima, sua } \\
\text { régua de lançamento ficou em } 4,30 \text { m e não em } 7 \mathrm{~m} \text { (o que } \\
\text { exigiria mais caminhões na alimentação). } \\
\text { - A vibroacabadora ficou paralisada em alguns momentos por } \\
\text { falta de alimentação. }\end{array}$ \\
\hline \multirow[t]{2}{*}{ Frente junta ou separada } & $\begin{array}{l}\text { Contribui no incremento da produtividade se as frentes forem } \\
\text { juntas (diminui a ociosidade). }\end{array}$ \\
\hline & $\begin{array}{l}\text { Exemplos de ocorrência: } \\
\text { - A patrulha atendeu duas frentes em um mesma pista (diminuiu } \\
\text { a ociosidade) }\end{array}$ \\
\hline \multirow[t]{2}{*}{ Outros } & Interdependência entre tarefas. \\
\hline & $\begin{array}{l}\text { Exemplo de ocorrência: } \\
\text { - Não lançará o BGS, enquanto uma travessia não ficar pronta. }\end{array}$ \\
\hline
\end{tabular}

A Tabela 52 apresenta a faixa de valores (produtividade variável) e a Tabela 53 apresenta a síntese das anormalidades e fatores relativos ao serviço de brita graduada tratada com cimento - BGTC.

Tabela 52 - Faixa de valores de BGTC - esp. até $20 \mathrm{~cm}$

\begin{tabular}{|c|c|c|c|c|c|c|c|}
\hline \multirow{2}{*}{$\begin{array}{c}\text { Discriminação } \\
\text { Patrulha }\end{array}$} & \multirow[b]{2}{*}{ Qtde } & \multicolumn{3}{|c|}{ Produção Unitária (m²/Hserv) } & \multicolumn{3}{|c|}{ Hfuncionamento } \\
\hline & & 1ㅇ Quartil & Mediana & 3 Quartil & 1Q Quartil & Mediana & 3 Quartil \\
\hline Vibroacabadora & 1 & 109,7 & 116,7 & 123,7 & $26 \%$ & $27 \%$ & $27 \%$ \\
\hline Rolo de pneus & 1 & 142,3 & 182,0 & 221,7 & $24 \%$ & $25 \%$ & $26 \%$ \\
\hline Rolo tandem & 1 & 142,3 & 182,0 & 221,7 & $31 \%$ & $32 \%$ & $34 \%$ \\
\hline Caminhão tanque & 1 & 142,3 & 182,0 & 221,7 & $4 \%$ & $5 \%$ & $6 \%$ \\
\hline Serventes & 6 & 23,7 & 30,3 & 36,9 & & & \\
\hline
\end{tabular}

As diferenças de produção unitária (PU) da vibroacabadora para os serviços de BGS (Tabela 50) e BGTC (Tabela 52) são justificadas como segue: são duas equipes diferentes executando os serviços e no caso da BGS a equipe de trabalho (empresa terceirizada pelo construtor) se apresentou em melhores condições de executar o serviço do que no caso da BGTC (equipe do construtor). 
Tabela 53 - Anormalidades e fatores encontrados na produção de BGTC (continua)

\begin{tabular}{|c|c|}
\hline ANORMALIDADES & OBSERVAÇÕES \\
\hline Chuva & Paralisa a atividade no dia e no seguinte. \\
\hline \multirow[t]{2}{*}{ Camada saturada } & Paralisa a atividade no dia e pode paralisar no seguinte. \\
\hline & $\begin{array}{l}\text { Exemplos de ocorrência: } \\
\text { - Choveu forte na madrugada, o trecho ficou sem acesso e a } \\
\text { BGTC saturada (na usina). Sem atividades no BGTC. }\end{array}$ \\
\hline FATORES DE CONTEÚDO & OBSERVAÇÕES \\
\hline \multirow[t]{2}{*}{ Largura } & Condicionante para formação da patrulha \\
\hline & $\begin{array}{l}\begin{array}{l}\text { Exemplos de ocorrência: } \\
\text { - A vibroacabadora não trabalhou na capacidade máxima, sua } \\
\text { régua de lançamento ficou em } 4,30 \mathrm{~m} \text { e não em } 7 \mathrm{~m} \text {. }\end{array} \\
\end{array}$ \\
\hline Espessura & $\begin{array}{l}\text { Condicionante para formação da patrulha, determina o no de } \\
\text { fechas para atingir o GC. }\end{array}$ \\
\hline \multirow[t]{2}{*}{ Proctor } & $\begin{array}{l}\text { Condicionante para formação da patrulha, determina o no de } \\
\text { fechas para atingir o GC. }\end{array}$ \\
\hline & $\begin{array}{l}\text { Exemplos de ocorrência: } \\
\text { - O plano de amostragem para determinação do GC influencia } \\
\text { no incremento da produtividade. }\end{array}$ \\
\hline Umidade & $\begin{array}{l}\text { Determina o no de fechas, condicionante para atingir o GC e para } \\
\text { execução dos serviços. }\end{array}$ \\
\hline Reta, curva ou rampa & À princípio o grau de dificuldade é o mesmo. \\
\hline FATORES DE CONTEXTO & OBSERVAÇÕES \\
\hline № de frentes & $\begin{array}{l}\text { Quanto mais frentes mais horas operativas dos equipamentos } \\
\text { (evita ociosidade). }\end{array}$ \\
\hline \multirow[t]{2}{*}{ Mudança de equipamento } & Pode contribuir ou não na patrulha. \\
\hline & $\begin{array}{l}\text { Exemplos de ocorrência: } \\
\text { - Na parte da tarde chegou outro rolo de pneus. (melhorou a } \\
\text { produtividade). } \\
\text { - Acrescentou uma vibroacabadora (não fez efeito na } \\
\text { produtividade). }\end{array}$ \\
\hline Viga Benkelman & O serviço de BGTC é paralisado até sua execução. \\
\hline \multirow[t]{2}{*}{ Composição da patrulha } & $\begin{array}{l}\text { É essencial para o incremento da produtividade, determina o } \\
\text { número de fechas. }\end{array}$ \\
\hline & $\begin{array}{l}\text { Exemplos de ocorrência: } \\
\text { - } \quad \text { Cada equipamento tem uma função específica. } \\
\quad \text { Vibroacabadora + tandem + rolo de pneus }\end{array}$ \\
\hline \multirow[t]{2}{*}{ Composição da equipe } & É essencial para o incremento da produtividade. \\
\hline & $\begin{array}{l}\text { Exemplos de ocorrência: } \\
\text { - A equipe (operadores e serventes) não está, totalmente, } \\
\text { treinada. Tem muitos conflitos entre as experiências passadas } \\
\text { e a necessidade da obra (os operadores fazem diferente ao } \\
\text { acordado quando o encarregado não está presente). }\end{array}$ \\
\hline \multirow[t]{2}{*}{ Produção de BGTC na usina } & É essencial para o incremento da produtividade. \\
\hline & $\begin{array}{l}\text { Exemplos de ocorrência: } \\
\text { - A usina não trabalhou na capacidade máxima (era o início das } \\
\text { atividades, a pá carregadora não é suficiente para manter os } \\
\text { silos carregados o tempo todo e o número de caminhões foi } \\
\text { insuficiente). } \\
\text { - A vibroacabadora ficou paralisada em alguns momentos por } \\
\text { falta de alimentação. }\end{array}$ \\
\hline
\end{tabular}


Tabela 53 - Anormalidades e fatores encontrados na produção de BGTC (conclusão)

\begin{tabular}{|c|c|}
\hline \multirow[t]{2}{*}{ Quantidade de caminhões } & É essencial para o incremento da produtividade. \\
\hline & $\begin{array}{l}\text { Exemplos de ocorrência: } \\
\text { - A vibroacabadora não trabalhou na capacidade máxima, sua } \\
\text { régua de lançamento ficou em } 4,30 \mathrm{~m} \text { e não em } 7 \mathrm{~m} \text { (o que } \\
\text { exigiria mais caminhões na alimentação). } \\
\text { - A vibroacabadora ficou paralisada em alguns momentos por } \\
\text { falta de alimentação. }\end{array}$ \\
\hline \multirow[t]{2}{*}{ Frente junta ou separada } & $\begin{array}{l}\text { Contribui no incremento da produtividade se as frentes forem } \\
\text { juntas (diminui a ociosidade). }\end{array}$ \\
\hline & $\begin{array}{l}\text { Exemplos de ocorrência: } \\
\text { - A patrulha atendeu duas frentes em um mesma pista } \\
\text { (diminuiu a ociosidade) }\end{array}$ \\
\hline \multirow[t]{2}{*}{ Outros } & Interdependência entre tarefas. \\
\hline & $\begin{array}{l}\text { Exemplos de ocorrência: } \\
\text { - Não lançará o BGTC, enquanto a imprimação da camada } \\
\text { anterior não estiver curada. } \\
\text { Equipe parada das 8h às 10:35. A fiscalização detectou os } \\
\text { seguintes problemas: } 1 \text {. foi feita junta longitudinal (não é } \\
\text { permitido); 2. terminaram de compactar às } 18 \mathrm{~h} \text {, não } \\
\text { verificaram o GC e não imprimaram para cura (não admitido); } \\
\text { 3. hoje, pela manhã, o laboratorista teve dificuldades para } \\
\text { verificar o GC (ensaio de areia - virou "rocha"); } 4 \text {. As bordas } \\
\text { ficaram esbranquiçadas, terá que retirar uma faixa de } 30 \mathrm{~cm} \text {, } \\
\text { umedecer, para depois imprimar. Para o lançamento das } \\
\text { atividades do dia, ficaram discutindo tudo que foi feito de } \\
\text { errado e preparando para lançamento (já havia chegado } 6 \\
\text { caminhões, como o tempo de } \\
\text { transporte+lançamento+compactação do BGTC é de } 3 \mathrm{~h}, \text { o } \\
\text { primeiro caminhão quase foi desprezado) os demais foram } \\
\text { lançados no limite. }\end{array}$ \\
\hline
\end{tabular}

A Tabela 54 apresenta a faixa de valores (produtividade variável) e a Tabela 55 apresenta a síntese das anormalidades e fatores relativos ao serviço de binder.

Tabela 54 - Faixa de valores de binder - esp. até $5 \mathrm{~cm}$

\begin{tabular}{|c|c|c|c|c|c|c|c|}
\hline \multirow{2}{*}{$\begin{array}{c}\text { Discriminação } \\
\text { Patrulha }\end{array}$} & \multirow[b]{2}{*}{ Qtde } & \multicolumn{3}{|c|}{ Produção Unitária ( $\left.\mathrm{m}^{2} / \mathrm{Hserv}\right)$} & \multicolumn{3}{|c|}{ Hfuncionamento } \\
\hline & & 1Quartil & Mediana & 3 Quartil & 10 Quartil & Mediana & 3 Quartil \\
\hline Vibroacabadora & 1 & 128,3 & 185,6 & 283,6 & $12 \%$ & $16 \%$ & $24 \%$ \\
\hline Rolo de pneus & 2 & 528,0 & 684,0 & 738,0 & $14 \%$ & $16 \%$ & $35 \%$ \\
\hline Rolo tandem & 1 & 684,0 & 960,0 & 1368,0 & $12 \%$ & $14 \%$ & $25 \%$ \\
\hline $\begin{array}{l}\text { Caminhão } \\
\text { espargidor }\end{array}$ & 1 & 1322,7 & 1346,0 & 1389,3 & $18 \%$ & $18 \%$ & $18 \%$ \\
\hline $\begin{array}{l}\text { Trator agrícola mais } \\
\text { compressor }\end{array}$ & 1 & 960,0 & 1368,0 & 1368,0 & $13 \%$ & $13 \%$ & $13 \%$ \\
\hline Caminhão tanque & 1 & 684,0 & 960,0 & 1368,0 & $8 \%$ & $9 \%$ & $11 \%$ \\
\hline Serventes & 5 & 83,1 & 97,7 & 126,2 & & & \\
\hline
\end{tabular}


Tabela 55 - Anormalidades e fatores encontrados na produção de binder (continua)

\begin{tabular}{|c|c|}
\hline ANORMALIDADES & OBSERVAÇÕES \\
\hline Chuva & Paralisa a atividade no dia e no seguinte. \\
\hline \multirow{2}{*}{ Camada saturada } & Paralisa a atividade no dia e pode paralisar no seguinte. \\
\hline & $\begin{array}{l}\text { Exemplo de ocorrência: } \\
\text { - Choveu forte na madrugada, o trecho ficou sem acesso. Sem } \\
\text { atividades. }\end{array}$ \\
\hline Outras & $\begin{array}{l}\text { - Logo no início dos trabalhos a acabadora quebrou (equipe } \\
\text { aguardando o conserto). } \\
\text { - Execução de frezagem nas estacas } 1081 \text { a } 1083,1090 \text { a } \\
\text { 1092, } 1097 \text { a } 1102,1085 \text { a } 10861^{\text {a }} \text { faixa - motivo: trincas no } \\
\text { pavimento. }\end{array}$ \\
\hline FATORES DE CONTEÚDO & OBSERVAÇÕES \\
\hline \multirow[t]{2}{*}{ Largura } & Condicionante para formação da patrulha. \\
\hline & $\begin{array}{l}\text { Exemplo de ocorrência: } \\
\text { - A vibroacabadora não trabalhou na capacidade máxima, sua } \\
\text { régua de lançamento ficou em } 4,30 \mathrm{~m} \text { e não em } 7 \mathrm{~m} \text {. }\end{array}$ \\
\hline Espessura & $\begin{array}{l}\text { Condicionante para formação da patrulha, determina o } n^{\circ} \text { de } \\
\text { fechas para atingir o GC. }\end{array}$ \\
\hline \multirow[t]{2}{*}{ Proctor } & $\begin{array}{l}\text { Condicionante para formação da patrulha, determina o } \mathrm{n}^{\circ} \text { de } \\
\text { fechas para atingir o GC. }\end{array}$ \\
\hline & $\begin{array}{l}\text { Exemplo de ocorrência: } \\
\text { - O plano de amostragem para determinação do GC influencia } \\
\text { no incremento da produtividade. }\end{array}$ \\
\hline Reta, curva ou rampa & À princípio o grau de dificuldade é o mesmo. \\
\hline \multirow{2}{*}{$\begin{array}{l}\text { Imprimação ou pintura de } \\
\text { ligação }\end{array}$} & Condicionante no incremento da produtividade. \\
\hline & $\begin{array}{l}\text { Exemplo de ocorrência: } \\
\text { - } \quad \text { Aguardando cura de } 48 \mathrm{~h} \text { para lançamento do Binder. }\end{array}$ \\
\hline \multirow{2}{*}{ Temperatura } & Condicionante para a execução dos serviços. \\
\hline & $\begin{array}{l}\text { Exemplos de ocorrência: } \\
\text { - A acabadora não pôde lançar um comprimento muito longo } \\
\text { devido a temperatura da massa. A massa tem que ser } \\
\text { lançada na acabadora nas temperaturas de } 140^{\circ} \text { a } 177^{\circ}, \\
\text { sendo que o ideal é de } 140^{\circ} \text { a } 165^{\circ} \text {. O rolo de pneus trabalha } \\
\text { com a temperatura um pouco abaixo e o tandem deve } \\
\text { trabalhar na temperatura entre } 60^{\circ} \text { a } 80^{\circ}, \text { sendo que o ideal é } \\
60^{\circ} \text {. A usina liberou material na temperatura de } 200^{\circ} \text {, o } \\
\text { material foi rejeitado pela fiscalização, gerando impasse com } \\
\text { a empreiteira. }\end{array}$ \\
\hline FATORES DE CONTEXTO & OBSERVAÇÕES \\
\hline \multirow[t]{2}{*}{ № de frentes } & $\begin{array}{l}\text { Quanto mais frentes mais horas operativas dos equipamentos } \\
\text { (evita ociosidade). }\end{array}$ \\
\hline & $\begin{array}{l}\text { Exemplo de ocorrência: } \\
\text { - A equipe da empreiteira está sem frente de serviço. }\end{array}$ \\
\hline \multirow[t]{2}{*}{ Mudança de equipamento } & Pode contribuir ou não na eficiência do serviço. \\
\hline & $\begin{array}{l}\text { Exemplos de ocorrência: } \\
\text { - Na parte da tarde chegou outro rolo de pneus (melhorou a } \\
\text { produtividade). } \\
\text { - Acrescentou uma vibroacabadora (não fez efeito na } \\
\text { produtividade). }\end{array}$ \\
\hline Viga Benkelman & ado até sua execução. \\
\hline
\end{tabular}


Tabela 55 - Anormalidades e fatores encontrados na produção de binder (continua)

\begin{tabular}{|c|c|}
\hline \multirow[t]{2}{*}{ Composição da patrulha } & $\begin{array}{l}\text { É essencial para o incremento da produtividade, determina o } \\
\text { número de fechas. }\end{array}$ \\
\hline & $\begin{array}{l}\text { Exemplos de ocorrência: } \\
\text { - Cada equipamento tem uma função específica. Exemplo: } \\
\text { Vibroacabadora + tandem + rolo de pneus. Após a acabadora } \\
\text { lançar a massa, vem o tandem (acomodar o material), depois } \\
\text { o rolo de pneus (para compactar - usa } 8 \text { fechas), e em } \\
\text { seguida volta o tandem para tirar as marcas do rolo de pneus } \\
\text { (2 fechas). O ideal é utilizar } 2 \text { rolos de pneus }+1 \text { tandem para } \\
\text { cada acabadora. A frente tem utilizado } 1 \text { rolo de pneus. Como } \\
\text { só tem um rolo de pneus, a acabadora não pode lançar um } \\
\text { comprimento muito longo, devido a temperatura da massa. } \\
\text { Estão trabalhando com } 1 \text { rolo pneus } 4 \times 5 \text { e } 1 \text { rolo } 3 \times 4 \text { o ideal é } \\
\text { usar os } 2 \text { rolos com o mesmo peso e tipo. }\end{array}$ \\
\hline \multirow[t]{2}{*}{ Composição da equipe } & É essencial para o incremento da produtividade \\
\hline & $\begin{array}{l}\text { Exemplos de ocorrência: } \\
\text { - Segundo relato dos encarregados da empreiteira e da } \\
\text { fiscalização, a falta de preparo/treinamento de sua mão de } \\
\text { obra de pavimentação (operadores e serventes) tem sido um } \\
\text { dos maiores problemas no trecho. } \\
\text { - A falta de treinamento tem gerado uma grande discordância } \\
\text { entre a fiscalização e empreiteiros. } \\
\text { - No início definiram o lançamento em } 3 \text { faixas. Depois } \\
\text { mudaram para } 2 \text { faixas, mas perceberam que o sensor da } \\
\text { acabadora não lê o cabo guia nesta largura. Ficaram } \\
\text { discutindo/parados (demoraram das } 8 \text { às 9:35 para decidirem } \\
\text { como iniciariam os trabalhos). Haviam } 4 \text { caminhões } \\
\text { esperando, que chegou no trecho às } 8: 30 \text {. A equipe teve o dia } \\
\text { anterior para se preparar e hoje o início foi muito confuso. } \\
\text { Estão fazendo tentativas. }\end{array}$ \\
\hline \multirow[t]{2}{*}{$\begin{array}{l}\text { Produção de BINDER na } \\
\text { usina }\end{array}$} & É essencial para o incremento da produtividade \\
\hline & $\begin{array}{l}\text { Exemplos de ocorrência: } \\
\text { - A usina não trabalhou na capacidade máxima. A usina está } \\
\text { com dificuldades em controlar a temperatura. A temperatura } \\
\text { da massa é verificada na usina, no caminhão (quando chega } \\
\text { na acabadora) e após lançada. Um termômetro com haste é } \\
\text { utilizado. } \\
\text { - A pouca produção na usina e a menor quantidade de } \\
\text { caminhões impede uma melhor produtividade. } \\
\text { A vibroacabadora ficou paralisada em alguns momentos por } \\
\text { falta de alimentação. }\end{array}$ \\
\hline \multirow[t]{2}{*}{ Quantidade de caminhões } & É essencial para o incremento da produtividade \\
\hline & $\begin{array}{l}\text { Exemplos de ocorrência: } \\
\text { - A vibroacabadora não trabalhou na capacidade máxima, sua } \\
\text { régua de lançamento ficou em } 4,30 \mathrm{~m} \text { e não em } 7 \mathrm{~m} \text { (o que } \\
\text { exigiria mais caminhões na alimentação). } \\
\text { - A vibroacabadora ficou paralisada em alguns momentos por } \\
\text { falta de alimentação. }\end{array}$ \\
\hline
\end{tabular}


Tabela 55 - Anormalidades e fatores encontrados na produção de binder (conclusão)

Frente junta ou separada
Contribui no incremento da produtividade se as frentes forem juntas (diminui a ociosidade).

\section{Exemplo de ocorrências:}

- A patrulha atendeu duas frentes em uma mesma pista (alguns equipamentos).

- A equipe do consórcio que estava no ramo A-PI se deslocou para PI-A. A acabadora foi transportada por uma carreta. O deslocamento/preparativos durou o dia todo. Pretende-se lançar massa asfáltica amanhã.

Outros

Interdependência entre tarefas.
Exemplos de ocorrência:

- Não lançará o binder, enquanto a imprimação da camada anterior não estiver curada.

- Lançou binder entre as estacas 4036 -4019 e 1122-1120. Parou por falta de frente (à partir da estaca 4036 estava imprimando, o que requer $48 \mathrm{~h}$ de espera).

- Equipe parada das 8h às 10:35. A fiscalização detectou os seguintes problemas: 1 . foi feita junta longitudinal (não é permitido); 2. terminaram de compactar às $18 \mathrm{~h}$, não verificaram o GC e não imprimaram para cura (não admitido); 3. hoje, pela manhã, o laboratorista teve dificuldades para verificar o GC (ensaio de areia - virou "rocha"); 4. As bordas ficaram esbranquiçadas, terá que retirar uma faixa de $30 \mathrm{~cm}$, umedecer, para depois imprimar. Para o lançamento das atividades do dia, ficaram discutindo tudo que foi feito de errado e preparando para lançamento (já havia chegado 6 caminhões, como o tempo de transporte+lançamento+compactação do binder é de 3h, o primeiro caminhão quase foi desprezado) os demais foram lançados no limite.

A Tabela 56 apresenta a faixa de valores (produtividade variável) e a Tabela 57 apresenta a síntese das anormalidades e fatores relativos aos serviços de imprimação e pintura de ligação.

Tabela 56 - Faixas de valores de imprimação e pintura de ligação

\begin{tabular}{|c|c|c|c|c|c|c|c|}
\hline Imprimação & \multirow[b]{2}{*}{ Qtde } & \multicolumn{3}{|c|}{ Produção Unitária (m²/Hserv) } & \multicolumn{3}{|c|}{ Hfuncionamento } \\
\hline Patrulha & & $1^{\circ}$ Quartil & Mediana & 3 Quartil & $1^{\circ}$ Quartil & Mediana & 3ํo Quartil \\
\hline $\begin{array}{l}\text { Caminhão } \\
\text { espargidor }\end{array}$ & 1 & 215,0 & 243,7 & 315,3 & & $6 \%$ & \\
\hline Auxiliar & 1 & 215,0 & 243,7 & 315,3 & & & \\
\hline Pintura de Ligação & \multirow[t]{2}{*}{ Qtde } & \multicolumn{3}{|c|}{ Produção Unitária (m²/Hserv) } & \multicolumn{3}{|c|}{ Hfuncionamento } \\
\hline Patrulha & & 1ํ Quartil & Mediana & 3ํ Quartil & 1ㅇ Quartil & Mediana & 3 Quartil \\
\hline $\begin{array}{l}\text { Caminhão } \\
\text { espargidor }\end{array}$ & 1 & 215,0 & 243,7 & 315,3 & & $6 \%$ & \\
\hline Auxiliar & 1 & 215,0 & 243,7 & 315,3 & & & \\
\hline
\end{tabular}


Tabela 57 - Anormalidades e fatores encontrados na produção de imprimação e pintura de ligação

\begin{tabular}{l|l}
\hline ANORMALIDADES & OBSERVAÇÕES \\
\hline Chuva & Paralisa a atividade no dia e no seguinte. \\
\hline Falta de operador & Equipamento parado devido à falta do motorista. \\
\hline Falta de combustível & Equipamento parado devido à falta de combustível. \\
\hline FATORES DE CONTEXTO & OBSERVAÇÕES \\
\hline $\begin{array}{l}\text { Falta de planejamento das } \\
\text { atividades }\end{array}$ & Equipe parada devido à falta de planejamento das atividades. \\
\hline Velocidade & Velocidade de lançamento compatível com a camada. \\
\hline Auxiliar treinado & Facilita a execução dos serviços. \\
\hline Operador treinado & Garante a qualidade dos serviços. \\
\hline Eficiência dos equipamentos & Relacionado às horas em funcionamento do equipamento. \\
\hline Atividades preliminares & Atividades preliminares prontas, exemplo: base a ser revestida. \\
\hline Sequência & $\begin{array}{l}\text { Sequência entre as atividades proporciona incremento na } \\
\text { produtividade. }\end{array}$ \\
\hline
\end{tabular}

\subsection{Reflexões do Capítulo 6}

Este capítulo apresentou dois estudos de caso: Aeroporto Internacional de Guarulhos; e o Rodoanel Mário Covas. Partiu-se do método de coleta para o registro dos dados coletados. Na sequência o processamento dos dados foi efetuado, resultando, nas faixas de valores (produtividade variável) acompanhadas das anormalidades e dos fatores (de conteúdo e de contexto).

Em relação ao estudo de caso do Aeroporto Internacional de Guarulhos é importante salientar:

a) trata-se de uma obra diferenciada, quando comparada, principalmente, à obras rodoviárias;

b) fatores de conteúdo (por exemplo: os de projetos) e fatores de contexto (por exemplo: execução da obra com o aeroporto em funcionamento) causam uma grande variação da RUP diária.

No mesmo sentido, em relação ao estudo de caso do Rodoanel Mário Covas é importante salientar:

a) a quantidade de frentes de trabalho em execução ao mesmo tempo dificulta a alocação de equipamentos e o seu devido acompanhamento;

b) mesmo que a equipe de execução da camada de terraplenagem e/ou da pavimentação asfáltica seja eficiente, a conclusão dos trabalhos somente se dará com a sincronia da equipe de execução com a equipe de laboratórios (que 
aprova ou rejeita a camada) e neste caso, definir os critérios de medição é um desafio;

c) percebeu que equipes de trabalho diferentes executando o mesmo serviço e/ou serviços similares podem produzir indicadores de produtividade diferentes, como foi o caso da BGS e BGTC.

O processo de acompanhamento dos dois estudos de caso gerou um grande aprendizado no tocante a identificar os fatores e anormalidades de cada etapa dos serviços de terraplenagem e pavimentação asfáltica. Esta aquisição de conhecimento foi extremamente importante para o sucesso do trabalho, haja vista que possibilitou o emprego e as correções da metodologia proposta.

Estas informações (com base no método experimental) subsidiarão a proposição do método em desenvolvimento. 


\section{INDICADORES DOS MANUAIS CONFORME NOVA PROPOSTA DE ABORDAGEM}

Este capítulo visa apresentar os indicadores dos manuais conforme nova abordagem para as composições (apresentada no Capítulo 5).

O resultado da compilação dos manuais é originado do sistema apresentado na Figura 52.

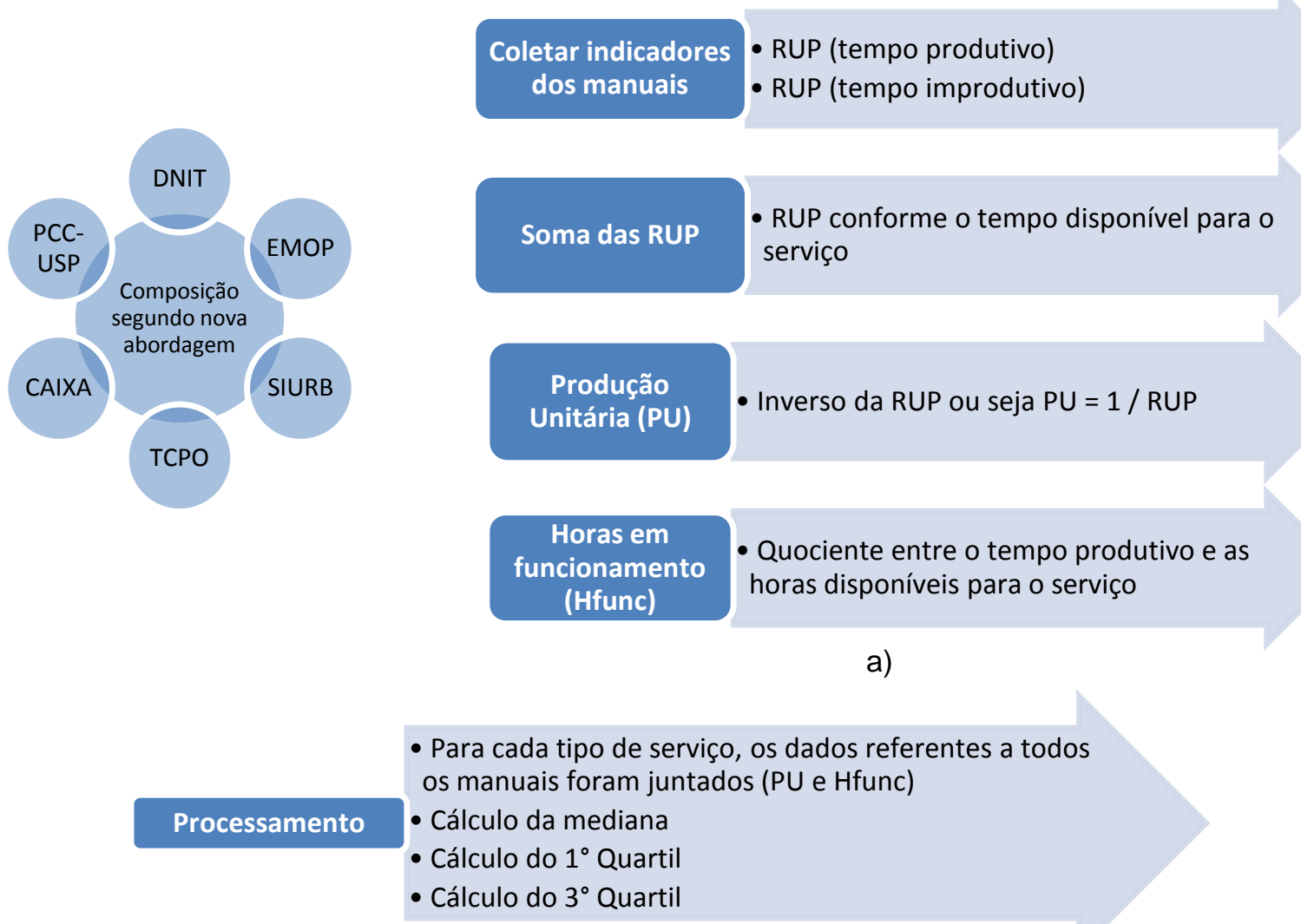

b)

Figura 52 - Compilação dos manuais conforme nova abordagem

Os passos trilhados para esta compilação são apresentados a seguir.

a) Os manuais em geral trabalham com a RUP dos equipamentos como sendo a soma de uma RUP durante o tempo produtivo com a do tempo improdutivo. Para tornar estas informações coerentes com a apresentação da eficiência do equipamento em termos da PU, foram necessárias transformações baseadas nos seguintes aspectos: 
- a soma das RUP para os tempos produtivo e improdutivo fornece a RUP no tempo disponível,

- o inverso desta RUP leva à PU no tempo disponível,

- a comparação da RUP no tempo produtivo com a relativa ao tempo disponível nos leva à \% de tempo em funcionamento do equipamento. Estas operações foram feitas para todos os manuais.

b) Posteriormente, para se ter um conjunto de informações representativo dos manuais, juntaram-se os dados referentes a todos os manuais conforme o tipo de serviço e, para este, calcularam-se os valores mediano, $1^{\circ}$ e $3^{\circ}$ quartis para, com isto, apresentar a faixa de valores de PU a ser adotado neste trabalho como representando o conhecimento existente nos manuais de orçamentação. Procedeu-se analogamente também para registrar a faixa de tempos produtivos para cada caso.

\subsection{Listagem de Tabelas Conforme o Manual}

A listagem de tabelas e os dados compilados de cada manual, referentes aos serviços de terraplenagem e pavimentação asfáltica, estão contidos no Apêndice E e no Apêndice F.

Conforme a lista de estudo, os serviços levantados são apresentados a seguir:
a) escavação de material de $1^{\text {a }}$ categoria com trator de esteiras $\left(\mathrm{m}^{3}\right)$;
b) escavação de material de $1^{\text {a }}$ categoria com escavadeira hidráulica $\left(\mathrm{m}^{3}\right)$;
c) compactação de aterro - espessura até $30 \mathrm{~cm}\left(\mathrm{~m}^{2}\right)$;
d) base de solo cimento com mistura na pista - esp. até $20 \mathrm{~cm}\left(\mathrm{~m}^{2}\right)$;
e) brita graduada simples - BGS com distribuidor de agregados - esp. até $20 \mathrm{~cm}$ $\left(\mathrm{m}^{2}\right)$;
f) brita graduada simples - BGS com vibroacabadora - esp. até $20 \mathrm{~cm}\left(\mathrm{~m}^{2}\right)$;
g) brita graduada tratada com cimento - BGTC - esp. até $20 \mathrm{~cm}\left(\mathrm{~m}^{2}\right)$;
h) concreto betuminoso usinado a quente - capa ou binder - esp. até $5 \mathrm{~cm}\left(\mathrm{~m}^{2}\right)$;
i) imprimação $\left(\mathrm{m}^{2}\right)$;
j) pintura de ligação $\left(\mathrm{m}^{2}\right)$. 


\subsection{Composições Orçamentárias Conforme Nova Proposta de Abordagem}

Conforme o Capítulo 5, a produtividade dos equipamentos e da mão de obra pode apresentar variações segundo faixas de amplitude bastante grande. Conceitualmente, o Modelo dos Fatores permitiria buscar uma resposta à questão. $A$ proposta de abordagem para as composições é aplicar os conceitos de Produtividade Variável, ou seja, apresentar os indicadores relativos aos recursos demandados para se fazer uma unidade de produto, por meio da postura: em lugar de apenas citar um valor médio histórico, inclui-se a apresentação de uma faixa de valores (indicando-se os valores $1^{\circ}$ Quartil, mediano e $3^{\circ}$ Quartil) para o consumo de mão de obra e equipamentos. Os momentos de incidência das horas de equipamentos utilizados são: as horas disponíveis para o serviço (Hserv.); e as horas em funcionamento (Hfunc ou Hfuncionamento).

\subsubsection{Escavação e carga de material de $1^{\text {a }}$ Categoria}

Este serviço foi dividido em dois:

a) Escavação e carga de material de $1^{\text {a }}$ categoria utilizando trator de esteiras e carregadeira de pneus (Tabela 58);

b) Escavação e carga de material de $1^{\underline{a}}$ categoria utilizando escavadeira hidráulica (Tabela 59).

Tabela 58 - Escavação e carga de material de $1^{\underline{a}}$ categoria: com trator de esteiras (resumo dos manuais)

\begin{tabular}{l|c|c|c|c|c|c}
\hline \multirow{2}{*}{ Discriminação } & \multicolumn{3}{|c|}{ Produção Unitária (m³/Hserv) } & \multicolumn{4}{c}{ Hfuncionamento } \\
\cline { 2 - 7 } & $1^{\circ}$ Quartil & Mediana & $3^{\circ}$ Quartil & $1^{\circ}$ Quartil & Mediana & $3^{\circ}$ Quartil \\
\hline $\begin{array}{l}\text { Trator de esteiras, com } \\
\text { lâmina }\end{array}$ & 172,4 & 172,4 & 192,0 & $94 \%$ & $95 \%$ & $96 \%$ \\
\hline $\begin{array}{l}\text { Carregadeira de pneus } \\
\left(3,1 \mathrm{~m}^{3}\right)\end{array}$ & 112,4 & 112,4 & 202,1 & $96 \%$ & $96 \%$ & $97 \%$ \\
\hline Servente & 69,5 & 71,4 & 71,4 & & & \\
\hline
\end{tabular}


Tabela 59 - Escavação e carga de material de $1^{\text {a }}$ categoria: com escavadeira hidráulica (resumo dos manuais)

\begin{tabular}{l|c|c|c|c|c|c}
\hline \multirow{2}{*}{ Discriminação } & \multicolumn{2}{|c|}{ Produção Unitária (m³/Hserv) } & \multicolumn{3}{c}{ Hfuncionamento } \\
\cline { 2 - 7 } & 10 Quartil $^{\circ}$ & Mediana & $3^{\circ}$ Quartil & $1^{\circ}$ Quartil & Mediana & 30 Quartil \\
\hline $\begin{array}{l}\text { Escavadeira hidráulica - sobre } \\
\text { esteira c/ caçamba }\left(1.5 \mathrm{~m}^{3}\right)\end{array}$ & & 198,1 & & & $97 \%$ & \\
\hline Servente & & 63,7 & & & & \\
\hline
\end{tabular}

\subsubsection{Compactação de aterros}

Este serviço contempla a atividade de compactação de aterros, em camadas de até $30 \mathrm{~cm}$ (Tabela 60)

Tabela 60 - Compactação de aterros - esp. até $30 \mathrm{~cm}$ (resumo dos manuais)

\begin{tabular}{l|c|c|c|c|c|c}
\hline \multirow{2}{*}{ Discriminação } & \multicolumn{3}{c|}{$\begin{array}{c}\text { Produção Unitária } \\
\left(\mathrm{m}^{2} / \text { Hserv) }\right.\end{array}$} & \multicolumn{3}{c}{ Hfuncionamento } \\
\cline { 2 - 8 } & $\begin{array}{c}1^{0} \\
\text { Quartil }\end{array}$ & Mediana & $\begin{array}{c}3^{0} \\
\text { Quartil }\end{array}$ & $\begin{array}{c}1^{\circ} \\
\text { Quartil }\end{array}$ & Mediana & $\begin{array}{c}3^{\circ} \\
\text { Quartil }\end{array}$ \\
\hline Grade de discos rebocável & 540,5 & 694,4 & 1355,0 & $76 \%$ & $76 \%$ & $97 \%$ \\
\hline Motoniveladora & 1136,4 & 1300,7 & 1918,5 & $49 \%$ & $50 \%$ & $97 \%$ \\
\hline Trator de esteiras, com lâmina & 250,0 & 250,0 & 250,0 & & & \\
\hline Rolo compactador pé de carneiro & 875,0 & 1000,0 & 1041,7 & $88 \%$ & $88 \%$ & $97 \%$ \\
\hline Caminhão tanque (10.000 I) & 621,0 & 730,4 & 776,7 & $69 \%$ & $69 \%$ & $97 \%$ \\
\hline Trator agrícola & 500,0 & 1162,8 & 1388,9 & $70 \%$ & $75 \%$ & $92 \%$ \\
\hline Servente & 333,3 & 420,2 & 561,8 & & & \\
\hline
\end{tabular}

\subsubsection{Base de brita graduada simples - BGS}

Este serviço foi dividido em dois:

a) Base de brita graduada utilizando distribuidor e agregados (Tabela 61);

Tabela 61 - Base de brita graduada, com distribuidor de agregados - esp. até $20 \mathrm{~cm}$ (resumo dos manuais)

\begin{tabular}{l|c|c|c|c|c|c}
\hline \multirow{2}{*}{ Discriminação } & \multicolumn{3}{c|}{$\begin{array}{c}\text { Produção Unitária } \\
\left(\mathrm{m}^{2} / \text { Hserv }\right.\end{array}$} & \multicolumn{3}{c}{ Hfuncionamento } \\
\cline { 2 - 7 } & $\begin{array}{c}1^{\underline{0}} \\
\text { Quartil }\end{array}$ & Mediana & $\begin{array}{c}3^{\circ} \\
\text { Quartil }\end{array}$ & $\begin{array}{c}1^{\underline{0}} \\
\text { Quartil }\end{array}$ & Mediana & $\begin{array}{c}3^{\text {o }} \\
\text { Quartil }\end{array}$ \\
\hline Carregadeira de pneus $\left(3,1 \mathrm{~m}^{3}\right)$ & 370,4 & 370,4 & 370,4 & & & \\
\hline $\begin{array}{l}\text { Distribuidor de agregados - } \\
\text { autopropelido }\end{array}$ & 520,3 & 629,2 & 1019,6 & $86 \%$ & $97 \%$ & $97 \%$ \\
\hline Rolo compactador de pneus & 544,3 & 692,7 & 783,0 & $97 \%$ & $97 \%$ & $97 \%$ \\
\hline Rolo compactador tipo tandem & 544,3 & 705,7 & 809,1 & $97 \%$ & $97 \%$ & $97 \%$ \\
\hline Caminhão tanque (10.000 I) & 603,5 & 837,0 & 837,0 & $59 \%$ & $97 \%$ & $97 \%$ \\
\hline Motoniveladora & 370,1 & 370,1 & 370,1 & & & \\
\hline Servente & 52,4 & 141,0 & 220,3 & & & \\
\hline
\end{tabular}


b) Base de brita graduada utilizando vibroacabadora (Tabela 62).

Tabela 62 - Base de brita graduada, com vibroacabadora - esp. até $20 \mathrm{~cm}$ (resumo dos manuais)

\begin{tabular}{l|c|c|c|c|c|c}
\hline \multirow{2}{*}{ Discriminação } & \multicolumn{3}{|c|}{ Produção Unitária (m²/Hserv) } & \multicolumn{3}{c}{ Hfuncionamento } \\
\cline { 2 - 7 } & 1 10 Quartil $^{2}$ & Mediana & $3^{\circ}$ Quartil & $1^{\circ}$ Quartil & Mediana & $3^{\circ}$ Quartil \\
\hline $\begin{array}{l}\text { Vibroacabadora de asfalto - } \\
\text { sobre esteiras }\end{array}$ & 121,3 & 130,9 & 140,5 & $69 \%$ & $76 \%$ & $83 \%$ \\
\hline Rolo compactador de pneus & 198,5 & 255,8 & 313,1 & $58 \%$ & $58 \%$ & $58 \%$ \\
\hline Rolo compactador tipo tandem & 286,7 & 314,6 & 342,5 & $65 \%$ & $65 \%$ & $65 \%$ \\
\hline Caminhão tanque (10.000 I) & 1785,7 & 1785,7 & 1785,7 & & & \\
\hline Carregadeira de pneus (3,1 m $\left.\mathrm{m}^{3}\right)$ & 474,8 & 474,8 & 474,8 & & & \\
\hline Motoniveladora & 370,4 & 370,4 & 370,4 & & & \\
\hline Servente & 30,7 & 41,0 & 51,4 & & & \\
\hline
\end{tabular}

\subsubsection{Base de brita graduada tratada com cimento - BGTC}

Este serviço foi dividido em dois:

a) Base de brita graduada tratada com cimento utilizando distribuidor de agregados (Tabela 63);

Tabela 63 - Base de brita graduada tratada com cimento, com distribuidor de agregados - esp. até $20 \mathrm{~cm}$ (resumo dos manuais)

\begin{tabular}{l|c|c|c|c|c|c}
\hline \multirow{2}{*}{ Discriminação } & \multicolumn{3}{c|}{$\begin{array}{c}\text { Produção Unitária } \\
\left(\mathrm{m}^{2} / \text { Hserv }\right.\end{array}$} & \multicolumn{3}{c}{ Hfuncionamento } \\
\cline { 2 - 8 } & $\begin{array}{c}1^{0} \\
\text { Quartil }\end{array}$ & Mediana & $\begin{array}{c}3^{\circ} \\
\text { Quartil }\end{array}$ & $\begin{array}{c}1^{\circ} \\
\text { Quartil }\end{array}$ & Mediana & $\begin{array}{c}3^{\text {o }} \\
\text { Quartil }\end{array}$ \\
\hline Carregadeira de pneus $\left(3,1 \mathrm{~m}^{3}\right)$ & 370,4 & 370,4 & 370,4 & & & \\
\hline $\begin{array}{l}\text { Distribuidor de agregados - } \\
\text { Autopropelido }\end{array}$ & 520,3 & 629,2 & 1019,6 & $86 \%$ & $97 \%$ & $97 \%$ \\
\hline Rolo compactador de pneus & 544,3 & 692,7 & 783,0 & $97 \%$ & $97 \%$ & $97 \%$ \\
\hline Rolo compactador tipo tandem & 544,3 & 705,7 & 809,1 & $97 \%$ & $97 \%$ & $97 \%$ \\
\hline Caminhão tanque (10.000 I) & 603,5 & 837,0 & 837,0 & $59 \%$ & $97 \%$ & $97 \%$ \\
\hline Motoniveladora & 370,1 & 370,1 & 370,1 & & & \\
\hline Servente & 52,4 & 141,0 & 220,3 & & & \\
\hline
\end{tabular}


b) Base de brita graduada tratada com cimento utilizando vibroacabadora (Tabela $64)$.

Tabela 64 - Base de brita graduada tratada com cimento, com vibroacabadora - esp. até $20 \mathrm{~cm}$ (resumo dos manuais)

\begin{tabular}{|c|c|c|c|c|c|c|}
\hline \multirow{2}{*}{ Discriminação } & \multicolumn{3}{|c|}{ Produção Unitária ( $\mathrm{m}^{2} / H$ serv) } & \multicolumn{3}{|c|}{ Hfuncionamento } \\
\hline & 1ㅇ Quartil & Mediana & 3 Quartil & 1ㅇ Quartil & Mediana & 3 Quartil \\
\hline $\begin{array}{l}\text { Vibroacabadora de asfalto - } \\
\text { sobre esteiras }\end{array}$ & 121,3 & 130,9 & 140,5 & $69 \%$ & $76 \%$ & $83 \%$ \\
\hline Rolo compactador de pneus & 198,5 & 255,8 & 313,1 & $58 \%$ & $58 \%$ & $58 \%$ \\
\hline Rolo compactador tipo tandem & 286,7 & 314,6 & 342,5 & $65 \%$ & $65 \%$ & $65 \%$ \\
\hline Caminhão tanque (10.000 I) & 1785,7 & 1785,7 & 1785,7 & & & \\
\hline $\begin{array}{l}\text { Carregadeira de pneus ( } 3,1 \\
\mathrm{~m}^{3} \text { ) }\end{array}$ & 474,8 & 474,8 & 474,8 & & & \\
\hline Motoniveladora & 370,4 & 370,4 & 370,4 & & & \\
\hline Servente & 30,7 & 41,0 & 51,4 & & & \\
\hline
\end{tabular}

\subsubsection{Base de solo cimento e mistura na pista}

Este serviço contempla a atividade de base de solo cimento e mistura na pista (Tabela 65).

Tabela 65 - Base de solo cimento e mistura na pista - esp. até $20 \mathrm{~cm}$ (resumo dos manuais)

\begin{tabular}{l|c|c|c|c|c|c}
\hline \multirow{2}{*}{ Discriminação } & \multicolumn{3}{c}{$\begin{array}{c}\text { Produc̃ão Unitária } \\
\left(\mathrm{m}^{2} / \text { Hserv) }\right.\end{array}$} & \multicolumn{3}{c}{ Hfuncionamento } \\
\cline { 2 - 8 } & $\begin{array}{c}1^{\circ} \\
\text { Quartil }\end{array}$ & Mediana & $\begin{array}{c}3^{\circ} \\
\text { Quartil }\end{array}$ & $\begin{array}{c}1^{\circ} \\
\text { Quartil }\end{array}$ & Mediana & $\begin{array}{c}3^{\circ} \\
\text { Quartil }\end{array}$ \\
\hline Grade de discos rebocável & 413,2 & 670,1 & 927,1 & $97 \%$ & $97 \%$ & $97 \%$ \\
\hline Motoniveladora & 290,6 & 424,9 & 559,2 & $97 \%$ & $97 \%$ & $97 \%$ \\
\hline Rolo compactador de pneus & 739,2 & 1055,3 & 1152,6 & $73 \%$ & $81 \%$ & $89 \%$ \\
\hline Rolo compactador tipo tandem & 319,5 & 482,7 & 645,9 & $97 \%$ & $97 \%$ & $97 \%$ \\
\hline Rolo compactador pé de carneiro & 625,0 & 625,0 & 625,0 & & & \\
\hline Trator agrícola & 413,2 & 670,1 & 927,1 & $97 \%$ & $97 \%$ & $97 \%$ \\
\hline Caminhão tanque (10.000 I) & 424,0 & 535,5 & 647,0 & $97 \%$ & $97 \%$ & $97 \%$ \\
\hline Servente & 34,4 & 53,1 & 146,8 & & & \\
\hline
\end{tabular}

\subsubsection{Imprimação}

Este serviço contempla a atividade de imprimação (Tabela 66) 
Tabela 66 - Imprimação (resumo dos manuais)

\begin{tabular}{l|c|c|c|c|c|c}
\hline \multirow{2}{*}{ Discriminação } & \multicolumn{3}{c|}{$\begin{array}{c}\text { Produção Unitária } \\
\left(\mathrm{m}^{2} / \text { Hserv }\right.\end{array}$} & \multicolumn{3}{c}{ Hfuncionamento } \\
\cline { 2 - 8 } & $\begin{array}{c}1^{0} \\
\text { Quartil }\end{array}$ & Mediana & $\begin{array}{c}3^{\circ} \\
\text { Quartil }\end{array}$ & $\begin{array}{c}1^{\circ} \\
\text { Quartil }\end{array}$ & Mediana & $\begin{array}{c}3^{\circ} \\
\text { Quartil }\end{array}$ \\
\hline Asfalto diluído CM 30 & 690,5 & 714,3 & 773,8 & & & \\
\hline Distribuidor de betume (6.000 I) & 270,3 & 416,7 & 1078,7 & $42 \%$ & $61 \%$ & $79 \%$ \\
\hline $\begin{array}{l}\text { Tanque de estocagem de asfalto - } \\
(20000 \text { I) }\end{array}$ & 820,3 & 1078,7 & 1243,4 & $97 \%$ & $97 \%$ & $97 \%$ \\
\hline Trator agrícola & 1865,1 & 2322,2 & 2779,2 & $53 \%$ & $68 \%$ & $82 \%$ \\
\hline Vassoura mecânica rebocável & 1865,1 & 2322,2 & 2779,2 & $53 \%$ & $68 \%$ & $82 \%$ \\
\hline Servente & 169,5 & 234,7 & 246,9 & & & \\
\hline
\end{tabular}

\subsubsection{Pintura de ligação}

Este serviço contempla a atividade de pintura de ligação (Tabela 67)

Tabela 67 - Pintura de ligação (resumo dos manuais)

\begin{tabular}{l|c|c|c|c|c|c}
\hline \multirow{2}{*}{ Discriminação } & \multicolumn{3}{c|}{$\begin{array}{c}\text { Produção Unitária } \\
\left(\mathrm{m}^{2} / \text { Hserv) }\right.\end{array}$} & \multicolumn{3}{c}{ Hfuncionamento } \\
\cline { 2 - 7 } & $\begin{array}{c}11^{0} \\
\text { Quartil }\end{array}$ & Mediana & $\begin{array}{c}3^{\circ} \\
\text { Quartil }\end{array}$ & $\begin{array}{c}1 \% \\
\text { Quartil }\end{array}$ & Mediana & $\begin{array}{c}3^{0} \\
\text { Quartil }\end{array}$ \\
\hline Emulsão asfáltica RR-1C & 1663,8 & 1950,7 & 1960,8 & $97 \%$ & $97 \%$ & $97 \%$ \\
\hline Distribuidor de betume (6.000 I) & 253,4 & 862,8 & 1989,2 & $35 \%$ & $56 \%$ & $77 \%$ \\
\hline $\begin{array}{l}\text { Tanque de estocagem de asfalto - } \\
(20000 \text { I) }\end{array}$ & 1808,4 & 2188,2 & 2656,6 & & & \\
\hline Trator agrícola & 2094,3 & 2188,7 & 2344,3 & $59 \%$ & $59 \%$ & $59 \%$ \\
\hline Vassoura mecânica rebocável & 2094,3 & 2188,7 & 2344,3 & $59 \%$ & $59 \%$ & $59 \%$ \\
\hline Servente & 222,5 & 268,8 & 345,0 & & & \\
\hline
\end{tabular}

\subsubsection{Concreto betuminoso usinado a quente - capa de rolamento}

Este serviço contempla a atividade de concreto betuminoso usinado a quente - capa de rolamento (Tabela 68 ).

Tabela 68 - Concreto betuminoso usinado a quente (capa de rolamento) - esp. até $5 \mathrm{~cm}$ (resumo dos manuais)

\begin{tabular}{l|c|c|c|c|c|c}
\hline \multirow{2}{*}{ Discriminação } & \multicolumn{3}{c}{$\begin{array}{c}\text { Produção Unitária } \\
\left(\mathrm{m}^{2} / \text { Hserv) }\right.\end{array}$} & \multicolumn{3}{c}{ Hfuncionamento } \\
\cline { 2 - 7 } & $\begin{array}{c}1^{0} \\
\text { Quartil }\end{array}$ & Mediana & $\begin{array}{c}3^{\circ} \\
\text { Quartil }\end{array}$ & $\begin{array}{c}1^{\underline{0}} \\
\text { Quartil }\end{array}$ & Mediana & $\begin{array}{c}3^{0} \\
\text { Quartil }\end{array}$ \\
\hline $\begin{array}{l}\text { Vibroacabadora de asfalto - sobre } \\
\text { esteiras }\end{array}$ & 624,0 & 832,9 & 1344,4 & $44 \%$ & $64 \%$ & $88 \%$ \\
\hline Rolo compactador de pneus & 553,9 & 688,9 & 1020,0 & $27 \%$ & $40 \%$ & $84 \%$ \\
\hline Rolo compactador tipo tandem & 576,0 & 960,0 & 1364,6 & $56 \%$ & $80 \%$ & $90 \%$ \\
\hline Trator agrícola & 14563,1 & 14563,1 & 14563,1 & $97 \%$ & $97 \%$ & $97 \%$ \\
\hline Vassoura mecânica rebocável & 14563,1 & 14563,1 & 14563,1 & $97 \%$ & $97 \%$ & $97 \%$ \\
\hline Servente & 115,4 & 464,9 & 744,0 & & & \\
\hline
\end{tabular}




\subsubsection{Concreto betuminoso usinado a quente - binder}

Este serviço contempla a atividade de concreto betuminoso usinado a quente Binder (Tabela 69)

Tabela 69 - Concreto betuminoso usinado a quente (binder) - esp. até $5 \mathrm{~cm}$ (resumo dos manuais)

\begin{tabular}{l|c|c|c|c|c|c}
\hline \multirow{2}{*}{ Discriminação } & \multicolumn{3}{c|}{$\begin{array}{c}\text { Produção Unitária } \\
\left(\mathrm{m}^{2} / \text { Hserv) }\right.\end{array}$} & \multicolumn{3}{c}{ Hfuncionamento } \\
\cline { 2 - 7 } & $\begin{array}{c}1^{0} \\
\text { Quartil }\end{array}$ & Mediana & $\begin{array}{c}3^{0} \\
\text { Quartil }\end{array}$ & $\begin{array}{c}1^{0} \\
\text { Quartil }\end{array}$ & Mediana & $\begin{array}{c}3^{0} \\
\text { Quartil }\end{array}$ \\
\hline $\begin{array}{l}\text { Vibroacabadora de asfalto - sobre } \\
\text { esteiras }\end{array}$ & 665,3 & 1227,3 & 2422,2 & $72 \%$ & $93 \%$ & $95 \%$ \\
\hline Rolo compactador de pneus & 617,7 & 653,8 & 2020,7 & $64 \%$ & $97 \%$ & $98 \%$ \\
\hline Rolo compactador tipo tandem & 665,3 & 1103,0 & 2700,3 & $80 \%$ & $90 \%$ & $94 \%$ \\
\hline Trator agrícola & 14563,1 & 14563,1 & 14563,1 & $97 \%$ & $97 \%$ & $97 \%$ \\
\hline Vassoura mecânica rebocável & 14563,1 & 14563,1 & 14563,1 & $97 \%$ & $97 \%$ & $97 \%$ \\
\hline Servente & 135,2 & 225,3 & 348,8 & & & \\
\hline
\end{tabular}

\subsection{Reflexões do Capítulo 7}

Este capítulo apresentou os indicadores dos manuais conforme a nova proposta de abordagem. Procurou-se manter os equipamentos apresentados pelos manuais, mesmo que na prática, conforme verificação em obra, a equipe seja montada diferentemente. Estas incoerências são corrigidas no Capítulo 8, momento em que são analisadas as entrevistas com os especialistas. As informações contidas no Capítulo 6 e neste Capítulo subsidiarão a proposição do método em desenvolvimento. 


\section{MANUAL DE APLICAÇÃO NAS ENTREVISTAS COM OS ESPECIALISTAS}

Como apresentado na introdução desta tese, a proposição de um método, que subsidiasse o prognóstico da produtividade na execução de rodovias: terraplenagem e pavimentação asfáltica, partiu da constatação de que muitos métodos disponíveis assumem posturas que inviabilizam a tomada de diversas decisões: das relacionadas à orçamentação até aquelas associadas à gestão da produção.

Deste modo a tese surgiu com o objetivo inovador de: a) de ser fundamentada na opinião de especialistas; b) empregar métodos teóricos e experimentais; c) de rever as diferentes fases executivas de cada tipo de serviço; d) apresentar os indicadores destes serviços por meio de faixas de valores (que representam a produtividade variável); e) e aliados às faixas estão os fatores orientadores para a tomada de decisão sobre qual valor adotar. Portanto, com base nas faixas de valores (produtividade variável), dos fatores e das anormalidades que afetam a produtividade dos serviços de terraplenagem e pavimentação asfáltica, dados originados das oito fontes levantadas (seis manuais e duas obras) e embasados nos estudos bibliográficos (Figura 53), neste capítulo apresenta-se o manual de aplicação das entrevistas com os especialistas.

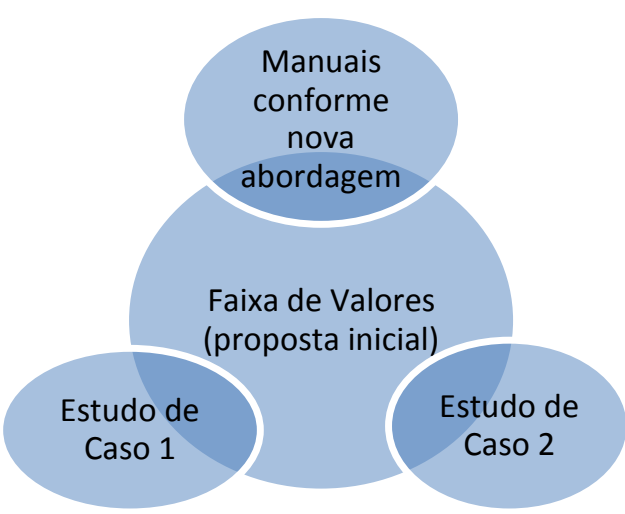

Figura 53 - Sistema de compilação: produtividade variável, fatores e anormalidades

\subsection{Fatores e Anormalidades}

Os fatores e anormalidades apresentados neste capítulo foram definidos com base 
nos fatores vistos nos levantamentos de campo, no levantamento bibliográfico e nos manuais, com o julgamento do autor para eliminar coisas muito semelhantes, superpostas e mesmo para inserir algum aspecto não contemplado nestas fontes mas considerados importante pelo autor em função da experiência que ganhou no entendimento dos serviços abordados desta tese.

\subsection{Etapas de Aplicação das Entrevistas}

Para se realizarem as entrevistas com os especialistas, as seguintes etapas foram previstas:

a) apresentar as três faixas, todas com $1^{\circ}$ quartil, mediana e $3^{\circ}$ quartil, relativamente em separado aos valores dos manuais, dos valores diários de Guarulhos e dos valores diários do Rodoanel;

b) apresentar uma lista dos fatores e anormalidades com suas possíveis ocorrências;

c) ensinar ao especialista a ideia de quartis para dizer que a faixa não apresenta valores extremos e que, ao olhar os fatores, não vai pensar numa situação de tudo $100 \%$ ruim ou tudo $100 \%$ muito bom (estes poderiam ser valores máximos e mínimos, que normalmente não cabem em situações de orçamentação);

d) o especialista vai indicar os valores medianos e os quartis (em outras palavras, a faixa de valores que adotaria) para representar a situação mediana e as situações boas ou ruins em termos dos fatores considerados importantes. O especialista vai se posicionar frente a duas classes de faixas: a das produções unitárias; e a das horas em funcionamento. $O$ pesquisador tirará a mediana das notas dadas pelos especialistas resultando nas faixas de valores relativas à produtividade variável (primeiro quartil, mediana e terceiro quartil);

e) no caso dos fatores e das anormalidades, a lista apresentada será criticada pelos especialistas, que indicarão os fatores mais importantes e os menos, eventualmente indicando fatores adicionais a serem acrescentados. A crítica será registrada da seguinte forma: 
- eles vão dar nota para cada fator (e para eventual adicional que acrescentarem); tais notas podem variar de 0 a 10, mas um fator importante tem de receber pelo menos 5.

f) o pesquisador tirará a mediana das notas para cada fator ou anormalidade, conforme as notas dadas por todos os especialistas questionados. As notas medianas abaixo de 5 terão seus fatores eliminados. Para os acima de 5 , faixas serão criadas e os quartis calculados; os fatores com nota maior que o $3^{\circ}$ quartil serão chamados "mais importantes"; os abaixo do $1^{\circ}$ quartil de "menos importantes"; os entre quartis de "importantes".

\subsection{Caracterização do Grupo de Especialistas Consultados}

Acredita-se que, nesta etapa de avaliação dos indicadores (produção unitária) e das anormalidades e fatores, obteve-se uma excelente representatividade das principais áreas de conhecimento envolvidas na elaboração de orçamentação e na gestão da produção da execução de rodovias. A abrangência e a reconhecida experiência no tema, do grupo de especialistas consultados, também são pontos a serem destacados, já que a avaliação foi efetuada por pessoas que ocupam cargo de chefia, de coordenação de equipe e de professores renomados.

Um resumo das características do grupo de especialista é apresentado a seguir. As informações referentes aos entrevistados e o resultado da compilação das entrevistas estão no Apêndice G.

a) Quantidade:

- 14 especialistas consultados e 7 respostas efetivas.

b) Titulação:

- 2 mestres.

- 3 doutores.

- 2 engenheiros.

c) Áreas de atuação:

- Obras públicas de pavimentação e terraplenagem.

- Infraestrutura de transportes.

- Fiscalização de obras rodoviárias. 
- Universidades.

- Empresas privadas.

d) Cargo atual:

- 3 diretores.

- 1 secretário de transportes.

- 3 professores.

e) Experiência acumulada dos especialistas:

- 113 anos dedicados à execução de obra públicas de pavimentação e terraplenagem.

f) Órgãos atuantes

- Secretaria de Gestão dos Programas de Transportes do Governo Federal.

- Departamento de Estradas de Rodagem do Espírito Santo - DER/ES.

g) Região de atuação

- Sul;

- Centro oeste;

- Sudeste;

- Nordeste

\subsection{Lista dos Serviços Abrangidos nas Entrevistas}

Conforme a lista de estudo, os serviços abrangidos nas entrevistas são.

a) Escavação de material de $1^{\underline{a}}$ categoria com trator de esteiras;

b) Escavação de material de 1를 categoria com escavadeira hidráulica;

c) Compactação de aterro - espessura até $30 \mathrm{~cm}$;

d) Base de solo cimento com mistura na pista - esp. até $20 \mathrm{~cm}$;

e) Brita graduada simples - BGS com distribuidor de agregados - esp. até $20 \mathrm{~cm}$;

f) Brita graduada simples - BGS com vibroacabadora - esp. até $20 \mathrm{~cm}$;

g) Brita graduada tratada com cimento - BGTC - esp. até $20 \mathrm{~cm}$;

h) Concreto betuminoso usinado a quente - capa ou binder - esp. até $5 \mathrm{~cm}$;

i) Imprimação;

j) Pintura de ligação. 


\subsection{Faixas de Valores, Anormalidades e Fatores segundo cada serviço}

\subsubsection{Escavação e carga de material de 1ª categoria}

Tabela 70 - Escavação e carga de material de 1 a categoria com trator de esteiras $\left(\mathrm{m}^{3} / \mathrm{h}\right)$

a) Etapa: escavação do solo (o trator de esteiras escava o solo e o amontoa)

\begin{tabular}{r|c|c|c|c|c|c}
\hline $\begin{array}{l}\text { Trator de esteiras, } \\
\text { com lâmina }\end{array}$ & \multicolumn{3}{|c|}{ Produção Unitária (m³/Hserv) } & \multicolumn{4}{c}{ Hfuncionamento } \\
\hline Discriminação & 10 Quartil & Mediana & 30 Quartil & 10 Quartil & Mediana & 30 Quartil \\
\hline Manuais & 172,4 & 172,4 & 192,0 & $94 \%$ & $95 \%$ & $96 \%$ \\
\hline Guarulhos & & & & & & \\
\hline Rodoanel & & & & & & \\
\hline $\begin{array}{l}\text { Proposta dos } \\
\text { especialistas }\end{array}$ & & & & & & \\
\hline
\end{tabular}

b) Etapa: carregamento do caminhão (a carregadeira de pneus coloca o solo nos caminhões)

\begin{tabular}{|c|c|c|c|c|c|c|}
\hline \multirow{2}{*}{$\begin{array}{l}\begin{array}{l}\text { Carregadeira de } \\
\text { pneus - cap. } 3,1 \mathrm{~m}^{3}\end{array} \\
\text { Discriminação } \\
\end{array}$} & \multicolumn{3}{|c|}{ Produção Unitária ( $\mathrm{m}^{3} /$ Hserv) } & \multicolumn{3}{|c|}{ Hfuncionamento } \\
\hline & 10 Quartil & Mediana & 3 Quartil & 10 Quartil & Mediana & 3Q Quartil \\
\hline Manuais & 112,4 & 112,4 & 202,1 & $96 \%$ & $96 \%$ & $97 \%$ \\
\hline \multicolumn{7}{|l|}{ Guarulhos } \\
\hline \multicolumn{7}{|l|}{ Rodoanel } \\
\hline $\begin{array}{l}\text { Proposta dos } \\
\text { especialistas }\end{array}$ & & & & & & \\
\hline
\end{tabular}

Tabela 71 - Escavação e carga de material de 1ํㅡㄹ categoria com escavadeira hidráulica $\left(\mathrm{m}^{3} / \mathrm{h}\right)$

a) Etapa: escavação do solo e carregamento do caminhão

\begin{tabular}{|c|c|c|c|c|c|c|}
\hline $\begin{array}{l}\text { Escavadeira } \\
\text { hidráulica }\end{array}$ & Produçã & Unitária ( & $3^{3} /$ Hserv) & & Incionamer & \\
\hline Discriminação & 10 Quartil & Mediana & 3ㅇ Quartil & 1ㅇ Quartil & Mediana & 3 Quartil \\
\hline Manuais & & 198,1 & & & $97 \%$ & \\
\hline Guarulhos & 42,9 & 87,9 & 152,2 & $42 \%$ & $69 \%$ & $92 \%$ \\
\hline Rodoanel & 59,5 & 73,1 & 103,1 & $74 \%$ & $82 \%$ & $95 \%$ \\
\hline $\begin{array}{l}\text { Proposta dos } \\
\text { especialistas }\end{array}$ & & & & & & \\
\hline
\end{tabular}


Tabela 72 - Síntese dos fatores e das anormalidades: escavação e carga de material de $1^{\text {a }}$ categoria

\begin{tabular}{|c|c|c|}
\hline Aproxima do $1^{\circ}$ Quartil & Aproxima do $3^{\circ}$ Quartil & Nota (0 a 10) \\
\hline Condições climáticas instáveis & Condições climáticas estáveis & \\
\hline $\begin{array}{l}\text { Umidade do solo maior do que a } \\
\text { projetada }\end{array}$ & $\begin{array}{l}\text { Umidade do solo compatível com } \\
\text { a projetada }\end{array}$ & \\
\hline $\begin{array}{l}\text { Solo com maior dificuldade de } \\
\text { penetração }\end{array}$ & Solo facilmente penetrável & \\
\hline Escavação no nível do terreno & $\begin{array}{l}\text { Escavação em barranco (diminui o } \\
\text { tempo de ciclo entre a escavação, } \\
\text { carga e a manobra, aumentando a } \\
\text { eficiência) }\end{array}$ & \\
\hline Terreno muito acidentado & Terreno pouco acidentado & \\
\hline $\begin{array}{l}\text { Equipamento de escavação } \\
\text { menos compatível com as } \\
\text { características do terreno }\end{array}$ & $\begin{array}{l}\text { Equipamento de escavação } \\
\text { compatível com as características } \\
\text { do terreno }\end{array}$ & \\
\hline $\begin{array}{l}\text { Equipamento com alta } \\
\text { manutenção durante a operação }\end{array}$ & $\begin{array}{l}\text { Equipamento com baixa } \\
\text { manutenção durante a operação }\end{array}$ & \\
\hline $\begin{array}{l}\text { Problemas com abastecimento de } \\
\text { combustível (falta combustível) }\end{array}$ & $\begin{array}{l}\text { Equipamento abastecido } \\
\text { (combustível) }\end{array}$ & \\
\hline $\begin{array}{l}\text { Alto índice de ausência do } \\
\text { operador (tem muitas faltas) }\end{array}$ & $\begin{array}{l}\text { Baixo índice de ausência do } \\
\text { operador (tem poucas faltas) }\end{array}$ & \\
\hline Operador menos treinado & Operador treinado & \\
\hline $\begin{array}{l}\text { Comete erros grosseiros em } \\
\text { relação ao projetado (retrabalho) }\end{array}$ & $\begin{array}{l}\text { Serviço executado de acordo com } \\
\text { o projeto (evita erros grosseiros } \\
\text { que poderiam aumentar o volume } \\
\text { da escavação) }\end{array}$ & \\
\hline $\begin{array}{l}\text { Mais tempo para executar a } \\
\text { atividade (prazos extensos) }\end{array}$ & $\begin{array}{l}\text { Pouco tempo para executar a } \\
\text { atividade (prazos enxutos) }\end{array}$ & \\
\hline $\begin{array}{l}\text { Má continuidade e sequência de } \\
\text { operações entre cada atividade }\end{array}$ & $\begin{array}{l}\text { Boa continuidade e sequência de } \\
\text { operações entre cada atividade }\end{array}$ & \\
\hline $\begin{array}{l}\text { Menos frentes sendo atendidas } \\
\text { (de aterro ou } \mathrm{DME}^{65} \text { ) }\end{array}$ & $\begin{array}{l}\text { Mais frentes sendo atendidas (de } \\
\text { aterro ou DME) }\end{array}$ & \\
\hline $\begin{array}{l}\text { Quantidade e capacidade de } \\
\text { caminhões menos compatível com } \\
\text { a frente de serviço }\end{array}$ & $\begin{array}{l}\text { Quantidade e capacidade de } \\
\text { caminhões compatível com a } \\
\text { frente de serviço }\end{array}$ & \\
\hline $\begin{array}{l}\mathrm{DMT}^{66} \text { maior (distância entre o } \\
\text { corte e o aterro atendido) }\end{array}$ & $\begin{array}{l}\text { DMT menor (distância entre o } \\
\text { corte e o aterro atendido) }\end{array}$ & \\
\hline
\end{tabular}

${ }^{65}$ DME: depósito de material excedente

${ }^{66}$ DMT: distância média de transporte 


\subsubsection{Compactação de aterro}

Tabela 73 - Compactação de aterro - esp. até $30 \mathrm{~cm}\left(\mathrm{~m}^{2}\right)$

a) Etapa: espalhamento do solo (após a descarga pelos caminhões o trator de esteiras espalha o solo)

\begin{tabular}{|c|c|c|c|c|c|c|}
\hline $\begin{array}{l}\text { Trator de esteiras, com } \\
\text { lâmina }\end{array}$ & Produçã & Unitária ( $r$ & $n^{2} /$ Hserv) & & Hfuncionan & nento \\
\hline Discriminação & 1 Quartil & Mediana & 3 Quartil & 1Q Quartil & Mediana & 3 Quartil \\
\hline Manuais & 250,0 & 250,0 & 250,0 & & & \\
\hline Guarulhos & 670,8 & 1277,1 & 2596,2 & $47 \%$ & $71 \%$ & $86 \%$ \\
\hline Rodoanel & 221,7 & 311,1 & 387,6 & & & \\
\hline $\begin{array}{l}\text { Proposta dos } \\
\text { especialistas }\end{array}$ & & & & & & \\
\hline
\end{tabular}

b) Etapa: nivelamento da camada (a motoniveladora nivela a camada de solo)

\begin{tabular}{|c|c|c|c|c|c|c|}
\hline Motoniveladora & Produçã & Unitária $(r$ & $n^{2} /$ Hserv) & & Ifuncionan & ento \\
\hline Discriminação & 10 Quartil & Mediana & 3ㅇQ Quartil & 1ㅇ Quartil & Mediana & 3 Quartil \\
\hline Manuais & 1136,4 & 1300,7 & 1918,5 & $49 \%$ & $50 \%$ & $97 \%$ \\
\hline Guarulhos & 788,8 & 1501,5 & 2779,2 & $77 \%$ & $82 \%$ & $91 \%$ \\
\hline Rodoanel & 221,7 & 311,1 & 387,6 & & & \\
\hline $\begin{array}{l}\text { Proposta dos } \\
\text { especialistas }\end{array}$ & & & & & & \\
\hline
\end{tabular}

c) Etapa: aeração e/ou homogeneização da camada (se precisar o trator com grade faz a aeração ou a homogeneização do solo)

\begin{tabular}{|c|c|c|c|c|c|c|}
\hline $\begin{array}{l}\text { Trator agrícola com } \\
\text { grade de disco }\end{array}$ & Produçã & Unitária ( $r$ & $\mathrm{n}^{2} /$ Hserv) & & Hfuncionan & ento \\
\hline Discriminação & $1^{\circ}$ Quartil & Mediana & 3 Quartil & 10 Quartil & Mediana & 3 Quarti \\
\hline Manuais & 500,0 & 1162,8 & 1388,9 & $70 \%$ & $75 \%$ & $92 \%$ \\
\hline Guarulhos & 842,2 & 1596,8 & 2752,1 & $55 \%$ & $57 \%$ & $63 \%$ \\
\hline Rodoanel & 221,7 & 311,1 & 387,6 & & & \\
\hline $\begin{array}{l}\text { Proposta dos } \\
\text { especialistas }\end{array}$ & & & & & & \\
\hline
\end{tabular}

d) Etapa: umidificação da camada (se precisar o caminhão tanque umedece o solo)

\begin{tabular}{r|c|c|c|c|c|c}
\hline Caminhão tanque & \multicolumn{3}{|c|}{ Produção Unitária $\left(\mathrm{m}^{2} /\right.$ Hserv) } & \multicolumn{3}{c}{ Hfuncionamento } \\
\hline Discriminação & 1 10 Quartil & Mediana & $3^{\circ}$ Quartil & 1 Quartil $^{\circ}$ Mediana & $3^{\circ}$ Quartil \\
\hline Manuais & 621,0 & 730,4 & 776,7 & $69 \%$ & $69 \%$ & $97 \%$ \\
\hline Guarulhos & 1032,7 & 1608,3 & 2756,4 & $18 \%$ & $29 \%$ & $31 \%$ \\
\hline Rodoanel & 997,5 & 1400,0 & 1744,2 & & & \\
\hline $\begin{array}{l}\text { Proposta dos } \\
\text { especialistas }\end{array}$ & & & & & & \\
\hline
\end{tabular}

e) Etapa: compactação da camada

\begin{tabular}{|c|c|c|c|c|c|c|}
\hline \multirow{2}{*}{$\begin{array}{l}\begin{array}{l}\text { Rolo compactador pé } \\
\text { de carneiro }\end{array} \\
\text { Discriminação }\end{array}$} & \multicolumn{3}{|c|}{ Produção Unitária (m²/Hserv) } & \multicolumn{3}{|c|}{ Hfuncionamento } \\
\hline & 10 Quartil & Mediana & 3ㅇQ Quartil & 1Q Quartil & Mediana & 3 Quartil \\
\hline Manuais & 875,0 & 1000,0 & 1041,7 & $88 \%$ & $88 \%$ & $97 \%$ \\
\hline Guarulhos & 884,1 & 1592,2 & 2746,4 & $31 \%$ & $36 \%$ & $49 \%$ \\
\hline Rodoanel & 55,4 & 77,8 & 96,9 & & & \\
\hline $\begin{array}{l}\text { Proposta dos } \\
\text { especialistas }\end{array}$ & & & & & & \\
\hline
\end{tabular}


Tabela 74 - Síntese dos fatores e das anormalidades: Compactação de Aterro (continua)

\begin{tabular}{l|l|l}
\hline \multicolumn{1}{c|}{ Aproxima do 10 Quartil } & \multicolumn{1}{c|}{ Aproxima do 3o Quartil } & \multicolumn{1}{c}{ Nota (0 a 10) } \\
\hline Condições climáticas instáveis & Condições climáticas estáveis & \\
\hline $\begin{array}{l}\text { Baixa capacidade efetiva do } \\
\text { equipamento (menor quantidade } \\
\text { de horas em funcionamento) }\end{array}$ & $\begin{array}{l}\text { Alta capacidade efetiva do } \\
\text { equipamento (maior quantidade } \\
\text { de horas em funcionamento) }\end{array}$ & \\
\hline $\begin{array}{l}\text { Equipamento com alta } \\
\text { manutenção durante a operação }\end{array}$ & $\begin{array}{l}\text { Equipamento com baixa } \\
\text { manutenção durante a operação }\end{array}$ & \\
\hline $\begin{array}{l}\text { Problemas com abastecimento de } \\
\text { combustível (equipamento sem } \\
\text { combustível) }\end{array}$ & $\begin{array}{l}\text { Equipamento abastecido } \\
\text { (combustível) }\end{array}$ & \\
\hline $\begin{array}{l}\text { Alto índice de ausência do } \\
\text { operador (faltas) }\end{array}$ & $\begin{array}{l}\text { Baixo índice de ausência do } \\
\text { operador (faltas) }\end{array}$ & \\
\hline Prevalece a improvisação & $\begin{array}{l}\text { Planeja antecipadamente as } \\
\text { atividades }\end{array}$ & \\
\hline Operador menos treinado & Operador treinado & \\
\hline $\begin{array}{l}\text { Mais tempo para executar a } \\
\text { atividade (prazos extensos) }\end{array}$ & $\begin{array}{l}\text { Pouco tempo para executar a } \\
\text { atividade (prazos enxutos) }\end{array}$ & \\
\hline $\begin{array}{l}\text { Má continuidade e sequência de } \\
\text { operações }\end{array}$ & $\begin{array}{l}\text { Boa continuidade e sequência de } \\
\text { operações }\end{array}$ & \\
\hline Menos frentes sendo atendidas & Mais frentes sendo atendidas & \\
\hline Frentes de trabalho mais distantes & Frentes de trabalho mais próximas & \\
\hline $\begin{array}{l}\text { Tarefas preliminares a executar } \\
\text { (ex. drenos) }\end{array}$ & $\begin{array}{l}\text { Tarefas preliminares prontas (ex. } \\
\text { drenos) }\end{array}$ & \\
\hline & conocoEs ESPECiFICAS & \\
\hline
\end{tabular}

\section{CONDIÇÕES ESPECÍFICAS}

\section{Espalhamento do solo e nivelamento da camada}

Quantidade e capacidade de caminhões menos compatível com a frente a ser abastecida

DMT maior (demora no trajeto corte/aterro)
Quantidade e capacidade de caminhões compatível com a frente a ser abastecida

DMT menor (rapidez no trajeto corte/aterro)

\begin{tabular}{l|l|l}
\hline \multicolumn{1}{l}{ Aeração, homogeneização e umidificação da camada } & \multicolumn{2}{l}{} \\
\hline $\begin{array}{l}\text { Umidade do solo maior do que a } \\
\text { projetada }\end{array}$ & $\begin{array}{l}\text { Umidade do solo compatível com } \\
\text { a projetada }\end{array}$ & \\
\hline Solo menos homogêneo & Solo mais homogêneo & \\
\hline Compactação da camada & $\begin{array}{l}\text { Camadas menos espessas } \\
\text { (<20cm) }\end{array}$ & \\
\hline $\begin{array}{l}\text { Camadas mais espessas (>20cm } \\
\text { e <30cm) }\end{array}$ & $\begin{array}{l}\text { Menor deformabilidade da } \\
\text { camada inferior }\end{array}$ & \\
\hline $\begin{array}{l}\text { Maior a deformabilidade da } \\
\text { camada inferior }\end{array}$ & $\begin{array}{l}\text { Menor quantidade de passadas } \\
\text { dos compactadores (número de } \\
\text { fechas para atingir o GC) }\end{array}$ & \\
\hline $\begin{array}{l}\text { Maior quantidade de passadas compactadores (número de } \\
\text { dos cochas para atingir o GC) }\end{array}$ &
\end{tabular}


Tabela 74 - Síntese dos fatores e das anormalidades: Compactação de Aterro (conclusão)

Equipe de equipamentos menos compatível (equipamentos diferentes, pesos diferentes, quantidade incompatível com o GC)

Equipe de laboratório menos treinada
Equipe de equipamentos compatível (equipamentos semelhantes, pesos parecidos, quantidade compatível com o GC)

Equipe de laboratório treinada

\subsubsection{Base de solo cimento com mistura na pista}

Tabela 75 - Base de solo cimento com mistura na pista - esp. até $20 \mathrm{~cm}\left(\mathrm{~m}^{2}\right)$ (continua)

a) Etapa: espalhamento do solo (após a descarga pelos caminhões o trator de esteiras espalha o solo)

\begin{tabular}{r|c|c|c|c|c|c}
\hline $\begin{array}{l}\text { Trator de esteiras, com } \\
\text { lâmina }\end{array}$ & \multicolumn{2}{|c|}{ Produção Unitária (m²/Hserv) } & \multicolumn{3}{c}{ Hfuncionamento } \\
\hline \multicolumn{1}{c|}{ Discriminação } & $1^{\circ}$ Quartil & Mediana & $3^{\circ}$ Quartil & $1^{\circ}$ Quartil & Mediana & 3 Quartil \\
\hline Manuais & & & & & & \\
\hline Guarulhos & & & & & & \\
\hline $\begin{array}{l}\text { Rodoanel } \\
\text { Proposta dos }\end{array}$ & 512,3 & 654,7 & 748,0 & $12 \%$ & $28 \%$ & $34 \%$ \\
\hline
\end{tabular}

b) Etapa: nivelamento da camada (a motoniveladora nivela a camada de solo)

\begin{tabular}{r|c|c|c|c|c|c}
\hline Motoniveladora & \multicolumn{2}{|c|}{ Produção Unitária $\left(\mathrm{m}^{2} /\right.$ Hserv) } & \multicolumn{3}{c}{ Hfuncionamento } \\
\hline Discriminação & 1 10 Quartil & Mediana & $3^{\circ}$ Quartil & 10 Quartil & Mediana & 30 Quartil \\
\hline Manuais & 290,6 & 424,9 & 559,2 & $97 \%$ & $97 \%$ & $97 \%$ \\
\hline Guarulhos & & & & & & \\
\hline $\begin{array}{l}\text { Rodoanel } \\
\text { Proposta dos } \\
\text { especialistas }\end{array}$ & 229,9 & 389,7 & 439,0 & $36 \%$ & $60 \%$ & $79 \%$ \\
\hline
\end{tabular}

c) Etapa: distribuição do cimento na camada

\begin{tabular}{|c|c|c|c|c|c|c|}
\hline \multirow{2}{*}{$\begin{array}{l}\begin{array}{l}\text { Distribuidor de } \\
\text { cimento }\end{array} \\
\text { Discriminação }\end{array}$} & \multicolumn{3}{|c|}{ Produção Unitária (m²/Hserv) } & \multicolumn{3}{|c|}{ Hfuncionamento } \\
\hline & 10 Quartil & Mediana & 3 Quartil & 10 Quartil & Mediana & 3 Quartil \\
\hline Manuais & & & & & & \\
\hline Guarulhos & & & & & & \\
\hline Rodoanel & 369,7 & 444,7 & 581,7 & $6 \%$ & $8 \%$ & $13 \%$ \\
\hline $\begin{array}{l}\text { Proposta dos } \\
\text { especialistas }\end{array}$ & & & & & & \\
\hline
\end{tabular}


Tabela 75 - Base de solo cimento com mistura na pista - esp. até $20 \mathrm{~cm}\left(\mathrm{~m}^{2}\right)$ (conclusão)

d) Etapa: aeração e/ou homogeneização da camada (se precisar o trator com grade faz a aeração ou a homogeneização do solo)

\begin{tabular}{|c|c|c|c|c|c|c|}
\hline $\begin{array}{l}\text { Trator agrícola com } \\
\text { grade de disco }\end{array}$ & \multicolumn{3}{|c|}{ Produção Unitária ( $\mathrm{m}^{2} /$ Hserv) } & \multicolumn{3}{|c|}{ Hfuncionamento } \\
\hline Discriminação & 10 Quartil & Mediana & 3으artil & $1^{\circ}$ Q Quartil & Mediana & 3 Quartil \\
\hline Manuais & 413,2 & 670,1 & 927,1 & $97 \%$ & $97 \%$ & $97 \%$ \\
\hline Guarulhos & & & & & & \\
\hline Rodoanel & & & & & & \\
\hline $\begin{array}{l}\text { Proposta dos } \\
\text { especialistas }\end{array}$ & & & & & & \\
\hline
\end{tabular}

e) Etapa: mistura do cimento na camada (a recicladora automaticamente mistura o cimento com o solo)

\begin{tabular}{|c|c|c|c|c|c|c|}
\hline Recicladora & \multicolumn{3}{|c|}{ Produção Unitária (m²/Hserv) } & \multicolumn{3}{|c|}{ Hfuncionamento } \\
\hline Discriminação & 1ㅇ Quartil & Mediana & 3 Quartil & $1^{\circ}$ Quartil & Mediana & 3 Quartil \\
\hline Manuais & & & & & & \\
\hline Guarulhos & & & & & & \\
\hline Rodoanel & 399,7 & 464,7 & 777,4 & $11 \%$ & $23 \%$ & $25 \%$ \\
\hline $\begin{array}{l}\text { Proposta dos } \\
\text { especialistas }\end{array}$ & & & & & & \\
\hline
\end{tabular}

f) Etapa: umidificação da camada (se precisar o caminhão tanque umedece o solo)

\begin{tabular}{r|c|c|c|c|c|c}
\hline Caminhão tanque & \multicolumn{2}{|c|}{ Produção Unitária $\left(\mathrm{m}^{2} /\right.$ Hserv) } & \multicolumn{3}{c}{ Hfuncionamento } \\
\hline Discriminação & $1{ }^{\circ}$ Quartil & Mediana & $3^{\circ}$ Quartil & $1^{\circ}$ Quartil & Mediana & $3^{\circ}$ Quartil \\
\hline Manuais & 424,0 & 535,5 & 647,0 & $97 \%$ & $97 \%$ & $97 \%$ \\
\hline Guarulhos & & & & & & \\
\hline $\begin{array}{r}\text { Rodoanel } \\
\text { Proposta dos }\end{array}$ & 424,7 & 588,8 & 793,8 & $10 \%$ & $15 \%$ & $25 \%$ \\
\hline
\end{tabular}

g) Etapa: compactação da camada

\begin{tabular}{r|c|c|c|c|c|c}
\hline $\begin{array}{l}\text { Rolo compactador pé } \\
\text { de carneiro }\end{array}$ & \multicolumn{3}{|c|}{ Produção Unitária (m²/Hserv) } & \multicolumn{3}{c}{ Hfuncionamento } \\
\hline \multicolumn{1}{c|}{ Discriminação } & 1 10 Quartil & Mediana & 30 Quartil & 10 Quartil & Mediana & 30 Quartil \\
\hline Manuais & 625,0 & 625,0 & 625,0 & & & \\
\hline Guarulhos & & & & & & \\
\hline Rodoanel & 79,3 & 112,2 & 151,7 & $44 \%$ & $53 \%$ & $72 \%$ \\
\hline $\begin{array}{l}\text { Proposta dos } \\
\text { especialistas }\end{array}$ & & & & & & \\
\hline
\end{tabular}

h) Etapa: acabamento da camada (após a compactação o rolo compactador de pneus , protege a camada, ou seja, sela a camada)

\begin{tabular}{r|c|c|c|c|c|c}
\hline $\begin{array}{l}\text { Rolo compactador de } \\
\text { pneus }\end{array}$ & \multicolumn{3}{|c|}{ Produção Unitária $\left(\mathrm{m}^{2} / \mathrm{Hserv}\right)$} & \multicolumn{3}{c}{ Hfuncionamento } \\
\hline \multicolumn{1}{c|}{ Discriminação } & 1 \% Quartil & Mediana & 3 \% Quartil & 1 0 Quartil & Mediana & 30 Quartil \\
\hline Manuais & 739,2 & 1055,3 & 1152,6 & $73 \%$ & $81 \%$ & $89 \%$ \\
\hline Guarulhos & & & & & & \\
\hline $\begin{array}{r}\text { Rodoanel } \\
\text { especialistas }\end{array}$ & 371,3 & 453,8 & 852,9 & $6 \%$ & $8 \%$ & $10 \%$ \\
\hline
\end{tabular}


Tabela 76 - Síntese dos fatores e das anormalidades: Base de solo cimento com mistura na pista (continua)

\begin{tabular}{|c|c|c|}
\hline Aproxima do 1ㅇ Quartil & Aproxima do 3ㅇ Quartil & Nota (0 a 10) \\
\hline \multicolumn{3}{|c|}{ CONDIÇÕES GERAIS } \\
\hline Condições climáticas instáveis & Condições climáticas estáveis & \\
\hline $\begin{array}{l}\text { Baixa capacidade efetiva do } \\
\text { equipamento (menor quantidade } \\
\text { de horas em funcionamento) }\end{array}$ & $\begin{array}{l}\text { Alta capacidade efetiva do } \\
\text { equipamento (maior quantidade } \\
\text { de horas em funcionamento) }\end{array}$ & \\
\hline $\begin{array}{l}\text { Equipamento com alta } \\
\text { manutenção durante a operação }\end{array}$ & $\begin{array}{l}\text { Equipamento com baixa } \\
\text { manutenção durante a operação }\end{array}$ & \\
\hline $\begin{array}{l}\text { Problemas com abastecimento de } \\
\text { combustível (equipamento sem } \\
\text { combustível) }\end{array}$ & $\begin{array}{l}\text { Equipamento abastecido } \\
\text { (combustível) }\end{array}$ & \\
\hline $\begin{array}{l}\text { Alto índice de ausência do } \\
\text { operador (faltas) }\end{array}$ & $\begin{array}{l}\text { Baixo índice de ausência do } \\
\text { operador (faltas) }\end{array}$ & \\
\hline Prevalece a improvisação & $\begin{array}{l}\text { Planeja antecipadamente as } \\
\text { atividades }\end{array}$ & \\
\hline Operador menos treinado & Operador treinado & \\
\hline $\begin{array}{l}\text { Mais tempo para executar a } \\
\text { atividade (prazos extensos) }\end{array}$ & $\begin{array}{l}\text { Pouco tempo para executar a } \\
\text { atividade (prazos enxutos) }\end{array}$ & \\
\hline $\begin{array}{l}\text { Má continuidade e sequência de } \\
\text { operações }\end{array}$ & $\begin{array}{l}\text { Boa continuidade e sequência de } \\
\text { operações }\end{array}$ & \\
\hline Menos frentes sendo atendidas & Mais frentes sendo atendidas & \\
\hline Frentes de trabalho mais distantes & Frentes de trabalho mais próximas & \\
\hline $\begin{array}{l}\text { Tarefas preliminares a executar } \\
\text { (ex. drenos) }\end{array}$ & $\begin{array}{l}\text { Tarefas preliminares prontas (ex. } \\
\text { drenos) }\end{array}$ & \\
\hline
\end{tabular}

\section{CONDIÇÕES ESPECÍFICAS}

\section{Espalhamento do solo e nivelamento da camada}

Quantidade e capacidade de caminhões (ou mão de obra para serviço manual) menos compatível com a frente a ser abastecida

DMT maior (demora no trajeto corte/aterro)
Quantidade e capacidade de caminhões (ou mão de obra para serviço manual) compatível com a frente a ser abastecida

DMT menor (rapidez no trajeto corte/aterro)

\section{Aeração, homogeneização e umidificação da camada}

Umidade do solo maior do que a projetada

Solo menos homogêneo
Umidade do solo compatível com a projetada

Solo mais homogêneo

\section{Compactação da camada}

Camadas mais espessas (>20cm e $<30 \mathrm{~cm}$ )

Maior a deformabilidade da camada inferior
Camadas menos espessas $(<20 \mathrm{~cm})$

Menor deformabilidade da camada inferior 
Tabela 76 - Síntese dos fatores e das anormalidades: Base de solo cimento com mistura na pista (conclusão)

\begin{tabular}{l|l|l}
\hline $\begin{array}{l}\text { Maior quantidade de passadas } \\
\text { dos compactadores (número de } \\
\text { fechas para atingir o GC) }\end{array}$ & $\begin{array}{l}\text { Menor quantidade de passadas } \\
\text { dos compactadores (número de } \\
\text { fechas para atingir o GC) }\end{array}$ & \\
\hline $\begin{array}{l}\text { Equipe de equipamentos menos } \\
\text { compatível (equipamentos } \\
\text { diferentes, pesos diferentes, } \\
\text { quantidade incompatível com o }\end{array}$ & $\begin{array}{l}\text { Equipe de equipamentos } \\
\text { compatível (equipamentos } \\
\text { semelhantes, pesos parecidos, } \\
\text { quantidade compatível com o GC) }\end{array}$ & \\
\hline $\begin{array}{l}\text { Equipe de laboratório menos } \\
\text { treinada }\end{array}$ & Equipe de laboratório treinada & \\
\hline
\end{tabular}

\subsubsection{Brita graduada simples - BGS}

Tabela 77 - Brita graduada simples - BGS com distribuidor de agregados - esp. até $20 \mathrm{~cm}$ $\left(\mathrm{m}^{2}\right)$ (continua)

a) Etapa: espalhamento da BGS (os caminhões abastecem o distribuidor de agregados com BGS e este espalha o material)

\begin{tabular}{|c|c|c|c|c|c|c|}
\hline $\begin{array}{l}\text { Distribuidor de } \\
\text { Agregados - }\end{array}$ & \multicolumn{3}{|c|}{ Produção Unitária (m²/Hserv) } & \multicolumn{3}{|c|}{ Hfuncionamento } \\
\hline Discriminação & 10 Quartil & Mediana & 3ํo Quartil & 10 Quartil & Mediana & 3 Quartil \\
\hline Manuais & 520,3 & 629,2 & 1019,6 & $86 \%$ & $97 \%$ & $97 \%$ \\
\hline Guarulhos & & & & & & \\
\hline Rodoanel & & & & & & \\
\hline $\begin{array}{l}\text { Proposta dos } \\
\text { especialistas }\end{array}$ & & & & & & \\
\hline
\end{tabular}

b) Etapa: nivelamento da camada (a motoniveladora nivela a camada de BGS)

\begin{tabular}{|c|c|c|c|c|c|c|}
\hline Motoniveladora & \multicolumn{3}{|c|}{ Produção Unitária ( $\left.\mathrm{m}^{2} / \mathrm{Hserv}\right)$} & \multicolumn{3}{|c|}{ Hfuncionamento } \\
\hline Discriminação & 10 Quartil & Mediana & 3 Quartil & 1ㅇ Quartil & Mediana & 3 Quartil \\
\hline Manuais & 370,1 & 370,1 & 370,1 & & & \\
\hline Guarulhos & & & & & & \\
\hline Rodoanel & & & & & & \\
\hline $\begin{array}{l}\text { Proposta dos } \\
\text { especialistas }\end{array}$ & & & & & & \\
\hline
\end{tabular}

c) Etapa: umidificação da camada (se precisar o caminhão tanque umedece a camada)

\begin{tabular}{|c|c|c|c|c|c|c|}
\hline Caminhão tanque & \multicolumn{3}{|c|}{ Produção Unitária ( $\left.\mathrm{m}^{2} / \mathrm{Hserv}\right)$} & \multicolumn{3}{|c|}{ Hfuncionamento } \\
\hline Discriminação & 10 Quartil & Mediana & 3 Quartil & 1ㅇ Quartil & Mediana & 3 Quartil \\
\hline Manuais & 603,5 & 837,0 & 837,0 & $59 \%$ & $97 \%$ & $97 \%$ \\
\hline Guarulhos & & & & & & \\
\hline Rodoanel & & & & & & \\
\hline $\begin{array}{l}\text { Proposta dos } \\
\text { especialistas }\end{array}$ & & & & & & \\
\hline
\end{tabular}


Tabela 77 - Brita Graduada Simples - BGS com distribuidor de agregados - esp. até $20 \mathrm{~cm}$ $\left(\mathrm{m}^{2}\right)$ (conclusão)

d) Etapa: Compactação da camada

d1) Pré-compactação e acabamento (o rolo compactador tipo tandem inicia a compactação fazendo a acomodação inicial do material. Após a compactação propriamente dita, pelo compactador de pneus, o tandem retorna e dá o acabamento da camada).

\begin{tabular}{r|c|c|c|c|c|c}
\hline $\begin{array}{l}\text { Rolo compactador tipo } \\
\text { tandem }\end{array}$ & \multicolumn{3}{|c|}{ Produção Unitária (m²/Hserv) } & \multicolumn{3}{c}{ Hfuncionamento } \\
\hline Discriminação & 1 10 Quartil & Mediana & $3^{\circ}$ Quartil & 10 Quartil & Mediana & $3^{\text {O Q Quartil }}$ \\
\hline Manuais & 544,3 & 705,7 & 809,1 & $97 \%$ & $97 \%$ & $97 \%$ \\
\hline Guarulhos & & & & & & \\
\hline Rodoanel & & & & & & \\
\hline $\begin{array}{l}\text { Proposta dos } \\
\text { especialistas }\end{array}$ & & & & & & \\
\hline
\end{tabular}

d2) Compactação da camada (após a pré-compactação, executada pelo compactador tipo tandem, o rolo compactador de pneus faz a compactação propriamente dita)

\begin{tabular}{|c|c|c|c|c|c|c|}
\hline $\begin{array}{l}\text { Rolo compactador de } \\
\text { pneus }\end{array}$ & \multicolumn{3}{|c|}{ Produção Unitária (m²/Hserv) } & \multicolumn{3}{|c|}{ Hfuncionamento } \\
\hline Discriminação & $1^{\circ}$ Quartil & Mediana & 3 Quartil & $1^{\circ}$ Quartil & Mediana & 3 Quartil \\
\hline Manuais & 544,3 & 692,7 & 783,0 & $97 \%$ & $97 \%$ & $97 \%$ \\
\hline \multicolumn{7}{|l|}{ Guarulhos } \\
\hline \multicolumn{7}{|l|}{ Rodoanel } \\
\hline $\begin{array}{l}\text { Proposta dos } \\
\text { especialistas }\end{array}$ & & & & & & \\
\hline
\end{tabular}

e) Etapa: apoio

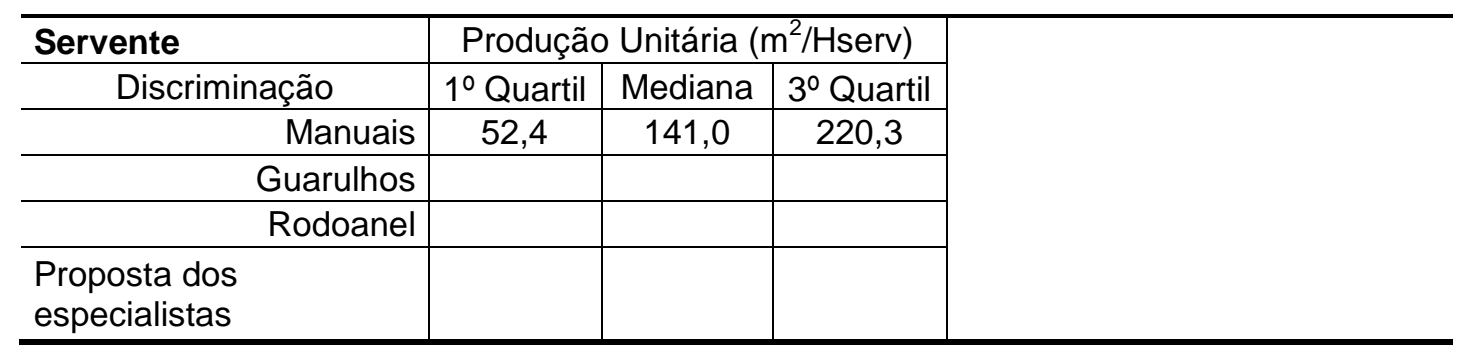


Tabela 78 - Brita graduada simples - BGS com vibroacabadora - esp. até $20 \mathrm{~cm}\left(\mathrm{~m}^{2}\right)$ (continua)

a) Etapa: espalhamento e nivelamento da BGS (os caminhões abastecem a vibroacabadora com BGS e esta espalha o material e nivela a camada)

\begin{tabular}{r|c|c|c|c|c|c}
\hline $\begin{array}{l}\text { Vibroacabadora de } \\
\text { Asfalto }\end{array}$ & \multicolumn{3}{|c|}{ Produção Unitária (m2/Hserv) } & \multicolumn{3}{c}{ Hfuncionamento } \\
\hline \multicolumn{1}{c}{ Discriminação } & 1 10 Quartil & Mediana & 3o Quartil & 1ㅇ Quartil & Mediana & 3\% Quartil \\
\hline Manuais & 121,3 & 130,9 & 140,5 & $69 \%$ & $76 \%$ & $83 \%$ \\
\hline Guarulhos & 82,0 & 103,1 & 143,4 & $46 \%$ & $61 \%$ & $78 \%$ \\
\hline Rodoanel & 193,5 & 200,7 & 207,8 & $26 \%$ & $27 \%$ & $27 \%$ \\
\hline $\begin{array}{l}\text { Proposta dos } \\
\text { especialistas }\end{array}$ & & & & & & \\
\hline
\end{tabular}

b) Etapa: compactação da camada

b1) Pré-compactação e acabamento (o rolo compactador tipo tandem inicia a compactação fazendo a acomodação inicial do material. Após a compactação propriamente dita, pelo compactador de pneus, o tandem retorna e dá o acabamento da camada)

\begin{tabular}{r|c|c|c|c|c|c}
\hline $\begin{array}{l}\text { Rolo compactador tipo } \\
\text { tandem }\end{array}$ & \multicolumn{3}{|c|}{ Produção Unitária (m2/Hserv) } & \multicolumn{3}{c}{ Hfuncionamento } \\
\hline Discriminação & 1 ㅇ Quartil & Mediana & 3 \% Quartil & 10 Quartil & Mediana & 30 Quartil \\
\hline Manuais & 286,7 & 314,6 & 342,5 & $65 \%$ & $65 \%$ & $65 \%$ \\
\hline Guarulhos & 70,9 & 92,0 & 130,8 & $46 \%$ & $63 \%$ & $90 \%$ \\
\hline Rodoanel & 193,5 & 200,7 & 207,8 & $31 \%$ & $32 \%$ & $34 \%$ \\
\hline $\begin{array}{l}\text { Proposta dos } \\
\text { especialistas }\end{array}$ & & & & & & \\
\hline
\end{tabular}

b2) Compactação da camada (após a pré-compactação, executada pelo compactador tipo tandem, o rolo compactador de pneus faz a compactação propriamente dita)

\begin{tabular}{r|c|c|c|c|c|c}
\hline $\begin{array}{l}\text { Rolo compactador de } \\
\text { pneus }\end{array}$ & \multicolumn{3}{|c|}{ Produção Unitária (m2/Hserv) } & \multicolumn{3}{c}{ Hfuncionamento } \\
\hline \multicolumn{1}{c}{ Discriminação } & 1 o Quartil & Mediana & 3 0 Quartil & 10 Quartil & Mediana & 3 o Quartil \\
\hline Manuais & 198,5 & 255,8 & 313,1 & $58 \%$ & $58 \%$ & $58 \%$ \\
\hline Guarulhos & 42,3 & 69,5 & 78,2 & $45 \%$ & $59 \%$ & $75 \%$ \\
\hline Rodoanel & 136,2 & 143,3 & 169,6 & $24 \%$ & $25 \%$ & $26 \%$ \\
\hline $\begin{array}{l}\text { Proposta dos } \\
\text { especialistas }\end{array}$ & & & & & & \\
\hline
\end{tabular}

c) Etapa: umidificação da camada (se precisar o caminhão tanque umedece a camada)

\begin{tabular}{|c|c|c|c|c|c|c|}
\hline Caminhão tanque & \multicolumn{3}{|c|}{ Produção Unitária (m2/Hserv) } & \multicolumn{3}{|c|}{ Hfuncionamento } \\
\hline Discriminação & 1Q Quartil & Mediana & 3 Quartil & 10 Quartil & Mediana & 3Q Quartil \\
\hline Manuais & 1785,7 & 1785,7 & 1785,7 & & & \\
\hline Guarulhos & & & & & & \\
\hline Rodoanel & 193,5 & 200,7 & 265,2 & $4 \%$ & $5 \%$ & $6 \%$ \\
\hline $\begin{array}{l}\text { Proposta dos } \\
\text { especialistas }\end{array}$ & & & & & & \\
\hline
\end{tabular}


Tabela 78 - Brita graduada simples - BGS com vibroacabadora - esp. até $20 \mathrm{~cm}\left(\mathrm{~m}^{2}\right)$ (conclusão)

d) Etapa: apoio

\begin{tabular}{|c|c|c|c|}
\hline Servente & \multicolumn{3}{|c|}{ Produção Unitária (m2/Hserv) } \\
\hline Discriminação & 1ㅇ Quartil & Mediana & 3 Quartil \\
\hline Manuais & 30,7 & 41,0 & 51,4 \\
\hline Guarulhos & 15,9 & 21,6 & 28,1 \\
\hline Rodoanel & 29,1 & 31,6 & 38,9 \\
\hline $\begin{array}{l}\text { Proposta dos } \\
\text { especialistas }\end{array}$ & & & \\
\hline
\end{tabular}

Tabela 79 - Síntese dos fatores e das anormalidades: Brita Graduada Simples - BGS (continua)

\begin{tabular}{|c|c|c|}
\hline Aproxima do 1ㅇ Quartil & Aproxima do 3 Quartil & Nota (0 a 10) \\
\hline \multicolumn{3}{|c|}{ CONDIÇÕES GERAIS } \\
\hline Condições climáticas instáveis & Condições climáticas estáveis & \\
\hline $\begin{array}{l}\text { Baixa capacidade efetiva do } \\
\text { equipamento (menor quantidade } \\
\text { de horas em funcionamento) }\end{array}$ & $\begin{array}{l}\text { Alta capacidade efetiva do } \\
\text { equipamento (maior quantidade } \\
\text { de horas em funcionamento) }\end{array}$ & \\
\hline $\begin{array}{l}\text { Equipamento com alta } \\
\text { manutenção durante a operação }\end{array}$ & $\begin{array}{l}\text { Equipamento com baixa } \\
\text { manutenção durante a operação }\end{array}$ & \\
\hline $\begin{array}{l}\text { Problemas com abastecimento de } \\
\text { combustível (equipamento sem } \\
\text { combustível) }\end{array}$ & $\begin{array}{l}\text { Equipamento abastecido } \\
\text { (combustível) }\end{array}$ & \\
\hline $\begin{array}{l}\text { Equipamentos em más condições } \\
\text { e descalibrados }\end{array}$ & $\begin{array}{l}\text { Equipamentos em boas condições } \\
\text { e calibrados }\end{array}$ & \\
\hline Baixa capacidade efetiva da usina & Alta capacidade efetiva da usina & \\
\hline $\begin{array}{l}\text { Baixa qualidade da massa } \\
\text { produzida na usina }\end{array}$ & $\begin{array}{l}\text { Alta qualidade da massa } \\
\text { produzida na usina }\end{array}$ & \\
\hline $\begin{array}{l}\text { Alto índice de ausência do } \\
\text { operador (faltas) }\end{array}$ & $\begin{array}{l}\text { Baixo índice de ausência do } \\
\text { operador (faltas) }\end{array}$ & \\
\hline Prevalece a improvisação & $\begin{array}{l}\text { Planeja antecipadamente as } \\
\text { atividades }\end{array}$ & \\
\hline Operador menos treinado & Operador treinado & \\
\hline $\begin{array}{l}\text { Mais tempo para executar a } \\
\text { atividade (prazos extensos) }\end{array}$ & $\begin{array}{l}\text { Pouco tempo para executar a } \\
\text { atividade (prazos enxutos) }\end{array}$ & \\
\hline $\begin{array}{l}\text { Má continuidade e sequência de } \\
\text { operações }\end{array}$ & $\begin{array}{l}\text { Boa continuidade e sequência de } \\
\text { operações }\end{array}$ & \\
\hline Menos frentes sendo atendidas & Mais frentes sendo atendidas & \\
\hline Frentes de trabalho mais distantes & Frentes de trabalho mais próximas & \\
\hline $\begin{array}{l}\text { Tarefas preliminares a executar } \\
\text { (ex. travessias) }\end{array}$ & $\begin{array}{l}\text { Tarefas preliminares prontas (ex. } \\
\text { travessias) }\end{array}$ & \\
\hline
\end{tabular}


Tabela 79 - Síntese dos fatores e das anormalidades: Brita Graduada Simples - BGS (conclusão)

\section{CONDIÇÕES ESPECÍFICAS}

\begin{tabular}{l|l|l}
\hline \multicolumn{3}{l}{ Espalhamento da BGS e nivelamento da camada } \\
\hline $\begin{array}{l}\text { Quantidade e capacidade de } \\
\text { caminhões menos compatível com } \\
\text { a frente a ser abastecida }\end{array}$ & $\begin{array}{l}\text { Quantidade e capacidade de } \\
\text { caminhões compatível com a } \\
\text { frente a ser abastecida }\end{array}$ & \\
\hline $\begin{array}{l}\text { DMT maior (demora no trajeto } \\
\text { usina/frente) }\end{array}$ & $\begin{array}{l}\text { DMT menor (rapidez no trajeto } \\
\text { usina/frente) }\end{array}$ & \\
\hline Equipe de apoio em treinamento & Equipe de apoio treinada & \\
\hline Umidificação da camada & \multicolumn{2}{|l}{} \\
\hline $\begin{array}{l}\text { Umidade dos agregados maior do } \\
\text { que a projetada }\end{array}$ & $\begin{array}{l}\text { Umidade dos agregados } \\
\text { compatível com a projetada }\end{array}$ & \\
\hline Compactação da camada & $\begin{array}{l}\text { Camadas menos espessas } \\
\text { (<10cm) }\end{array}$ & \\
\hline $\begin{array}{l}\text { Camadas mais espessas (>10cm } \\
\text { e <20cm) }\end{array}$ & $\begin{array}{l}\text { Menor deformabilidade da } \\
\text { camada inferior }\end{array}$ & \\
\hline $\begin{array}{l}\text { Maior a deformabilidade da } \\
\text { camada inferior }\end{array}$ & $\begin{array}{l}\text { Menor quantidade de passadas } \\
\text { dos compactadores (número de } \\
\text { fechas para atingir o GC) }\end{array}$ & \\
\hline $\begin{array}{l}\text { Maior quantidade de passadas } \\
\text { dos compactadores (número de } \\
\text { fechas para atingir o GC) }\end{array}$ & $\begin{array}{l}\text { Equipe de equipamentos } \\
\text { compatível (equipamentos } \\
\text { semelhantes, pesos parecidos, } \\
\text { quantidade compatível com o GC) }\end{array}$ & \\
\hline $\begin{array}{l}\text { Equipe de equipamentos menos } \\
\text { compatível (equipamentos } \\
\text { diferentes, pesos diferentes, } \\
\text { quantidade incompatível com o } \\
\text { GC) }\end{array}$ & Equipe de laboratório treinada & $\begin{array}{l}\text { Velocidade de rolagem compatível } \\
\text { com a camada }\end{array}$ \\
\hline $\begin{array}{l}\text { Equipe de laboratório menos } \\
\text { treinada }\end{array}$ & $\begin{array}{l}\text { Velocidade de rolagem menos } \\
\text { compatível com a camada }\end{array}$ & \\
\hline
\end{tabular}




\subsubsection{Brita graduada tratada com cimento - BGTC}

Tabela 80 - Brita graduada tratada com cimento - BGTC - esp. até $20 \mathrm{~cm}\left(\mathrm{~m}^{2}\right)$ (continua)

a) Etapa: espalhamento e nivelamento da BGTC (os caminhões abastecem a vibroacabadora com BGTC e esta espalha o material e nivela a camada)

\begin{tabular}{r|c|c|c|c|c|c}
\hline $\begin{array}{l}\text { Vibroacabadora de } \\
\text { Asfalto }\end{array}$ & \multicolumn{3}{|c|}{ Produção Unitária $\left(\mathrm{m}^{2} /\right.$ Hserv) } & \multicolumn{3}{c}{ Hfuncionamento } \\
\hline \multicolumn{1}{c|}{ Discriminação } & $1{ }^{\circ}$ Quartil & Mediana & 3 0 Quartil & $1^{\circ}$ Quartil & Mediana & 3 0 Quartil \\
\hline Manuais & 121,3 & 130,9 & 140,5 & $69 \%$ & $76 \%$ & $83 \%$ \\
\hline Guarulhos & 82,0 & 103,1 & 143,4 & $46 \%$ & $61 \%$ & $78 \%$ \\
\hline Rodoanel & 109,7 & 116,7 & 123,7 & $26 \%$ & $27 \%$ & $27 \%$ \\
\hline $\begin{array}{l}\text { Proposta dos } \\
\text { especialistas }\end{array}$ & & & & & & \\
\hline
\end{tabular}

b) Etapa: compactação da camada

b1) Pré-compactação e acabamento (o rolo compactador tipo tandem inicia a compactação fazendo a acomodação inicial do material. Após a compactação propriamente dita, pelo compactador de pneus, o tandem retorna e dá o acabamento da camada)

\begin{tabular}{r|c|c|c|c|c|c}
\hline $\begin{array}{l}\text { Rolo compactador tipo } \\
\text { tandem }\end{array}$ & \multicolumn{3}{|c|}{ Produção Unitária $\left(\mathrm{m}^{2} /\right.$ Hserv) } & \multicolumn{3}{c}{ Hfuncionamento } \\
\hline \multicolumn{1}{c|}{ Discriminação } & 1 o Quartil & Mediana & 3 \% Quartil & $1^{\circ}$ Quartil & Mediana & 3 \% Quartil \\
\hline Manuais & 286,7 & 314,6 & 342,5 & $65 \%$ & $65 \%$ & $65 \%$ \\
\hline Guarulhos & 70,9 & 92,0 & 130,8 & $46 \%$ & $63 \%$ & $90 \%$ \\
\hline Rodoanel & 142,3 & 182,0 & 221,7 & $31 \%$ & $32 \%$ & $34 \%$ \\
\hline $\begin{array}{l}\text { Proposta dos } \\
\text { especialistas }\end{array}$ & & & & & & \\
\hline
\end{tabular}

b2) Compactação da camada (após a pré-compactação, executada pelo compactador tipo tandem, o rolo compactador de pneus faz a compactação propriamente dita)

\begin{tabular}{|c|c|c|c|c|c|c|}
\hline $\begin{array}{l}\text { Rolo compactador de } \\
\text { pneus }\end{array}$ & Produçãc & Unitária ( & $n^{2} /$ Hserv) & & incionamer & \\
\hline Discriminação & 10 Quartil & Mediana & 3ㅇ Quartil & 10 Quartil & Mediana & 3ㅇQ Quartil \\
\hline Manuais & 198,5 & 255,8 & 313,1 & $58 \%$ & $58 \%$ & $58 \%$ \\
\hline Guarulhos & 42,3 & 69,5 & 78,2 & $45 \%$ & $59 \%$ & $75 \%$ \\
\hline Rodoanel & 142,3 & 182,0 & 221,7 & $24 \%$ & $25 \%$ & $26 \%$ \\
\hline $\begin{array}{l}\text { Proposta dos } \\
\text { especialistas }\end{array}$ & & & & & & \\
\hline
\end{tabular}

c) Etapa: umidificação da camada (se precisar o caminhão tanque umedece a camada)

\begin{tabular}{r|c|c|c|c|c|c}
\hline Caminhão tanque & \multicolumn{2}{|c|}{ Produção Unitária $\left(\mathrm{m}^{2} /\right.$ Hserv) } & \multicolumn{3}{c}{ Hfuncionamento } \\
\hline Discriminação & $1^{\circ}$ Quartil & Mediana & $3^{\circ}$ Quartil & $1^{\circ}$ Quartil & Mediana & $3^{\circ}$ Quartil \\
\hline Manuais & 1785,7 & 1785,7 & 1785,7 & & & \\
\hline Guarulhos & & & & & & \\
\hline $\begin{array}{l}\text { Rodoanel } \\
\text { Proposta dos }\end{array}$ & 142,3 & 182,0 & 221,7 & $4 \%$ & $5 \%$ & $6 \%$ \\
\hline especialistas
\end{tabular}


Tabela 80 - Brita graduada tratada com cimento - BGTC - esp. até $20 \mathrm{~cm}$ (m2) (conclusão)

d) Etapa: apoio

\begin{tabular}{|c|c|c|c|}
\hline Servente & \multicolumn{3}{|c|}{ Produção Unitária (m²/Hserv) } \\
\hline Discriminação & 1ㅇ Quartil & Mediana & 3 Quartil \\
\hline Manuais & 30,7 & 41,0 & 51,4 \\
\hline Guarulhos & 15,9 & 21,6 & 28,1 \\
\hline Rodoanel & 23,7 & 30,3 & 36,9 \\
\hline $\begin{array}{l}\text { Proposta dos } \\
\text { especialistas }\end{array}$ & & & \\
\hline
\end{tabular}

Tabela 81 - Síntese dos fatores e das anormalidades: Brita graduada tratada com cimento BGTC (continua)

\begin{tabular}{|c|c|c|}
\hline Aproxima do $1^{\circ}$ Quartil & Aproxima do 3 Quartil & Nota (0 a 10) \\
\hline \multicolumn{3}{|c|}{ CONDIÇÕES GERAIS } \\
\hline Condições climáticas instáveis & Condições climáticas estáveis & \\
\hline $\begin{array}{l}\text { Baixa capacidade efetiva do } \\
\text { equipamento (menor quantidade } \\
\text { de horas em funcionamento) }\end{array}$ & $\begin{array}{l}\text { Alta capacidade efetiva do } \\
\text { equipamento (maior quantidade } \\
\text { de horas em funcionamento) }\end{array}$ & \\
\hline $\begin{array}{l}\text { Equipamento com alta } \\
\text { manutenção durante a operação }\end{array}$ & $\begin{array}{l}\text { Equipamento com baixa } \\
\text { manutenção durante a operação }\end{array}$ & \\
\hline $\begin{array}{l}\text { Problemas com abastecimento de } \\
\text { combustível (equipamento sem } \\
\text { combustível) }\end{array}$ & $\begin{array}{l}\text { Equipamento abastecido } \\
\text { (combustível) }\end{array}$ & \\
\hline $\begin{array}{l}\text { Equipamentos em más condições } \\
\text { e descalibrados }\end{array}$ & $\begin{array}{l}\text { Equipamentos em boas condições } \\
\text { e calibrados }\end{array}$ & \\
\hline Baixa capacidade efetiva da usina & Alta capacidade efetiva da usina & \\
\hline $\begin{array}{l}\text { Baixa qualidade da massa } \\
\text { produzida na usina }\end{array}$ & $\begin{array}{l}\text { Alta qualidade da massa } \\
\text { produzida na usina }\end{array}$ & \\
\hline $\begin{array}{l}\text { Alto índice de ausência do } \\
\text { operador (faltas) }\end{array}$ & $\begin{array}{l}\text { Baixo índice de ausência do } \\
\text { operador (faltas) }\end{array}$ & \\
\hline Prevalece a improvisação & $\begin{array}{l}\text { Planeja antecipadamente as } \\
\text { atividades }\end{array}$ & \\
\hline Operador menos treinado & Operador treinado & \\
\hline $\begin{array}{l}\text { Mais tempo para executar a } \\
\text { atividade (prazos extensos) }\end{array}$ & $\begin{array}{l}\text { Pouco tempo para executar a } \\
\text { atividade (prazos enxutos) }\end{array}$ & \\
\hline $\begin{array}{l}\text { Má continuidade e sequência de } \\
\text { operações }\end{array}$ & $\begin{array}{l}\text { Boa continuidade e sequência de } \\
\text { operações }\end{array}$ & \\
\hline Menos frentes sendo atendidas & Mais frentes sendo atendidas & \\
\hline Frentes de trabalho mais distantes & Frentes de trabalho mais próximas & \\
\hline $\begin{array}{l}\text { Tarefas preliminares a executar } \\
\text { (ex. travessias) }\end{array}$ & $\begin{array}{l}\text { Tarefas preliminares prontas (ex. } \\
\text { travessias) }\end{array}$ & \\
\hline
\end{tabular}


Tabela 81 - Síntese dos fatores e das anormalidades: Brita graduada tratada com cimento BGTC (conclusão)

\begin{tabular}{|c|c|c|}
\hline \multicolumn{2}{|c|}{ CONDIÇÕES ESPECÍFICAS } & \\
\hline \multicolumn{3}{|c|}{ Espalhamento da BGTC e nivelamento da camada } \\
\hline $\begin{array}{l}\text { Quantidade e capacidade de } \\
\text { caminhões menos compatível com } \\
\text { a frente a ser abastecida }\end{array}$ & $\begin{array}{l}\text { Quantidade e capacidade de } \\
\text { caminhões compatível com a } \\
\text { frente a ser abastecida }\end{array}$ & \\
\hline $\begin{array}{l}\text { DMT maior (demora no trajeto } \\
\text { usina/frente) }\end{array}$ & $\begin{array}{l}\text { DMT menor (rapidez no trajeto } \\
\text { usina/frente) }\end{array}$ & \\
\hline Equipe de apoio em treinamento & Equipe de apoio treinada & \\
\hline \multicolumn{3}{|l|}{ Umidificação da camada } \\
\hline $\begin{array}{l}\text { Umidade dos agregados maior do } \\
\text { que a projetada }\end{array}$ & $\begin{array}{l}\text { Umidade dos agregados } \\
\text { compatível com a projetada }\end{array}$ & \\
\hline \multicolumn{3}{|l|}{ Compactação da camada } \\
\hline $\begin{array}{l}\text { Camadas mais espessas }(>10 \mathrm{~cm} \\
\mathrm{e}<20 \mathrm{~cm})\end{array}$ & $\begin{array}{l}\text { Camadas menos espessas } \\
(<10 \mathrm{~cm})\end{array}$ & \\
\hline $\begin{array}{l}\text { Maior a deformabilidade da } \\
\text { camada inferior }\end{array}$ & $\begin{array}{l}\text { Menor deformabilidade da } \\
\text { camada inferior }\end{array}$ & \\
\hline $\begin{array}{l}\text { Maior quantidade de passadas } \\
\text { dos compactadores (número de } \\
\text { fechas para atingir o GC) }\end{array}$ & $\begin{array}{l}\text { Menor quantidade de passadas } \\
\text { dos compactadores (número de } \\
\text { fechas para atingir o GC) }\end{array}$ & \\
\hline $\begin{array}{l}\text { Equipe de equipamentos menos } \\
\text { compatível (equipamentos } \\
\text { diferentes, pesos diferentes, } \\
\text { quantidade incompatível com o } \\
\text { GC) }\end{array}$ & $\begin{array}{l}\text { Equipe de equipamentos } \\
\text { compatível (equipamentos } \\
\text { semelhantes, pesos parecidos, } \\
\text { quantidade compatível com o GC) }\end{array}$ & \\
\hline $\begin{array}{l}\text { Equipe de laboratório menos } \\
\text { treinada }\end{array}$ & Equipe de laboratório treinada & \\
\hline $\begin{array}{l}\text { Velocidade de rolagem menos } \\
\text { compatível com a camada }\end{array}$ & $\begin{array}{l}\text { Velocidade de rolagem compatível } \\
\text { com a camada }\end{array}$ & \\
\hline
\end{tabular}




\subsubsection{Concreto betuminoso usinado a quente}

Tabela 82 - Concreto betuminoso usinado a quente - capa ou binder - esp. até $5 \mathrm{~cm}\left(\mathrm{~m}^{2}\right)$ (continua)

a) Etapa: espalhamento e nivelamento do revestimento asfáltico (os caminhões abastecem a vibroacabadora e esta espalha o material e nivela a camada)

\begin{tabular}{r|c|c|c|c|c|c}
\hline $\begin{array}{l}\text { Vibroacabadora de } \\
\text { Asfalto }\end{array}$ & \multicolumn{3}{|c|}{ Produção Unitária (m2/Hserv) } & \multicolumn{3}{c}{ Hfuncionamento } \\
\hline \multicolumn{1}{c|}{ Discriminação } & $1^{\circ}$ Quartil & Mediana & $3^{\circ}$ Quartil & $1^{\circ}$ Quartil & Mediana & 30 Quartil \\
\hline Manuais (capa) & 624,0 & 832,9 & 1344,4 & $44 \%$ & $64 \%$ & $88 \%$ \\
\hline Manuais (binder) & 665,3 & 1227,3 & 2422,2 & $72 \%$ & $93 \%$ & $95 \%$ \\
\hline Guarulhos & 229,5 & 272,4 & 407,0 & $87 \%$ & $100 \%$ & $100 \%$ \\
\hline Rodoanel & 128,3 & 185,6 & 283,6 & $12 \%$ & $16 \%$ & $24 \%$ \\
\hline $\begin{array}{l}\text { Proposta dos } \\
\text { especialistas }\end{array}$ & & & & & & \\
\hline
\end{tabular}

b) Etapa: Compactação da camada

b1) Pré-compactação e acabamento (o rolo compactador tipo tandem inicia a compactação fazendo a acomodação inicial do material. Após a compactação propriamente dita, pelo compactador de pneus, o tandem retorna e dá o acabamento da camada)

\begin{tabular}{r|c|c|c|c|c|c}
\hline $\begin{array}{l}\text { Rolo compactador tipo } \\
\text { tandem }\end{array}$ & \multicolumn{3}{|c|}{ Produção Unitária (m2/Hserv) } & \multicolumn{3}{c}{ Hfuncionamento } \\
\hline Discriminação & $11^{\circ}$ Quartil & Mediana & 3 \% Quartil & 1 ㅇ Quartil & Mediana & 30 Quartil \\
\hline Manuais (capa) & 576,0 & 960,0 & 1364,6 & $56 \%$ & $80 \%$ & $90 \%$ \\
\hline Manuais (binder) & 665,3 & 1103,0 & 2700,3 & $80 \%$ & $90 \%$ & $94 \%$ \\
\hline Guarulhos & 193,7 & 249,6 & 420,1 & $75 \%$ & $100 \%$ & $100 \%$ \\
\hline Rodoanel & 684,0 & 960,0 & 1368,0 & $12 \%$ & $14 \%$ & $25 \%$ \\
\hline $\begin{array}{l}\text { Proposta dos } \\
\text { especialistas }\end{array}$ & & & & & & \\
\hline
\end{tabular}

b2) Compactação da camada (após a pré-compactação, executada pelo compactador tipo tandem, o rolo compactador de pneus faz a compactação propriamente dita)

\begin{tabular}{r|c|c|c|c|c|c}
\hline $\begin{array}{l}\text { Rolo compactador de } \\
\text { pneus }\end{array}$ & \multicolumn{2}{|c|}{ Produção Unitária (m2/Hserv) } & \multicolumn{3}{c}{ Hfuncionamento } \\
\hline \multicolumn{1}{c}{ Discriminação } & $1^{\circ}$ Quartil & Mediana & $3^{\circ}$ Quartil & 1을 Quartil & Mediana & $3^{\circ}$ Quartil \\
\hline Manuais (capa) & 553,9 & 688,9 & 1020,0 & $27 \%$ & $40 \%$ & $84 \%$ \\
\hline Manuais (binder) & 617,7 & 653,8 & 2020,7 & $64 \%$ & $97 \%$ & $98 \%$ \\
\hline Guarulhos & 60,6 & 101,8 & 144,3 & $100 \%$ & $100 \%$ & $100 \%$ \\
\hline Rodoanel & 528,0 & 684,0 & 738,0 & $14 \%$ & $16 \%$ & $35 \%$ \\
\hline $\begin{array}{l}\text { Proposta dos } \\
\text { especialistas }\end{array}$ & & & & & &
\end{tabular}


Tabela 82 - Concreto betuminoso usinado a quente - capa ou binder - esp. até $5 \mathrm{~cm}\left(\mathrm{~m}^{2}\right)$ (conclusão)

c) Etapa: apoio

c1) Fornecimento de óleo (um caminhão tanque fica à disposição para fornecer óleo para a frente de serviço)

\begin{tabular}{r|c|c|c|c|c|c}
\hline $\begin{array}{l}\text { Caminhão para } \\
\text { abastecimento }\end{array}$ & \multicolumn{2}{|c|}{ Produção Unitária (m2/Hserv) } & \multicolumn{3}{c}{ Hfuncionamento } \\
\hline Discriminação & $1{ }^{\circ}$ Quartil & Mediana & 30 Quartil & $1^{\circ}$ Quartil & Mediana & $3^{\text {0 Quartil }}$ \\
\hline Manuais (capa) & & & & & & \\
\hline Manuais (binder) & & & & & & \\
\hline Guarulhos & & & & & & \\
\hline Rodoanel & 1322,7 & 1346,0 & 1389,3 & $18 \%$ & $18 \%$ & $18 \%$ \\
\hline $\begin{array}{l}\text { Proposta dos } \\
\text { especialistas }\end{array}$ & & & & & & \\
\hline
\end{tabular}

c2) Limpeza (antes dos rolos compactadores entrarem na pista a ser pavimentada, eles são lavados ou limpados)

\begin{tabular}{r|c|c|c|c|c|c}
\hline $\begin{array}{l}\text { Trator agrícola com } \\
\text { compressor }\end{array}$ & \multicolumn{3}{|c|}{ Produção Unitária (m2/Hserv) } & \multicolumn{3}{c}{ Hfuncionamento } \\
\hline Discriminação & $1^{\circ}$ Quartil & Mediana & $3^{\circ}$ Quartil & $1^{\circ}$ Quartil & Mediana & $3^{\circ}$ Quartil \\
\hline Manuais (capa) & 14563,1 & 14563,1 & 14563,1 & $97 \%$ & $97 \%$ & $97 \%$ \\
\hline Manuais (binder) & 14563,1 & 14563,1 & 14563,1 & $97 \%$ & $97 \%$ & $97 \%$ \\
\hline Guarulhos & & & & & & \\
\hline Rodoanel & 960,0 & 1368,0 & 1368,0 & $13 \%$ & $13 \%$ & $13 \%$ \\
\hline $\begin{array}{l}\text { Proposta dos } \\
\text { especialistas }\end{array}$ & & & & & & \\
\hline
\end{tabular}

c3) Fornecimento de água para os compactadores lisos (um caminhão tanque fica à disposição para fornecer água para os compactadores lisos)

\begin{tabular}{r|c|c|c|c|c|c}
\hline Caminhão tanque & \multicolumn{2}{|c|}{ Produção Unitária (m2/Hserv) } & \multicolumn{3}{c}{ Hfuncionamento } \\
\hline Discriminação & $1^{\circ}$ Quartil & Mediana & $3^{\circ}$ Quartil & 10 Quartil & Mediana & $3^{\circ}$ Quartil \\
\hline Manuais & & & & & & \\
\hline Guarulhos & & & & & & \\
\hline $\begin{array}{l}\text { Rodoanel } \\
\text { especialistas }\end{array}$ & 684,0 & 960,0 & 1368,0 & $8 \%$ & $9 \%$ & $11 \%$ \\
\hline
\end{tabular}

c4) Apoio

\begin{tabular}{r|c|c|c|}
\hline \multicolumn{1}{l|}{ Servente } & \multicolumn{3}{|c|}{ Produção Unitária $\left(\mathrm{m}^{2} /\right.$ Hserv) } \\
\hline Discriminação & 10 Quartil & Mediana & $3^{\circ}$ Quartil \\
\hline Manuais (capa) & 115,4 & 464,9 & 744,0 \\
\hline Manuais (binder) & 135,2 & 225,3 & 348,8 \\
\hline Guarulhos & 24,5 & 45,3 & 57,8 \\
\hline $\begin{array}{l}\text { Rodoanel } \\
\text { Proposta dos }\end{array}$ & 83,1 & 97,7 & 126,2 \\
\hline
\end{tabular}


Tabela 83 - Síntese dos fatores e das anormalidades: CBUQ (continua)

\begin{tabular}{|c|c|c|}
\hline Aproxima do 1 Quartil & Aproxima do 3 Quartil & Nota (0 a 10) \\
\hline \multicolumn{3}{|c|}{ CONDIÇÕES GERAIS } \\
\hline Condições climáticas instáveis & Condições climáticas estáveis & \\
\hline $\begin{array}{l}\text { Baixa capacidade efetiva da usina } \\
\text { (menor quantidade de horas em } \\
\text { funcionamento) }\end{array}$ & $\begin{array}{l}\text { Alta capacidade efetiva da usina } \\
\text { (maior quantidade de horas em } \\
\text { funcionamento) }\end{array}$ & \\
\hline $\begin{array}{l}\text { Baixa qualidade da massa } \\
\text { produzida na usina }\end{array}$ & $\begin{array}{l}\text { Alta qualidade da massa } \\
\text { produzida na usina }\end{array}$ & \\
\hline $\begin{array}{l}\text { Há dificuldade em se manter a } \\
\text { temperatura da mistura asfáltica } \\
\text { conforme parâmetros de projeto }\end{array}$ & $\begin{array}{l}\text { Mantém a temperatura da mistura } \\
\text { asfáltica conforme parâmetros de } \\
\text { projeto }\end{array}$ & \\
\hline $\begin{array}{l}\text { Baixa capacidade efetiva do } \\
\text { equipamento (menor quantidade } \\
\text { de horas em funcionamento) }\end{array}$ & $\begin{array}{l}\text { Alta capacidade efetiva do } \\
\text { equipamento (maior quantidade } \\
\text { de horas em funcionamento) }\end{array}$ & \\
\hline $\begin{array}{l}\text { Equipamento com alta } \\
\text { manutenção durante a operação }\end{array}$ & $\begin{array}{l}\text { Equipamento com baixa } \\
\text { manutenção durante a operação }\end{array}$ & \\
\hline $\begin{array}{l}\text { Problemas com abastecimento de } \\
\text { combustível (equipamento sem } \\
\text { combustível) }\end{array}$ & $\begin{array}{l}\text { Equipamento abastecido } \\
\text { (combustível) }\end{array}$ & \\
\hline $\begin{array}{l}\text { Equipamentos em más condições } \\
\text { e descalibrados }\end{array}$ & $\begin{array}{l}\text { Equipamentos em boas condições } \\
\text { e calibrados }\end{array}$ & \\
\hline $\begin{array}{l}\text { Alto índice de ausência do } \\
\text { operador (faltas) }\end{array}$ & $\begin{array}{l}\text { Baixo índice de ausência do } \\
\text { operador (faltas) }\end{array}$ & \\
\hline Prevalece a improvisação & $\begin{array}{l}\text { Planeja antecipadamente as } \\
\text { atividades }\end{array}$ & \\
\hline Operador menos treinado & Operador treinado & \\
\hline $\begin{array}{l}\text { Mais tempo para executar a } \\
\text { atividade (prazos extensos) }\end{array}$ & $\begin{array}{l}\text { Pouco tempo para executar a } \\
\text { atividade (prazos enxutos) }\end{array}$ & \\
\hline $\begin{array}{l}\text { Má continuidade e sequência de } \\
\text { operações }\end{array}$ & $\begin{array}{l}\text { Boa continuidade e sequência de } \\
\text { operações }\end{array}$ & \\
\hline Menos frentes sendo atendidas & Mais frentes sendo atendidas & \\
\hline Frentes mais distantes & Frentes mais próximas & \\
\hline $\begin{array}{l}\text { Tarefas preliminares a executar } \\
\text { (ex. pintura de ligação) }\end{array}$ & $\begin{array}{l}\text { Tarefas preliminares prontas (ex. } \\
\text { pintura de ligação) }\end{array}$ & \\
\hline
\end{tabular}

\section{CONDIÇÕES ESPECÍFICAS}

\section{Espalhamento e nivelamento do revestimento asfáltico}

\begin{tabular}{l|l|l}
\hline $\begin{array}{l}\text { Quantidade e capacidade de } \\
\text { caminhões menos compatível com } \\
\text { a frente a ser abastecida }\end{array}$ & $\begin{array}{l}\text { Quantidade e capacidade de } \\
\text { caminhões compatível com a } \\
\text { frente a ser abastecida }\end{array}$ & \\
\hline $\begin{array}{l}\text { DMT maior (demora no trajeto } \\
\text { usina/frente) }\end{array}$ & $\begin{array}{l}\text { DMT menor (rapidez no trajeto } \\
\text { usina/frente) }\end{array}$ & \\
\hline Equipe de apoio em treinamento & Equipe de apoio treinada &
\end{tabular}


Tabela 83 - Síntese dos fatores e das anormalidades: CBUQ (conclusão)

\section{Compactação da camada}

\begin{tabular}{|c|c|}
\hline $\begin{array}{l}\text { Camadas mais espessas }(>2,5 \mathrm{~cm} \\
\mathrm{e}<5 \mathrm{~cm})\end{array}$ & $\begin{array}{l}\text { Camadas menos espessas } \\
(<2,5 \mathrm{~cm})\end{array}$ \\
\hline $\begin{array}{l}\text { Maior a deformabilidade da } \\
\text { camada inferior }\end{array}$ & $\begin{array}{l}\text { Menor deformabilidade da } \\
\text { camada inferior }\end{array}$ \\
\hline $\begin{array}{l}\text { Maior quantidade de passadas } \\
\text { dos compactadores (número de } \\
\text { fechas para atingir o GC) }\end{array}$ & $\begin{array}{l}\text { Menor quantidade de passadas } \\
\text { dos compactadores (número de } \\
\text { fechas para atingir o GC) }\end{array}$ \\
\hline $\begin{array}{l}\text { Equipe de equipamentos menos } \\
\text { compatível (equipamentos } \\
\text { diferentes, pesos diferentes, } \\
\text { quantidade incompatível com o } \\
\text { GC) }\end{array}$ & $\begin{array}{l}\text { Equipe de equipamentos } \\
\text { compatível (equipamentos } \\
\text { semelhantes, pesos parecidos, } \\
\text { quantidade compatível com o GC) }\end{array}$ \\
\hline $\begin{array}{l}\text { Equipe de laboratório menos } \\
\text { treinada }\end{array}$ & Equipe de laboratório treinada \\
\hline $\begin{array}{l}\text { Velocidade de rolagem menos } \\
\text { compatível com a camada }\end{array}$ & $\begin{array}{l}\text { Velocidade de rolagem compatível } \\
\text { com a camada }\end{array}$ \\
\hline
\end{tabular}

\subsubsection{Imprimação}

Tabela 84 - Imprimação $\left(\mathrm{m}^{2}\right)$

a) Etapa: limpeza (antes da execução da imprimação uma limpeza da pista é realizada)

\begin{tabular}{r|c|c|c|c|c|c}
\hline $\begin{array}{l}\text { Trator agrícola com } \\
\text { vassoura mecânica }\end{array}$ & \multicolumn{2}{|c|}{ Produção Unitária (m²/Hserv) } & \multicolumn{3}{c}{ Hfuncionamento } \\
\hline Discriminação & $1^{\circ}$ Quartil & Mediana & $3^{\circ}$ Quartil & $1^{\circ}$ Quartil & Mediana & $3^{\circ}$ Quartil \\
\hline Manuais & 1865,1 & 2322,2 & 2779,2 & $53 \%$ & $68 \%$ & $82 \%$ \\
\hline Guarulhos & & & & & & \\
\hline $\begin{array}{r}\text { Rodoanel } \\
\text { Proposta dos }\end{array}$ & & & & & & \\
\hline
\end{tabular}

b) Etapa: lançamento de cobertura

\begin{tabular}{|c|c|c|c|c|c|c|}
\hline Caminhão espargidor & \multicolumn{3}{|c|}{ Produção Unitária ( $\left.\mathrm{m}^{2} / \mathrm{Hserv}\right)$} & \multicolumn{3}{|c|}{ Hfuncionamento } \\
\hline Discriminação & 1ㅇ Quartil & Mediana & 3ㅇ Quartil & 1ㅇQ Quartil & Mediana & 3ํ Quartil \\
\hline Manuais & 270,3 & 416,7 & 1078,7 & $42 \%$ & $61 \%$ & $79 \%$ \\
\hline Guarulhos & 152,8 & 214,4 & 378,3 & $6 \%$ & $8 \%$ & $13 \%$ \\
\hline Rodoanel & 215,0 & 243,7 & 315,3 & & $6 \%$ & \\
\hline $\begin{array}{l}\text { Proposta dos } \\
\text { especialistas }\end{array}$ & & & & & & \\
\hline Servente & \multicolumn{3}{|c|}{ Produção Unitária (m²/Hserv) } & & & \\
\hline Discriminação & 1Q Quartil & Mediana & 3 Quartil & & & \\
\hline Manuais & 169,5 & 234,7 & 246,9 & & & \\
\hline Guarulhos & 158,1 & 224,9 & 261,3 & & & \\
\hline Rodoanel & 215,0 & 243,7 & 315,3 & & & \\
\hline $\begin{array}{l}\text { Proposta dos } \\
\text { especialistas }\end{array}$ & & & & & & \\
\hline
\end{tabular}


Tabela 85 - Síntese dos fatores e das anormalidades: Imprimação

\begin{tabular}{|c|c|c|}
\hline Aproxima do $1^{\circ}$ Quartil & Aproxima do 3 Quartil & Nota (0 a 10) \\
\hline Condições climáticas instáveis & Condições climáticas estáveis & \\
\hline $\begin{array}{l}\text { Baixa capacidade efetiva do } \\
\text { equipamento (menor quantidade } \\
\text { de horas em funcionamento) }\end{array}$ & $\begin{array}{l}\text { Alta capacidade efetiva do } \\
\text { equipamento (maior quantidade } \\
\text { de horas em funcionamento) }\end{array}$ & \\
\hline $\begin{array}{l}\text { Equipamento com alta } \\
\text { manutenção durante a operação }\end{array}$ & $\begin{array}{l}\text { Equipamento com baixa } \\
\text { manutenção durante a operação }\end{array}$ & \\
\hline $\begin{array}{l}\text { Problemas com abastecimento de } \\
\text { combustível (equipamento sem } \\
\text { combustível) }\end{array}$ & $\begin{array}{l}\text { Equipamento abastecido } \\
\text { (combustível) }\end{array}$ & \\
\hline $\begin{array}{l}\text { Equipamentos em más condições } \\
\text { e descalibrados }\end{array}$ & $\begin{array}{l}\text { Equipamentos em boas condições } \\
\text { e calibrados }\end{array}$ & \\
\hline $\begin{array}{l}\text { Há dificuldade em se manter a } \\
\text { temperatura da solução conforme } \\
\text { parâmetros de projeto }\end{array}$ & $\begin{array}{l}\text { Mantém a temperatura da solução } \\
\text { conforme parâmetros de projeto }\end{array}$ & \\
\hline $\begin{array}{l}\text { Alto índice de ausência do } \\
\text { operador (faltas) }\end{array}$ & $\begin{array}{l}\text { Baixo índice de ausência do } \\
\text { operador (faltas) }\end{array}$ & \\
\hline Prevalece a improvisação & $\begin{array}{l}\text { Planeja antecipadamente as } \\
\text { atividades }\end{array}$ & \\
\hline Operador menos treinado & Operador treinado & \\
\hline $\begin{array}{l}\text { Equipe de laboratório menos } \\
\text { treinada }\end{array}$ & Equipe de laboratório treinada & \\
\hline $\begin{array}{l}\text { Má continuidade e sequência de } \\
\text { operações }\end{array}$ & $\begin{array}{l}\text { Boa continuidade e sequência de } \\
\text { operações }\end{array}$ & \\
\hline $\begin{array}{l}\text { Velocidade de aplicação menos } \\
\text { compatível com a camada }\end{array}$ & $\begin{array}{l}\text { Velocidade de aplicação } \\
\text { compatível com a camada }\end{array}$ & \\
\hline Menos frentes sendo atendidas & Mais frentes sendo atendidas & \\
\hline $\begin{array}{l}\text { Tarefas preliminares a executar } \\
\text { (ex. base a ser revestida) }\end{array}$ & $\begin{array}{l}\text { Tarefas preliminares prontas (ex. } \\
\text { base a ser revestida) }\end{array}$ & \\
\hline
\end{tabular}




\subsubsection{Pintura de ligação}

Tabela 86 - Pintura de ligação $\left(\mathrm{m}^{2}\right)$

a) Etapa: limpeza (antes da pintura de ligação uma limpeza da pista é realizada)

\begin{tabular}{r|c|c|c|c|c|c}
\hline $\begin{array}{l}\text { Trator agrícola com } \\
\text { vassoura mecânica }\end{array}$ & \multicolumn{2}{|c|}{ Produção Unitária $\left(\mathrm{m}^{2} / \mathrm{Hserv}\right)$} & \multicolumn{3}{c}{ Hfuncionamento } \\
\hline Discriminação & $1^{\circ}$ Quartil & Mediana & $3^{\circ}$ Quartil & $1^{\circ}$ Quartil & Mediana & 3 0 Quartil \\
\hline Manuais & 2094,3 & 2188,7 & 2344,3 & $59 \%$ & $59 \%$ & $59 \%$ \\
\hline Guarulhos & & & & & & \\
\hline Rodoanel & & & & & & \\
\hline $\begin{array}{l}\text { Proposta dos } \\
\text { especialistas }\end{array}$ & & & & & & \\
\hline
\end{tabular}

b) Etapa: lançamento de cobertura

\begin{tabular}{|c|c|c|c|c|c|c|}
\hline Caminhão espargidor & \multicolumn{3}{|c|}{ Produção Unitária ( $\left.\mathrm{m}^{2} / \mathrm{Hserv}\right)$} & \multicolumn{3}{|c|}{ Hfuncionamento } \\
\hline Discriminação & 10 Quartil & Mediana & 3 Quartil & 1ㅇ Quartil & Mediana & 3Q Quartil \\
\hline Manuais & 253,4 & 862,8 & 1989,2 & $35 \%$ & $56 \%$ & $77 \%$ \\
\hline Guarulhos & 158,1 & 224,9 & 261,3 & $11 \%$ & $13 \%$ & $16 \%$ \\
\hline Rodoanel & 215,0 & 243,7 & 315,3 & & $6 \%$ & \\
\hline \multicolumn{7}{|l|}{$\begin{array}{l}\text { Proposta dos } \\
\text { especialistas }\end{array}$} \\
\hline Servente & \multicolumn{3}{|c|}{ Produção Unitária $\left(\mathrm{m}^{2} / \mathrm{Hserv}\right)$} & & & \\
\hline Discriminação & 10 Quartil & Mediana & 3 Quartil & & & \\
\hline Manuais & 222,5 & 268,8 & 345,0 & & & \\
\hline Guarulhos & 158,1 & 224,9 & 261,3 & & & \\
\hline Rodoanel & 215,0 & 243,7 & 315,3 & & & \\
\hline $\begin{array}{l}\text { Proposta dos } \\
\text { especialistas }\end{array}$ & & & & & & \\
\hline
\end{tabular}

Tabela 87 - Síntese dos fatores e das anormalidades: Pintura de ligação (continua)

\begin{tabular}{l|l|l}
\hline \multicolumn{1}{c|}{ Aproxima do 1 Quartil } & \multicolumn{1}{c}{ Aproxima do 30 Quartil } & Nota (0 a 10) \\
\hline Condições climáticas instáveis & Condições climáticas estáveis & \\
\hline $\begin{array}{l}\text { Baixa capacidade efetiva do } \\
\text { equipamento (menor quantidade } \\
\text { de horas em funcionamento) }\end{array}$ & $\begin{array}{l}\text { Alta capacidade efetiva do } \\
\text { equipamento (maior quantidade } \\
\text { de horas em funcionamento) }\end{array}$ & \\
\hline $\begin{array}{l}\text { Equipamento com alta } \\
\text { manutenção durante a operação }\end{array}$ & $\begin{array}{l}\text { Equipamento com baixa } \\
\text { manutenção durante a operação }\end{array}$ & \\
\hline $\begin{array}{l}\text { Problemas com abastecimento de } \\
\text { combustível (equipamento sem } \\
\text { combustível) }\end{array}$ & $\begin{array}{l}\text { Equipamento abastecido } \\
\text { (combustível) }\end{array}$ & \\
\hline $\begin{array}{l}\text { Equipamentos em más condições } \\
\text { e descalibrados }\end{array}$ & $\begin{array}{l}\text { Equipamentos em boas condições } \\
\text { e calibrados }\end{array}$ &
\end{tabular}


Tabela 87 - Síntese dos fatores e das anormalidades: Pintura de ligação (conclusão)

\begin{tabular}{|c|c|}
\hline $\begin{array}{l}\text { Há dificuldade em se manter a } \\
\text { temperatura da mistura asfáltica } \\
\text { conforme parâmetros de projeto }\end{array}$ & $\begin{array}{l}\text { Mantém a temperatura da solução } \\
\text { conforme parâmetros de projeto }\end{array}$ \\
\hline $\begin{array}{l}\text { Alto índice de ausência do } \\
\text { operador (faltas) }\end{array}$ & $\begin{array}{l}\text { Baixo índice de ausência do } \\
\text { operador (faltas) }\end{array}$ \\
\hline Prevalece a improvisação & $\begin{array}{l}\text { Planeja antecipadamente as } \\
\text { atividades }\end{array}$ \\
\hline Operador menos treinado & Operador treinado \\
\hline $\begin{array}{l}\text { Equipe de laboratório menos } \\
\text { treinada }\end{array}$ & Equipe de laboratório treinada \\
\hline $\begin{array}{l}\text { Má continuidade e sequência de } \\
\text { operações }\end{array}$ & $\begin{array}{l}\text { Boa continuidade e sequência de } \\
\text { operações }\end{array}$ \\
\hline $\begin{array}{l}\text { Velocidade de rolagem menos } \\
\text { compatível com a camada }\end{array}$ & $\begin{array}{l}\text { Velocidade de rolagem compatível } \\
\text { com a camada }\end{array}$ \\
\hline Menos frentes sendo atendidas & Mais frentes sendo atendidas \\
\hline $\begin{array}{l}\text { Tarefas preliminares a executar } \\
\text { (ex. base a ser revestida) }\end{array}$ & $\begin{array}{l}\text { Tarefas preliminares prontas (ex. } \\
\text { base a ser revestida) }\end{array}$ \\
\hline
\end{tabular}

\subsection{Reflexões do Capítulo 8}

A definição dos especialista foi uma tarefa difícil (procurou-se por especialistas que tinham experiência comprovada na área da pesquisa) e para aumentar a chance de sucesso, algumas indicações surgiram por parte dos próprios especialistas.

Outra questão foi motivar a participação de todos os especialistas, o que em partes não surtiu muito efeito, pois, de quatorze consultados somente sete participaram efetivamente na pesquisa.

A grande variabilidade dos indicadores de produtividade (PU), apresentados pelos manuais e estudos de caso, foi um desafio a mais.

Ao final, percebeu que é importante agrupar especialistas conforme as obras e/ou serviços de sua especialidade. 


\section{MÉTODO PARA PROGNÓSTICO DA PRODUTIVIDADE}

Este capítulo visa apresentar as faixas de valores e fatores influenciadores relativos à produtividade variável, para equipamentos (junto com os operadores) e mão de obra (ajudantes diretos). Trata-se do método para prognóstico da produtividade na execução de rodovias: terraplenagem e pavimentação asfáltica.

\subsection{Algumas Reflexões Sobre o Método}

Conforme se apresenta na Figura 54, várias etapas foram vencidas até a proposição deste "Método".

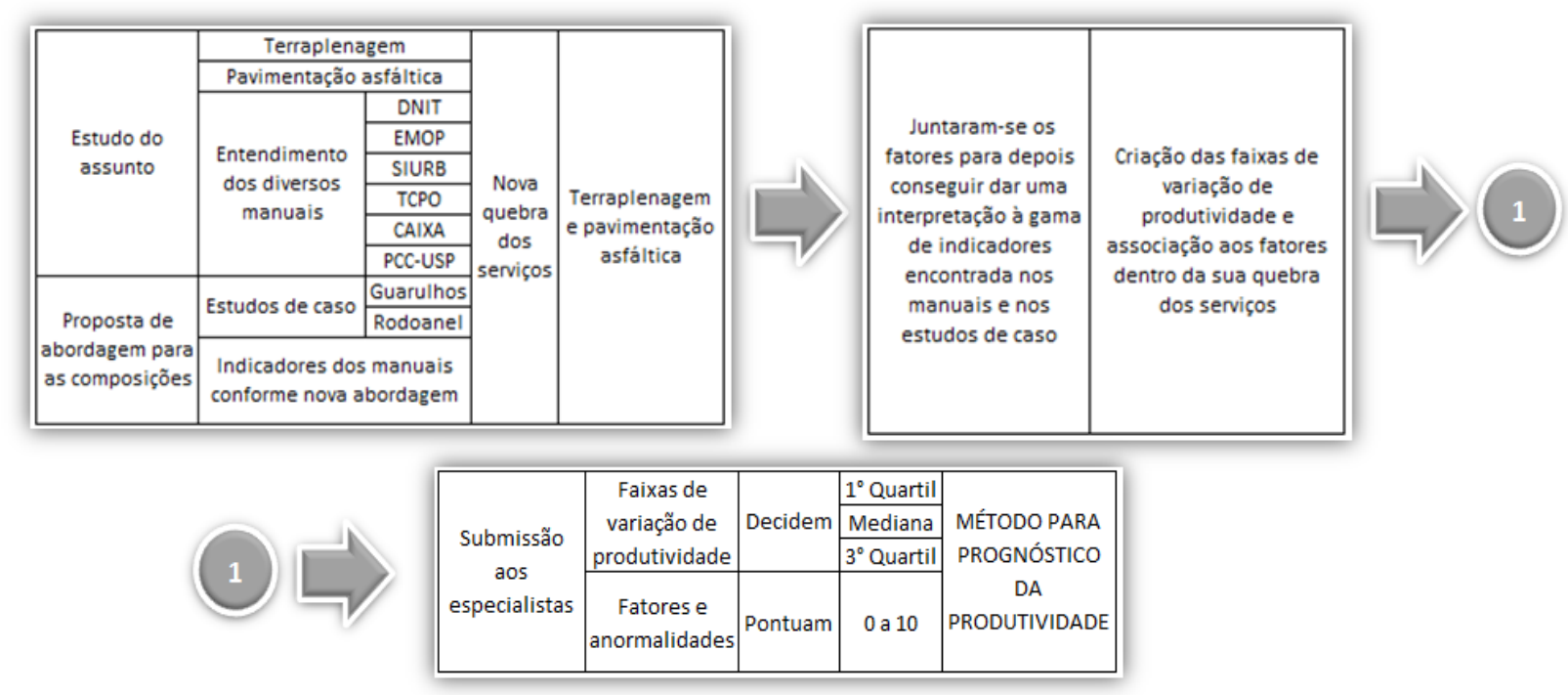

Figura 54 - Etapas para o desenvolvimento do método.

Estudou-se o assunto (bibliografia, manuais e estudos de caso). Verificou-se como os serviços eram tratados/quebrados pelos manuais. Propôs-se uma nova quebra destes serviços. Uma proposta de abordagem para as composições foi efetuada. Os indicadores dos manuais foram adequados de acordo com esta proposta. Faixas contemplando a produtividade variável $\left(1^{\circ}\right.$ quartil, mediana, $3^{\circ}$ quartil), referentes aos manuais e estudos de caso, foram desenvolvidas. Com base em todo $o$ aprendizado adquirido identificaram-se as anormalidades e os fatores que fazem a produtividade destas faixas variar. Este estudo foi apresentado aos especialistas, que opinaram sobre os indicadores e pontuaram as anormalidades e fatores. $O$ resultado desta pesquisa gerou o método para 0 
prognóstico da produtividade na execução de rodovias com ênfase na terraplenagem e pavimentação asfáltica.

\subsection{Abrangência do Método}

Os serviços, de terraplenagem e pavimentação asfáltica, abrangidos por este método são descritos como segue:

a) Escavação de material de $1^{\text {a }}$ categoria com trator de esteiras;

b) Escavação de material de 1ํㅡ categoria com escavadeira hidráulica;

c) Compactação de aterro - espessura até $30 \mathrm{~cm}$;

d) Base de solo cimento com mistura na pista - esp. até $20 \mathrm{~cm}$;

e) Brita graduada simples - BGS com distribuidor de agregados - esp. até $20 \mathrm{~cm}$;

f) Brita graduada simples - BGS com vibroacabadora - esp. até $20 \mathrm{~cm}$;

g) Brita graduada tratada com cimento - BGTC - esp. até $20 \mathrm{~cm}$;

h) Concreto betuminoso usinado a quente - capa ou binder - esp. até $5 \mathrm{~cm}$;

i) Imprimação;

j) Pintura de ligação.

\subsection{Escavação de Material de 1ª Categoria}

Fazem parte deste serviço a escavação e carga de materiais de 1ª categoria. Em termos dos diferentes equipamentos para a escavação, os valores a serem mostrados contemplam o trator de esteira e a escavadeira hidráulica.

O assunto será tratado separando a escavação em função destes dois equipamentos. Para cada grupo discutem-se a produção unitária dos equipamentos e da mão de obra.

As faixas de valores de produção unitária dos equipamentos, mostradas a seguir, foram feitas com as seguintes considerações:

a) mostram-se faixas de valores, referentes à produção unitária, contemplando os equipamentos (incluindo o operador) e os serventes (aqueles que acompanham os equipamentos quando da execução do serviço) (Tabela 88 e Tabela 89). 
b) tais faixas vêm associadas aos fatores que levam a uma expectativa pior ou melhor quanto ao valor do indicador de produção unitária, isto é, uma proximidade maior do extremo direito ou esquerdo, respectivamente, da faixa (Tabela 90).

Tabela 88 - Escavação e carga de material de $1^{\text {a }}$ categoria, com trator de esteiras

\begin{tabular}{|c|c|c|c|c|c|c|}
\hline \multirow{2}{*}{ Equipamento } & \multicolumn{3}{|c|}{ Produção Unitária ( $\mathrm{m}^{3} /$ Hserv) } & \multicolumn{3}{|c|}{ Hfuncionamento } \\
\hline & 1Q Quartil & Mediana & 3ㅇQ Quartil & 1ㅇ Quartil & Mediana & 3 Quartil \\
\hline $\begin{array}{l}\text { Trator de esteiras, com } \\
\text { lâmina }\end{array}$ & 140 & 165 & 190 & $85 \%$ & $90 \%$ & $96 \%$ \\
\hline \multicolumn{7}{|c|}{$\begin{array}{l}\text { b) Etapa: carregamento do caminhão (a carregadeira de pneus coloca o solo nos } \\
\text { caminhões) }\end{array}$} \\
\hline Equipamento & \multicolumn{3}{|c|}{ Produção Unitária (m³/Hserv) } & \multicolumn{3}{|c|}{ Hfuncionamento } \\
\hline Carregadeira de pneus & 138 & 159,5 & 176 & $85 \%$ & $90 \%$ & $97 \%$ \\
\hline
\end{tabular}

Tabela 89 - Escavação e carga de material de 1ª categoria, com escavadeira hidráulica

\begin{tabular}{|c|c|c|c|c|c|c|}
\hline \multirow{2}{*}{ Equipamento } & \multicolumn{3}{|c|}{ Produção Unitária ( $\mathrm{m}^{3} /$ Hserv) } & \multicolumn{3}{|c|}{ Hfuncionamento } \\
\hline & 1ㅇ Quartil & Mediana & 3o Quartil & 1ㅇ Quartil & Mediana & 3ㅇ Quartil \\
\hline Escavadeira hidráulica & 120 & 140 & 160 & $80 \%$ & $90 \%$ & $95 \%$ \\
\hline
\end{tabular}


Tabela 90 - Fatores e anormalidades: escavação e carga de material de 1aㅡ categoria

\begin{tabular}{|c|c|c|}
\hline Aproxima do $1^{\circ}$ Quartil & Aproxima do $3^{\circ}$ Quartil & Importância \\
\hline Condições climáticas instáveis & Condições climáticas estáveis & Muito importante \\
\hline $\begin{array}{l}\text { Equipamento de escavação } \\
\text { menos compatível com as } \\
\text { características do terreno }\end{array}$ & $\begin{array}{l}\text { Equipamento de escavação compatível } \\
\text { com as características do terreno }\end{array}$ & Importante \\
\hline $\begin{array}{l}\text { Equipamento com alta } \\
\text { manutenção durante a operação }\end{array}$ & $\begin{array}{l}\text { Equipamento com baixa manutenção } \\
\text { durante a operação }\end{array}$ & Importante \\
\hline $\begin{array}{l}\text { Problemas com abastecimento } \\
\text { de combustível (falta } \\
\text { combustível) }\end{array}$ & Equipamento abastecido (combustível) & Importante \\
\hline $\begin{array}{l}\text { Comete erros grosseiros em } \\
\text { relação ao projetado (retrabalho) }\end{array}$ & $\begin{array}{l}\text { Serviço executado de acordo com o } \\
\text { projeto (evita erros grosseiros que } \\
\text { poderiam aumentar o volume da } \\
\text { escavação) }\end{array}$ & Importante \\
\hline $\begin{array}{l}\text { Má continuidade e sequência de } \\
\text { operações entre cada atividade }\end{array}$ & $\begin{array}{l}\text { Boa continuidade e sequência de } \\
\text { operações entre cada atividade }\end{array}$ & Importante \\
\hline $\begin{array}{l}\text { Quantidade e capacidade de } \\
\text { caminhões menos compatível } \\
\text { com a frente de serviço }\end{array}$ & $\begin{array}{l}\text { Quantidade e capacidade de } \\
\text { caminhões compatível com a frente de } \\
\text { serviço }\end{array}$ & Importante \\
\hline Escavação no nível do terreno & $\begin{array}{l}\text { Escavação em barranco (diminui o } \\
\text { tempo de ciclo entre a escavação, } \\
\text { carga e a manobra, aumentando a } \\
\text { eficiência) }\end{array}$ & Importante \\
\hline Terreno muito acidentado & Terreno pouco acidentado & Importante \\
\hline $\begin{array}{l}\text { Alto índice de ausência do } \\
\text { operador (tem muitas faltas) }\end{array}$ & $\begin{array}{l}\text { Baixo índice de ausência do operador } \\
\text { (tem poucas faltas) }\end{array}$ & Importante \\
\hline Operador menos treinado & Operador treinado & Importante \\
\hline $\begin{array}{l}\text { Mais tempo para executar a } \\
\text { atividade (prazos extensos) }\end{array}$ & $\begin{array}{l}\text { Pouco tempo para executar a atividade } \\
\text { (prazos enxutos) }\end{array}$ & Importante \\
\hline $\begin{array}{l}\text { Umidade do solo maior do que a } \\
\text { projetada }\end{array}$ & $\begin{array}{l}\text { Umidade do solo compatível com a } \\
\text { projetada }\end{array}$ & Pouco importante \\
\hline $\begin{array}{l}\text { Solo com maior dificuldade de } \\
\text { penetração }\end{array}$ & Solo facilmente penetrável & Pouco importante \\
\hline $\begin{array}{l}\text { Menos frentes sendo atendidas } \\
\text { (de aterro ou DME) }\end{array}$ & $\begin{array}{l}\text { Mais frentes sendo atendidas (de aterro } \\
\text { ou DME) }\end{array}$ & Pouco importante \\
\hline $\begin{array}{l}\text { DMT maior (distância entre o } \\
\text { corte e o aterro atendido) }\end{array}$ & $\begin{array}{l}\text { DMT menor (distância entre o corte e o } \\
\text { aterro atendido) }\end{array}$ & Pouco importante \\
\hline
\end{tabular}

\subsection{Compactação de Aterro}

Em termos das diferentes partes do serviço de compactação de aterro, fazem parte do escopo, quanto aos valores a serem mostrados: o lançamento; o nivelamento; o tratamento (possível aeração ou umidificação); e a compactação da camada. 
As faixas de valores de produção unitária dos equipamentos, mostradas a seguir, foram feitas com as seguintes considerações:

a) mostram-se faixas de valores, referentes à produção unitária, contemplando os equipamentos (incluindo o operador) e os serventes (aqueles que acompanham os equipamentos quando da execução do serviço) (

b) Tabela 91).

c) tais faixas vêm associadas aos fatores que levam a uma expectativa pior ou melhor quanto ao valor do indicador de produção unitária, isto é, uma proximidade maior do extremo direito ou esquerdo, respectivamente, da faixa (Tabela 92).

Tabela 91 - Compactação de aterro - esp. até $30 \mathrm{~cm}$

a) Etapa: espalhamento do solo (após a descarga pelos caminhões o trator de esteiras espalha o solo)

\begin{tabular}{l|c|c|c|c|c|c}
\hline \multirow{2}{*}{ Equipamento } & \multicolumn{2}{|c|}{ Produção Unitária (m²/Hserv) } & \multicolumn{3}{c}{ Hfuncionamento } \\
\cline { 2 - 7 } & 10 Quartil & Mediana & 3 Quartil & 10 Quartil & Mediana & 3 Quartil \\
\hline $\begin{array}{l}\text { Trator de esteiras, com } \\
\text { lâmina }\end{array}$ & 250 & 300 & 350 & $50 \%$ & $68 \%$ & $80 \%$ \\
\hline
\end{tabular}

b) Etapa: nivelamento da camada (a motoniveladora nivela a camada de solo)

\begin{tabular}{|c|c|c|c|c|c|c|}
\hline \multirow{2}{*}{ Equipamento } & \multicolumn{3}{|c|}{ Produção Unitária ( $\mathrm{m}^{2} /$ Hserv) } & \multicolumn{3}{|c|}{ Hfuncionamento } \\
\hline & 1ㅇ Quartil & Mediana & 3 Quartil & 10 Quartil & Mediana & 3ㅇ Quartil \\
\hline Motoniveladora & 1000 & 1200 & 1400 & $80 \%$ & $83 \%$ & $90 \%$ \\
\hline \multicolumn{7}{|c|}{$\begin{array}{l}\text { c) Etapa: aeração e/ou homogeneização da camada (se precisar o trator com grade faz a } \\
\text { aeração ou a homogeneização do solo) }\end{array}$} \\
\hline \multirow{2}{*}{ Equipamento } & \multicolumn{3}{|c|}{ Produção Unitária (m²/Hserv) } & \multicolumn{3}{|c|}{ Hfuncionamento } \\
\hline & 10 Quartil & Mediana & 3 Quartil & 1Q Quartil & Mediana & 3 Quartil \\
\hline $\begin{array}{l}\text { Trator agrícola com grade } \\
\text { de disco }\end{array}$ & 1000 & 1200 & 1400 & $68 \%$ & $73 \%$ & $90 \%$ \\
\hline
\end{tabular}

d) Etapa: umidificação da camada (se precisar o caminhão tanque umedece o solo)

\begin{tabular}{|c|c|c|c|c|c|c|}
\hline \multirow{2}{*}{ Equipamento } & \multicolumn{3}{|c|}{ Produção Unitária (m²/Hserv) } & \multicolumn{3}{|c|}{ Hfuncionamento } \\
\hline & 10 Quartil & Mediana & 3 Quartil & 1Q Quartil & Mediana & 3 Quartil \\
\hline Caminhão tanque & 1075 & 1322,5 & 1500 & $58 \%$ & $65 \%$ & $70 \%$ \\
\hline \multicolumn{7}{|c|}{ e) Etapa: compactação da camada } \\
\hline \multirow{2}{*}{ Equipamento } & \multicolumn{3}{|c|}{ Produção Unitária ( $\mathrm{m}^{2} /$ Hserv) } & \multicolumn{3}{|c|}{ Hfuncionamento } \\
\hline & 1ㅇ Quartil & Mediana & 3 Quartil & 1ํ Quartil & Mediana & 3 Quartil \\
\hline $\begin{array}{l}\text { Rolo compactador pé de } \\
\text { carneiro }\end{array}$ & 300 & 450 & 600 & $70 \%$ & $83 \%$ & $90 \%$ \\
\hline
\end{tabular}


Tabela 92 - Fatores e anormalidades: compactação de aterro

\begin{tabular}{|c|c|c|}
\hline Aproxima do 1ㅇ Quartil & Aproxima do 3 Q Quartil & \multirow{2}{*}{ Importância } \\
\hline \multicolumn{2}{|c|}{ CONDIÇÕES GERAIS } & \\
\hline Condições climáticas instáveis & Condições climáticas estáveis & Muito importante \\
\hline $\begin{array}{l}\text { Equipamento com alta manutenção } \\
\text { durante a operação }\end{array}$ & $\begin{array}{l}\text { Equipamento com baixa } \\
\text { manutenção durante a operação }\end{array}$ & Importante \\
\hline $\begin{array}{l}\text { Tarefas preliminares a executar (ex. } \\
\text { drenos) }\end{array}$ & $\begin{array}{l}\text { Tarefas preliminares prontas (ex. } \\
\text { drenos) }\end{array}$ & Importante \\
\hline Prevalece a improvisação & $\begin{array}{l}\text { Planeja antecipadamente as } \\
\text { atividades }\end{array}$ & Importante \\
\hline Operador menos treinado & Operador treinado & Importante \\
\hline $\begin{array}{l}\text { Mais tempo para executar a } \\
\text { atividade (prazos extensos) }\end{array}$ & $\begin{array}{l}\text { Pouco tempo para executar a } \\
\text { atividade (prazos enxutos) }\end{array}$ & Importante \\
\hline $\begin{array}{l}\text { Má continuidade e sequência de } \\
\text { operações }\end{array}$ & $\begin{array}{l}\text { Boa continuidade e sequência de } \\
\text { operações }\end{array}$ & Importante \\
\hline Menos frentes sendo atendidas & Mais frentes sendo atendidas & Importante \\
\hline Frentes de trabalho mais distantes & Frentes de trabalho mais próximas & Importante \\
\hline $\begin{array}{l}\text { Problemas com abastecimento de } \\
\text { combustível (equipamento sem } \\
\text { combustível) }\end{array}$ & $\begin{array}{l}\text { Equipamento abastecido } \\
\text { (combustível) }\end{array}$ & Importante \\
\hline $\begin{array}{l}\text { Alto índice de ausência do operador } \\
\text { (faltas) }\end{array}$ & $\begin{array}{l}\text { Baixo índice de ausência do } \\
\text { operador (faltas) }\end{array}$ & Importante \\
\hline \multicolumn{3}{|c|}{ CONDIÇÕES ESPECÍFICAS } \\
\hline \multicolumn{3}{|c|}{ Espalhamento do solo e nivelamento da camada } \\
\hline $\begin{array}{l}\text { Quantidade e capacidade de } \\
\text { caminhões menos compatível com a } \\
\text { frente a ser abastecida }\end{array}$ & $\begin{array}{l}\text { Quantidade e capacidade de } \\
\text { caminhões compatível com a frente } \\
\text { a ser abastecida }\end{array}$ & Importante \\
\hline $\begin{array}{l}\text { DMT maior (demora no trajeto } \\
\text { corte/aterro) }\end{array}$ & $\begin{array}{l}\text { DMT menor (rapidez no trajeto } \\
\text { corte/aterro) }\end{array}$ & Importante \\
\hline \multicolumn{3}{|c|}{ Aeração, homogeneização e umidificação da camada } \\
\hline $\begin{array}{l}\text { Umidade do solo maior do que a } \\
\text { projetada }\end{array}$ & $\begin{array}{l}\text { Umidade do solo compatível com a } \\
\text { projetada }\end{array}$ & Importante \\
\hline Solo menos homogêneo & Solo mais homogêneo & Importante \\
\hline \multicolumn{3}{|l|}{ Compactação da camada } \\
\hline $\begin{array}{l}\text { Equipe de equipamentos menos } \\
\text { compatível (equipamentos } \\
\text { diferentes, pesos diferentes, } \\
\text { quantidade incompatível com o GC) }\end{array}$ & $\begin{array}{l}\text { Equipe de equipamentos compatível } \\
\text { (equipamentos semelhantes, pesos } \\
\text { parecidos, quantidade compatível } \\
\text { com o GC) }\end{array}$ & Importante \\
\hline $\begin{array}{l}\text { Maior quantidade de passadas dos } \\
\text { compactadores (número de fechas } \\
\text { para atingir o GC) }\end{array}$ & $\begin{array}{l}\text { Menor quantidade de passadas dos } \\
\text { compactadores (número de fechas } \\
\text { para atingir o GC) }\end{array}$ & Importante \\
\hline $\begin{array}{l}\text { Equipe de laboratório menos } \\
\text { treinada }\end{array}$ & Equipe de laboratório treinada & Importante \\
\hline $\begin{array}{l}\text { Camadas mais espessas }(>20 \mathrm{~cm} \mathrm{e} \\
<30 \mathrm{~cm})\end{array}$ & Camadas menos espessas $(<20 \mathrm{~cm})$ & Importante \\
\hline $\begin{array}{l}\text { Maior a deformabilidade da camada } \\
\text { inferior }\end{array}$ & $\begin{array}{l}\text { Menor deformabilidade da camada } \\
\text { inferior }\end{array}$ & Importante \\
\hline
\end{tabular}




\subsection{Base de Solo Cimento com Mistura na Pista}

Em termos das diferentes partes do serviço de base de solo cimento com mistura na pista, fazem parte do escopo, quanto aos valores a serem mostrados: o lançamento; o nivelamento; a distribuição do cimento (se não ocorrer em usina); a aeração (se precisar); a mistura do cimento (se não ocorrer em usina); a umidificação (se precisar); a compactação; e o acabamento.

As faixas de valores de produção unitária dos equipamentos, mostradas a seguir, foram feitas com as seguintes considerações:

a) mostram-se faixas de valores, referentes à produção unitária, contemplando os equipamentos (incluindo o operador) e os serventes (aqueles que acompanham os equipamentos quando da execução do serviço) (Tabela 93).

b) tais faixas vêm associadas aos fatores que levam a uma expectativa pior ou melhor quanto ao valor do indicador de produção unitária, isto é, uma proximidade maior do extremo direito ou esquerdo, respectivamente, da faixa (Tabela 94). 
Tabela 93 - Base de solo cimento com mistura na pista - esp. até $20 \mathrm{~cm}$

a) Etapa: espalhamento do solo (após a descarga pelos caminhões o trator de esteiras espalha o solo)

\begin{tabular}{l|c|c|c|c|c|c}
\hline \multirow{2}{*}{ Equipamento } & \multicolumn{2}{|c|}{ Produção Unitária (m²/Hserv) } & \multicolumn{3}{c}{ Hfuncionamento } \\
\cline { 2 - 6 } & 1º Quartil & Mediana & 3 Quartil & 1ㅇ Quartil & Mediana & 3 Quartil \\
\hline $\begin{array}{l}\text { Trator de esteiras, com } \\
\text { lâmina }\end{array}$ & 200 & 250 & 350 & $25 \%$ & $40 \%$ & $60 \%$ \\
\hline b) Etapa: nivelamento da camada (a motoniveladora nivela a camada de solo) \\
\hline
\end{tabular}

b) Etapa: nivelamento da camada (a motoniveladora nivela a camada de solo)

\begin{tabular}{|c|c|c|c|c|c|c|}
\hline \multirow{2}{*}{ Equipamento } & \multicolumn{3}{|c|}{ Produção Unitária (m²/Hserv) } & \multicolumn{3}{|c|}{ Hfuncionamento } \\
\hline & 10 Quartil & Mediana & 3Quartil & 1ㅇ Quartil & Mediana & 3Q Quartil \\
\hline Motoniveladora & 350 & 450 & 550 & $48 \%$ & $68 \%$ & $80 \%$ \\
\hline
\end{tabular}

c) Etapa: distribuição do cimento na camada (obs.: este serviço pode ser feito manualmente e neste caso, deve ser prevista a "abertura de sacaria de cimento")

\begin{tabular}{|c|c|c|c|c|c|c|}
\hline \multirow{2}{*}{ Equipamento } & \multicolumn{3}{|c|}{ Produção Unitária (m²/Hserv) } & \multicolumn{3}{|c|}{ Hfuncionamento } \\
\hline & 10 Quartil & Mediana & 3 Quartil & 10 Quartil & Mediana & 3 Quartil \\
\hline Distribuidor de cimento & 330 & 588 & 700 & $14 \%$ & $21 \%$ & $25 \%$ \\
\hline \multicolumn{7}{|c|}{$\begin{array}{l}\text { d) Etapa: aeração e/ou homogeneização da camada (se precisar o trator com grade faz a } \\
\text { aeração ou a homogeneização do solo) }\end{array}$} \\
\hline \multirow{2}{*}{ Equipamento } & \multicolumn{3}{|c|}{ Produção Unitária (m²/Hserv) } & \multicolumn{3}{|c|}{ Hfuncionamento } \\
\hline & 10 Quartil & Mediana & 3 Quartil & 10 Quartil & Mediana & 3 Quartil \\
\hline $\begin{array}{l}\text { Trator agrícola com } \\
\text { grade de disco }\end{array}$ & 525 & 650 & 775 & $76 \%$ & $83 \%$ & $91 \%$ \\
\hline
\end{tabular}

e) Etapa: mistura do cimento na camada (a recicladora automaticamente mistura o cimento com o solo)

\begin{tabular}{l|c|c|c|c|c|c}
\hline \multirow{2}{*}{ Equipamento } & \multicolumn{2}{|c|}{ Produção Unitária (m²/Hserv) } & \multicolumn{3}{c}{ Hfuncionamento } \\
\cline { 2 - 7 } & 1ํ Quartil & Mediana & 3 Quartil & 1 Quartil & Mediana & 3 Quartil \\
\hline Recicladora & 330 & 588 & 700 & $15 \%$ & $21 \%$ & $25 \%$ \\
\hline
\end{tabular}

f) Etapa: umidificação da camada (se precisar o caminhão tanque umedece o solo)

\begin{tabular}{|c|c|c|c|c|c|c|}
\hline \multirow{2}{*}{ Equipamento } & \multicolumn{3}{|c|}{ Produção Unitária (m²/Hserv) } & \multicolumn{3}{|c|}{ Hfuncionamento } \\
\hline & 1 Quartil & Mediana & 3Q Quartil & 10 Quartil & Mediana & 3 Quartil \\
\hline Caminhão tanque & 400 & 600 & 800 & $17 \%$ & $24 \%$ & $32 \%$ \\
\hline
\end{tabular}

g) Etapa: compactação da camada

\begin{tabular}{l|c|c|c|c|c|c}
\hline \multirow{2}{*}{ Equipamento } & \multicolumn{2}{|c|}{ Produção Unitária (m²/Hserv) } & \multicolumn{3}{c}{ Hfuncionamento } \\
\cline { 2 - 7 } & 1 Quartil & Mediana & 3 Quartil & 1 Quartil & Mediana & 30 Quartil \\
\hline $\begin{array}{l}\text { Rolo compactador pé de } \\
\text { carneiro }\end{array}$ & 400 & 555 & 605 & $52 \%$ & $65 \%$ & $75 \%$ \\
\hline
\end{tabular}

h) Etapa: acabamento da camada (após a compactação o rolo compactador de pneus , protege a camada, ou seja, sela a camada)

\begin{tabular}{l|c|c|c|c|c|c}
\hline \multirow{2}{*}{ Equipamento } & \multicolumn{2}{c|}{ Produção Unitária (m²/Hserv) } & \multicolumn{3}{c}{ Hfuncionamento } \\
\cline { 2 - 7 } & 1\% Quartil & Mediana & $3^{\circ}$ Quartil & 10 Quartil & Mediana & 30 Quartil \\
\hline $\begin{array}{l}\text { Rolo compactador de } \\
\text { pneus }\end{array}$ & 400 & 600 & 800 & $15 \%$ & $33 \%$ & $45 \%$ \\
\hline
\end{tabular}


Tabela 94 - Fatores e anormalidades: base de solo cimento com mistura na pista

\begin{tabular}{|c|c|c|}
\hline Aproxima do $1^{\circ}$ Quartil & Aproxima do $3^{\circ}$ Quartil & \multirow{2}{*}{ Importância } \\
\hline \multicolumn{2}{|c|}{ CONDIÇÕES GERAIS } & \\
\hline Condições climáticas instáveis & Condições climáticas estáveis & Muito importante \\
\hline $\begin{array}{l}\text { Equipamento com alta manutenção } \\
\text { durante a operação }\end{array}$ & $\begin{array}{l}\text { Equipamento com baixa manutenção } \\
\text { durante a operação }\end{array}$ & Importante \\
\hline Prevalece a improvisação & Planeja antecipadamente as atividades & Importante \\
\hline Operador menos treinado & Operador treinado & Importante \\
\hline $\begin{array}{l}\text { Má continuidade e sequência de } \\
\text { operações }\end{array}$ & $\begin{array}{l}\text { Boa continuidade e sequência de } \\
\text { operações }\end{array}$ & Importante \\
\hline Menos frentes sendo atendidas & Mais frentes sendo atendidas & Importante \\
\hline $\begin{array}{l}\text { Tarefas preliminares a executar (ex. } \\
\text { drenos) }\end{array}$ & $\begin{array}{l}\text { Tarefas preliminares prontas (ex. } \\
\text { drenos) }\end{array}$ & Importante \\
\hline $\begin{array}{l}\text { Problemas com abastecimento de } \\
\text { combustível (equipamento sem } \\
\text { combustível) }\end{array}$ & Equipamento abastecido (combustível) & $\begin{array}{l}\text { Pouco } \\
\text { importante }\end{array}$ \\
\hline $\begin{array}{l}\text { Alto índice de ausência do operador } \\
\text { (faltas) }\end{array}$ & $\begin{array}{l}\text { Baixo índice de ausência do operador } \\
\text { (faltas) }\end{array}$ & $\begin{array}{l}\text { Pouco } \\
\text { importante }\end{array}$ \\
\hline $\begin{array}{l}\text { Mais tempo para executar a } \\
\text { atividade (prazos extensos) }\end{array}$ & $\begin{array}{l}\text { Pouco tempo para executar a atividade } \\
\text { (prazos enxutos) }\end{array}$ & $\begin{array}{l}\text { Pouco } \\
\text { importante }\end{array}$ \\
\hline Frentes de trabalho mais distantes & Frentes de trabalho mais próximas & $\begin{array}{l}\text { Pouco } \\
\text { importante }\end{array}$ \\
\hline \multicolumn{3}{|c|}{ CONDIÇÕES ESPECÍFICAS } \\
\hline \multicolumn{3}{|c|}{ Espalhamento do solo e nivelamento da camada } \\
\hline $\begin{array}{l}\text { Quantidade e capacidade de } \\
\text { caminhões (ou mão de obra para } \\
\text { serviço manual) menos compatível } \\
\text { com a frente a ser abastecida }\end{array}$ & $\begin{array}{l}\text { Quantidade e capacidade de } \\
\text { caminhões (ou mão de obra para } \\
\text { serviço manual) compatível com a } \\
\text { frente a ser abastecida }\end{array}$ & Importante \\
\hline $\begin{array}{l}\text { DMT maior (demora no trajeto } \\
\text { corte/aterro) }\end{array}$ & $\begin{array}{l}\text { DMT menor (rapidez no trajeto } \\
\text { corte/aterro) }\end{array}$ & Importante \\
\hline \multicolumn{3}{|c|}{ Aeração, homogeneização e umidificação da camada } \\
\hline $\begin{array}{l}\text { Umidade do solo maior do que a } \\
\text { projetada }\end{array}$ & $\begin{array}{l}\text { Umidade do solo compatível com a } \\
\text { projetada }\end{array}$ & Importante \\
\hline Solo menos homogêneo & Solo mais homogêneo & Importante \\
\hline \multicolumn{3}{|l|}{ Compactação da camada } \\
\hline $\begin{array}{l}\text { Maior quantidade de passadas dos } \\
\text { compactadores (número de fechas } \\
\text { para atingir o GC) }\end{array}$ & $\begin{array}{l}\text { Menor quantidade de passadas dos } \\
\text { compactadores (número de fechas } \\
\text { para atingir o GC) }\end{array}$ & Muito importante \\
\hline $\begin{array}{l}\text { Equipe de equipamentos menos } \\
\text { compatível (equipamentos } \\
\text { diferentes, pesos diferentes, } \\
\text { quantidade incompatível com o GC) }\end{array}$ & $\begin{array}{l}\text { Equipe de equipamentos compatível } \\
\text { (equipamentos semelhantes, pesos } \\
\text { parecidos, quantidade compatível com } \\
\text { o GC) }\end{array}$ & Importante \\
\hline $\begin{array}{l}\text { Camadas mais espessas }(>20 \mathrm{~cm} \mathrm{e} \\
<30 \mathrm{~cm})\end{array}$ & Camadas menos espessas $(<20 \mathrm{~cm})$ & Importante \\
\hline $\begin{array}{l}\text { Equipe de laboratório menos } \\
\text { treinada }\end{array}$ & Equipe de laboratório treinada & Importante \\
\hline $\begin{array}{l}\text { Maior a deformabilidade da camada } \\
\text { inferior }\end{array}$ & $\begin{array}{l}\text { Menor deformabilidade da camada } \\
\text { inferior }\end{array}$ & $\begin{array}{c}\text { Pouco } \\
\text { importante }\end{array}$ \\
\hline
\end{tabular}




\subsection{Base de Brita Graduada Simples - BGS}

Em termos dos diferentes equipamentos para a BGS, os valores a serem mostrados contemplam o distribuidor de agregados e a vibroacabadora.

O assunto será tratado separando a BGS em função destes dois equipamentos. Para cada grupo discutem-se a produção unitária dos equipamentos e da mão de obra.

Em termos das diferentes partes do serviço de BGS fazem parte do escopo: o lançamento (com espalhamento e posterior nivelamento); a umidificação (se precisar); a compactação; e o apoio (acompanha o processo de produção).

As faixas de valores de produção unitária dos equipamentos, mostradas a seguir, foram feitas com as seguintes considerações:

a) mostram-se faixas de valores, referentes à produção unitária, contemplando os equipamentos (incluindo o operador) e os serventes (aqueles que acompanham os equipamentos quando da execução do serviço) (Tabela $95 \mathrm{e}$ Tabela 96).

b) tais faixas vêm associadas aos fatores que levam a uma expectativa pior ou melhor quanto ao valor do indicador de produção unitária, isto é, uma proximidade maior do extremo direito ou esquerdo, respectivamente, da faixa (Tabela 97). 
Tabela 95 - Base de brita graduada simples - BGS com distribuidor de agregados - esp. até 20 $\mathrm{cm}$

a) Etapa: espalhamento da BGS (os caminhões abastecem o distribuidor de agregados com BGS e este espalha o material)

\begin{tabular}{l|c|c|c|c|c|c}
\hline \multirow{2}{*}{ Equipamento } & \multicolumn{2}{|c|}{ Produção Unitária $\left(\mathrm{m}^{2} /\right.$ Hserv) } & \multicolumn{3}{c}{ Hfuncionamento } \\
\cline { 2 - 7 } & 10 Quartil & Mediana & $3^{\circ}$ Quartil & 1\% Quartil & Mediana & 3 Quartil \\
\hline $\begin{array}{l}\text { Distribuidor de } \\
\text { Agregados - } \\
\text { Autopropelido }\end{array}$ & 300 & 400 & 600 & $70 \%$ & $80 \%$ & $90 \%$ \\
\hline \begin{tabular}{l} 
b) Etapa: nivelamento da camada (a motoniveladora nivela a camada de BGS) \\
\hline
\end{tabular}
\end{tabular}

b) Etapa: nivelamento da camada (a motoniveladora nivela a camada de BGS)

\begin{tabular}{|c|c|c|c|c|c|c|}
\hline \multirow{2}{*}{ Equipamento } & \multicolumn{3}{|c|}{ Produção Unitária (m²/Hserv) } & \multicolumn{3}{|c|}{ Hfuncionamento } \\
\hline & 10 Quartil & Mediana & 3 Quartil & 10 Quartil & Mediana & 3 Quartil \\
\hline Motoniveladora & 200 & 300 & 400 & $63 \%$ & $73 \%$ & $83 \%$ \\
\hline
\end{tabular}

\begin{tabular}{c|c|c|c|c|c|c}
\hline \multirow{2}{*}{ Equipamento } & \multicolumn{2}{|c|}{ Produção Unitária $\left(\mathrm{m}^{2} /\right.$ Hserv $)$} & \multicolumn{3}{c}{ Hfuncionamento } \\
\cline { 2 - 7 } & 1ํ Quartil & Mediana & $3^{\circ}$ Q Quartil & 1 Quartil & Mediana & $3^{\circ}$ Quartil \\
\hline Caminhão tanque & 600 & 800 & 1000 & $35 \%$ & $50 \%$ & $65 \%$ \\
\hline
\end{tabular}

d) Etapa: Compactação da camada

d1) Pré-compactação e acabamento (o rolo compactador tipo tandem inicia a compactação fazendo a acomodação inicial do material. Após a compactação propriamente dita, pelo compactador de pneus, o tandem retorna e dá o acabamento da camada).

\begin{tabular}{|c|c|c|c|c|c|c|}
\hline \multirow{2}{*}{ Equipamento } & \multicolumn{3}{|c|}{ Produção Unitária (m²/Hserv) } & \multicolumn{3}{|c|}{ Hfuncionamento } \\
\hline & 10 Quartil & Mediana & 3 Quartil & 10 Quartil & Mediana & 3Q Quartil \\
\hline $\begin{array}{l}\text { Rolo compactador tipo } \\
\text { tandem }\end{array}$ & 380 & 530 & 655 & $80 \%$ & $85 \%$ & $95 \%$ \\
\hline
\end{tabular}

d2) Compactação da camada (após a pré-compactação, executada pelo compactador tipo tandem, o rolo compactador de pneus faz a compactação propriamente dita)

\begin{tabular}{|c|c|c|c|c|c|c|}
\hline \multirow{2}{*}{ Equipamento } & \multicolumn{3}{|c|}{ Produção Unitária (m²/Hserv) } & \multicolumn{3}{|c|}{ Hfuncionamento } \\
\hline & 1ㅇ Quartil & Mediana & 3 Quartil & 1ㅇ Quartil & Mediana & 30 Quartil \\
\hline $\begin{array}{l}\text { Rolo compactador de } \\
\text { pneus }\end{array}$ & 370 & 520 & 645 & $80 \%$ & $85 \%$ & $95 \%$ \\
\hline \multicolumn{7}{|l|}{ e) Etapa: apoio } \\
\hline \multirow{2}{*}{ Mão de obra } & \multicolumn{3}{|c|}{ Produção Unitária ( $\mathrm{m}^{2} /$ Hserv) } & & & \\
\hline & 10 Quartil & Mediana & 3 Quartil & & & \\
\hline Servente & 122,5 & 235 & 295 & & & \\
\hline
\end{tabular}


Tabela 96 - Base de brita graduada simples - BGS com vibroacabadora - esp. até $20 \mathrm{~cm}$

a) Etapa: espalhamento e nivelamento da BGS (os caminhões abastecem a vibroacabadora com BGS e esta espalha o material e nivela a camada)

\begin{tabular}{l|c|c|c|c|c|c}
\hline \multirow{2}{*}{ Equipamento } & \multicolumn{2}{|c|}{ Produção Unitária (m2/Hserv) } & \multicolumn{3}{c}{ Hfuncionamento } \\
\cline { 2 - 7 } & 10 Quartil & Mediana & 3 Quartil & 1 Quartil & Mediana & 3 Quartil \\
\hline $\begin{array}{l}\text { Vibroacabadora de } \\
\text { asfalto }\end{array}$ & 120 & 160 & 200 & $70 \%$ & $78 \%$ & $85 \%$ \\
\hline
\end{tabular}

b) Etapa: compactação da camada

b1) Pré-compactação e acabamento (o rolo compactador tipo tandem inicia a compactação fazendo a acomodação inicial do material. Após a compactação propriamente dita, pelo compactador de pneus, o tandem retorna e dá o acabamento da camada)

\begin{tabular}{l|c|c|c|c|c|c}
\hline \multirow{2}{*}{ Equipamento } & \multicolumn{2}{|c|}{ Produção Unitária (m2/Hserv) } & \multicolumn{3}{c}{ Hfuncionamento } \\
\cline { 2 - 7 } & 1 Quartil $^{\circ}$ & Mediana & 3o Quartil & 10 Quartil & Mediana & $3^{\circ}$ Quartil \\
\hline $\begin{array}{l}\text { Rolo compactador tipo } \\
\text { tandem }\end{array}$ & 200 & 250 & 300 & $38 \%$ & $48 \%$ & $60 \%$ \\
\hline
\end{tabular}

b2) Compactação da camada (após a pré-compactação, executada pelo compactador tipo tandem, o rolo compactador de pneus faz a compactação propriamente dita)

\begin{tabular}{l|c|c|c|c|c|c}
\hline \multirow{2}{*}{ Equipamento } & \multicolumn{2}{|c|}{ Produção Unitária (m2/Hserv) } & \multicolumn{3}{c}{ Hfuncionamento } \\
\cline { 2 - 7 } & 1\% Quartil & Mediana & 3\% Quartil & 1 Quartil & Mediana & 30 Quartil \\
\hline $\begin{array}{l}\text { Rolo compactador de } \\
\text { pneus }\end{array}$ & 200 & 250 & 300 & $55 \%$ & $68 \%$ & $83 \%$ \\
\hline
\end{tabular}

c) Etapa: umidificação da camada (se precisar o caminhão tanque umedece a camada)

\begin{tabular}{|c|c|c|c|c|c|c|}
\hline \multirow{2}{*}{ Equipamento } & \multicolumn{3}{|c|}{ Produção Unitária (m2/Hserv) } & \multicolumn{3}{|c|}{ Hfuncionamento } \\
\hline & 1ㅇ Quartil & Mediana & 3ํ. Quartil & 1ㅇ Quartil & Mediana & 3ํ Quartil \\
\hline Caminhão tanque & 1000 & 1300 & 1500 & $10 \%$ & $20 \%$ & $30 \%$ \\
\hline \multicolumn{7}{|l|}{ d) Etapa: apoio } \\
\hline \multirow{2}{*}{ Mão de obra } & \multicolumn{3}{|c|}{ Produção Unitária (m2/Hserv) } & & & \\
\hline & 1ㅇ Quartil & Mediana & 3 Quartil & & & \\
\hline Servente & 50 & 70 & 90 & & & \\
\hline
\end{tabular}


Tabela 97 - Fatores e anormalidades: brita graduada simples

\begin{tabular}{|c|c|c|}
\hline Aproxima do $1^{\circ}$ Quartil & Aproxima do $3^{\circ}$ Quartil & \multirow{2}{*}{ Importância } \\
\hline \multicolumn{2}{|c|}{ CONDIÇÕES GERAIS } & \\
\hline Condições climáticas instáveis & Condições climáticas estáveis & Muito importante \\
\hline Baixa capacidade efetiva da usina & Alta capacidade efetiva da usina & Importante \\
\hline $\begin{array}{l}\text { Equipamentos em más condições e } \\
\text { descalibrados }\end{array}$ & $\begin{array}{l}\text { Equipamentos em boas condições e } \\
\text { calibrados }\end{array}$ & Importante \\
\hline Prevalece a improvisação & Planeja antecipadamente as atividades & Importante \\
\hline Operador menos treinado & Operador treinado & Importante \\
\hline $\begin{array}{l}\text { Má continuidade e sequência de } \\
\text { operações }\end{array}$ & $\begin{array}{l}\text { Boa continuidade e sequência de } \\
\text { operações }\end{array}$ & Importante \\
\hline $\begin{array}{l}\text { Tarefas preliminares a executar (ex. } \\
\text { travessias) }\end{array}$ & $\begin{array}{l}\text { Tarefas preliminares prontas (ex. } \\
\text { travessias) }\end{array}$ & Importante \\
\hline $\begin{array}{l}\text { Problemas com abastecimento de } \\
\text { combustível (equipamento sem } \\
\text { combustível) }\end{array}$ & Equipamento abastecido (combustível) & Importante \\
\hline $\begin{array}{l}\text { Alto índice de ausência do operador } \\
\text { (faltas) }\end{array}$ & $\begin{array}{l}\text { Baixo índice de ausência do operador } \\
\text { (faltas) }\end{array}$ & Importante \\
\hline $\begin{array}{l}\text { Mais tempo para executar a atividade } \\
\text { (prazos extensos) }\end{array}$ & $\begin{array}{l}\text { Pouco tempo para executar a atividade } \\
\text { (prazos enxutos) }\end{array}$ & Importante \\
\hline Menos frentes sendo atendidas & Mais frentes sendo atendidas & Importante \\
\hline $\begin{array}{l}\text { Baixa qualidade da massa produzida na } \\
\text { usina }\end{array}$ & $\begin{array}{l}\text { Alta qualidade da massa produzida na } \\
\text { usina }\end{array}$ & Pouco importante \\
\hline Frentes de trabalho mais distantes & Frentes de trabalho mais próximas & Pouco importante \\
\hline \multicolumn{3}{|c|}{ CONDIÇÕES ESPECÍFICAS } \\
\hline \multicolumn{2}{|c|}{ Espalhamento da BGS e nivelamento da camada } & \\
\hline $\begin{array}{l}\text { Quantidade e capacidade de caminhões } \\
\text { menos compatível com a frente a ser } \\
\text { abastecida }\end{array}$ & $\begin{array}{l}\text { Quantidade e capacidade de caminhões } \\
\text { compatível com a frente a ser } \\
\text { abastecida }\end{array}$ & Importante \\
\hline Equipe de apoio em treinamento & Equipe de apoio treinada & Importante \\
\hline $\begin{array}{l}\text { DMT maior (demora no trajeto } \\
\text { usina/frente) }\end{array}$ & $\begin{array}{l}\text { DMT menor (rapidez no trajeto } \\
\text { usina/frente) }\end{array}$ & Importante \\
\hline \multicolumn{3}{|l|}{ Umidificação da camada } \\
\hline $\begin{array}{l}\text { Umidade dos agregados maior do que a } \\
\text { projetada }\end{array}$ & $\begin{array}{l}\text { Umidade dos agregados compatível } \\
\text { com a projetada }\end{array}$ & Importante \\
\hline \multicolumn{3}{|l|}{ Compactação da camada } \\
\hline $\begin{array}{l}\text { Camadas mais espessas }(>10 \mathrm{~cm} \mathrm{e} \\
<20 \mathrm{~cm})\end{array}$ & Camadas menos espessas $(<10 \mathrm{~cm})$ & Importante \\
\hline $\begin{array}{l}\text { Maior quantidade de passadas dos } \\
\text { compactadores (número de fechas para } \\
\text { atingir o GC) }\end{array}$ & $\begin{array}{l}\text { Menor quantidade de passadas dos } \\
\text { compactadores (número de fechas para } \\
\text { atingir o GC) }\end{array}$ & Importante \\
\hline $\begin{array}{l}\text { Equipe de equipamentos menos } \\
\text { compatível (equipamentos diferentes, } \\
\text { pesos diferentes, quantidade } \\
\text { incompatível com o GC) }\end{array}$ & $\begin{array}{l}\text { Equipe de equipamentos compatível } \\
\text { (equipamentos semelhantes, pesos } \\
\text { parecidos, quantidade compatível com } \\
\text { o GC) }\end{array}$ & Importante \\
\hline Equipe de laboratório menos treinada & Equipe de laboratório treinada & Importante \\
\hline $\begin{array}{l}\text { Maior a deformabilidade da camada } \\
\text { inferior }\end{array}$ & $\begin{array}{l}\text { Menor deformabilidade da camada } \\
\text { inferior }\end{array}$ & Importante \\
\hline $\begin{array}{l}\text { Velocidade de rolagem menos } \\
\text { compatível com a camada }\end{array}$ & $\begin{array}{l}\text { Velocidade de rolagem compatível com } \\
\text { a camada }\end{array}$ & Importante \\
\hline
\end{tabular}




\subsection{Base de Brita Graduada Tratada com Cimento - BGTC}

Em termos das diferentes partes do serviço de BGTC fazem parte do escopo: o lançamento (com espalhamento e posterior nivelamento); a umidificação (se precisar); a compactação; e o apoio (acompanha o processo de produção).

As faixas de valores de produção unitária dos equipamentos, mostradas a seguir, foram feitas com as seguintes considerações:

a) mostram-se faixas de valores, referentes à produção unitária, contemplando os equipamentos (incluindo o operador) e os serventes (aqueles que acompanham os equipamentos quando da execução do serviço) (Tabela 98).

b) tais faixas vêm associadas aos fatores que levam a uma expectativa pior ou melhor quanto ao valor do indicador de produção unitária, isto é, uma proximidade maior do extremo direito ou esquerdo, respectivamente, da faixa (Tabela 99).

Tabela 98 - Base de brita graduada tratada com cimento - BGTC - esp. até $20 \mathrm{~cm}$

a) Etapa: espalhamento e nivelamento da BGTC (os caminhões abastecem a vibroacabadora com BGTC e esta espalha o material e nivela a camada)

\begin{tabular}{c|c|c|c|c|c|c|}
\hline \multirow{2}{*}{ Equipamento } & \multicolumn{3}{|c|}{ Produção Unitária $\left(\mathrm{m}^{2} /\right.$ Hserv) } & \multicolumn{3}{c}{ Hfuncionamento } \\
\cline { 2 - 8 } & $1^{\circ}$ Quartil & Mediana & $3^{\circ}$ Quartil & 1 Quartil & Mediana & $3^{\circ}$ Quarti \\
\hline Vibroacabadora de asfalto & 120 & 160 & 200 & $70 \%$ & $78 \%$ & $85 \%$ \\
\hline
\end{tabular}

b) Etapa: compactação da camada

b1) Pré-compactação e acabamento (o rolo compactador tipo tandem inicia a compactação fazendo a acomodação inicial do material. Após a compactação propriamente dita, pelo compactador de pneus, o tandem retorna e dá o acabamento da camada)

\begin{tabular}{l|c|c|c|c|c|c}
\hline \multirow{2}{*}{ Equipamento } & \multicolumn{3}{|c|}{ Produção Unitária (m²/Hserv) } & \multicolumn{3}{c}{ Hfuncionamento } \\
\cline { 2 - 7 } & 1\% Quartil & Mediana & $3^{\circ}$ Quartil & 10 Quartil & Mediana & $3^{\circ}$ Quartil \\
\hline $\begin{array}{l}\text { Rolo compactador tipo } \\
\text { tandem }\end{array}$ & 200 & 250 & 300 & $38 \%$ & $48 \%$ & $60 \%$ \\
\hline $\begin{array}{l}\text { b2) Compactação da camada (após a pré-compactação, executada pelo compactador tipo } \\
\text { tandem, o rolo compactador de pneus faz a compactação propriamente dita) }\end{array}$ \\
\hline
\end{tabular}

\begin{tabular}{l|c|c|c|c|c|c}
\multicolumn{1}{c}{ Equipamento } & \multicolumn{2}{|c|}{ Produção Unitária $\left(\mathrm{m}^{2} /\right.$ Hserv) } & \multicolumn{3}{c}{ Hfuncionamento } \\
\cline { 2 - 7 } & $1^{\circ}$ Quartil & Mediana & $3^{\circ}$ Quartil & 10 Quartil & Mediana & 30 Quartil \\
\hline $\begin{array}{l}\text { Rolo compactador de } \\
\text { pneus }\end{array}$ & 200 & 250 & 300 & $55 \%$ & $68 \%$ & $83 \%$ \\
\hline
\end{tabular}

c) Etapa: umidificação da camada (se precisar o caminhão tanque umedece a camada)

\begin{tabular}{|c|c|c|c|c|c|c|}
\hline \multirow{2}{*}{ Equipamento } & \multicolumn{3}{|c|}{ Produção Unitária (m²/Hserv) } & \multicolumn{3}{|c|}{ Hfuncionamento } \\
\hline & 1ㅇ Quartil & Mediana & 3 Quartil & 1 Quartil & Mediana & 3 Quartil \\
\hline Caminhão tanque & 1000 & 1300 & 1500 & $10 \%$ & $20 \%$ & $30 \%$ \\
\hline \multicolumn{7}{|l|}{ d) Etapa: apoio } \\
\hline \multirow{2}{*}{ Mão de obra } & \multicolumn{3}{|c|}{ Produção Unitária (m²/Hserv) } & & & \\
\hline & 1ㅇ Quartil & Mediana & 3ํ Quartil & & & \\
\hline Servente & 50 & 70 & 90 & & & \\
\hline
\end{tabular}


Tabela 99 - Fatores e anormalidades: brita graduada tratada com cimento

\begin{tabular}{|c|c|c|}
\hline Aproxima do $1^{\circ}$ Quartil & Aproxima do $3^{\circ}$ Quartil & \multirow{2}{*}{ Importância } \\
\hline \multicolumn{2}{|c|}{ CONDIÇÕES GERAIS } & \\
\hline Condições climáticas instáveis & Condições climáticas estáveis & Muito importante \\
\hline Prevalece a improvisação & Planeja antecipadamente as atividades & Muito importante \\
\hline Baixa capacidade efetiva da usina & Alta capacidade efetiva da usina & Muito importante \\
\hline $\begin{array}{l}\text { Equipamentos em más condições e } \\
\text { descalibrados }\end{array}$ & $\begin{array}{l}\text { Equipamentos em boas condições e } \\
\text { calibrados }\end{array}$ & Importante \\
\hline $\begin{array}{l}\text { Alto índice de ausência do operador } \\
\text { (faltas) }\end{array}$ & $\begin{array}{l}\text { Baixo índice de ausência do operador } \\
\text { (faltas) }\end{array}$ & Importante \\
\hline Operador menos treinado & Operador treinado & Importante \\
\hline $\begin{array}{l}\text { Má continuidade e sequência de } \\
\text { operações }\end{array}$ & $\begin{array}{l}\text { Boa continuidade e sequência de } \\
\text { operações }\end{array}$ & Importante \\
\hline Menos frentes sendo atendidas & Mais frentes sendo atendidas & Importante \\
\hline $\begin{array}{l}\text { Problemas com abastecimento de } \\
\text { combustível (equipamento sem } \\
\text { combustível) }\end{array}$ & Equipamento abastecido (combustível) & Pouco importante \\
\hline $\begin{array}{l}\text { Baixa qualidade da massa produzida } \\
\text { na usina }\end{array}$ & $\begin{array}{l}\text { Alta qualidade da massa produzida na } \\
\text { usina }\end{array}$ & Pouco importante \\
\hline $\begin{array}{l}\text { Mais tempo para executar a atividade } \\
\text { (prazos extensos) }\end{array}$ & $\begin{array}{l}\text { Pouco tempo para executar a atividade } \\
\text { (prazos enxutos) }\end{array}$ & Pouco importante \\
\hline Frentes de trabalho mais distantes & Frentes de trabalho mais próximas & Pouco importante \\
\hline $\begin{array}{l}\text { Tarefas preliminares a executar (ex. } \\
\text { travessias) }\end{array}$ & $\begin{array}{l}\text { Tarefas preliminares prontas (ex. } \\
\text { travessias) }\end{array}$ & Pouco importante \\
\hline \multicolumn{3}{|c|}{ CONDIÇÕES ESPECÍFICAS } \\
\hline \multicolumn{2}{|c|}{ Espalhamento da BGTC e nivelamento da camada } & \\
\hline $\begin{array}{l}\text { Quantidade e capacidade de } \\
\text { caminhões menos compatível com a } \\
\text { frente a ser abastecida }\end{array}$ & $\begin{array}{l}\text { Quantidade e capacidade de caminhões } \\
\text { compatível com a frente a ser } \\
\text { abastecida }\end{array}$ & Muito importante \\
\hline Equipe de apoio em treinamento & Equipe de apoio treinada & Muito importante \\
\hline $\begin{array}{l}\text { DMT maior (demora no trajeto } \\
\text { usina/frente) }\end{array}$ & $\begin{array}{l}\text { DMT menor (rapidez no trajeto } \\
\text { usina/frente) }\end{array}$ & Importante \\
\hline \multicolumn{3}{|l|}{ Umidificação da camada } \\
\hline $\begin{array}{l}\text { Umidade dos agregados maior do que } \\
\text { a projetada }\end{array}$ & $\begin{array}{l}\text { Umidade dos agregados compatível } \\
\text { com a projetada }\end{array}$ & Importante \\
\hline \multicolumn{3}{|l|}{ Compactação da camada } \\
\hline $\begin{array}{l}\text { Camadas mais espessas }(>10 \mathrm{~cm} \mathrm{e} \\
<20 \mathrm{~cm})\end{array}$ & Camadas menos espessas $(<10 \mathrm{~cm})$ & Muito importante \\
\hline $\begin{array}{l}\text { Maior quantidade de passadas dos } \\
\text { compactadores (número de fechas } \\
\text { para atingir o GC) }\end{array}$ & $\begin{array}{l}\text { Menor quantidade de passadas dos } \\
\text { compactadores (número de fechas para } \\
\text { atingir o GC) }\end{array}$ & Muito importante \\
\hline $\begin{array}{l}\text { Velocidade de rolagem menos } \\
\text { compatível com a camada }\end{array}$ & $\begin{array}{l}\text { Velocidade de rolagem compatível com } \\
\text { a camada }\end{array}$ & Muito importante \\
\hline $\begin{array}{l}\text { Equipe de equipamentos menos } \\
\text { compatível (equipamentos diferentes, } \\
\text { pesos diferentes, quantidade } \\
\text { incompatível com o GC) }\end{array}$ & $\begin{array}{l}\text { Equipe de equipamentos compatível } \\
\text { (equipamentos semelhantes, pesos } \\
\text { parecidos, quantidade compatível com } \\
\text { o GC) }\end{array}$ & Importante \\
\hline Equipe de laboratório menos treinada & Equipe de laboratório treinada & Importante \\
\hline $\begin{array}{l}\text { Maior a deformabilidade da camada } \\
\text { inferior }\end{array}$ & $\begin{array}{l}\text { Menor deformabilidade da camada } \\
\text { inferior }\end{array}$ & Pouco importante \\
\hline
\end{tabular}




\subsection{Concreto Betuminoso Usinado a Quente CBUQ - Capa e Binder}

Em termos das diferentes partes do serviço do concreto betuminoso usinado a quente - capa ou binder, fazem parte do escopo, quanto aos valores mostrados a seguir: a limpeza; o lançamento (descarga, espalhamento, nivelamento e précompactação); e a compactação de massa asfáltica.

As faixas de valores de produção unitária dos equipamentos, mostradas a seguir, foram feitas com as seguintes considerações:

a) mostram-se faixas de valores, referentes à produção unitária, contemplando os equipamentos (incluindo o operador) e os serventes (aqueles que acompanham os equipamentos quando da execução do serviço) (Tabela 100).

b) tais faixas vêm associadas aos fatores que levam a uma expectativa pior ou melhor quanto ao valor do indicador de produção unitária, isto é, uma proximidade maior do extremo direito ou esquerdo, respectivamente, da faixa (Tabela 101).

Tabela 100 - Concreto betuminoso usinado a quente - capa ou binder - esp. até $5 \mathrm{~cm}$

a) Etapa: espalhamento e nivelamento do revestimento asfáltico (os caminhões abastecem a vibroacabadora e esta espalha o material e nivela a camada)

\begin{tabular}{c|c|c|c|c|c|c}
\hline \multirow{2}{*}{ Equipamento } & \multicolumn{2}{|c|}{ Produção Unitária (m2/Hserv) } & \multicolumn{3}{c}{ Hfuncionamento } \\
\cline { 2 - 7 } & 1 Quartil & Mediana & 3ㅇ Quartil & 1 Quartil & Mediana & 3 Quartil \\
\hline Vibroacabadora de asfalto & 400 & 600 & 800 & $70 \%$ & $80 \%$ & $90 \%$ \\
\hline
\end{tabular}

b) Etapa: Compactação da camada

b1) Pré-compactação e acabamento (o rolo compactador tipo tandem inicia a compactação fazendo a acomodação inicial do material. Após a compactação propriamente dita, pelo compactador de pneus, o tandem retorna e dá o acabamento da camada)

\begin{tabular}{|c|c|c|c|c|c|c|}
\hline \multirow{2}{*}{ Equipamento } & \multicolumn{3}{|c|}{ Produção Unitária (m2/Hserv) } & \multicolumn{3}{|c|}{ Hfuncionamento } \\
\hline & 1ㅇ Quartil & Mediana & 3ํQuartil & 10 Quartil & Mediana & 3 Quartil \\
\hline $\begin{array}{l}\text { Rolo compactador tipo } \\
\text { tandem }\end{array}$ & 400 & 650 & 820 & $70 \%$ & $80 \%$ & $90 \%$ \\
\hline
\end{tabular}

b2) Compactação da camada (após a pré-compactação, executada pelo compactador tipo tandem, o rolo compactador de pneus faz a compactação propriamente dita)

\begin{tabular}{|c|c|c|c|c|c|c|}
\hline \multirow{2}{*}{ Equipamento } & \multicolumn{3}{|c|}{ Produção Unitária (m2/Hserv) } & \multicolumn{3}{|c|}{ Hfuncionamento } \\
\hline & $1^{\circ}$ Quartil & Mediana & 3ㅇ Quartil & $1^{\circ}$ Quartil & Mediana & 3ํo Quartil \\
\hline Rolo compactador de pneus & 400 & 550 & 715 & $70 \%$ & $80 \%$ & $90 \%$ \\
\hline c) Etapa: apoio & & & & & & \\
\hline
\end{tabular}

\begin{tabular}{|c|c|c|c|c|c|c|}
\hline \multirow{2}{*}{ Equipamento } & \multicolumn{3}{|c|}{ Produção Unitária (m2/Hserv) } & \multicolumn{3}{|c|}{ Hfuncionamento } \\
\hline & 10 Quartil & Mediana & 3 Quartil & 1 Quartil & Mediana & 3० Quartil \\
\hline Caminhão tanque & 400 & 500 & 650 & $10 \%$ & $15 \%$ & $20 \%$ \\
\hline \multicolumn{7}{|l|}{ c2) Apoio } \\
\hline \multirow{2}{*}{ Mão de obra } & \multicolumn{3}{|c|}{ Produção Unitária (m²/Hserv) } & & & \\
\hline & 1ㅇ Quartil & Mediana & 3 Quartil & & & \\
\hline Servente & 95 & 170 & 225 & & & \\
\hline
\end{tabular}


Tabela 101 - Fatores e anormalidades: concreto betuminoso usinado a quente - capa ou binder

\begin{tabular}{|c|c|c|}
\hline Aproxima do 1ㅇ Quartil & Aproxima do 3 Q Quartil & \multirow{2}{*}{ Importância } \\
\hline \multicolumn{2}{|c|}{ CONDICÕES GERAIS } & \\
\hline Condições climáticas instáveis & Condições climáticas estáveis & Muito importante \\
\hline $\begin{array}{l}\text { Baixa capacidade efetiva da usina } \\
\text { (menor quantidade de horas em } \\
\text { funcionamento) }\end{array}$ & $\begin{array}{l}\text { Alta capacidade efetiva da usina (maior } \\
\text { quantidade de horas em funcionamento) }\end{array}$ & Importante \\
\hline Operador menos treinado & Operador treinado & Importante \\
\hline $\begin{array}{l}\text { Má continuidade e sequência de } \\
\text { operações }\end{array}$ & $\begin{array}{l}\text { Boa continuidade e sequência de } \\
\text { operações }\end{array}$ & Importante \\
\hline Menos frentes sendo atendidas & Mais frentes sendo atendidas & Importante \\
\hline Frentes mais distantes & Frentes mais próximas & Importante \\
\hline $\begin{array}{l}\text { Tarefas preliminares a executar (ex. } \\
\text { pintura de ligação) }\end{array}$ & $\begin{array}{l}\text { Tarefas preliminares prontas (ex. pintura } \\
\text { de ligação) }\end{array}$ & Importante \\
\hline $\begin{array}{l}\text { Baixa qualidade da massa produzida } \\
\text { na usina }\end{array}$ & $\begin{array}{l}\text { Alta qualidade da massa produzida na } \\
\text { usina }\end{array}$ & Importante \\
\hline $\begin{array}{l}\text { Equipamentos em más condições e } \\
\text { descalibrados }\end{array}$ & $\begin{array}{l}\text { Equipamentos em boas condições e } \\
\text { calibrados }\end{array}$ & Importante \\
\hline Prevalece a improvisação & Planeja antecipadamente as atividades & $1 \mathrm{mr}$ \\
\hline $\begin{array}{l}\text { Há dificuldade em se manter a } \\
\text { temperatura da mistura asfáltica } \\
\text { conforme parâmetros de projeto }\end{array}$ & $\begin{array}{l}\text { Mantém a } \\
\text { asfáltica cc } \\
\text { projeto }\end{array}$ & Pouco importante \\
\hline $\begin{array}{l}\text { Problemas com abastecimento de } \\
\text { combustível (equipamento sem } \\
\text { combustível) }\end{array}$ & Equipamento abastecido (combustível) & Pouco importante \\
\hline $\begin{array}{l}\text { Alto índice de ausência do operador } \\
\text { (faltas) }\end{array}$ & $\begin{array}{l}\text { Baixo índice de ausência do operador } \\
\text { (faltas) }\end{array}$ & Pouco importante \\
\hline $\begin{array}{l}\text { Mais tempo para executar a atividade } \\
\text { (prazos extensos) }\end{array}$ & $\begin{array}{l}\text { Pouco tempo para executar a atividade } \\
\text { (prazos enxutos) }\end{array}$ & Pouco importante \\
\hline \multicolumn{3}{|c|}{ CONDIÇÕES ESPECÍFICAS } \\
\hline \multicolumn{2}{|c|}{ Espalhamento e nivelamento do revestimento asfáltico } & \\
\hline $\begin{array}{l}\text { Quantidade e capacidade de } \\
\text { caminhões menos compatível com a } \\
\text { frente a ser abastecida }\end{array}$ & $\begin{array}{l}\text { Quantidade e capacidade de caminhões } \\
\text { compatível com a frente a ser } \\
\text { abastecida }\end{array}$ & Importante \\
\hline $\begin{array}{l}\text { DMT maior (demora no trajeto } \\
\text { usina/frente) }\end{array}$ & $\begin{array}{l}\text { DMT menor (rapidez no trajeto } \\
\text { usina/frente) }\end{array}$ & Importante \\
\hline Equipe de apoio em treinamento & Equipe de apoio treinada & Importante \\
\hline \multicolumn{2}{|l|}{ Compactação da camada } & \\
\hline $\begin{array}{l}\text { Camadas mais espessas }(>2,5 \mathrm{~cm} \mathrm{e} \\
<5 \mathrm{~cm})\end{array}$ & Camadas menos espessas $(<2,5 \mathrm{~cm})$ & Importante \\
\hline $\begin{array}{l}\text { Equipe de equipamentos menos } \\
\text { compatível (equipamentos diferentes, } \\
\text { pesos diferentes, quantidade } \\
\text { incompatível com o GC) }\end{array}$ & $\begin{array}{l}\text { Equipe de equipamentos compatível } \\
\text { (equipamentos semelhantes, pesos } \\
\text { parecidos, quantidade compatível com o } \\
\text { GC) }\end{array}$ & Importante \\
\hline Equipe de laboratório menos treinada & Equipe de laboratório treinada & Importante \\
\hline $\begin{array}{l}\text { Velocidade de rolagem menos } \\
\text { compatível com a camada }\end{array}$ & $\begin{array}{l}\text { Velocidade de rolagem compatível com } \\
\text { a camada }\end{array}$ & Importante \\
\hline $\begin{array}{l}\text { Maior quantidade de passadas dos } \\
\text { compactadores (número de fechas } \\
\text { para atingir o GC) }\end{array}$ & $\begin{array}{l}\text { Menor quantidade de passadas dos } \\
\text { compactadores (número de fechas para } \\
\text { atingir o GC) }\end{array}$ & Pouco importante \\
\hline $\begin{array}{l}\text { Maior a deformabilidade da camada } \\
\text { inferior }\end{array}$ & $\begin{array}{l}\text { Menor deformabilidade da camada } \\
\text { inferior }\end{array}$ & Pouco importante \\
\hline
\end{tabular}




\subsection{Imprimação}

Em termos das diferentes partes do serviço de imprimação, fazem parte do escopo, quanto aos valores mostrados a seguir: a limpeza; e o lançamento do asfalto diluído.

As faixas de valores de produção unitária dos equipamentos, mostradas a seguir, foram feitas com as seguintes considerações:

a) mostram-se faixas de valores, referentes à produção unitária, contemplando os equipamentos (incluindo o operador) e os serventes (aqueles que acompanham os equipamentos quando da execução do serviço) (Tabela 102).

b) tais faixas vêm associadas aos fatores que levam a uma expectativa pior ou melhor quanto ao valor do indicador de produção unitária, isto é, uma proximidade maior do extremo direito ou esquerdo, respectivamente, da faixa (Tabela 103).

Tabela 102 - Imprimação

\begin{tabular}{|c|c|c|c|c|c|c|}
\hline \multirow{2}{*}{ Equipamento } & \multicolumn{3}{|c|}{ Produção Unitária (m²/Hserv) } & \multicolumn{3}{|c|}{ Hfuncionamento } \\
\hline & 1Q Quartil & Mediana & 3Q Quartil & $1^{\circ}$ Quartil & Mediana & 3 Quartil \\
\hline $\begin{array}{l}\text { Trator agrícola com } \\
\text { vassoura mecânica }\end{array}$ & 1600 & 1900 & 2300 & $30 \%$ & $40 \%$ & $50 \%$ \\
\hline \multicolumn{7}{|c|}{ b) Etapa: Iançamento de cobertura } \\
\hline \multirow{2}{*}{ Equipamento } & \multicolumn{3}{|c|}{ Produção Unitária ( $\mathrm{m}^{2} /$ Hserv) } & \multicolumn{3}{|c|}{ Hfuncionamento } \\
\hline & 10 Quartil & Mediana & 3 Quartil & 10 Quartil & Mediana & 3으uartil \\
\hline Caminhão espargidor & 300 & 425 & 600 & $40 \%$ & $50 \%$ & $60 \%$ \\
\hline \multirow{2}{*}{ Mão de obra } & \multicolumn{3}{|c|}{ Produção Unitária (m²/Hserv) } & & & \\
\hline & 1Q Quartil & Mediana & 3Q Quartil & & & \\
\hline Servente & 229 & 325 & 425 & & & \\
\hline
\end{tabular}


Tabela 103 - Fatores e anormalidades: imprimação

\begin{tabular}{|c|c|c|}
\hline Aproxima do 1ㅇ Quartil & Aproxima do $3^{\circ}$ Quartil & Importância \\
\hline Condições climáticas instáveis & Condições climáticas estáveis & Muito importante \\
\hline $\begin{array}{l}\text { Equipamentos em más condições } \\
\text { e descalibrados }\end{array}$ & $\begin{array}{l}\text { Equipamentos em boas condições } \\
\text { e calibrados }\end{array}$ & Muito importante \\
\hline Operador menos treinado & Operador treinado & Importante \\
\hline $\begin{array}{l}\text { Má continuidade e sequência de } \\
\text { operações }\end{array}$ & $\begin{array}{l}\text { Boa continuidade e sequência de } \\
\text { operações }\end{array}$ & Importante \\
\hline $\begin{array}{l}\text { Problemas com abastecimento de } \\
\text { combustível (equipamento sem } \\
\text { combustível) }\end{array}$ & $\begin{array}{l}\text { Equipamento abastecido } \\
\text { (combustível) }\end{array}$ & Importante \\
\hline $\begin{array}{l}\text { Há dificuldade em se manter a } \\
\text { temperatura da solução conforme } \\
\text { parâmetros de projeto }\end{array}$ & $\begin{array}{l}\text { Mantém a temperatura da solução } \\
\text { conforme parâmetros de projeto }\end{array}$ & Importante \\
\hline $\begin{array}{l}\text { Alto índice de ausência do } \\
\text { operador (faltas) }\end{array}$ & $\begin{array}{l}\text { Baixo índice de ausência do } \\
\text { operador (faltas) }\end{array}$ & Importante \\
\hline Prevalece a improvisação & $\begin{array}{l}\text { Planeja antecipadamente as } \\
\text { atividades }\end{array}$ & Importante \\
\hline $\begin{array}{l}\text { Tarefas preliminares a executar } \\
\text { (ex. base a ser revestida) }\end{array}$ & $\begin{array}{l}\text { Tarefas preliminares prontas (ex. } \\
\text { base a ser revestida) }\end{array}$ & Importante \\
\hline $\begin{array}{l}\text { Equipe de laboratório menos } \\
\text { treinada }\end{array}$ & Equipe de laboratório treinada & Pouco importante \\
\hline Menos frentes sendo atendidas & Mais frentes sendo atendidas & Pouco importante \\
\hline
\end{tabular}

\subsection{Pintura de Ligação}

Em termos das diferentes partes do serviço de pintura de ligação, fazem parte do escopo, quanto aos valores mostrados a seguir: a limpeza; e o lançamento da emulsão asfáltica.

As faixas de valores de produção unitária dos equipamentos, mostradas a seguir, foram feitas com as seguintes considerações:

a) mostram-se faixas de valores, referentes à produção unitária, contemplando os equipamentos (incluindo o operador) e os serventes (aqueles que acompanham os equipamentos quando da execução do serviço) (Tabela 104).

b) tais faixas vêm associadas aos fatores que levam a uma expectativa pior ou melhor quanto ao valor do indicador de produção unitária, isto é, uma proximidade maior do extremo direito ou esquerdo, respectivamente, da faixa (Tabela 105). 
Tabela 104 - Pintura de ligação

\begin{tabular}{|c|c|c|c|c|c|c|}
\hline \multirow{2}{*}{ Equipamento } & \multicolumn{3}{|c|}{ Produção Unitária ( $\mathrm{m}^{2} /$ Hserv) } & \multicolumn{3}{|c|}{ Hfuncionamento } \\
\hline & 10 Quartil & Mediana & 3 Quartil & 1 Quartil & Mediana & 3Q Quartil \\
\hline $\begin{array}{l}\text { Trator agrícola com } \\
\text { vassoura mecânica }\end{array}$ & 1600 & 1900 & 2300 & $45 \%$ & $60 \%$ & $64 \%$ \\
\hline \multicolumn{7}{|c|}{ b) Etapa: lançamento de cobertura } \\
\hline \multirow{2}{*}{ Equipamento } & \multicolumn{3}{|c|}{ Produção Unitária ( $\mathrm{m}^{2} /$ Hserv) } & \multicolumn{3}{|c|}{ Hfuncionamento } \\
\hline & 10 Quartil & Mediana & 3ㅇ Quartil & 10 Quartil & Mediana & 3 Quartil \\
\hline Caminhão espargidor & 300 & 425 & 600 & $40 \%$ & $50 \%$ & $60 \%$ \\
\hline \multirow{2}{*}{ Mão de obra } & \multicolumn{3}{|c|}{ Produção Unitária (m²/Hserv) } & & & \\
\hline & 10 Quartil & Mediana & 3ㅇ Quartil & & & \\
\hline Servente & 300 & 375 & 432,5 & & & \\
\hline
\end{tabular}

Tabela 105 - Fatores e anormalidades: pintura de ligação

\begin{tabular}{l|l|c}
\hline \multicolumn{1}{c|}{ Aproxima do 10 Quartil } & \multicolumn{1}{c|}{ Aproxima do 30 Quartil $^{\text {Importância }}$} \\
\hline Condições climáticas instáveis & Condições climáticas estáveis & Muito importante \\
\hline $\begin{array}{l}\text { Equipamentos em más condições } \\
\text { e descalibrados }\end{array}$ & $\begin{array}{l}\text { Equipamentos em boas condições } \\
\text { e calibrados }\end{array}$ & Importante \\
\hline $\begin{array}{l}\text { Há dificuldade em se manter a } \\
\text { temperatura da mistura asfáltica } \\
\text { conforme parâmetros de projeto }\end{array}$ & $\begin{array}{l}\text { Mantém a temperatura da solução } \\
\text { conforme parâmetros de projeto }\end{array}$ & Importante \\
\hline $\begin{array}{l}\text { Má continuidade e sequência de } \\
\text { operações }\end{array}$ & $\begin{array}{l}\text { Boa continuidade e sequência de } \\
\text { operações }\end{array}$ & Importante \\
\hline $\begin{array}{l}\text { Problemas com abastecimento de } \\
\text { combustível (equipamento sem } \\
\text { combustível) }\end{array}$ & $\begin{array}{l}\text { Equipamento abastecido } \\
\text { (combustível) }\end{array}$ & Importante \\
\hline $\begin{array}{l}\text { Prevalece a improvisação } \\
\text { Operador menos treinado }\end{array}$ & $\begin{array}{l}\text { Planeja antecipadamente as } \\
\text { atividades }\end{array}$ & Importante \\
\hline $\begin{array}{l}\text { Equipe de laboratório menos } \\
\text { treinada }\end{array}$ & Operador treinado & Importante \\
\hline $\begin{array}{l}\text { Tarefas preliminares a executar } \\
\text { (ex. base a ser revestida) }\end{array}$ & $\begin{array}{l}\text { Tarefas preliminares prontas (ex. } \\
\text { base a ser revestida) }\end{array}$ & Importante \\
\hline $\begin{array}{l}\text { Alto índice de ausência do } \\
\text { operador (faltas) }\end{array}$ & $\begin{array}{l}\text { Baixo índice de ausência do } \\
\text { operador (faltas) }\end{array}$ & Pouco importante \\
\hline $\begin{array}{l}\text { Velocidade de rolagem menos } \\
\text { compatível com a camada }\end{array}$ & $\begin{array}{l}\text { Velocidade de rolagem compatível } \\
\text { com a camada }\end{array}$ & Pouco importante \\
\hline $\begin{array}{l}\text { Menos frentes sendo atendidas } \\
\text { Mais frentes sendo atendidas }\end{array}$ & Pouco importante \\
\hline
\end{tabular}

\subsection{Reflexões do Capítulo 9}

Este capítulo sintetiza as etapas da metodologia utilizada, quais sejam: conhecimento básico sobre o assunto; padronização quanto à medição da produção unitária (PU) e definição de um modelo explanatório complementar; levantamentos de dados; e análise destes dados por especialistas. 
No que se refere à pesquisa bibliográfica preliminar, conforme apresentado nos Capítulos 2, 3 e 4, vários fatores foram levantados como possíveis influenciadores da produtividade e uma nova quebra dos serviços foi proposta. No Capítulo 5 uma nova proposta de abordagem para as composições foi apresentada e amplamente discutida. Quando do levantamento de dados (Capítulo 6), as produções unitárias (PU) e os fatores foram levantados, a nova quebra dos serviços e a proposta de abordagem foi implementada. No Capítulo 7 os indicadores dos manuais foram readequados conforme a nova abordagem. Esta implementação e readequação possibilitaram novos conhecimentos e o desenvolvimento do manual de aplicação nas entrevistas com os especialistas (Capítulo 8).

Observa-se que o método proposto promove uma série de melhorias quando comparado com os manuais estudados: elimina a necessidade de se considerar a existência de ritmo constante de trabalho; diminui o esforço dispendido na coleta de informações; facilita a influência das características do meio e das variações do conteúdo do trabalho sobre a produtividade.

No que diz respeito à experiência pessoal e à retroalimentação, quanto maior elas forem, maior a probabilidade de se chegar a resultados significativos. Porém, há que se posicionar de uma maneira aberta quanto aos resultados advindos do desenvolvimento da metodologia: os conhecimentos prévios e o bom senso do técnico devem ser auxiliares na interpretação dos resultados, e não ser tomados como verdades finais. Os resultados que vão sendo obtidos, isto sim, devem servir a uma reavaliação de tal conhecimento, ampliando o horizonte do próprio trabalho (SOUZA, 1996).

Tendo em vista a observação de um fenômeno real por um certo período de tempo, o intuito do método aqui proposto é permitir o seu "conhecimento", a "explicação" do que se viu acontecer e o "prognóstico" de futuros eventos. 


\section{CONCLUSÕES}

Estudos na área de crescimento econômico indicam que o desenvolvimento da infraestrutura é essencial na determinação do nível de renda "per capita" de um país. Prover a infraestrutura representa grandes investimentos públicos e um planejamento de longo prazo. No Brasil, nas ultimas décadas, o investimento em infraestrutura rodoviária se encontra bem aquém das necessidades do país além de apresentar sérios conflitos em obras públicas, tais como: licitações mal feitas, obras paralisadas e/ou abandonadas. Considera-se, portanto, que as rodovias constituem uma área tecnológica com potencial de desenvolvimento e que necessita de investimentos ordenados em vários setores. Em relação aos serviços de terraplenagem e pavimentação asfáltica, existem muitos manuais de orçamentação mas, os indicadores apresentados são por vezes de base teórica sem comprovação experimental, extremamente variáveis e os fatores que os fazem variar não são percebidos. Esta imprecisão dificulta a tomada de decisões confiáveis, comprometendo os processos orçamentários e de gestão da produção. A nova abordagem para se fazer o prognóstico da produtividade destes serviços, aqui proposta, pode resolver estas falhas e, assim, contribuir para levar o processo de gestão da produção de rodovias a um novo patamar de produtividade e eficiência.

\subsection{Cumprimento dos Objetivos}

Acredita-se que os objetivos desta tese foram cumpridos, na medida em que um novo modelo de prognóstico da produtividade na execução de rodovias, para terraplenagem e pavimentação asfáltica, foi desenvolvido. Depois de organizar os indicadores e fatores que os fazem variar a partir de todo o conhecimento adquirido, via estudo dos principais manuais, pesquisa sobre 0 assunto $e$ acompanhamento da execução dos serviços em obras, foi acrescentado o conhecimento de especialistas. A ajuda de especialistas definiu as faixas de produtividade variável e os fatores orientadores sobre qual valor adotar. 


\subsection{Confirmação da Tese}

Esta proposta, do Método para Prognóstico da Produtividade na Execução de Rodovias: terraplenagem e pavimentação asfáltica, confirma a tese apresentada no Capítulo 1, ou seja:

"As imprecisões contidas nos manuais orçamentários estudados (quebra de serviço diferenciada, embasamento teórico, indicadores variáveis e ausência dos fatores de conteúdo, contexto e anormalidades) impossibilita a tomada de decisões confiáveis, inviabilizando os processos de orçamentação e a gestão da produção. Para aprimorar os manuais existentes, a proposição de um novo modelo de prognóstico da produtividade na execução de terraplenagem e pavimentação asfáltica é fundamental."

\subsection{Importância dos Resultados}

Esta tese é um trabalho impar e promove contribuições inovadoras: apresenta um melhor detalhamento das diferentes partes dos serviços estudados; é mais abrangente em relação aos outros manuais (apresenta faixas de valores para os indicadores de produtividade); é mais orientador (contem os fatores que orientam sobre qual indicador adotar); é mais aprimorado (embasado na opinião de especialistas). O método desenvolvido, em função da metodologia empregada, têm uma grande chance de gerar "aceitação" no meio técnico.

Este trabalho emprega uma abordagem probabilística baseada nas medidas de tendência central (mediana) e contempla suas variabilidades. Ele se aplica às etapas: de orçamentação e planejamento (proporciona segurança para a correta estimativa); e de gestão da produção (verificação dos parâmetros de produtividade, permitindo lidar-se com o projeto de processos).

Espera-se que a explicitação minuciosa do "método para prognóstico da produtividade na execução de rodovias: terraplenagem e pavimentação asfáltica" seja um instrumento útil para a melhoria contínua dos sistemas de gestão da produção de rodovias e contribua na adequação da transmissão dos 
conhecimentos dessa área da engenharia, por meio dos resultados desta pesquisa. Que contribua na formação de usuários no exercício constante de entender melhor a produtividade variável, o que constitui uma capacidade altamente valorizável no ambiente mutável e competitivo em que as empresas de construção civil atuam.

\subsection{Futuros Trabalhos}

Seguramente há ainda um campo enorme a ser explorado quanto ao tema proposto neste trabalho e sua extrapolação a outros serviços de execução de rodovias.

Inicialmente destaca-se a necessidade de ampliar a base de especialistas (especialistas em um determinado tipo de obra analisando as obras de sua especialidade).

Além disso, é importante aumentar o número de estudos de caso para os serviços contemplados nesta tese (diferentes obras e diferentes regiões). Tal sugestão está relacionada aos resultados encontrados neste trabalho, pois este autor acredita que os resultados obtidos podem ainda ser manipulados no sentido de refinar mais ainda os indicadores propostos, quantificando a influência dos fatores detectados e relacionados.

Nesta mesma linha, o refinamento dos indicadores e a quantificação da influência dos fatores devem ser feitos empregando métodos estatísticos mais aprimorados. Paralelamente a estes novos estudos, deve-se ampliar a quantidade de serviços abrangidos na execução de pavimentação asfáltica (novos serviços e novos equipamentos).

Finalmente, acredita-se que este trabalho seja um incentivo no desenvolvimento de pesquisas que envolvam os conceitos de produtividade variável. Pois, além da possibilidade de ampliar os estudos referentes à execução de pavimentos asfálticos, existem outros tipos de pavimentos a serem estudados, como, por exemplo, pavimentos de concreto, onde o método proposto é totalmente aplicável. 
Enfim, além de desdobramentos específicos relativos ao uso do método proposto, se imagina que a tese pode ser usada como inspiração para outros desenvolvimentos que levem ao aprimoramento do prognóstico dos esforços relativos aos serviços de construção. E como já sugerido em outras partes deste texto, este autor acredita que uma boa base orçamentária pode contribuir para 0 desenvolvimento da Construção Civil como um todo. 


\section{REFERÊNCIAS BIBLIOGRÁFICAS}

1. AASHTO. Guide Specifications for Highway Construction. Washington D.C.: 1985. American Association of State Highway and Transportation Official.

2. ABDIB. Relatório Anual: Uma década de transformação na Infraestrutura. Associação Brasileira da Infraestrutura e Indústrias de Base. São Paulo: ABDIB, 2011.

3. ADAMOR JÚNIOR, T.; ROCHA, I. O.; SABÁ, R. F. B. Realização de estudo de tempos e movimentos numa indústria de colchões. Anais. In: XXII Encontro Nacional de Engenharia de Produção. Curitiba: ENEGEP, 2002.

4. ALBUQUERQUE, C.; COSTA K.; PEREIRA I. Indicadores de desempenho e metas baseadas na realidade de mercado. Rio de Janeiro: Controllab, 2007.

5. ARANOVICH, A. Curso de HDM: Operação do Programa HDM Manager. Porto Alegre: ABDIB, 1998. 3 v.

6. ASSOCIAÇÃO BRASILEIRA DE NORMAS TÉCNICAS. NBR 6141: máquinas rodoviárias - equipamentos, máquinas e implementos de terraplenagem e compactação - terminologia e classificação. Rio de Janeiro, 1996. 7 p.

7. NBR 7182. solo - ensaio de compactação. Rio de Janeiro, 1986.

8. BALBO, J. T. Pavimentação asfáltica: materiais, projeto e restauração. São Paulo: Oficina de Textos, 2007.

9. BALESTRASSI, P. P.; PAIVA, A. P. Estatística aplicada. Itajuba: UNIFEI, 2007.

10.BARNES, R. Estudo de movimentos e de tempos. São Paulo: Edgard Blucher Ltda., 1963.

11. BARNES, R. Estudo de tempos e movimentos: projeto e medida do trabalho. São Paulo: Edgard Blucher Ltda., 1977.

12. BEAUD, M. Arte da tese: como preparar e redigir uma tese de mestrado, uma monografia ou qualquer outro trabalho universitário. Rio de Janeiro: Bertrande Brasil, 2002.

13. BERNUCCI, L. B. Pavimentação asfáltica: formação básica para engenheiros. Rio de Janeiro: ABEDA, Petrobrás, 2007.

14. AEROPORTOS BRASILEIROS, INFRAERO. Orçamento de referência: Aeroporto Internacional de São Paulo - Guarulhos. FUA/GRL Guarulhos: Infraero, 2005. 
15. BRASIL. Plano de aceleração do crescimento: romper barreiras e superar limites - investimento em infraestrutura. Disponível em: < http://www.planejamento.gov.br/arquivos_down/noticias/pac/070123_PAC_IN FRA-ESTRUTURA.pdf>.: Acesso em: 19 de novembro de 2007.

16. DEPARTAMENTO NACIONAL DE INFRAESTRUTURA DE TRANSPORTES, DNIT. Manual de custos rodoviários. Anexo 1: Manual de pesquisa de preços de equipamentos e materiais. Diretoria Geral. Rio de Janeiro, 2003. 3. ed.

17. Manual de Pavimentação. Diretoria Geral. Rio de Janeiro, 2006. 3. ed.

18. Manual de Custos de Infraestrutura de Transportes Volume 1: Metodologia e Conceitos. Diretoria Geral. Rio de Janeiro, 2007a. 1. ed.

19. Manual de Custos de Infraestrutura de Transportes Volume 4: Manual de Custos Unitários de Obras Rodoviárias. Diretoria Geral. Rio de Janeiro, 2007b. 1. ed.

20. Manual de Custos de Infraestrutura de Transportes Volume 8: Manual de Aferição das Composições de Custos. Diretoria Geral. Rio de Janeiro, 2007c. 1. ed.

21. Manual de Custos de Infraestrutura de Transportes Volume 9, Tomo 2/6: Composições de Custos Unitários. Diretoria Geral. Rio de Janeiro, 2007d. 1. ed.

22. Manual de Custos de Infraestrutura de Transportes Volume 9, Tomo 5/6: Composições de Custos Unitários. Diretoria Geral. Rio de Janeiro, 2007e. 1. ed.

23. Manual de Custos de Infraestrutura de Transportes Volume 9, Tomo 6/6: Composições de Custos Unitários. Diretoria Geral. Rio de Janeiro, 2007f. 1. ed.

24._Apresentação. Disponível em: <http://www.dnit.gov.br/menu /institucional>. Acesso em: 05 de janeiro de 2010.

25. CARDOSO, F. F.; SHIMIZU, J. Y. Serviços de escavação: equipamentos e aspectos executivos. Notas de aula: PCC - 2435: Tecnologia da Construção de Edifícios I. São Paulo: PCC-USP, 2002.

26. CARVALHO, L, O; HEINECK, L. F.; JUNGLES, A. E. Uma metodologia para obtenção de constantes orçamentárias utilizando a técnica da amostragem do trabalho. Anais. XXIV Encontro Nacional de Engenharia de Produção, ENEGEP. Florianópolis. 2004. 1 CD-ROM.

27.CATERPILLAR. Manual de produção - página 5 (modelo 330). EUA, Peoria: Caterpillar Inc., 2000. 31 ed. 
28. Pá carregadeira sobre esteiras. Disponível em: <http://xml.catmms .com/servlet/ImageServlet?imageld=C453361 >. Acesso em: 15 de abril de 2012a.

29._Retroescavadeira. Disponível em: <http://brasil.cat.com/cda /layout? $m=423056 \& x=12>$. Acesso em: 15 de abril de 2012b.

30.

Rolo liso metálico para compactação de pavimento. Disponível em: <http://brasil.cat.com/cda/layout?m=308466\&x=12>. Acesso em: 15 de abril de 2012c.

31.

Rolo de pneus para compactação de pavimento. Disponível em: <http://brasil.cat.com/cda/layout?m=308476\&x=12>. Acesso em: 15 de abril de $2012 d$

32. CIMINO, R. Planejar para construir. São Paulo: Pini, 1987.

33. CONSTRUÇÃO, U. N. A construção do desenvolvimento sustentado: a importância da construção na vida econômica do país, 2006. Disponível em: <http://www.sindusconsp.com.br/especiais/Uniao_ nacionalconstrucao /doc_unc.pdf>.: Acesso em: 07 de agosto de 2008.

34. Departamento Autônomo de Estradas de Rodagem do Estado do Rio Grande do Sul, DAER-RS. Tabela de custos. Disponível em: <http://www.daer.rs.gov.br/site/index.php>. Acesso em: 24 de abril de 2012.

35. DANIEL FILHO, O. C. Expansão da capacidade produtiva no setor de corte de uma empresa têxtil. 2010. 72 p. Trabalho de conclusão de curso (Graduação) - Universidade Federal de Juiz de Fora, Juiz de Fora, 2010.

36. DEPARTAMENTO DE ESTRADAS DE RODAGEM DO ESTADO DE SÃO PAULO, DER-SP. M 196. classificação de solos tropicais segundo a metodologia MCT. São Paulo, 1989

37. ET-DE-Q00/002: escavação e carga de material. São Paulo, 2006a. $11 \mathrm{p}$.

38. ET-DE-Q00/003: aterro. São Paulo, 2006b. 17p.

39.DESENVOLVIMENTO RODOVIÁRIO S/A., DERSA. Álbum de fotos. Disponível em: <http://www.dersa.sp.gov.br/albuns/tracado.php>. Acesso em: 20/10/2011.

40. DEPARTAMENTO NACIONAL DE ESTRADAS DE RODAGEM, DNER. Manual de implantação básica. Rio de Janeiro, 1996. 2 ed.

41. DNER-ES 280/97: terraplenagem - cortes. Rio de Janeiro, 1997. 6p.

42. DNER-ES 282/97: terraplenagem - aterros. Rio de Janeiro, 1997. $11 \mathrm{p}$. 
43. DIAB, M. F.; NASSAR, K. Using Risk Assessment to Improve Highway Construction Project Performance. ANAIS. $48^{\text {th }}$ ASC Annual International Conference Proceedings. Associated Schools of Construction. England: Birmingham City University, 2012.

44.DODGE. Heavy Construction Cost Book. USA: Mcgraw-Hill Trade, 1998.

45.DOUGLAS, G. D.; POPSCU, C.; RYAN, R. C. Construction Equipment Management for Engineers, Estimators, and Owners. USA: CRC Press, 2006. p 416.

46. DUARTE, H. C. F.; LAMOUNIER, W. M. Análise financeira de empresas da construção civil por comparação com índices padrão. Paraná: Universidade Estadual de Maringá-UEM, 2007.

47.DYNAPAC. Manual de instruções - ICC224HF-1BR4. Suécia: Dynapac, 2010.

48.ESCOLA POLITÉCNICA DA UNIVERSIDADE DE SÃO PAULO, EPUSP. Pesquisa visando o desenvolvimento de diretrizes para 0 aprimoramento do Sistema Nacional de Pesquisa de Custos e Índices da Construção Civil - SINAPI com referência à Construção Aeroportuária: Relatório R17: Relatório Final. São Paulo: EPUSP, 2008a.

49. Relatório R2: Método para Levantamento de Informações Existentes e Estudos de Campo. São Paulo: EPUSP, 2008b.

50.FACHIN, O. Fundamentos de Metodologia. São Paulo: Atlas, 1993.

51.FEHRL. NR2C - New Road Construction Concepts: Towards reliable, green, safe\&smart and human infrastructure in Europe. Sixth Framework Programme of th European Union. 2008.

52. FWA, T. F. Highway and Airport Pavement Design. In: CHEN, W. F.; LIEW, R. J. Y. The Civil Engineering Handbook. 2ed. Washington, D.C.: CRC Press LLC, 2003. p. 62 -1 a $62-78$.

53. GADELHA, L. G. C. Orçamento na Construção Pesada. Recife: Edições Bagaço, 2006.

54. GOKHALE, T. I. Equipment Productivity. In: CHEN, W. F.; LIEW, R. J. Y. The Civil Engineering Handbook. (2. ed.). Washington, D.C.: 2003. CRC Press LLC.

55. HONGYAN, Y.; SUOZHONG, C. Design and implementation of roadway geological sketch picture drawing system based on MapGIS. IEEE, 2010.

56.INOUYE, K. P.; SOUZA, U. E. Estudo dos fatores que influenciam a variação do volume de terraplenagem em empreendimentos habitacionais horizontais. Anais. In: X Encontro Nacional de Tecnologia no Ambiente Construído. São Paulo: ENTAC, 2004. 1 CD-ROM. 
57. INOUYE, K. P. Proposição de um método para subsidiar o prognóstico de custos de urbanização de conjuntos habitacionais horizontais com base em indicadores físicos. 2009. 313 p. Tese (Doutorado) - Escola Politécnica da Universidade de São Paulo, São Paulo, 2009.

58. JLARC. Joint Legislative Audit and Review Commission. Estimating Optimum Mileage for Vehicle Retirement. Disponível em: <jlarc.state.va.us/reports/techappn.pdf>. July 15, 2008.

59. JOHN, R. C.; SULLIVAN, W. G.; KULONDA, D. J.; WHITE, J. A. Capital Investment Analysis for Engineering and Management. Upper Saddle River, NJ: Pearson- Prentice Hall, 2005. 3rd Edition.

60. JONES, P. C.; ZYDIAK, J. L.; HOPP, W. J. Stable Economic Depreciation and Neutral Replacement Decisions. The Engineering Economist, v. 1, p. 115-128. 1989.

61. JONES, P. C.; ZYDIAK, J. L.; HOPP, W. J. Capital Asset Valuation and Depreciation for Stochastically Deteriorating Equipment. The Engineering Economist, v. 38, p. 19-30. 1992.

62. JONES, P. C.; ZYDIAK, J. L. A Further Note on the Fleet Design Problem. Engineering Economist, v. 45. 1999.

63. JÚNIO A.; ROCHA I. O.; SABÁ, R. F. B. Realização de estudo de tempos e movimentos numa indústria de colchões. Anais. In: XXII Encontro Nacional de Engenharia de Produção. Curitiba: ENEGEP, 2002.

64.KANGA, M.; JHA, M. K.; SCHONFELD. P. Applicability of highway alignment optimization models. Transportation Research, Elsevier, 2012. Part C 21 pg 257-286.

65.KAUFFMANN, P. et al. Fleet Management Criteria: Identification Of Optimal Disposal Points Using Equivalent Uniform Annual Cost. North Carolina: North Carolina Department of Transportation: Equipment \& Inventory Control Unit, 2011.

66. KIMLEY-HORN. Pearce Pavilion Parking Area Construction. FSP № 201102147. Texas: Engineering, Design \& Construction Serviçes. College Station, 2012.

67.KOMATSU. Specifications \& Application Handbook. Japan: Komatsu, 2006. Ed. 27.

68. Trator de esteira com lâmina frontal. Disponível em: <http://www.komatsu.com.br/pt/catalogo.php?categoria=223|Tratores de Esteira $>$. Acesso em: 15 de maio de 2012a.

69. Trator de esteiras com lâmina frontal e escarificador traseiro. Disponível em: <http://www.komatsu.com.br/pt/catalogo.php?categoria $=223$ |Tratores de Esteira>. Acesso em: 15 de maio de 2012b. 
70._ Pá carregadeira sobre pneus. Disponível em: <http://www.komatsu.com.br/pt/catalogo.php?categoria=218|Carregadeiras >. Acesso em: 15 de maio de 2012c.

71. Escavadeira hidráulica. Disponível em: <http://www.komatsu. com.br/pt/catalogo.php?categoria=219|Escavadeiras >. Acesso em: $15 \mathrm{de}$ maio de 2012d.

72. Motoniveladora. Disponível em: <http://www.komatsu.com.br /pt/catalogo.php?categoria=220|Motoniveladoras $>$. Acesso em: 15 de maio de 2012 e.

73.LAKATOS, E. M. Fundamentos de metodologia científica. (4. ed.). São Paulo: Atlas, 2001.

74.LAPINSKI, M. Road and Bridge Construction Handbook. New York: Van Nostrand Reinhold Compan, 1978.

75. LI, Z. Highway Asset Management. In: CHEN, W. F.; LIEW, R. J. Y. The Civil Engineering Handbook. 2ed. Washington, D.C.: CRC Press LLC, 2003.

76. MARCHIORI, F. F. Desenvolvimento de um método para elaboração de redes de composições de custo para orçamentação de obras de edificações. 2009. 237 p. Tese (Doutorado) - Escola Politécnica da Universidade de São Paulo, São Paulo, 2009.

77.MEYBOOM, A. Infrastructure as Practice. Journal of Architectural Education. ACSA, 2009. p. 72-81.

78. MIGUEL, M. I. R.; COUTINHO, C. Q. S. Uma reflexão didática sobre o conceito de mediana e quartis. Disponível em: < http://alb.com.br/arquivomorto/edicoes_anteriores/anais16/sem15dpf/sm15ss08_04.pdf>. Acesso em: janeiro de $201 \overline{2}$.

79. MICHAELIS. Moderno dicionário da língua portuguesa: terraplenagem. Disponível em: <http://michaelis.uol.com.br/moderno/portugues/index.php?I ingua $=$ portugues-portugues\&palavra=terraplenagem $>$. Acesso em: 14 de maio de 2012.

80.NOVASKI, O.; SUGAI, M. MTM como ferramenta para redução de custos: O taylorismo aplicado com sucesso nas empresas de hoje. Campinas: Unicamp, 2001

81.PALIARI, J. C. Método para prognóstico da produtividade da mão de obra e consumo unitário de materiais: sistemas prediais hidráulicos. 2008. 696 p. Tese (Doutorado) - Escola Politécnica da Universidade de São Paulo, São Paulo, 2008.

82. PAPACOSTAS, C. S. PREVEDOUROS, P. D. Transportation Engineering \& Planning. Singapore: Prentice Hall, 2005. 
83.PARK, C. S.; GUNTER, P. S. B. Advanced Engineering Economics. John Wiley, New 6 York, 1990.

84. PASTANA, C. E. T. Pavimentações de Estradas II. Notas de aula. Marília: Universidade de Marília, 2006.

85.PEDROZO, L. G. Custos da Infraestrutura Rodoviária: Análise e Sistematização. Porto Alegre: Programa de pós-graduação em engenharia. 2001. 183 p. Dissertação (Mestrado Profissionalizante) - Escola de Engenharia da Universidade Federal do Rio Grande do Sul, 2001.

86. PEREIRA, D. M. et al. Introdução à terraplenagem. Notas de aula. Paraná: UFPR, 2010.

87.PINDYCK, R.S.; RUBINFELD, D. L. Microeconomia. 4. ed. São Paulo: Makron Books, 1999. 791p.

88. POTTS, K. Construction Cost Management - Learning From Case Studies. USA: Taylor \& Francis, 2008.

89. PRONACI. Manual pedagógico: métodos e tempos. Programa Nacional de Qualificação de Chefias Intermédias. Portugal: Associação Empresarial de Portugal, 2003.

90.RAMOS, E. M. L. S. Aperfeiçoamento e desenvolvimento de ferramentas do controle estatístico da qualidade - Utilizando quartis para estimar o desvio padrão. Florianópolis: Programa de Pós-Graduação em Engenharia de Produção. 2003. 130 p. Tese (Doutorado em Engenharia de Produção). Universidade Federal de Santa Catarina, Florianópolis, 2003.

91.REIS, D. A. Administração da Produção: Sistemas, Planejamento e Controle. São Paulo: Atlas, 1978.

92. RICARDO, H. S.; CATALANI, G. Manual prático de escavação. São Paulo: Pini, 1990. 2 Ed.

93. RIO DE JANEIRO. Secretaria de Estado de Obras e Serviços Públicos. Empresa de Obras Públicas do Estado do Rio de Janeiro, EMOP. Catálogo de Composição de Serviços: Sistema de Custos Unitários. Niterói: Imprensa Oficial do Estado do Rio de Janeiro, 1999. 2ª Edição.

94.ROBINSON, R.; DANIELSON, U.; SNAITH, M. Road Maintenance Management - Concepts and Systems. New York: Palgrave, 1988.

95. ROCHA, A. P. Serviços de terraplenagem. Construção Mercado. São Paulo: Pini, 2009. ed. 93.

96. ROCHA, A. P. Inaugurado o trecho sul do Rodoanel Mario Covas. Disponível em: < http://piniweb.pini.com.br/construcao/infra-estrutura/inaugurado-otrecho-sul-do-rodoanel-mario-covas-168457-1.aspx>. Acesso em: abril de 2010. 
97.ROWINGS JR, J. E. Construction Estimating. In: CHEN, W. F.; LIEW, R. J. Y. The Civil Engineering Handbook. (2. ed. ed.). Washington, D.C: CRC Press LLC, 2003.

98. RS MEANS. Heavy Construction Cost Data. USA: John Wliley Profession, 2012. 26th Edition.

99.SALIM NETO, J. J. Diretrizes de projeto para melhorar a produtividade na montagem de componentes pré-cortados e pré-dobrados de aço para estruturas de concreto armado de edifícios. São Paulo: Programa de pósgraduação em engenharia civil. 2009. 242 p. Dissertação (Mestrado em Engenharia Civil) - Escola Politécnica da Universidade de São Paulo, 2009.

100.SAMPIERI, R. H.; COLLADO, C. F.; LUCIO, P. B. Metodologia de pesquisa. (3. ed. ed.). São Paulo: McGraw-Hill, 2006.

101.SECRETARIA DE INFRAESTRUTURA URBANA E OBRAS, SIURB. Tabelas de Custos Unitários: Edificações e Infraestrutura Urbana. Prefeitura do Município de São Paulo. Disponível em: <http://www2.prefeitura.sp.gov.br/secretarias/infraestruturaurbana/tabela_de_ precos/0023 >. Acesso em: janeiro de 2010.

102. SEINFRA-CE. Tabela de custos. Secretaria da Infraestrutura do Estado do Ceará. Disponível em:<http://www.seinfra.ce.gov.br/>. Acesso em: 24 de abril de 2012.

103. SEINFRA-GO. Tabela de custos. Secretaria de Estado de Infraestrutura de Goiás. Disponível em: <http://www.seinfra.go.gov.br/>. Acesso em: 24 de abril de 2012.

104. SENÇO, W. Terraplenagem. São Paulo: Universidade de São Paulo, Grêmio Politécnico, 1980.

105. vol. $1,2^{a}$ ed.

106. $2,2^{\mathrm{a}}$ ed.

Manual de técnicas de pavimentação. São Paulo: Pini, 2008a.

107.SHIMIZU, J. Y. Movimento de terra. São Paulo: PCC-USP, 2002.

108. SOTOMAYOR, R. W. R. Sobre a estimativa de produção de equipamentos de construção de pavimentos rodoviários. Campinas: Programa de pós-graduação em engenharia civil, arquitetura e urbanismo. 2008. Dissertação (Mestrado) - Universidade Estadual de Campinas, Faculdade de Engenharia Civil, Arquitetura e Urbanismo. 2008.

109. SOUZA, U. E. Metodologia para o estudo da produtividade da mão de obra no serviço de fôrmas para estruturas de concreto armado. São Paulo: Programa de pós-graduação em engenharia civil. 1996. 280 p. Tese (Doutorado em Engenharia Civil) - Escola Politécnica da Universidade de São Paulo, 1996. 
110. SOUZA, U. E. L. Produtividade e Custos dos Sistemas de Vedação Vertical. ANAIS. Seminário Tecnologia e Gestão na Produção de Edifícios Vedações Verticais. São Paulo: PCC/EPUSP, 1998.

111. SOUZA, U. E. Como aumentar a eficiência da mão de obra: manual de gestão da produtividade na construção civil. São Paulo: Pini, 2006.

112. TATUM, C. B. et al. Systems Analysis of Technical Advancement in Earthmoving Equipment. Journal of Construction Engineering and Management, Vol. 132, No. 9, September 2006.

113. TCPO. Tabela de Composição de Preços para Orçamentos. São Paulo: Pini, 2008. Ed. 13ㄹ.

114.TEXAS HIGHWAY DEPARTMENT. Standard Specifications for Construction of Highways, Streets and Bridges. Texas: Texas Highway Department, 1972.

115. VILLELA, A. R. A. Estudo de camada de base asfáltica de módulo elevado para restauração de rodovias de tráfego muito pesado. 2012. 206 p. Tese (Doutorado) - Escola Politécnica da Universidade de São Paulo, São Paulo, 2012.

116.WORLDWIDE MACHINERY. Moto-scraper. Disponível em: $<$ http://www.worldwidemachinery.com/wwm/Scraper?gclid=COSj3r3T0asCFQ 9S7Aod8X4sZw>. Acesso em: 15 de abril de 2012.

117. YIN, R. K. Estudo de caso: planejamento e métodos. Porto Alegre: Bookman, 2005. 


\section{APÊNDICE A - EXEMPLO DE APLICAÇÃO DO MÉTODO TEÓRICO DO DNIT}

A seguir, é apresentado um exemplo de aplicação do método teórico do DNIT apresentado no Capítulo 4.

Primeiramente, parte-se para o preenchimento da Planilha de Composição das Equipes Mecânicas.

Tabela 106 - Exemplo de aplicação da planilha de composição

\begin{tabular}{|c|c|c|c|c|}
\hline Código & \multicolumn{3}{|l|}{ Serviço: } & Unidade \\
\hline \multirow[t]{3}{*}{402109} & \multicolumn{3}{|c|}{$\begin{array}{l}\text { Escav Carga Transp Mat 1a Cat DMT } 50 \text { a } 200 \mathrm{~m} \text { - Cam Serv em } \\
\text { leito Natural: c/ esc e caminhão bascul } 14 \mathrm{~m} 3\end{array}$} & M3 \\
\hline & \multicolumn{2}{|l|}{ Variáveis Intervenientes } & \multicolumn{2}{|c|}{ Equipamentos } \\
\hline & & Unidade & \begin{tabular}{|c|} 
Escavadeira \\
Hidráulica de \\
Esteiras 166 \\
kW \\
\end{tabular} & $\begin{array}{l}\text { Caminhão } \\
\text { Basculante } 14 \\
\text { m3 } 235 \text { kW }\end{array}$ \\
\hline a & Afastamento & & & \\
\hline b & Capacidade & $\mathrm{m} 3$ & 1,5 & 14 \\
\hline c & Consumo (quantidade) & & & \\
\hline d & Distância & $\mathrm{m} 3$ & & 200 \\
\hline $\mathrm{e}$ & Espaçamento & & & \\
\hline $\mathrm{f}$ & Espessura & & & \\
\hline $\mathrm{g}$ & Fator de carga & & 0,9 & 0,9 \\
\hline $\mathrm{h}$ & Fator de conversão & & 0,77 & 0,77 \\
\hline $\mathrm{i}$ & Fator de eficiência & & 0,83 & 0,83 \\
\hline j & Largura de operação & $\mathrm{m}$ & & \\
\hline 1 & Largura de superposição & $\mathrm{m}$ & & \\
\hline $\mathrm{m}$ & Largura útil & $\mathrm{m}$ & & \\
\hline $\mathrm{n}$ & Número de passadas & & & \\
\hline 0 & Profundidade & & & \\
\hline$p$ & Tempo fixo (carga, descarga e manobra) & $\min$ & & 2,81 \\
\hline q & Tempo percurso (ida) & $\min$ & & 4,43 \\
\hline$r$ & Tempo retorno & $\min$ & & 2,61 \\
\hline $\mathrm{s}$ & Tempo total de ciclo & $\min$ & 0,27 & 9,85 \\
\hline $\mathrm{t}$ & Velocidade (ida) média & $\mathrm{km} / \mathrm{h}$ & & 2,71 \\
\hline $\mathrm{u}$ & Velocidade retorno & $\mathrm{km} / \mathrm{h}$ & & 4,6 \\
\hline$z$ & Número de unidades & & 1 & 4 \\
\hline \multirow{2}{*}{\multicolumn{3}{|c|}{$\begin{array}{l}\text { Observações: o número de unidades foi calculado } \\
\text { dividindo a produção horária do equipamento principal pela } \\
\text { produção horária do equipamento da patrulha. } \\
\text { Ex.:192/49=4 }\end{array}$}} & Fórmulas & Fórmulas \\
\hline & & & $P=(60$. b.g.h..$) / s$ & $P=(60$.b.g.h.i $) / s$ \\
\hline \multicolumn{3}{|c|}{ Produção horária } & 192 & 49 \\
\hline \multicolumn{3}{|c|}{ Coeficiente unitário (1 / produção horária) } & 0,0052 & 0,0204 \\
\hline \multicolumn{3}{|c|}{ Utilização produtiva } & 1 & 0,98 \\
\hline \multicolumn{3}{|c|}{ Utilização improdutiva } & 0 & 0,02 \\
\hline \multicolumn{3}{|c|}{ PRODUÇÂO DA EQUIPE (m3/h) } & \multicolumn{2}{|c|}{192} \\
\hline
\end{tabular}

Fonte: DNIT (2007d) 
Caso seja necessário, busca-se informações no banco de dados da empresa. Por exemplo: as informações relacionadas ao caminhão foram tiradas da planilha apresentada na Figura 55.

\begin{tabular}{|c|c|c|c|c|c|c|c|c|}
\hline $\begin{array}{l}\text { DMT } \\
(\mathrm{m})\end{array}$ & $\begin{array}{l}\text { Carga } \\
\text { (min) }\end{array}$ & $\begin{array}{l}\text { Ida } \\
\text { (min) }\end{array}$ & $\begin{array}{c}\text { Manobra } \\
\text { Descarga } \\
\text { (min) }\end{array}$ & $\begin{array}{c}\text { Retorno } \\
\text { (min) }\end{array}$ & $\begin{array}{c}\text { Manobras } \\
\text { nova carga } \\
\text { (min) }\end{array}$ & Total & $\begin{array}{l}\text { Veloc. } \\
\text { Ida } \\
(\mathrm{km} / \mathrm{h})\end{array}$ & $\begin{array}{l}\text { Veloc. } \\
\text { Retorno } \\
(\mathrm{km} / \mathrm{h})\end{array}$ \\
\hline 50 a 200 & 1,71 & 4,43 & 0,50 & 2,61 & 0,60 & 9,85 & 2,71 & 4,60 \\
\hline
\end{tabular}

Figura 55 - Tempos de ciclo (min) e produção horária do caminhão basculante de $14 \mathrm{~m}^{3}$ no transporte de material de $1^{\text {a }}$ categoria em rodovia em leito natural - carga com escavadeira Fonte: DNIT (2007b)

Finalmente, apresenta-se o resumo da composição unitária, ver Figura 56, originada da Planilha de Composição das Equipes Mecânicas (ver Tabela 106).

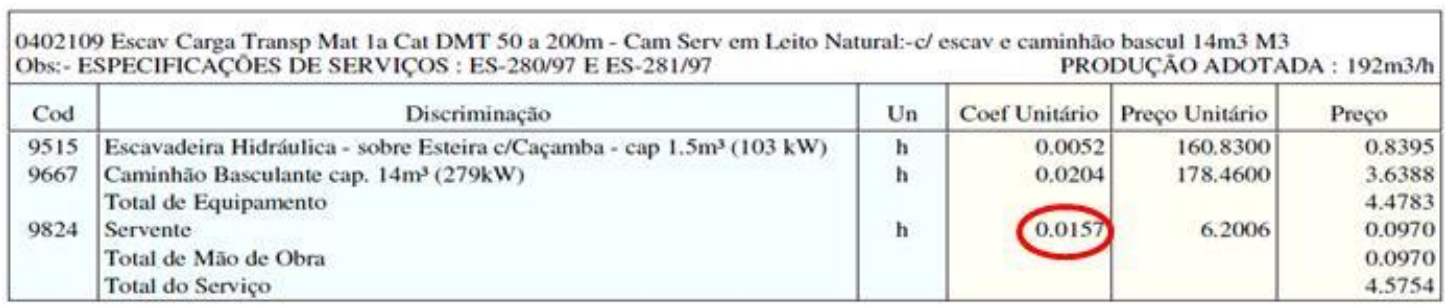

Figura 56 - Exemplo de composição do serviço de escavação Fonte: DNIT (2007d)

O indicador de mão de obra igual a 0,0157 indica 3 serventes apoiando o serviço $(0,0157 * 192=3$ serventes $)$. 


\section{APÊNDICE B - CONJUNTO DE DADOS DO AEROPORTO DE GUARULHOS}

A seguir, são apresentados o conjunto dos dados (detalhados) apresentados no Capítulo 6.

Tabela 107 - Escavação de material de 1a categoria. Etapa: escavação e carga $\left(m^{3}\right)$ - Guarulhos

\begin{tabular}{|c|c|c|c|c|c|c|c|c|c|}
\hline \multicolumn{10}{|c|}{ ESCAVADEIRA HIDRÁULICA 320C } \\
\hline \multirow[b]{2}{*}{ Data } & \multirow[b]{2}{*}{ Etapa } & \multirow{2}{*}{$\begin{array}{l}\text { QS } \\
\text { m3 }\end{array}$} & \multicolumn{2}{|c|}{ Horas } & \multirow{2}{*}{$\begin{array}{c}\begin{array}{c}P_{\mathrm{U}_{\mathrm{d}}} \\
\left(\mathrm{m}^{3} / \mathrm{Eh}\right)\end{array} \\
\text { Hserv } \\
\end{array}$} & \multirow{2}{*}{$\begin{array}{l}\begin{array}{c}\mathrm{PU}_{\text {cum }} \\
\left(\mathrm{m}^{3} / \mathrm{Eh}\right)\end{array} \\
\text { Hserv } \\
\end{array}$} & \multirow{2}{*}{$\begin{array}{c}\begin{array}{c}\mathrm{PU}_{\text {pot }} \\
\left(\mathrm{m}^{3} / \mathrm{Eh}\right)\end{array} \\
\text { Hserv }\end{array}$} & \multirow[b]{2}{*}{ Hfunc } & \multirow[b]{2}{*}{$\Delta$} \\
\hline & & & Hfunc & Himprod & & & & & \\
\hline 06/jun & 1 & 787,8 & 4,42 & 3,58 & 98,5 & 98,5 & \multirow{10}{*}{196,8} & $55 \%$ & \multirow{10}{*}{108,9} \\
\hline 14/jun & 2 & 2259,9 & 9,5 & 0 & 237,9 & 174,2 & & $100 \%$ & \\
\hline 19/jun & 3 & 1245,8 & 4,5 & 3,5 & 155,7 & 168,4 & & $56 \%$ & \\
\hline 20/jun & 4 & 3060,5 & 10,5 & 0 & 291,5 & 204,3 & & $100 \%$ & \\
\hline 21/jun & 5 & 3803,9 & 21,83 & 5 & 141,8 & 177,6 & & $81 \%$ & \\
\hline 28/jun & 6 & 618,3 & 3 & 5 & 77,3 & 166,3 & & $38 \%$ & \\
\hline 23/jan & 7 & 679,7 & 15,33 & 0,67 & 42,5 & 143,5 & & $96 \%$ & \\
\hline 24/jan & 8 & 580,5 & 13 & 3 & 36,3 & 126,8 & & $81 \%$ & \\
\hline 25/jan & 9 & 245,3 & 2 & 6 & 30,7 & 119,8 & & $25 \%$ & \\
\hline 25/jan & 10 & 353,3 & 3 & 5 & 44,2 & 114,7 & & $38 \%$ & \\
\hline
\end{tabular}

Tabela 108 - Escavação de material de 1 a categoria - mão de obra $\left(\mathrm{m}^{3}\right)$ - Guarulhos

MÃO DE OBRA DE APOIO - SERVENTE

\begin{tabular}{|c|c|c|c|c|c|c|c|c|}
\hline \multirow[b]{2}{*}{ Data } & \multirow[b]{2}{*}{ Etapa } & QS & \multirow[b]{2}{*}{ Horas } & \multirow{2}{*}{$\begin{array}{c}\mathrm{PU}_{\mathrm{d}} \\
\left(\mathrm{m}^{3} / \mathrm{Eh}\right)\end{array}$} & \multirow{2}{*}{$\begin{array}{c}\mathrm{PU}_{\text {cum }} \\
\left(\mathrm{m}^{3} / \mathrm{Eh}\right)\end{array}$} & \multirow{2}{*}{$\begin{array}{c}\mathrm{PU}_{\text {pot }} \\
\left(\mathrm{m}^{3} / \mathrm{Eh}\right)\end{array}$} & \multirow{2}{*}{$\begin{array}{l}\text { Média } \\
\text { Funcion. }\end{array}$} & \multirow{2}{*}{$\Delta$} \\
\hline & & m3 & & & & & & \\
\hline 14/jun & 2 & 2259,9 & 9,5 & 237,9 & 237,9 & \multirow{8}{*}{213,7} & 1 & \multirow{9}{*}{128,8} \\
\hline 19/jun & 3 & 1245,8 & 5,8 & 213,7 & 228,7 & & 1 & \\
\hline 20/jun & 4 & 3060,5 & 21,0 & 145,7 & 180,7 & & 3 & \\
\hline $21 /$ jun & 5 & 3803,9 & 44,8 & 84,9 & 127,8 & & 6 & \\
\hline 28/jun & 6 & & 0,0 & & 127,8 & & 0 & \\
\hline 23/jan & 7 & 679,7 & 18,0 & 37,8 & 111,4 & & 2 & \\
\hline 24/jan & 8 & 580,5 & 10,0 & 58,1 & 106,5 & & 1 & \\
\hline 25/jan & 9 & 245,3 & 4,5 & 54,5 & 104,5 & & 1 & \\
\hline & & & & & & Mediana & 1 & \\
\hline
\end{tabular}

Tabela 109 - Compactação de aterro $\left(\mathrm{m}^{3}\right)$ - Guarulhos

\begin{tabular}{c|c|c|c|c|c|c|c|c|c|c}
\hline \multicolumn{10}{c}{ COMPACTAÇÂO DE ATERRO (m3/Eh) - RESUMO } \\
\hline & Motoniveladora & \multicolumn{2}{|c|}{ Trator de pneus } & Trator de esteira D6D & \multicolumn{2}{c|}{ Rolo vibratório } & \multicolumn{2}{c}{ Caminhão Pipa - MB } \\
\hline $\begin{array}{c}\text { Valores } \\
\text { medianos }\end{array}$ & Hser & Hfunc & Hserv & Hfunc & Hserv & Hfunc & Hserv & Hfunc & Hserv & Hfunc \\
\hline $07 /$ mar & 22,8 & $73 \%$ & 26,3 & $53 \%$ & 19,3 & $71 \%$ & 52,8 & $27 \%$ & 137,1 & $6 \%$ \\
\hline $16 /$ set & 1217,1 & $82 \%$ & 1172,3 & $57 \%$ & 1174,6 & $23 \%$ & 1170,2 & $36 \%$ & 1171,3 & $32 \%$ \\
\hline $20 /$ set & 450,5 & $100 \%$ & 479,0 & $69 \%$ & 383,1 & $100 \%$ & 477,7 & $63 \%$ & 482,5 & $29 \%$ \\
\hline $\mathbf{1}^{\circ}$ Quartil & 236,6 & $77 \%$ & 252,7 & $55 \%$ & 201,2 & $47 \%$ & 265,2 & $31 \%$ & 309,8 & $18 \%$ \\
\hline Mediana & 450,5 & $82 \%$ & 479,0 & $57 \%$ & 383,1 & $71 \%$ & 477,7 & $36 \%$ & 482,5 & $29 \%$ \\
\hline $\mathbf{3}^{\circ}$ Quartil & 833,8 & $91 \%$ & 825,6 & $63 \%$ & 778,9 & $86 \%$ & 823,9 & $49 \%$ & 826,9 & $31 \%$ \\
\hline
\end{tabular}


Tabela 110 - Brita graduada tratada com cimento - BGTC $\left(\mathrm{m}^{3}\right)$ : acabadora - Guarulhos

\begin{tabular}{|c|c|c|c|c|c|c|c|c|c|c|}
\hline \multicolumn{11}{|c|}{ ACABADORA } \\
\hline \multirow[b]{2}{*}{ Data } & \multirow[b]{2}{*}{ Etapa } & \multirow[b]{2}{*}{$\begin{array}{l}\text { Dia da } \\
\text { semana }\end{array}$} & \multirow{2}{*}{$\begin{array}{l}\text { QS } \\
\text { m3 }\end{array}$} & \multicolumn{2}{|c|}{ Horas } & \multirow{2}{*}{$\begin{array}{c}\begin{array}{c}\mathrm{PU}_{\mathrm{d}} \\
\left(\mathrm{m}^{3} / \mathrm{Eh}\right)\end{array} \\
\text { Hserv }\end{array}$} & \multirow{2}{*}{$\begin{array}{c}\begin{array}{c}\mathrm{PU}_{\text {cum }} \\
\left(\mathrm{m}^{3} / \mathrm{Eh}\right)\end{array} \\
\text { Hserv }\end{array}$} & \multirow{2}{*}{$\begin{array}{c}\begin{array}{c}\mathrm{PU}_{\text {pot }} \\
\left(\mathrm{m}^{3} / \mathrm{Eh}\right)\end{array} \\
\text { Hserv }\end{array}$} & \multirow[b]{2}{*}{ Hfunc } & \multirow[b]{2}{*}{$\Delta$} \\
\hline & & & & Hfunc & Himprod & & & & & \\
\hline $14 /$ set & 1 & sex & 147,2 & 3,5 & 4,5 & 18,4 & 18,4 & \multirow{16}{*}{30,1} & $44 \%$ & \multirow{16}{*}{9,4} \\
\hline $15 /$ set & 2 & sab & 222,3 & 5,0 & 3,0 & 27,8 & 23,1 & & $63 \%$ & \\
\hline $17 /$ set & 3 & seg & 84,9 & 3,0 & 5,0 & 10,6 & 18,9 & & $38 \%$ & \\
\hline $18 /$ set & 4 & ter & 114,6 & 3,8 & 4,2 & 14,3 & 17,8 & & $48 \%$ & \\
\hline $19 /$ set & 5 & qua & 247,0 & 8,8 & 0,0 & 28,2 & 20,0 & & $100 \%$ & \\
\hline $20 /$ set & 6 & qui & 240,5 & 7,0 & 1,1 & 30,1 & 21,7 & & $87 \%$ & \\
\hline $21 /$ set & 7 & sex & 119,2 & 3,7 & 4,3 & 14,9 & 20,7 & & $46 \%$ & \\
\hline 11/jan & 8 & sex & 196,2 & 7,0 & 1,0 & 24,5 & 21,2 & & $88 \%$ & \\
\hline 14/jan & 9 & seg & 135,3 & 3,7 & 4,3 & 16,9 & 20,7 & & $46 \%$ & \\
\hline 15/jan & 10 & ter & 259,9 & 6,0 & 2,0 & 32,5 & 21,9 & & $75 \%$ & \\
\hline 17/jan & 11 & qua & 288,6 & 5,5 & 2,5 & 36,1 & 23,2 & & $69 \%$ & \\
\hline 18/jan & 12 & qui & 153,8 & 5,0 & 3,0 & 19,2 & 22,8 & & $63 \%$ & \\
\hline 24/jan & 13 & qui & 347,5 & 7,0 & 1,0 & 43,4 & 24,4 & & $88 \%$ & \\
\hline 25/jan & 14 & sex & 112,2 & 4,8 & 3,2 & 14,0 & 23,7 & & $60 \%$ & \\
\hline 26/jan & 15 & $s a b$ & 135,7 & 2,3 & 5,8 & 17,0 & 23,2 & & $28 \%$ & \\
\hline 28/jan & 16 & seg & 176,0 & 4,2 & 3,8 & 22,0 & 23,2 & & $52 \%$ & \\
\hline
\end{tabular}

Tabela 111 -Brita graduada tratada com cimento - BGTC - mão de obra $\left(\mathrm{m}^{3}\right)$ - Guarulhos

\begin{tabular}{|c|c|c|c|c|c|c|c|c|c|}
\hline \multicolumn{10}{|c|}{ MÃO DE OBRA DE APOIO - SERVENTE } \\
\hline Data & Etapa & $\begin{array}{c}\text { Dia da } \\
\text { semana }\end{array}$ & $\begin{array}{l}\text { QS } \\
\text { m3 }\end{array}$ & Horas & $\begin{array}{c}\mathrm{PU}_{\mathrm{d}} \\
\left(\mathrm{m}^{3} / \mathrm{Eh}\right)\end{array}$ & $\begin{array}{l}\mathrm{PU}_{\text {cum }} \\
\left.\text { ( } \mathrm{m}^{3} / \mathrm{Eh}\right)\end{array}$ & $\begin{array}{c}\mathrm{PU}_{\text {pot }} \\
\left(\mathrm{m}^{3} / \mathrm{Eh}\right)\end{array}$ & $\begin{array}{c}\text { Média } \\
\text { Funcion. }\end{array}$ & $\Delta$ \\
\hline $14 /$ set & 1 & sex & 147,2 & 58,5 & 2,5 & 2,5 & \multirow{16}{*}{5,6} & 7 & \multirow{17}{*}{1,3} \\
\hline $15 /$ set & 2 & sab & 222,3 & 44,0 & 5,1 & 3,6 & & 6 & \\
\hline $17 /$ set & 3 & seg & 84,9 & 27,0 & 3,1 & 3,5 & & 3 & \\
\hline $18 /$ set & 4 & ter & 114,6 & 35,5 & 3,2 & 3,4 & & 4 & \\
\hline $19 /$ set & 5 & qua & 247,0 & 78,8 & 3,1 & 3,3 & & 10 & \\
\hline $20 /$ set & 6 & qui & 240,5 & 58,5 & 4,1 & 3,5 & & 7 & \\
\hline $21 /$ set & 7 & sex & 119,2 & 33,0 & 3,6 & 3,5 & & 4 & \\
\hline 11/jan & 8 & sex & 196,2 & 35,0 & 5,6 & 3,7 & & 4 & \\
\hline 14/jan & 9 & seg & 135,3 & 24,0 & 5,6 & 3,8 & & 3 & \\
\hline 15/jan & 10 & ter & 259,9 & 36,0 & 7,2 & 4,1 & & 5 & \\
\hline 17/jan & 11 & qua & 288,6 & 64,0 & 4,5 & 4,2 & & 8 & \\
\hline 18/jan & 12 & qui & 153,8 & 48,0 & 3,2 & 4,1 & & 6 & \\
\hline 24/jan & 13 & qui & 347,5 & 66,0 & 5,3 & 4,2 & & 8 & \\
\hline $25 /$ jan & 14 & sex & 112,2 & 44,7 & 2,5 & 4,1 & & 6 & \\
\hline 26/jan & 15 & sab & 135,7 & 16,0 & 8,5 & 4,2 & & 2 & \\
\hline 28/jan & 16 & seg & 176,0 & 16,0 & 11,0 & 4,4 & & 2 & \\
\hline & & & & & & & Mediana & 5 & \\
\hline
\end{tabular}


Tabela 112 - Brita graduada tratada com cimento - BGTC $\left(\mathrm{m}^{3}\right)$ : rolo compactador - Guarulhos

\begin{tabular}{|c|c|c|c|c|c|c|c|c|c|c|}
\hline \multicolumn{11}{|c|}{ ROLO COMPR TANDEM = CC43 } \\
\hline \multirow{2}{*}{ Data } & \multirow{2}{*}{ Etapa } & \multirow{2}{*}{$\begin{array}{c}\text { Dia da } \\
\text { semana }\end{array}$} & \multirow{2}{*}{$\begin{array}{c}\text { QS } \\
\text { m3 }\end{array}$} & \multicolumn{2}{|c|}{ Horas } & \multirow{2}{*}{\begin{tabular}{|c}
$\begin{array}{c}\mathrm{PU}_{\mathrm{d}} \\
\left(\mathrm{m}^{3} / \mathrm{Eh}\right)\end{array}$ \\
Hserv
\end{tabular}} & \multirow{2}{*}{$\begin{array}{c}\begin{array}{c}\mathrm{PU}_{\text {cum }} \\
\left(\mathrm{m}^{3} / \mathrm{Eh}\right)\end{array} \\
\text { Hserv }\end{array}$} & \multirow{2}{*}{$\begin{array}{c}\begin{array}{c}\mathrm{PU}_{\text {pot }} \\
\left(\mathrm{m}^{3} / \mathrm{Eh}\right)\end{array} \\
\text { Hserv }\end{array}$} & \multirow[b]{2}{*}{ Hfunc } & \multirow[b]{2}{*}{$\Delta$} \\
\hline & & & & Hfunc & Himprod & & & & & \\
\hline $14 /$ set & 1 & sex & 147,2 & 3,5 & 4,5 & 18,4 & 18,4 & \multirow{16}{*}{28,0} & $44 \%$ & \multirow{16}{*}{9,6} \\
\hline $15 /$ set & 2 & sab & 222,3 & 5,0 & 3,0 & 27,8 & 23,1 & & $63 \%$ & \\
\hline $17 /$ set & 3 & seg & 84,9 & 3,0 & 5,0 & 10,6 & 18,9 & & $38 \%$ & \\
\hline $18 /$ set & 4 & ter & 114,6 & 3,8 & 4,2 & 14,3 & 17,8 & & $48 \%$ & \\
\hline $19 /$ set & 5 & qua & 247,0 & 8,8 & 0,0 & 28,2 & 20,0 & & $100 \%$ & \\
\hline $20 /$ set & 6 & qui & 240,5 & 6,5 & 1,5 & 30,1 & 21,7 & & $81 \%$ & \\
\hline $21 /$ set & 7 & sex & 0,0 & 0,0 & 0,0 & & 21,7 & & & \\
\hline 11/jan & 8 & sex & 196,2 & 5,0 & 3,0 & 24,5 & 22,1 & & $63 \%$ & \\
\hline 14/jan & 9 & seg & 0,0 & 0,0 & 0,0 & & 22,1 & & & \\
\hline 15/jan & 10 & ter & 0,0 & 0,0 & 0,0 & & 22,1 & & & \\
\hline $17 /$ jan & 11 & qua & 0,0 & 0,0 & 0,0 & & 22,1 & & & \\
\hline 18/jan & 12 & qui & 0,0 & 0,0 & 0,0 & & 22,1 & & & \\
\hline 24/jan & 13 & qui & 0,0 & 8,0 & 0,0 & 0,0 & 19,3 & & $100 \%$ & \\
\hline $25 /$ jan & 14 & sex & 112,2 & 7,8 & 0,2 & 14,0 & 18,8 & & $98 \%$ & \\
\hline $26 /$ jan & 15 & sab & 135,7 & 2,3 & 5,8 & 17,0 & 18,6 & & $28 \%$ & \\
\hline $28 /$ jan & 16 & seg & 176,0 & 4,2 & 3,8 & 22,0 & 18,9 & & $52 \%$ & \\
\hline
\end{tabular}

Tabela 113 - Brita graduada tratada com cimento - BGTC $\left(\mathrm{m}^{3}\right)$ : rolo de pneus - Guarulhos

\begin{tabular}{|c|c|c|c|c|c|c|c|c|c|c|}
\hline \multicolumn{11}{|c|}{ ROLO PNEUS AUTOPROPULSOR CP27 } \\
\hline \multirow{2}{*}{ Data } & \multirow{2}{*}{ Etapa } & \multirow{2}{*}{$\begin{array}{c}\text { Dia da } \\
\text { semana }\end{array}$} & \multirow{2}{*}{$\begin{array}{l}\text { QS } \\
\text { m3 }\end{array}$} & \multicolumn{2}{|c|}{ Horas } & \multirow{2}{*}{$\begin{array}{c}\begin{array}{c}\mathrm{PU}_{\mathrm{d}} \\
\left(\mathrm{m}^{3} / \mathrm{Eh}\right)\end{array} \\
\text { Hserv }\end{array}$} & \multirow{2}{*}{$\begin{array}{l}\begin{array}{c}\mathrm{PU}_{\text {cum }} \\
\left(\mathrm{m}^{3} / \mathrm{Eh}\right)\end{array} \\
\text { Hserv }\end{array}$} & \multirow{2}{*}{$\begin{array}{c}\begin{array}{c}\mathrm{PU}_{\text {pot }} \\
\left(\mathrm{m}^{3} / \mathrm{Eh}\right)\end{array} \\
\text { Hserv }\end{array}$} & \multirow[b]{2}{*}{ Hfunc } & \multirow[b]{2}{*}{$\Delta$} \\
\hline & & & & Hfunc & Himprod & & & & & \\
\hline $14 /$ set & 1 & sex & 147,2 & 7,0 & 9,0 & 9,2 & 9,2 & \multirow{15}{*}{15,6} & $44 \%$ & \multirow{15}{*}{1,7} \\
\hline $15 /$ set & 2 & sab & 222,3 & 10,0 & 6,0 & 13,9 & 11,5 & & $63 \%$ & \\
\hline $17 /$ set & 3 & seg & 84,9 & 6,0 & 10,0 & 5,3 & 9,5 & & $38 \%$ & \\
\hline $18 /$ set & 4 & ter & 114,6 & 7,7 & 8,3 & 7,2 & 8,9 & & $48 \%$ & \\
\hline $19 /$ set & 5 & qua & 247,0 & 17,5 & 0,0 & 14,1 & 10,0 & & $100 \%$ & \\
\hline $20 /$ set & 6 & qui & 240,5 & 13,0 & 3,0 & 15,0 & 10,8 & & $81 \%$ & \\
\hline $21 /$ set & 7 & sex & 119,2 & 7,3 & 8,7 & 7,5 & 10,4 & & $46 \%$ & \\
\hline 11/jan & 8 & sex & 196,2 & 5,0 & 3,0 & 24,5 & 11,3 & & $63 \%$ & \\
\hline 14/jan & 9 & seg & 135,3 & 7,3 & 8,7 & 8,5 & 11,0 & & $46 \%$ & \\
\hline 15/jan & 10 & ter & 259,9 & 12,0 & 4,0 & 16,2 & 11,5 & & $75 \%$ & \\
\hline 17/jan & 11 & qua & 288,6 & 9,5 & 6,5 & 18,0 & 12,1 & & $59 \%$ & \\
\hline 18/jan & 12 & qui & 153,8 & 5,0 & 11,0 & 9,6 & 11,9 & & $31 \%$ & \\
\hline 24/jan & 13 & qui & 347,5 & 12,0 & 4,0 & 21,7 & 12,7 & & $75 \%$ & \\
\hline 25/jan & 14 & sex & 112,2 & 7,1 & 0,9 & 14,0 & 12,7 & & $88 \%$ & \\
\hline 26/jan & 15 & sab & 135,7 & 4,5 & 11,5 & 8,5 & 12,4 & & $28 \%$ & \\
\hline
\end{tabular}


Tabela 114 - Concreto betuminoso usinado a quente - CBUQ. Etapa: lançamento e acabamento $\left(\mathrm{m}^{3}\right)$ - Guarulhos

\begin{tabular}{|c|c|c|c|c|c|c|c|c|c|}
\hline \multicolumn{10}{|c|}{ VIBROACABADORA } \\
\hline \multirow[b]{2}{*}{ Data } & \multirow[b]{2}{*}{ Etapa } & \multirow{2}{*}{$\begin{array}{l}\text { QS } \\
\text { m3 }\end{array}$} & \multicolumn{2}{|c|}{ Horas } & \multirow{2}{*}{$\begin{array}{c}\begin{array}{c}\mathbf{P U}_{\mathrm{d}} \\
\left(\mathrm{m}^{3} / \mathrm{Eh}\right)\end{array} \\
\text { Hserv }\end{array}$} & \multirow{2}{*}{$\begin{array}{c}\begin{array}{c}\mathrm{PU}_{\text {cum }} \\
\left(\mathrm{m}^{3} / \mathrm{Eh}\right)\end{array} \\
\text { Hserv }\end{array}$} & \multirow{2}{*}{$\begin{array}{c}\begin{array}{c}\mathrm{PU}_{\text {pot }} \\
\left(\mathrm{m}^{3} / \mathrm{Eh}\right)\end{array} \\
\\
\text { Hserv }\end{array}$} & \multirow[b]{2}{*}{ Hfunc } & \multirow[b]{2}{*}{$\Delta$} \\
\hline & & & Hfunc & Himprod & & & & & \\
\hline $01 /$ set & 1 & 146,7 & 4,0 & 4,0 & 18,3 & 18,3 & \multirow{21}{*}{23,0} & $50 \%$ & \multirow{21}{*}{9,4} \\
\hline $05 /$ set & 2 & 216,9 & 11,0 & 0,0 & 19,7 & 19,1 & & $100 \%$ & \\
\hline $06 /$ set & 3 & 360,8 & 12,0 & 0,0 & 30,1 & 23,4 & & $100 \%$ & \\
\hline $07 /$ set & 4 & 351,4 & 13,0 & 0,0 & 27,0 & 24,4 & & $100 \%$ & \\
\hline $10 /$ set & 5 & 146,6 & 12,0 & 0,0 & 12,2 & 21,8 & & $100 \%$ & \\
\hline $11 /$ set & 6 & 244,2 & 12,0 & 0,0 & 20,4 & 21,6 & & $100 \%$ & \\
\hline $12 /$ set & 7 & 325,3 & 24,0 & 0,0 & 13,6 & 19,5 & & $100 \%$ & \\
\hline $14 /$ set & 8 & 126,6 & 24,0 & 0,0 & 5,3 & 16,5 & & $100 \%$ & \\
\hline $15 /$ set & 9 & 117,7 & 17,7 & 0,0 & 6,7 & 15,2 & & $100 \%$ & \\
\hline $17 /$ set & 10 & 236,6 & 5,7 & 2,3 & 29,6 & 16,0 & & $71 \%$ & \\
\hline $18 /$ set & 11 & 247,9 & 16,5 & 2,6 & 13,0 & 15,7 & & $87 \%$ & \\
\hline $19 /$ set & 12 & 277,0 & 4,5 & 3,5 & 34,6 & 16,6 & & $56 \%$ & \\
\hline $20 /$ set & 13 & 167,4 & 11,0 & 0,0 & 15,2 & 16,5 & & $100 \%$ & \\
\hline $23 /$ set & 15 & 148,9 & 8,0 & 0,0 & 18,6 & 16,6 & & $100 \%$ & \\
\hline $25 /$ set & 16 & 91,2 & 11,0 & 0,0 & 8,3 & 16,1 & & $100 \%$ & \\
\hline $26 /$ set & 17 & 121,2 & 10,0 & 0,0 & 12,1 & 15,9 & & $100 \%$ & \\
\hline $27 /$ set & 18 & 109,9 & 12,0 & 0,0 & 9,2 & 15,6 & & $100 \%$ & \\
\hline $28 /$ set & 19 & 114,8 & 10,0 & 0,0 & 11,5 & 15,4 & & $100 \%$ & \\
\hline $29 /$ set & 20 & 183,8 & 7,3 & 0,7 & 23,0 & 15,6 & & $92 \%$ & \\
\hline $30 /$ set & 21 & 80,6 & 6,0 & 2,0 & 10,1 & 15,5 & & $75 \%$ & \\
\hline 31/jan & 22 & 108,9 & 6,0 & 2,0 & 13,6 & 15,4 & & $75 \%$ & \\
\hline
\end{tabular}

Tabela 115 - Concreto betuminoso usinado a quente - CBUQ. Mão de obra $\left(\mathrm{m}^{3}\right)$ - Guarulhos (continua)

\begin{tabular}{|c|c|c|c|c|c|c|c|c|}
\hline \multicolumn{9}{|c|}{ MÃO DE OBRA DE APOIO - SERVENTE } \\
\hline \multirow[b]{2}{*}{ Data } & \multirow[b]{2}{*}{ Etapa } & QS & \multirow[b]{2}{*}{ Horas } & \multirow{2}{*}{$\begin{array}{c}P_{d} \\
\left(m^{3} / E h\right)\end{array}$} & \multirow{2}{*}{$\begin{array}{c}\mathrm{PU}_{\text {cum }} \\
\left(\mathrm{m}^{3} / \mathrm{Eh}\right)\end{array}$} & \multirow{2}{*}{$\begin{array}{c}\mathrm{PU}_{\text {pot }} \\
\left(\mathrm{m}^{3} / \mathrm{Eh}\right)\end{array}$} & \multirow{2}{*}{$\begin{array}{c}\text { Média } \\
\text { Funcion. }\end{array}$} & \multirow[b]{2}{*}{$\Delta$} \\
\hline & & m3 & & & & & & \\
\hline $05 /$ set & 2 & 216,9 & 103,3 & 2,1 & 2,1 & \multirow{17}{*}{2,95} & 13 & \multirow{17}{*}{0,65} \\
\hline $06 /$ set & 3 & 360,8 & 121,7 & 3,0 & 2,6 & & 15 & \\
\hline $07 /$ set & 4 & 351,4 & 97,8 & 3,6 & 2,9 & & 12 & \\
\hline $10 /$ set & 5 & 146,6 & 103,0 & 1,4 & 2,5 & & 13 & \\
\hline $11 /$ set & 6 & 244,2 & 96,0 & 2,5 & 2,5 & & 12 & \\
\hline $12 /$ set & 7 & 325,3 & 133,8 & 2,4 & 2,5 & & 17 & \\
\hline $14 /$ set & 8 & 126,6 & 112,2 & 1,1 & 2,3 & & 14 & \\
\hline $15 /$ set & 9 & 117,7 & 114,8 & 1,0 & 2,1 & & 14 & \\
\hline $17 /$ set & 10 & 236,6 & 61,3 & 3,9 & 2,3 & & 8 & \\
\hline $18 /$ set & 11 & 247,9 & 60,0 & 4,1 & 2,4 & & 8 & \\
\hline 19/set & 12 & 277,0 & 82,0 & 3,4 & 2,4 & & 10 & \\
\hline 20/set & 13 & 167,4 & 63,0 & 2,7 & 2,5 & & 8 & \\
\hline $23 /$ set & 15 & 148,9 & 91,7 & 1,6 & 2,4 & & 11 & \\
\hline $25 /$ set & 16 & 91,2 & 95,5 & 1,0 & 2,3 & & 12 & \\
\hline $26 /$ set & 17 & 121,2 & 113,7 & 1,1 & 2,2 & & 14 & \\
\hline $27 /$ set & 18 & 109,9 & 88,0 & 1,2 & 2,1 & & 11 & \\
\hline $28 /$ set & 19 & 114,8 & 99,0 & 1,2 & 2,1 & & 12 & \\
\hline
\end{tabular}


Tabela 115 - Concreto betuminoso usinado a quente - CBUQ. Mão de obra $\left(\mathrm{m}^{3}\right)$ - Guarulhos (conclusão)

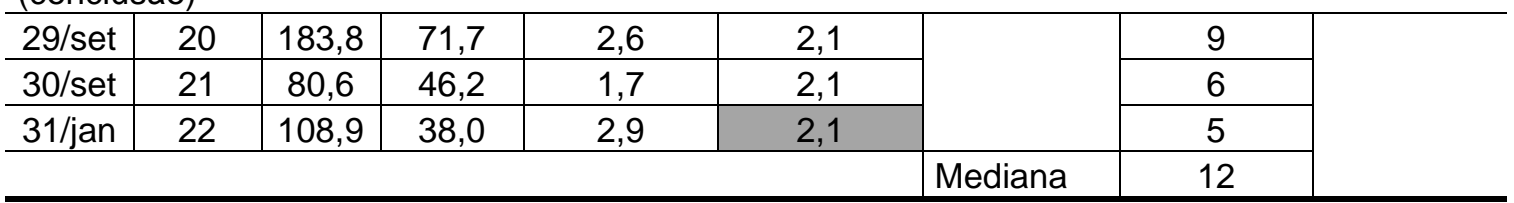

Tabela 116 - Concreto betuminoso usinado a quente - CBUQ. Rolo compactador $\left(\mathrm{m}^{3}\right)-$ Guarulhos

\begin{tabular}{|c|c|c|c|c|c|c|c|c|c|}
\hline \multicolumn{10}{|c|}{ ROLO COMPR. TANDEM = CC43 } \\
\hline \multirow{2}{*}{ Data } & \multirow{2}{*}{ Etapa } & \multirow{2}{*}{$\begin{array}{l}\text { QS } \\
\mathrm{m} 3\end{array}$} & \multicolumn{2}{|c|}{ Horas } & \multirow{2}{*}{$\begin{array}{c}\begin{array}{c}\mathrm{PU}_{\mathrm{d}} \\
\left(\mathrm{m}^{3} / \mathrm{Eh}\right)\end{array} \\
\text { Hserv }\end{array}$} & \multirow{2}{*}{$\begin{array}{c}\begin{array}{c}\mathrm{PU}_{\text {cum }} \\
\left(\mathrm{m}^{3} / \mathrm{Eh}\right)\end{array} \\
\text { Hserv }\end{array}$} & \multirow{2}{*}{$\begin{array}{c}\begin{array}{c}\mathrm{PU}_{\text {pot }} \\
\left(\mathrm{m}^{3} / \mathrm{Eh}\right)\end{array} \\
\text { Hserv }\end{array}$} & \multirow[b]{2}{*}{ Hfunc } & \multirow[b]{2}{*}{$\Delta$} \\
\hline & & & Hfunc & Himprod & & & & & \\
\hline $01 / \mathrm{set}$ & 1 & 146,7 & 7,5 & 8,5 & 9,2 & 9,2 & \multirow{20}{*}{23,0} & $47 \%$ & \multirow{20}{*}{10,5} \\
\hline $05 /$ set & 2 & 216,9 & 22,0 & 0,0 & 9,9 & 9,6 & & $100 \%$ & \\
\hline $06 /$ set & 3 & 360,8 & 12,0 & 0,0 & 30,1 & 14,5 & & $100 \%$ & \\
\hline 10/set & 5 & 146,6 & 24,0 & 0,0 & 6,1 & 11,8 & & $100 \%$ & \\
\hline $11 /$ set & 6 & 244,2 & 12,0 & 0,0 & 20,4 & 13,0 & & $100 \%$ & \\
\hline $12 /$ set & 7 & 325,3 & 24,0 & 0,0 & 13,6 & 13,1 & & $100 \%$ & \\
\hline $14 /$ set & 8 & 126,6 & 24,0 & 0,0 & 5,3 & 11,7 & & $100 \%$ & \\
\hline $15 /$ set & 9 & 117,7 & 9,2 & 0,0 & 12,8 & 11,8 & & $100 \%$ & \\
\hline $17 /$ set & 10 & 236,6 & 5,5 & 2,5 & 29,6 & 12,7 & & $69 \%$ & \\
\hline $18 /$ set & 11 & 247,9 & 4,5 & 3,5 & 31,0 & 13,6 & & $56 \%$ & \\
\hline $19 /$ set & 12 & 277,0 & 2,5 & 5,5 & 34,6 & 14,6 & & $31 \%$ & \\
\hline $20 /$ set & 13 & 167,4 & 16,0 & 0,0 & 10,5 & 14,3 & & $100 \%$ & \\
\hline $23 /$ set & 15 & 148,9 & 6,5 & 1,5 & 18,6 & 14,5 & & $81 \%$ & \\
\hline $25 /$ set & 16 & 91,2 & 22,0 & 0,0 & 4,1 & 13,4 & & $100 \%$ & \\
\hline $26 /$ set & 17 & 121,2 & 10,0 & 0,0 & 12,1 & 13,3 & & $100 \%$ & \\
\hline $27 /$ set & 18 & 109,9 & 12,0 & 0,0 & 9,2 & 13,1 & & $100 \%$ & \\
\hline $28 /$ set & 19 & 114,8 & 10,0 & 0,0 & 11,5 & 13,1 & & $100 \%$ & \\
\hline $29 /$ set & 20 & 183,8 & 7,3 & 0,7 & 23,0 & 13,4 & & $92 \%$ & \\
\hline $30 /$ set & 21 & 80,6 & 6,0 & 2,0 & 10,1 & 13,3 & & $75 \%$ & \\
\hline 31/jan & 22 & 108,9 & 6,0 & 2,0 & 13,6 & 13,3 & & $75 \%$ & \\
\hline
\end{tabular}

Tabela 117 - Concreto betuminoso usinado a quente - CBUQ. Rolo pneus $\left(\mathrm{m}^{3}\right)$ - Guarulhos (continua)

\begin{tabular}{|c|c|c|c|c|c|c|c|c|c|}
\hline \multicolumn{10}{|c|}{ ROLO PNEUS AUTOPROPULSOR CP27 } \\
\hline \multirow{2}{*}{ Data } & \multirow{2}{*}{ Etapa } & \multirow{2}{*}{$\frac{\mathrm{QS}}{\mathrm{m} 3}$} & \multicolumn{2}{|c|}{ Horas } & \multirow{2}{*}{$\begin{array}{c}\begin{array}{c}\mathrm{PU}_{\mathrm{d}} \\
\left(\mathrm{m}^{3} / \mathrm{Eh}\right)\end{array} \\
\text { Hserv }\end{array}$} & \multirow{2}{*}{$\begin{array}{c}\begin{array}{c}\text { PU }_{\text {cum }} \\
\left(\mathrm{m}^{3} / \mathrm{Eh}\right)\end{array} \\
\text { Hserv }\end{array}$} & \multirow{2}{*}{$\begin{array}{c}\begin{array}{c}\mathrm{PU}_{\text {pot }} \\
\left(\mathrm{m}^{3} / \mathrm{Eh}\right)\end{array} \\
\\
\text { Hserv }\end{array}$} & \multirow[b]{2}{*}{ Hfunc } & \multirow[b]{2}{*}{$\Delta$} \\
\hline & & & Hfunc & Himprod & & & & & \\
\hline $01 / \mathrm{set}$ & 1 & 146,7 & 7,5 & 8,5 & 9,2 & 9,2 & \multirow[b]{7}{*}{6,55} & $47 \%$ & \multirow[b]{7}{*}{1,45} \\
\hline $05 /$ set & 2 & 216,9 & 37,3 & 0,0 & 5,8 & 6,8 & & $100 \%$ & \\
\hline $06 /$ set & 3 & 360,8 & 50,0 & 0,0 & 7,2 & 7,0 & & $100 \%$ & \\
\hline $07 /$ set & 4 & 351,4 & 60,0 & 0,0 & 5,9 & 6,6 & & $100 \%$ & \\
\hline $10 /$ set & 5 & 146,6 & 60,0 & 0,0 & 2,4 & 5,5 & & $100 \%$ & \\
\hline $11 /$ set & 6 & 244,2 & 48,0 & 0,0 & 5,1 & 5,4 & & $100 \%$ & \\
\hline $12 / \mathrm{set}$ & 7 & 325,3 & 60,0 & 0,0 & 5,4 & 5,4 & & $100 \%$ & \\
\hline
\end{tabular}


Tabela 117 - Concreto betuminoso usinado a quente - CBUQ. Rolo pneus $\left(\mathrm{m}^{3}\right)$ - Guarulhos (conclusão)

\begin{tabular}{|c|c|c|c|c|c|c|c|}
\hline $14 /$ set & 8 & 126,6 & 48,0 & 0,0 & 2,6 & 5,1 & $100 \%$ \\
\hline $15 /$ set & 9 & 117,7 & 38,5 & 0,0 & 3,1 & 4,9 & $100 \%$ \\
\hline $17 /$ set & 10 & 236,6 & 22,5 & 0,0 & 10,5 & 5,2 & $100 \%$ \\
\hline $18 /$ set & 11 & 247,9 & 18,8 & 0,0 & 13,2 & 5,5 & $100 \%$ \\
\hline $19 /$ set & 12 & 277,0 & 17,0 & 0,0 & 16,3 & 5,9 & $100 \%$ \\
\hline $20 /$ set & 13 & 167,4 & 36,0 & 0,0 & 4,6 & 5,8 & $100 \%$ \\
\hline $23 /$ set & 15 & 148,9 & 29,5 & 0,0 & 5,0 & 5,7 & $100 \%$ \\
\hline $25 /$ set & 16 & 91,2 & 45,0 & 0,0 & 2,0 & 5,5 & $100 \%$ \\
\hline $26 /$ set & 17 & 121,2 & 40,0 & 0,0 & 3,0 & 5,3 & $100 \%$ \\
\hline $27 /$ set & 18 & 109,9 & 48,0 & 0,0 & 2,3 & 5,1 & $100 \%$ \\
\hline $28 /$ set & 19 & 114,8 & 40,0 & 0,0 & 2,9 & 5,0 & $100 \%$ \\
\hline $29 /$ set & 20 & 183,8 & 34,8 & 0,0 & 5,3 & 5,0 & $100 \%$ \\
\hline $30 /$ set & 21 & 80,6 & 18,0 & 2,0 & 4,0 & 5,0 & $90 \%$ \\
\hline 31/jan & 22 & 108,9 & 12,0 & 0,0 & 9,1 & 5,0 & $100 \%$ \\
\hline
\end{tabular}

Tabela 118 - Imprimação $\left(\mathrm{m}^{2}\right)$ - Guarulhos

\section{CAMINHÃO DISTRIBUIDOR DE BETUME}

\begin{tabular}{|c|c|c|c|c|c|c|c|c|c|}
\hline \multirow[b]{2}{*}{ Data } & \multirow[b]{2}{*}{ Etapa } & \multirow{2}{*}{$\begin{array}{l}\text { QS } \\
\mathbf{m}^{2}\end{array}$} & \multicolumn{2}{|c|}{ Horas } & \multirow{2}{*}{$\begin{array}{c}\begin{array}{c}\mathrm{PU}_{\mathrm{d}} \\
\left(\mathrm{m}^{3} / \mathrm{Eh}\right)\end{array} \\
\text { Hserv }\end{array}$} & \multirow{2}{*}{$\begin{array}{c}\begin{array}{c}\mathbf{P U}_{\text {cum }} \\
\left(\mathrm{m}^{3} / \mathrm{Eh}\right)\end{array} \\
\text { Hserv } \\
\end{array}$} & \multirow{2}{*}{$\begin{array}{c}\begin{array}{c}\mathrm{PU}_{\text {pot }} \\
\left(\mathrm{m}^{3} / \mathrm{Eh}\right)\end{array} \\
\text { Hserv }\end{array}$} & \multirow[b]{2}{*}{ Hfunc } & \multirow[b]{2}{*}{$\Delta$} \\
\hline & & & Hfunc & Himprod & & & & & \\
\hline 04/ago & 1 & 2908,1 & 0,7 & 7,3 & 363,5 & 363,5 & \multirow{9}{*}{472,9} & $8,4 \%$ & \multirow{9}{*}{258,5} \\
\hline 07/ago & 2 & 1257,1 & 0,5 & 7,5 & 157,1 & 260,3 & & $6,3 \%$ & \\
\hline 10/ago & 3 & 4539,2 & 0,5 & 7,5 & 567,4 & 362,7 & & $6,3 \%$ & \\
\hline $21 /$ ago & 4 & 1222,2 & 0,3 & 7,7 & 152,8 & 310,2 & & $4,1 \%$ & \\
\hline 22/ago & 5 & 1715,0 & 0,3 & 7,7 & 214,4 & 291,0 & & $4,1 \%$ & \\
\hline 25/ago & 6 & 3026,4 & 1,0 & 7,0 & 378,3 & 305,6 & & $12,5 \%$ & \\
\hline 29/ago & 7 & 6435,0 & 1,0 & 7,0 & 804,4 & 376,8 & & $12,5 \%$ & \\
\hline 11/jan & 8 & 1152,4 & 1,2 & 6,8 & 144,0 & 347,7 & & $14,6 \%$ & \\
\hline 16/jan & 9 & 1028,2 & 1,0 & 7,0 & 128,5 & 323,4 & & $12,5 \%$ & \\
\hline
\end{tabular}

Tabela 119 - Pintura de ligação $\left(\mathrm{m}^{2}\right)$ - Guarulhos

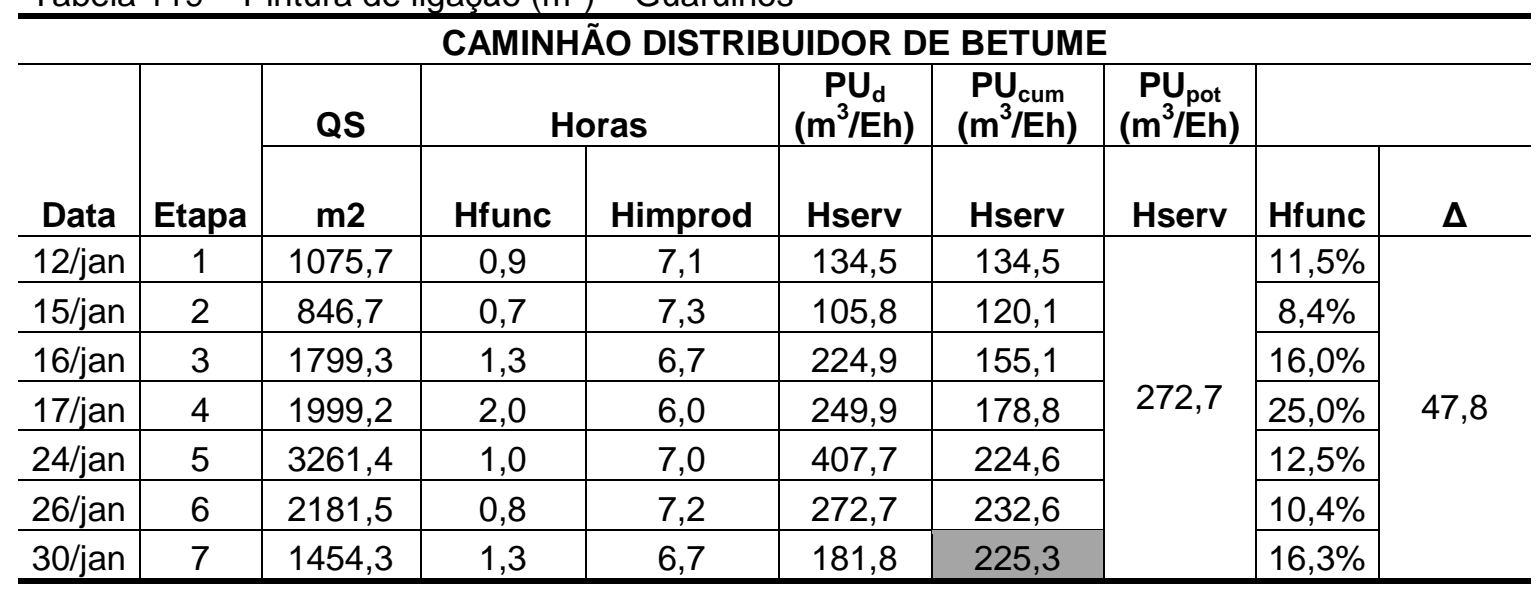




\section{APÊNDICE C - MÉTODO DE COLETA DE DADOS DO RODOANEL}

Partindo da visita à obra, a Figura 57 apresenta os passos trilhados para o levantamento de dados.

a) Escolha do serviço
b) Escolha do ramo
c) Quebra do serviço em partes
e) Equipe/patrulha envolvida
e) Entendimento do método de trabalho das atividades
- determinação do tempo de ciclo dos equipamentos
- anotação das horas produtivias "Método das Observações
Instantâneas"
• anotação dos fatores e anormalidades

Figura 57 - Método de coleta

Cada uma das etapas representadas no método de coleta é detalhada a seguir.

a) A escolha do serviço a ser acompanhado se deu conforme as atividades em execução (pode ser mais de um serviço), exemplo: camada final de terraplenagem (CFT).

b) A escolha do ramo a ser acompanhado o serviço se deu conforme a viabilidade de acompanhamento das atividades (pode ser mais de um local), exemplo: Ramo 204, Ramo A-PI, Ramo PI-A.

c) A quebra dos serviços em partes visou contemplar todas as atividades necessárias à sua execução, exemplo: serviço - camada final de terraplenagem (ver Figura 58). 


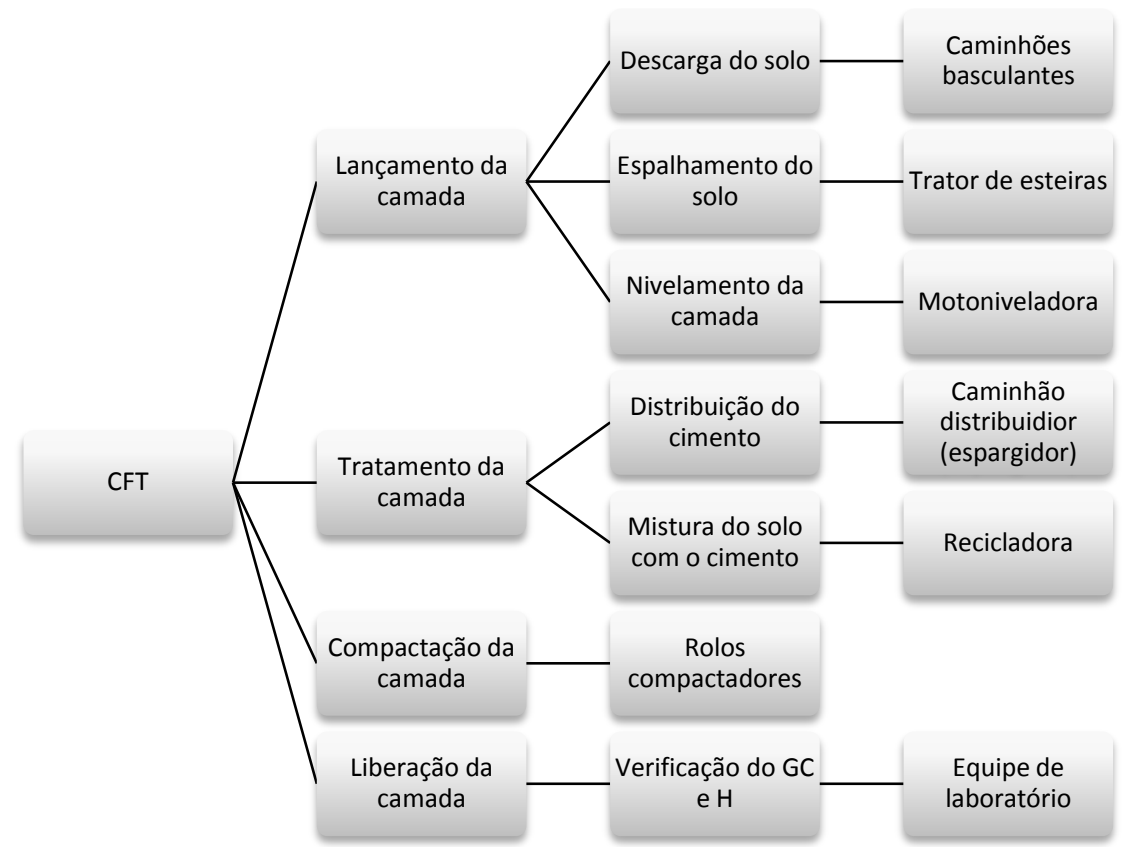

Figura 58 - Quebra do serviço: camada final de terraplenagem

d) Na medida que o serviço era executado, o registro da equipe/patrulha, envolvida na atividade, era efetuado, exemplo: camada final de terraplenagem (ver Figura $58)$.

e) Buscando uma visão geral, foram elaborados esboços das atividades em execução (ver exemplo na Figura 59). Este exemplo apresenta a ilustração das duas pistas do Rodoanel, a externa e a interna, as cinco áreas onde podem acontecer atividades, o seu estaqueamento e a largura das pistas. É importante entender que em um Ramo, podem acorrer várias frentes de serviço, como é o caso do exemplo abaixo. É possível que em (1) se tenha terminado a compactação, em (2) se tenha lançado o solo, distribuído cimento, reciclado e compactado a camada, em (3) lançado o solo, distribuído cimento e reciclado, em (4) distribuído cimento, reciclado e compactado a camada e em (5) nivelando e cortado a camada. Tudo executado com os equipamentos e equipe disponíveis para o Ramo. 
Esquema de produção (visto em planta):

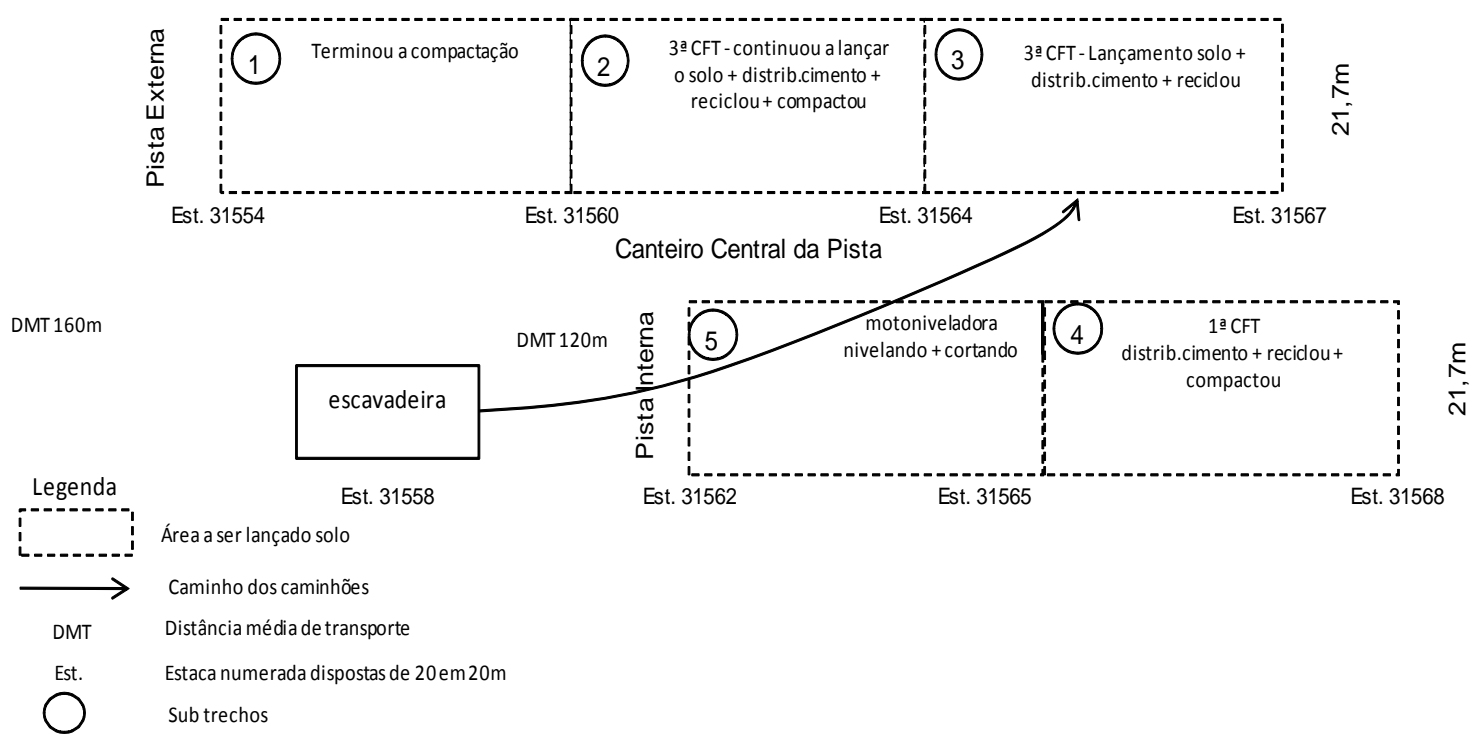

Figura 59 - Modelo de esquema de produção das atividades em execução - camada final de terraplenagem

f) Entendimento do método de trabalho (da construtora) para executar os serviços, exemplo:

- Quantos e quais equipamentos?

- Quantas e quais conjuntos de mão de obra?

- Quantos e quais materiais?

- Conhecimento dos índices físicos;

- Quantos e quais ensaios de campo? Exemplo:

- ensaio de areia (densidade específica aparente "in situ" e determinação da umidade);

- Proctor ( $100 \%$ GC para CFT com $2 \%$ de umidade e $95 \%$ GC para aterro com $3 \%$ de umidade);

- Entendimento da logística;

- Terminologia;

- $\mathrm{n}^{\circ}$ de fechas ${ }^{67}$ para atingir o GC;

- horas produtivas e horas improdutivas;

- Entendimento do tipo de solo (exemplo: silte/arenoso/com pouca argila/com pedregulho);

- Entendimento de ciclos dos equipamentos para diferentes serviços;

${ }^{67}$ Uma fecha corresponde à somatória de percursos de ida e de percursos de volta do equipamento. 
- Entendimento do peso/energia dos diferentes arranjos de patrulhas de rolos compactadores.

g) Coleta dos dados referentes à execução dos serviços, conforme apresentado na sequência.

- Acompanhamento da execução dos serviços, registrando os apontamentos em papel rascunho (requereu a presença do pesquisador na obra, ao longo do período de trabalho). Tentou-se utilizar o modelo de Ponto Diário Equipamento (ver Tabela 120) utilizado pelo apontador local. Neste registro o apontador da construtora procura registrar, para cada equipamento, as horas trabalhadas e as horas paralisadas (uma legenda de códigos o auxilia a identificar as causas da paralisação). A utilização desta tabela está melhor detalhada na seção 6.1.1. Normalmente, o apontador não cedia, para este pesquisador, os apontamentos do trecho em estudo e não sabia detalhar as atividades ali executadas, situação que inviabilizou a sua utilização;

- Acompanhamento e registro (em papel rascunho e por meio de filmagem) do tempo de ciclo de cada operação (medido aleatoriamente);

- Acompanhamento e registro (em papel rascunho) das horas produtivas e improdutivas, por meio do "Método das Observações Instantâneas". O pesquisador registrou ${ }^{68}$ uma sucessão de "108" observações ou seja uma a cada $5 \mathrm{~min}$ no qual constituiu uma amostra e definiu o percentual de vezes em que cada uma das fases de trabalho (trabalhando ou disponível para o serviço) foi observada. A Tabela 121 apresenta um exemplo de sua aplicação.

- Na medida que os serviços eram executados, o registro (em papel rascunho) dos fatores e anormalidades era realizado.

${ }^{68}$ Este trabalho foi efetuado somente nos dias em que o pesquisador se encontrava na obra. Como existiam várias frentes de trabalho, aleatoriamente, uma delas era eleita para este acompanhamento. 
Tabela 120 - Modelo de planilha de acompanhamento das atividades de cada equipamento

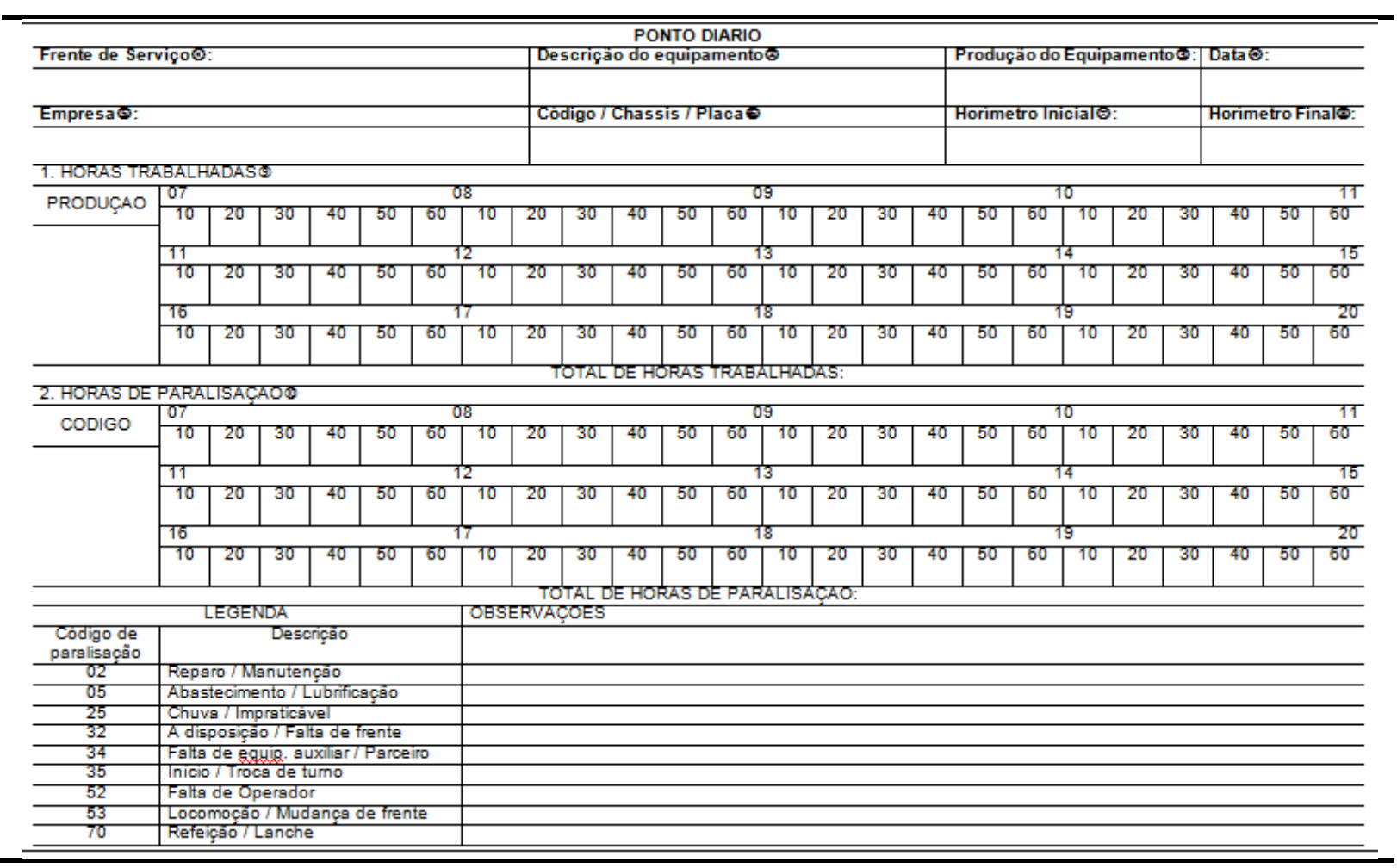

Tabela 121 - Planilha modelo e exemplo de aplicação do Método das Observações Instantâneas"

\begin{tabular}{|c|c|c|c|c|c|c|c|c|}
\hline \multicolumn{7}{|c|}{ Serviço: Camada final de terraplenagem - nivelamento } & \multicolumn{2}{|c|}{ Data: $20 / 04 / 2009$} \\
\hline \multicolumn{9}{|c|}{ Equipamento: Motoniveladora } \\
\hline Minutos & Trabalhando & Disponível & Minutos & Trabalhando & Disponível & Minutos & Trabalhando & Disponível \\
\hline 08:00 & $x$ & & 09:00 & $x$ & & $10: 00$ & $\mathrm{x}$ & \\
\hline 08:05 & $x$ & & 09:05 & & $x$ & 10:05 & $\mathrm{x}$ & \\
\hline 08:10 & $x$ & & 09:10 & & $x$ & 10:10 & $x$ & \\
\hline 08:15 & $x$ & & 09:15 & & $x$ & $10: 15$ & $\mathrm{x}$ & \\
\hline 08:20 & $x$ & & 09:20 & $x$ & & $10: 20$ & $x$ & \\
\hline 08:25 & $x$ & & $09: 25$ & $x$ & & $10: 25$ & $x$ & \\
\hline 08:30 & $x$ & & 09:30 & $x$ & & $10: 30$ & $x$ & \\
\hline 08:35 & $x$ & & 09:35 & $x$ & & $10: 35$ & & $x$ \\
\hline $08: 40$ & $x$ & & 09:40 & $x$ & & $10: 40$ & & $x$ \\
\hline $08: 45$ & $x$ & & $09: 45$ & $x$ & & $10: 45$ & & $x$ \\
\hline $08: 50$ & $x$ & & 09:50 & $x$ & & $10: 50$ & & $x$ \\
\hline $08: 55$ & & $x$ & 09:55 & $x$ & & $10: 55$ & $x$ & \\
\hline 09:00 & & $x$ & $10: 00$ & $x$ & & 11:00 & $x$ & \\
\hline
\end{tabular}




\section{REGISTRO DOS DADOS COLETADOS}

O registro dos dados coletados foi efetuado e melhorado na medida em que os conhecimentos do pesquisador evoluíam. A Figura 60 apresenta um resumo da metodologia empregada. Duas formas de registro foram utilizadas: registro simplificado e registro complexo.

a) Registro Simplificado

- Registro simplificado do término da tarefa

- Registro simplificado das horas disponíveis dos equipamentos

b) Registro Complexo

- Registro detalhado do término da tarefa

- Método das Observações Instantâneas

- Ciclo dos equipamentos

- Mão-de-obra envolvida

- Visualização das camadas conforme local de atividades

- Detalhamento das atividades conforme as camadas

Figura 60 - Metodologia para o registro dos dados coletados

\section{a) Registro simplificado}

O registro diário simplificado, de uma determinada "porção" do serviço (conjunto de frentes coberto por certa patrulha), detecta apenas o dia em que termina a tarefa em uma frente (ver exemplo na Figura 61), ou seja, na medida em que as atividades ocorriam, o pesquisador registrava o seu término. O registro dos equipamentos disponíveis é feito conforme exemplo da Figura 62. 


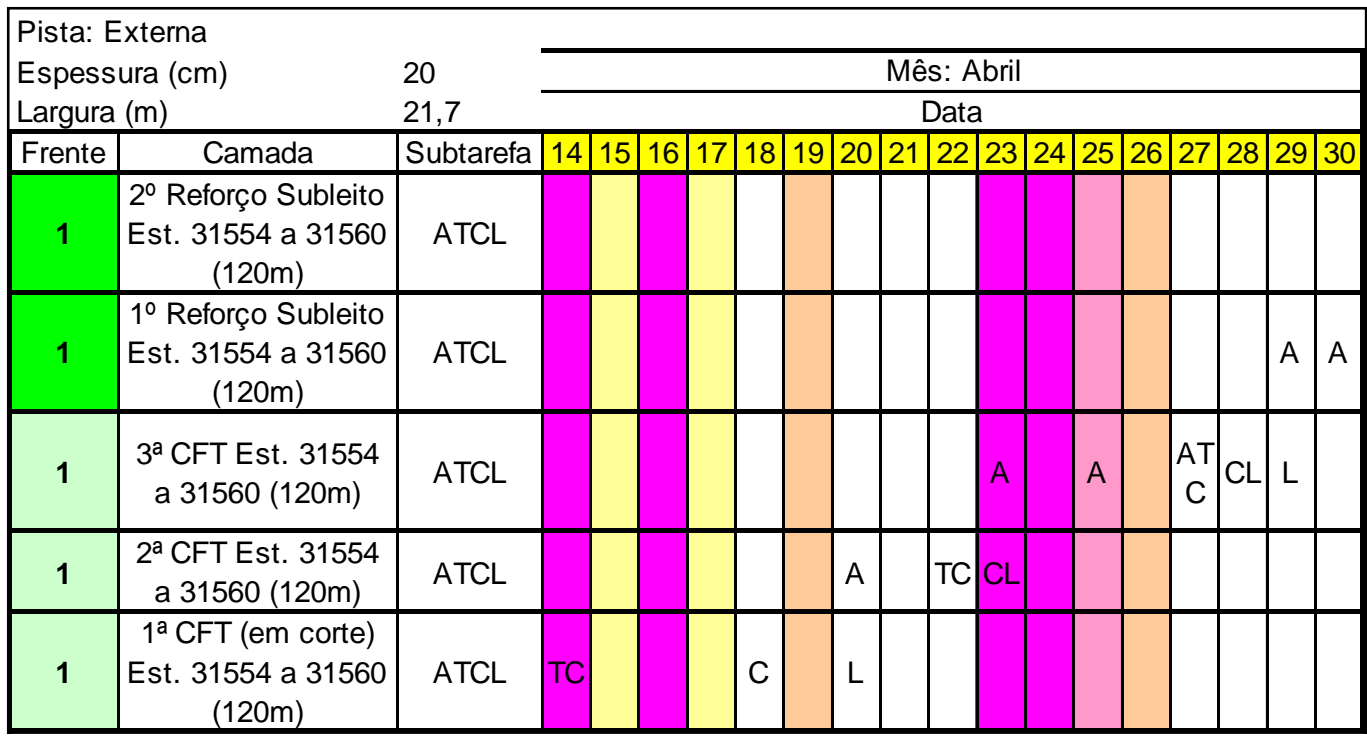

Legenda:

Chuva forte

Chuva fraca

Sem atividade devido a chuva

Domingo ou feriado não trabalhado
Tarefas:

A - Lançamento da camada

T - Tratamento da camada

C - Compactação da camada

L - Liberação da camada

Figura 61 - Registro simplificado do dia em que termina a subtarefa

\begin{tabular}{|c|c|c|c|c|c|c|c|c|c|c|c|c|c|c|c|c|}
\hline & \multicolumn{16}{|c|}{ Mês: Abril } \\
\hline & \multicolumn{16}{|c|}{ Data } \\
\hline & 14 & 15 & 16 & 17 & 18 & 19 & 20 & 21 & 22 & 23 & 24 & 25 & \begin{tabular}{l|l}
26 & 27 \\
\end{tabular} & 28 & 29 & 30 \\
\hline Trator esteiras & 1 & 1 & 1 & 1 & 1 & & 1 & 1 & 1 & 1 & $\overline{1}$ & 1 & 1 & 1 & 1 & 1 \\
\hline Motoniveladora & 1 & 1 & 1 & 1 & 1 & & 1 & 1 & 1 & & & 1 & 1 & 1 & 1 & 1 \\
\hline Distrib. Cimento & 1 & 1 & 1 & 1 & 1 & & 1 & & 1 & 1 & & & 1 & 1 & 1 & 1 \\
\hline Recicladora & 1 & 1 & 1 & 1 & 1 & & 1 & 1 & 1 & 1 & 1 & 1 & 1 & 1 & 1 & 1 \\
\hline Rolo p.d.c. 1 (CAT) & 1 & 1 & 1 & 1 & 1 & & 1 & 1 & 1 & 1 & 1 & & 1 & 1 & 1 & 1 \\
\hline Rolo p.d.c. 2 (Chinês) & 1 & 1 & 1 & 1 & 1 & & 1 & 1 & 1 & 1 & 1 & & 1 & 1 & 1 & 1 \\
\hline Rolo p.d.c. 3 (Chinês) & & 1 & 1 & 1 & 1 & & 1 & 1 & 1 & 1 & 1 & & 1 & 1 & 1 & 1 \\
\hline Rolo p.d.c. 4 (Escad) & & & & & & & & & & & & & 1 & 1 & 1 & 1 \\
\hline Rolo tanden & 1 & 1 & 1 & 1 & 1 & & 1 & 1 & 1 & 1 & 1 & 1 & 1 & 1 & 1 & 1 \\
\hline Caminhão pipa 1 & & 1 & 1 & 1 & 1 & & & & 1 & 1 & 1 & 1 & 1 & 1 & 1 & 1 \\
\hline Caminhão pipa 2 & & & & & & & & & & & & & & & 1 & 1 \\
\hline
\end{tabular}

Figura 62 - Registro diário dos equipamentos disponíveis ( 1 = quantidade de equipamento)

\section{b) Registro complexo}

O registro diário complexo, de uma determinada "porção" do serviço (conjunto de frentes coberto por certa patrulha), detecta o dia em que terminam as subtarefas da frente de trabalho, ver exemplo na Figura 63 (este registro é mais detalhado do que o anterior). 


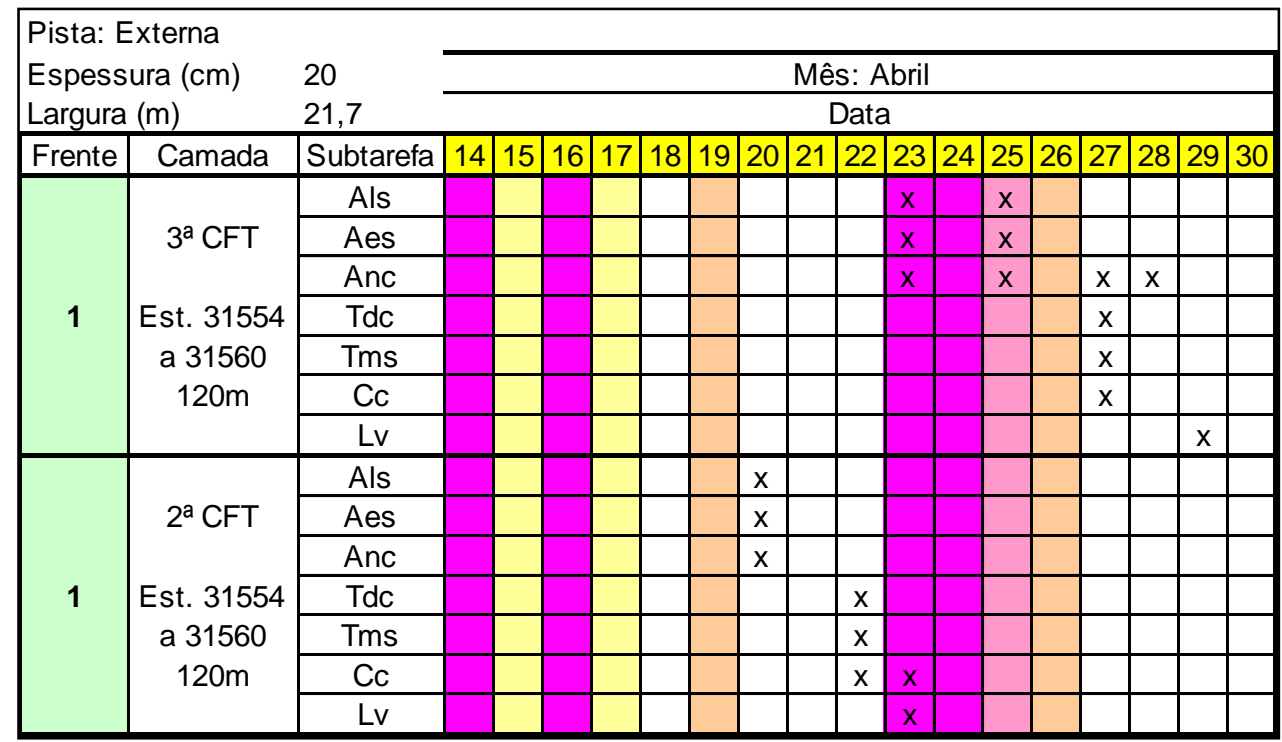

Legenda:

Als: Aterro - lançamento do solo

Aes: Aterro - espalhamento do solo

Anc: Aterro - nivelamento da camada

Tdc: Tratamento da camada - distribuição do cimento
Tms: Tratamento da camada - mistura do solo com cimento

Cc: Compactação da camada

Lv: Liberação da camada - verificação do $\mathrm{GC} / \mathrm{H}$

Figura 63 - Registro detalhado do dia em que termina a subtarefa

A Tabela 122 apresenta um exemplo de registro das horas em funcionamento originadas do Método das Observações Instantâneas.

Tabela 122 - Registro detalhado de horas em funcionamento (originado do Método das Observações Instantâneas)

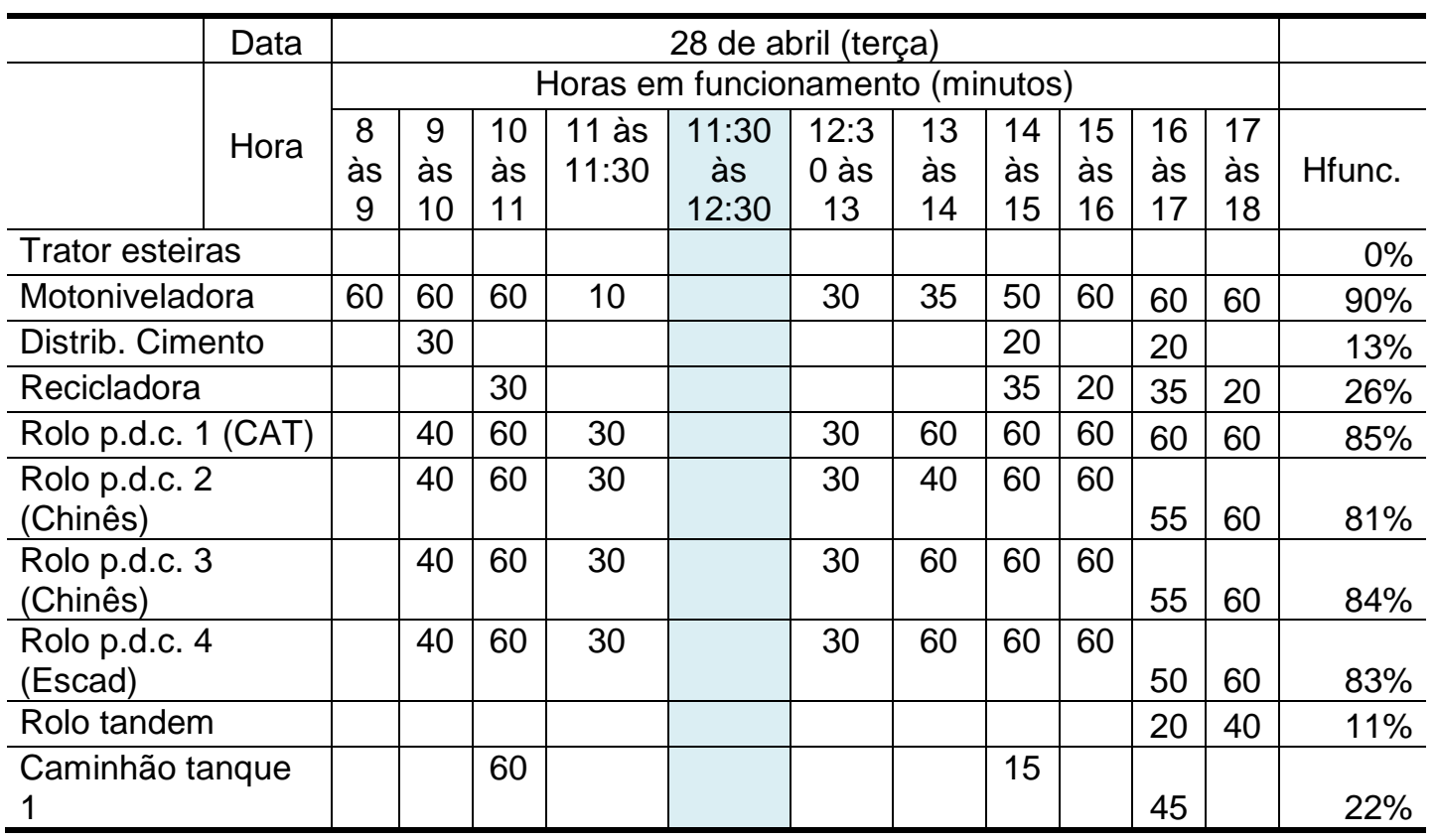


A Tabela 123 apresenta um exemplo de registro dos ciclos dos equipamentos, medidos por filmagem.

Tabela 123 - Medição do ciclo dos equipamentos na execução de camada final de terraplenagem.

\begin{tabular}{|c|c|c|c|c|c|}
\hline EQUIPAMENTO & Dia & Local & $\begin{array}{l}\text { Comprimento "m" } \\
\text { (ida + volta) }\end{array}$ & $\begin{array}{c}\text { Tempo } \\
\text { (minutos) }\end{array}$ & \multirow{6}{*}{$\begin{array}{c}\text { Faixa de } \\
20 \mathrm{~cm} \\
\text { esp e } \\
1,9 \mathrm{~m} d e \\
\text { largura }\end{array}$} \\
\hline Rolo pé de carneiro CAT 12 ton & $22 / a b r$ & RAMO 204 & 240 & $04: 22$ & \\
\hline $\begin{array}{l}\text { Rolo pé de carneiro - Chinês - } \\
\text { XS } 120 \text { PD XCMG } 20 \text { ton }\end{array}$ & 22/abr & RAMO 204 & 240 & 04:22 & \\
\hline $\begin{array}{l}\text { Caminhão distribuidor de } \\
\text { cimento (espargidor) }\end{array}$ & 22/abr & RAMO 204 & 480 & $06: 10$ & \\
\hline Recicladora TEREX & $22 / a b r$ & RAMO 204 & 160 & $06: 10$ & \\
\hline Caminhão Pipa & $22 / a b r$ & RAMO 204 & 120 & $03: 34$ & \\
\hline
\end{tabular}

A Tabela 124 apresenta um exemplo de registro da mão de obra utilizada na execução do serviço.

Tabela 124 - Camada final de terraplenagem: Ramo 204 (mão de obra)

\begin{tabular}{c|c|c}
\hline Data & Greidista & Servente \\
\hline $13 / \mathrm{abr}$ & 1 & 2 \\
\hline $14 / \mathrm{abr}$ & 1 & 2 \\
\hline $20 / \mathrm{abr}$ & 1 & 2 \\
\hline $21 / \mathrm{abr}$ & 1 & 2 \\
\hline $22 / \mathrm{abr}$ & 1 & 2 \\
\hline $23 / \mathrm{abr}$ & 1 & 2 \\
\hline
\end{tabular}


A Figura 64 apresenta, para as diferentes camadas, a data em que finalizou a compactação da camada. As características da pista, tais como: a espessura, a largura e o comprimento (representado pelas estacas) podem ser observadas.

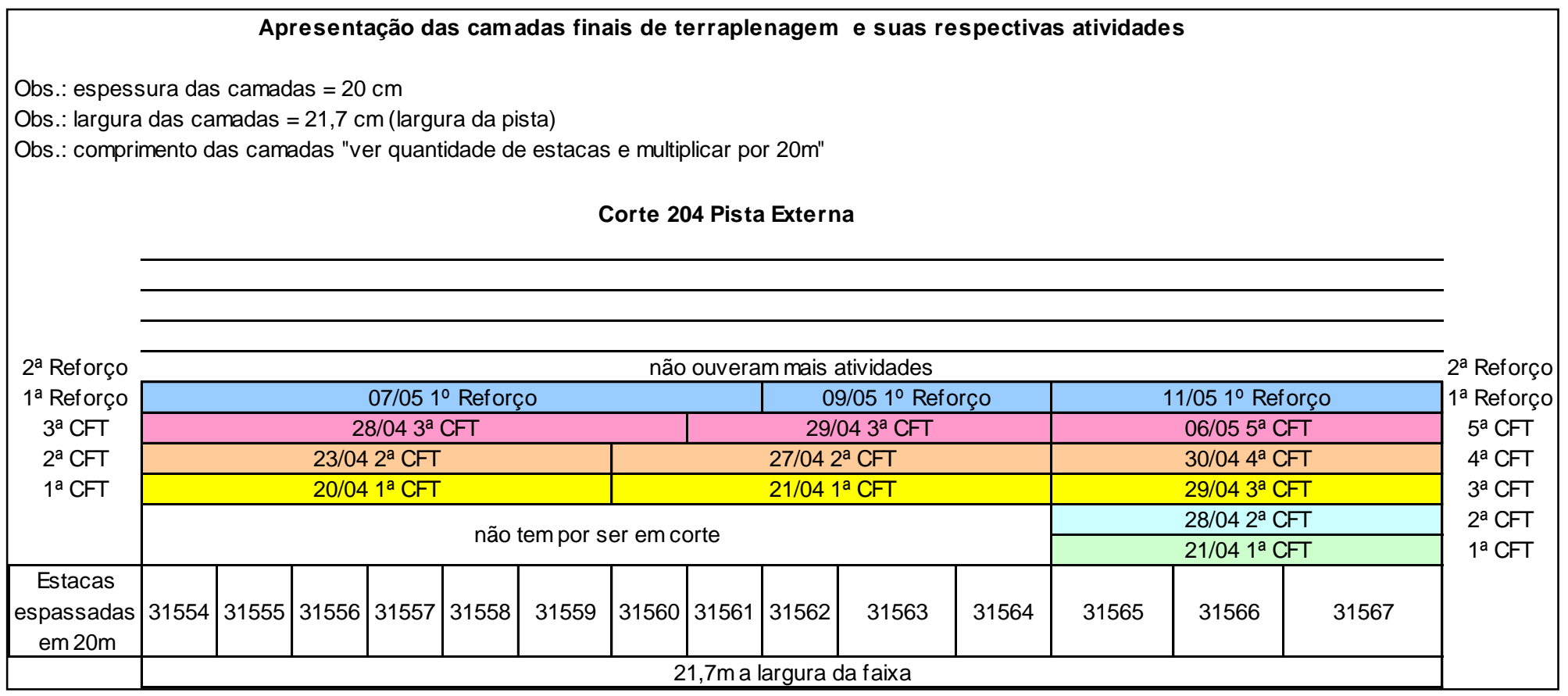

Figura 64 - Apresentação das camadas finais de terraplenagem e a data final de conclusão de suas atividades: Corte 204 - Pista externa 
A Figura 65 detalha as atividades ocorridas, conforme o registro na Figura 64. Exemplo: em 07/05, entre as estacas 31554 e 31561 , ocorreram as seguintes atividades - $1^{\circ}$ : verificação do GC; $2^{\circ}$ : aprovação e liberação da $1^{\text {a }}$ camada de reforço do subleito; $3^{\circ}$ : espalhamento de solo (só forrou).

\begin{tabular}{|c|c|c|c|c|}
\hline \multicolumn{4}{|c|}{ Corte 204 Pista Externa (atividades detalhadas) } & \\
\hline \multirow[b]{2}{*}{$2^{\circ}$ Reforço } & 08/05 - aguardando dreno & 13/05 - aguardando dreno & 11/05 - aguardando dreno & \multirow[b]{2}{*}{$\begin{array}{l}2^{\circ} \\
\text { Reforço }\end{array}$} \\
\hline & 07/05 - espalhamento de solo (só forrou) & $\begin{array}{l}\text { 09/05 - espalhamento de } \\
\text { solo (só forrou) }\end{array}$ & $\begin{array}{l}\text { 11/05 - espalhamento de solo (só } \\
\text { forrou) }\end{array}$ & \\
\hline \multirow{13}{*}{$1^{\circ}$ Reforço } & \multirow[t]{6}{*}{ 07/05 - liberação do $1^{\circ}$ reforço do sub-leito } & \multirow[t]{3}{*}{$\begin{array}{l}09 / 05 \text { - liberação do } 1^{0} \\
\text { reforço do sub-leito }\end{array}$} & $\begin{array}{l}\text { 11/05 - liberação do } 1^{\circ} \text { reforço do sub- } \\
\text { leito }\end{array}$ & \multirow{13}{*}{ I0 Reforçc } \\
\hline & & & $\begin{array}{l}11 / 05 \text { - distrib.cimento + reciclou + } \\
\text { compactou }\end{array}$ & \\
\hline & & & 10/05 - domingo & \\
\hline & & 09/05 - recompactou & 09/05 - sem atividade & \\
\hline & & 08/05 - verificação GC & 08/05 - sem atividade & \\
\hline & & $\begin{array}{l}07 / 05 \text { - distrib.cimento + } \\
\text { reciclou + compactou }\end{array}$ & \multirow[t]{2}{*}{ 07/05 - nivelamento } & \\
\hline & 07/05 - verificou o GC & 07/05 - nivelamento & & \\
\hline & $\begin{array}{l}\text { 06/05 - compactou + verificou o GC (não passou) + } \\
\text { recompactou }\end{array}$ & 06/05 - controlou a umidade & \multirow[t]{6}{*}{$06 / 05$ - espalhamento de solo } & \\
\hline & $\begin{array}{l}\text { 05/05 - nivelou + distrib.cimento + reciclou + compactou (não } \\
\text { terminou) }\end{array}$ & 05/05 - nivelou & & \\
\hline & 04/05 - atividade nas outras frentes (choveu à tarde) & $\begin{array}{l}\text { 04/05 - atividade nas outras } \\
\text { frentes (choveu à tarde) }\end{array}$ & & \\
\hline & 01,02 e $03 / 05$ - feriado e domingo & $\begin{array}{l}\text { 01, } 02 \text { e } 03 / 05 \text { - feriado e } \\
\text { domingo }\end{array}$ & & \\
\hline & 30/04 - espalhamento de solo + nivelamento & $\begin{array}{l}\text { 30/04 - espalhamento de } \\
\text { solo + nivelamento }\end{array}$ & & \\
\hline & 29/04 - espalhamento de solo (não terminou) & $\begin{array}{l}\text { 29/04 - espalhamento de } \\
\text { solo (não terminou) }\end{array}$ & & \\
\hline
\end{tabular}

Figura 65 - Detalhamento das atividades ocorridas, conforme execução de camada final de terraplenagem: no Corte 204 - Pista externa 


\section{APÊNDICE D - CONJUNTO DE DADOS DO RODOANEL}

A seguir, são apresentados o conjunto dos dados (resumo) apresentados no Capítulo 6.

a) Terraplenagem

- Escavação e carga de material de $1^{\text {a }}$ categoria $\left(\mathrm{m}^{3}\right)$;

- Compactação de aterro $\left(\mathrm{m}^{2}\right)$;

- Compactação de aterro $\left(\mathrm{m}^{3}\right)$;

- Camada final de terraplenagem $\left(\mathrm{m}^{2}\right)$;

- Camada final de terraplenagem $\left(\mathrm{m}^{3}\right)$;

b) Pavimentação asfáltica

- Brita graduada simples $\left(\mathrm{m}^{2}\right)$;

- Brita graduada simples $\left(\mathrm{m}^{3}\right)$;

- Brita graduada tratada com cimento $\left(\mathrm{m}^{2}\right)$;

- Brita graduada tratada com cimento $\left(\mathrm{m}^{3}\right)$;

- Binder $\left(\mathrm{m}^{2}\right)$;

- Binder $\left(\mathrm{m}^{3}\right)$;

- Imprimação $\left(\mathrm{m}^{2}\right)$;

c) Método das Observações Instantâneas

- Camada final de terraplenagem;

- Brita graduada simples;

- Brita graduada tratada com cimento;

- Binder. 
Tabela 125 - Escavação e carga de material de $1^{\text {a }}$ categoria - resumo

\begin{tabular}{l|c|c|c}
\hline \multirow{2}{*}{ Cortes } & \multicolumn{3}{|c}{ Produção Unitária $\left(\mathrm{m}^{3} /\right.$ Hserv) } \\
\cline { 2 - 4 } & 1ํ Quartil & Mediana & $3^{\circ}$ Quartil \\
\hline Corte 203 & 91,78 & 140,00 & 168,00 \\
\hline Corte 206 & 59,50 & 66,31 & 78,56 \\
\hline Corte 207 & 50,36 & 92,94 & 116,28 \\
\hline Corte 208 & 43,44 & 52,89 & 57,56 \\
\hline Corte 209 & 68,44 & 73,11 & 77,78 \\
\hline Corte 213 & 84,00 & 143,50 & 206,69 \\
\hline Corte 204 & 53,03 & 66,05 & 103,14 \\
\hline
\end{tabular}

Tabela 126 - Compactação de aterros - resumo (continua)

\begin{tabular}{|c|c|c|c|}
\hline & \multicolumn{3}{|c|}{ Prod. Unit ( $\left.\mathrm{m}^{2} / \mathrm{Hserv}\right)$} \\
\hline Trator de esteira & 1Q Quartil & Mediana & 3 Quartil \\
\hline Aterro 210 & 51,9 & 62,2 & 72,6 \\
\hline Aterro 211 & 290,4 & 420,0 & 622,2 \\
\hline Aterro 212 & 178,9 & 259,3 & 313,7 \\
\hline Aterro 218 & 264,4 & 363,0 & 461,5 \\
\hline \multirow[t]{2}{*}{ Mediana } & 221,7 & 311,1 & 387,6 \\
\hline & \multicolumn{3}{|c|}{ Prod. Unit $\left(\mathrm{m}^{2} /\right.$ Hserv $)$} \\
\hline $\begin{array}{l}\text { Trator agrícola com } \\
\text { grade de disco }\end{array}$ & 1Q Quartil & Mediana & 3 Quartil \\
\hline Aterro 210 & 51,9 & 62,2 & 72,6 \\
\hline Aterro 211 & 290,4 & 420,0 & 622,2 \\
\hline Aterro 212 & 178,9 & 259,3 & 313,7 \\
\hline Aterro 218 & 264,4 & 363,0 & 461,5 \\
\hline \multirow[t]{2}{*}{ Mediana } & 221,7 & 311,1 & 387,6 \\
\hline & \multicolumn{3}{|c|}{ Prod. Unit ( $\mathrm{m}^{2} /$ Hserv) } \\
\hline Caminhão tanque & 1ㅇ Quartil & Mediana & 3ํ Quartil \\
\hline Aterro 210 & 233,3 & 280,0 & 326,7 \\
\hline Aterro 211 & 1306,7 & 1890,0 & 2800,0 \\
\hline Aterro 212 & 805,0 & 1166,7 & 1411,7 \\
\hline Aterro 218 & 1190,0 & 1633,3 & 2076,7 \\
\hline \multirow[t]{2}{*}{ Mediana } & 997,5 & 1400,0 & 1744,2 \\
\hline & \multicolumn{3}{|c|}{ Prod. Unit ( $\mathrm{m}^{2} /$ Hserv) } \\
\hline Rolo pé de carneiro & 1ㅇ Quartil & Mediana & 3 Quartil \\
\hline Aterro 210 & 13,0 & 15,6 & 18,1 \\
\hline Aterro 211 & 72,6 & 105,0 & 155,6 \\
\hline Aterro 212 & 44,7 & 64,8 & 78,4 \\
\hline Aterro 218 & 66,1 & 90,7 & 115,4 \\
\hline Mediana & 55,4 & 77,8 & 96,9 \\
\hline
\end{tabular}


Tabela 126 - Compactação de aterros - resumo (conclusão)

\begin{tabular}{l|c|c|c}
\hline & \multicolumn{3}{|c}{ Prod. Unit (m²/Hserv) } \\
\hline Motoniveladora & 1 Quartil & Mediana & 3 Quartil \\
\hline Aterro 210 & 51,9 & 62,2 & 72,6 \\
\hline Aterro 211 & 290,4 & 420,0 & 622,2 \\
\hline Aterro 212 & 178,9 & 259,3 & 313,7 \\
\hline Aterro 218 & 264,4 & 363,0 & 461,5 \\
\hline Mediana & 221,7 & 311,1 & 387,6 \\
\hline
\end{tabular}

Tabela 127 - Camada final de terraplenagem - Ramo 204 - resumo

\begin{tabular}{l|c|c|c|c|c|c|c}
\hline & \multirow{2}{*}{ Qtde } & \multicolumn{3}{|c|}{ Produção Unitária (m²/Hserv) } & \multicolumn{3}{c}{ Hfuncionamento } \\
\cline { 3 - 8 } & & 10 Quartil $^{\circ}$ & Mediana & $3^{\circ}$ Quartil & $1^{\circ}$ Quartil & Mediana & $3^{\circ}$ Quartil \\
\hline Trator esteiras & 1 & 144,67 & 289,33 & 446,06 & $12 \%$ & $28 \%$ & $34 \%$ \\
\hline Motoniveladora & 1 & 253,17 & 446,06 & 477,92 & $36 \%$ & $60 \%$ & $79 \%$ \\
\hline Distrib. Cimento & 1 & 289,33 & 289,33 & 363,39 & $6 \%$ & $8 \%$ & $13 \%$ \\
\hline Recicladora & 1 & 289,33 & 289,33 & 363,39 & $11 \%$ & $23 \%$ & $25 \%$ \\
\hline $\begin{array}{l}\text { Rolo pés-de- } \\
\text { caneiro }\end{array}$ & 4 & 72,33 & 84,39 & 120,56 & $44 \%$ & $53 \%$ & $72 \%$ \\
\hline Rolo de pneus & 1 & 237,67 & 337,56 & 385,78 & $6 \%$ & $8 \%$ & $10 \%$ \\
\hline Caminhão tanque & 1 & 289,33 & 337,56 & 396,11 & $10 \%$ & $15 \%$ & $25 \%$ \\
\hline Serventes & 3 & 84,39 & 148,69 & 159,31 & & & \\
\hline
\end{tabular}

Tabela 128 - Camada final de terraplenagem - outros ramos - resumo

\begin{tabular}{l|c|c|c|c}
\hline \multirow{2}{*}{} & \multirow{2}{*}{ Qtde } & \multicolumn{3}{|c}{ Produção Unitária (m²/Hserv) } \\
\cline { 3 - 5 } & & $1^{\circ}$ Quartil & Mediana & $3^{\circ}$ Quartil \\
\hline Trator esteiras & 1 & 880,00 & 1020,00 & 1050,00 \\
\hline Motoniveladora & 1 & 206,67 & 333,33 & 400,00 \\
\hline Distrib. Cimento & 1 & 450,00 & 600,00 & 800,00 \\
\hline Recicladora & 1 & 510,00 & 640,00 & 1191,43 \\
\hline Rolo pés-de-caneiro & 4 & 86,19 & 140,00 & 182,86 \\
\hline Rolo de pneus & 1 & 505,00 & 570,00 & 1320,00 \\
\hline Caminhão tanque & 1 & 560,00 & 840,00 & 1191,43 \\
\hline Serventes & 3 & 93,33 & 140,00 & 198,57 \\
\hline
\end{tabular}


Tabela 129 - Camada final de terraplenagem "observações instantâneas"

\begin{tabular}{|c|c|c|c|c|c|c|c|c|c|c|c|c|c|c|c|c|}
\hline & 14/abr & $20 / a b r$ & $21 / a b r$ & 22/abr & 23/abr & 25/abr & $27 / a b r$ & $28 / a b r$ & 30/abr & 04/mai & 05/mai & 06/mai & $1^{\circ} \mathrm{Q}$ & Mediana & $3^{\circ} \mathrm{Q}$ & Erro \\
\hline Trator esteiras & & $31 \%$ & $26 \%$ & & $35 \%$ & $33 \%$ & & & $60 \%$ & $9 \%$ & $13 \%$ & $7 \%$ & $12 \%$ & $28 \%$ & $34 \%$ & $3 \%$ \\
\hline Motoniveladora & & $67 \%$ & $19 \%$ & $33 \%$ & & $44 \%$ & $80 \%$ & $90 \%$ & $88 \%$ & $6 \%$ & $53 \%$ & $78 \%$ & $36 \%$ & $60 \%$ & $79 \%$ & $3 \%$ \\
\hline Distrib. Cimento & $17 \%$ & $3 \%$ & & $19 \%$ & $6 \%$ & & $6 \%$ & $13 \%$ & $2 \%$ & $8 \%$ & $8 \%$ & & $6 \%$ & $8 \%$ & $13 \%$ & $2 \%$ \\
\hline Recicladora & $23 \%$ & $6 \%$ & & $34 \%$ & $11 \%$ & & $16 \%$ & $26 \%$ & $8 \%$ & $23 \%$ & $25 \%$ & & $11 \%$ & $23 \%$ & $25 \%$ & $3 \%$ \\
\hline $\begin{array}{c}\text { Rolo p.d.c. } 1 \\
\text { (CAT) }\end{array}$ & $56 \%$ & $55 \%$ & $17 \%$ & $89 \%$ & $54 \%$ & & $53 \%$ & $85 \%$ & $49 \%$ & $44 \%$ & $62 \%$ & $84 \%$ & $51 \%$ & $55 \%$ & $73 \%$ & $3 \%$ \\
\hline $\begin{array}{l}\text { Rolo p.d.c. } 2 \\
\text { (Chinês) }\end{array}$ & $56 \%$ & $24 \%$ & $17 \%$ & $91 \%$ & $53 \%$ & & $51 \%$ & $81 \%$ & $43 \%$ & $43 \%$ & $62 \%$ & $85 \%$ & $43 \%$ & $53 \%$ & $71 \%$ & $3 \%$ \\
\hline $\begin{array}{l}\text { Rolo p.d.c. } 3 \\
\text { (Chinês) }\end{array}$ & & $52 \%$ & $17 \%$ & $92 \%$ & $53 \%$ & & $51 \%$ & $84 \%$ & $41 \%$ & $43 \%$ & $62 \%$ & $85 \%$ & $45 \%$ & $52 \%$ & $79 \%$ & $3 \%$ \\
\hline $\begin{array}{c}\text { Rolo p.d.c. } 4 \\
\text { (Escad) }\end{array}$ & & & & & & & $51 \%$ & $83 \%$ & $49 \%$ & $44 \%$ & $36 \%$ & $31 \%$ & $38 \%$ & $46 \%$ & $50 \%$ & $4 \%$ \\
\hline Rolo tandem & & & $9 \%$ & & & $11 \%$ & $8 \%$ & $14 \%$ & & $6 \%$ & $6 \%$ & $4 \%$ & $6 \%$ & $8 \%$ & $10 \%$ & $2 \%$ \\
\hline $\begin{array}{c}\text { Caminhão } \\
\text { tanque } 1\end{array}$ & & & & $14 \%$ & $5 \%$ & & & $13 \%$ & $24 \%$ & $8 \%$ & $4 \%$ & $3 \%$ & $4 \%$ & $8 \%$ & $13 \%$ & $2 \%$ \\
\hline $\begin{array}{l}\text { Caminhão } \\
\text { tanque } 2\end{array}$ & & & & $6 \%$ & & & & & $12 \%$ & $6 \%$ & $4 \%$ & $21 \%$ & $6 \%$ & $6 \%$ & $12 \%$ & $2 \%$ \\
\hline
\end{tabular}

Tabela 130 - BGS e BGTC "observações instantâneas"

\begin{tabular}{l|c|c|c|c|c|c}
\hline & BGS & BGTC & $1 \%$ Q & MED & $3 \%$ Q & Erro \\
\hline Vibroacabadora 1 & $28 \%$ & $26 \%$ & $26 \%$ & $27 \%$ & $27 \%$ & $6 \%$ \\
\hline tandem 1 & $35 \%$ & $30 \%$ & $31 \%$ & $32 \%$ & $34 \%$ & $6 \%$ \\
\hline Rolo de pneus 1 & $27 \%$ & $24 \%$ & $25 \%$ & $25 \%$ & $26 \%$ & $6 \%$ \\
\hline Rolo de pneus 2 & $15 \%$ & & $15 \%$ & $15 \%$ & $15 \%$ & $5 \%$ \\
\hline Caminhão tanque & $3 \%$ & $7 \%$ & $4 \%$ & $5 \%$ & $6 \%$ & $3 \%$ \\
\hline
\end{tabular}


Tabela 131 - Brita graduada simples BGS - resumo

\begin{tabular}{|c|c|c|c|c|c|c|c|c|c|c|c|c|c|c|c|}
\hline & \multirow{2}{*}{\multicolumn{3}{|c|}{$\begin{array}{c}\text { Vibroacabadora } \\
\text { Produção Unitária } \\
\left(\mathrm{m}^{2} / \text { Hserv }\right)\end{array}$}} & \multirow{2}{*}{\multicolumn{3}{|c|}{$\begin{array}{c}\text { Rolo de pneus } \\
\text { Produção Unitária } \\
\left(\mathrm{m}^{2} / \text { Hserv }\right)\end{array}$}} & \multirow{2}{*}{\multicolumn{3}{|c|}{$\begin{array}{l}\text { Rolo tandem } \\
\text { rodução Unitária } \\
\left(\mathrm{m}^{2} / \text { Hserv }\right)\end{array}$}} & \multirow{2}{*}{\multicolumn{3}{|c|}{$\begin{array}{l}\text { Pipa } \\
\text { dução Unitária } \\
\mathrm{m}^{2} / \text { Hserv) }\end{array}$}} & \multirow{2}{*}{\multicolumn{3}{|c|}{$\begin{array}{l}\text { Serventes } \\
\text { dução Unitária } \\
\left(\mathrm{m}^{2} / \text { Hserv }\right)\end{array}$}} \\
\hline BGS & & & & & & & & & & & & & & & \\
\hline Ramo & $1^{\circ} \mathrm{Q}$ & Mediana & $3^{\circ} Q$ & $1^{\circ} \mathrm{Q}$ & Mediana & $3^{\circ} \mathrm{Q}$ & $1^{\circ} \mathrm{Q}$ & Mediana & 3ㅇ $Q$ & $1 \stackrel{Q}{ } Q$ & Mediana & $3^{\circ} Q$ & $1^{\circ} \mathrm{Q}$ & Mediana & $3^{\circ} \mathrm{Q}$ \\
\hline APS-PE & 229,3 & 229,3 & 229,3 & 229,3 & 229,3 & 229,3 & 229,3 & 229,3 & 229,3 & 229,3 & 229,3 & 344,0 & 32,8 & 32,8 & 62,2 \\
\hline A-PI & 76,4 & 86,0 & 95,6 & 86,0 & 95,6 & 152,9 & 86,0 & 95,6 & 152,9 & 0,0 & 0,0 & 0,0 & 25,5 & 30,4 & 31,9 \\
\hline $\mathrm{PI}-\mathrm{A}$ & 157,7 & 172,0 & 186,3 & 157,7 & 172,0 & 186,3 & 157,7 & 172,0 & 186,3 & 157,7 & 172,0 & 186,3 & 17,0 & 17,3 & 17,6 \\
\hline PE-APN & 229,3 & 229,3 & 229,3 & 114,7 & 114,7 & 114,7 & 229,3 & 229,3 & 229,3 & 0,0 & 0,0 & 0,0 & 45,9 & 45,9 & 45,9 \\
\hline Mediana & 193,5 & 200,7 & 207,8 & 136,2 & 143,3 & 169,6 & 193,5 & 200,7 & 207,8 & 193,5 & 200,7 & 265,2 & 29,1 & 31,6 & 38,9 \\
\hline
\end{tabular}

Tabela 132 - Ramo AP-I e EIXO (BGTC)

\begin{tabular}{l|c|c|c|c|c|c|c}
\hline & \multirow{2}{*}{ Qtde } & \multicolumn{2}{|c|}{ Produção Unitária (m2/Hserv) } & \multicolumn{3}{c}{ Hfuncionamento } \\
\cline { 3 - 8 } & & 1ㅇ Quartil & Mediana & 3 Quartil & 1ㅇ Quartil & Mediana & 3 Quartil \\
\hline Vibroacabadora & 1 & 109,67 & 116,67 & 123,67 & $26 \%$ & $27 \%$ & $27 \%$ \\
\hline Rolo de pneus & 1 & 142,33 & 182,00 & 221,67 & $24 \%$ & $25 \%$ & $26 \%$ \\
\hline Rolo tandem & 1 & 142,33 & 182,00 & 221,67 & $31 \%$ & $32 \%$ & $34 \%$ \\
\hline Pipa & 1 & 142,33 & 182,00 & 221,67 & $4 \%$ & $5 \%$ & $6 \%$ \\
\hline Serventes & 6 & 23,72 & 30,33 & 36,94 & & & \\
\hline
\end{tabular}

Tabela 133 - Binder: "observações instantâneas"

\begin{tabular}{|c|c|c|c|c|c|c|c|c|c|c|c|c|c|c|}
\hline \multicolumn{11}{|c|}{ Método das Observações Instantâneas } & $1^{\circ} \mathrm{Q}$. & Mediana & $3^{\circ} Q$ & Erro \\
\hline Vibroacabadora & $26 \%$ & $16 \%$ & $7 \%$ & $11 \%$ & $17 \%$ & $27 \%$ & & & & & $12 \%$ & $16 \%$ & $24 \%$ & $3 \%$ \\
\hline Rolo pneus & $48 \%$ & $16 \%$ & $7 \%$ & $13 \%$ & $33 \%$ & $36 \%$ & $42 \%$ & $16 \%$ & $4 \%$ & $16 \%$ & $14 \%$ & $16 \%$ & $35 \%$ & $2 \%$ \\
\hline Rolo tandem & $29 \%$ & $16 \%$ & $9 \%$ & $13 \%$ & $12 \%$ & $41 \%$ & & & & & $12 \%$ & $14 \%$ & $25 \%$ & $3 \%$ \\
\hline $\begin{array}{l}\text { Caminhão } \\
\text { espargidor }\end{array}$ & $18 \%$ & & & & & & & & & & $18 \%$ & $18 \%$ & $18 \%$ & $7 \%$ \\
\hline $\begin{array}{l}\text { Trator agrícola } \\
\text { com compressor }\end{array}$ & $13 \%$ & & & & & & & & & & $13 \%$ & $13 \%$ & $13 \%$ & $6 \%$ \\
\hline Caminhão tanque & $12 \%$ & $6 \%$ & & & & & & & & & $8 \%$ & $9 \%$ & $11 \%$ & $4 \%$ \\
\hline
\end{tabular}


Tabela 134 - Binder - resumo

\begin{tabular}{|c|c|c|c|c|c|c|c|c|c|c|c|c|}
\hline \multirow[b]{3}{*}{ Ramo } & \multicolumn{3}{|c|}{ Vibroacabadora } & \multicolumn{3}{|c|}{ Serventes } & \multicolumn{3}{|c|}{ Rolo de pneus } & \multicolumn{3}{|c|}{ Rolo tandem } \\
\hline & \multicolumn{3}{|c|}{ Produção Unitária (m²/Hserv) } & \multicolumn{3}{|c|}{ Produção Unitária (m²/Hserv) } & \multicolumn{3}{|c|}{$\begin{array}{l}\text { Produção Unitária } \\
\left(\mathrm{m}^{2} / \mathrm{Hserv}\right)\end{array}$} & \multicolumn{3}{|c|}{ Produção Unitária (m²/Hserv) } \\
\hline & 1ㅇ. $\mathrm{Q}$. & Mediana & 3 $\mathrm{Q}$. & $10 \mathrm{Q}$. & Mediana & 3 $\mathrm{Q}$. & 1ㅇ․ $\mathrm{Q}$. & Mediana & 3ㅇ. $\mathrm{Q}$. & $1 \stackrel{0}{ } \mathrm{Q}$. & Mediana & 3 $\mathrm{Q}$. \\
\hline APS-PE & 128,3 & 185,6 & 288,6 & 9,2 & 17,1 & 24,8 & 64,2 & 126,7 & 186,9 & 128,3 & 155,6 & 240,0 \\
\hline A-PI & 76,0 & 106,7 & 152,0 & 83,1 & 97,7 & 126,2 & 528,0 & 684,0 & 738,0 & 684,0 & 960,0 & 1368,0 \\
\hline $\mathrm{PI}-\mathrm{A}$ & 283,6 & 283,6 & 283,6 & 364,6 & 364,6 & 364,6 & 1276,0 & 1276,0 & 1276,0 & 2552,0 & 2552,0 & 2552,0 \\
\hline Mediana & 128,3 & 185,6 & 283,6 & 83,1 & 97,7 & 126,2 & 528,0 & 684,0 & 738,0 & 684,0 & 960,0 & 1368,0 \\
\hline \multirow{3}{*}{ Ramo } & \multicolumn{3}{|c|}{ Caminhão Espargidor } & \multicolumn{3}{|c|}{ Caminhão Pipa } & \multicolumn{3}{|c|}{$\begin{array}{c}\text { Trator Agrícola com } \\
\text { Compressor }\end{array}$} & & & \\
\hline & \multicolumn{3}{|c|}{ Produção Unitária (m²/Hserv) } & \multicolumn{3}{|c|}{ Produção Unitária (m²/Hserv) } & \multicolumn{3}{|c|}{$\begin{array}{l}\text { Produção Unitária } \\
\left(\mathrm{m}^{2} / \mathrm{Hserv}\right)\end{array}$} & & & \\
\hline & 1ㅇ. $\mathrm{Q}$. & Mediana & $3^{\circ} \mathrm{Q}$. & $1^{\circ} \mathrm{Q}$ & Mediana & 3ㅇ. & $1^{\circ} \mathrm{Q}$ & Mediana & 3ํ. & & & \\
\hline APS-PE & 93,3 & 140,0 & 226,7 & & & & & & & & & \\
\hline A-PI & & & & 684,0 & 960,0 & 1368,0 & 960,0 & 1368,0 & 1368,0 & & & \\
\hline $\mathrm{PI}-\mathrm{A}$ & 2552,0 & 2552,0 & 2552,0 & & & & & & & & & \\
\hline Mediana & 1322,7 & 1346,0 & 1389,3 & 684,0 & 960,0 & 1368,0 & 960,0 & 1368,0 & 1368,0 & & & \\
\hline
\end{tabular}


Tabela 135 - Imprimação (resumo)

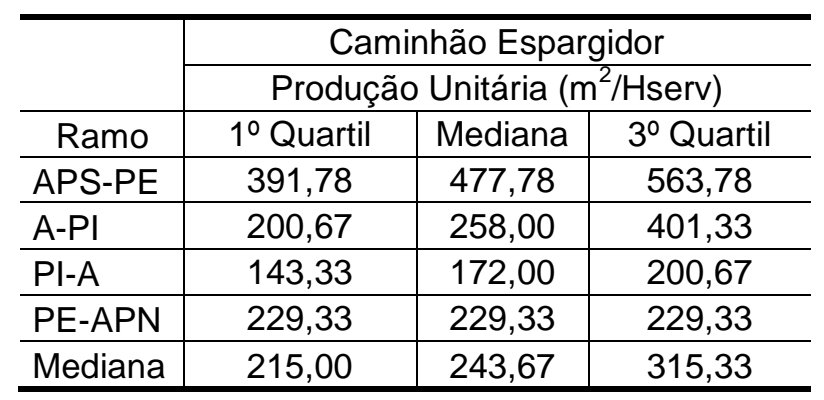

Tabela 136 - Imprimação "observações instantâneas"

\begin{tabular}{c|c|c|c}
\hline Data & Ramo & Prod. & Erro \\
\hline 03/jun & APS-PE & $6 \%$ & $4 \%$ \\
\hline $16 /$ jun & A-PI & $6 \%$ & $4 \%$ \\
\hline $16 /$ jun & PE-APN & $6 \%$ & $4 \%$ \\
\hline
\end{tabular}




\section{APÊNDICE E - INDICADORES INICIAIS DOS MANUAIS}

A seguir, são apresentados os resumos dos dados retirados de cada um dos Manuais apresentados no Capítulo 7.

- Terraplenagem

- Escavação e carga de material de 1a categoria,

- Compactação de aterros, em camadas de 20 cm, GC: de 90 a 95\%,

- Compactação de aterros, em camadas de $20 \mathrm{~cm}$, GC: 100\%,

- Construção de reforço de subleito.

- Pavimentação asfáltica

- Base de brita graduada,

- Base de brita graduada com distribuidor de agregados com controle de greide,

- Brita graduada tratada com cimento,

- Base de solo cimento com 3\% de cimento e mistura na pista,

- Base de solo cimento com 4\% de cimento e mistura na pista,

- Imprimação,

- Pintura de ligação,

- Concreto betuminoso usinado a quente - capa de rolamento,

- Concreto betuminoso usinado a quente - binder,

- PMQ com asfalto polímero, 
Tabela 137 - Escavação e carga material de $1^{\text {a }}$ categoria $\left(\mathrm{m}^{3} / \mathrm{h}\right)$

\begin{tabular}{|c|c|c|c|c|c|c|c|c|c|}
\hline $\begin{array}{l}\text { Escavação e Carga } \\
\text { Material de } 1^{\text {a }} \text { Categoria }\end{array}$ & DNIT & DNIT & EMOP & EMOP & EMOP & SIURB & TCPO & CAIXA & PCC-USP \\
\hline & Várias & Várias & $03.026 .010-0$ & $03.026 .015-0$ & Várias & 41100 & 02335.8.5.19 & 02.04 .201 & 91129 \\
\hline Discriminação & PU & $\mathrm{PU}$ & $\mathrm{PU}$ & PU & PU & PU & PU & PU & PU \\
\hline $\begin{array}{l}\text { Trator de esteiras, com } \\
\text { lâmina, } 67 \mathrm{~kW} \text { (D5) }\end{array}$ & & & & & 50,0 & 35,7 & & & \\
\hline $\begin{array}{l}\text { Trator de esteiras, com } \\
\text { lâmina, } 106 \mathrm{~kW} \text { (D6) }\end{array}$ & & & & 127,0 & & & & & \\
\hline $\begin{array}{l}\text { Trator de esteiras, com } \\
\text { lâmina, } 228 \text { kW (D8) }\end{array}$ & & 234,9 & 192,0 & & & & 172,4 & 172,4 & 161,3 \\
\hline $\begin{array}{l}\text { Escavadeira Hidráulica - } \\
\text { sobre Esteira c/Caçamba } \\
\text { - cap } 1.5 m^{3}\end{array}$ & 192,3 & & & & & & & & \\
\hline $\begin{array}{l}\text { Carregadeira de pneus - } \\
\text { cap } 1,3 \mathrm{~m}^{3}\end{array}$ & & & & & 50,0 & & & & \\
\hline $\begin{array}{l}\text { Carregadeira de pneus - } \\
\text { cap } 1,8 \mathrm{~m}^{3}\end{array}$ & & & & & & 35,7 & & & \\
\hline $\begin{array}{l}\text { Carregadeira de pneus - } \\
\text { cap } 3,1 \mathrm{~m}^{3}\end{array}$ & & 214,0 & 192,0 & 127,0 & & & 112,4 & 112,4 & 112,4 \\
\hline Servente & 63,7 & 71,3 & 64,0 & 42,3 & 25,0 & & & 71,4 & 71,4 \\
\hline
\end{tabular}

DNIT - Utilização Improdutiva $=3 \%$ da Utilização Operativa 
Tabela 138 - Compactação de aterros, em camadas de $20 \mathrm{~cm}, \mathrm{GC}$ : de $90 \%$ a $95 \%\left(\mathrm{~m}^{3} / \mathrm{h}\right)$

\begin{tabular}{|c|c|c|c|c|c|c|c|}
\hline & DNIT & PCC-USP & CAIXA & EMOP & EMOP & SIURB & TCPO \\
\hline & 402976 & 91134 & 02.04 .302 & 03.010.001-0 & $\begin{array}{c}20.004 .003- \\
1\end{array}$ & $04-32-00$ & 02315.8 .9 .1 \\
\hline & $\begin{array}{l}\text { Proctor } \\
\text { Normal }\end{array}$ & $\begin{array}{l}\text { Proctor } \\
\text { Normal }\end{array}$ & $\begin{array}{c}\text { Proctor } \\
\text { Modificado }\end{array}$ & Indefinido & Indefinido & Indefinido & $\begin{array}{l}\text { Proctor } \\
\text { Normal }\end{array}$ \\
\hline & GC: $95 \%$ & $\mathrm{GC}=95 \%$ & $\mathrm{GC}=90 \%$ & GC: $90 \%$ & $\mathrm{GC}=?$ & $\mathrm{GC}=?$ & $\mathrm{GC}=?$ \\
\hline Discriminação & $\mathrm{PU}$ & $\mathrm{PU}$ & $\mathrm{PU}$ & $\mathrm{PU}$ & $\mathrm{PU}$ & PU & $\mathrm{PU}$ \\
\hline Grade de discos rebocável & 313,2 & 138,9 & 238,8 & & & 100,0 & 100,0 \\
\hline Motoniveladora & 539,4 & 285,7 & 238,8 & & 350 & 200,0 & 200,0 \\
\hline $\begin{array}{l}\text { Trator de esteiras, com lâmina, } 67 \text { kW } \\
\text { (D5) }\end{array}$ & & & & 50,0 & & & \\
\hline $\begin{array}{l}\text { Rolo compactador pé de carneiro } \\
\text { vibratório autoprop.- } 6.9 \mathrm{t}\end{array}$ & 215,7 & 208,3 & 238,8 & 50,0 & 175 & 200,0 & 200,0 \\
\hline $\begin{array}{l}\text { Rolo compactador pé de carneiro } \\
\text { vibratório autoprop.- } 7.5 \mathrm{t}\end{array}$ & & & & & & 200,0 & \\
\hline Caminhão tanque - cap.6.000 I & & & & 50,0 & 175 & 100,0 & \\
\hline Caminhão tanque - cap.10000 I & 156,6 & 277,8 & 119,5 & & & & 100,0 \\
\hline Trator agrícola & 303,4 & 277,8 & 238,8 & 50,0 & 175 & 100,0 & 100,0 \\
\hline Servente & 112,4 & 89,3 & 119,4 & 25,0 & 350 & 20,4 & 66,7 \\
\hline
\end{tabular}

DNIT - Utilização Improdutiva = 3\% da Utilização Operativa 
Tabela 139 - Compactação de aterros, em camadas de $20 \mathrm{~cm}, \mathrm{GC}: 100 \%\left(\mathrm{~m}^{3} / \mathrm{h}\right)$

\begin{tabular}{l|c|c}
\hline \multirow{2}{*}{ Discriminação } & DNIT & PCC-USP \\
\cline { 2 - 3 } & 402976 & 91133 \\
\cline { 2 - 3 } & Proctor Normal & Proctor Normal \\
\cline { 2 - 3 } & GC: $100 \%$ & GC $=100 \%$ \\
\hline \multicolumn{1}{c|}{ Gu } & PU \\
\hline Motoniveladora & 313,2 & 117,6 \\
\hline $\begin{array}{l}\text { Rolo compactador pé de carneiro vibratório } \\
\text { autoprop.- 6.9 t }\end{array}$ & 539,4 & 238,1 \\
\hline Caminhão tanque - cap.10000 I & 161,8 & 175,4 \\
\hline Trator agrícola & 151,7 & 140,8 \\
\hline Servente & 303,4 & 232,6 \\
\hline DNIT- & 84,0 & 74,1 \\
\hline
\end{tabular}

DNIT - Utilização Improdutiva $=3 \%$ da Utilização Operativa

Tabela 140 - Construção de reforço de subleito $\left(\mathrm{m}^{3} / \mathrm{h}\right)$

\begin{tabular}{l|c}
\hline \multirow{2}{*}{\multicolumn{1}{c|}{ Discriminação }} & EMOP \\
\cline { 2 - 2 } & $20.004 .006-0$ \\
\hline & $\mathrm{GC}=?$ \\
\hline Caminhão tanque - cap.6.000 I & $\mathrm{PU}$ \\
\hline Trator agrícola & 78,0 \\
\hline Motoniveladora & 23,0 \\
\hline Grade de discos rebocável & 234,0 \\
\hline Rolo compactador pé de carneiro vibratório autoprop.- $6.9 \mathrm{t}$ & 117,0 \\
\hline Rolo compactador de pneus, autopropelido, 20t & 234,0 \\
\hline Servente & 23,4 \\
\hline
\end{tabular}


Tabela 141 - Base de brita graduada $\left(\mathrm{m}^{3} / \mathrm{h}\right)$

\begin{tabular}{|c|c|c|c|c|c|c|}
\hline & $\begin{array}{c}\text { DNIT } \\
\text { Planilha }\end{array}$ & $\begin{array}{c}\text { EMOP } \\
\text { Planilha }\end{array}$ & $\begin{array}{l}\text { SIURB } \\
\text { Planilha }\end{array}$ & $\begin{array}{c}\text { TCPO } \\
\text { Planilha }\end{array}$ & \begin{tabular}{|c|} 
CAIXA \\
Planilha
\end{tabular} & \begin{tabular}{|c|} 
PCC-USP \\
Planilha91092
\end{tabular} \\
\hline & $\begin{array}{c}\text { Planilha } \\
2010872 \text { e } \\
2010873 \\
\end{array}$ & $\begin{array}{c}\text { Planilha } \\
\text { 20.008.001-0 }\end{array}$ & $\begin{array}{l}\text { Planilha } \\
05.48 .00\end{array}$ & $\begin{array}{c}\text { Planilha } \\
\text { 02720.8.3.1 }\end{array}$ & $\begin{array}{l}\text { Planilha } \\
\text { 04.05.301 }\end{array}$ & \\
\hline Discriminação & PU & PU & PU & PU & PU & PU \\
\hline Trator agrícola & & 91,0 & & & & \\
\hline Carregadeira de pneus - cap. $3,1 \mathrm{~m}^{3}$ & & & & & 74,1 & \\
\hline Distribuidor de agregados - autopropelido & 131,2 & & & 120,5 & 54,8 & \\
\hline Vibroacabadora de asfalto - sobre esteiras & & & & & & 30,0 \\
\hline Rolo compactador de pneus autopropelido (21t) & 156,6 & 91,0 & & 120,5 & & \\
\hline Rolo compactador de pneus autopropelido (27t) & & & & & 74,0 & 28,2 \\
\hline Rolo compactador tipo tandem (7t) & & 91,0 & 13,3 & & & \\
\hline Rolo compactador tipo tandem (10,9t) & 161,8 & & & & & \\
\hline Rolo compactador tipo tandem (12t) & & & & 120,5 & 74,0 & 51,8 \\
\hline Caminhão tanque de $6.000 \mathrm{I}$ & & & 30,8 & & 74,0 & \\
\hline Caminhão tanque de $10.000 \mathrm{I}$ & 167,4 & & & & & \\
\hline Motoniveladora & & 91,0 & 21,5 & & 74,0 & \\
\hline Servente & 44,1 & 7,6 & 6,5 & 5,0 & 12,3 & 4,1 \\
\hline
\end{tabular}

DNIT - Utilização Improdutiva = 3\% da Utilização Operativa 
Tabela 142 - Base de brita graduada com distribuidor de agregados com controle de greide $\left(\mathrm{m}^{3} / \mathrm{h}\right)$

\begin{tabular}{|c|c|}
\hline \multicolumn{2}{|c|}{ DNIT: Planilha 2010874 e 2010875} \\
\hline Discriminação & $\mathrm{PU}$ \\
\hline Caminhão tanque de $10.000 \mathrm{I}$ & 167,4 \\
\hline Distribuidora / fresadora - c/ controle de greide & 422,1 \\
\hline Rolo compactador de pneus autopropelido (21t) & 156,6 \\
\hline Rolo compactador tipo tandem $(10,9 t)$ & 161,8 \\
\hline Servente & 44,1 \\
\hline
\end{tabular}

DNIT - Utilização Improdutiva = 3\% da Utilização Operativa

Tabela 143 - Base de brita graduada tratada com cimento $\left(\mathrm{m}^{3} / \mathrm{h}\right)$

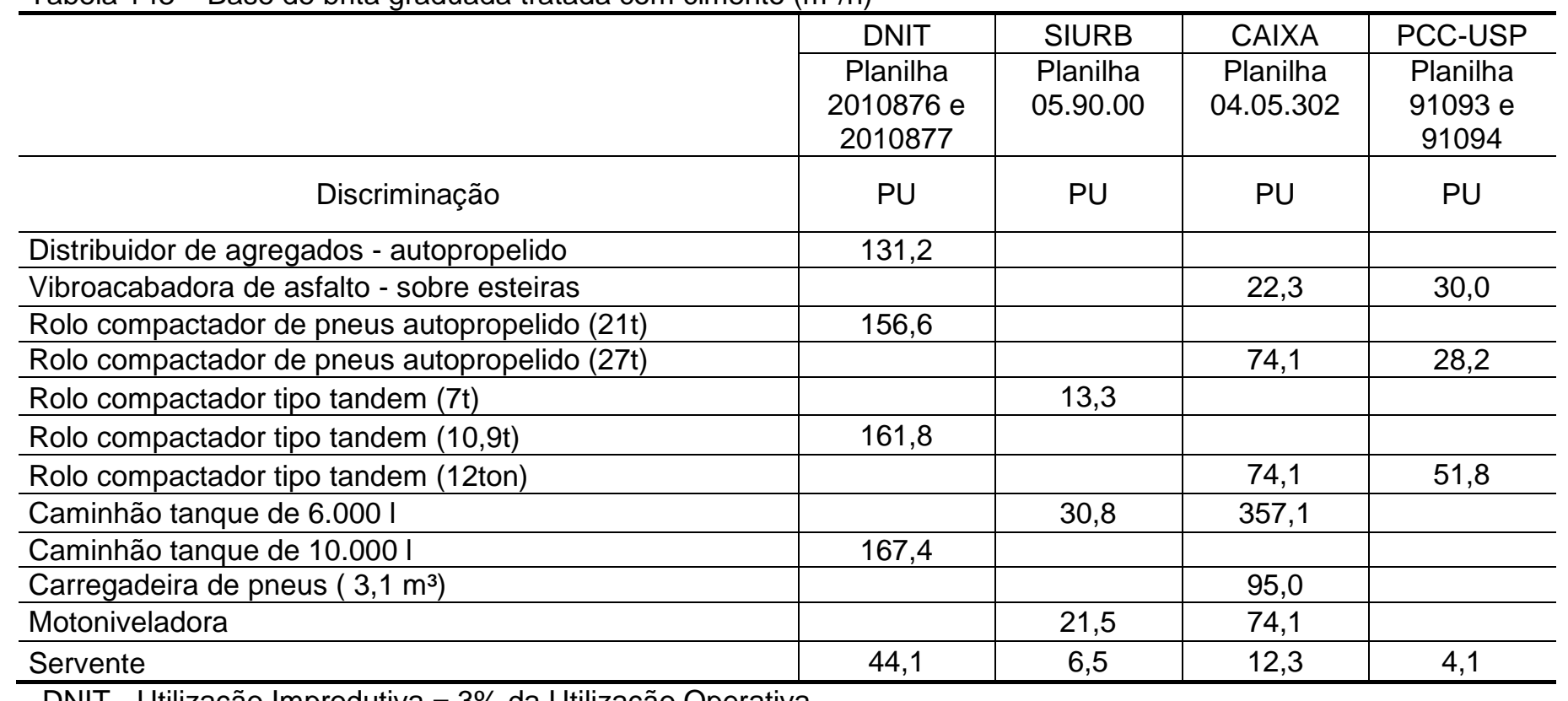

DNIT - Utilização Improdutiva = 3\% da Utilização Operativa 
Tabela 144 - Base de solo cimento com $3 \%$ de cimento e mistura na pista $\left(\mathrm{m}^{3} / \mathrm{h}\right)$

\begin{tabular}{|c|c|c|c|}
\hline & DNIT & EMOP & SIURB \\
\hline & $\begin{array}{c}\text { Planilha } \\
2010880, \\
2010881 \text { e } \\
2010882\end{array}$ & $\begin{array}{c}\text { Planilha } \\
20.006 .003-0\end{array}$ & $\begin{array}{l}\text { Planilha } \\
05.54 .00\end{array}$ \\
\hline Discriminação & PU & $\mathrm{PU}$ & $\mathrm{PU}$ \\
\hline Grade de discos rebocável & 236,8 & & 31,3 \\
\hline Pulvomisturador & & 85,0 & \\
\hline Motoniveladora & 138,7 & & 31,3 \\
\hline Rolo compactador de pneus autopropelido (21t) & 211,1 & 85,0 & \\
\hline Rolo compactador de pneus autopropelido (27t) & & & 250,0 \\
\hline Rolo compactador tipo tandem $(7 \mathrm{t})$ & & & 31,3 \\
\hline Rolo compactador tipo tandem $(10,9 t)$ & 161,8 & & \\
\hline $\begin{array}{l}\text { Rolo compactador pé de carneiro vibratório } \\
\text { autopropelido }-7.5 \mathrm{t}\end{array}$ & & & 125,0 \\
\hline Trator agrícola & 236,8 & & 31,3 \\
\hline Caminhão tanque de $6.000 \mathrm{I}$ & & & 62,5 \\
\hline Caminhão tanque de 10.000 I & 151,7 & & \\
\hline Servente & 48,1 & 10,6 & 3,1 \\
\hline
\end{tabular}

DNIT - Utilização Improdutiva $=3 \%$ da Utilização Operativa 
Tabela 145 - Base de solo cimento com $4 \%$ de cimento e mistura na pista $\left(\mathrm{m}^{3} / \mathrm{h}\right)$

\begin{tabular}{l|c|c}
\hline \multirow{1}{c|}{ Discriminação } & DNIT & SIURB \\
\cline { 2 - 3 } & $\begin{array}{c}\text { Planilha } \\
2010883, \\
2010884 \text { e } \\
2010885\end{array}$ & $\begin{array}{c}\text { Planilha } \\
05.55 .00\end{array}$ \\
\hline Grade de discos rebocável & PU & PU \\
\hline Motoniveladora & 236,8 & 31,3 \\
\hline Rolo compactador de pneus autopropelido (21t) & 138,7 & 31,3 \\
\hline Rolo compactador de pneus autopropelido (27t) & 211,1 & \\
\hline Rolo compactador tipo tandem (7t) & & 250,0 \\
\hline Rolo compactador tipo tandem (10,9t) & 161,8 & 125,0 \\
\hline Rolo compactador pé de carneiro vibratório & & \\
autopropelido - 7.5 t & 236,8 & 31,3 \\
\hline Trator agrícola & & 62,5 \\
\hline Caminhão tanque de 6.000 I & 151,7 & \\
\hline Caminhão tanque de 10.000 I & 48,1 & 3,1 \\
\hline Servente & &
\end{tabular}

DNIT - Utilização Improdutiva = 3\% da Utilização Operativa 
Tabela 146 - Imprimação $\left(\mathrm{m}^{2} / \mathrm{h}\right)$

\begin{tabular}{l|c|c|c|c|c}
\hline & DNIT & EMOP & SIURB & TCPO & PCC-USP \\
\cline { 2 - 6 } & Planilha & Planilha \\
\multicolumn{1}{c|}{ Discriminação } & PU & Planilha & $\begin{array}{c}\text { Planilha } \\
20.009 .001-1\end{array}$ & 05.27 .00 & $\begin{array}{c}\text { Planilha } \\
91110\end{array}$ \\
\hline Distribuidor de betume (6.000 I) & & PU & PU & PU \\
\hline Tanque de estocagem de asfalto - 20000 I & 1078,7 & 1408,1 & 169,5 & 416,7 & 270,3 \\
\hline Trator agrícola & 1078,7 & 1408,1 & & & 561,8 \\
\hline Vassoura mecânica rebocável & 3236,2 & 1408,1 & & & \\
\hline Servente & 3236,2 & 1408,1 & & & \\
\hline DNT - & 370,4 & 234,7 & 169,5 & 33,3 & 246,9 \\
\hline
\end{tabular}

DNIT - Utilização Improdutiva = 3\% da Utilização Operativa

Tabela 147 - Pintura de ligação $\left(\mathrm{m}^{2} / \mathrm{h}\right)$

\begin{tabular}{l|c|c|c|c|c|c}
\hline & DNIT & EMOP & SIURB & TCPO & CAIXA & PCC-USP \\
\cline { 2 - 7 } & $\begin{array}{c}\text { Planilha } \\
2010941 \mathrm{e} \\
2010942\end{array}$ & $\begin{array}{c}\text { Planilha } \\
20.009 .002-1\end{array}$ & $\begin{array}{c}\text { Planilha } \\
05.26 .00\end{array}$ & $\begin{array}{c}\text { Planilha } \\
02710.8 .5 .2\end{array}$ & $\begin{array}{c}\text { Planilha } \\
04.05 .402\end{array}$ & $\begin{array}{c}\text { Planilha } \\
91111\end{array}$ \\
\hline \multicolumn{1}{c|}{ Discriminação } & PU & PU & PU & PU & PU & PU \\
\hline Distribuidor de betume (6.000 I) & 1387,0 & 2188,2 & 212,8 & 333,3 & 3125,0 & 234,7 \\
\hline $\begin{array}{l}\text { Tanque de estocagem de asfalto - } \\
\text { 20000 I }\end{array}$ & 1387,0 & 2188,2 & & & 3125,0 & \\
\hline Trator agrícola & 2427,2 & 2188,7 & & & 2000,0 & \\
\hline Vassoura mecânica rebocável & 2427,2 & 2188,7 & & & 2000,0 & \\
\hline Servente & 500,0 & 364,7 & 212,8 & 12,5 & 285,7 & 33,3 \\
\hline
\end{tabular}

DNIT - Utilização Improdutiva $=3 \%$ da Utilização Operativa 
Tabela 148 - Concreto betuminoso usinado a quente - capa de rolamento (t/h)

\begin{tabular}{|c|c|c|c|c|c|c|c|c|}
\hline & DNIT & EMOP & EMOP & EMOP & EMOP & SIURB & TCPO & PCC-USP \\
\hline & $\begin{array}{c}\text { Planilha } \\
2010999 \text { e } \\
2011000\end{array}$ & $\begin{array}{c}\text { Planilha } \\
20.009 .025-0 \text { e } \\
20.009 .060-0\end{array}$ & $\begin{array}{c}\text { Planilha } \\
20.009 .028-0 \text { e } \\
20.009 .063-0\end{array}$ & $\begin{array}{c}\text { Planilha } \\
20.009 .030-0 \text { e } \\
20.009 .065-0\end{array}$ & $\begin{array}{c}\text { Planilha } \\
20.009 .033-0 \text { e } \\
20.009 .068-0\end{array}$ & $\begin{array}{l}\text { Planilha } \\
\text { 05.28.00 }\end{array}$ & $\begin{array}{c}\text { Planilha } \\
\text { 02.740.8.1.1 }\end{array}$ & $\begin{array}{l}\text { Planilha } \\
91100\end{array}$ \\
\hline & & $\begin{array}{l}\text { Prod. Usina } \\
10 \mathrm{~m} 3 / \mathrm{h}\end{array}$ & $\begin{array}{c}\text { Prod. Usina } \\
14 \mathrm{~m} 3 / \mathrm{h}\end{array}$ & $\begin{array}{l}\text { Prod. Usina } \\
20 \mathrm{~m} 3 / \mathrm{h}\end{array}$ & $\begin{array}{l}\text { Prod. Usina } \\
25 \mathrm{~m} 3 / \mathrm{h}\end{array}$ & & & \\
\hline Discriminação & PU & PU & PU & PU & PU & PU & PU & PU \\
\hline $\begin{array}{l}\text { Vibroacabadora de asfalto - } \\
\text { sobre esteiras }\end{array}$ & 90,7 & 10,0 & 14,0 & 20,0 & 25,0 & 7,2 & 14,7 & 37,0 \\
\hline $\begin{array}{l}\text { Rolo compactador de pneus } \\
\text { autopropelido ( } 21 \mathrm{t})\end{array}$ & 126,1 & 10,0 & 14,0 & 20,0 & 25,0 & & 14,7 & \\
\hline $\begin{array}{l}\text { Rolo compactador de pneus } \\
\text { autopropelido }(27 \mathrm{t})\end{array}$ & & & & & & 7,2 & & 12,1 \\
\hline $\begin{array}{l}\text { Rolo compactador tipo } \\
\text { tandem }(7 \mathrm{t})\end{array}$ & & & & & & 7,2 & & \\
\hline $\begin{array}{l}\text { Rolo compactador tipo } \\
\text { tandem }(10,9 \mathrm{t})\end{array}$ & 129,4 & 10,0 & 14,0 & 20,0 & 25,0 & & & \\
\hline Trator agrícola & 303,4 & & & & & & & \\
\hline Vassoura mecânica rebocável & 303,4 & & & & & & & \\
\hline Servente & 9,4 & 10,0 & 14,0 & 20,0 & 25,0 & 1,2 & 0,5 & 2,8 \\
\hline Laboratorista de solos A & & 10,0 & 14,0 & 20,0 & 25,0 & & & \\
\hline Rasteleiro & & & & & & 3,6 & & \\
\hline
\end{tabular}

DNIT - Utilização Improdutiva = 3\% da Utilização Operativa 
Tabela 149 - Concreto betuminoso usinado a quente - binder (t/h)

\begin{tabular}{l|c|c|c|c}
\hline & DNIT & EMOP & SIURB & PCC-USP \\
\cline { 2 - 4 } & $\begin{array}{c}\text { Planilha } \\
2011001, \\
2011002, \\
2011009 \mathrm{e} \\
2011010\end{array}$ & $\begin{array}{c}\text { Planilha } \\
20.009 .012-0\end{array}$ & $\begin{array}{c}\text { Planilha } \\
05.25 .01 \mathrm{e} \\
05.25 .02\end{array}$ & $\begin{array}{c}\text { Planilha } \\
91100\end{array}$ \\
\hline \multicolumn{1}{c|}{ Discriminação } & PU & PU & PU & PU \\
\hline $\begin{array}{l}\text { Vibroacabadora de asfalto - sobre } \\
\text { esteiras }\end{array}$ & 90,7 & 14,1 & 13,1 & 37,0 \\
\hline $\begin{array}{l}\text { Rolo compactador de pneus } \\
\text { autopropelido (21t) }\end{array}$ & 126,1 & 14,1 & & \\
\hline $\begin{array}{l}\text { Rolo compactador de pneus } \\
\text { autopropelido (27t) }\end{array}$ & & & 13,1 & 12,1 \\
\hline Rolo compactador tipo tandem (7t) & & & 13,1 & \\
\hline Rolo compactador tipo tandem (10,9t) & 129,5 & 14,1 & & \\
\hline Rolo compactador tipo tandem (12t) & & & & \\
\hline Trator agrícola & 303,4 & & & \\
\hline Vassoura mecânica rebocável & 303,4 & & 13,1 & \\
\hline Servente & 9,4 & 2,8 & & \\
\hline Rasteleiro & & & & \\
\hline
\end{tabular}

DNIT - Utilização Improdutiva = 3\% da Utilização Operativa 


\section{APÊNDICE F - PROCESSAMENTO DOS INDICADORES DOS MANUAIS}

A seguir, são apresentados os resumos do processamento dos indicadores dos manuais. Este processamento se deu por meio do cálculo do $1^{\circ}$ e $3^{\circ}$ Quartil e da Mediana, condensando todos os manuais em uma única composição unitária, conforme o tipo de serviço.

Tabela 150 - Resumo do processamento dos indicadores dos manuais (continua)

\begin{tabular}{|c|c|c|c|c|c|c|}
\hline \multirow{2}{*}{$\begin{array}{l}\text { Escavação de Material de } 1^{\text {a }} \\
\text { Categoria. Etapa: escavação } \\
\text { com trator de esteiras e carga } \\
\text { com carregadeira }\left(\mathrm{m}^{3}\right) \\
\frac{\text { Discriminação }}{}\end{array}$} & \multicolumn{3}{|c|}{ Produção Unitária (m³/Hserv) } & \multicolumn{3}{|c|}{ Hfuncionamento } \\
\hline & 1 Quartil & Mediana & 3 Quartil & 10 Quartil & Mediana & 3 Quartil \\
\hline $\begin{array}{l}\text { Trator de esteiras, com lâmina, } \\
228 \mathrm{~kW} \text { (D8) }\end{array}$ & 172,4 & 172,4 & 192,0 & $94 \%$ & $95 \%$ & $96 \%$ \\
\hline $\begin{array}{l}\text { Carregadeira de pneus - cap. } \\
3,1 \mathrm{~m}^{3}\end{array}$ & 112,4 & 112,4 & 192,0 & $96 \%$ & $96 \%$ & $97 \%$ \\
\hline Servente & 69,5 & 71,4 & 71,4 & & & \\
\hline $\begin{array}{l}\text { Escavação de Material de } 1^{\underline{a}} \\
\text { Categoria com escavadeira } \\
\left(\mathrm{m}^{3}\right)\end{array}$ & \multicolumn{3}{|c|}{ Produção Unitária (m³/Hserv) } & \multicolumn{3}{|c|}{ Hfuncionamento } \\
\hline Discriminação & 10 Quartil & Mediana & 3 Quartil & 1Q Quartil & Mediana & 3Q Quartil \\
\hline $\begin{array}{l}\text { Escavadeira hidráulica - sobre } \\
\text { esteira c/caçamba - cap. } 1.5 \mathrm{~m}^{3}\end{array}$ & & 198,08 & & & $97 \%$ & \\
\hline Servente & & 63,69 & & & & \\
\hline $\begin{array}{l}\text { Compactação de aterro - esp. } \\
\text { até } 30 \mathrm{~cm}\left(\mathrm{~m}^{3}\right)\end{array}$ & \multicolumn{3}{|c|}{ Produção Unitária (m³/Hserv) } & \multicolumn{3}{|c|}{ Hfuncionamento } \\
\hline Discriminação & 10 Quartil & Mediana & 3 Quartil & 1ㅇ Quartil & Mediana & 3ㅇ Quartil \\
\hline Grade de discos rebocável & 108,1 & 138,9 & 271,0 & $76 \%$ & $76 \%$ & $97 \%$ \\
\hline Motoniveladora & 227,3 & 260,1 & 383,7 & $49 \%$ & $50 \%$ & $97 \%$ \\
\hline $\begin{array}{l}\text { Trator de esteiras, com lâmina, } \\
67 \text { kW (D5) }\end{array}$ & 50,0 & 50,0 & 50,0 & - & - & - \\
\hline $\begin{array}{l}\text { Rolo compactador pé de } \\
\text { carneiro }\end{array}$ & 175,0 & 200,0 & 208,3 & $88 \%$ & $88 \%$ & $97 \%$ \\
\hline Caminhão tanque - cap.10000 I & 124,2 & 146,1 & 155,3 & $69 \%$ & $69 \%$ & $97 \%$ \\
\hline Trator agrícola & 100,0 & 232,6 & 277,8 & $70 \%$ & $75 \%$ & $92 \%$ \\
\hline Servente & 66,7 & 84,0 & 112,4 & & & \\
\hline
\end{tabular}


Tabela 150 - Resumo do processamento dos indicadores dos manuais (continua)

\begin{tabular}{|c|c|c|c|c|c|c|}
\hline \multirow{2}{*}{ 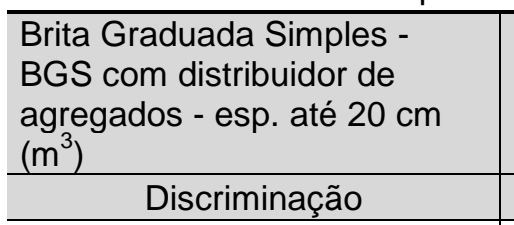 } & \multicolumn{3}{|c|}{ Produção Unitária (m³/Hserv) } & \multicolumn{3}{|c|}{ Hfuncionamento } \\
\hline & 10 Quartil & Mediana & 3 Quartil & 1ㅇ Quartil & Mediana & 3 Quartil \\
\hline $\begin{array}{l}\text { Carregadeira de pneus - cap. } \\
3,1 \mathrm{~m}^{3}\end{array}$ & 74,1 & 74,1 & 74,1 & & & \\
\hline $\begin{array}{l}\text { Distribuidor de agregados - } \\
\text { autopropelido }\end{array}$ & 104,1 & 125,8 & 203,9 & $86 \%$ & $97 \%$ & $97 \%$ \\
\hline $\begin{array}{l}\text { Rolo compactador de pneus } \\
\text { autopropelido }\end{array}$ & 108,9 & 138,5 & 156,6 & $97 \%$ & $97 \%$ & $97 \%$ \\
\hline $\begin{array}{l}\text { Rolo compactador tipo } \\
\text { tandem }\end{array}$ & 108,9 & 141,1 & 161,8 & $97 \%$ & $97 \%$ & $97 \%$ \\
\hline Caminhão tanque & 120,7 & 167,4 & 167,4 & $59 \%$ & $97 \%$ & $97 \%$ \\
\hline Motoniveladora & 74,0 & 74,0 & 74,0 & & & \\
\hline Servente & 10,5 & 28,2 & 44,1 & & & \\
\hline $\begin{array}{l}\text { Brita Graduada Simples - } \\
\text { BGS com vibroacabadora- } \\
\text { esp. até } 20 \mathrm{~cm}\left(\mathrm{~m}^{3}\right)\end{array}$ & \multicolumn{3}{|c|}{ Produção Unitária ( $\mathrm{m}^{3} /$ Hserv) } & \multicolumn{3}{|c|}{ Hfuncionamento } \\
\hline Discriminação & 10 Quartil & Mediana & 3 Quartil & 1ㅇaㅁtil & Mediana & 3 Quartil \\
\hline $\begin{array}{l}\text { Vibroacabadora de asfalto - } \\
\text { sobre esteiras }\end{array}$ & 24,3 & 26,2 & 28,1 & $69 \%$ & $76 \%$ & $83 \%$ \\
\hline $\begin{array}{l}\text { Rolo compactador de pneus } \\
\text { autopropelido (27t) }\end{array}$ & 39,7 & 51,2 & 62,6 & $58 \%$ & $58 \%$ & $58 \%$ \\
\hline $\begin{array}{l}\text { Rolo compactador tipo } \\
\text { tandem (12t) }\end{array}$ & 57,3 & 62,9 & 68,5 & $65 \%$ & $65 \%$ & $65 \%$ \\
\hline Caminhão tanque de $6.000 \mathrm{I}$ & 357,1 & 357,1 & 357,1 & & & \\
\hline Carregadeira de pneus $\left(3,1 \mathrm{~m}^{3}\right)$ & 95,0 & 95,0 & 95,0 & & & \\
\hline Motoniveladora & 74,1 & 74,1 & 74,1 & & & \\
\hline Servente & 6,1 & 8,2 & 10,3 & & & \\
\hline 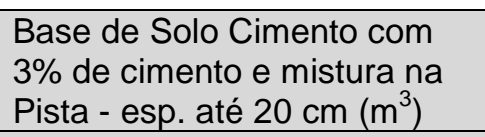 & \multicolumn{3}{|c|}{ Produção Unitária ( $\left.\mathrm{m}^{3} / \mathrm{Hserv}\right)$} & \multicolumn{3}{|c|}{ Hfuncionamento } \\
\hline Discriminação & 10 Quartil & Mediana & 3 Quartil & 1Q Quartil & Mediana & 3 Quartil \\
\hline Grade de discos rebocável & 82,6 & 134,0 & 185,4 & $97 \%$ & $97 \%$ & $97 \%$ \\
\hline Motoniveladora & 58,1 & 85,0 & 111,8 & $97 \%$ & $97 \%$ & $97 \%$ \\
\hline $\begin{array}{l}\text { Rolo compactador de pneus } \\
\text { autopropelido (21t) }\end{array}$ & 147,8 & 211,1 & 230,5 & $73 \%$ & $81 \%$ & $89 \%$ \\
\hline $\begin{array}{l}\text { Rolo compactador tipo } \\
\text { tandem }(7 \mathrm{t})\end{array}$ & 63,9 & 96,5 & 129,2 & $97 \%$ & $97 \%$ & $97 \%$ \\
\hline $\begin{array}{l}\text { Rolo compactador pé de } \\
\text { carneiro }\end{array}$ & 125,0 & 125,0 & 125,0 & & & \\
\hline Trator agrícola & 82,6 & 134,0 & 185,4 & $97 \%$ & $97 \%$ & $97 \%$ \\
\hline Caminhão tanque de 10.000 I & 84,8 & 107,1 & 129,4 & $97 \%$ & $97 \%$ & $97 \%$ \\
\hline Servente & 6,9 & 10,6 & 29,4 & & & \\
\hline
\end{tabular}


Tabela 150 - Resumo do processamento dos indicadores dos manuais (conclusão)

\begin{tabular}{|c|c|c|c|c|c|c|}
\hline \multirow{2}{*}{$\frac{\text { Imprimação }\left(\mathrm{m}^{2}\right)}{\text { Discriminação }}$} & \multicolumn{3}{|c|}{ Produção Unitária ( $\left.\mathrm{m}^{2} / \mathrm{Hserv}\right)$} & \multicolumn{3}{|c|}{ Hfuncionamento } \\
\hline & 1ㅇ Quartil & Mediana & 3 Quartil & 1ㅇQ Quartil & Mediana & 3Q Quartil \\
\hline Asfalto diluído CM 30 & 690,5 & 714,3 & 773,8 & & & \\
\hline Distribuidor de betume $(6.000 \mathrm{I})$ & 270,3 & 416,7 & 1078,7 & $42 \%$ & $61 \%$ & $79 \%$ \\
\hline $\begin{array}{l}\text { Tanque de estocagem de } \\
\text { asfalto - } 20000 \text { I }\end{array}$ & 820,3 & 1078,7 & 1243,4 & $97 \%$ & $97 \%$ & $97 \%$ \\
\hline Trator agrícola & 1865,1 & 2322,2 & 2779,2 & $53 \%$ & $68 \%$ & $82 \%$ \\
\hline Vassoura mecânica rebocável & 1865,1 & 2322,2 & 2779,2 & $53 \%$ & $68 \%$ & $82 \%$ \\
\hline Servente & 169,5 & 234,7 & 246,9 & & & \\
\hline Pintura de Ligação $\left(\mathrm{m}^{2}\right)$ & \multicolumn{3}{|c|}{ Produção Unitária ( $\left.\mathrm{m}^{2} / \mathrm{Hserv}\right)$} & \multicolumn{3}{|c|}{ Hfuncionamento } \\
\hline Discriminação & 1ㅇ Quartil & Mediana & 3 Quartil & 1ㅇ Quartil & Mediana & 3 Quartil \\
\hline Emulsão asfáltica RR-1C & 1663,8 & 1950,7 & 1960,8 & $97 \%$ & $97 \%$ & $97 \%$ \\
\hline Distribuidor de betume (6.000 I) & 253,4 & 862,8 & 1989,2 & $35 \%$ & $56 \%$ & $77 \%$ \\
\hline $\begin{array}{l}\text { Tanque de estocagem de } \\
\text { asfalto - } 20000 \text { I }\end{array}$ & 1808,4 & 2188,2 & 2656,6 & & & \\
\hline Trator agrícola & 2094,3 & 2188,7 & 2344,3 & $59 \%$ & $59 \%$ & $59 \%$ \\
\hline Vassoura mecânica rebocável & 2094,3 & 2188,7 & 2344,3 & $59 \%$ & $59 \%$ & $59 \%$ \\
\hline Servente & 222,5 & 268,8 & 345,0 & & & \\
\hline $\begin{array}{l}\text { Concreto Betuminoso Usinado } \\
\text { a Quente - capa de rolamento } \\
\left(\mathrm{m}^{3}\right)\end{array}$ & \multicolumn{3}{|c|}{ Produção Unitária ( $\left.\mathrm{m}^{3} / \mathrm{Hserv}\right)$} & \multicolumn{3}{|c|}{ Hfuncionamento } \\
\hline Discriminação & 1ㅇQ Quartil & Mediana & 3 Quartil & 1ㅇQuartil & Mediana & 3 Quartil \\
\hline $\begin{array}{l}\text { Vibroacabadora de asfalto - } \\
\text { sobre esteiras }\end{array}$ & 31,2 & 41,6 & 67,2 & $44 \%$ & $64 \%$ & $88 \%$ \\
\hline $\begin{array}{l}\text { Rolo compactador de pneus } \\
\text { autopropelido (21t) }\end{array}$ & 27,7 & 34,4 & 51,0 & $27 \%$ & $40 \%$ & $84 \%$ \\
\hline $\begin{array}{l}\text { Rolo compactador tipo tandem } \\
(10,9 t)\end{array}$ & 28,8 & 48,0 & 68,2 & $56 \%$ & $80 \%$ & $90 \%$ \\
\hline Trator agrícola & 728,2 & 728,2 & 728,2 & $97 \%$ & $97 \%$ & $97 \%$ \\
\hline Vassoura mecânica rebocável & 728,2 & 728,2 & 728,2 & $97 \%$ & $97 \%$ & $97 \%$ \\
\hline Servente & 5,8 & 23,2 & 37,2 & & & \\
\hline $\begin{array}{l}\text { Concreto Betuminoso Usinado } \\
\text { a Quente - binder }\left(\mathrm{m}^{3}\right)\end{array}$ & \multicolumn{3}{|c|}{ Produção Unitária (m³/Hserv) } & \multicolumn{3}{|c|}{ Hfuncionamento } \\
\hline Discriminação & 1ㅇ Quartil & Mediana & 3 Quartil & 1ㅇ Quartil & Mediana & 3 Quartil \\
\hline $\begin{array}{l}\text { Vibroacabadora de asfalto - } \\
\text { sobre esteiras }\end{array}$ & 33,3 & 61,4 & 121,1 & $72 \%$ & $93 \%$ & $95 \%$ \\
\hline $\begin{array}{l}\text { Rolo compactador de pneus } \\
\text { autopropelido (21t) }\end{array}$ & 30,9 & 32,7 & 101,0 & $64 \%$ & $97 \%$ & $98 \%$ \\
\hline $\begin{array}{l}\text { Rolo compactador tipo tandem } \\
(10,9 t)\end{array}$ & 33,3 & 55,1 & 135,0 & $80 \%$ & $90 \%$ & $94 \%$ \\
\hline Trator agrícola & 728,2 & 728,2 & 728,2 & $97 \%$ & $97 \%$ & $97 \%$ \\
\hline Vassoura mecânica rebocável & 728,2 & 728,2 & 728,2 & $97 \%$ & $97 \%$ & $97 \%$ \\
\hline Servente & 6,8 & 11,3 & 17,4 & & & \\
\hline
\end{tabular}




\section{APÊNDICE G - PROCESSAMENTO DOS INDICADORES INDICADOS PELOS ESPECIALISTAS}

A seguir, são apresentados os resumos dos processamentos dos indicadores indicados pelos especialistas. Este processamento se deu conforme apresentado no Capítulo 8 ou seja:

a) os especialistas, uma vez que Ihes foi dado conhecimento dos valores reunidos por este pesquisador (advindos do levantamento nos manuais e dos estudos de campo, indicaram os valores medianos e os quartis (em outras palavras, a faixa de valores que adotariam) para representar a situação mediana e as situações boas ou ruins em termos dos fatores considerados importantes. Os especialistas se posicionaram frente a duas classes de faixas: a das produções unitárias; e a das horas em funcionamento;

b) no caso dos fatores e das anormalidades, a lista apresentada foi criticada pelos especialistas, que indicaram os fatores mais importantes e os menos. A crítica foi registrada da seguinte forma:

- eles deram nota para cada fator (e para eventual adicional que acrescentassem); tais notas variaram de 0 a 10, mas um fator importante recebeu pelo menos 5 .

c) o pesquisador tirou a mediana das notas para cada fator ou anormalidade, conforme as notas dadas por todos os especialistas questionados. As notas medianas abaixo de 5 tiveram seus fatores eliminados. Para os acima de 5, faixas foram criadas e os quartis calculados; os fatores com nota maior que o $3^{\circ}$ quartil foram chamados "mais importantes"; os abaixo do $1^{\circ}$ quartil de "menos importantes"; os entre quartis de "importantes".

Apresentam-se aqui os resultados do processamento das informações obtidas dos

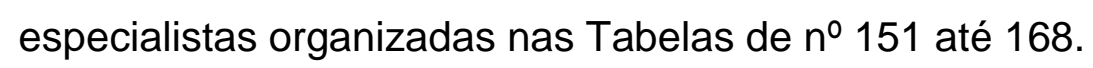


Tabela 151 - Escavação e carga de material de $1^{\text {a }}$ categoria com trator de esteiras (especialistas)

a) Etapa: escavação do solo (o trator de esteiras escava o solo e o amontoa)

\begin{tabular}{|c|c|c|c|c|c|c|}
\hline \multirow{2}{*}{$\begin{array}{l}\text { Trator de esteiras, com } \\
\text { lâmina } \\
\text { Especialistas }\end{array}$} & \multicolumn{3}{|c|}{ Produção Unitária (m³/Hserv) } & \multicolumn{3}{|c|}{ Hfuncionamento } \\
\hline & 10 Quartil & Mediana & 3 Quartil & 1Q Quartil & Mediana & 3 Quartil \\
\hline $\mathrm{A}$ & & & & $91 \%$ & $95 \%$ & $99 \%$ \\
\hline \multicolumn{7}{|l|}{$\mathrm{B}$} \\
\hline $\mathrm{C}$ & 120 & 150 & 180 & $85 \%$ & $90 \%$ & $95 \%$ \\
\hline $\mathrm{D}$ & 116 & 116 & 139 & $94 \%$ & $96 \%$ & $96 \%$ \\
\hline$E$ & 180 & 200 & 220 & $80 \%$ & $90 \%$ & $100 \%$ \\
\hline \multicolumn{7}{|l|}{$F$} \\
\hline $\mathrm{G}$ & 160 & 180 & 200 & $85 \%$ & $90 \%$ & $95 \%$ \\
\hline Mediana & 140 & 165 & 190 & $85 \%$ & $90 \%$ & $96 \%$ \\
\hline
\end{tabular}

b) Etapa: carregamento do caminhão (a carregadeira de pneus coloca o solo nos caminhões)

\begin{tabular}{c|c|c|c|c|c|c}
\hline $\begin{array}{l}\text { Carregadeira de pneus - } \\
\text { cap. 3,1 m }\end{array}$ & \multicolumn{2}{|c|}{} & \multicolumn{4}{c}{ Hfuncionamento } \\
\hline A & \multicolumn{2}{|c|}{ Produção Unitária $\left(\mathrm{m}^{3} /\right.$ Hserv) } & \multicolumn{3}{c}{9} \\
\hline B & & & & $91 \%$ & $95 \%$ & $99 \%$ \\
\hline C & & & & & & $95 \%$ \\
\hline D & 70 & 90 & 110 & $85 \%$ & $90 \%$ & $95 \%$ \\
\hline E & 116 & 139 & 152 & $96 \%$ & $96 \%$ & $97 \%$ \\
\hline F & 180 & 200 & 220 & $80 \%$ & $90 \%$ & $100 \%$ \\
\hline G & & & & & & 9 \\
\hline Mediana & 160 & 180 & 200 & $70 \%$ & $80 \%$ & $90 \%$ \\
\hline
\end{tabular}

Tabela 152 - Escavação e carga de material de $1^{\underline{a}}$ categoria com escavadeira hidráulica (especialistas)

\begin{tabular}{c|c|c|c|c|c|c}
\hline a) Etapa: escavação do solo e carregamento do caminhão \\
\hline Escavadeira hidráulica & \multicolumn{2}{|c|}{ Produção Unitária ( $^{3} /$ Hserv) } & \multicolumn{3}{c}{ Hfuncionamento } \\
\hline Discriminação & $1^{\circ}$ Quartil & Mediana & $3 \%$ Quartil & 10 Quartil & Mediana & 30 Quartil \\
\hline A & & & & $85 \%$ & $95 \%$ & $99 \%$ \\
\hline B & & & & & & \\
\hline C & 110 & 130 & 150 & $85 \%$ & $90 \%$ & $95 \%$ \\
\hline D & 65 & 80 & 100 & $71 \%$ & $75 \%$ & $85 \%$ \\
\hline E & 130 & 150 & 170 & $80 \%$ & $90 \%$ & $100 \%$ \\
\hline F & & & & & & \\
\hline Mediana & 130 & 150 & 170 & $75 \%$ & $85 \%$ & $95 \%$ \\
\hline
\end{tabular}


Tabela 153 - Compactação de aterro - esp. até $30 \mathrm{~cm}$ (especialistas)

a) Etapa: espalhamento do solo (após a descarga pelos caminhões o trator de esteiras espalha 0 solo)

Trator de esteiras, com

lâmina

Produção Unitária ( $\mathrm{m}^{2} /$ Hserv)

Hfuncionamento

\begin{tabular}{c|c|c|c|c|c|c}
\hline Discriminação & 1 Quartil & Mediana & 3 Quartil & 1 Quartil & Mediana & 3 Quartil \\
\hline A & & & & $50 \%$ & $75 \%$ & $85 \%$ \\
\hline B & & & & & & \\
\hline C & 400 & 800 & 1200 & $60 \%$ & $70 \%$ & $80 \%$ \\
\hline D & & $1300^{*}$ & & & $70 \%$ & \\
\hline E & 250 & 300 & 350 & $30 \%$ & $50 \%$ & $80 \%$ \\
\hline F & & & & & & \\
\hline Mediana & 200 & 250 & 300 & $50 \%$ & $65 \%$ & $80 \%$ \\
\hline
\end{tabular}

b) Etapa: nivelamento da camada (a motoniveladora nivela a camada de solo)

\begin{tabular}{c|c|c|c|c|c|c}
\hline Motoniveladora & \multicolumn{2}{|c|}{ Produção Unitária $\left(\mathrm{m}^{2} / \mathrm{Hserv}\right)$} & \multicolumn{3}{c}{ Hfuncionamento } \\
\hline Discriminação & $1{ }^{\circ}$ Quartil & Mediana & $3^{\circ}$ Quartil & $1^{\circ}$ Quartil & Mediana & $3^{\circ}$ Quartil \\
\hline A & & & & $50 \%$ & $60 \%$ & $70 \%$ \\
\hline B & & & & & & \\
\hline C & 180 & 280 & 380 & $80 \%$ & $90 \%$ & $95 \%$ \\
\hline D & & 1500 & & & $80 \%$ & \\
\hline E & 1000 & 1200 & 1400 & $85 \%$ & $90 \%$ & $95 \%$ \\
\hline G & & & & & & \\
\hline Mediana & 1000 & 1200 & 1400 & $80 \%$ & $85 \%$ & $90 \%$ \\
\hline
\end{tabular}

c) Etapa: aeração e/ou homogeneização da camada (se precisar o trator com grade faz a aeração ou a homogeneização do solo)

Trator agrícola com grade de disco

Produção Unitária ( $\mathrm{m}^{2} /$ Hserv)

Hfuncionamento

\begin{tabular}{c|c|c|c|c|c|c}
\hline Discriminação & 1 Quartil & Mediana & 3\% Quartil & 1\% Quartil & Mediana & 3\% Quartil \\
\hline A & & & & $55 \%$ & $60 \%$ & $65 \%$ \\
\hline B & & & & & & \\
\hline C & 180 & 280 & 380 & $75 \%$ & $85 \%$ & $95 \%$ \\
\hline E & 1300 & 1500 & 1800 & $46 \%$ & $50 \%$ & $60 \%$ \\
\hline F & 1000 & 1200 & 1400 & $80 \%$ & $90 \%$ & $100 \%$ \\
\hline G & & & & & & \\
\hline Mediana & 1000 & 1200 & 1400 & $80 \%$ & $85 \%$ & $90 \%$ \\
\hline
\end{tabular}

d) Etapa: umidificação da camada (se precisar o caminhão tanque umedece o solo)

\begin{tabular}{c|c|c|c|c|c|c}
\hline Caminhão tanque & \multicolumn{2}{|c|}{ Produção Unitária $\left(\mathrm{m}^{2} / \mathrm{Hserv}\right)$} & \multicolumn{3}{c}{ Hfuncionamento } \\
\hline Discriminação & $1^{\circ}$ Quartil & Mediana & $3^{\circ}$ Quartil & $1^{\circ}$ Quartil & Mediana & $3^{\circ}$ Quartil \\
\hline A & & & & $30 \%$ & $40 \%$ & $50 \%$ \\
\hline B & & & & & & \\
\hline C & 360 & 560 & 760 & $60 \%$ & $70 \%$ & $80 \%$ \\
\hline D & 1150 & 1445 & 1600 & $36 \%$ & $45 \%$ & $49 \%$ \\
\hline F & 1200 & 1500 & 1800 & $80 \%$ & $90 \%$ & $100 \%$ \\
\hline G & & & & & & \\
\hline Mediana & 1000 & 1200 & 1400 & $80 \%$ & $85 \%$ & $90 \%$ \\
\hline
\end{tabular}

* Em função da grande divergência entre os demais pesquisadores, este dado foi desconsiderado pelo pesquisador 
e) Etapa: compactação da camada

\section{Rolo compactador pé de} carneiro

\begin{tabular}{c|c|c|c|c|c|c}
\hline Discriminação & 1\% Quartil & Mediana & 30 Quartil & 10 Quartil & Mediana & 30 Quartil \\
\hline A & & & & $80 \%$ & $85 \%$ & $90 \%$ \\
\hline B & & & & & & \\
\hline C & 90 & 140 & 190 & $30 \%$ & $40 \%$ & $50 \%$ \\
\hline D & 1000 & 1300 & 2000 & $31 \%$ & $40 \%$ & $60 \%$ \\
\hline E & 400 & 500 & 600 & $60 \%$ & $80 \%$ & $100 \%$ \\
\hline F & & & & & & \\
\hline G & 200 & 400 & 600 & $80 \%$ & $85 \%$ & $90 \%$ \\
\hline Mediana & $\mathbf{3 0 0}$ & $\mathbf{4 5 0}$ & $\mathbf{6 0 0}$ & $\mathbf{7 0 \%}$ & $\mathbf{8 3 \%}$ & $\mathbf{9 0 \%}$ \\
\hline
\end{tabular}

Tabela 154 - Base de solo cimento com mistura na pista - esp. até $20 \mathrm{~cm}$ (especialistas)

a) Etapa: espalhamento do solo (após a descarga pelos caminhões o trator de esteiras espalha o solo)

\begin{tabular}{|c|c|c|c|c|c|c|}
\hline \multirow{2}{*}{$\begin{array}{l}\text { Trator de esteiras, com } \\
\text { lâmina } \\
\text { Discriminação } \\
\end{array}$} & \multicolumn{3}{|c|}{ Produção Unitária (m²/Hserv) } & \multicolumn{3}{|c|}{ Hfuncionamento } \\
\hline & 1ㅇ Quartil & Mediana & 3 Quartil & 10 Quartil & Mediana & 3 Quartil \\
\hline A & & & & $20 \%$ & $30 \%$ & $40 \%$ \\
\hline \multicolumn{7}{|l|}{$B$} \\
\hline \multicolumn{7}{|l|}{ C } \\
\hline $\mathrm{D}$ & 430 & 750 & 865 & $15 \%$ & $26 \%$ & $30 \%$ \\
\hline$E$ & 150 & 250 & 350 & $30 \%$ & $50 \%$ & $80 \%$ \\
\hline \multicolumn{7}{|l|}{$\mathrm{F}$} \\
\hline$G$ & 200 & 250 & 300 & $50 \%$ & $65 \%$ & $80 \%$ \\
\hline Mediana & 200 & 250 & 350 & $25 \%$ & $40 \%$ & $60 \%$ \\
\hline
\end{tabular}

b) Etapa: nivelamento da camada (a motoniveladora nivela a camada de solo)

\begin{tabular}{c|c|c|c|c|c|c}
\hline Motoniveladora & \multicolumn{2}{|c|}{ Produção Unitária $\left(\mathrm{m}^{2} /\right.$ Hserv) } & \multicolumn{3}{|c}{ Hfuncionamento } \\
\hline Discriminação & 1 Quartil & Mediana & 30 Quartil & 1\% Quartil & Mediana & 30 Quartil \\
\hline A & & & & $25 \%$ & $35 \%$ & $45 \%$ \\
\hline B & & & & & & \\
\hline C & 180 & 280 & 380 & $85 \%$ & $90 \%$ & $95 \%$ \\
\hline D & 380 & 550 & 600 & $45 \%$ & $65 \%$ & $70 \%$ \\
\hline E & & & & $85 \%$ & $90 \%$ & $95 \%$ \\
\hline F & & & & & & \\
\hline G & 350 & 450 & 550 & $50 \%$ & $70 \%$ & $90 \%$ \\
\hline Mediana & $\mathbf{3 5 0}$ & $\mathbf{4 5 0}$ & $\mathbf{5 5 0}$ & $\mathbf{4 8 \%}$ & $\mathbf{6 8 \%}$ & $\mathbf{8 0 \%}$ \\
\hline
\end{tabular}

c) Etapa: distribuição do cimento na camada (obs.: este serviço pode ser feito manualmente e neste caso, deve ser prevista a "abertura de sacaria de cimento")

\begin{tabular}{l|l|l}
\hline Distribuidor de cimento & Produção Unitária $\left(\mathrm{m}^{2} / \mathrm{Hserv}\right)$ & Hfuncionamento \\
\hline
\end{tabular}

\begin{tabular}{c|c|c|c|c|c|c}
\hline Discriminação & 10 Quartil & Mediana & 3 Quartil & 1ㅇ Quartil & Mediana & 3 Quartil \\
\hline A & & & & $20 \%$ & $25 \%$ & $30 \%$ \\
\hline B & & & & & & \\
\hline C & 240 & 480 & 640 & $50 \%$ & $75 \%$ & $95 \%$ \\
\hline E & 330 & 588 & 700 & $12 \%$ & $21 \%$ & $25 \%$ \\
\hline F & & & & $5 \%$ & $10 \%$ & $20 \%$ \\
\hline G & & & & & & \\
\hline Mediana & $\mathbf{3 3 0}$ & 600 & 800 & $15 \%$ & $20 \%$ & $25 \%$ \\
\hline
\end{tabular}


d) Etapa: aeração e/ou homogeneização da camada (se precisar o trator com grade faz a aeração ou a homogeneização do solo)

\begin{tabular}{c|c|c|c|c|c|c}
\hline $\begin{array}{l}\text { Trator agrícola com grade } \\
\text { de disco }\end{array}$ & \multicolumn{2}{|c|}{ Produção Unitária (m²/Hserv) } & \multicolumn{3}{c}{ Hfuncionamento } \\
\hline Discriminação & $1{ }^{\circ}$ Quartil & Mediana & $3 \%$ Quartil & $1 \%$ Quartil & Mediana & $3 \%$ Quartil \\
\hline A & & & & $75 \%$ & $85 \%$ & $95 \%$ \\
\hline B & & & & & & \\
\hline C & & & & & & \\
\hline D & 650 & 700 & 750 & $76 \%$ & $80 \%$ & $86 \%$ \\
\hline E & & & & $80 \%$ & $90 \%$ & $100 \%$ \\
\hline F & & & & & & \\
\hline G & 400 & 600 & 800 & $15 \%$ & $20 \%$ & $25 \%$ \\
\hline Mediana & 525 & 650 & 775 & $76 \%$ & $83 \%$ & $91 \%$ \\
\hline
\end{tabular}

e) Etapa: mistura do cimento na camada (a recicladora automaticamente mistura o cimento com o solo)

\begin{tabular}{|c|c|c|c|c|c|c|}
\hline Recicladora & Produçã & Unitária ( & ${ }^{2} /$ Hserv) & & ncioname & \\
\hline Discriminação & 10 Quartil & Mediana & 3 Quartil & 10 Quartil & Mediana & 3 Quartil \\
\hline$A$ & & & & $15 \%$ & $20 \%$ & $25 \%$ \\
\hline$B$ & & & & & & \\
\hline $\mathrm{C}$ & 240 & 480 & 640 & $40 \%$ & $60 \%$ & $80 \%$ \\
\hline $\mathrm{D}$ & 330 & 588 & 700 & $12 \%$ & $21 \%$ & $25 \%$ \\
\hline$E$ & & & & $85 \%$ & $90 \%$ & $95 \%$ \\
\hline $\mathrm{F}$ & & & & & & \\
\hline $\mathrm{G}$ & 400 & 600 & 800 & $15 \%$ & $20 \%$ & $25 \%$ \\
\hline Mediana & 330 & 588 & 700 & $15 \%$ & $21 \%$ & $25 \%$ \\
\hline
\end{tabular}

f) Etapa: umidificação da camada (se precisar o caminhão tanque umedece o solo)

\begin{tabular}{l|l|l}
\hline Caminhão tanque & Produção Unitária $\left(\mathrm{m}^{2} / \mathrm{Hserv}\right)$ & Hfuncionamento \\
\hline
\end{tabular}

\begin{tabular}{c|c|c|c|c|c|c}
\hline Discriminação & 1\% Quartil & Mediana & 3\% Quartil & 1\% Quartil & Mediana & 3\% Quartil \\
\hline A & & & & $10 \%$ & $15 \%$ & $20 \%$ \\
\hline B & & & & & & \\
\hline C & 120 & 240 & 320 & $40 \%$ & $60 \%$ & $80 \%$ \\
\hline D & 435 & 655 & 800 & $18 \%$ & $27 \%$ & $33 \%$ \\
\hline E & & & & $80 \%$ & $90 \%$ & $100 \%$ \\
\hline G & & & & & & \\
\hline Mediana & 400 & 600 & 800 & $15 \%$ & $20 \%$ & $30 \%$ \\
\hline
\end{tabular}

g) Etapa: compactação da camada

\begin{tabular}{c|c|c|c|c|c|c}
\hline $\begin{array}{l}\text { Rolo compactador pé de } \\
\text { carneiro }\end{array}$ & \multicolumn{2}{|c|}{ Produção Unitária (m²/Hserv) } & \multicolumn{4}{c}{ Hfuncionamento } \\
\hline Discriminação & $1 \%$ Quartil & Mediana & 30 Quartil & $1 \%$ Quartil & Mediana & $3 \%$ Quartil \\
\hline A & & & & $35 \%$ & $40 \%$ & $45 \%$ \\
\hline B & & & & & & \\
\hline C & 60 & 120 & 160 & $40 \%$ & $60 \%$ & $80 \%$ \\
\hline D & 470 & 555 & 605 & $54 \%$ & $64 \%$ & $70 \%$ \\
\hline E & & & & $60 \%$ & $80 \%$ & $100 \%$ \\
\hline F & & & & & & \\
\hline Mediana & 400 & 600 & 800 & $50 \%$ & $65 \%$ & $80 \%$ \\
\hline & 400 & 555 & 605 & $52 \%$ & $65 \%$ & $75 \%$ \\
\hline
\end{tabular}


h) Etapa: acabamento da camada (após a compactação o rolo compactador de pneus , protege a camada, ou seja, sela a camada)

\begin{tabular}{|c|c|c|c|c|c|c|}
\hline \multirow{2}{*}{$\begin{array}{l}\begin{array}{l}\text { Rolo compactador de } \\
\text { pneus }\end{array} \\
\text { Discriminação }\end{array}$} & \multicolumn{3}{|c|}{ Produção Unitária ( $\left.\mathrm{m}^{2} / \mathrm{Hserv}\right)$} & \multicolumn{3}{|c|}{ Hfuncionamento } \\
\hline & 10 Quartil & Mediana & 3ㅇ Quartil & 10 Quartil & Mediana & 3 Quartil \\
\hline$A$ & & & & $10 \%$ & $15 \%$ & $20 \%$ \\
\hline$B$ & & & & & & \\
\hline C & 60 & 120 & 160 & $5 \%$ & $10 \%$ & $20 \%$ \\
\hline D & 675 & 856 & 907 & $55 \%$ & $66 \%$ & $70 \%$ \\
\hline$E$ & & & & $20 \%$ & $50 \%$ & $70 \%$ \\
\hline $\mathrm{F}$ & & & & & & \\
\hline G & 400 & 600 & 800 & $10 \%$ & $15 \%$ & $20 \%$ \\
\hline Mediana & 400 & 600 & 800 & $15 \%$ & $33 \%$ & $45 \%$ \\
\hline
\end{tabular}

Tabela 155 - Brita graduada simples - BGS com distribuidor de agregados - esp. até $20 \mathrm{~cm}$ (especialistas)

\begin{tabular}{|c|c|c|c|c|c|c|}
\hline \multicolumn{7}{|c|}{$\begin{array}{l}\text { a) Etapa: espalhamento da BGS (os caminhões abastecem o distribuidor de agregados com BGS } \\
\text { e este espalha o material) }\end{array}$} \\
\hline $\begin{array}{l}\text { Distribuidor de Agregados } \\
\text { - Autopropelido }\end{array}$ & \multicolumn{3}{|c|}{ Produção Unitária (m²/Hserv) } & \multicolumn{3}{|c|}{ Hfuncionamento } \\
\hline Discriminação & 1Q Quartil & Mediana & 3 Quartil & 1 Quartil & Mediana & 3 Quartil \\
\hline$A$ & & & & $55 \%$ & $65 \%$ & $75 \%$ \\
\hline$B$ & & & & & & \\
\hline $\mathrm{C}$ & 500 & 600 & 800 & $85 \%$ & $90 \%$ & $95 \%$ \\
\hline $\mathrm{D}$ & & & & & & \\
\hline$E$ & 200 & 400 & 600 & $70 \%$ & $80 \%$ & $90 \%$ \\
\hline $\mathrm{F}$ & & & & & & \\
\hline$G$ & 300 & 400 & 500 & $70 \%$ & $80 \%$ & $90 \%$ \\
\hline Mediana & 300 & 400 & 600 & $70 \%$ & $80 \%$ & $90 \%$ \\
\hline
\end{tabular}

b) Etapa: nivelamento da camada (a motoniveladora nivela a camada de BGS)

\begin{tabular}{c|c|c|c|c|c|c}
\hline Motoniveladora & \multicolumn{3}{|c|}{ Produção Unitária ( $\mathrm{m}^{2} /$ Hserv) } & \multicolumn{3}{c}{ Hfuncionamento } \\
\hline Discriminação & 10 Quartil & Mediana & 3 3 Quartil & 10 Quartil & Mediana & $3^{\circ}$ Quartil \\
\hline A & & & & $55 \%$ & $65 \%$ & $75 \%$ \\
\hline B & & & & & & \\
\hline C & 180 & 280 & 380 & $80 \%$ & $90 \%$ & $95 \%$ \\
\hline E & & & & & & \\
\hline F & 200 & 300 & 400 & $70 \%$ & $80 \%$ & $90 \%$ \\
\hline G & & & & & & \\
\hline Mediana & $\mathbf{2 0 0}$ & 400 & 500 & $55 \%$ & $65 \%$ & $75 \%$ \\
\hline
\end{tabular}

c) Etapa: umidificação da camada (se precisar o caminhão tanque umedece a camada)

\begin{tabular}{l|l|l}
\hline Caminhão tanque & Produção Unitária $\left(\mathrm{m}^{2} / \mathrm{Hserv}\right)$ & Hfuncionamento \\
\hline
\end{tabular}

\begin{tabular}{|c|c|c|c|c|c|c|}
\hline Discriminação & 1ㅇ Quartil & Mediana & 3 Quartil & 1ㅇ Quartil & Mediana & 3 Quartil \\
\hline A & & & & $30 \%$ & $40 \%$ & $50 \%$ \\
\hline \multicolumn{7}{|l|}{ B } \\
\hline C & 360 & 560 & 760 & $80 \%$ & $90 \%$ & $95 \%$ \\
\hline \multicolumn{7}{|l|}{$\mathrm{D}$} \\
\hline $\mathrm{E}$ & 1200 & 1500 & 1700 & $30 \%$ & $50 \%$ & $70 \%$ \\
\hline \multicolumn{7}{|l|}{$\mathrm{F}$} \\
\hline$G$ & 600 & 800 & 1000 & $40 \%$ & $50 \%$ & $60 \%$ \\
\hline Mediana & 600 & 800 & 1000 & $35 \%$ & $50 \%$ & $65 \%$ \\
\hline
\end{tabular}


d) Etapa: Compactação da camada

d1) Pré-compactação e acabamento (o rolo compactador tipo tandem inicia a compactação fazendo a acomodação inicial do material. Após a compactação propriamente dita, pelo compactador de pneus, o tandem retorna e dá o acabamento da camada).

Rolo compactador tipo tandem

Produção Unitária ( $\mathrm{m}^{2} /$ Hserv)

Hfuncionamento

\begin{tabular}{c|c|c|c|c|c|c}
\hline Discriminação & 1 Quartil & Mediana & 3 Quartil & 1 Quartil & Mediana & 3 Quartil \\
\hline A & & & & $80 \%$ & $85 \%$ & $95 \%$ \\
\hline B & & & & & & \\
\hline C & 360 & 560 & 760 & $80 \%$ & $90 \%$ & $95 \%$ \\
\hline E & 400 & 500 & 550 & $40 \%$ & $50 \%$ & $55 \%$ \\
\hline F & 500 & 800 & 1000 & $80 \%$ & $90 \%$ & $100 \%$ \\
\hline G & & & & & & \\
\hline Mediana & 300 & 400 & 500 & $40 \%$ & $45 \%$ & $50 \%$ \\
\hline
\end{tabular}

d2) Compactação da camada (após a pré-compactação, executada pelo compactador tipo tandem, o rolo compactador de pneus faz a compactação propriamente dita)

\section{Rolo compactador de} pneus

\begin{tabular}{c|c|c|c|c|c|c}
\hline Discriminação & $1^{\circ}$ Quartil & Mediana & 3\% Quartil & 1 Quartil & Mediana & 3\% Quartil \\
\hline A & & & & $80 \%$ & $85 \%$ & $95 \%$ \\
\hline B & & & & & & \\
\hline C & 360 & 560 & 760 & $80 \%$ & $90 \%$ & $95 \%$ \\
\hline D & 380 & 480 & 530 & $40 \%$ & $50 \%$ & $55 \%$ \\
\hline F & 800 & 1000 & 1200 & $80 \%$ & $90 \%$ & $100 \%$ \\
\hline G & & & & & & \\
\hline Mediana & 300 & 400 & 500 & $80 \%$ & $85 \%$ & $90 \%$ \\
\hline
\end{tabular}

e) Etapa: apoio

\begin{tabular}{c|c|c|c|}
\hline Servente & \multicolumn{3}{|c|}{ Produção Unitária $\left(\mathrm{m}^{2} /\right.$ Hserv $)$} \\
\hline Discriminação & 1 Quartil & Mediana & 3 Quartil \\
\hline A & & & \\
\hline B & & & \\
\hline C & 45 & 70 & 90 \\
\hline D & 40 & 50 & 73 \\
\hline E & 200 & 400 & 600 \\
\hline F & & & \\
\hline G & 300 & 400 & 500 \\
\hline Mediana & $\mathbf{1 2 2 , 5}$ & $\mathbf{2 3 5}$ & $\mathbf{2 9 5}$
\end{tabular}


Tabela 156 - Brita graduada simples - BGS com vibroacabadora - esp. até $20 \mathrm{~cm}$ (especialistas)

a) Etapa: espalhamento e nivelamento da BGS (os caminhões abastecem a vibroacabadora com BGS e esta espalha o material e nivela a camada)

Vibroacabadora de Asfalto Produção Unitária (m2/Hserv)

Hfuncionamento

\begin{tabular}{c|c|c|c|c|c|c}
\hline Discriminação & 10 Quartil & Mediana & 3o Quartil & 10 Quartil & Mediana & 3o Quartil \\
\hline A & & & & $40 \%$ & $55 \%$ & $75 \%$ \\
\hline B & & & & & & \\
\hline C & 120 & 160 & 200 & $70 \%$ & $80 \%$ & $90 \%$ \\
\hline D & & & & & & \\
\hline E & 50 & 70 & 90 & $80 \%$ & $90 \%$ & $100 \%$ \\
\hline F & & & & & & \\
\hline Mediana & 200 & 250 & 300 & $70 \%$ & $75 \%$ & $80 \%$ \\
\hline
\end{tabular}

b) Etapa: compactação da camada

b1) Pré-compactação e acabamento (o rolo compactador tipo tandem inicia a compactação fazendo a acomodação inicial do material. Após a compactação propriamente dita, pelo compactador de pneus, o tandem retorna e dá o acabamento da camada)

Rolo compactador tipo tandem Discriminação A B C

D E $\mathrm{F}$ G

Produção Unitária (m2/Hserv) 1Q Quartil Mediana 3 Quartil
Hfuncionamento

\begin{tabular}{|c|c|c|}
\hline 10 Quartil & Mediana & 3o Quartil \\
\hline $40 \%$ & $55 \%$ & $75 \%$ \\
\hline $35 \%$ & $40 \%$ & $45 \%$ \\
\hline $60 \%$ & $70 \%$ & $80 \%$ \\
\hline $35 \%$ & $40 \%$ & $45 \%$ \\
\hline $38 \%$ & $48 \%$ & $60 \%$ \\
\hline
\end{tabular}

250300

b2) Compactação da camada (após a pré-compactação, executada pelo compactador tipo tandem, o rolo compactador de pneus faz a compactação propriamente dita)

\begin{tabular}{|c|c|c|c|c|c|c|}
\hline \multirow{2}{*}{$\begin{array}{l}\text { Rolo compactador de } \\
\text { pneus } \\
\text { Discriminação }\end{array}$} & \multicolumn{3}{|c|}{ Produção Unitária (m2/Hserv) } & \multicolumn{3}{|c|}{ Hfuncionamento } \\
\hline & 1ㅇ Quartil & Mediana & 3 Quartil & $1^{\circ}$ Quartil & Mediana & 3ㅇQ Quartil \\
\hline A & & & & $40 \%$ & $55 \%$ & $75 \%$ \\
\hline \multicolumn{7}{|l|}{$B$} \\
\hline C & 60 & 80 & 100 & $20 \%$ & $20 \%$ & $25 \%$ \\
\hline \multicolumn{7}{|l|}{$\mathrm{D}$} \\
\hline$E$ & 800 & 1000 & 1200 & $70 \%$ & $80 \%$ & $90 \%$ \\
\hline \multicolumn{7}{|l|}{$\mathrm{F}$} \\
\hline$G$ & 200 & 250 & 300 & $70 \%$ & $80 \%$ & $90 \%$ \\
\hline Mediana & 200 & 250 & 300 & $55 \%$ & $68 \%$ & $83 \%$ \\
\hline
\end{tabular}

c) Etapa: umidificação da camada (se precisar o caminhão tanque umedece a camada)

\begin{tabular}{c|c|c|c|c|c|c}
\hline Caminhão tanque & \multicolumn{2}{|c|}{ Produção Unitária (m2/Hserv) } & \multicolumn{3}{c}{ Hfuncionamento } \\
\hline Discriminação & 10 Quartil & Mediana & $3^{\circ}$ Quartil & 1 10 Quartil & Mediana & $3^{\circ}$ Quartil \\
\hline A & & & & $10 \%$ & $20 \%$ & $30 \%$ \\
\hline B & & & & & & \\
\hline C & 240 & 320 & 400 & $10 \%$ & $20 \%$ & $30 \%$ \\
\hline D & & & & & & \\
\hline E & 1200 & 1500 & 1700 & $10 \%$ & $20 \%$ & $30 \%$ \\
\hline F & & & & & & \\
\hline G & 1000 & 1300 & 1500 & $10 \%$ & $20 \%$ & $30 \%$ \\
\hline Mediana & $\mathbf{1 0 0 0}$ & $\mathbf{1 3 0 0}$ & $\mathbf{1 5 0 0}$ & $\mathbf{1 0 \%}$ & $\mathbf{2 0 \%}$ & $\mathbf{3 0 \%}$ \\
\hline
\end{tabular}




\begin{tabular}{|c|c|c|c|}
\hline \multicolumn{4}{|l|}{ d) Etapa: apoio } \\
\hline \multirow{2}{*}{$\begin{array}{l}\text { Servente } \\
\text { Discriminação }\end{array}$} & \multicolumn{3}{|c|}{ Produção Unitária (m2/Hserv) } \\
\hline & 10 Quartil & Mediana & 3 Quartil \\
\hline \multicolumn{4}{|l|}{ A } \\
\hline \multicolumn{4}{|l|}{$B$} \\
\hline $\mathrm{C}$ & 45 & 70 & 90 \\
\hline \multicolumn{4}{|l|}{$\mathrm{D}$} \\
\hline $\mathrm{E}$ & 50 & 70 & 90 \\
\hline \multicolumn{4}{|l|}{$\mathrm{F}$} \\
\hline$G$ & 50 & 70 & 90 \\
\hline Mediana & 50 & 70 & 90 \\
\hline
\end{tabular}

Tabela 157 - Brita graduada tratada com cimento - BGTC - esp. até $20 \mathrm{~cm}$ (especialistas)

a) Etapa: espalhamento e nivelamento da BGTC (os caminhões abastecem a vibroacabadora com BGTC e esta espalha o material e nivela a camada)

\begin{tabular}{|c|c|c|c|c|c|c|}
\hline \multirow{2}{*}{$\begin{array}{c}\text { Vibroacabadora de Asfalto } \\
\text { Discriminação }\end{array}$} & \multicolumn{3}{|c|}{ Produção Unitária ( $\left.\mathrm{m}^{2} / \mathrm{Hserv}\right)$} & \multicolumn{3}{|c|}{ Hfuncionamento } \\
\hline & 1ㅇ Quartil & Mediana & 3ํ Quartil & 1ㅇ Quartil & Mediana & 3ㅇ Quartil \\
\hline$A$ & & & & $40 \%$ & $55 \%$ & $75 \%$ \\
\hline $\mathrm{B}$ & & & & & & \\
\hline $\mathrm{C}$ & 120 & 160 & 200 & $70 \%$ & $80 \%$ & $90 \%$ \\
\hline D & & & & & & \\
\hline$E$ & 50 & 70 & 90 & $80 \%$ & $90 \%$ & $100 \%$ \\
\hline $\mathrm{F}$ & & & & & & \\
\hline G & 200 & 250 & 300 & $70 \%$ & $75 \%$ & $80 \%$ \\
\hline Mediana & 120 & 160 & 200 & $70 \%$ & $78 \%$ & $85 \%$ \\
\hline
\end{tabular}

b) Etapa: compactação da camada

b1) Pré-compactação e acabamento (o rolo compactador tipo tandem inicia a compactação fazendo a acomodação inicial do material. Após a compactação propriamente dita, pelo compactador de pneus, o tandem retorna e dá o acabamento da camada)

\begin{tabular}{|c|c|c|c|c|c|c|}
\hline \multirow{2}{*}{$\begin{array}{l}\begin{array}{l}\text { Rolo compactador tipo } \\
\text { tandem }\end{array} \\
\text { Discriminação }\end{array}$} & \multicolumn{3}{|c|}{ Produção Unitária ( $\mathrm{m}^{2} /$ Hserv) } & \multicolumn{3}{|c|}{ Hfuncionamento } \\
\hline & 10 Quartil & Mediana & 3ㅇ Quartil & 1ㅇ Quartil & Mediana & 3 Quartil \\
\hline A & & & & $40 \%$ & $55 \%$ & $75 \%$ \\
\hline \multicolumn{7}{|l|}{$B$} \\
\hline C & 120 & 160 & 200 & $35 \%$ & $40 \%$ & $45 \%$ \\
\hline \multicolumn{7}{|l|}{$\mathrm{D}$} \\
\hline$E$ & 500 & 800 & 1000 & $60 \%$ & $70 \%$ & $80 \%$ \\
\hline \multicolumn{7}{|l|}{$\mathrm{F}$} \\
\hline $\mathrm{G}$ & 200 & 250 & 300 & $35 \%$ & $40 \%$ & $45 \%$ \\
\hline Mediana & 200 & 250 & 300 & $38 \%$ & $48 \%$ & $60 \%$ \\
\hline
\end{tabular}


b2) Compactação da camada (após a pré-compactação, executada pelo compactador tipo tandem, o rolo compactador de pneus faz a compactação propriamente dita)

Rolo compactador de pneus

\begin{tabular}{|c|c|c|c|c|c|c|}
\hline \multirow{2}{*}{$\begin{array}{l}\text { pneus } \\
\text { Discriminação }\end{array}$} & \multicolumn{3}{|c|}{ Produção Unitária ( $\mathrm{m}^{2} / \mathrm{Hserv}$ ) } & \multicolumn{3}{|c|}{ Hfuncionamento } \\
\hline & 10 Quartil & Mediana & 3 Quartil & 1ㅇ Quartil & Mediana & 3 Quartil \\
\hline A & & & & $40 \%$ & $55 \%$ & $75 \%$ \\
\hline$B$ & & & & & & \\
\hline C & 60 & 80 & 100 & $20 \%$ & $20 \%$ & $25 \%$ \\
\hline $\mathrm{D}$ & & & & & & \\
\hline$E$ & 800 & 1000 & 1200 & $70 \%$ & $80 \%$ & $90 \%$ \\
\hline $\mathrm{F}$ & & & & & & \\
\hline$G$ & 200 & 250 & 300 & $70 \%$ & $80 \%$ & $90 \%$ \\
\hline Mediana & 200 & 250 & 300 & $55 \%$ & $68 \%$ & $83 \%$ \\
\hline
\end{tabular}

c) Etapa: umidificação da camada (se precisar o caminhão tanque umedece a camada)

\begin{tabular}{c|c|c|c|c|c|c|}
\hline Caminhão tanque & \multicolumn{2}{|c|}{ Produção Unitária $\left(\mathrm{m}^{2} /\right.$ Hserv) } & \multicolumn{3}{c}{ Hfuncionamento } \\
\hline Discriminação & 1 \% Quartil & Mediana & 3o Quartil & 10 Quartil & Mediana & 3o Quartil \\
\hline A & & & & $10 \%$ & $20 \%$ & $25 \%$ \\
\hline B & & & & & & \\
\hline C & 240 & 320 & 400 & $10 \%$ & $20 \%$ & $30 \%$ \\
\hline D & & & & & & \\
\hline E & 1200 & 1500 & 1700 & $10 \%$ & $20 \%$ & $30 \%$ \\
\hline F & & & & & & \\
\hline G & 1000 & 1300 & 1500 & $10 \%$ & $20 \%$ & $30 \%$ \\
\hline Mediana & $\mathbf{1 0 0 0}$ & $\mathbf{1 3 0 0}$ & $\mathbf{1 5 0 0}$ & $\mathbf{1 0 \%}$ & $\mathbf{2 0} \%$ & $\mathbf{3 0 \%}$ \\
\hline
\end{tabular}

d) Etapa: apoio

Servente

Produção Unitária $\left(\mathrm{m}^{2} / \mathrm{Hserv}\right)$

\begin{tabular}{|c|c|c|c|}
\hline \multirow[b]{2}{*}{ Discriminação } & \\
\hline & 1ㅇ Quartil & Mediana & 3Q Quartil \\
\hline \multicolumn{4}{|l|}{$\mathrm{A}$} \\
\hline \multicolumn{4}{|l|}{$B$} \\
\hline C & 45 & 70 & 90 \\
\hline \multicolumn{4}{|l|}{$\mathrm{D}$} \\
\hline $\mathrm{E}$ & 50 & 70 & 90 \\
\hline \multicolumn{4}{|l|}{$\mathrm{F}$} \\
\hline$G$ & 50 & 70 & 90 \\
\hline Mediana & 50 & 70 & 90 \\
\hline
\end{tabular}

Tabela 158 - Concreto betuminoso usinado a quente - capa ou binder - esp. até $5 \mathrm{~cm}$ (especialistas)

a) Etapa: espalhamento e nivelamento do revestimento asfáltico (os caminhões abastecem a vibroacabadora e esta espalha o material e nivela a camada)

Vibroacabadora de Asfalto Produção Unitária (m2/Hserv)

Hfuncionamento

\begin{tabular}{c|c|c|c|c|c|c}
\hline Discriminação & 1ํ Quartil & Mediana & $3^{\circ}$ Quartil & 1 Quartil & Mediana & 3 Quartil \\
\hline A & & & & $70 \%$ & $95 \%$ & $100 \%$ \\
\hline B & & & & & & \\
\hline C & 400 & 600 & 800 & $70 \%$ & $80 \%$ & $90 \%$ \\
\hline D & 290 & 350 & 380 & $42 \%$ & $50 \%$ & $56 \%$ \\
\hline E & 500 & 700 & 900 & $80 \%$ & $90 \%$ & $100 \%$ \\
\hline G & & & & & & \\
\hline Mediana & 400 & 600 & 800 & $70 \%$ & $75 \%$ & $80 \%$ \\
\hline
\end{tabular}


b) Etapa: Compactação da camada

b1) Pré-compactação e acabamento (o rolo compactador tipo tandem inicia a compactação fazendo a acomodação inicial do material. Após a compactação propriamente dita, pelo compactador de pneus, o tandem retorna e dá o acabamento da camada)

Rolo compactador tipo tandem

Produção Unitária (m2/Hserv)

\begin{tabular}{c|c|c|c|c|c|c}
\hline Discriminação & 1 Quartil & Mediana & 3 Quartil & 1\% Quartil & Mediana & 3 Quartil \\
\hline A & & & & $70 \%$ & $95 \%$ & $100 \%$ \\
\hline B & & & & & & \\
\hline C & 400 & 600 & 800 & $70 \%$ & $80 \%$ & $90 \%$ \\
\hline E & 400 & 700 & 840 & $14 \%$ & $25 \%$ & $29 \%$ \\
\hline F & 500 & 700 & 900 & $80 \%$ & $90 \%$ & $100 \%$ \\
\hline G & & & & & & \\
\hline Mediana & 400 & 600 & 800 & $35 \%$ & $40 \%$ & $45 \%$ \\
\hline
\end{tabular}

b2) Compactação da camada (após a pré-compactação, executada pelo compactador tipo tandem, o rolo compactador de pneus faz a compactação propriamente dita)

\begin{tabular}{|c|c|c|c|c|c|c|}
\hline \multirow{2}{*}{$\begin{array}{l}\begin{array}{l}\text { Rolo compactador de } \\
\text { pneus }\end{array} \\
\text { Discriminação }\end{array}$} & \multicolumn{3}{|c|}{ Produção Unitária (m2/Hserv) } & \multicolumn{3}{|c|}{ Hfuncionamento } \\
\hline & 10 Quartil & Mediana & 3 Quartil & 1Q Quartil & Mediana & 3 Quartil \\
\hline $\mathrm{A}$ & & & & $70 \%$ & $95 \%$ & $100 \%$ \\
\hline \multicolumn{7}{|l|}{$\mathrm{B}$} \\
\hline $\mathrm{C}$ & 200 & 300 & 400 & $70 \%$ & $80 \%$ & $90 \%$ \\
\hline $\mathrm{D}$ & 530 & 640 & 730 & $16 \%$ & $27 \%$ & $31 \%$ \\
\hline$E$ & 400 & 500 & 700 & $75 \%$ & $85 \%$ & $95 \%$ \\
\hline \multicolumn{7}{|l|}{$\mathrm{F}$} \\
\hline $\mathrm{G}$ & 400 & 600 & 800 & $70 \%$ & $80 \%$ & $90 \%$ \\
\hline Mediana & 400 & 550 & 715 & $70 \%$ & $80 \%$ & $90 \%$ \\
\hline \multicolumn{7}{|l|}{ c) Etapa: apoio } \\
\hline \multicolumn{7}{|c|}{$\begin{array}{l}\text { c1) Fornecimento de óleo (um caminhão tanque fica à disposição para fornecer óleo para a frente } \\
\text { de serviço) }\end{array}$} \\
\hline $\begin{array}{l}\text { Caminhão para } \\
\text { abastecimento }\end{array}$ & \multicolumn{3}{|c|}{ Produção Unitária (m2/Hserv) } & \multicolumn{3}{|c|}{ Hfuncionamento } \\
\hline Discriminação & 1ㅇ Quartil & Mediana & 3 Quartil & 1ㅇ Quartil & Mediana & 3으artil \\
\hline $\mathrm{A}$ & & & & $10 \%$ & $15 \%$ & $20 \%$ \\
\hline \multicolumn{7}{|l|}{ B } \\
\hline \multicolumn{7}{|l|}{ C } \\
\hline \multicolumn{7}{|l|}{$\mathrm{D}$} \\
\hline \multicolumn{7}{|l|}{$\mathrm{E}$} \\
\hline \multicolumn{7}{|l|}{$\mathrm{F}$} \\
\hline \multicolumn{7}{|l|}{ G } \\
\hline Mediana & & & & $10 \%$ & $15 \%$ & $20 \%$ \\
\hline
\end{tabular}


c2) Limpeza (antes dos rolos compactadores entrarem na pista a ser pavimentada, eles são lavados ou limpados)

\begin{tabular}{|c|c|c|c|c|c|c|}
\hline $\begin{array}{l}\text { Trator agrícola com } \\
\text { compressor }\end{array}$ & \multicolumn{3}{|c|}{ Produção Unitária (m2/Hserv) } & \multicolumn{3}{|c|}{ Hfuncionamento } \\
\hline Discriminação & 1ㅇ Quartil & Mediana & 3 Quartil & 1ㅇ Quartil & Mediana & 3 Quartil \\
\hline $\mathrm{A}$ & & & & $10 \%$ & $15 \%$ & $20 \%$ \\
\hline $\mathrm{B}$ & & & & & & \\
\hline $\mathrm{C}$ & & & & & & \\
\hline $\mathrm{D}$ & 3000 & 3000 & 3040 & $10 * \%$ & $10 \%$ & $10 \%$ \\
\hline$E$ & & & & & & \\
\hline $\mathrm{F}$ & & & & & & \\
\hline $\mathrm{G}$ & & & & & & \\
\hline Mediana & 3000 & 3000 & 3040 & $10 \%$ & $13 \%$ & $15 \%$ \\
\hline
\end{tabular}

c3) Fornecimento de água para os compactadores lisos (um caminhão tanque fica à disposição para fornecer água para os compactadores lisos)

\begin{tabular}{|c|c|c|c|c|c|c|}
\hline \multirow{2}{*}{$\begin{array}{r}\text { Caminhão tanque } \\
\text { Discriminação }\end{array}$} & \multicolumn{3}{|c|}{ Produção Unitária (m2/Hserv) } & \multicolumn{3}{|c|}{ Hfuncionamento } \\
\hline & 1 Quartil & Mediana & 3 Quartil & 1ㅇ Quartil & Mediana & 3 Quartil \\
\hline A & & & & $10 \%$ & $15 \%$ & $20 \%$ \\
\hline \multicolumn{7}{|l|}{$\mathrm{B}$} \\
\hline \multicolumn{7}{|l|}{ C } \\
\hline \multicolumn{7}{|l|}{$\mathrm{D}$} \\
\hline$E$ & 400 & 500 & 700 & $10 \%$ & $20 \%$ & $30 \%$ \\
\hline \multicolumn{7}{|l|}{$\mathrm{F}$} \\
\hline G & 400 & 500 & 600 & $10 \%$ & $15 \%$ & $20 \%$ \\
\hline Mediana & 400 & 500 & 650 & $10 \%$ & $15 \%$ & $20 \%$ \\
\hline \multicolumn{7}{|l|}{ c4) Apoio } \\
\hline Servente & \multicolumn{3}{|c|}{ Produção Unitária (m²/Hserv) } & & & \\
\hline Discriminação & 1Q Quartil & Mediana & 3Q Quartil & & & \\
\hline \multicolumn{7}{|l|}{ A } \\
\hline \multicolumn{7}{|l|}{$\mathrm{B}$} \\
\hline C & 90 & 140 & 180 & & & \\
\hline $\mathrm{D}$ & 39 & 32 & 65 & & & \\
\hline$E$ & 150 & 210 & 270 & & & \\
\hline \multicolumn{7}{|l|}{$\mathrm{F}$} \\
\hline $\mathrm{G}$ & 100 & 200 & 300 & & & \\
\hline Mediana & 95 & 170 & 225 & & & \\
\hline
\end{tabular}


Tabela 159 - Imprimação (especialistas)

\begin{tabular}{|c|c|c|c|c|c|c|}
\hline \multirow{2}{*}{$\begin{array}{r}\text { Trator agrícola com } \\
\text { vassoura mecânica } \\
\text { Discriminação }\end{array}$} & \multicolumn{3}{|c|}{ Produção Unitária ( $\mathrm{m}^{2} /$ Hserv) } & \multicolumn{3}{|c|}{ Hfuncionamento } \\
\hline & 10 Quartil & Mediana & 3Q Quartil & 10 Quartil & Mediana & 3 Quartil \\
\hline $\mathrm{A}$ & & & & $30 \%$ & $40 \%$ & $50 \%$ \\
\hline \multicolumn{7}{|l|}{$\mathrm{B}$} \\
\hline C & 1800 & 2200 & 2800 & $60 \%$ & $70 \%$ & $80 \%$ \\
\hline $\mathrm{D}$ & 2700 & 3000 & 3500 & $15 \%$ & $20 \%$ & $25 \%$ \\
\hline$E$ & 1400 & 1600 & 1800 & $70 \%$ & $80 \%$ & $90 \%$ \\
\hline \multicolumn{7}{|l|}{$\mathrm{F}$} \\
\hline $\mathrm{G}$ & 1000 & 1200 & 1400 & $15 \%$ & $20 \%$ & $25 \%$ \\
\hline Mediana & 1600 & 1900 & 2300 & $30 \%$ & $40 \%$ & $50 \%$ \\
\hline \multicolumn{7}{|c|}{ b) Etapa: lançamento de cobertura } \\
\hline Caminhão espargidor & \multicolumn{3}{|c|}{ Produção Unitária ( $\mathrm{m}^{2} /$ Hserv) } & \multicolumn{3}{|c|}{ Hfuncionamento } \\
\hline Discriminação & 1ㅇ Quartil & Mediana & 3 Quartil & 10 Quartil & Mediana & 3 Quartil \\
\hline A & & & & $50 \%$ & $60 \%$ & $70 \%$ \\
\hline \multicolumn{7}{|l|}{$B$} \\
\hline C & 300 & 450 & 450 & $7 \%$ & $10 \%$ & $10 \%$ \\
\hline $\mathrm{D}$ & 950 & 1200 & 1300 & $81 \%$ & $90 \%$ & $96 \%$ \\
\hline$E$ & 300 & 400 & 700 & $40 \%$ & $50 \%$ & $60 \%$ \\
\hline \multicolumn{7}{|l|}{$\mathrm{F}$} \\
\hline $\mathrm{G}$ & 300 & 400 & 500 & $10 \%$ & $15 \%$ & $20 \%$ \\
\hline Mediana & 300 & 425 & 600 & $40 \%$ & $50 \%$ & $60 \%$ \\
\hline Servente & \multicolumn{3}{|c|}{ Produção Unitária (m²/Hserv) } & & & \\
\hline Discriminação & 1Q Quartil & Mediana & 3 Quartil & & & \\
\hline \multicolumn{7}{|l|}{ A } \\
\hline \multicolumn{7}{|l|}{$\mathrm{B}$} \\
\hline $\mathrm{C}$ & 150 & 250 & 350 & & & \\
\hline $\mathrm{D}$ & 158 & 200 & 220 & & & \\
\hline$E$ & 300 & 400 & 700 & & & \\
\hline \multicolumn{7}{|l|}{$\mathrm{F}$} \\
\hline $\mathrm{G}$ & 300 & 400 & 500 & & & \\
\hline Mediana & 229 & 325 & 425 & & & \\
\hline
\end{tabular}


Tabela 160 - Pintura de ligação (especialistas)

\begin{tabular}{|c|c|c|c|c|c|c|}
\hline \multirow{2}{*}{$\begin{array}{r}\text { Trator agrícola com } \\
\text { vassoura mecânica } \\
\text { Discriminação }\end{array}$} & \multicolumn{3}{|c|}{ Produção Unitária (m²/Hserv) } & \multicolumn{3}{|c|}{ Hfuncionamento } \\
\hline & 10 Quartil & Mediana & 3 Quartil & 10 Quartil & Mediana & 3Q Quartil \\
\hline A & & & & $30 \%$ & $40 \%$ & $50 \%$ \\
\hline \multicolumn{7}{|l|}{$\mathrm{B}$} \\
\hline C & 1800 & 2200 & 2800 & $60 \%$ & $70 \%$ & $80 \%$ \\
\hline $\mathrm{D}$ & 1950 & 2800 & 3000 & $41 \%$ & $60 \%$ & $64 \%$ \\
\hline$E$ & 1400 & 1600 & 1800 & $70 \%$ & $80 \%$ & $90 \%$ \\
\hline \multicolumn{7}{|l|}{$\mathrm{F}$} \\
\hline G & 1000 & 1200 & 1400 & $15 \%$ & $20 \%$ & $25 \%$ \\
\hline Mediana & 1600 & 1900 & 2300 & $45 \%$ & $60 \%$ & $64 \%$ \\
\hline \multicolumn{7}{|c|}{ b) Etapa: lançamento de cobertura } \\
\hline Caminhão espargidor & \multicolumn{3}{|c|}{ Produção Unitária (m²/Hserv) } & \multicolumn{3}{|c|}{ Hfuncionamento } \\
\hline Discriminação & 10 Quartil & Mediana & 3 Quartil & 1Q Quartil & Mediana & 3 Quartil \\
\hline A & & & & $50 \%$ & $60 \%$ & $70 \%$ \\
\hline \multicolumn{7}{|l|}{$\mathrm{B}$} \\
\hline C & 300 & 450 & 450 & $7 \%$ & $10 \%$ & $10 \%$ \\
\hline $\mathrm{D}$ & 2800 & 3250 & 3500 & $80 \%$ & $90 \%$ & $94 \%$ \\
\hline$E$ & 300 & 400 & 700 & $40 \%$ & $50 \%$ & $60 \%$ \\
\hline \multicolumn{7}{|l|}{$\mathrm{F}$} \\
\hline $\mathrm{G}$ & 300 & 400 & 500 & $10 \%$ & $15 \%$ & $20 \%$ \\
\hline Mediana & 300 & 425 & 600 & $40 \%$ & $50 \%$ & $60 \%$ \\
\hline Servente & \multicolumn{3}{|c|}{ Produção Unitária (m²/Hserv) } & & & \\
\hline Discriminação & 1Q Quartil & Mediana & 3 Quartil & & & \\
\hline \multicolumn{7}{|l|}{$A$} \\
\hline \multicolumn{7}{|l|}{$B$} \\
\hline C & 150 & 250 & 350 & & & \\
\hline D & 300 & 350 & 365 & & & \\
\hline$E$ & 300 & 400 & 700 & & & \\
\hline \multicolumn{7}{|l|}{$\mathrm{F}$} \\
\hline $\mathrm{G}$ & 300 & 400 & 500 & & & \\
\hline Mediana & 300 & 375 & 432,5 & & & \\
\hline
\end{tabular}


Tabela 161 - Síntese dos fatores e das anormalidades: escavação e carga de material de $1^{\text {a }}$ categoria

\begin{tabular}{|c|c|c|c|c|c|c|c|c|c|}
\hline Aproxima do $1^{\circ}$ Quartil & Aproxima do $3^{\circ}$ Quartil & A & B & C & D & $E$ & $\mathbf{F}$ & G & MEDIANA \\
\hline Condições climáticas instáveis & $\begin{array}{l}\text { Condições climáticas } \\
\text { estáveis }\end{array}$ & 8 & 10 & 9 & 8 & 9 & 9 & 10 & 9 \\
\hline $\begin{array}{l}\text { Umidade do solo maior do que } \\
\text { a projetada }\end{array}$ & $\begin{array}{l}\text { Umidade do solo } \\
\text { compatível com a } \\
\text { projetada }\end{array}$ & 6 & 6 & 5 & 6 & 6 & 8 & 7 & 6 \\
\hline $\begin{array}{l}\text { Solo com maior dificuldade de } \\
\text { penetração }\end{array}$ & $\begin{array}{l}\text { Solo facilmente } \\
\text { penetrável }\end{array}$ & 8 & 8 & 6 & 8 & 6 & 5 & 5 & 6 \\
\hline Escavação no nível do terreno & $\begin{array}{l}\text { Escavação em barranco } \\
\text { (diminui o tempo de ciclo } \\
\text { entre a escavação, } \\
\text { carga e a manobra, } \\
\text { aumentando a } \\
\text { eficiência) }\end{array}$ & 8 & 8 & 7 & 5 & 7 & 5 & 6 & 7 \\
\hline Terreno muito acidentado & $\begin{array}{l}\text { Terreno pouco } \\
\text { acidentado }\end{array}$ & 7 & 7 & 5 & 5 & 10 & 8 & 8 & 7 \\
\hline $\begin{array}{l}\text { Equipamento de escavação } \\
\text { menos compatível com as } \\
\text { características do terreno }\end{array}$ & $\begin{array}{l}\text { Equipamento de } \\
\text { escavação compatível } \\
\text { com as características } \\
\text { do terreno }\end{array}$ & 9 & 9 & 8 & 6 & 9 & 8 & 8 & 8 \\
\hline $\begin{array}{l}\text { Equipamento com alta } \\
\text { manutenção durante a } \\
\text { operação }\end{array}$ & $\begin{array}{l}\text { Equipamento com baixa } \\
\text { manutenção durante a } \\
\text { operação }\end{array}$ & 8 & 10 & 6 & 8 & 9 & 7 & 7 & 8 \\
\hline $\begin{array}{l}\text { Problemas com abastecimento } \\
\text { de combustível (falta } \\
\text { combustível) }\end{array}$ & $\begin{array}{l}\text { Equipamento abastecido } \\
\text { (combustível) }\end{array}$ & 9 & 9 & 5 & 8 & 10 & 6 & 5 & 8 \\
\hline $\begin{array}{l}\text { Alto índice de ausência do } \\
\text { operador (tem muitas faltas) }\end{array}$ & $\begin{array}{l}\text { Baixo índice de } \\
\text { ausência do operador } \\
\text { (tem poucas faltas) }\end{array}$ & 8 & 7 & 6 & 8 & 7 & 6 & 5 & 7 \\
\hline Operador menos treinado & Operador treinado & 7 & 8 & 8 & 10 & 7 & 5 & 5 & 7 \\
\hline $\begin{array}{l}\text { Comete erros grosseiros em } \\
\text { relação ao projetado } \\
\text { (retrabalho) }\end{array}$ & $\begin{array}{l}\text { Serviço executado de } \\
\text { acordo com o projeto } \\
\text { (evita erros grosseiros } \\
\text { que poderiam aumentar } \\
\text { o volume da escavação) }\end{array}$ & 8 & 9 & 5 & 8 & 5 & 8 & 9 & 8 \\
\hline $\begin{array}{l}\text { Mais tempo para executar a } \\
\text { atividade (prazos extensos) }\end{array}$ & $\begin{array}{l}\text { Pouco tempo para } \\
\text { executar a atividade } \\
\text { (prazos enxutos) }\end{array}$ & 7 & 6 & 0 & 10 & 7 & 8 & 8 & 7 \\
\hline $\begin{array}{l}\text { Má continuidade e sequência } \\
\text { de operações entre cada } \\
\text { atividade }\end{array}$ & $\begin{array}{l}\text { Boa continuidade e } \\
\text { sequência de operações } \\
\text { entre cada atividade }\end{array}$ & 8 & 6 & 8 & 8 & 6 & 7 & 8 & 8 \\
\hline $\begin{array}{l}\text { Menos frentes sendo atendidas } \\
\text { (de aterro ou DME) }\end{array}$ & $\begin{array}{l}\text { Mais frentes sendo } \\
\text { atendidas (de aterro ou } \\
\text { DME) }\end{array}$ & 5 & 5 & 8 & 4 & 5 & 8 & 9 & 5 \\
\hline $\begin{array}{l}\text { Quantidade e capacidade de } \\
\text { caminhões menos compatível } \\
\text { com a frente de serviço }\end{array}$ & $\begin{array}{l}\text { Quantidade e } \\
\text { capacidade de } \\
\text { caminhões compatível } \\
\text { com a frente de serviço }\end{array}$ & 5 & 8 & 8 & 10 & 8 & 7 & 7 & 8 \\
\hline $\begin{array}{l}\text { DMT maior (distância entre o } \\
\text { corte e o aterro atendido) }\end{array}$ & $\begin{array}{l}\text { DMT menor (distância } \\
\text { entre o corte e o aterro } \\
\text { atendido) }\end{array}$ & 5 & 10 & 0 & 2 & 5 & 8 & 8 & 5 \\
\hline
\end{tabular}


Tabela 162 - Síntese dos fatores e das anormalidades: compactação de aterro

\begin{tabular}{|c|c|c|c|c|c|c|c|c|c|}
\hline Aproxima do $1^{\circ}$ Quartil & Aproxima do 3 Q Quartil & $\mathbf{A}$ & B & $\mathbf{C}$ & D & $E$ & $\mathbf{F}$ & $\mathbf{G}$ & MEDIANA \\
\hline \multicolumn{10}{|c|}{ CONDIÇÕES GERAIS } \\
\hline Condições climáticas instáveis & $\begin{array}{l}\text { Condições climáticas } \\
\text { estáveis }\end{array}$ & 8 & 10 & 9 & 10 & 10 & 9 & 10 & 10 \\
\hline $\begin{array}{l}\text { Baixa capacidade efetiva do } \\
\text { equipamento (menor } \\
\text { quantidade de horas em } \\
\text { funcionamento) }\end{array}$ & $\begin{array}{l}\text { Alta capacidade efetiva do } \\
\text { equipamento (maior } \\
\text { quantidade de horas em } \\
\text { funcionamento) }\end{array}$ & 6 & 10 & 7 & 8 & 5 & 9 & 9 & 8 \\
\hline $\begin{array}{l}\text { Equipamento com alta } \\
\text { manutenção durante a } \\
\text { operação }\end{array}$ & $\begin{array}{l}\text { Equipamento com baixa } \\
\text { manutenção durante a } \\
\text { operação }\end{array}$ & 7 & 10 & 7 & 6 & 9 & 8 & 8 & 8 \\
\hline $\begin{array}{l}\text { Problemas com abastecimento } \\
\text { de combustível (equipamento } \\
\text { sem combustível) }\end{array}$ & $\begin{array}{l}\text { Equipamento abastecido } \\
\text { (combustível) }\end{array}$ & 7 & 9 & 4 & 6 & 4 & 6 & 5 & 6 \\
\hline $\begin{array}{l}\text { Alto índice de ausência do } \\
\text { operador (faltas) }\end{array}$ & $\begin{array}{l}\text { Baixo índice de ausência } \\
\text { do operador (faltas) }\end{array}$ & 7 & 7 & 7 & 6 & 4 & 6 & 5 & 6 \\
\hline Prevalece a improvisação & $\begin{array}{l}\text { Planeja antecipadamente } \\
\text { as atividades }\end{array}$ & 8 & 9 & 6 & 6 & 7 & 7 & 7 & 7 \\
\hline Operador menos treinado & Operador treinado & 7 & 8 & 6 & 8 & 7 & 6 & 6 & 7 \\
\hline $\begin{array}{l}\text { Mais tempo para executar a } \\
\text { atividade (prazos extensos) }\end{array}$ & $\begin{array}{l}\text { Pouco tempo para } \\
\text { executar a atividade } \\
\text { (prazos enxutos) }\end{array}$ & 7 & 6 & 0 & 8 & 7 & 8 & 8 & 7 \\
\hline $\begin{array}{l}\text { Má continuidade e sequência } \\
\text { de operações }\end{array}$ & $\begin{array}{l}\text { Boa continuidade e } \\
\text { sequência de operações }\end{array}$ & 8 & 7 & 7 & 6 & 7 & 8 & 9 & 7 \\
\hline Menos frentes sendo atendidas & $\begin{array}{l}\text { Mais frentes sendo } \\
\text { atendidas }\end{array}$ & 5 & 6 & 7 & 8 & 6 & 7 & 8 & 7 \\
\hline $\begin{array}{l}\text { Frentes de trabalho mais } \\
\text { distantes }\end{array}$ & $\begin{array}{l}\text { Frentes de trabalho mais } \\
\text { próximas }\end{array}$ & 5 & 6 & 7 & 6 & 5 & 7 & 8 & 6 \\
\hline $\begin{array}{l}\text { Tarefas preliminares a executar } \\
\text { (ex. drenos) }\end{array}$ & $\begin{array}{l}\text { Tarefas preliminares } \\
\text { prontas (ex. drenos) }\end{array}$ & 5 & 10 & 0 & 10 & 5 & 8 & 9 & 8 \\
\hline \multicolumn{10}{|c|}{ CONDIÇÕES ESPECÍFICAS } \\
\hline \multicolumn{10}{|c|}{ Espalhamento do solo e nivelamento da camada } \\
\hline $\begin{array}{l}\text { Quantidade e capacidade de } \\
\text { caminhões menos compatível } \\
\text { com a frente a ser abastecida }\end{array}$ & $\begin{array}{l}\text { Quantidade e capacidade } \\
\text { de caminhões compatível } \\
\text { com a frente a ser } \\
\text { abastecida }\end{array}$ & 8 & 9 & 9 & 8 & 9 & 7 & 6 & 8 \\
\hline $\begin{array}{l}\text { DMT maior (demora no trajeto } \\
\text { corte/aterro) }\end{array}$ & $\begin{array}{l}\text { DMT menor (rapidez no } \\
\text { trajeto corte/aterro) }\end{array}$ & 7 & 9 & 0 & 8 & 6 & 8 & 8 & 8 \\
\hline \multicolumn{10}{|c|}{ Aeração, homogeneização e umidificação da camada } \\
\hline $\begin{array}{l}\text { Umidade do solo maior do que } \\
\text { a projetada }\end{array}$ & $\begin{array}{l}\text { Umidade do solo } \\
\text { compatível com a } \\
\text { projetada }\end{array}$ & 8 & 9 & 9 & 8 & 8 & 8 & 8 & 8 \\
\hline Solo menos homogêneo & Solo mais homogêneo & 8 & 9 & 7 & 8 & 4 & 7 & 7 & 7 \\
\hline \multicolumn{10}{|l|}{ Compactação da camada } \\
\hline $\begin{array}{l}\text { Camadas mais espessas } \\
(>20 \mathrm{~cm} \mathrm{e}<30 \mathrm{~cm})\end{array}$ & \begin{tabular}{|l|} 
Camadas menos \\
espessas $(<20 \mathrm{~cm})$ \\
\end{tabular} & 9 & 6 & 7 & 6 & 10 & 6 & 5 & 6 \\
\hline $\begin{array}{l}\text { Maior a deformabilidade da } \\
\text { camada inferior }\end{array}$ & $\begin{array}{l}\text { Menor deformabilidade da } \\
\text { camada inferior }\end{array}$ & 7 & 7 & 6 & 6 & 10 & 6 & 5 & 6 \\
\hline $\begin{array}{l}\text { Maior quantidade de passadas } \\
\text { dos compactadores (número de } \\
\text { fechas para atingir o GC) }\end{array}$ & $\begin{array}{l}\text { Menor quantidade de } \\
\text { passadas dos } \\
\text { compactadores (número } \\
\text { de fechas para atingir o } \\
\text { GC) }\end{array}$ & 6 & 10 & 7 & 8 & 10 & 6 & 7 & 7 \\
\hline
\end{tabular}




\begin{tabular}{|c|c|c|c|c|c|c|c|c|c|}
\hline $\begin{array}{l}\text { Equipe de equipamentos } \\
\text { menos compatível } \\
\text { (equipamentos diferentes, } \\
\text { pesos diferentes, quantidade } \\
\text { incompatível com o GC) }\end{array}$ & $\begin{array}{l}\text { Equipe de equipamentos } \\
\text { compatível (equipamentos } \\
\text { semelhantes, pesos } \\
\text { parecidos, quantidade } \\
\text { compatível com o GC) }\end{array}$ & 8 & 9 & 8 & 8 & 8 & 7 & 7 & 8 \\
\hline $\begin{array}{l}\text { Equipe de laboratório menos } \\
\text { treinada }\end{array}$ & $\begin{array}{l}\text { Equipe de laboratório } \\
\text { treinada }\end{array}$ & 6 & 7 & 8 & 6 & 8 & 5 & 6 & 6 \\
\hline
\end{tabular}


Tabela 163 - Síntese dos fatores e das anormalidades: base de solo cimento com mistura na pista

\begin{tabular}{|c|c|c|c|c|c|c|c|c|c|}
\hline Aproxima do 1ㅇ Quartil & Aproxima do 3 Quartil & $\mathbf{A}$ & B & $\mathbf{C}$ & $\bar{D}$ & $E$ & $\mathbf{F}$ & $\mathbf{G}$ & MEDIANA \\
\hline \multicolumn{10}{|c|}{ CONDIÇÕES GERAIS } \\
\hline Condições climáticas instáveis & $\begin{array}{l}\text { Condições climáticas } \\
\text { estáveis }\end{array}$ & 8 & 10 & 9 & 10 & 10 & 9 & 10 & 10 \\
\hline $\begin{array}{l}\text { Baixa capacidade efetiva do } \\
\text { equipamento (menor } \\
\text { quantidade de horas em } \\
\text { funcionamento) }\end{array}$ & $\begin{array}{l}\text { Alta capacidade efetiva do } \\
\text { equipamento (maior } \\
\text { quantidade de horas em } \\
\text { funcionamento) }\end{array}$ & 6 & 10 & 8 & 8 & 6 & 9 & 9 & 8 \\
\hline $\begin{array}{l}\text { Equipamento com alta } \\
\text { manutenção durante a } \\
\text { operação }\end{array}$ & $\begin{array}{l}\text { Equipamento com baixa } \\
\text { manutenção durante a } \\
\text { operação }\end{array}$ & 7 & 10 & 8 & 8 & 9 & 8 & 8 & 8 \\
\hline $\begin{array}{l}\text { Problemas com abastecimento } \\
\text { de combustível (equipamento } \\
\text { sem combustível) }\end{array}$ & $\begin{array}{l}\text { Equipamento abastecido } \\
\text { (combustível) }\end{array}$ & 6 & 9 & 5 & 6 & 4 & 7 & 5 & 6 \\
\hline $\begin{array}{l}\text { Alto índice de ausência do } \\
\text { operador (faltas) }\end{array}$ & $\begin{array}{l}\text { Baixo índice de ausência } \\
\text { do operador (faltas) }\end{array}$ & 6 & 7 & 6 & 6 & 4 & 6 & 5 & 6 \\
\hline Prevalece a improvisação & $\begin{array}{l}\text { Planeja antecipadamente } \\
\text { as atividades }\end{array}$ & 8 & 9 & 7 & 6 & 7 & 7 & 7 & 7 \\
\hline Operador menos treinado & Operador treinado & 7 & 7 & 8 & 8 & 9 & 6 & 6 & 7 \\
\hline $\begin{array}{l}\text { Mais tempo para executar a } \\
\text { atividade (prazos extensos) }\end{array}$ & $\begin{array}{l}\text { Pouco tempo para } \\
\text { executar a atividade } \\
\text { (prazos enxutos) }\end{array}$ & 6 & 6 & 0 & 8 & 7 & 8 & 6 & 6 \\
\hline $\begin{array}{l}\text { Má continuidade e sequência } \\
\text { de operações }\end{array}$ & $\begin{array}{l}\text { Boa continuidade e } \\
\text { sequência de operações }\end{array}$ & 8 & 10 & 7 & 6 & 7 & 7 & 8 & 7 \\
\hline Menos frentes sendo atendidas & $\begin{array}{l}\text { Mais frentes sendo } \\
\text { atendidas }\end{array}$ & 7 & 6 & 7 & 6 & 6 & 7 & 8 & 7 \\
\hline $\begin{array}{l}\text { Frentes de trabalho mais } \\
\text { distantes }\end{array}$ & $\begin{array}{l}\text { Frentes de trabalho mais } \\
\text { próximas }\end{array}$ & 6 & 5 & 7 & 6 & 5 & 7 & 7 & 6 \\
\hline $\begin{array}{l}\text { Tarefas preliminares a executar } \\
\text { (ex. drenos) }\end{array}$ & $\begin{array}{l}\text { Tarefas preliminares } \\
\text { prontas (ex. drenos) }\end{array}$ & 6 & $?$ & 0 & 10 & 5 & 7 & 8 & 6,5 \\
\hline \multicolumn{10}{|c|}{ CONDIÇÕES ESPECÍFICAS } \\
\hline
\end{tabular}

\section{Espalhamento do solo e nivelamento da camada}

Quantidade e capacidade de caminhões (ou mão de obra para serviço manual) menos compatível com a frente a ser abastecida

DMT maior (demora no trajeto corte/aterro)
Quantidade e capacidade de caminhões (ou mão de obra para serviço manual) compatível com a frente a ser abastecida

DMT menor (rapidez no trajeto corte/aterro)

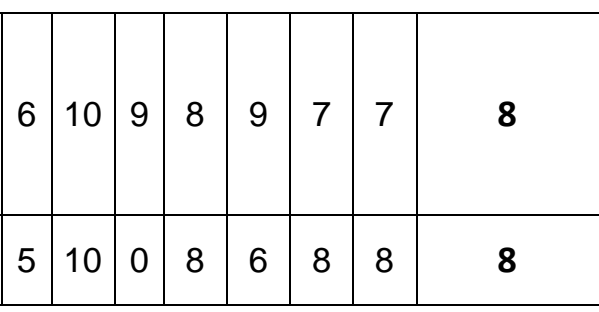

Aeração, homogeneização e umidificação da camada

\begin{tabular}{|c|c|c|c|c|c|c|c|c|c|}
\hline $\begin{array}{l}\text { Umidade do solo maior do que } \\
\text { a projetada }\end{array}$ & $\begin{array}{l}\text { Umidade do solo } \\
\text { compatível com a } \\
\text { projetada }\end{array}$ & 8 & 9 & 8 & 8 & 8 & 7 & 7 & 8 \\
\hline Solo menos homogêneo & Solo mais homogêneo & 8 & 10 & 7 & 8 & 4 & 6 & 5 & 7 \\
\hline \multicolumn{10}{|l|}{ Compactação da camada } \\
\hline $\begin{array}{l}\text { Camadas mais espessas } \\
(>20 \mathrm{~cm} \mathrm{e}<30 \mathrm{~cm})\end{array}$ & $\begin{array}{l}\text { Camadas menos } \\
\text { espessas }(<20 \mathrm{~cm})\end{array}$ & 8 & 7 & 6 & 6 & 10 & 7 & 5 & 7 \\
\hline $\begin{array}{l}\text { Maior a deformabilidade da } \\
\text { camada inferior }\end{array}$ & $\begin{array}{l}\text { Menor deformabilidade da } \\
\text { camada inferior }\end{array}$ & 5 & 6 & 6 & 6 & 10 & 5 & 4 & 6 \\
\hline $\begin{array}{l}\text { Maior quantidade de passadas } \\
\text { dos compactadores (número de } \\
\text { fechas para atingir o GC) }\end{array}$ & $\begin{array}{l}\text { Menor quantidade de } \\
\text { passadas dos } \\
\text { compactadores (número } \\
\text { de fechas para atingir o } \\
\text { GC) }\end{array}$ & 5 & 8 & 6 & 8 & 10 & 7 & 8 & 8 \\
\hline
\end{tabular}


Equipe de equipamentos menos compatível

(equipamentos diferentes, pesos diferentes, quantidade incompatível com o GC)

Equipe de laboratório menos treinada

Equipe de equipamentos compatível (equipamentos semelhantes, pesos parecidos, quantidade compatível com o GC)

Equipe de laboratório treinada $\begin{array}{lllllllll}8 & 10 & 7 & 8 & 8 & 6 & 7\end{array}$

8 
Tabela 164 - Síntese dos fatores e das anormalidades: brita graduada simples - BGS

\begin{tabular}{|c|c|c|c|c|c|c|c|c|c|}
\hline Aproxima do $1^{\circ}$ Quartil & Aproxima do 3 Q Quartil & $\mathbf{A}$ & B & $\mathbf{C}$ & D & $E$ & $\mathbf{F}$ & $\mathbf{G}$ & MEDIANA \\
\hline \multicolumn{10}{|c|}{ CONDIÇÕES GERAIS } \\
\hline Condições climáticas instáveis & $\begin{array}{l}\text { Condições climáticas } \\
\text { estáveis }\end{array}$ & 9 & 6 & 8 & 8 & 10 & 9 & 10 & 9 \\
\hline $\begin{array}{l}\text { Baixa capacidade efetiva do } \\
\text { equipamento (menor } \\
\text { quantidade de horas em } \\
\text { funcionamento) }\end{array}$ & $\begin{array}{l}\text { Alta capacidade efetiva do } \\
\text { equipamento (maior } \\
\text { quantidade de horas em } \\
\text { funcionamento) }\end{array}$ & 8 & 10 & 7 & 8 & 6 & 8 & 8 & 8 \\
\hline $\begin{array}{l}\text { Equipamento com alta } \\
\text { manutenção durante a } \\
\text { operação }\end{array}$ & $\begin{array}{l}\text { Equipamento com baixa } \\
\text { manutenção durante a } \\
\text { operação }\end{array}$ & 8 & 10 & 7 & 6 & 9 & 8 & 7 & 8 \\
\hline $\begin{array}{l}\text { Problemas com abastecimento } \\
\text { de combustível (equipamento } \\
\text { sem combustível) }\end{array}$ & $\begin{array}{l}\text { Equipamento abastecido } \\
\text { (combustível) }\end{array}$ & 7 & 9 & 5 & 6 & 4 & 6 & 5 & 6 \\
\hline $\begin{array}{l}\text { Equipamentos em más } \\
\text { condições e descalibrados }\end{array}$ & $\begin{array}{l}\text { Equipamentos em boas } \\
\text { condições e calibrados }\end{array}$ & 7 & 10 & 7 & 4 & 6 & 7 & 6 & 7 \\
\hline $\begin{array}{l}\text { Baixa capacidade efetiva da } \\
\text { usina }\end{array}$ & $\begin{array}{l}\text { Alta capacidade efetiva da } \\
\text { usina }\end{array}$ & 8 & 10 & 8 & 8 & 8 & 8 & 8 & 8 \\
\hline $\begin{array}{l}\text { Baixa qualidade da massa } \\
\text { produzida na usina }\end{array}$ & $\begin{array}{l}\text { Alta qualidade da massa } \\
\text { produzida na usina }\end{array}$ & 8 & $?$ & 0 & 8 & 5 & 5 & 5 & 5 \\
\hline $\begin{array}{l}\text { Alto índice de ausência do } \\
\text { operador (faltas) }\end{array}$ & $\begin{array}{l}\text { Baixo índice de ausência } \\
\text { do operador (faltas) }\end{array}$ & 7 & 7 & 5 & 6 & 4 & 6 & 5 & 6 \\
\hline Prevalece a improvisação & $\begin{array}{l}\text { Planeja antecipadamente } \\
\text { as atividades }\end{array}$ & 8 & 9 & 8 & 6 & 7 & 6 & 5 & 7 \\
\hline Operador menos treinado & Operador treinado & 5 & 7 & 8 & 8 & 9 & 7 & 7 & 7 \\
\hline $\begin{array}{l}\text { Mais tempo para executar a } \\
\text { atividade (prazos extensos) }\end{array}$ & $\begin{array}{l}\text { Pouco tempo para } \\
\text { executar a atividade } \\
\text { (prazos enxutos) }\end{array}$ & 6 & 6 & 0 & 8 & 7 & 8 & 6 & 6 \\
\hline $\begin{array}{l}\text { Má continuidade e sequência } \\
\text { de operações }\end{array}$ & $\begin{array}{l}\text { Boa continuidade e } \\
\text { sequência de operações }\end{array}$ & 6 & 9 & 7 & 6 & 7 & 7 & 8 & 7 \\
\hline Menos frentes sendo atendidas & $\begin{array}{l}\text { Mais frentes sendo } \\
\text { atendidas }\end{array}$ & 5 & 5 & 7 & 6 & 6 & 7 & 7 & 6 \\
\hline $\begin{array}{l}\text { Frentes de trabalho mais } \\
\text { distantes }\end{array}$ & $\begin{array}{l}\text { Frentes de trabalho mais } \\
\text { próximas }\end{array}$ & 5 & 5 & 7 & 4 & 5 & 7 & 7 & 5 \\
\hline $\begin{array}{l}\text { Tarefas preliminares a executar } \\
\text { (ex. travessias) }\end{array}$ & $\begin{array}{l}\text { Tarefas preliminares } \\
\text { prontas (ex. travessias) }\end{array}$ & 6 & 8 & 0 & 10 & 5 & 7 & 8 & 7 \\
\hline \multicolumn{10}{|c|}{ CONDIÇÕES ESPECÍFICAS } \\
\hline \multicolumn{10}{|c|}{ Espalhamento da BGS e nivelamento da camada } \\
\hline $\begin{array}{l}\text { Quantidade e capacidade de } \\
\text { caminhões menos compatível } \\
\text { com a frente a ser abastecida }\end{array}$ & $\begin{array}{l}\text { Quantidade e capacidade } \\
\text { de caminhões compatível } \\
\text { com a frente a ser } \\
\text { abastecida }\end{array}$ & 6 & 10 & 8 & 8 & 9 & 8 & 7 & 8 \\
\hline $\begin{array}{l}\text { DMT maior (demora no trajeto } \\
\text { usina/frente) }\end{array}$ & $\begin{array}{l}\text { DMT menor (rapidez no } \\
\text { trajeto usina/frente) }\end{array}$ & 6 & 10 & 3 & 6 & 6 & 8 & 8 & 6 \\
\hline $\begin{array}{l}\text { Equipe de apoio em } \\
\text { treinamento }\end{array}$ & Equipe de apoio treinada & 6 & 7 & 8 & 8 & 5 & 8 & 8 & 8 \\
\hline \multicolumn{10}{|l|}{ Umidificação da camada } \\
\hline $\begin{array}{l}\text { Umidade dos agregados maior } \\
\text { do que a projetada }\end{array}$ & $\begin{array}{l}\text { Umidade dos agregados } \\
\text { compatível com a } \\
\text { projetada }\end{array}$ & 5 & 6 & 8 & 8 & 8 & 7 & 7 & 7 \\
\hline
\end{tabular}




\begin{tabular}{|c|c|c|c|c|c|c|c|c|c|}
\hline \multicolumn{10}{|l|}{ Compactação da camada } \\
\hline $\begin{array}{l}\text { Camadas mais espessas } \\
(>10 \mathrm{~cm} \text { e }<20 \mathrm{~cm})\end{array}$ & $\begin{array}{l}\text { Camadas menos } \\
\text { espessas }(<10 \mathrm{~cm})\end{array}$ & 8 & 6 & 7 & 6 & 10 & 9 & 8 & 8 \\
\hline $\begin{array}{l}\text { Maior a deformabilidade da } \\
\text { camada inferior }\end{array}$ & $\begin{array}{l}\text { Menor deformabilidade da } \\
\text { camada inferior }\end{array}$ & 6 & 6 & 3 & 6 & 10 & 8 & 7 & 6 \\
\hline $\begin{array}{l}\text { Maior quantidade de passadas } \\
\text { dos compactadores (número de } \\
\text { fechas para atingir o GC) }\end{array}$ & $\begin{array}{l}\text { Menor quantidade de } \\
\text { passadas dos } \\
\text { compactadores (número } \\
\text { de fechas para atingir o } \\
\text { GC) }\end{array}$ & 6 & 9 & 5 & 4 & 10 & 7 & 8 & 7 \\
\hline $\begin{array}{l}\text { Equipe de equipamentos } \\
\text { menos compatível } \\
\text { (equipamentos diferentes, } \\
\text { pesos diferentes, quantidade } \\
\text { incompatível com o GC) }\end{array}$ & $\begin{array}{l}\text { Equipe de equipamentos } \\
\text { compatível (equipamentos } \\
\text { semelhantes, pesos } \\
\text { parecidos, quantidade } \\
\text { compatível com o GC) }\end{array}$ & 8 & 9 & 2 & 4 & 6 & 7 & 8 & 7 \\
\hline $\begin{array}{l}\text { Equipe de laboratório menos } \\
\text { treinada }\end{array}$ & $\begin{array}{l}\text { Equipe de laboratório } \\
\text { treinada }\end{array}$ & 5 & 7 & 7 & 4 & 8 & 6 & 7 & 7 \\
\hline $\begin{array}{l}\text { Velocidade de rolagem menos } \\
\text { compatível com a camada }\end{array}$ & $\begin{array}{l}\text { Velocidade de rolagem } \\
\text { compatível com a camada }\end{array}$ & 7 & 9 & 3 & 4 & 9 & 6 & 5 & 6 \\
\hline
\end{tabular}


Tabela 165 - Síntese dos fatores e das anormalidades: brita graduada tratada com cimento BGTC

\begin{tabular}{|c|c|c|c|c|c|c|c|c|c|}
\hline Aproxima do $1^{\circ}$ Quartil & Aproxima do $3^{\circ}$ Quartil & A & B & C & D & $\mathbf{E}$ & $\mathbf{F}$ & $\mathbf{G}$ & MEDIANA \\
\hline \multicolumn{10}{|c|}{ CONDIÇÕES GERAIS } \\
\hline Condições climáticas instáveis & $\begin{array}{l}\text { Condições climáticas } \\
\text { estáveis }\end{array}$ & 8 & 10 & 8 & & 10 & 9 & 10 & 10 \\
\hline $\begin{array}{l}\text { Baixa capacidade efetiva do } \\
\text { equipamento (menor } \\
\text { quantidade de horas em } \\
\text { funcionamento) }\end{array}$ & $\begin{array}{l}\text { Alta capacidade efetiva do } \\
\text { equipamento (maior } \\
\text { quantidade de horas em } \\
\text { funcionamento) }\end{array}$ & 8 & 10 & 7 & & 6 & 8 & 8 & 8 \\
\hline $\begin{array}{l}\text { Equipamento com alta } \\
\text { manutenção durante a } \\
\text { operação }\end{array}$ & $\begin{array}{l}\text { Equipamento com baixa } \\
\text { manutenção durante a } \\
\text { operação }\end{array}$ & 7 & 10 & 7 & & 9 & 8 & 7 & 8 \\
\hline $\begin{array}{l}\text { Problemas com abastecimento } \\
\text { de combustível (equipamento } \\
\text { sem combustível) }\end{array}$ & $\begin{array}{l}\text { Equipamento abastecido } \\
\text { (combustível) }\end{array}$ & 7 & 9 & 5 & & 4 & 6 & 5 & 6 \\
\hline $\begin{array}{l}\text { Equipamentos em más } \\
\text { condições e descalibrados }\end{array}$ & $\begin{array}{l}\text { Equipamentos em boas } \\
\text { condições e calibrados }\end{array}$ & 7 & 10 & 7 & & 6 & 7 & 6 & 7 \\
\hline $\begin{array}{l}\text { Baixa capacidade efetiva da } \\
\text { usina }\end{array}$ & $\begin{array}{l}\text { Alta capacidade efetiva da } \\
\text { usina }\end{array}$ & 8 & 10 & 8 & & 8 & 8 & 8 & 8 \\
\hline $\begin{array}{l}\text { Baixa qualidade da massa } \\
\text { produzida na usina }\end{array}$ & $\begin{array}{l}\text { Alta qualidade da massa } \\
\text { produzida na usina }\end{array}$ & 8 & 9 & 4 & & 5 & 5 & 6 & 6 \\
\hline $\begin{array}{l}\text { Alto índice de ausência do } \\
\text { operador (faltas) }\end{array}$ & $\begin{array}{l}\text { Baixo índice de ausência } \\
\text { do operador (faltas) }\end{array}$ & 7 & 7 & 7 & & 4 & 6 & 5 & 7 \\
\hline Prevalece a improvisação & $\begin{array}{l}\text { Planeja antecipadamente } \\
\text { as atividades }\end{array}$ & 8 & 9 & 8 & & 7 & 6 & 5 & 8 \\
\hline Operador menos treinado & Operador treinado & 6 & 7 & 8 & & 9 & 7 & 7 & 7 \\
\hline $\begin{array}{l}\text { Mais tempo para executar a } \\
\text { atividade (prazos extensos) }\end{array}$ & $\begin{array}{l}\text { Pouco tempo para } \\
\text { executar a atividade } \\
\text { (prazos enxutos) }\end{array}$ & 6 & 6 & 3 & & 7 & 8 & 6 & 6 \\
\hline $\begin{array}{l}\text { Má continuidade e sequência } \\
\text { de operações }\end{array}$ & $\begin{array}{l}\text { Boa continuidade e } \\
\text { sequência de operações }\end{array}$ & 7 & 9 & 7 & & 7 & 7 & 8 & 7 \\
\hline Menos frentes sendo atendidas & $\begin{array}{l}\text { Mais frentes sendo } \\
\text { atendidas }\end{array}$ & 6 & 5 & 7 & & 6 & 7 & 7 & 7 \\
\hline $\begin{array}{l}\text { Frentes de trabalho mais } \\
\text { distantes }\end{array}$ & $\begin{array}{l}\text { Frentes de trabalho mais } \\
\text { próximas }\end{array}$ & 5 & 5 & 7 & & 5 & 7 & 7 & 6 \\
\hline $\begin{array}{l}\text { Tarefas preliminares a executar } \\
\text { (ex. travessias) }\end{array}$ & $\begin{array}{l}\text { Tarefas preliminares } \\
\text { prontas (ex. travessias) }\end{array}$ & 5 & 6 & 2 & & 5 & 7 & 8 & 6 \\
\hline \multicolumn{10}{|c|}{ CONDIÇÕES ESPECÍFICAS } \\
\hline \multicolumn{10}{|c|}{ Espalhamento da BGTC e nivelamento da camada } \\
\hline $\begin{array}{l}\text { Quantidade e capacidade de } \\
\text { caminhões menos compatível } \\
\text { com a frente a ser abastecida }\end{array}$ & $\begin{array}{l}\text { Quantidade e capacidade } \\
\text { de caminhões compatível } \\
\text { com a frente a ser } \\
\text { abastecida } \\
\end{array}$ & 6 & 10 & 8 & & 9 & 8 & 7 & 8 \\
\hline $\begin{array}{l}\text { DMT maior (demora no trajeto } \\
\text { usina/frente) }\end{array}$ & \begin{tabular}{|l|} 
DMT menor (rapidez no \\
trajeto usina/frente)
\end{tabular} & 6 & 10 & 3 & & 6 & 8 & 8 & 7 \\
\hline $\begin{array}{l}\text { Equipe de apoio em } \\
\text { treinamento }\end{array}$ & Equipe de apoio treinada & 6 & 7 & 8 & & 5 & 8 & 8 & 8 \\
\hline \multicolumn{10}{|l|}{ Umidificação da camada } \\
\hline $\begin{array}{l}\text { Umidade dos agregados maior } \\
\text { do que a projetada }\end{array}$ & $\begin{array}{l}\text { Umidade dos agregados } \\
\text { compatível com a } \\
\text { projetada }\end{array}$ & 7 & 10 & 7 & & 8 & 7 & 7 & 7 \\
\hline
\end{tabular}




\begin{tabular}{|c|c|c|c|c|c|c|c|c|}
\hline \multicolumn{9}{|l|}{ Compactação da camada } \\
\hline $\begin{array}{l}\text { Camadas mais espessas } \\
(>10 \mathrm{~cm} \mathrm{e}<20 \mathrm{~cm})\end{array}$ & $\begin{array}{l}\text { Camadas menos } \\
\text { espessas }(<10 \mathrm{~cm})\end{array}$ & 8 & 6 & 7 & 10 & 6 & 8 & 8 \\
\hline $\begin{array}{l}\text { Maior a deformabilidade da } \\
\text { camada inferior }\end{array}$ & $\begin{array}{l}\text { Menor deformabilidade da } \\
\text { camada inferior }\end{array}$ & 6 & 6 & 5 & 10 & 5 & 7 & 6 \\
\hline $\begin{array}{l}\text { Maior quantidade de passadas } \\
\text { dos compactadores (número de } \\
\text { fechas para atingir o GC) }\end{array}$ & $\begin{array}{l}\text { Menor quantidade de } \\
\text { passadas dos } \\
\text { compactadores (número } \\
\text { de fechas para atingir o } \\
\text { GC) } \\
\end{array}$ & 6 & 8 & 6 & 10 & 7 & 8 & 8 \\
\hline $\begin{array}{l}\text { Equipe de equipamentos } \\
\text { menos compatível } \\
\text { (equipamentos diferentes, } \\
\text { pesos diferentes, quantidade } \\
\text { incompatível com o GC) }\end{array}$ & $\begin{array}{l}\text { Equipe de equipamentos } \\
\text { compatível (equipamentos } \\
\text { semelhantes, pesos } \\
\text { parecidos, quantidade } \\
\text { compatível com o GC) }\end{array}$ & 6 & 8 & 5 & 6 & 7 & 8 & 7 \\
\hline $\begin{array}{l}\text { Equipe de laboratório menos } \\
\text { treinada }\end{array}$ & $\begin{array}{l}\text { Equipe de laboratório } \\
\text { treinada }\end{array}$ & 6 & 7 & 8 & 8 & 6 & 7 & 7 \\
\hline $\begin{array}{l}\text { Velocidade de rolagem menos } \\
\text { compatível com a camada }\end{array}$ & $\begin{array}{l}\text { Velocidade de rolagem } \\
\text { compatível com a camada }\end{array}$ & 8 & 9 & 7 & 9 & 6 & 5 & 8 \\
\hline
\end{tabular}


Tabela 166 - Síntese dos fatores e das anormalidades: CBUQ

\begin{tabular}{|c|c|c|c|c|c|c|c|c|c|}
\hline Aproxima do $1^{\circ}$ Quartil & Aproxima do $3 \circ$ Quartil & A & B & C & D & $\mathbf{E}$ & $\mathbf{F}$ & G & MEDIANA \\
\hline \multicolumn{10}{|c|}{ CONDIÇÕES GERAIS } \\
\hline Condições climáticas instáveis & $\begin{array}{l}\text { Condições climáticas } \\
\text { estáveis }\end{array}$ & 9 & 10 & 8 & 6 & 10 & 10 & 10 & 10 \\
\hline $\begin{array}{l}\text { Baixa capacidade efetiva da } \\
\text { usina (menor quantidade de } \\
\text { horas em funcionamento) }\end{array}$ & $\begin{array}{l}\text { Alta capacidade efetiva da } \\
\text { usina (maior quantidade } \\
\text { de horas em } \\
\text { funcionamento) }\end{array}$ & 8 & 10 & 8 & 10 & 10 & 8 & 8 & 8 \\
\hline $\begin{array}{l}\text { Baixa qualidade da massa } \\
\text { produzida na usina }\end{array}$ & $\begin{array}{l}\text { Alta qualidade da massa } \\
\text { produzida na usina }\end{array}$ & 8 & 10 & 3 & 4 & 10 & 7 & 7 & 7 \\
\hline $\begin{array}{l}\text { Há dificuldade em se manter a } \\
\text { temperatura da mistura } \\
\text { asfáltica conforme parâmetros } \\
\text { de projeto }\end{array}$ & $\begin{array}{l}\text { Mantém a temperatura da } \\
\text { mistura asfáltica conforme } \\
\text { parâmetros de projeto }\end{array}$ & 7 & 10 & 3 & 6 & 10 & 6 & 6 & 6 \\
\hline $\begin{array}{l}\text { Baixa capacidade efetiva do } \\
\text { equipamento (menor } \\
\text { quantidade de horas em } \\
\text { funcionamento) }\end{array}$ & $\begin{array}{l}\text { Alta capacidade efetiva do } \\
\text { equipamento (maior } \\
\text { quantidade de horas em } \\
\text { funcionamento) }\end{array}$ & 8 & 9 & 6 & 6 & 7 & 8 & 8 & 8 \\
\hline $\begin{array}{l}\text { Equipamento com alta } \\
\text { manutenção durante a } \\
\text { operação }\end{array}$ & $\begin{array}{l}\text { Equipamento com baixa } \\
\text { manutenção durante a } \\
\text { operação }\end{array}$ & 8 & 10 & 7 & 6 & 7 & 8 & 8 & 8 \\
\hline $\begin{array}{l}\text { Problemas com abastecimento } \\
\text { de combustível (equipamento } \\
\text { sem combustível) }\end{array}$ & $\begin{array}{l}\text { Equipamento abastecido } \\
\text { (combustível) }\end{array}$ & 7 & 9 & 5 & 6 & 4 & 6 & 5 & 6 \\
\hline $\begin{array}{l}\text { Equipamentos em más } \\
\text { condições e descalibrados }\end{array}$ & $\begin{array}{l}\text { Equipamentos em boas } \\
\text { condições e calibrados }\end{array}$ & 8 & 10 & 7 & 4 & 5 & 7 & 7 & 7 \\
\hline $\begin{array}{l}\text { Alto índice de ausência do } \\
\text { operador (faltas) }\end{array}$ & $\begin{array}{l}\text { Baixo índice de ausência } \\
\text { do operador (faltas) }\end{array}$ & 8 & 7 & 6 & 6 & 4 & 7 & 5 & 6 \\
\hline Prevalece a improvisação & $\begin{array}{l}\text { Planeja antecipadamente } \\
\text { as atividades }\end{array}$ & 8 & 9 & 8 & 6 & 7 & 7 & 7 & 7 \\
\hline Operador menos treinado & Operador treinado & 8 & 7 & 8 & 8 & 9 & 6 & 6 & 8 \\
\hline $\begin{array}{l}\text { Mais tempo para executar a } \\
\text { atividade (prazos extensos) }\end{array}$ & $\begin{array}{l}\text { Pouco tempo para } \\
\text { executar a atividade } \\
\text { (prazos enxutos) }\end{array}$ & 8 & 6 & 2 & 6 & 7 & 7 & 5 & 6 \\
\hline $\begin{array}{l}\text { Má continuidade e sequência } \\
\text { de operações }\end{array}$ & $\begin{array}{l}\text { Boa continuidade e } \\
\text { sequência de operações }\end{array}$ & 8 & 9 & 7 & 6 & 9 & 8 & 8 & 8 \\
\hline Menos frentes sendo atendidas & $\begin{array}{l}\text { Mais frentes sendo } \\
\text { atendidas }\end{array}$ & 7 & 5 & 7 & 4 & 6 & 7 & 8 & 7 \\
\hline Frentes mais distantes & Frentes mais próximas & 7 & 9 & 7 & 6 & 5 & 8 & 8 & 7 \\
\hline $\begin{array}{l}\text { Tarefas preliminares a executar } \\
\text { (ex. pintura de ligação) }\end{array}$ & $\begin{array}{l}\text { Tarefas preliminares } \\
\text { prontas (ex. pintura de } \\
\text { ligação) }\end{array}$ & 7 & 10 & 3 & 10 & 5 & 6 & 7 & 7 \\
\hline \multicolumn{10}{|c|}{ CONDIÇÕES ESPECÍFICAS } \\
\hline \multicolumn{10}{|c|}{ Espalhamento e nivelamento do revestimento asfáltico } \\
\hline $\begin{array}{l}\text { Quantidade e capacidade de } \\
\text { caminhões menos compatível } \\
\text { com a frente a ser abastecida }\end{array}$ & $\begin{array}{l}\text { Quantidade e capacidade } \\
\text { de caminhões compatível } \\
\text { com a frente a ser } \\
\text { abastecida }\end{array}$ & 7 & 10 & 8 & 8 & 10 & 8 & 8 & 8 \\
\hline $\begin{array}{l}\text { DMT maior (demora no trajeto } \\
\text { usina/frente) }\end{array}$ & $\begin{array}{l}\text { DMT menor (rapidez no } \\
\text { trajeto usina/frente) }\end{array}$ & 7 & 10 & 3 & 8 & 8 & 8 & 8 & 8 \\
\hline $\begin{array}{l}\text { Equipe de apoio em } \\
\text { treinamento }\end{array}$ & Equipe de apoio treinada & 8 & 5 & 7 & 8 & 8 & 8 & 8 & 8 \\
\hline
\end{tabular}




\begin{tabular}{|c|c|c|c|c|c|c|c|c|c|}
\hline \multicolumn{10}{|l|}{ Compactação da camada } \\
\hline $\begin{array}{l}\text { Camadas mais espessas } \\
(>2,5 \mathrm{~cm} \mathrm{e}<5 \mathrm{~cm})\end{array}$ & $\begin{array}{l}\text { Camadas menos } \\
\text { espessas }(<2,5 \mathrm{~cm})\end{array}$ & 7 & 6 & 7 & 8 & 10 & 8 & 8 & 8 \\
\hline $\begin{array}{l}\text { Maior a deformabilidade da } \\
\text { camada inferior }\end{array}$ & $\begin{array}{l}\text { Menor deformabilidade da } \\
\text { camada inferior }\end{array}$ & 6 & 5 & 4 & 4 & 6 & 6 & 5 & 5 \\
\hline $\begin{array}{l}\text { Maior quantidade de passadas } \\
\text { dos compactadores (número de } \\
\text { fechas para atingir o GC) }\end{array}$ & $\begin{array}{l}\text { Menor quantidade de } \\
\text { passadas dos } \\
\text { compactadores (número } \\
\text { de fechas para atingir o } \\
\text { GC) }\end{array}$ & 6 & 6 & 4 & 4 & 10 & 8 & 8 & 6 \\
\hline $\begin{array}{l}\text { Equipe de equipamentos } \\
\text { menos compatível } \\
\text { (equipamentos diferentes, } \\
\text { pesos diferentes, quantidade } \\
\text { incompatível com o GC) }\end{array}$ & $\begin{array}{l}\text { Equipe de equipamentos } \\
\text { compatível (equipamentos } \\
\text { semelhantes, pesos } \\
\text { parecidos, quantidade } \\
\text { compatível com o GC) }\end{array}$ & 8 & 8 & 7 & 6 & 10 & 8 & 8 & 8 \\
\hline $\begin{array}{l}\text { Equipe de laboratório menos } \\
\text { treinada }\end{array}$ & $\begin{array}{l}\text { Equipe de laboratório } \\
\text { treinada }\end{array}$ & 7 & 7 & 8 & 4 & 10 & 6 & 7 & 7 \\
\hline $\begin{array}{l}\text { Velocidade de rolagem menos } \\
\text { compatível com a camada }\end{array}$ & $\begin{array}{l}\text { Velocidade de rolagem } \\
\text { compatível com a camada }\end{array}$ & 7 & 7 & 7 & 4 & 10 & 6 & 5 & 7 \\
\hline
\end{tabular}


Tabela 167 - Síntese dos fatores e das anormalidades: imprimação

\begin{tabular}{|c|c|c|c|c|c|c|c|c|c|}
\hline Aproxima do $1^{\circ}$ Quartil & Aproxima do 3 Q Quartil & $\bar{A}$ & B & C & D & $E$ & $\mathbf{F}$ & $\mathbf{G}$ & MEDIANA \\
\hline Condições climáticas instáveis & $\begin{array}{l}\text { Condições climáticas } \\
\text { estáveis }\end{array}$ & 8 & 10 & 7 & 8 & 10 & 10 & 10 & 10 \\
\hline $\begin{array}{l}\text { Baixa capacidade efetiva do } \\
\text { equipamento (menor } \\
\text { quantidade de horas em } \\
\text { funcionamento) }\end{array}$ & $\begin{array}{l}\text { Alta capacidade efetiva do } \\
\text { equipamento (maior } \\
\text { quantidade de horas em } \\
\text { funcionamento) }\end{array}$ & 8 & 10 & 8 & 6 & 5 & 7 & 7 & 7 \\
\hline $\begin{array}{l}\text { Equipamento com alta } \\
\text { manutenção durante a } \\
\text { operação }\end{array}$ & $\begin{array}{l}\text { Equipamento com baixa } \\
\text { manutenção durante a } \\
\text { operação }\end{array}$ & 8 & 10 & 8 & 6 & 4 & 8 & 7 & 8 \\
\hline $\begin{array}{l}\text { Problemas com abastecimento } \\
\text { de combustível (equipamento } \\
\text { sem combustível) }\end{array}$ & $\begin{array}{l}\text { Equipamento abastecido } \\
\text { (combustível) }\end{array}$ & 7 & 9 & 5 & 6 & 4 & 7 & 5 & 6 \\
\hline $\begin{array}{l}\text { Equipamentos em más } \\
\text { condições e descalibrados }\end{array}$ & $\begin{array}{l}\text { Equipamentos em boas } \\
\text { condições e calibrados }\end{array}$ & 8 & 10 & 9 & 8 & 5 & 7 & 7 & 8 \\
\hline $\begin{array}{l}\text { Há dificuldade em se manter a } \\
\text { temperatura da solução } \\
\text { conforme parâmetros de } \\
\text { projeto }\end{array}$ & $\begin{array}{l}\text { Mantém a temperatura da } \\
\text { solução conforme } \\
\text { parâmetros de projeto }\end{array}$ & 7 & & 7 & 8 & 0 & 4 & 0 & 6 \\
\hline $\begin{array}{l}\text { Alto índice de ausência do } \\
\text { operador (faltas) }\end{array}$ & $\begin{array}{l}\text { Baixo índice de ausência } \\
\text { do operador (faltas) }\end{array}$ & 8 & 7 & 7 & 6 & 4 & 5 & 3 & 6 \\
\hline Prevalece a improvisação & $\begin{array}{l}\text { Planeja antecipadamente } \\
\text { as atividades }\end{array}$ & 9 & 7 & 8 & 6 & 4 & 5 & 3 & 6 \\
\hline Operador menos treinado & Operador treinado & 8 & 7 & 8 & 8 & 5 & 5 & 3 & 7 \\
\hline $\begin{array}{l}\text { Equipe de laboratório menos } \\
\text { treinada }\end{array}$ & $\begin{array}{l}\text { Equipe de laboratório } \\
\text { treinada }\end{array}$ & 7 & 7 & 6 & 4 & 4 & 5 & 5 & 5 \\
\hline $\begin{array}{l}\text { Má continuidade e sequência } \\
\text { de operações }\end{array}$ & $\begin{array}{l}\text { Boa continuidade e } \\
\text { sequência de operações }\end{array}$ & 7 & 6 & 8 & 4 & 4 & 7 & 7 & 7 \\
\hline $\begin{array}{l}\text { Velocidade de aplicação menos } \\
\text { compatível com a camada }\end{array}$ & $\begin{array}{l}\text { Velocidade de aplicação } \\
\text { compatível com a camada }\end{array}$ & 5 & 8 & 0 & 2 & 5 & 0 & 0 & 2 \\
\hline Menos frentes sendo atendidas & $\begin{array}{l}\text { Mais frentes sendo } \\
\text { atendidas }\end{array}$ & 5 & 5 & 5 & 4 & 4 & 5 & 5 & 5 \\
\hline $\begin{array}{l}\text { Tarefas preliminares a executar } \\
\text { (ex. base a ser revestida) }\end{array}$ & $\begin{array}{l}\text { Tarefas preliminares } \\
\text { prontas (ex. base a ser } \\
\text { revestida) }\end{array}$ & 6 & 10 & 7 & 10 & 4 & 6 & 6 & 6 \\
\hline
\end{tabular}


Tabela 168 - Síntese dos fatores e das anormalidades: pintura de ligação

\begin{tabular}{|c|c|c|c|c|c|c|c|c|c|}
\hline Aproxima do $1^{\circ}$ Quartil & Aproxima do 3 Q Quartil & $\mathbf{A}$ & B & C & $\bar{D}$ & $\bar{E}$ & $\mathbf{F}$ & $\mathbf{G}$ & MEDIANA \\
\hline Condições climáticas instáveis & $\begin{array}{l}\text { Condições climáticas } \\
\text { estáveis }\end{array}$ & 8 & 10 & 8 & & 10 & 8 & 10 & 9 \\
\hline $\begin{array}{l}\text { Baixa capacidade efetiva do } \\
\text { equipamento (menor } \\
\text { quantidade de horas em } \\
\text { funcionamento) }\end{array}$ & $\begin{array}{l}\text { Alta capacidade efetiva do } \\
\text { equipamento (maior } \\
\text { quantidade de horas em } \\
\text { funcionamento) }\end{array}$ & 8 & 10 & 7 & & 5 & 7 & 7 & 7 \\
\hline $\begin{array}{l}\text { Equipamento com alta } \\
\text { manutenção durante a } \\
\text { operação }\end{array}$ & $\begin{array}{l}\text { Equipamento com baixa } \\
\text { manutenção durante a } \\
\text { operação }\end{array}$ & 8 & 10 & 7 & & 4 & 6 & 7 & 7 \\
\hline $\begin{array}{l}\text { Problemas com abastecimento } \\
\text { de combustível (equipamento } \\
\text { sem combustível) }\end{array}$ & $\begin{array}{l}\text { Equipamento abastecido } \\
\text { (combustível) }\end{array}$ & 7 & 9 & 5 & & 4 & 6 & 5 & 6 \\
\hline $\begin{array}{l}\text { Equipamentos em más } \\
\text { condições e descalibrados }\end{array}$ & $\begin{array}{l}\text { Equipamentos em boas } \\
\text { condições e calibrados }\end{array}$ & 8 & 10 & 7 & & 5 & 6 & 7 & 7 \\
\hline $\begin{array}{l}\text { Há dificuldade em se manter a } \\
\text { temperatura da mistura } \\
\text { asfáltica conforme parâmetros } \\
\text { de projeto }\end{array}$ & $\begin{array}{l}\text { Mantém a temperatura da } \\
\text { solução conforme } \\
\text { parâmetros de projeto }\end{array}$ & 7 & $?$ & 3 & & 8 & 0 & 8 & 7 \\
\hline $\begin{array}{l}\text { Alto índice de ausência do } \\
\text { operador (faltas) }\end{array}$ & $\begin{array}{l}\text { Baixo índice de ausência } \\
\text { do operador (faltas) }\end{array}$ & 8 & 6 & 7 & & 4 & 4 & 3 & 5 \\
\hline Prevalece a improvisação & $\begin{array}{l}\text { Planeja antecipadamente } \\
\text { as atividades }\end{array}$ & 9 & 7 & 7 & & 4 & 5 & 3 & 6 \\
\hline Operador menos treinado & Operador treinado & 8 & 7 & 7 & & 5 & 5 & 3 & 6 \\
\hline $\begin{array}{l}\text { Equipe de laboratório menos } \\
\text { treinada }\end{array}$ & $\begin{array}{l}\text { Equipe de laboratório } \\
\text { treinada }\end{array}$ & 7 & 7 & 7 & & 4 & 5 & 5 & 6 \\
\hline $\begin{array}{l}\text { Má continuidade e sequência } \\
\text { de operações }\end{array}$ & $\begin{array}{l}\text { Boa continuidade e } \\
\text { sequência de operações }\end{array}$ & 7 & 6 & 7 & & 4 & 6 & 7 & 7 \\
\hline $\begin{array}{l}\text { Velocidade de rolagem menos } \\
\text { compatível com a camada }\end{array}$ & $\begin{array}{l}\text { Velocidade de rolagem } \\
\text { compatível com a camada }\end{array}$ & 5 & 5 & 3 & & 5 & 0 & 5 & 5 \\
\hline Menos frentes sendo atendidas & $\begin{array}{l}\text { Mais frentes sendo } \\
\text { atendidas }\end{array}$ & 5 & 5 & 6 & & 4 & 6 & 5 & 5 \\
\hline $\begin{array}{l}\text { Tarefas preliminares a executar } \\
\text { (ex. base a ser revestida) }\end{array}$ & \begin{tabular}{|l|} 
Tarefas preliminares \\
prontas (ex. base a ser \\
revestida)
\end{tabular} & 5 & 10 & 7 & & 4 & 6 & 6 & 6 \\
\hline
\end{tabular}

